UNITED STATES DEPARTMENT OF THE INTERIOR

Harold L. Ickes, Secretary

GEOLOGICAL SURVEX

W. C. Mendenhall, Director

Water-Supply Paper 639

GE0LOGY AND GROUND-WATER RESOURCES OF THE ROSWELL ARTESIAN BASIE

NEW MEXICO

BY

ALBERT G. FIEDLER

AND

S. SPENCER NYE

Prepared in cooperation with the
NEW MEXICO STATE ENGINEER
and CHAVES AND EDDY COUNTIES

Prepared in cooperation with the
NEW MEXICO STATE ENGINEER
and CHAVES AND EDDY COUNTIES

Prepared in cooperation with the
NEW MEXICO STATE ENGINEER
and CHAVES AND EDDY COUNTIES
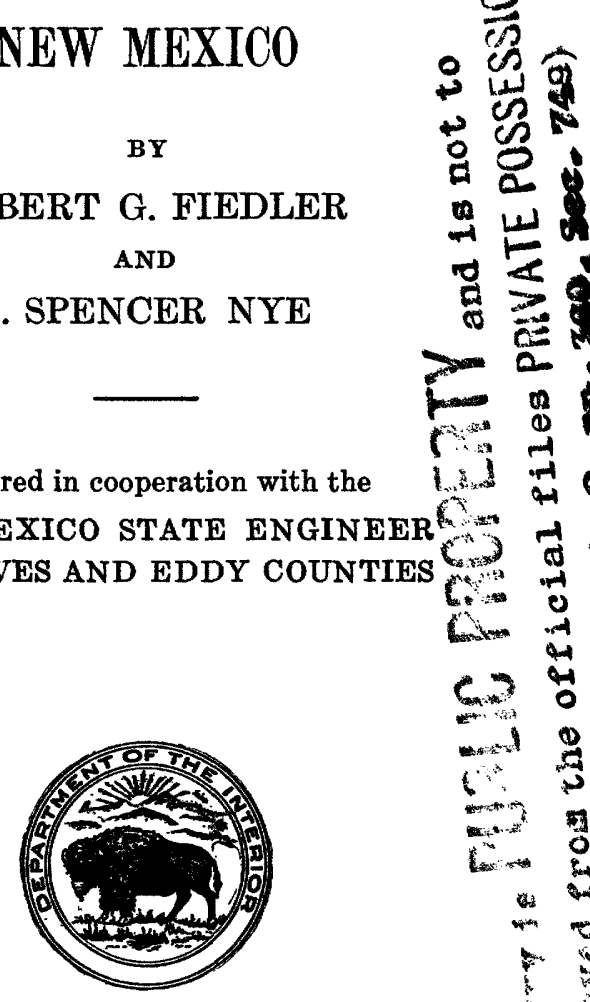

¿
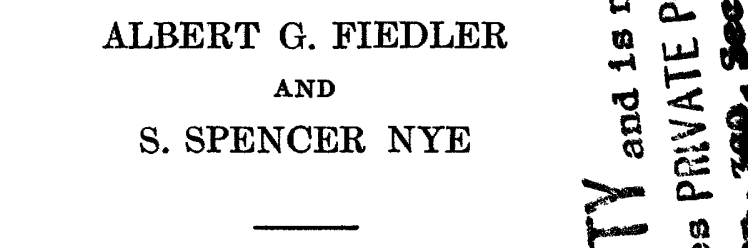

(1)

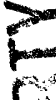

2

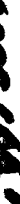

$+1$

(x)

$\left(x^{2}\right.$

$C$

anto

C. 45

$-1$

12

1.

$\therefore$

$-1$

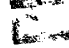

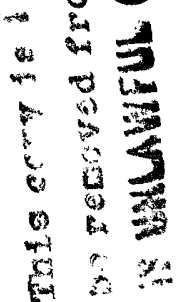

UNITED STATES

GOVERNMENT PRINTING OFEICE

WASHINGTON : 1933

For sale by the Superintendent of Documents, Washington, D. C. . - Price $\$ 1.00$ (paper covers) 



\section{CONTENTS}

\section{LIBRARY COPY}

Page

Abstract..... 1

Introduction, by A. G. Fiedler..... 1

Location and general features of the area.

Previous investigations.

History and scope of the present investigation 3

Acknowledgments.

Climate, by A. G. Fiedler... 6

Physiography, by S. S. Nye._. 7

General features.

Drainage... 7

Streams.

Lakes........ 8

Aluvial basin

Definition and character....... 10

Terraces.............. 10

Lakewood terrace.... 10

Orchard Park terrace

Blackdom terrace.

Gravel-capped mesas.

Limestone uplands _...... 13

Definition and character.......... 13

Diamond A plain

Sacramento plain.

Mountains_.

Llano Estacado _.

Area between the Pecos River and the Llano Estacado _._._._. 16

Dissected areas of soft rocks west of the Pecos River.

Seven Rivers cuesta.

Valleys and stream channels $\ldots \ldots \ldots$

Geology, by S. S. Nye 18

Previous geologic work

Stratigraphy

General relations... 22

Quaternary system 25

General relations

Character and distribution..... 25

Thickness....... 26

Origin

Stages of deposition

Determination of age

Recent series....... 28

Alluvium

Travertine deposits. 29

Pleistocene series_... 30

Undifferentiated alluvial deposits_._._.

Deposits of the Orchard Park terrace..... 31

Deposits of the Blackdom terrace........ 32

Quartzose conglomerate...... 35 
Geology, by S. S. Nye-Continued.

Stratigraphy-Continued.

Quaternary system-Continued.

Pleistocene series-Continued.

Page

Limestone conglomerate

High-level gravel deposits

Caliche

Tertiary system.

Cretaceous system.

Triassic system

Carboniferous system

Permian series

Formations included

Nomenclature adopted in this report

Pecos formation

Carlsbad limestone tongue of the Capitan limestone...

Picacho limestone

Nogal formation . . .

Igneous'rocks

Structure

Structural features resulting from regional earth movements...Faults.

Border Hills fault

Sixmile Hill fault

Y-O fault

Other faults

Folds

Black Hills anticline

Manning dome

Dunken dome

Local structural features resulting from solution.

Structure of the original area of artesian flow

Sources of the data.

Erosion and solution during Permian time

Possible changes in conditions of deposition.

Regional earth movements.

Geologic history, by S. S. Nye.

Proterozoic era

Paleozoic era

Mesozoic era

Cenozoic era

Tertiary period

Quaternary period.

History of the Pecos River and changes in the channels of its major tributaries in the artesian basin . . . . . .

Pecos River.

Rio Hondo . . . .

Rio Felix and Cottonwood Creek

Rio Penasco

Origin of the Diamond A plain

Origin of the alluvial basin . . .

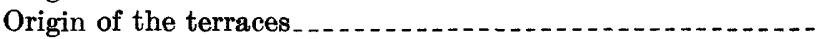

Age of the quartzose conglomerate.......

Relation of physiographic history to glacial stages. 
Page

Ground-water conditions, by S. S. Nye._. 113

General relations._._. 113

Occurrence of the ground water in the artesian basin 113

Source of the ground water. 115

The water table._. 116

Movement and disposal of the ground water. 117

Artesian conditions. 118

Water in the valley fill

Occurrence.......... 120

Sources

Surface drainage $\ldots \ldots \ldots 121$

Local precipitation _... 123

Artesian water. 123

Leaky artesian wells._._. 123

Irrigation losses

Summary _._. 124

Water table. 124

Movement and disposal.

Wells

Future development._._. 128

Water in the Pecos formation

In the outcrop areas._. 129

General ground-water conditions_._. 129

Wells._._. 130

Underlying the alluvial basin

Ground-water conditions west of the artesian area...... 130

Artesian conditions. 130

Artesian aquifers and confining beds_... 130

Head of the artesian water. 131

Movement and disposal of the artesian water._._._. 132

Utilization of the artesian water. 133

Source._. 133

Water in the Picacho limestone. 134

Occurrence............ 134

West of the artesian area

Main water table..... 136

Perched ground water

Wells_._. 138

In the artesian area. 140

General artesian conditions...... 140

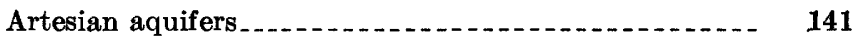

Confining beds... 143

Upper confining beds._. 143

Lower confining beds._._. 144

Differences in the head of the artesian water....... 145

Areas of large and small yield._. 145

Wells._._._._. 146

Local artesian conditions._._. 147

Source and quantity of the water. 148

Movement of the water. 152

Disposal of the water... 154

Limits of the artesian basin 
Ground-water conditions, by S. S. Nye-Continued. Page

Water in the Nogal formation .

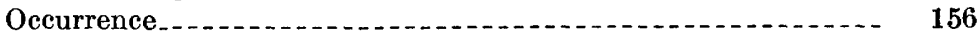

Source

Movement and disposal

Perched-water conditions . . . . .

Ground water.

Springs_...

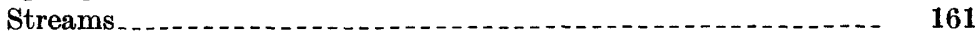

Chemical character of the ground water................ 161

Source and significance of the mineral constituents, by M. D. Foster

Water from the valley fill ...

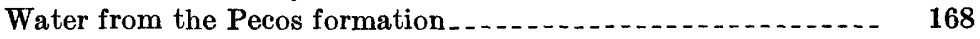

Water from the Picacho limestone.................... 169

Water from the Nogal formation........ 173

Utility of the ground water.......... 176

Origin of the solution openings in the Permian limestone of the Ros-

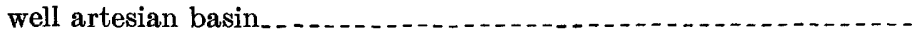

Requisite conditions for the formation of solution openings in

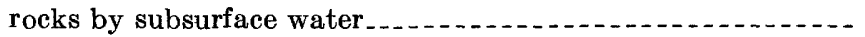

Solvents in subsurface water

Circulation of subsurface water.

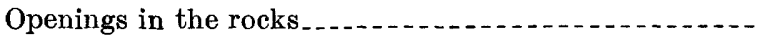

Outlets for the escape of the water in the rocks.......

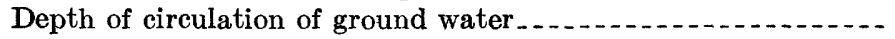

Hypotheses of the origin of the solution openings . . . . . . .

Evidence of artesian circulation and of solution during the

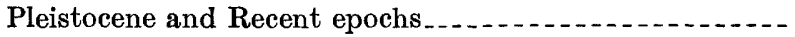

Springs - . -

Recharge of water in the Pecos formation and the valley fill . . . . . . . . .

Cavernous limestone in the Pecos formation..........

Absence of highly saline water in the Picacho lime-

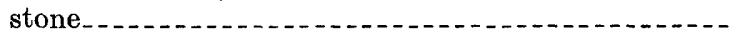

Relation of areas of great permeability to major drainage lines..........................................

Evidence of ground-water circulation and of solution under water-table conditions during Permian time............

Unconformity between the Picacho limestone and the

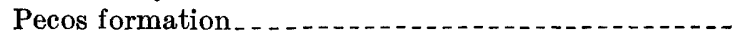

Cavernous zones in the limestone east of the Pecos

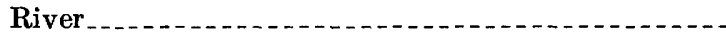

Higher permeability of the lower cavernous zones and scarcity of cavernous zones in the lower half of the

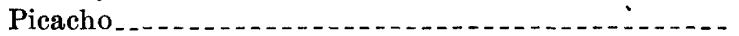

High permeability of the cavernous zones in all parts of the artesian area....

Conclusions .......

Early irrigation development_...

Development of the artesian water................... 190

Development of the water. in the valley fill ............. 194 
Ground-water development, by A. G. Fiedler-Continued. Page

Head of the artesian water.

Original head ........... 194

Head in 1926, 1927, and 1928_...... 196

Decline in head............. 199

Decline in the artesian area.......... 199

Decline in the intake area

Head of the artesian aquifers... 205

Fluctuations in head.

Interference of wells

Fluctuations caused by rainfall $\ldots \ldots \ldots \ldots$

Seasonal fluctuations . .

Atmospheric pressure

Area of artesian flow

Specific capacity of wells..._._.

Quantity of water discharged by artesian wells_.............. 224

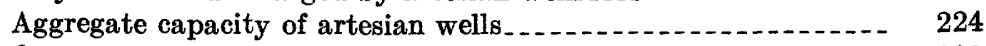

Quantity used for irrigation. 228

Surface waste of artesian water. 229

Discharge at the surface $\ldots \ldots \ldots$

Underground waste....... 231

Importance of the problem. 231

Methods of determining underground leakage $\ldots . . . . . . . . . \quad 232$

Test of specimen well......... 234

Quantity of underground waste.... 235

Conclusions regarding underground waste....... 236

Recharge._._.

General conditions............... 237

Intake area

Seepage losses on tributary streams

Compression of artesian aquifers

Relation of precipitation to recharge

Quantity of recharge...

Irrigation . .

Requirements of artesian water for irrigation

Value of crops produced from irrigated area..... 255

Extent of irrigated area and relation to artesian head........ 259

Irrigation along Cottonwood Creek

Felix shallow ground-water district. 260

Construction and repair of wells, by A. G. Fiedler. 263

Construction of artesian wells........ 263

Methods of drilling ........... 263

Hydraulic rotary method..... 263

Cable-tool percussion method........ 265

Cost of drilling

Causes of leakage. 268

Prevention of corrosion. 272

Repair of artesian wells. 274

Outline of methods..... 274

Inside recasing

Outside recasing .

Replacement of old casing 
Construction and repair of wells, by A. G. Fiedler-Continued. Page

Sealing of artesian wells.............. 277

Outline of methods

Water-well method used in Hawaii....................... 278

Oil-well methods.

Asphalt sealing . .

Construction of wells in the valley fill . . . . . .

Stovepipe method............. 281

Well-screen method...

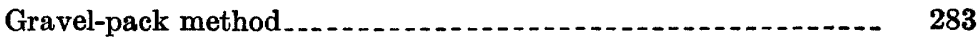

Legal provisions governing the use of the ground water, by A. G. Fiedler_ 284

Future policy for the conservation of the artesian water, by A. G. Fiedler_ 287

Well records......-_. 291

Index........... 


\section{ILLUSTRATIONS}

Plate 1. Map of New Mexico showing areas covered by this report and other publications of the United States Geological Survey --

2. Map of southeastern New Mexico showing outline of the Roswell artesian basin.

Page

3. Reconnaissance geologic map of the eastern part of the Roswell artesian basin......... In pocket.

4. Reconnaissance map of the Roswell alluvial basin . ...... In pocket.

5. $A, \mathrm{U}$-shaped valley cut in the Blackdom terrace by the Rio Felix; $B$, Capitan Mountains from a point north of the Rio Hondo

6. $A$, View eastward down the valley of the Rio Penasco in T. 16 S., R. 15 E.; $B$, Quartzose conglomerate exposed along north bank of Rio Felix in SW. 1/4 sec. 18, T. 14 S., R. 25 E. ....-

7. $A$, Sink hole developed in gypsiferous strata of the Pecos formation in T. 19 S., R. 23 E.; $B$, Valley of ephemeral stream that has been captured by sink hole shown in $A$.

8. $A$, Masses of travertine along Cottonwood Creek in T. $16 \mathrm{~S}$., R. 24 E.; $B$, Solution-faceted pebbles cemented by caliche.-

9. $A$, Impure limestone in Pecos formation exposed near southeast corner of T. 15 S., R. 22 E.; $B$, Gypsum and red shale of Pecos formation resting upon Picacho limestone in the W. $1 / 2$ sec. 19, T. 20 S., R. 23 E.; $C$, Seven Rivers cuesta, sec. 23, T. 21 S., R. 24 E.

10. $A$, Outcrop of Pecos formation near center of T. 19 S., R. 23 E.; $B$, Outcrop of Pecos formation in the northern part of T. 21 S., R. $21 \mathrm{E}$

11. A, Polished face of specimen of "worm-eaten" limestone from upper part of Picacho limestone; $B$, Ground face of specimen of cavernous limestone from upper part of Picacho lime-

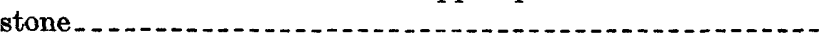

12. Photomicrograph of thin section of specimen shown in Plate $11, B \ldots$

13. $A$, Specimen of "worm-eaten" limestone from lower part of Pecos formation in T. 19 S., R. 23 E.; $B$, Sawed face of specimen shown in, $A$

14. Photomicrograph of thin section of specimen shown in Plate 13, A. . .

15. $A$, Weathered face of cavernous limestone from upper part of Picacho limestone; $B$, Polished face of specimen of "wormeaten" limestone from upper part of Picacho limestone...-

16. Ground face of specimen shown in Plate 15,

17. Details of thin sections of specimen shown in Plate 15, $A . .$.

18. $A$, Border Hills from point south of the Rio Hondo; $B$, Border Hills fault; $C$, Limestone in the lower part of the Picacho limestone exposed in T. 11 S., R. 20 E... 
Plate 19. A, Weathered face of specimen of gypsiferous limestone from upper part of Picacho limestone in southeastern part of $\mathrm{T}$. 18 S., R. 21 E.; $B$, Ground face of specimen shown in $A_{---}$

20. $A$, Polished face of part of specimen shown in Plate 19, $A ; B$, General view of thin section of specimen shown in Plate $19, A$

21. Detail of Plate 20, $B$

22. Photomicrograph of another thin section of specimen shown in Plate 19, $A$.

23. $A$, Cellular and brecciated limestone near top of Picacho limestone in sec. 8, T. 14 S., R. 23 E.; $B$, Limestone breccia near top of Picacho limestone in sec. 25, T. 14 S., R. 22 E.....-

24. $A, \mathrm{Y}-\mathrm{O}$ fault; $B$, Border Hills from a point along the RoswellAlamogordo highway

25. Contour map of the upper surface of the Picacho limestone and sections across the Roswell artesian area............ In pocket.

26. Map showing depth to the water table in the Roswell artesian

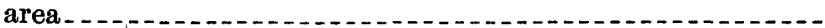

27. Graphic representation of analyses of water from the Picacho limestone within the Roswell artesian area

28. Number of artesian wells drilled, fluctuations of artesian head, and average annual precipitation in the Roswell artesian basin, 1895 to 1927

29. A, Well of Oasis Cotton Co., in the NW. $1 / 4$ sec. 22, T. 11 S., R. $25 \mathrm{E}$; $B$, Well of H. D. King, in the SW. 1/4 sec. 14, T. 11 S., R. $25 \mathrm{E}$

30. Map of the area of artesian flow of the Roswell artesian basin, showing altitude to which water would rise in tightly cased wells in the winter of $1926-27$

31. Hydraulic gradient along sections across the Roswell area of artesian flow.

32. Fluctuations in artesian head in the Berrendo, Orchard Park, and Artesia observation wells caused by rainfall and reduction in irrigation draft.

33. Head of typical artesian wells, 1904-1926

34. Mean monthly and mean annual artesian head in representative wells, August, 1925, to December, 1928

35. $A$, Automatic water-stage recorder installed over nonflowing artesian well; $B$, South Springs, head of the South Spring River.

36. Daily precipitation at Roswell and Artesia and fluctuations of artesian head in the Berrendo, Orchard Park, and Artesia observation wells, July 1, 1925, to December 31, 1928_....-

37. Artesian pressure in typical wells, 1926 ...................

38. Relation of fluctuations in artesian head to fluctuations in atmospheric pressure

39. Map of the area of artesian flow of the Roswell artesian basin, showing original area of flow, areas of flow in 1916 and 1926, and location of artesian wells. In pocket.

40. Map of eity of Roswell showing original area of artesian flow, areas of flow in 1916 and 1926, and location of artesian wells In pocket. 
Figure 18. Driller's log of well in SW. $1 / 4 \mathrm{NW} .1 / 4 \mathrm{NW} .1 / 4$ sec. 16, T. $17 \mathrm{~S}$, R. $26 \mathrm{E}$

19. Difference in conditions in wells in limestone not far apart....

20. Diagrammatic section of the valley of the Rio Hondo between the Diamond $A$ headquarters ranch and Border ranch, in the eastern part of T. $11 \mathrm{~S}$., R. $20 \mathrm{E}$.

21. Average depth in each township of artesian wells drawing from aquifers in the Picacho limestone ......................

22. Graphic representation of analyses of water from the valley fill.

23. Graphic representation of analyses of water from the Pecos

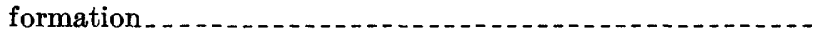

24. Graphic representation of analyses of water from the Picacho limestone in and near the outcrop area ........

25. Graphic representation of analyses of water from the deep

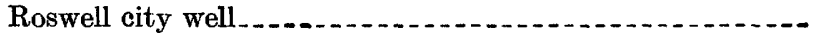

26. Lines of flow of ground water.......

27. Map showing location of early irrigation ditches in the vicinity of Roswell

28. Fluctuations in artesian head in well near Artesia caused by pumping during the period March 7-16, 1926...........

29. Effect of pumping on the piezometric surface and interference of wells . . . . . . . . . . .

30. Hypothetical section showing decrease in width of area of artesian flow with decline in artesian head...........

31. Specific capacity of seven artesian wells

32. Number of flowing and pumped wells used for irrigation, 1900 to 1925 , and total and average capacity of these wells.....

33. Relation of precipitation to altitude in the Roswell artesian

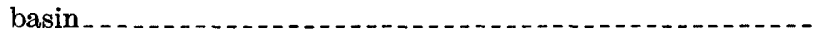

34. Effect of decrease in draft and increase of head in reservoir upon the hydraulic gradient. . . . . . . . . . . . . . . .

35. Map of Felix shallow-water district showing contours on the water table and area irrigated by pumping from shallow wells

36. Section along line $A-A^{\prime}$, Figure 35

37. Map of Felix shallow-water district showing depth of water table below the surface 
Plate 41. Map showing boundaries of areas having wells of large yield and areas having wells of small yield..................

42. $A, \mathrm{Au}$ deep-well current meter; $B$, Casing removed from defective well . . . . . . . .

43. $A$, Equipment set up for leakage examination; $B$, Automobile truck on which leakage equipment is mounted...........

44. Mean monthly precipitation, mean monthly deviation from normal precipitation, and mean annual precipitation on the Roswell artesian area.................................

45. Map of Roswell artesian area showing irrigated areas and height above or depth below land surface to which artesian water would rise in tightly cased wells ............. In pocket.

46. $A$, Pumping well in the NW. $1 / 4$ NW. $1 / 4$ sec. 1, T. 14 S., R. $25 \mathrm{E}$., in the Felix shallow ground-water district; $B$, Drilling with hydraulic rotary process . . . . .

Figdre 1. Generalized diagrammatic section showing relations of the physiographic features in the Roswell artesian basin and

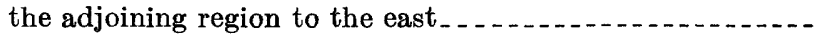

2. North-south section of the valley of the Rio Felix south of Roswell, near the west line of sec. 13, T. 14 S., R. 24 E...-

3. Generalized section across the valley of the Rio Hondo at Diamond A headquarters ranch, near the east line of sec.

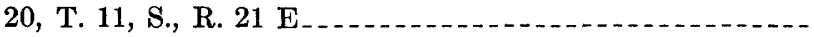

4. Generalized columnar section of Paleozoic formations exposed along west front of Sacramento Mountains. ............

5. Sections showing relations of deposits of the Orchard Park and Lakewood terraces and the Permian rocks about 18 miles north of Roswell

6. Partial section across the valley of El Macho Creek about half a mile west of the Roswell-Vaughn highway .........

7. Exposure of deformed and eroded quartzose conglomerate in north bank of Rio Felix in SW. 1/4 sec. 18, T. 14 S., R. 25 E_

8. Diagrammatic section of Permian rocks in the eastern part of the Roswell artesian basin, showing nomenclature adopted in this report.

260

9. Generalized columnar section of an exposure of the upper part of the Picacho limestone in the southeastern part of T. 18 S., R. $21 \mathrm{E}$

10. Relations of gypsum and limestone in upper part of Picacho limestone in outcrop about 9 miles south of Hope.........

11. Diagrammatic sections across the Border Hills in sec. $31, \mathrm{~T}$. 11 S., R. $20 \mathrm{E}$

12. Diagrammatic section of the upper valley of Cottonwood Creek in northeastern part of T. 16 S., R. 21 E.

13. Three perched zones of saturation above the main zone of

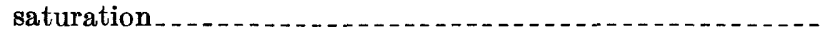

14. Types of interstices characterizing aquifers in the Roswell

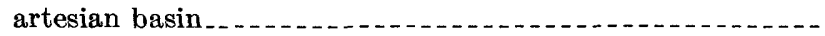

15. Ideal section illustrating the chief requisite conditions for artesian wells

16. Diagrammatic section illustrating artesian conditions commonly found along the Atlantic Coastal Plain .......... -

17. Erratic character and distribution of aquifers in the valley fill. 


\title{
GEOLOGY AND GROUND-WATER RESOURCES OF THE ROSWELL ARTESIAN BASIN, NEW MEXIC0
}

\author{
By Albert G. Fiedler and S. Spencer Nye
}

\section{ABSTRACT}

The Roswell artesian basin is in the Pecos Valley in southeastern New Mexico. The investigation, which covered a period of three years, 1925 to 1928, was made for the purpose of determining the available supply of artesian and other ground water within the area. The geologic formations of the region are of the Carboniferous (Permian series) and Quaternary systems. The Permian rocks consist of three units-an upper unit composed chiefly of clay, shale, and sand; a middle unit composed chiefly of limestone; and a lower unit composed chiefly of red beds, gypsum, and anhydrite. Most of the artesian water is obtained from the limestone beds of the middle unit, which has been designated the Picacho limestone.

Originally the area of artesian flow comprised 663 square miles; but largely on account of heavy draft upon the artesian reservoir, it decreased to 499 square miles in 1916 and to 425 square miles in 1925. The area irrigated by water derived directly or indirectly from the reservoir amounts to about 60,000 acres. The annual quantity of water derived from wells is about 200,000 acre-feet, and the total discharge at the surface from all sources is about 250,000 acre-feet. Recharge to the reservoir is derived from precipitation that falls on a catchment area of 4,000 square miles west of the artesian area.

In 1927 a law was passed by the State of New Mexico declaring underground waters to be public waters and subject to appropriation. This law was declared invalid because of a technicality, and in 1931 a new law was enacted, which furnishes a definite basis for the future regulation of ground waters in the area.

The investigation leads to the conclusion that no new land should be placed under irrigation with artesian water, but that the development of shallow ground water should be encouraged. The present decline of the artesian head is slight in comparison with that in earlier years, and there is ample evidence to show that the reservoir annually receives large quantities of recharge and that with proper conservation it will never be completely exhausted.

\section{INTRODUCTION}

By A. G. FIEDLer

This paper presents the results of studies made by the United States Geological Survey, in financial cooperation with the Engineering Department of the State of $\mathrm{New}$ Mexico and with Chaves and Eddy Counties, for the purpose of determining the available supply of artesian and other ground water in the Roswell artesian basin. 
The Roswell artesian basin is notable for the fact that about 75 per cent of its water supply for irrigation is directly of artesian origin and much of the rest is derived more or less indirectly from the same source. There are several known areas of artesian flow that are much larger and contain a greater number of wells, but in the Roswell area more artesian water is recovered than in any other artesian area of like size in the United States and probably in the world.

\section{IOCATION AND GENERAI FEATURES OF THE AREA}

The area lies in the Pecos Valley, in southeastern New Mexico, and receives its artesian-water supply from rain and snow that fall on the broad eastern slope of the Sacramento Mountains and on the higher parts of the west side of the Pecos Valley. (See pl. 1.) Irrigation farming has been practiced here since about 1880. The water for irrigation was at first obtained from the large springs near Roswell and diversions from the tributaries of the Pecos River that cross the area, and it was not until about 1905 that irrigation with water obtained from artesian wells began to assume proportions of vital importance to the area. The large development of artesian water brought about numerous problems related to the proper use, conservation, and protection of this valued resource, and it was for the purpose of studying these problems that this investigation was undertaken.

The area of artesian flow of the Roswell basin is approximately 7 miles wide by 60 miles long and comprises about 425 square miles; it lies chiefly on the west side of the Pecos River in Chaves and Eddy Counties and extends from a point 7 miles north of Roswell about to the mouth of the Seven Rivers. The eastern limit of the area is marked approximately by the escarpment that parallels the Pecos River on its east side. The northern boundary of the area lies at an altitude of about 3,600 feet above sea level and the southern boundary at about 3,200 feet above sea level.

The Roswell artesian basin forms one of the most productive agricultural areas in the State. The area of artesian flow and adjacent pumping area in 1925 contained about 17,000 inhabitants, of whom 9,000 lived in Roswell, the county seat of Chaves County and the second largest city in the State. The region is served by a line of the Atchison, Topeka \& Santa Fe Railway that is connected with the Belen cut-off of the Santa Fe system at Clovis, N. Mex., and with the Texas \& Pacific Railway at Pecos, Tex. The principal automobile road between Amarillo and El Paso, Tex., passes through Roswell. A main north-south highway follows the valley of the Pecos River south to Carlsbad, N. Mex., and connects with the Bankhead Highway of western Texas at Pecos. 
The soil is chiefly loam and clay loam and when properly watered is very productive. The water supply for irrigation is derived from artesian wells and, in small part, from the streams that rise in the Sacramento Mountains and flow eastward into the Pecos. The chief streams are the Rio Hondo, the Rio Felix, the Rio Penasco, and the Seven Rivers. In the high levels, near their sources, those streams are perennial, but farther down the slope they become intermittent, and in the Pecos Valley they flow only after periods of heavy precipitation. (See pl. 2.)

\section{PREVIOUS INVESTIGATIONS}

During 1904 and 1905 C. A. Fisher, ${ }^{1}$ of the United States Geological Survey, made a preliminary investigation of the broad general relations of the region and defined the probable extent of the area of artesian flow. In 1905 there were 485 artesian wells in the area. Although at that time the water supply appeared to many people to be inexhaustible, Fisher pointed out the consequences that were likely to result from the misuse and waste of artesian water. His prophecy made even at that early date has been largely fulfilled, and numerous problems have arisen for solution.

In 1916 O. E. Meinzer made a reconnaissance survey of the area and remapped the area of artesian flow, which had become considerably smaller since the time of Fisher's investigation. On the west side of the basin much land had been abandoned because of the increased pumping lift, and on the east side much land had become water-logged and later required the installation of drainage systems at great expense. It was evident that an intensive investigation was necessary so that the proper plans might be formulated to safeguard the artesian-water resources. Mr. Meinzer in 1916 developed plans for such an investigation; but because of the World War and for other reasons, it could not be undertaken until July, 1925.

\section{HISTORY AND SCOPE OF THE PRESENT INVESTIGATION}

The earlier studies of conditions in the Roswell artesian basin led to the enactment of laws in 1905, 1909, and 1912 the purpose of which was to regulate the use of water from artesian wells and to prevent waste. (See also pp. 285-286.) Each succeeding law contained new regulations designed to meet the changing conditions. Though these laws were never rigidly enforced, considerable benefit has resulted from even partial enforcement. The area has, however, developed largely without adequate basic knowledge concerning methods of development that would insure the fullest utilization of

\footnotetext{
1 Fisher, C. A., Preliminary report on the geology and underground waters of the Roswell artesian basin; U. S. Geol. Survey Water-Supply Paper 158, 1906.
} 
its water resources. The demand for such information has increased during the last few years since it became apparent that the decline in artesian head was still continuing. As this condition was threatening the prosperity of the valley, a number of public-spirited citizens, through the Roswell Chamber of Commerce, took steps in 1924 and 1925 to obtain full information upon which to base a constructive program for the protection of the artesian water supply. Through their efforts the State legislature ${ }^{2}$ in 1925 provided an appropriation of $\$ 5,000$ and authorized the State engineer to enter into an agreement with the United States Geological Survey for the purpose of making a comprehensive investigation. Such an agreement was made in the spring of 1925, and the Geological Survey also provided $\$ 5,000$ out of the regular Federal appropriation for the investigation of the water resources of the United States. In 1926 the county commissioners of Chaves County appropriated $\$ 3,000$ out of the county artesian-well fund to continue the investigation, and later a similar appropriation of $\$ 1,500$ was made by the commissioners of Eddy County, it being agreed that amounts to match the county appropriations would be provided by the Federal Government. The 1927 session of the State legislature ${ }^{3}$ appropriated $\$ 5,000$ to complete the investigation, and the State engineer transferred $\$ 4,500$ of this fund to the Geological Survey.

The investigation was conducted under the supervision of Oscar E. Meinzer, geologist in charge of the division of ground water, United States Geological Survey. The hydraulic engineering and general study of the problem of conservation were assigned to Albert G. Fiedler and the geologic work to B. Coleman Renick. Mr. Renick resigned during the course of the investigation and was succeeded by S. Spencer Nye.

The investigation was begun July 6, 1925, and from that date to June 8, 1928, an office was maintained at Roswell by Mr. Fiedler and his assistants. Mr. Meinzer spent some time in the area in July and August, 1925, August, 1926, and September, 1927. Further field work was done by Mr. Nye in the summer of 1929 .

As a result of work done during the first year of the investigation a preliminary report ${ }^{4}$ was published. Many additional data have been gathered since the publication of this preliminary report, and some of the figures contained therein have been revised in view of the more complete data and longer records that are now available.

\footnotetext{
2 New Mexico State Legislature, 7th sess., Laws, ch. 127, approved March 19, 1925.

3 New Mexico State Legislature, 8th sess., Laws, ch. 161, approved March 15, 1927.

* Fiedler. A. G., Report on investigations of the Roswell artesian basin, Chaves and Eddy Counties, N. Mex., during the year ending June 30, 1926 : New Mexico State Engineer Seventh Bienn. Rept., pp. 21-60, 1926.
} 


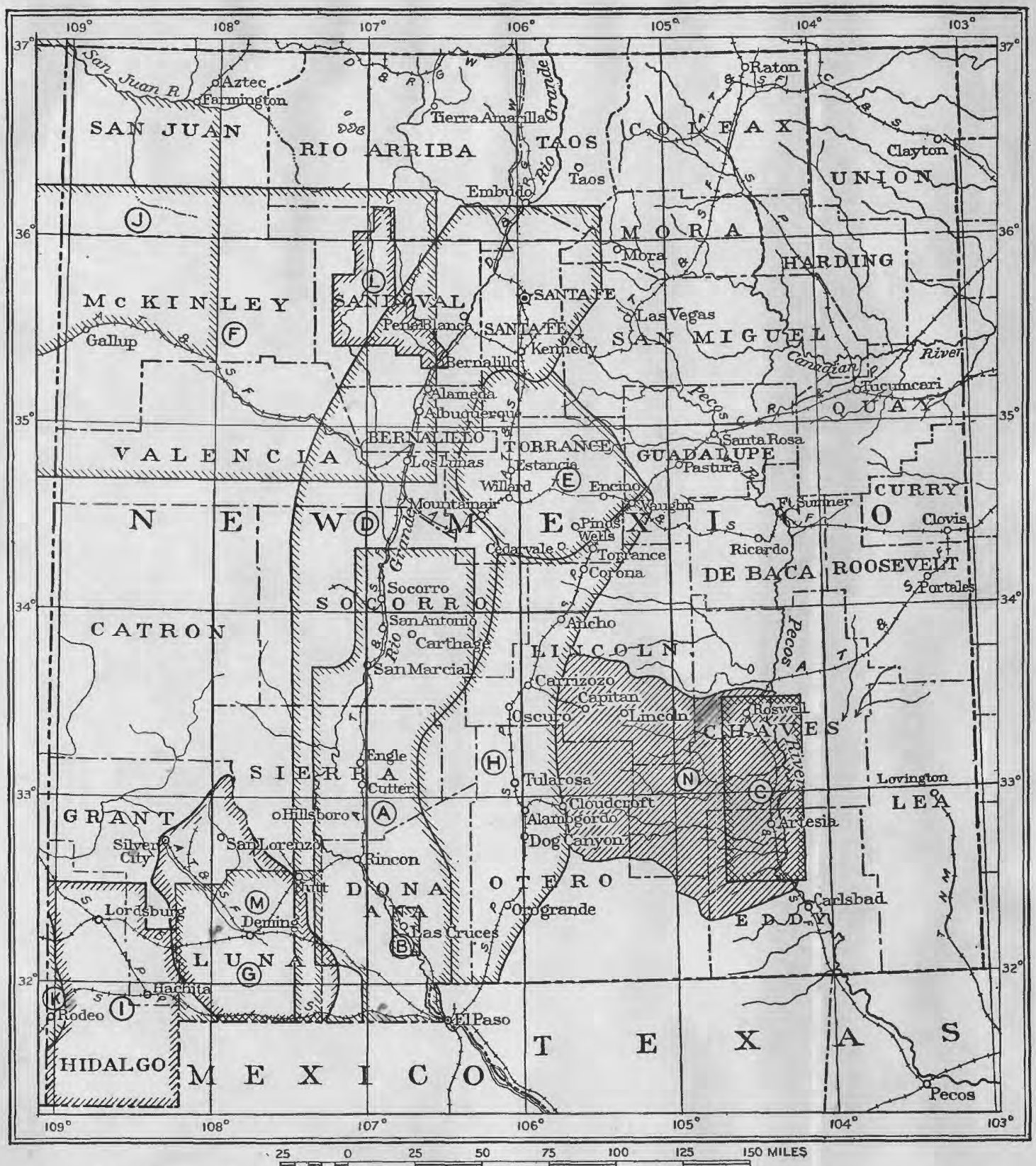

MAP OF NEW MEXICO SHOWING AREAS COVERED BY THIS REPORT (SHADED AREA) AND OTHER PUBLICATIONS OF THE UNITED STATES GEOLOGICAL SURVEY

$A$, Water-Supply Paper 123; B, Water-Supply Paper 141; C, Water-Supply Paper 158; D, Water-Supply Paper 188; $E$, Water-Supply Paper 275; $F$, Bulletin 435; $G$, Water-Supply Paper 345-C and Bulletin 618; $H$, Water-Supply Paper 343; $I$, Water-Supply Paper 422; $J$, Water-Supply Paper 380; K, Water-Supply Paper 425-A; L, Water-Supply Paper 620; M, Water-Supply Paper.637-B; $N$, Water-Supply Paper 639. 


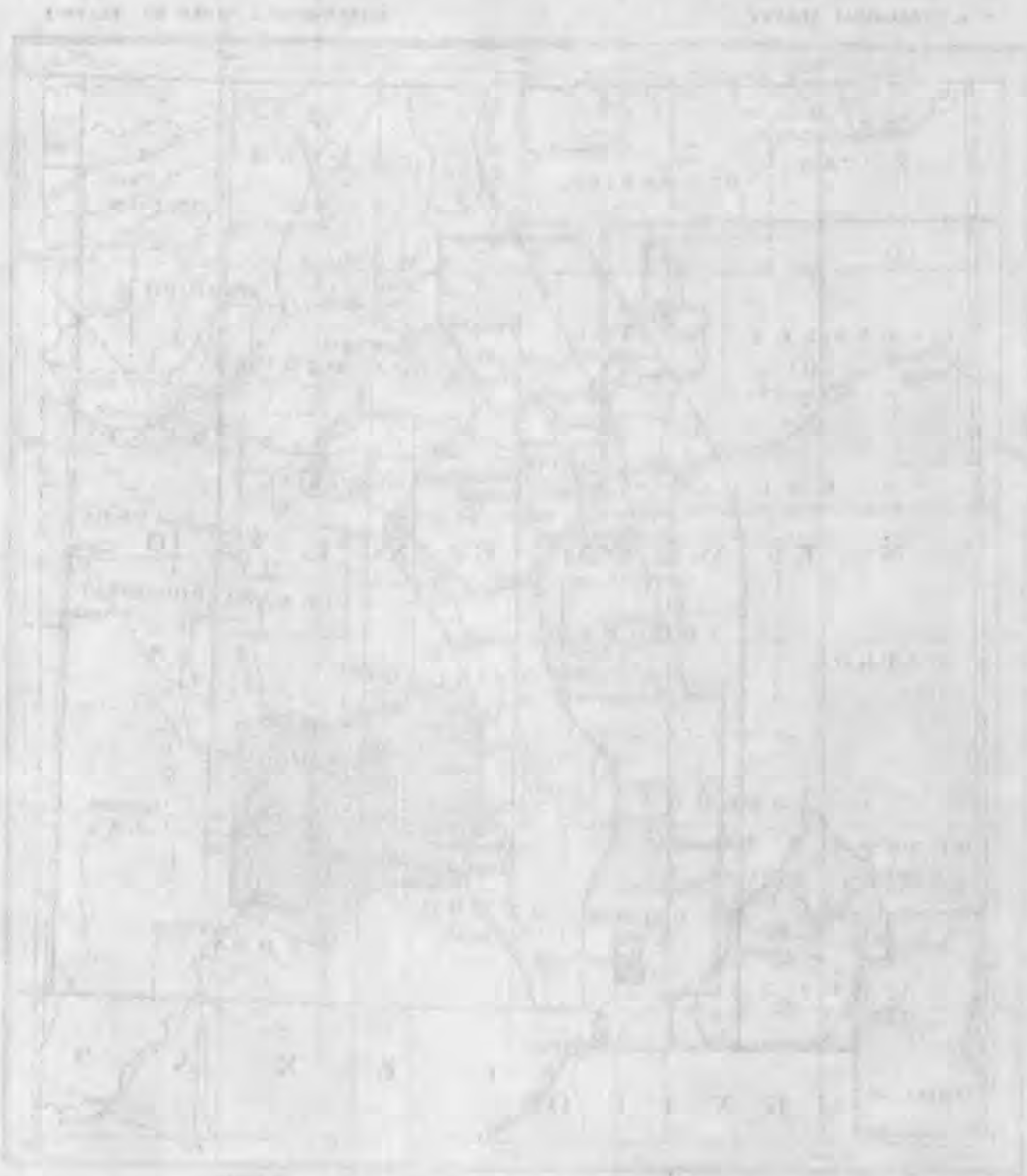

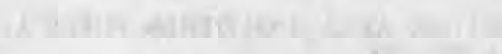

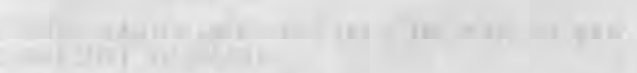

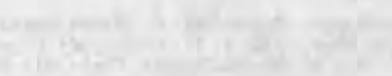


In order that some of the results of the geologic studies might be available to the public, a press notice ${ }^{5}$ was issued summarizing the artesian conditions and general geologic features of the area. In 1928 another report ${ }^{6}$ was published giving an abstract of the findings of the entire investigation and recommendations for a policy of conservation. In 1930 further information which the writers wished to bring to the attention of the residents of the artesian area at that time was published.?

\section{ACKNOWLEDGMENTS}

Grateful acknowledgment is made to O. E. Meinzer for constructive suggestions and criticism at all stages of the investigation and for the critical review of this report; to George $M$. Neel and Herbert W. Yeo, State engineers of New Mexico, during whose terms of office the investigation was conducted, for their helpful cooperation; to D. G. Thompson, of the United States Geological Survey, who reviewed portions of the manuscript; to the Roswell Chamber of Commerce, which furnished data on crop acreage and production and assisted greatly in obtaining the cooperation of the residents of the area. Especial acknowledgments are due to Austin D. Crile and Claude Simpson, president and secretary, respectively, of the Roswell Chamber of Commerce, for their hearty cooperation. Through the cooperation of the county commissioners of Chaves and Eddy Counties the assistance of the county well supervisors was made available. Acknowledgments are due to T. M. McClure and J. L. Saunders, well supervisors in Chaves County, and C. V. Brainard, well supervisor in Eddy County, who furnished the results of inspections of wells, assisted in making leakage measurements, and compiled data concerning the early history of the artesian development. W. B. Lang, of the United States Geological Survey; Paul McCune; Morgan Davis; Harold S. Cave; Frank S. Prout; Russell. Lloyd; Kenneth $\mathbf{H}$. Crandall; and other petroleum geologists furnished well logs and much general information and rendered valuable assistance through many discussions of the geology of the region and in other ways. Kirk Bryan, of the United States Geological Survey, spent several days in the field with Mr. Nye, who is indebted to him for helpful discussions of the physiography of the area. Acknowledgments are also due to Cleve Hallenbeck, meteorologist.

\footnotetext{
The Roswell artesian basin, N. Mex.: U. S. Dept. Interior Press Memorandum 24973, July 14, 1928.

Fiedler, A. G., and Nye, S. S., Ground water investigation of the Roswell artesian. basin, N. Mex. : New Mexico State Flngineer Eighth Blenn. Rept., pp. 81-107, 1928.

Tfiedler, A. G., and Nye, S. S., Recommendations for a more efficient utilization of thewater resources of the Roswell artesian basin, N. Mex. : New Mexico State Engineer Ninth Blenn. Rept., pp. 387-421, 1930.
}

$135252-33-2$ 
in charge of the Roswell office of the United States Weather Bureau, who made daily measurements of the water level in his well on the Berrendo tract during the entire period of the investigation and supplied valuable climatic records; to W. A. Wilson, county engineer of Chaves County, who furnished much helpful information; to M. H. Hunter, civil engineer in Roswell, who afforded free access to files and maps compiled by his office; to L. E. Foster and J. R. Yates, of the United States Bureau of Reclamation, who furnished records of stream flow and data on the quantities of water used in the irrigation of different crops; to Samuel P. Butler, of the Diamond A Cattle Co., who spent several days in the field with Mr. Nye and furnished information regarding wells belonging to the company; to water-well drillers who furnished well logs and general information; and to the many residents throughout the area who were helpful in many ways.

\section{CLIMATE}

By A. G. FIEDLher

The climate of the artesian area adjacent to the Pecos River is semiarid, and crop production is not practicable without irrigation. The winter and spring are normally dry. The months of greatest rainfall are generally July, August, and September, and during these months most of the precipitation occurs in the form of afternoon and evening showers, which at times are torrential in character. The air is normally dry, and though the midsummer days are usually warm, yet on account of the relatively low humidity the summer temperatures are quite bearable. During most of the year the average wind movement rarely exceeds that of a moderate breeze, but during the spring, which is the windiest season, the average daytime movement is classed as a strong wind.

In the higher western part of the artesian basin the climatic conditions are somewhat different. The mean annual precipitation increases more or less uniformly from about 13 inches for the valley portion of the basin, which is at an average altitude of 3,400 feet, to more than 23 inches for Cloudcroft, which is near the crest of the mountains at an altitude of 8,650 feet. The snowfall is relatively light in the lower part of the area, but in the higher mountainous part it is generally fairly heavy. The mean annual temperature is lower at the higher levels, and the average length of the growing season is correspondingly shorter. In view of the greater precipitation in the highlands small tracts in the more fertile valleys of the highland area are successfully cultivated without irrigation or with the addition of only a small amount of water from the mountain streams when such water is available. 
The chief climatic data for the area are summarized in the following table:

Summary of climatio data for seven stations in or near the Roswell artesian basin, New Mexioo

[From U. S. Weather Bureau]

\begin{tabular}{|c|c|c|c|c|c|c|c|c|}
\hline & \multirow{2}{*}{$\begin{array}{c}\text { Altitude } \\
\text { above sea } \\
\text { level } \\
\text { (feet) }\end{array}$} & \multicolumn{2}{|c|}{ Precipitation } & \multicolumn{2}{|c|}{ Temperature } & \multirow{2}{*}{$\begin{array}{l}\text { A verage } \\
\text { length of } \\
\text { growing } \\
\text { season } \\
\text { (days) }\end{array}$} & \multicolumn{2}{|c|}{ Snowfall } \\
\hline & & $\begin{array}{l}\text { Length } \\
\text { of record } \\
\text { (years) }\end{array}$ & $\begin{array}{c}\text { Mean } \\
\text { annual } \\
\text { (inches) }\end{array}$ & $\begin{array}{l}\text { Length } \\
\text { of record } \\
\text { (years) }\end{array}$ & $\begin{array}{c}\text { Mean } \\
\text { annual } \\
\left({ }^{\circ} \mathrm{F} .\right)\end{array}$ & & $\begin{array}{c}\text { Length } \\
\text { of record } \\
\text { (years) }\end{array}$ & $\begin{array}{c}\text { Mean } \\
\text { annual } \\
\text { (inches) }\end{array}$ \\
\hline $\begin{array}{l}\text { Roswell } \\
\text { Artesia } \\
\text { Carlsbad. } \\
\text { Elk } \\
\text { Fort Stanton } \\
\text { Mescalero } \\
\text { Clouderoft } \\
\end{array}$ & $\begin{array}{l}3,578 \\
3,350 \\
3,120 \\
5,350 \\
6,231 \\
6,627 \\
8,650\end{array}$ & $\begin{array}{l}36 \\
21 \\
34 \\
21 \\
52 \\
16 \\
27\end{array}$ & $\begin{array}{l}14.06 \\
12.06 \\
13.16 \\
18.54 \\
16.34 \\
18.92 \\
23.69\end{array}$ & $\begin{array}{l}35 \\
21 \\
33 \\
19 \\
49 \\
15 \\
26\end{array}$ & $\begin{array}{l}59.3 \\
60.7 \\
63.2 \\
53.3 \\
53.7 \\
49.4 \\
45.8\end{array}$ & $\begin{array}{l}201 \\
203 \\
210 \\
185 \\
157 \\
168 \\
140\end{array}$ & \begin{tabular}{r|}
27 \\
13 \\
24 \\
12 \\
22 \\
\hdashline 18
\end{tabular} & $\begin{array}{r}12.2 \\
8.5 \\
6.3 \\
17.6 \\
27.3 \\
-75.9\end{array}$ \\
\hline
\end{tabular}

\section{PHYSIOGRAPHY}

By S. S. NYE

\section{GENERAT FEATURES}

The chief physiographic features of this area are the wide, almost featureless topographic basin that slopes gently eastward from the western uplands to the Pecos River and the irregular bluffs that border the Pecos on the east and rise 100 to 300 feet above a former flood plain. The basin extends from the vicinity of Roswell to the Seven Rivers, a distance of about 60 miles. A prominent northward-facing escarpment on the south side of the Seven Rivers, near Lake McMillan, marks its southern limit. The altitude of the east side of the basin near the Pecos River is about 3,500 feet above sea level east of Roswell and about 3,300 feet near Lakewood. The west side of the basin merges in many places into a limestone upland that rises gradually to the summits of the Sacramento Mountains, which attain an altitude of over 9,000 feet near Cloudcroft. Cerro Blanco, the highest peak in southeastern New Mexico, and the Capitan Mountains, in the northwestern part of the area, rise conspicuously above the limestone upland. The limestone upland is deeply dissected by numerous streams that originate on the high eastern slope of the mountains and are tributary to the Pecos River.

\section{DRAINAGE}

STREAMS

The Pecos River, which has its source in the Sangre de Cristo Range northeast of Santa Fe, is the principal drainage channel of southeastern New Mexico. It enters the area from the north and 
flows in a southerly direction along the east edge of the alluvial basin. From Lake McMillan southward, except near the mouth of the Seven Rivers, the river occupies a rather narrow valley bordered by uplands of moderate relief; this constriction of the valley is due to the outcrop of resistant rocks. Throughout this area the Pecos has a small but perennial flow.

Numerous tributary streams enter from the west, and a few short unimportant ones from the east. The chief tributary streams from the west are the Rio Hondo, the Rio Felix, Eagle Draw, the Rio Penasco, Fourmile Draw, and the Seven Rivers. The Rio Hondo and the Rio Penasco have their sources near the summits of the Sierra Blanca and Sacramento Mountains, respectively. The Rio Felix, Eagle Draw, and Fourmile Draw head farther down in the limestone uplands and drain much smaller areas. The tributaries of the Seven Rivers originate in the northern part of the Guadalupe Mountains and in the southern part of the Sacramento Mountains. Walnut Draw and Cottonwood Creek are the principal smaller tributaries and head near the eastern edge of the limestone uplands. The Rio Hondo and the Rio Penasco are perennial streams in the upland region, but before they reach the alluvial basin part of the water is diverted for irrigation and the rest sinks into the ground. Within the alluvial basin, except near the Pecos, all the tributary streams are ephemeral-that is, they flow only in direct response to precipitation. All the tributary streams from the east are ephemeral and drain small areas. The larger ones are Comanche Draw and Long Arroyo.

\section{LAKES}

There are a number of small shallow undrained depressions in the swampy lowland adjoining the Pecos and a few lakes on higher land, which are probably fed in part by seepage losses from irrigation and in part by springs. Before the artesian water was extensively developed there were lakes of moderate size at the heads of the North and Middle Berrendo Rivers and the North and South Spring Rivers ${ }^{8}$ and on the South Berrendo River, all of which were fed by springs of the first magnitude. ${ }^{9}$ As a result of the extensive development of the artesian water, the flow of these springs has declined greatly or the springs have gone dry. (See p. 251.)

There are a number of small deep lakes, called the Bottomless Lakes, along the base of the bluffs on the east side of the Pecos about 12 miles southeast of Roswell. The largest of these is Dimmit Lake. These lakes are sink holes due to the solution and removal of gypsum

\footnotetext{
8 Fisher, C. A., Preliminary report on the geology and underground waters of the Roswell artesian area, N. Mex.: U. S. Geol. Survey Water-Supply Paper 158, p. 6, 1906.

Meinzer, O. E. Large springs in the United States: U. S. Geol. Survey Water-Supply Paper 557, pp. 89-90, 1927. Gives detailed description of the springs.
} 
and other soluble rocks in the Permian red beds by percolating water. The location of the lakes along the base of the bluffs suggests that the sink holes were started by surface drainage from the east, which, in falling over the bluffs, excavated depressions at the base, and that the water filling these depressions after heavy rains percolated downward, forming solution passages that now extend below the water table.

The following description of the lakes near Roswell is taken from a report by Nettleton ${ }^{10}$ on an investigation of the Pecos Valley made in February, 1891:

At Roswell we were informed of the existence of several small bottomless pools, which lie on the east side of the Pecos, about 12 miles southeasterly from Roswell * * * at the foot of a ledge of gypsum rock about 125 feet high. The surroundings of some of these pools resemble an immense circular excavation from 200 to 300 feet in diameter, cut down through the perpendicular face of the ledge to the bottom and extending into the water, and extending back into the ledge about one-half to three-quarters the diameter of the circle. * * * The walls seem to extend nearly perpendicularly into the water. The water is very clear and transparent; the rock sides can be plainly seen a considerable distance below the surface. *** The largest of these pools covers about 80 acres; two others are somewhat smaller in extent. These larger pools lie at the foot of the ledge, but not in a recess like the smaller ones. There is only a small amount of water flowing from any of these pools; that which does escape contains gypsum and lime in large quantities, which has been procipitated by evaporation until it has built up large mounds or banks of earthy material which slope gradually from the edge of the pools. * * * Our examination of these pools, or lakes, as they are commonly called, shows that no two of them are on the same level, in fact some of them differ as much as 60 feet in elevation; consequently, they can not be connected by underground passages, as supposed, nor is it probable that they are connected by any large underground lake, from the fact that when the rims of these pools have been cut down (as two or three of them have been, 3 or 4 feet) the water discharge was just simply that due to what was in the pool above the bottom of the opening, nor does any more water flow from the opening than before the surface was lowered. The depth of these pools as determined by us was a surprise to the people as well as to ourselves, for they all looked very deep. We had been told that cowboys had tied four picket ropes together and failed to find bottom, and also that a Doctor Alexander had sounded one of these pools with two spools of thread tied together (400 yards) and failed to reach bottom. *** We made a sounding off the edge of what appeared to be a projecting rock in one of these pools (the place where the cowboys had sounded with four ropes); we found only 48 feet of water at this place. The two most northerly pools were sounded by us all over the bottom. * * * We found the greatest depth of these two pools to be, respectively, 34 and 16 feet. On the bottom of each was found a thick growth of dark green moss; this was what gave the water the appearance of being so deep. I think it quite probable that some of the pools were deeper than those we sounded, but I doubt if any of them exceed 90 feet.

10 Nettleton, E. S., Artesian and underflow investigation, final report of the chief engtneer : 52d Cong., 1st sess., S. Ex. Doc. 41, pt. 2, pp. 14-15, 1892. 


\section{ALIUVIAL BASIN}

\section{DEFINITION AND CHARACTER}

The Roswell area of artesian flow lies within a wide topographic basin partly filled or veneered with alluvial materials to which the term alluvial basin is applied. The alluvial basin is bounded by higher land a few miles north of Roswell and south of the Seven Rivers, by the bluffs on the east side of the Pecos, and by the uplands on the west. Its limits correspond in general to the area of Quaternary deposits (see pl. 3), but the western boundary is indefinite in many places.

The deepest part of the alluvial basin is along the Pecos River; its shape from west to east is therefore asymmetrical. The present floor is a composite alluvial surface resulting from the formation and partial destruction of three terraces, which in many places form a series of broad steps rising from the Pecos toward the west. The alluvial surface in general has little relief. In some places, especially along the east side, it is remarkably smooth; in others it is very gently undulating. The relief increases toward the west, where the major streams have cut broad $U$-shaped valleys 50 to 80 feet below the general surface of the oldest alluvial terrace. Between the valleys of the major streams the maximum relief is generally less than 25 feet. Near the north and west sides of the alluvial basin are a few prominent mesas, smooth gravel-capped remnants of an ancient surface that is much higher and older than any of the terraces.

\section{TERRACES}

The alluvial basin comprises three distinct constructional surfaces or terraces, formed by alluvial fill. The lowest terrace is a flat plain that borders the Pecos and its larger tributaries and does not lie very far above them. The two higher ones are broad grassy plains on the west side of the Pecos that slope gently to the east and south. The middle terrace is little dissected and is therefore fairly continuous, but the upper one has been cut into segments by the larger streams and is modified by erosion. The three terraces, from lowest to highest, will be referred to, respectively, as the Lakewood terrace, the Orchard Park terrace, and the Blackdom terrace, because they are well developed and easily recognized at Lakewood, around Orchard Park, and in the vicinity of the Blackdom well. (See pl. 4 and fig. 1.)

Lakewood terrace.-The Lakewood terrace is most extensively developed along a comparatively narrow strip of land adjoining the Pecos River, in the valley of the Seven Rivers southwest of Lakewood, and along the Rio Hondo. The central part of the city of Roswell rests upon this surface in the valley of the North Spring 
River and the Rio Hondo. The Lakewood terrace extends in narrow strips up the valleys of the larger tributaries from the west and also along many of the smaller tributaries. It becomes less prominent westward. Along some of the tributaries it forms the floor of the valley and is more conspicuous than the Orchard Park terrace.

Along the Pecos River the Lakewood terrace is a smooth ancient flood plain in which the river has cut a narrow meandering channel to a depth of 20 to 30 feet. The Pecos no longer overflows this plain, even during the highest floods. A large part of this ancient flood plain is swampy, and there are many small shallow lakes on it. In many places, especially where the water table is close to the surface, the soil contains a considerable amount of alkali. Consequently only a small part of this terrace along the river is cultivated, the rest being used for stock grazing. In the lower valley of the Seven Rivers all the irrigated farms are on the Lakewood terrace.

The tributary. streams flow in narrow channels cut 10 to 25 feet below the terrace and occasionally overflow it during times of high floods.

Orchard Park terrace.-The Orchard Park terrace rises 5 to 10 feet above the Lakewood terrace and is 20 to 35 feet above the present stream channels. In many places there is a distinct topographic break between the Lakewood and Orchard Park terraces, but in others there is a more gradual change in slope, and the boundary between them is indefinite. The Orchard Park terrace occupies a wide irregular belt west of the Pecos in the vicinity of Orchard Park and Roswell and on both sides of the railroad as far south as the Rio Penasco. It extends up and is conspicuously developed in the valleys of many of the large tributary streams from the west. It is a broad, remarkably smooth grassy alluvial plain, very little dissected by streams and monotonously uniform in character. It

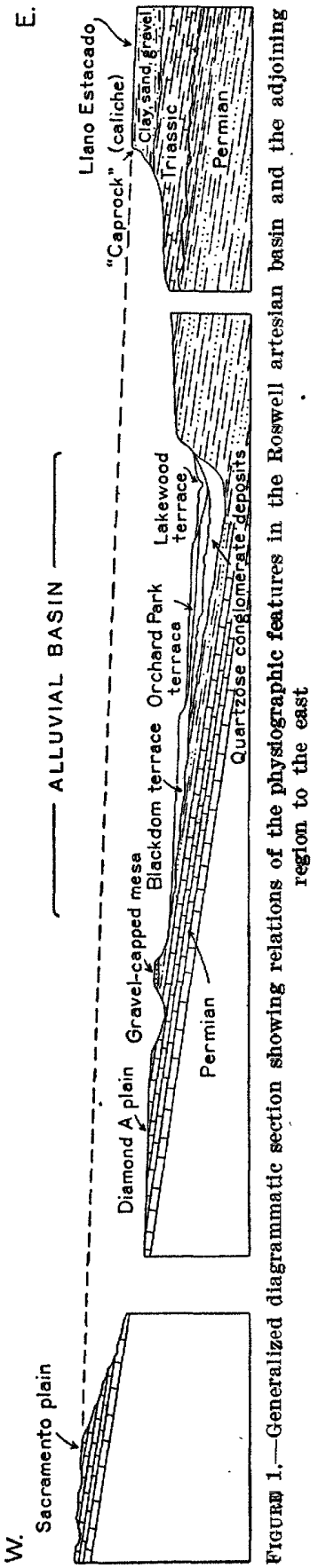


has an eastward slope of 20 to 30 feet to the mile. Nearly all the irrigated farms are on this surface.

Blackdom terrace.-The Blackdom terrace rises 30 to 50 feet higher than the Orchard Park terrace along its eastern 'margin and is generally 60 to 80 feet higher than the stream channels. It has an eastward gradient of 30 to 40 feet to the mile and is therefore 50 to 60 feet higher than the Orchard Park terrace in the valleys of the major tributaries of the Pecos near its western margin. The rise from the lower to the higher terrace is abrupt in some places and very gradual in others. The Blackdom terrace has been cut into segments which are separated by the broad $U$-shaped valleys of the larger streams. These segments are moderately dissected by more recent drainage that originated on them. Partial dissection and planation of the segments south of the Cottonwood by various types of streams in an

N. s.

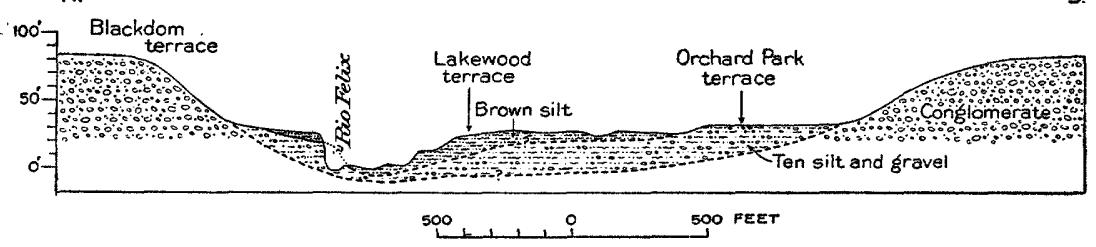

FigUR 2.-North-south section of valley of Rio Felix south of Roswell, near the west line of sec. 13, T. 14 S., R. 24 D.

earlier stage of erosion has resulted at some places in very confusing pseudoterraces. Outliers of the Blackdom terrace form low hills that rise above the Orchard Park terrace. A few of the larger outliers are shown in Plate 4. The segments of the Blackdom terrace are broader from north to south in Chaves County than in Eddy County, but in Eddy County they extend nearer the Pecos River. The broad interstream areas are smooth to gently undulating grassy plains. These segments are remnants of a once continuous alluvial plain that extended to the east side of the alluvial basin and was as smooth and featureless as the present Orchard Park terrace.

The relation of the Blackdom terrace to the two lower ones is most clearly seen in the valley of the Rio Felix south and southwest of Roswell. (See pl. 5, A, and fig. 2.) The Blackdom terrace probably corresponds to the 75-foot terrace along the Pecos south of Lake McMillan.11

Owing to its higher altitude and consequent greater depth to the water level in wells, the area occupied by the Blackdom terrace is utilized only for stock grazing.

\footnotetext{
II Meinzer, O. E., Renick, B. C., and Bryan, Kirk, Geology of the No. 3 reservoir site of the Carlsbad irrigation project, $\mathbf{N}$. Mex., with respect to water-tightness: $\boldsymbol{U}$. S. Geol. Survey Water-supply Paper 580, p. 6, 1927.
} 

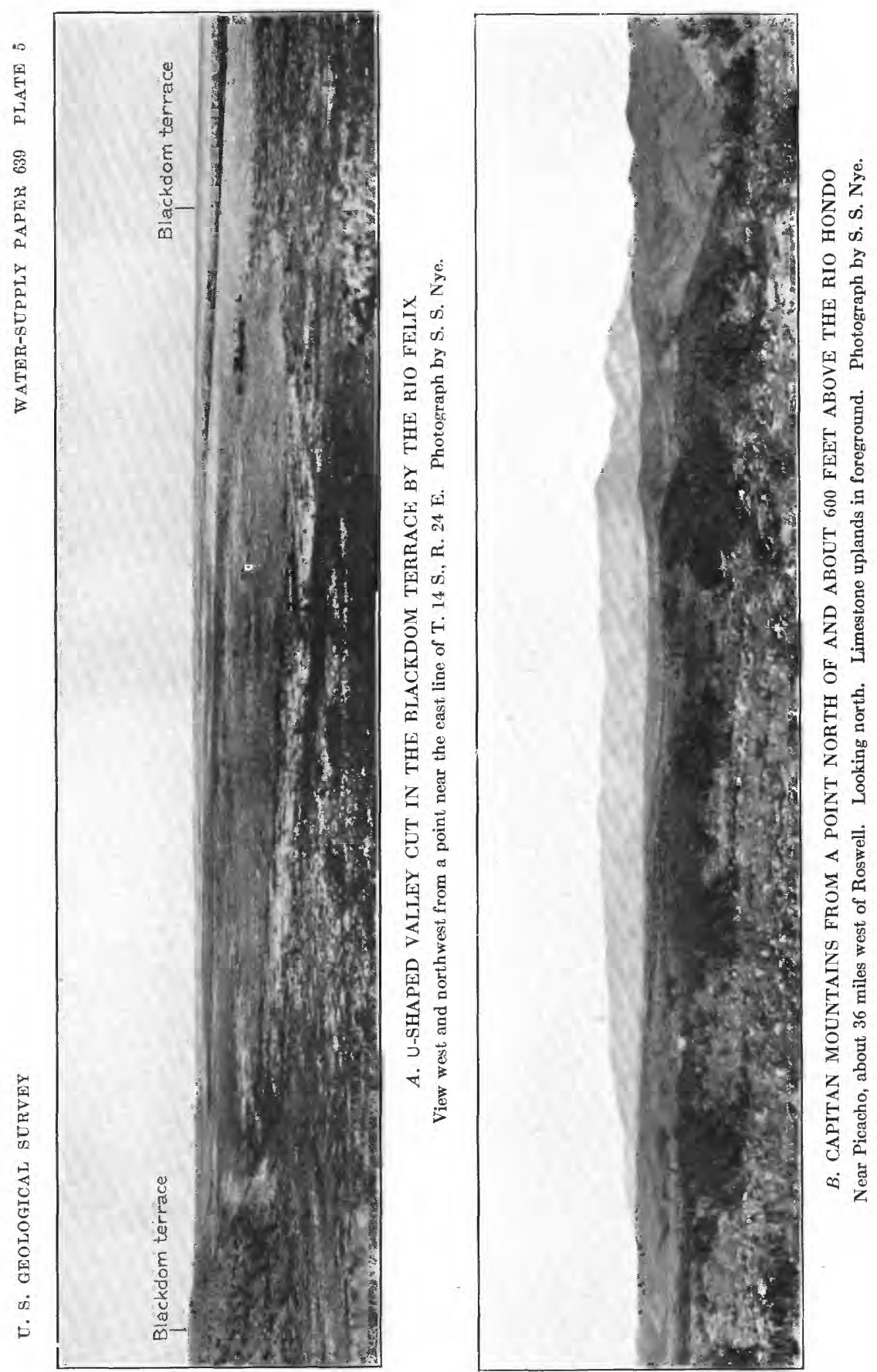


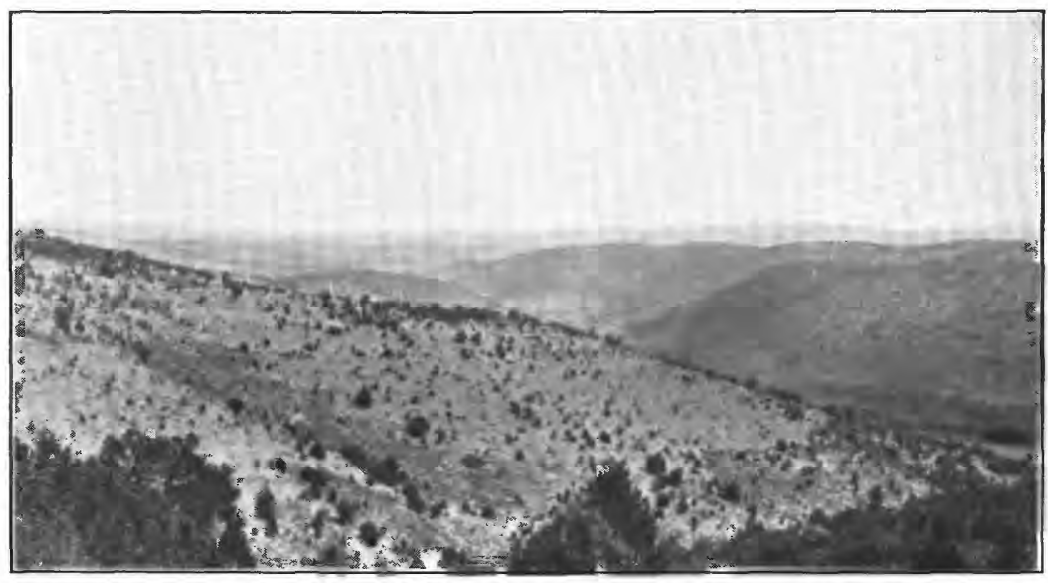

A. VIEW EASTWARD DOWIN THE VALLEY OF THE RIO PENASCO IN T. 16 S., R. 15 E.

Shows two distinct erosion surfaces. The higher one, forming the sky line, is the Sacramento plain; the lower one is probably an extension of the Diamond A plain. Photograph by S.'S. Nye.

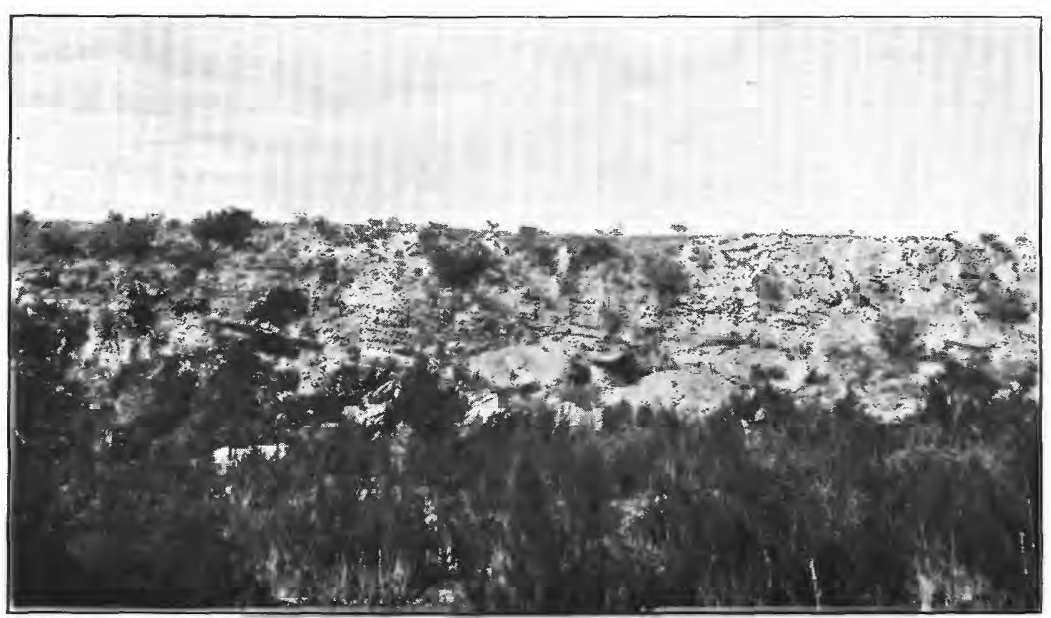

B. QUARTZOSE CONGLOMERATE EXPOSED ALONG THE NORTH BANK OF THE RIO FELIX IN THE SW. 1/4 SEC. 18, T. 14 S., R. 25 E.

Overlain by partly cemented limestone conglomerate of the deposits of the Orchard Park terrace. Photograph by S. S. Nye. 


\section{GRAVFLCAPTED MRSAS}

West of Melena, near the heads of the streams tributary to Cottenwood Creek, and along the north side of Eagle Draw a few miles north of Hope there are a number of mesas capped by conglomerate composed chiefly of limestone pebbles. The surface of the mesas is strewn with loose gravel and boulders. The mesas are remnants of an ancient surface that is distinctly higher and older than the alluvial terraces. The mesas are from 150 to 200 feet higher than the present stream channels and slope gently toward the east. They probably correspond to the 150-foot terrace along the Pecos south of Lake McMillan. ${ }^{12}$ They appear to correspond also to the Diamond A plain in the limestone uplands, described below.

The gravel-capped mesa along the north side of Eagle Draw is the largest. It is nearly 10 miles long and ranges in width from a few hundred feet to about 2 miles. The largest mesa near Melena has an area of several square miles. The central parts of the larger mesas are smooth, but the surfaces of the smaller ones are somewhat rounded and uneven as the result of erosion.

\section{LIMESTONE UPLANDS}

\section{DEFINITION AND CHARACTHR}

The Sacramento Mountains have a long, gentle, eastern slope formed chiefly by resistant limestone beds that cap the mountains and dip gently east beneath the Pecos Valley. The higher parts are beavily timbered, but below the timber line the limestone surface is remarkably bare. The term limestone uplands is here applied to the bare eastern slope between the mountains proper and the alluvial basin. The boundary between the limestone uplands and the mountains is indefinite but is arbitrarily considered here as the timber line.

The limestone uplands are deeply dissected by numerous streams, the largest of which rise near the crest of the mountains and drain eastward into the Pecos River. The amount of relief increases westward, ranging from 50 to 100 feet at the eastern edge to over 700 feet near the mountains.

The limestone uplands are too bare and rocky to be utilized other than for stock grazing, except in the canyons of the Rio Hondo and the Rio Penasco, which are floored with thick alluvial deposits and have water available for irrigation. There are numerous farms and orchards in the canyons of the Rio Grande and the Rio Penasco, and a number of cattle ranches on the limestone uplands.

\footnotetext{
12 Meinzer, O. E., Reniek, B. C., and Bryan, Kirk, op. cit., p. 6.
} 
In the limestone uplands for a distance of 20 to 25 miles west of the alluvial basin the tops of the higher hills and interstream divides are remnants of a comparatively smooth rock surface that slopes east with a gradient of 60 to 80 feet to the mile-that is, if the present canyons and valleys were filled to the height of these hills and interstream divides, the resultant surface would be a fairly smooth eastward-sloping plain. For convenience, this surface will be referred to as the Diamond A plain, the name being taken from the former headquarters of the Diamond $A$ ranch, in the canyon of the Rio Hondo, in the vicinity of which the plain is easily recognized.

The continuity of the Diamond A plain is interrupted by two prominent narrow northeastward-trending ridges. The ridge known locally as the Border Hills rises as much as 100 to 150 feet above the plain and is the more conspicuous of the two; it is crossed by the Roswell-El Paso highway about 25 miles west of Roswell. The other ridge, referred to by local geologists as the $\mathrm{Y}-\mathrm{O}$ overthrust, is crossed by the Hope-Cloudcroft highway about 15 miles west of Hope. Each of these ridges is intersected by the canyons of the Rio Hondo, the Rio Felix, the Rio Penasco, and other large streams and is, strictly speaking, a series of disconnected narrow ridges remarkably in line with one another and not a single, continuous ridge. The general location and trend of the ridges is indicated on Plate 3 by the Border Hills and Y-O faults, to which the existence of these ridges is due. (See also pp. 78-81.)

Many of the broad interstream divides forming the Diamond A plain are comparatively smooth rocky surfaces with very little soil, but some have small thin patches of coarse gravel and cobbles, which were deposited before the streams began cutting below this plain. The Diamond A plain as a whole, with the exception of the two ridges, is an erosion surface. It appears to have once been coextensive with the surface of the gravel-capped mesas.

\section{SACRAMENTO PLAIN}

About 25 miles west of the alluvial basin the hills and interstream divides appear to form an eastward-sloping surface 200 or 300 feet above the Diamond A plain and similar to it. This surface is here designated the Sacramento plain, because it is developed most prominently on the east side of the Sacramento Mountains. It extends westward to the mountains proper but is much less definite than the Diamond A plain. Being much older and higher, it is more thoroughly dissected; consequently the remnants are fewer, and most of them are reduced to rocky slopes. Moreover, there are hills which 
rise above it in places. The Sacramento plain east of Cloudcroft is shown in Plate 6, $A$.

\section{MOUNTAINS}

The Sacramento Mountains and the Sierra Blanca form a nearly continuous north-south range about 70 miles long and about 80 miles west of the Pecos River. The Sierra Blanca, locally referred to as the White Mountains, forms the northern part and extends for a distance of about 20 miles. The Capitan Mountains are an east-west range about 20 miles long, the western edge of which is about 15 miles east of the north end of the Sierra Blanca. The Guadalupe Mountains begin about halfway between the south end of the Sacramento Mountains and the Pecos Valley and extend in a southeasterly direction to Guadalupe Point, in Texas.

The mountains are heavily timbered, especially the Sacramento Mountains and the Sierra Blanca. A considerable part of the mountain area is included in the Lincoln National Forest and the Mescalero Apache Indian Reservation. There are several sawmills and lumber camps in the general vicinity of Cloudcroft, and many farms and ranches in the larger canyons in the mountains. Cloudcroft, on the crest of the Sacramento Mountains, and Ruidoso, in the Sierra Blanca near the Roswell-El Paso highway, are popular summer resorts for residents of the Pecos Valley and of El Paso. There are also a few summer cabins at Pine Lodge, on the eastern flank of the Capitan Mountains.

\section{LLANO ESTACADO}

The Llano Estacado, or Staked Plain, is a large plateau lying some distance east of the Roswell artesian basin, in eastern New Mexico and western Texas. It is described here because of its geologic relation to this basin. It is bounded in most places by a steep escarpment and rises 100 to 300 feet above the gently undulating plains that intervene between it and the Pecos River. Its surface is a remarkably smooth grassy plain having a gradient to the east and east-southeast of 10 to 15 feet to the mile. The western edge is about 4,500 feet above sea level and is marked by a steep north-south escarpment about 25 miles east of the Pecos River. This escarpment forms the eastern limit of the drainage area tributary to the Pecos. The Llano Estacado is a large remnant of the High Plains and is cut off from the rest of the High Plains by the valley of the Canadian River. In its western part caliche occurs near the surface and there is little soil; therefore, this part is utilized only for stock grazing. Farther east, however, in central and eastern Lea County, N. Mex., there are many dry farms and a few farms that are irrigated with water pumped from wells. 
AREA BETWEEN THE PECOS RIVER AND THE LLANO ESTACADO

The area between the Pecos River and the Llano Estacado is a gently undulating plain that rises gradually from the top of the bluffs along the east side of the Pecos River to the base of the escarpment at the western edge of the Llano Estacado. It is very poorly drained. All the streams are ephemeral and have relatively small drainage basins. This area is underlain by Triassic and Permian red beds, and owing to the presence of thick soluble beds of gypsum and salt there are numerous sink holes and large undrained depressions formed by the solution and removal of these rocks by subsurface water.

Beginning a few miles east of the Pecos River and continuing eastward to the Llano Estacado the surface is veneered with loose sand, which is constantly being shifted by the wind and piled into sand dunes, forming a hummocky surface. In places there are caliche-capped remnants of at least two distinct erosion surfaces. The relation of these surfaces to those in the artesian basin was not studied.

Largely because of the difficulty of obtaining potable water supplies and the poor character of the soil this area is sparsely settled and is used only for stock grazing.

\section{DISSECTED AREAS OF SOFT ROCKS WEST OF THE PECOS RIVER}

The areas on the west and south sides of the alluvial basin that are underlain by the Pecos formation (see pl. 3 and pp. 44-53), which consists chiefly of red beds and intercalated lenses of gypsum and limestone, are topographically distinct from the alluvial basins and the limestone uplands.

In the upper drainage basin of Cottonwood Creek the Pecos formation consists almost entirely of red beds with one or more beds or lenses of hard limestone several feet thick. In this area the surface is gently undulating and in general is below that of the Blackdom terrace. The Roswell and Orchard Park terraces, however, are recognizable along Cottonwood Creek and its tributaries in many parts of the area. Near the northwestern part of sec. 28, T. 15 S., R. 23 E., there are two small gravel-capped mesas, one of which is shown in Plate 4. They have been preserved not only by the gravel capping but also by a resistant limestone 3 to 4 feet thick. In some places there are small buttes, cuestas, and hogbacks formed by resistant limestone that has protected the soft underlying red beds from erosion. The upper Cottonwood and its tributaries have carved out a broad irregular valley in these soft rocks. There are several small ranches in this area, as potable ground-water supplies are obtainable from both the Picacho limestone and the red sands in the Pecos formation. 
On the south and southwest sides of the alluvial basin the Pecos formation includes a large amount of gypsum with intercalated thin lenses of limestone and dolomite. Consequently, there are numerous sink holes, undrained depressions, underground streams, and irregular topographic features. The sink holes and depressions are caused by the removal of soluble beds by ground water with consequent caving or slumping of the overlying beds. Other irregularities in the topography are due to the presence of resistant rocks that protect the soft underlying strata from the agencies of erosion and project above the surrounding surface. Drainage changes caused by the formation of sink holes are common. In the southwestern part of $T$. 19 S., R. 23 E., a large sink hole at the edge of a moderate-sized valley captured the stream that had excavated the valley, and the stream now drains into the sink hole. (See pl. 7.) The Roswell, Orchard Park, and Blackdom terraces are recognizable in many places in this area but are poorly developed. The Diamond A plain was probably developed here but has been destroyed or so modified by erosion and slumping that it is not easily recognized. There are several small ranches in this area devoted to stock grazing.

\section{SEVEN RIVERS CUESTA}

A high escarpment on the south side of the South Seven Rivers marks the southern limit of the area of artesian flow. It is capped by the hard Carlsbad limestone (see pls. 3 and 9, $C$ ), which dips to the southeast and forms a cuesta here called the Seven Rivers cuesta. This cuesta rises 200 to 300 feet above the alluvial basin and is one of the most prominent topographic features in this area, being plainly visible for many miles.

\section{VALLEYS AND STREAMI CHANNELS}

In the eastern part of the limestone uplands and in the area occupied by the remnants of the Blackdom terrace the valleys of the major streams, such as the Rio Hondo, the Rio Felix, and the Rio Penasco, are characteristically broad, U-shaped, and floored with alluvium, in which the present streams have cut narrow meandering trenches. Figures 2 and 3 show typical cross sections of major valleys in the Blackdom terrace and in the limestone uplands. The valleys of the younger tributary streams in the limestone uplands are generally narrow and $V$-shaped or nearly so. As a rule, the major valleys become narrower and deeper westward and the alluvial floor becomes thinner; in the mountains these valleys also are $V$-shaped. The valleys of the ephemeral streams originating on the Blackdom terrace are broadly V-shaped and comparatively shallow. 
At the edges of the limestone uplands and the Blackdom terrace the alluvial floors of the major valleys merge with the Orchard Park terrace.

In the areas occupied by the Orchard Park and Lakewood terraces the channels of the major streams are mere trenches incised to a depth of 10 to 30 feet in the smooth alluvial surface. The Pecos River within the alluvial basin flows in a meandering trench that is 20 to 30 feet deep and generally has nearly vertical banks. In the vicinity of Roswell the channel of the Rio Hondo is so insignificant that it could easily be mistaken for a moderate-sized irrigation ditch. The channels of the streams originating on the Blackdom terrace are characterized by a series of disconnected trenches cut a few feet below the grass-covered surface of the alluvial plain; these channels are very poorly developed and often fade out upon reaching the Orchard Park terrace.

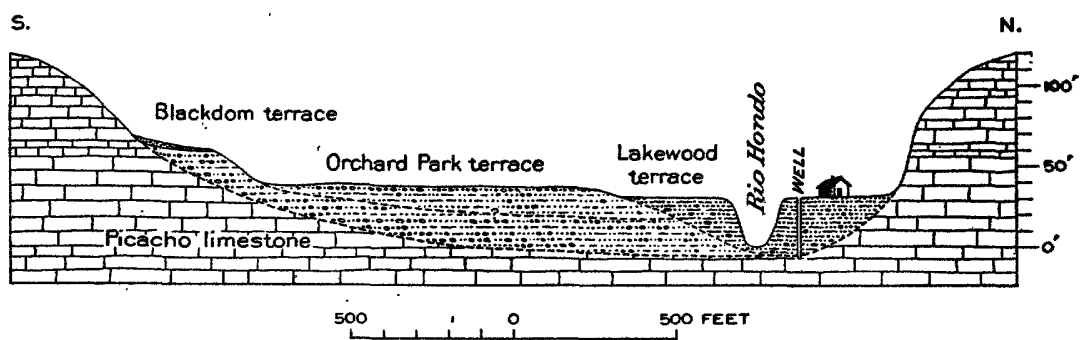

Figure 3.-Generalized section across the valley of the Rio Hondo at Diamond A headquarters ranch, near east line of sec. 20, T. 11 S., R. 21 E.

The channels of the major streams from the west are floored with gravel and boulders, although in many places in the limestone uplands and in the mountains they are down to bedrock. Near the west edge of the alluvial basin they are choked with large pebbles, cobbles, and boulders and are very irregular. In the streams of the Blackdom terrace gravel is absent except in a few of the trenches and in places where the surface is immediately underlain by gravel. The channel of the Pecos is generally floored with fine sand and silt, but in many places there are gravel deposits.

\section{GEOLOGY}

By S. S. NxE

\section{PREVIOUS GEOLOGIC WORK}

The early geologic explorations in eastern New Mexico were made chiefly along the lines of the $32 \mathrm{~d}$ and 35 th parallels. It was not until 1891, when W. F. Cummins and N. F. Drake, of the Texas Geological Survey, traversed the Pecos Valley from Fort Sumner south- 
ward into Texas, that geologic work worthy of note was done in any part of the Roswell artesian basin. It is interesting to find that even at that early date the red-bed series was classified in the Permian. The underlying limestone series was described briefly as the "Carboniferous formation." Cummins observed caliche in the alluvial deposits between Roswell and the Seven Rivers; and because it is very similar lithologically to the caliche capping the Llano Estacado, he assigned the alluvial-deposits to the Tertiary and represented them as such on the geologic map accompanying the reports by him and by Drake.

Cursory notes on the geology and ground water in parts of the artesian basin are given in the report by E. S. Nettleton on irrigation developments in the Pecos Valley, by R. T. Hill in his paper on the occurrence of ground water in Texas and eastern New Mexico, and by T. H. Means and F. D. Gardner in their report on the soil survey in the Pecos Valley. A geologic map of eastern New Mexico and western Texas accompanies Hill's report.

The first comprehensive description of the geology and ground water of the Roswell artesian basin is the report by C. A. Fisher in 1906. Since that time many geologists have visited this region and published contributions to the knowledge of its geology. The discovery of oil near Dayton and in other parts of southeastern New Mexico greatly stimulated geologic work in this region, and since about 1920 numerous oil geologists have made Roswell and Carlsbad their local headquarters. These men have done a great deal of geologic work in southeastern New Mexico, but very little of it has been published.

A nearly complete list of publications relating in whole or in part to the geology, ground water, and surface water resources of the Roswell artesian basin is given below.

Cummins, W. F., Report on the geography, topography, and geology of the Llano Estacado or Staked Plains, with notes; on the geology of the country west of the plains: Texas Geol. Survey Third Ann. Rept., for 1891, pp. 129-223, 1892. First published report on geology of Pecos Valley between Roswell and the Seven Rivers. Describes Permian red-bed series and mentions artesian wells and springs near Roswell.

Drake, N. F., Stratigraphy of the Triassic formation of northwest Texas: Texas Geol. Survey Third Ann. Rept., for 1891, pp. 227-247, 1892. Describes Triassic strata east of the Pecos River.

Hinton, R. J., A report on irrigation and the cultivation of the soil thereby: 52d Cong., 1st sess., S. Ex. Doc. 41, pt. 1, pp. 198-227, 1893 . Notes on irrigation developments in Pecos Valley and other parts of New Mexico.

Nettleton, E. S., Artesian and underflow investigation, final report of the chief engineer: 52d Cong., 1st sess., S. Ex. Doc. 41, pt. 2, pp. 11-19, 1892 . Notes on streams, springs, ground water, wells, geology, and irrigation in Pecos Valley between Roswell and Carlsbad. Gives soundings in "bottomless lakes." Plato 14 is a map of southeastern New Mexico. 
Hill, R. T., On the occurrence of artesian and other underground waters in Texas, eastern New Mexico, and Indian Territory, west of the 97th meridian: 52d Cong., 1st sess., S. Ex. Doc. 41, pt. 3, pp. 41-166, 1893. Describes red beds in Pecos Valley and gives notes on ground water in them east of Carlsbad.

Means, T. F., and Gardner, F. D., A soil survey in the Pecos Valley, N. Mex.: U. S. Dept. Agr. Rept. 64, pp. 36-76, 1900. Contains notes on geology and ground water in Roswell, Hagerman, and Carlsbad sections of Pecos Valley. Note three terraces in alluvial basin.

Fisher, C. A., Coal fields of the White Mountain region, N. Mex.: U. S. Geol. Survey Bull. 225, pp. 293-294, 1904. Very brief description of the occurrence of coal in Sierra Blanca region.

Herrick, H. N., Gypsum deposits in New Mexico: U. S. Geol. Survey Bull. 223, pp. 89-99, 1904. Mentions exposures of gypsum in red beds of lower Pecos Valley.

Fisher, C. A., Preliminary report on the geology and underground waters of the Roswell artesian area, N. Mex. : U. S. Geol. Survey Water-Supply Paper 158, 1906. First comprehensive description of topography, geology, and ground water in the Roswell artesian basin.

Campbell, M. R., Coal in the vicinity of Fort Stanton Reservation, Lincoln County, N. Mex. : U. S. Geol. Survey Bull. 316, pp. 431-434, 1907. Brief notes on geology and coal in vicinity of Fort Stanton.

Girty, G. H., The Guadalupian fauna and new stratigraphic evidence: New York Acad. Sci. Annals, vol. 19, pp. 135-147, 1909. Data on geology and paleontology of Sacramento Mountains obtained by Girty, G. B. Richardson, R. T. Hill, and C. A. Fisher. Gives list of fossils collected from limestone at Cloudcroft and underlying strata on west slope of mountains. Discusses relation of this fauna to Guadalupian fauna and concludes faunal differences due to environment.

Lindgren, Waldemar, Graton, L. C., and Gordon, C. H., The ore deposits of New Mexico: U. S. Geol. Survey Prof. Paper 68, pp. 175-190, 1910. Brief descriptions of geology and ore deposits in Lincoln and Otero Counties.

Richardson, G. B., Stratigraphy of the upper Carboniferous in west Texas and southeast New Mexico: Am. Jour. Sci., 4th ser., vol. 29, pp. 325-337, 1910. Gives brief description of stratigraphic sequences in trans-Pecos Texas, Guadalupe and Sacramento Mountains, east-central New Mexico between Manzano Range and Pecos River, and Rio Grande Valley, correlates various sections, and discusses relations of " red beds of Pecos Valley" to associated strata.

Beede, J. W., Correlation of the Guadalupian and the Kansas sections: Am. Jour. Sci., 4th ser., vol. 30, pp. 131-140, 1910. Notes on stratigraphy and paleontology of Pecos Valley and Guadalupe Mountains, with discussion of fossils collected from limestone capping Seven Rivers cuesta south of Lakewood.

Richardson, G. B., Petroleum near Dayton, N. Mex. : U. S. Geol. Survey Bull. 541, pp. 135-140, 1914. Describes occurrence of oil in relation to stratigraphy near Dayton.

Wegemann, C. H., Geology and coal resources of the Sierra Blanca coal fields, Lincoln and Otero Counties, N. Mex.: U. S. Geol. Survey Bull. 541, pp. 419-452, 1914. Most detailed published description of geology and coal in Sierra Blanca region.

Meinzer, O. E., and Hare, R. F., Geology and water resources of Tularosa Basin, N. Mex., U. S. Geol. Survey Water-Supply Paper 343, 1915. Contains brief description of geology of Sierra Blanca and Sacramento Mountains.

Darton, N. H., A comparison of Paleozoic sections in southern New Mexico: U. S. Geol. Survey Prof. Paper 108, pp. 31-55, 1917. Describes pre-Permian Paleozoic section on west flank of Sacramento Mountains. Gives section of 


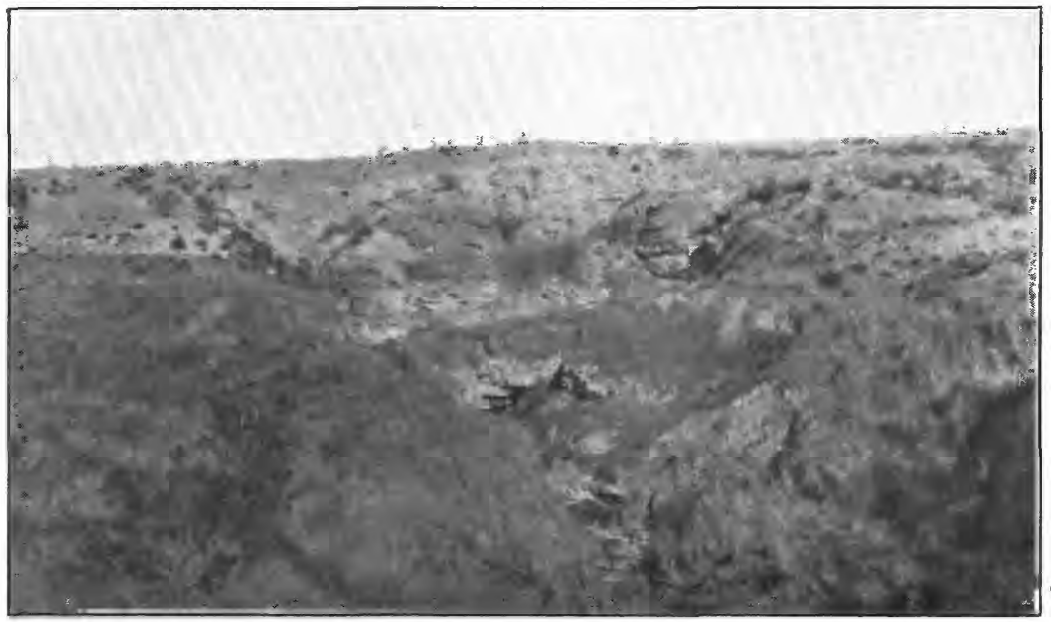

A. SINK HOLE DEVELOPED IN GYPSIFEROUS STRATA OF THE PECOS FORMATION IN T. 19 S., R. 23 E.

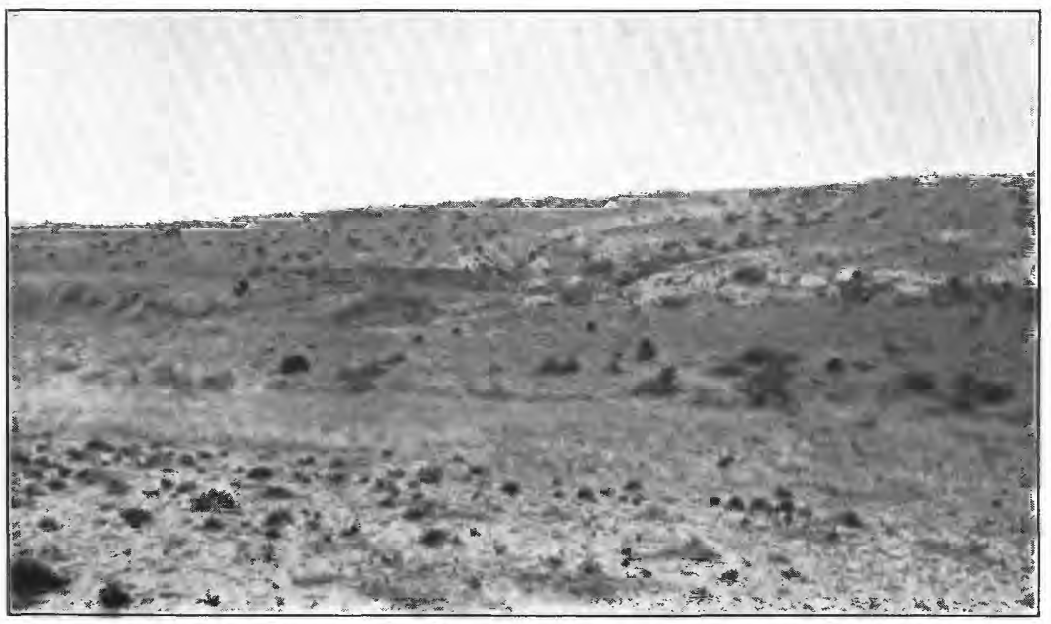

B. VALLEY OF EPHEMERAL STREAM THAT HAS BEEN CAPTURED BY THE SINK HOLE SHOWN IN $A$ 


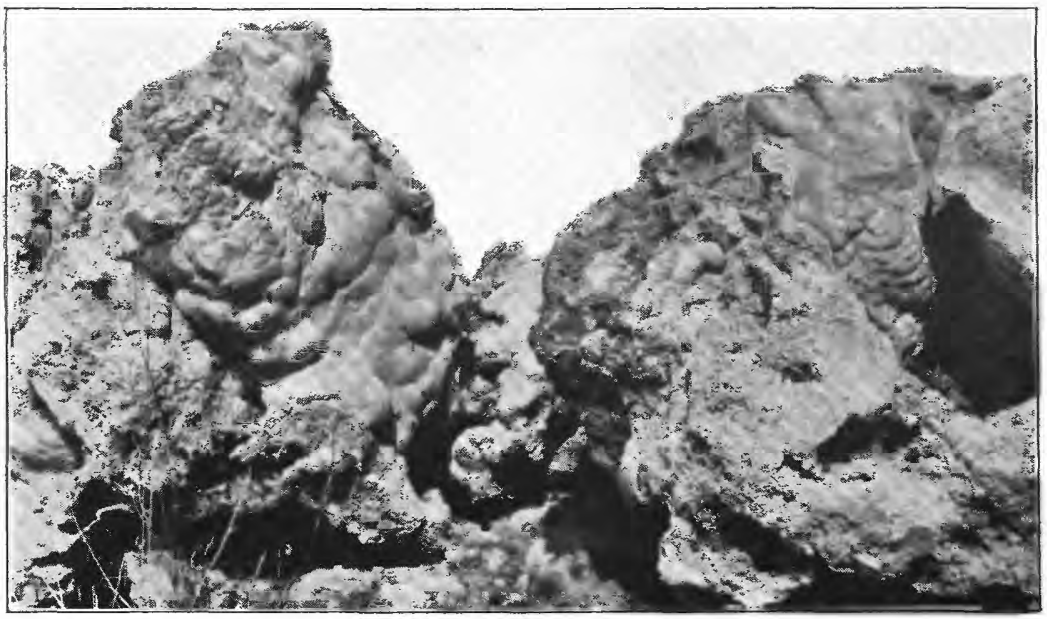

A. MASSES OF TRAVERTINE Along COTTONWOOD CREEK IN T. 16 S., R. 24 E. Photograph by S. S. Nye.

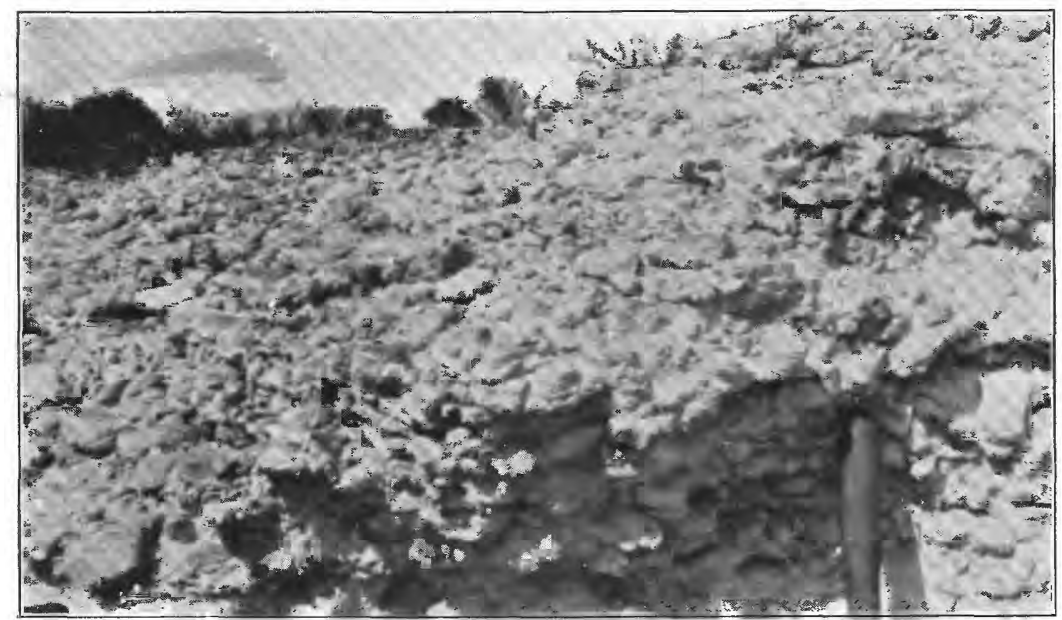

B. SOLUTION-FACETED PEBBLES CEMENTED BY CALICHE

Exposed in a gravel pit in the SW. 1/4 SW. 1/4, sec. 17, T. 17 S., R. 24 E. Photograph by S. S. Nye. 
west fromt of Sacramento Mountains 12 miles southeast of Alamogordo (fig. 13, p. 50) and applies name Manzano group for first time to post-Magdalena strata exposed along west front of Sacramento Mountains.

Phalen, W. C., Salt resources of the United States: U. S. Geol. Survey Bull. 669 , pp. 153-154, 1919. Mentions thick salt beds in the "Red Beds" underlying Pecos Valley and Staked Plain in Eddy, Chaves, and Roosevelt Counties, $N$. Mex.

Baker, C. L., Contributions to the stratigraphy of eastern New Mexico: Am. Jour. Sei., 4th ser., vol. 49, pp. 99-126, 1920. Gives descriptions of stratigraphy and structure of Sacramento and Guadalupe Mountains and Pecos Valley. First published description of Rocky Arroyo exposure, where thick section of gypsum and red beds merges into Carlsbad limestone. States that sandstone called Glarieta is basal part of Upper Triassic.

Merritt, J. W., Structures of western Chaves County, N. Mex.: Am. Assoc. Petroleum Geologists Bull., vol. 4, pp. 53-57, 1920. Brief notes on geologic structure.

Knox, J. K, Geology of New Mexico as an index to probable oil resources: Am. Asssoc. Petroleum Geologists Bull., vol. 4, pp. 95-112, 1920. Gives brief notes on stratigraphy, structure, and oil possibilities in Pecos Valley.

Semmes, D. R., Notes on the Tertiary intrusives of the lower Pecos Valley: Am. Jour. Sci., 4th ser., vol. 50, pp. 415-430, 1920. Gives descriptions of stratigraphy, structure, occurrence, petrography, and age of igneous rocks in Roswell artesian basin.

Darton, N. H., Gypsum deposits in New Mexico: U. S. Geol. Survey Bull. 697, pp. 161-186, 1920. Gives brief descriptions of occurrence of gypsum in Pecos Valley and Sacramento Mountains.

Rich, J. L., The stratigraphy of eastern New Mexico-a correction: Am. Jour. Sci. 5th ser., vol. 2, pp. 295-298, 1921. Criticism of paper by O. L. Baker listed above. States that Baker confused sandstone called Glorieta in parts of area with Santa Rosa sandstone, also lower red-bed series with upper red-bed :series.

Darton, N. H., Permian salt deposits of the south-central United States: U. S. Geol. Survey Bull. 715, pp. 205-223, 1921. Gives brief descriptions of occurrence of salt in eastern New Mexico.

Darton, N. H., Geologic structure of parts of New Mexico:- U. S. Geol. Survey Bull. 726, pp. 173-275, 1922. Describes stratigraphy and structure of Roswell artesian basin.

Hoots, H. W., Geology of a part of western Texas and southeastern New Mexico, with special reference to salt and potash: U. S. Geol. Survey Bull. 780, pp. 33-126, 1926. Describes " red beds of Pecos Valley" and occurrence of salt series in them.

Meinzer, O. E., Renick, B. C., and Bryan, Kirk, Geology of No. 3 reservoir site of the Carlsbad irrigation project, N. Mex., with reference to water-tightness : U. S. Geol. Survey Water-Supply Paper 580, pp. 1-39, 1926. Gives detailed description of geology of a portion of the Pecos Valley between Carlsbad and Lake McMillan.

Darton, N. H., The Permian of Arizona and New Mexico: Am. Assoc. Petroleum Geologists Bull., vol. 10, pp. 819-852, 1926. Contains brief description of Permian stratigraphy of Sacramento and Guadalupe Mountains and Pecos Valley.

Darton, N. H., and Reeside, J. B., jr., Guadalupe group: Geol. Soc. America Bull., vol. 37, pp. 413-428, 1926. Contains brief description of strata exposed in southern part of the Roswell artesian basin. 
Fiedler, A. G., Report on investigations of the Roswell artesian basin, Chaves and Eddy Counties, N. Mex. : New Mexico State Engineer Seventh Bienn. Rept., pp. 21-60, 1926. Preliminary report on development of artesian water, with map showing decrease in size of area of artesian flow and with recommendations for future policy in development.

Renick, B. C., Geology and ground-water resources of the drainage basin of the Rio Penasco above Hope, N. Mex., with an introduction by O. E. Meinzer: New Mexico State Engineer Seventh Bienn. Rept., pp. 61-75, 1926. Describes occurrence of perched ground water.

Gould, C. N., and Willis, Robin, Tentative correlation of the Permian formations of the southern Great Plains: Geol. Soc. America Bull., vol. 38, pp. 431-442, 1927. Brief notes on correlation and paleogeography, with correlation chart of Permian formations of southern Kansas, central and western Oklahoma, north-central Texas. panhandle of Texas, and northeastern New Mexico.

The Roswell artesian basin, N. Mex.: Dept. Interior Press Mem. 24973, July 14, 1928. Brief description of geology and occurrence of artesian water, with map showing drainage bașin, intake area of artesian aquifers, and area of artesian flow.

Nye, S. S., Geology of the Cactus Flat reservoir site for the Hope community, N. Mex. : New Mexico State Engineer Eighth Bienn. Rept., pp. 179-188, 1928.

Fiedler, A. G., and Nye, S. S., Ground-water investigation of the Roswell artesian basin, N. Mex.: New Mexico State Engineer Eighth Bienn. Rept., pp. 81-107, 1928. Preliminary report on the geology and on the occurrence and development of the artesian water. Contains geologic map of eastern part of the artesian basin.

Darton, N. H., "Red Beds" and associated formations in New Mexico: U. S. Geol. Survey Bull. 794, 1928. Contains descriptions of geology of Sierra Blanca, Sacramento and Guadalupe Mountains, and Pecos Valley.

Davis, M. J., Artesia field, Eddy County, N. Mex.: Structure of typical American oil fields, vol. 1, pp. 112-123, 1929. Brief description of stratigraphy, occurrence, and development of oil in the Artesia field.

Lloyd, E. R., Capitan limestone and associated formations of New Mexico and Texas: Am. Assoc. Petroleum Geologists Bull., vol. 13, pp. 645-658, 1929. Contains brief notes on the formations exposed in the Roswell artesian basin.

Blanchard, W. G., jr., and Davis, M. J., Permian stratigraphy and structure of parts of southeastern New Mexico and southwestern Texas: Am. Assoc. Petroleum Geologists Bull., vol. 13, pp. 957-996, 1929. Contains descriptions of formations exposed in the Roswell artesian basin and discussion of correlation of these formations with those in Guadalupe Mountains. Includes geologic map of southeastern New Mexico and western Texas.

Willis, Robin, Preliminary correlation of the Texas and New Mexico Permian: Am. Assoc. Petroleum Geologists Bull., vol, 13, pp. 997-1032, 1929.

Fiedler, A. G., and Nye, S. S., Recommendations for a more efficient utilization of the water resources of the Roswell artesian basin, N. Mex.: New Mexico State Engineer Ninth Bienn. Rept., pp. 389-421, 1930.

\section{STRATIִGRAPHY}

\section{GENERAL RELATIONS}

The geologic formations exposed throughout most of the Roswell artesian basin belong to two rock systems of widely different agesthe Carboniferous (Permian series) and the Quaternary. The Quaternary deposits, which consist chiefly of alluvial clay, sand, and 
gravel, were laid down upon the eroded surface of the Permian rocks by the Pecos River and streams tributary to the Pecos from the west. The Permian formations comprise beds of sand, sandstone, shale, limestone, dolomite, gypsum, anhydrite, and salt, which were deposited over broad areas in basins of water and in shallow seas. They may be divided, in descending order, into an upper series of red beds, gypsum, and salt; a middle series of thick limestone; and a lower series of red beds and gypsum. The limestone series forms the east slope of the Sacramento cuesta and dips beneath the surface near the west edge of the alluvial basin. The upper red-bed series crops out extensively east of the Pecos River and forms the bluffs along the east side of the river. The lower red-bed series is partly exposed in places in the deepest canyons west of tine alluvial basin.

According to Darton ${ }^{13}$ a nearly complete section of Paleozoic strata, including rocks of Cambrian (?), Ordovician, Silurian, Devonian, Mississippian, Pennsylvanian, and Permian age, resting on pre-Cambrian granite, is exposed on the west face of the Sacramento Mountains. The Paleozoic formations are, in ascending order, the Bliss (?) sandstone (Cambrian?), the El Paso limestone (Ordovician), the Montoya limestone (Ordovician), the Fusselman limestone (Silurian), the Percha shale (Devonian), the Lake Valley limestone (Mississippian), the Magdalena group (Pennsylvanian), the Abo sanustone (Permian), the Nogal formation (Permian), and the Picacho limestone ${ }^{14}$ (Permian). They are represented diagrammatically in Figure 4. These rocks dip east, and all of them may extend beneath the Pecos Valley. Though a few of the deepest wells drilled in the Pecos Valley may have penetrated rocks of Pennsylvanian age, most of the wells probably did not reach any rocks older than the Permian; consequently it is not known whether or not Paleozoic strata older than the Pennsylvanian underlie the Pecos Valley.

The Capitan Mountains and the central portions of the Sierra Blanca and its outliers to the north are formed by large masses of intrusive igneous rocks and small masses of extrusive rocks. The great mass of rock forming the Sierra Blanca and its northern extensions was intruded along the axis of a large structural basin ${ }^{15}$ in which the Permian rocks are overlain by a thick succession of strata believed to be of Triassic (?), Cretaceous, and Tertiary (?)

\footnotetext{
13 Darton, N. H., A comparison of Paleozoic sections in southern New Mexico: U. S. Geor Survey Prof. Paper 108, p. 50, 1917: "Red Beds" and associated formations in New Mexico : U. S. Geol. Survey Bull. 794, pp. 189-210, 1928.

${ }^{14}$ Nogal formation and Picacho limestone are formation names here adopted for stratigraphic units in the Roswell artesian basin that Darton included in the Chupadera formation. The name Chupadera formation is not applied in this report to rocks in this area. (See pp. 42-52.)

${ }^{15}$ Wegemann, C. H., Geology and coal resources of the Sierra Blanca coal field, N. Mex.: U. S. Geol. Survey Bull. 541, pp. 419-452, 1914.
} 

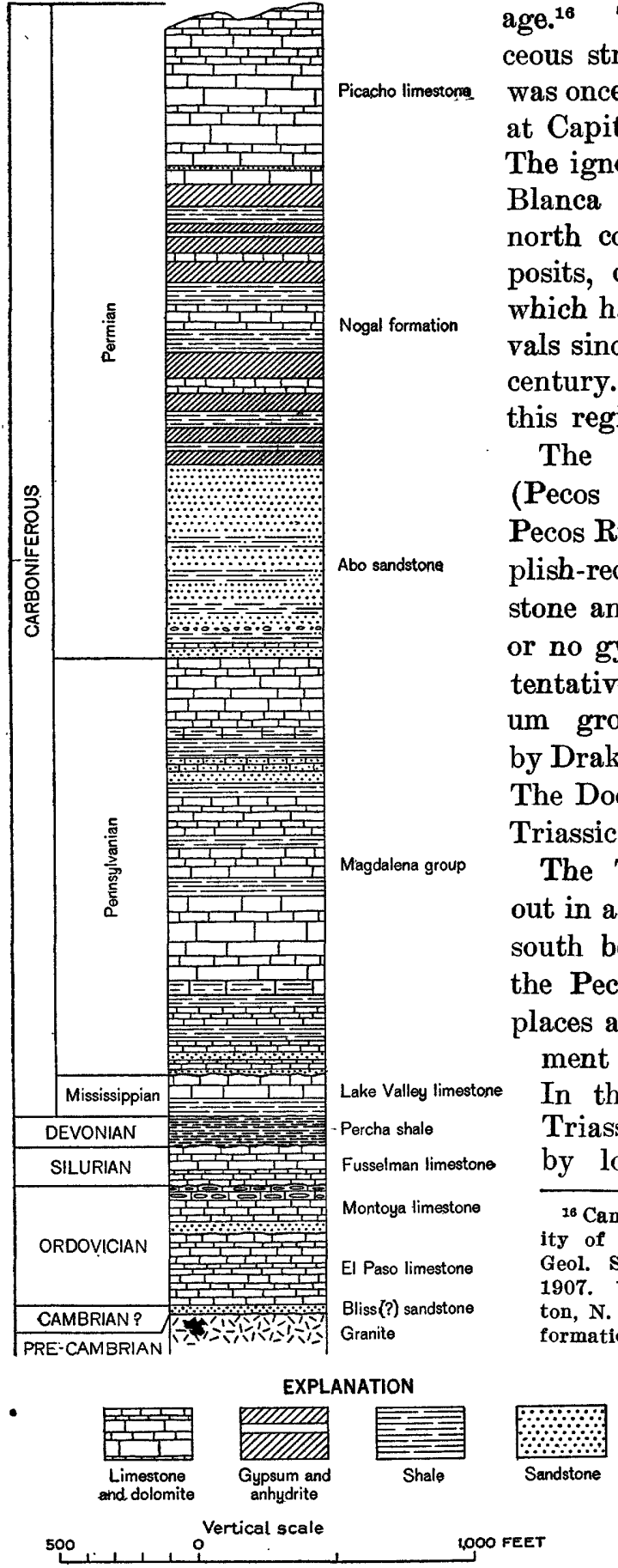

FIgure 4.-Generalized columnar section of Paleozoic formations exposed along the west front of the Sacramento Mountains age. ${ }^{16}$ The uppermost Cretaceous strata contain coal, which. was once mined in large quantity at Capitan and at White Oaks. The igneous rocks of the Sierra Blanca and its outliers to the north contain metalliferous deposits, chiefly gold and silver, which have been mined at intervals since the middle of the last century. Most of the mines in this region are now abandoned.

The gypsiferous red beds (Pecos formation) east of the Pecos River are overlain by purplish-red and red-brown sandstone and shale containing little or no gypsum, which have been tentatively assigned to the Dockum group of western Texas by Drake, ${ }^{17}$ Darton, ${ }^{18}$ and others. The Dockum group is of Upper Triassic age.

The Triassic red beds crop out in a narrow irregular northsouth belt a few miles east of the Pecos River and at a few places along the western escarpment of the Llano Estacado. In the intervening area the Triassic strata are concealed by loose sand, gravel, and

${ }^{16}$ Campbell, M. R., Coal in the vicinity of Fort Stanton, N. Mex.: U. S. Geol. Survey Bull. 316, pp. 431-434, 1907. Wegemann, C. H., op. cit. Darton, N. H., " Red Beds" and associated formations in New Mexico: U. S. Geol. Survey Bull. 794, p. 215, 1928.

${ }_{17}$ Drake, N. F., Stratigraphy of the Triassic formation of northwest Texas: Texas Geol. Survey Third Ann. Rept. for 1891, pp. 227-247, 1892.

18 Darton, $N_{\text {, H., "Red Beds" }}$ and associated formations of New Mexico, with an outline of the geology of the State: U. S. Geol. Survey Bull. 794, pp. 29, 32, 228, 234, 1928. 
caliche of Quaternary age, which are included by Darton under the general term "Mescalero sands." 19

The Llano Estacado, the western edge of which lies 25 to 35 miles east of the Pecos River, is formed by alluvial deposits of clay, sand, and gravel, capped by caliche and resting upon Triassic red beds of the Dockum group. The alluvial deposits are of Tertiary age, probably Miocene and Pliocene, according to Darton. ${ }^{20}$

\section{QUATERNARY SYSTEM GENERAL RELATIONS}

The Quaternary formations comprise extensive alluvial deposits of clay, silt, sand, gravel, conglomerate, and sandstone laid down by the Pecos River and its tributaries, scattered masses of travertine, and caliche. The alluvial deposits include valley fill and relatively thin scattered deposits of gravel, conglomerate, and sandstone that rest upon the Permian rocks at high levels. The valley fill was deposited upon a very irregular eroded surface of the Permian rocks.

CHARACTER AND DISTRIBUTION

Most of the valley fill occupies a broad irregular area, called in this report the alluvial basin, which extends approximately from Salt Creek to the North Seven Rivers and from the bluffs east of the Pecos to or near the limestone uplands.

The valley fill consists predominantly of clay, silt, and fine sand but contains large deposits of coarse sand and gravel. It is a heterogeneous mass of fine materials penetrated by irregular courses of gravel and coarse sand. As a rule the alluvial materials are unconsolidated or poorly consolidated, but in many places the coarse sand and gravel are so firmly cemented by calcium carbonate that they are recorded as " concrete" by the well drillers. The valley fill is capped by and contains irregular deposits of caliche in' many places. Masses of travertine rest upon valley fill along Cottonwood Creek, Rocky Arroyo, and the Rio Penasco.

The floors of nearly all the valleys in the outcrop areas of the Permian rocks are occupied in most places by valley fill similar in character to that in the alluvial basin.

The high-level alluvial deposits consist of scattered bodies of gravel and limestone conglomerate resting upon the Permian rocks of the upland surfaces west of the alluvial basin and high surfaces east of the Pecos River. The limestone conglomerate caps relatively small isolated mesas that project prominently above the surrounding level near Melena, along Eagle Draw north of Hope, and near the head of Cottonwood Creek.

10 Darton, N. H., op. eit., p. 59. Darton, N. H., and Reeside, J. B., jr., Guadalupe group : Geol. Soc. Ameriea Bull., vol. 37, p. 419, 1926.

${ }^{20}$ Darton, N. H., op. eit. (Bull. 794), p. 58. 
Owing to irregularities in the topography of the ancient surface upon which the valley fill was laid down, it varies considerably in thickness from place to place. As a general rule, it is about 50 to 200 feet thick on the east side of the alluvial basin and thins out westward. A number of wells near Roswell passed through 160 to 220 feet, possibly as much as 250 feet, of alluvial materials. According to the logs a few wells appear to have penetrated as much as 300 to 350 feet of alluvial materials. It was reported that the Layne well, in sec. 24 , T. 11 S., R. 25 E., encountered gravel at a depth of over 400 feet. $^{21}$

Fisher ${ }^{22}$ states that according to well records coarse gravel was encountered 500 to 700 feet below the surface in several deep wells around Artesia. According to the well records printed in his report ${ }^{23}$ gravel was found at 360 feet below the surface in a well near Roswell, at 535 and 806 feet in wells near Hagerman, and at 441, 460, and 751 feet in wells near Artesia.

The word "gravel" is used loosely by many of the drillers, and it is quite probable that the "gravels" recorded by many of them at depths of 500 to 700 feet or more below the surface may have been small fragments of broken rock or breccia in the red-bed series. However, it is not unlikely that there were many sink holes in the ancient red-bed surface upon which the valley fill was laid down and that some wells penetrated ancient sink holes filled with alluvial materials. The presence of gravel at depths of 500 to 700 feet or more below the surface in only a few wells can not be considered conclusive proof that the bottoms of the ancient valleys in the Permian rocks are so far below the present surface. The Layne well in sec. 24 , T. 11 S., R. 25 E., is the only one in which gravel is definitely known to have been encountered at a depth greater than 250 feet.

If the bottom of the ancient valley of the Pecos or one of its tributaries was about 750 feet below the present surface in the vicinity of Artesia, as is implied by the well records in Fisher's report, the surface upon which the valley fill was laid down must have been downwarped in that area at least 500 feet, for the test holes ${ }^{24}$ drilled near the Pecos a few miles south of Lake McMillan indicate that the valley fill there is less than 50 feet thick. The attitude of the Diamond A plain and of the alluvial terraces and the structure of the

21 MeCune, Paul, personal communication; report based on examination of samples.

22 Fisher, C. A., Preliminary report on the geology and underground waters of the Roswell artesian area, N. Mex.: U. S. Geol. Survey Water-Supply Paper 158, p. 9, 1906.

z Idem, pp. 11, 14, 16, and 17 .

${ }^{24}$ Meinzer, O. E., Renick, B. C., and Bryan, Kirk, Geology of No. 3 reservoir site of the Carlsbad irrigation project, N. Mex., with respect to water-tightness : U. S. Geol. Survey Water-Supply Paper 580, pp. 29-39, 1926. 
Quaternary deposits are such as to eliminate the possibility of any great amount of warping after the excavation of the alluvial basin. It is possible that from Lake McMillan southward the Pecos River may have flowed for some distance through an underground channel, but it does not seem probable that this channel could have been deep enough to allow excavation 750 feet below the present surface in the vicinity of Artesia.

A study of the well records shows that most of the wells probably passed through less than 200 feet of alluvial materials, but a few appear to have penetrated as much as 350 feet. It does not appear probable that the valley fill as a whole is much more than 300 or 350 feet thick, and at most places it is probably less than 150 feet thick.

\section{ORIGIN}

By far the greater part of the alluvial material composing the valley fill was derived from the limestone uplands and the mountains to the west and was deposited by tributaries of the Pecos River that originate principally on the eastern slopes of the Sacramento Mountains and the Sierra Blanca. A large part, however, was derived from regions to the north and was deposited by the Pecos River. The coarse material was deposited in the stream channels, and the bulk of the fine material was laid down in the interstream areas at times of high floods. The streams that laid down these materials probably subdivided and shifted constantly within the alluvial basin during the times when the deposits were being built up, and the structure reflects these changes.

STAGES OF DEPOSTTION

The valley fill was deposited during at least four stages, each of which was separated from the preceding one by a long period of erosion. Three of the stages are easily recognized in the three terraces, which have been designated, from youngest to oldest, the Lakewood terrace, the Orchard Park terrace, and the Blackdom terrace. The fourth stage is represented by quartzose conglomerate unconformably overlain by younger deposits and does not appear to be expressed as a terrace.

\section{DETERMINATION OF AGE}

The Quaternary deposits are divided on the geologic map (pl. 3) into three units-Recent alluvium, undifferentiated alluvial deposits, and Pleistocene limestone conglomerate. Only the larger areas of Quaternary deposits were mapped. The valley fill in the areas of outcrop of the Permian formations and the scattered deposits of gravel on the upland surfaces west of the alluvial basin were not mapped. 
The geologic age assigned to these deposits is based upon physiographic evidence, for no fossils were found in them. The Llano. Estacado, east of this area, is composed of alluvial materials that are considered to have been deposited by streams flowing eastward and southeastward from the Rocky Mountains and possibly from the mountains west of the Pecos Valley. The Llano Estacado is therefore considered to be a remnant of a vast débris apron which extended westward to the mountains and probably covered this entire area. The date of the building of the great débris sheet, so far as. included fossil remains would seem to determine it, might range anywhere from middle Tertiary to early Pleistocene. ${ }^{25}$

The Pecos established its drainage and removed the western extension of the great débris apron that once covered this area after the materials capping the Llano Estacado were deposited. The surficial materials overlying the Permian strata in the Roswell artesian basin were deposited after the extensive erosion of this. débris apron. Hence they are much younger than the deposits of the Llano Estacado and are probably not older than the Pleistocene. Consequently the surficial materials within the area shown on the geologic map (pl. 3) are believed to range in age from Pleistoceneto Recent.

The alluvium composing the Lakewood terrace was deposited during the Recent epoch of geologic time. The alluvial materials. of the Orchard Park and Blackdom terraces are probably all of Pleistocene age, although it is possible that those of the Orchard Park terrace may have been deposited during the early part of theRecent epoch. The relative age of the quartzose conglomerate is discussed on pages 109-110. The gravel deposits found on the high upland surface about 600 feet above the present channel of the Rio Hondo near Picacho may be of late Pliocene age, but it is believed that they are early Pleistocene.

\section{RECENT SERIES}

ALLUVIUM

The materials laid down during the Recent epoch consist of the unconsolidated alluvial deposits that underlie the Lakewood terrace and the loose materials in the present channels of the streams, which are much younger and consist largely of coarse sand, gravel, cobbles, and boulders that are constantly being shifted and transported by floods.

Most of the Recent alluvial materials that were mapped were deposited by the Pecos River and occupy a narrow strip of land about

20 Haworth, Erasmus, Physical properties of the Tertiary : Kansas Univ. Geol. Survey. vol. 2, p. 280, 1897. Cited by Johnson, W. D., The High Plains and their utilization: U. S. Geol. Survey Twenty-first Ann. Rept., pt. 4, pp. 629-631, 1901. 
1 to 4 miles wide, the Lakewood terrace, adjoining the Pecos on each side. Mappable amounts also occur near the Pecos along the Rio Hondo, Cottonwood Creek, the Rio Penasco, and the Seven Rivers. Smaller amounts occur in and along all the tributary streams. The Recent alluvium of the Lakewood terrace is 30 feet thick in many places and is probably as much as 50 feet thick in some places near the Pecos. Its maximum thickness, however, is not known.

The alluvium composing the Lakewood terrace is chiefly brown silt with interbedded lenses of gravel and sand. West of the alluvial basin it usually rests upon the eroded surface of the Permian rocks. Within the alluvial basin it generally rests unconformably upon older alluvial deposits, although there also it lies in places upon the Permian rocks. As a general rule it is distinguished lithologically from the older alluvial deposits by two prominent characteristics-the materials of which it is composed are nearly everywhere unconsolidated, and the silt is dominantly medium to dark brown, whereas the silt in the older deposits is usually light tan or reddish tan, and much of it is more firm. Most of the silt in the Recent alluvium is very calcareous. It generally forms a dark-brown loamy soil that is very fertile, but in many places near the Pecos River, especially in the swampy areas, it contains a considerable amount of "alkali" and is unfit for cultivation. In the valley of Salt Creek, northeast of Roswell, the Recent alluvium includes a large amount of gypsite or earthy gypsum. The gravel is predominantly made up of subangular to well-rounded limestone pebbles derived from the limestone uplands west of the alluvial basin, but in the northern part of the area it contains minor amounts of igneous and quartzose pebbles. The proportion of coarse sand and gravel in the Recent terraces increases westward.

The beds of the larger tributary streams west of the Pecos contain large amounts of coarse materials. Westward from the mouths of the streams the proportion of sand and silt to gravel decreases and the size of the pebbles and cobbles increases. Near the western edge of the alluvial basin the channels of the larger streams are choked with large limestone pebbles, cobbles, and boulders. Many of the boulders are over 2 feet in diameter. North of the Rio Felix the channels of the larger streams contain appreciable amounts of wellrounded pebbles and small cobbles derived from gray, green, and purple porphyritic igneous rocks in the Sierra Blanca and the Capitan Mountains. No igneous pebbles were found in the stream channels south of the Rio Felix.

TRAVERTINE DEPOSITS

Travertine is composed chiefly of calcium carbonate and is commonly deposited by springs. Large masses of travertine are scattered 
along Cottonwood Creek in the northeastern part of T. 16 S., R. 24 E., and the northwestern part of T. 16 S., R $25 \mathrm{E}$. The travertine rests upon alluvial materials on and near the banks of the stream and was therefore formed during Recent or late Pleistocene time. It is probably of Recent age and was probably deposited by springs. It is spongelike and very porous. Certain sides of the travertine are lined with peculiar mammiform crusts. The travertine masses are as much as 6 to 8 feet in largest dimension. Their character and appearance are shown in Plate $8, A$.

Large masses of travertine occur also along Rocky Arroyo in T. 21 S., R. 25 E., and along the Rio Penasco in T. 16 S., Rs. 16 and $17 \mathrm{E}$., and in T. 17 S., R. 18 E. The travertine deposits along the Rio Penasco are described by Renick. ${ }^{26}$

\section{PLEISTOCENE SERIES}

UNDTFFERENTIATED ALLUVIAL DEPOSITS

The term "undifferentiated alluvial deposits" is applied here, for convenience, to the surficial materials underlying the Orchard Park and Blackdom terraces within the alluvial basin. The general term "valley fill," used above, includes these undifferentiated deposits and the deposits underlying the Lakewood terrace.

The undifferentiated alluvial deposits are chiefly the result of three stages of deposition separated by considerable periods of erosion during which the deposits of the earliest stage were deformed and eroded. The earliest stage is not expressed in the present topography as a terrace but is represented in many places by quartzose conglomerate and firmly cemented sandstone, mudstone, and shale, which in places are very distinct lithologically and structurally from the deposits of the later stages. The deposition of these materials was followed by an interval of erosion during which the deposits were deformed in places as a result of the removal by solution of underlying rocks. During the second stage of deposition the alluvial basin was filled about to the level of the Blackdom terrace. After the formation of the Blackdom terrace there was a long interval of erosion during which valleys were eroded to a depth of 50 feet or more below its surface and to a width of half a mile to several miles. This was followed by the deposition of the materials forming the Orchard Park terrace. To simplify discussion the materials laid down during the three stages of deposition from youngest to oldest will be referred to hereafter as the deposits of the Orchard Park terrace, the deposits of the Blackdom terrace, and the quartzose conglomerate.

20 Renick, B. C., Geology and ground-water resources of the drainage basin of the Rio Penasco above Hope, N. Mex., with an introduction by O. E. Meinzer: New Mexico State Engineer Seventh Bienn. Rept., pp. 121, 123, 1926. 
Deposits of the Orchard Parte terrace.-The deposits of the Orchard Park terrace (see pl. 4) are very similar in general character to those of the Blackdom terrace and at many places are difficult to distinguish from them lithologically or structurally. As the relations are not clearly defined, the thickness of the deposits of the Orchard Park terrace is not definitely known but does not appear to be more than 20 feet. They appear to be simply a thin veneer of alluvial materials laid down on the erosion surface developed after the formation of the Blackdom terrace.

The deposits of the Orchard Park terrace consist chiefly of gravel, sand, and clay derived from the limestone uplands, from the Sacramento Mountains and the Sierra Blanca, and from the deposits of the Blackdom terrace.' As a whole they are unconsolidated or poorly consolidated, although in places the gravel is fairly well cemented by calcium carbonate. These deposits differ from the deposits of the Blackdom terrace chiefly in that they are usually much less consolidated, the gravel consists of smaller pebbles, and the clay is somewhat darker in color. These distinctions, however, are not everywhere sharply defined.

The gravel of the Orchard Park terrace varies considerably in character and composition. In the northern half of the alluvial basin it consists of fragments of limestone and igneous and quartzose rocks; in many places in the general vicinity of Roswell 40 to 50 per cent or more of the pebbles and cobbles are derived from igneous rocks. In the southern half of the basin the gravel consists almost entirely if not entirely of limestone pebbles and cobbles, and no igneous or quartzose pebbles were found on the Orchard Park terrace south of the Rio Felix. The average size of the larger pebbles is generally between 1 and 2 inches, although in places there are many cobbles 4 or 5 inches in longest dimension. These cobbles may have been derived from the deposits of the Blackdom terrace. The pebbles and cobbles are subangular to well rounded. The limestone pebbles are light to dark gray and black. They are derived from the limestone uplands and from the Sacramento and Guadalupe Mountains. The dark-gray and black limestone pebbles and cobbles are usually fossiliferous and are derived chiefly from the lower part of the Picacho limestone. The igneous pebbles and cobbles are gray, green, purple, and red and are derived almost entirely from the porphyritic igneous rocks in the Sierra Blanca and the Capitan Mountains. The igneous pebbles are generally less than 2 inches in diameter and are in places fairly well rounded, although igneous cobbles 4 or 5 inches in diameter are not uncommon. The quartzose pebbles consist of milky quartz, chert, jasper, and yellowish chalcedony. They are probably derived originally from regions to the 
north, presumably having been transported into this area by the Pecos River, although many were undoubtedly derived from the igneous rocks in the mountains on the west and from masses of chert found in the Picacho limestone. As a general rule the quartzose pebbles are smaller and better rounded than the igneous and limestone pebbles. They are usually less than 1 or $1 \frac{1}{2}$ inches in diameter.

The silt and clay in the deposits of the Orchard Park terrace are usually light brown to light tan and are calcareous. They are noticeably lighter colored than the silt in the Recent deposits, but in many places they do not differ greatly from those in the deposits of the Blackdom terrace. The deposits of the Orchard Park terrace in some places consist of a heterogeneous mixture of silt and gravel; in other places there is a thin veneer of pebbles on a surface consisting largely of silt and fine sand.

In many parts of the area the Orchard Park terrace appears to have been formed largely by the erosion of the Blackdom terrace by rain wash and small streams originating on the Blackdom terrace. Consequently the deposits of the Orchard Park terrace in these places are simply reworked and redeposited materials from the deposits of the Blackdom terrace.

In most places the deposits of the Orchard Park terrace rest upon the lower deposits of the Blackdom terrace, but in others they rest upon quartzose conglomerate or upon Permian rocks. The relations between the deposits of the Orchard Park terrace and the Recent deposits may be seen in many places, but they are most clearly revealed along the north bank of El Macho Creek where it is crossed by the Roswell-Vaughn highway, a few miles north of the alluvial basin. (See figs. 5 and 6.) The alluvial materials underlying the Orchard Park terrace are probably all of Pleistocene age, although it is possible that a part may have been deposited during the Recent epoch of geologic time.

Deposits of the Blackdom terrace.-The deposits of the Blackdom terrace (see pl. 4) are most clearly exposed along the edges of the remnants of this terrace. They also underlie the deposits of the Orchard Park terrace and the Recent deposits in many places and are penetrated by numerous wells in the artesian area. They consist largely of lenticular beds of gravel, conglomerate, sand, sandstone, clay, and silt. The deposits are nearly everywhere undeformed, but near the southwest corner of T. 12 S., R. 24 E., there are several low, rather narrow, elongated hills, which appear to be in line with the Y-O fault and may be due to movements along that fault, although there is no other evidence to support this conclusion.

The deposits of the Blackdom terrace consist predominantly of materials derived from the limestone uplands and the Sacramento Mountains and were deposited largely by streams originating in these 
uplands and mountains. Some of the materials were derived from the Sierra Blanca and the Guadalupe and Capitan Mountains and

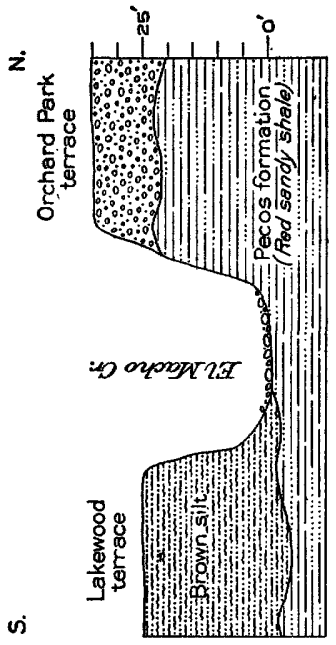

เง

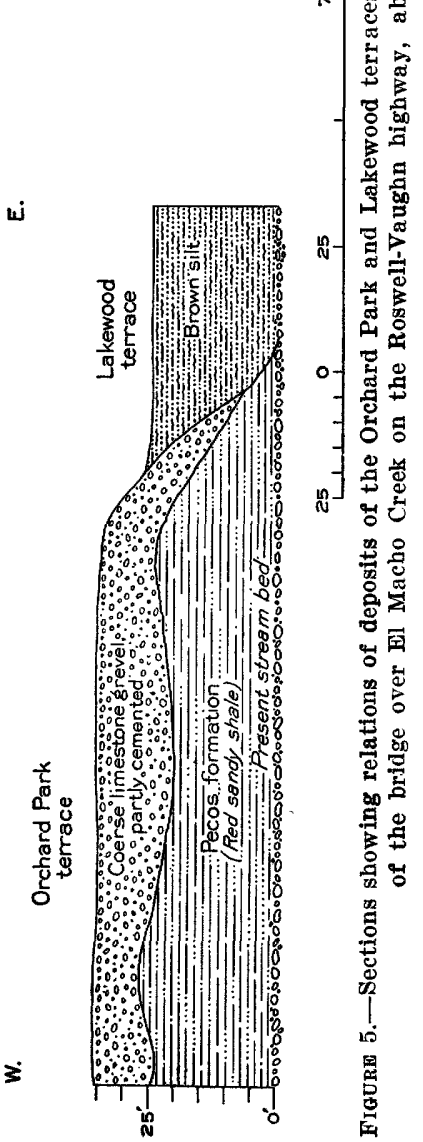

from regions to the north, but they constitute only a minor portion of the deposits as a whole. Except near the surface of the Blackdom terrace the gravel and sand in these deposits are usually fairly well cemented by calcium earbonate, and in places they are firmly cemented, forming hard con-

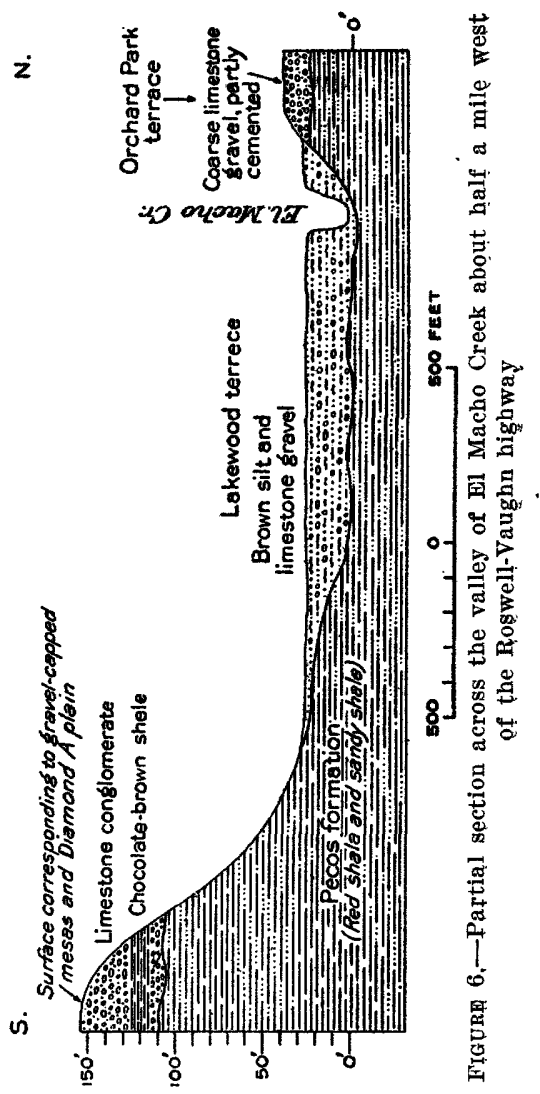

glomerate and sandstone. A bed of conglomerate about 5 feet thick forms a ledge along the side of a wash in sec. 6, T. 10 S., R. 24 E. The pebbles and cobbles in the conglomerate have a considerable range in size; the largest are about 6 inches, but the average is about 2 inches. They are subangu- 
lar to well rounded and consist chiefly of dark-gray limestone, but there are a few quartzose and igneous pebbles. Some of the limestone pebbles are fossiliferous. Loose boulders of light to dark gray and black limestone occur on the slope at the base of the ledge of conglomerate.

Coarse conglomerate is exposed along the south bank of Walnut Draw in T. 15 S., R. 24 E. It consists of pebbles averaging 1 to 2 inches in size in a matrix of coarse sand and lime cement. Most of these pebbles are limestone, but many are igneous or quartzose. Some of the limestone pebbles are dark gray and fossiliferous; the igneous pebbles are gray, green, and purple porphyritic rock; and the quartzose pebbles are chiefly jasper and yellowish chalcedony. There are a few large cobbles and boulders as much as 8 or 9 inches in longest dimension scattered through the conglomerate. Several other exposures of coarse conglomerate and a few outcrops of white coarse sandstone containing lenses of conglomerate were found in this township.

As a general rule the beds of gravel and conglomerate in the deposits of the Blackdom terrace contain a much larger proportion of large pebbles and cobbles than those in the deposits of the Orchard Park terrace, and the average size of the larger pebbles and cobbles is also greater. This applies especially to the deposits near the western edge of the Blackdom terrace, where there are numerous cobbles and boulders from 6 inches to a foot or more in diameter. A large percentage of the pebbles and cobbles are 2 to 4 inches in longest dimension. The bluffs on the south side of the Rio Felix in T. 14 S., R. 23 E., are veneered with numerous limestone boulders from about 8 inches to over a foot in diameter. Most of the cobbles and nearly all of the boulders are limestone and are subangular to fairly well rounded. In the northern part of the area the gravel and conglomerate contain many igneous and quartzose pebbles, although these constitute but a small percentage of the total. No igneous or quartzose pebbles were observed in the deposits of the Blackdom terrace south of the Cottonwood.

Solution-faceted limestone pebbles ${ }^{27}$ were found in gravel deposits partly cemented by caliche or calcium carbonate at several places along the Rio Felix and in a gravel pit near the Artesia-Hope highway in the SW. $1 / 4$ SW. $1 / 4$ sec. 17, T. 17 S., R. 24 E. The pebbles are shown in Plate $8, B$. They have a concave upper surface, which in many of them has no definite relation to the original shape of the pebble but is roughly parallel to the land surface. The under sides

\footnotetext{
${ }^{27}$ Bryan, Kirk, Solution-faceted pebbles: Am. Jour. Sci., 5th ser., vol. 18, pp. 193-208, 1929. Solution-faceted pebbles were first pointed out to the writer by Mr. Bryan, who observed them in many places on the surface near the Avalon Reservoir, north of Carlsbad. Similar pebbles were found in the gravel pit near Hope by Mr. Bryan and the writer.
} 
of the pebbles are rounded. These pebbles occur chiefly in the upper 3 or 4 feet of the gravel deposit, where it is cemented by caliche. Very few solution-faceted pebbles were found where there is no caliche. The caliche is hard at the top and decreases in firmness downward. The remainder of the gravel deposit consists of subrounded to rounded limestone pebbles and cobbles, many of which are 8 inches in diameter, and a few boulders as much as 2 feet in diameter. Most of the pebbles are 2 to 3 inches in diameter and are imbricated toward the east. The gravel in the lower part of the pit is poorly cemented. The solution-faceted pebbles testify to the slowness with which the upper part of the gravel deposit was built up.

Most of the clay and silt in the deposits of the Blackdom terrace is yellowish to reddish tan and reddish brown, but some is light to dark bluish gray. The reddish-tan or reddish-brown clay and the bluish-gray clay are often recorded by drillers as "red clay" and "blue clay," respectively. The clay and silt are very calcareous and are usually well compacted. In several places lumps or nodules of white lime were observed in reddish-tan clay near the surface. The lumps of lime decreased in size and number downward.

The sand in these deposits is generally composed of subangular to rounded quartz and limestone grains. The fine sand is usually argillaceous and calcareous, but deposits of very coarse clean sand have been encountered in wells. In places the sand is firmly cemented by calcium carbonate, forming hard sandstone.

The deposits of the Blackdom terrace rest unconformably upon quartzose conglomerate and upon Permian rocks. The maximum thickness of these deposits where they are exposed is at least 80 feet and may be considerably more.

Quartzose conglomerate.-Very firmly cemented quartzose conglomerate, sandstone, mudstone, and well-indurated shale were found underlying the deposits of the Orchard Park and Blackdom terraces along the Rio Felix in the SW. 1/4 sec. 17 and SW. 1/4 sec. 18, T. 14 S., R. 25 E., and along Walnut Draw near the southeast corner of sec. 20 , T. 15 S., R. 25 E. In the SW. $1 / 4$ sec. 18 , T. 14 S., R. 25 E., and near the southeast corner of sec. 20 , T. 15 S., R. 25 E., the quartzose conglomerate is tilted toward the east at angles of $7^{\circ}$ and $16^{\circ}$, respectively, and is beveled by an irregular pre-Blackdom erosion surface. In the SW. $1 / 4$ sec. 17, T. 14 S., R. 25 E., there is no appreciable discordance in bedding between the quartzose conglomerate and the overlying deposits of the Blackdom terrace, but there is an erosional unconformity between the two. A veneer of quartzose gravel and outcrops of quartzose conglomerate were found in many places in Tps. 14 and 15 S., R. $25 \mathrm{E}$. 
The quartzose conglomerate and associated strata are quite distinct lithologically from the younger alluvial deposits. The conglomerate is predominantly composed in most places of pebbles of milky quartz, yellowish to light olive-green chalcedony, and jasper in a matrix of coarse sand firmly cemented by calcium carbonate. The pebbles are usually separated from one another by the sand. Most of them are angular to subrounded, but some are well rounded. The largest are 1 or 2 inches in diameter, but most of them are less than half an inch, and a large proportion are less than a quarter of an inch. The conglomerate also contains in places a few wellrounded purple, lavender, and green igneous porphyry pebbles and varying amounts of subrounded to well rounded limestone pebbles. 1 to 3 inches in diameter. Locally the conglomerate grades within a few feet into a conglomeratic grit composed of angular to subangular quartzose fragments and pebbles less than a quarter of an inch in size, and in places into a coarse sandstone. These variations in texture and composition may occur within a single bed. Many of the angular fragments appear to be broken parts of well-rounded quartzose pebbles. In many places the conglomerate is composed almost entirely of quartzose pebbles and grit, and in others it grades: into coarse conglomerate composed chiefly of large limestone pebbles. in a matrix of coarse sand, with a few quartzose pebbles and occasional small lenses of quartzose grit or fine conglomerate. In many. places the quartzose sandstone, grit, and fine conglomerate are crossbedded at low angles. The conglomerate and grit are very hard and are so firmly cemented that when broken with a hammer the fracture cuts across the pebbles and fragments.

Hard argillaceous fine sandstone, mudstone, sandy shale, and shale are irregularly interbedded with the quartzose conglomerate, grit, and coarse sandstone. They are distinctly different from the fine materials in the younger alluvial deposits, chiefly in that they are well indurated and prominently stratified, and some are variegated in color. Many of the beds are 1 to 3 inches thick and are lenticular. The colors are light tan, yellow, pink, red, greenish yellow, and gray.

The outcrop of quartzose conglomerate and associated strata along the north bank of the Rio Felix in the SW. 1/4 sec. 18, T. 14 S., R. 25 $\mathrm{E}$., is shown in Plate $6, B$, and the relation of these deposits to the deposits of the Orchard Park terrace and the Recent deposits is shown in Figure 7. One of the beds of quartzose conglomerate and sandstone is 4 feet thick. The quartzose conglomerate here dips about $7^{\circ} \mathrm{E}$. and is overlain by the deposits of the Orchard Park terrace, which are 3 to 5 feet thick and consist of poorly cemented limestone pebbles and cobbles. The quartzose conglomerate exposed in the channel of Walnut Draw near the south quarter corner of: 
sec. 20 , T. 15 S., R. 25 E., dips steeply to the northeast and forms small cuestas and hogbacks in the bed of the stream. The strike of the beds of quartzose conglomerate at this place is $\mathrm{N} .25^{\circ} \mathrm{W}$., and the dip is about $16^{\circ} \mathrm{NE}$. The deposits here are fine quartzose conglomerate with a few scattered pebbles 2 to 3 inches in diameter, conglomeratic grit, light-brown coarse sandstone, yellow argillaceous fine sandstone, and reddish shale. In places the light-brown sandstone contains red clay balls and streaks of carbonaceous material. The quartzose conglomerate and associated strata at this place $u$ rest upon Permian red beds (Pecos formation) and are overlain by younger alluvial deposits.

The most noticeable differences between the quartzose conglomerate deposits and the younger alluvial deposits are that the former are usually well stratified, firmly cemented or indurated, and at some places deformed, whereas the latter are commonly rather structureless as a whole, unconsolidated or poorly cemented and indurated, and nearly everywhere undeformed. The quartzose conglomerate deposits also differ strikingly in lithology. The quartzose materials were presumably deposited chiefly by the Pecos River, for they appear to be derived largely from regions north of the alluvial basin. However, Boyer and Hansen ${ }^{28}$ state that the coal measures in the Sierra Blanca region are overlain by a series of conglomerate and sandstone beds 600 to 800 feet thick, which is regarded by them as fluviatile in origin and of Eocene (?) age. The conglomerate is said to consist of subangular to wellrounded gray, yellow, red, and brown chert pebbles. The quartzose pebbles in the con-

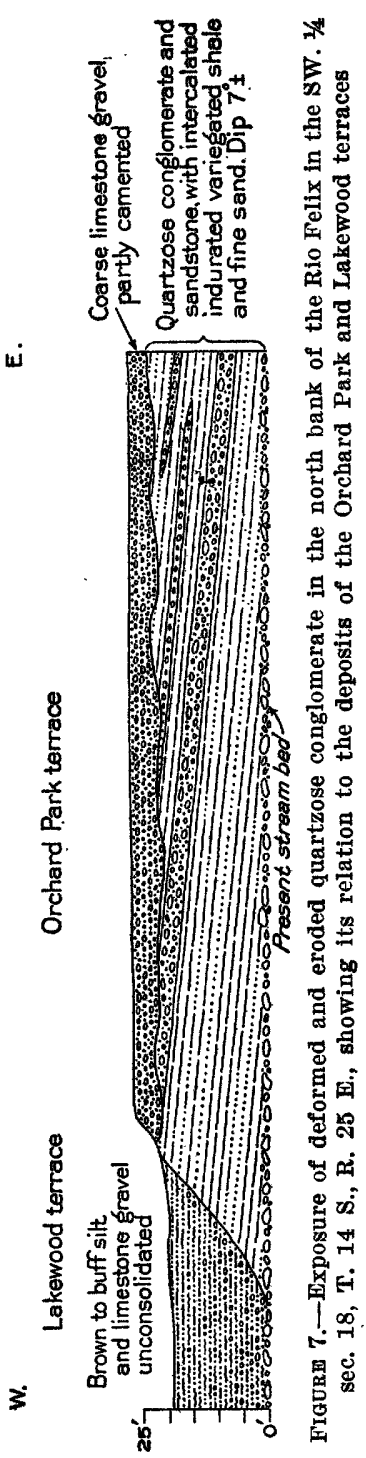
glomerate in the alluvial basin may have come originally from regions to the north but they may have been derived in part from the conglomerate and sandstone beds overlying the coal measures in the Sierra Blanca region.

${ }^{28}$ Boyer, W. W., and Hansen, G. H., Eastern part of the Sierra Blanca coal fleld, N. Mex. : U. S. Geol. Survey unpublished report.

135252-33-4 
The deformation of the quartzose conglomerate deposits appears to be due chiefly to slumping caused by the solution and removal of underlying soluble rocks, for the deformation is much greater in places than the regional deformation of the Permian rocks.

The maximum thickness of these deposits is not known, for they were not identified in well records. They presumably underlie most of the eastern half of the alluvial basin, and if so they may be as much as 100 to 200 feet thick in places. . The quartzose conglomerate in this area is very similar lithologically, structurally, and in stratigraphic position to the quartzose conglomerate in the No. 3 reservoir site of the Carlsbad irrigation project, described by Meinzer, Renick, and Bryan. ${ }^{29}$ Although the quartzose conglomerates in the two areas may not be contemporaneous and continuous, they are of approximately the same geologic age. The age of the quartzose conglomerate is considered further on pages 109-110.

\section{LIMESTONE CONGLOMERATE}

The limestone conglomerate capping the high mesas near Melena, along Eagle Draw north of Hope, and near the heads of Cottonwood Creek is believed to be of Pleistocene age. It is certainly much younger than the deposits capping the Llano Estacado. It corresponds approximately to the limestone conglomerate 150 to 185 feet above the Pecos River in the No. 3 reservoir site of the Carlsbad irrigation project. ${ }^{30}$ The conglomerate is 5 to 20 feet thick and rests unconformably upon red beds and limestone of Permian age. It is similar in appearance and composition to many of the conglomerates in the deposits of the Blackdom terrace, but it is very much older.

The conglomerate capping the mesas near Melena ranges in texture from a coarse-grained cross-bedded sandstone to coarse conglomerate. It is dominantly composed of light to dark gray limestone pebbles but contains many white, yellow, and milky quartz pebbles and a few of red and purple quartzite and buff sandstone. It also contains limestone cobbles and boulders ranging in size from several inches to about 1 foot. Most of the quartzose pebbles are less than half an inch in diameter. The pebbles are subangular to well rounded. The conglomerate is firmly cemented and hard. There are high hills 8 to 11 miles north of Roswell which are capped with gravel and limestone conglomerate and which appear to be dissected remnants of a surface that was once continuous with that of the mesas near Melena. The conglomerate is similar in character to that

\footnotetext{
${ }^{20}$ Meinzer, O. E., Renick, B. C., and Bryan, Kirk, Geology of No. 3 reservoir site of the Carlsbad irrigation project, N. Mex., with respect to water-tightness: U. S. Geol. Survey Water-Supply Paper 580, pp. 9-10, 1926.

so Idem, p. 8.
} 
just described. 'The conglomerate capping the high mesas north of Hope contains igneous pebbles similar to those in the alluvial fill, many dark-gray fossiliferous limestone pebbles and cobbles, and fewer quartzose pebbles. Otherwise it is very similar in composition and coarseness to the limestone conglomerate near Melena.

The conglomerate near Melena may have been deposited by the Pecos River, although the limestone pebbles, cobbles, and boulders and perhaps some of the siliceous pebbles were derived from the Permian limestone in the western uplands. Most of the siliceous pebbles probably originated in regions to the north, although the pebbles in these deposits may have been derived from the conglomerate and sandstone beds overlying the coal measures in the Sierra Blanca region. All the materials in the conglomerate forming the high mesas north of Hope were derived from the western uplands and mountains and were deposited by streams tributary to the Pecos.

HIGH-LEVEL GRAVEL DEPOSITS

Relatively small thin deposits of gravel were found at several places on the Diamond A plain west of the alluvial basin and on the high surfaces east of the Pecos River. Some of the gravel deposits on the Diamond A plain are 15 to 20 miles west of the alluvial basin. Those near the Rio Hondo consist of both igneous and limestone pebbles; those near the Rio Penasco consist solely of limestone pebbles. The gravel found on the high surfaces east of the Pecos River is composed almost entirely of siliceous pebbles.

As the gravel-capped mesas near Melena and north of Hope appear to correspond to the Diamond A plain the gravel deposits on this plain are probably of the same general age as the limestone conglomerate of the mesas. The plains between the Pecos River and the Llano Estacado were not studied in detail, and the relative ages of the gravel deposits on them are not known.

The gravel deposits found about 600 feet above the present channel of the Rio Hondo near Picacho are made up of igneous and limestone pebbles. They are much older than those of the Diamond A plain and may have been deposited during late Tertiary time, although it is possible that they are of Pleistocene age.

\section{CALICHE}

Caliche, consisting chiefly of calcium carbonate, is very commonly developed in this region at or near the surface by the evaporation of water containing calcium carbonate and other substances in solution. Within the alluvial basin it is most commonly found at the surface on the Blackdom terrace. Caliche is also commonly found lining watercourses in the limestone uplands. Many wells are re- 
ported to have encountered caliche at various depths in the valley fill. The valley fill was built up in several stages. Consequently caliche deposits were formed at or close to the surfaces existing at different times and were subsequently buried beneath later alluvial materials.

The deposits of caliche on the surface of the Blackdom terrace have the appearance, at first glance, of thin beds of impure bedded limestone and are commonly mistaken for limestone in the Permian series. The weathered surface of the caliche is often white and looks like a whitewashed rock. Broken fragments of the rock reveal a banded structure. The bands are roughly parallel to the upper surface and are light brown, light gray, and white. The brown bands have the appearance of flint. The caliche on the Blackdom terrace is in general firmly cemented and hard, but 3 to 5 feet of white, rather soft and chalklike caliche was found along the Rio Penasco due west of Dayton. The thin beds of caliche on the Blackdom terrace are usually but a few inches thick. Many of the gravel deposits capping the terrace, however, are cemented with caliche to a depth of 3 or 4 feet. The caliche is usually hard near the surface and decreases in firmness downward. The buried caliche in the alluvial fill is in places several feet thick, and some of it is very hard.

Small nodules of caliche and rather soft white caliche are common in the upper few feet of the deposits of the Orchard Park terrace, but caliche is not so common in these deposits as it is in the deposits of the Blackdom terrace.

The caliche lining stream courses in the limestone uplands is rather soft and looks like slaked lime or like the weathered surface of the caliche on the Blackdom terrace.

\section{TERTIARY SYSTEM}

The Llano Estacado is formed of alluvial deposits of clay, sand, and gravel, generally 200 to 300 feet thick, which are considered to be chiefly of late Tertiary age (Miocene and Pliocene), though the upper part in places is regarded as early Pleistocene. ${ }^{31}$ They rest upon Triassic and Permian red beds.

Boyer and Hansen ${ }^{32}$ state that between Capitan and Ruidoso the coal-bearing series is overlain by 600 to 800 feet of sediments consisting chiefly of massive beds of gray to yellowish conglomerate and sandstone, with intercalated beds of drab to grayish-brown sandstone and shale. The conglomerate is said to consist largely of gray, yellow, and brown subangular to well-rounded chert pebbles with an

\footnotetext{
${ }^{31}$ Johnson, W. D., The High Plains and their utilization: U. S. Geol. Survey Twentyfirst Ann. Rept., pt. 4, pp. 629-631, 1901. Baker, C. L., Geology and underground waters of the northern Llano Estacado: Texas Univ. Bull. 57, pp. 32, 34, 1915.

so Boyer, W. W., and Hansen, G. H., Eastern part of the Sierra Blanca coal fleld, N. Mex. : U. S. Geol. Survey unpublished report.
} 
abundance of sand grains, the largest of which are 4 or 5 millimeters in diameter. No fossils were found in these sediments, but they are tentatively regarded by Boyer and Hansen as Eocene and are considered to have been deposited by streams. It is stated that these sediments appear to be as highly folded as the underlying coalbearing series and that they have been intruded by igneous rocks.

\section{CRETACeOUS SYSTEM}

Strata of Cretaceous age are apparently absent in southeastern New Mexico east of the Pecos River, but there are Cretaceous strata in the Sierra Blanca region which have been described by Campbell ${ }^{33}$ and Wegemann. ${ }^{34}$ The two lower formations given in Wegemann's general section are doubtless the Picacho limestone and the Nogal formation, respectively, and according to him the Cretaceous strata presumably rest directly upon the Permian. Darton, ${ }^{85}$ however, states that the Morrison (?) formation rests upon "red beds presumably of the Dockum group" (Upper Triassic). It appears possible that the red beds mentioned by Darton may belong to the Pecos formation and may therefore be of Permian age.

\section{TRIASSIC SYSTEM}

Red sandstone and shale overlying the gypsiferous red-bed series (Pecos formation) east of the Pecos River are considered to belong to the Dockum group, which is of Upper Triassic age. These strata were first described and correlated with the Dockum group of Texas by Drake, ${ }^{36}$ who accompanied W. F. Cummins on his trip down the Pecos Valley in 1891.

The Triassic red beds are similar to the Permian red beds but differ chiefly in that they contain little or no gypsum and anhydrite and that their red color is darker and has a somewhat purplish hue. The criteria for differentiating the Triassic strata from the Permian red bed and gypsum series are discussed in some detail by Adams. ${ }^{37}$ Darton $^{38}$ states that red-brown sandstone exposed in places east of the Pecos River is tentatively regarded by him "as a possible southern extension of the Santa Rosa sandstone, here the basal formation of the Dockum group."

\footnotetext{
Campbell, M. R., Coal in the vicinity of Fort Stanton Reservation, Lincoln County, N. Mex.: U. S. Geol. Survey Bull. 316, pp. 431-434, 1907.

34 Wegemann, C. H., Geology and coal resources of the Sierra Blanca coal field, Lincoln and Otero Counties, N. Mex.: U. S. Geol. Survey Bull. 541, pp. 425-433, 1914.

${ }^{35}$ Darton, H. H., " Red Beds" and associated formations in New Mexico, with an outline of the geology of the State: U. S. Geol. Survey Bull. 794, p. 215, 1928.

${ }^{30}$ Drake, N. F., Stratigraphy of the Triassic formation of northwest Texas : Texas Geol. Survey, Third Ann. Rept., pp. 227-247, 1892.

${ }^{87}$ Adams, J. F., Triassic of west Texas : Am. Assoc. Petroleum Geologists Bull., vol. 13, pp. 1045-1054, 1929.

Darton, N. H., op. cit. (Bull. 794), p. 234.
} 
The Triassic strata are largely concealed by loose sands east of the Pecos River and farther east by the Tertiary sediments forming the Llano Estacado. Throughout the artesian basin west of the Pecos River they have apparently been removed by erosion, except possibly in the Sierra Blanca region, where, according to Darton, there are red beds overlying the Morrison (?) formation (Lower ? Cretaceous), which he tentatively assigns to the Dockum group.

\section{CARBONIFEROUS SYSTEM}

\section{PERMIAN SERIES}

\section{FORMATIONS INCLUDED}

The Permian strata in all but the southeastern part of this region may be divided into three distinct lithologic units-(1) an upper series of red beds, gypsum, and salt, (2) a thick series of limestone and dolomitic limestone, and (3) a lower series of red beds, gypsum, and salt, which on the west slope of the Sacramento Mountains may be seen to rest on the Abo sandstone. ${ }^{39}$ In the southeast corner of the area shown on the geologic map (pl. 3) a tongue of thin-bedded magnesian limestone projects from the south into the upper red-bed series and thins out (in the outcrop) almost due east of Lakewood. North of this point the strata above and below the limestone tongue merge and form a single gypsiferous red-bed series (unit 1), part of which is well exposed in the bluffs east of the Pecos River and parallel to it. Strata belonging to the lower part of the red-bed series also crop out in several places west of the Pecos, notably in the upper drainage basin of Cottonwood Creek and in the drainage basin of the Seven Rivers. The middle limestone series (unit 2) caps the Sacramento Mountains and forms the long, gentle east slope of the mountains. It passes beneath the surface at or near the west margin of the alluvial basin and extends underground far to the east. The artesian water is derived chiefly from this unit. The lower red-bed and gypsum series (unit 3), which immediately underlies the limestone unit, does not crop out within the area covered by the geologic

\footnotetext{
30 The Abo sandstone is not exposed within the Roswell artesian basin. It is at present classified in the Permian but the age of at least part of it is in dispute. (Böse, Emil, On the ammonoids from the Abo sandstone of New Mexico: Am. Jour. Sci., 4th ser., vol. 49, pp. 57-60, 1920. Beede, J. W., Am. Assoc. Petroleum Geologists Bull., vol. 5, p. 331, 1921. Darton, N. H., Geologic structure of parts of New Mexico: U. S. Geol. Survey Bull. 726, pp. 180-181, 1922; "Red Beds" and associated formations in New Mexico, with an outline of the geology of the State: U. S. Geol. Survey Bull. 794, pp. 20-21, 205, 1928.) Girty (oral communication) stated that he recently collected fossils from Böse's locality $\mathbf{1 . 2 5}$ miles east of Tularosa and that a preliminary examination of them indicates Pennsylvanian age. However, Darton (oral communication) stated that the beds from which Böse and Girty collected fossils are probably several hundred feet or more below the top of the Magdalena group (Pennsylvanian) and are not part of the Abo sandstone.
} 
map (pl. 3), but the upper part of it is exposed west of the area in the canyons of the Rio Hondo, the Rio Bonito, the Rio Ruidoso, the Rio Penasco, and some of their tributaries in and near the mountains.

\section{NOMENCLATURE ADOPTED IN THIS REPORT}

In view of the many pronounced lithologic changes now known within very short distances along both the strike and the dip in the Permian strata of southeastern New Mexico and in view of the uncertainties as to the exact relationships of the lithologic units in the Roswell artesian basin to those in adjoining regions, it seems necessary to use new local names for the recognizable units. Although it is realized that as a general rule the introduction of new formation names where others have been in use for years is not desirable, in the Roswell artesian basin the definition of the lithologic units has not been clear and the application of the names now in use, partly because of personal factors and partly because of variations in the sediments, has been so diverse that the older names are of little use. The diversity has already led to considerable confusion in discussion of the stratigraphy and would be likely to lead to more, for without much careful work the extension of formation names in: variable sediments far beyond their type localities, particularly if the units are relatively thin, is always hazardous. An excellent paper on correlation of Permian formations by Baker and Reeside $^{40}$ describes a comparable case. The writer believes that confusion in stratigraphic work in the region will be avoided at this time by applying local names to clearly defined lithologic units. When the relationships of the lithologic units to those in adjoining regions can be satisfactorily determined, the local names may be either modified or discarded.

The use of the name Chupadera formation, which was introduced by Darton, ${ }^{41}$ has therefore been discontinued in the Roswell artesian basin, and the following nomenclature has been adopted for the lithologic units in this area:

Pecos formation to be applied to the upper series of the red beds, gypsum, and salt between the base of the Triassic and the top of the thick limestone series.

Seven Rivers tongue of the Pecos formation to be substituted for Seven Rivers gypsiferous member of the Chupadera formation and applied to the tongue of gypsiferous red beds projecting into the Carlsbad limestone.

${ }^{40}$ Baker, A. A., and Reeside, J. B., jr., Correlation of the Permian of southern Utah, northern Arizona, northwestern New Mexico, and southwestern Colorado: Am. Assoc. Petroleum Geologists Bull., vol. 13, pp. 1413-1448, 1929.

41 Darton, N. H., Geologic structure of parts of New Mexico: U. S. Geological Survey Bull. 726, p. 1811922. 
Carlsbad limestone tongue of the Capitan limestone to be substituted for Carlsbad limestone member of the Chupadera formation and applied to the tongue of limestone that projects into the Pecos formation and overlies the Seven Rivers tongue. It is in part the stratigraphic equivalent of the Seven Rivers tongue.

Picacho limestone to be applied to the thick limestone series that underlies the Pecos formation and caps the Sacramento cuesta.

Nogal formation to be applied to the lower series of red beds and gypsum beneath the Picacho limestone and overlying the Abo sandstone.

It should be borne in mind that these names are applied to lithologic units and not to "time units" or units whose upper and lower limits are continuous stratigraphic or time horizons throughout the artesian basin. It would be very difficult to define a time unit whose upper and lower limits could be recognized over a wide area, because of the many rapid changes in lithology along the strike or dip of the strata in many parts of the artesian basin. It should also be remembered that these names are applied only to the lithologic units in the Roswell artesian basin. It is not intended that they should be carried far beyond the limits of this area until their relationships to units in adjoining areas can be satisfactorily determined.

A diagrammatic section of the Permian formations in this area with the names used in this report is given as Figure 8. The units are defined and described more fully in the following pages.

\section{PECOS FORMATION}

The uppermost strata assigned to the Permian in this region constitute a series of red beds, gypsum, and salt, which, in the Roswell artesian basin, is underlain by a thick series of limestone. The series of red beds and associated strata is designated the Pecos formation in this report. The base of the red-bed and gypsum series varies considerably in stratigraphic position, being lower north of Salt Creek than it is within the artesian basin and notably higher a few miles south of the mouth of the Seven Rivers. The red-bed and gypsum series is overlain east of the Pecos River by strata considered to be of Triassic age; consequently its top is probably defined by an unconformity. The Pecos formation, therefore, is a lithologic unit whose upper and lower limits are variable in stratigraphic position and time. The name is taken from the Pecos River, east of which strata of this formation are well exposed.

The strata constituting the Pecos formation are represented on Darton's geologic map of New Mexico ${ }^{42}$ as Chupadera formation

1928. Darton, N. H., U. S. Geol. Survey Geol. Atlas, State of New Mexico (geologic map),
. 
north of Lake McMillan and as Castile formation southeast of Lake McMillan. They have been referred to by other geologists as red

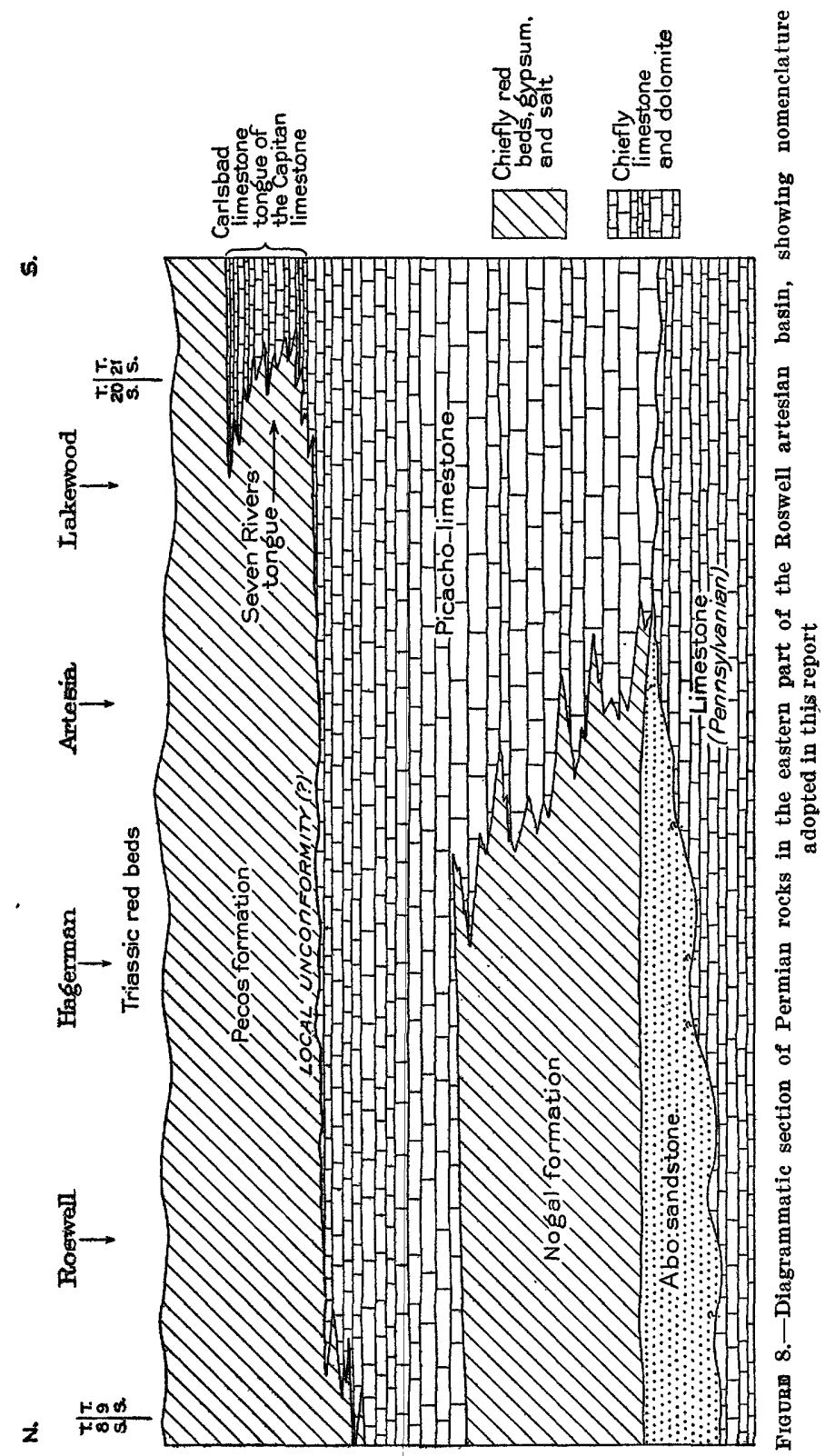

beds of Pecos Valley, "Pecos Valley red beds," Castile formation, Castile-Rustler, and Seven Rivers gypsiferous member of the Chupadera formation. 
In the southeastern part of the artesian basin a tongue of gypsum, red beds, and associated strata projects southward into and gives place to a limestone series, the Carlsbad limestone tongue. This tongue of gypsum and red beds is a part of the red-bed series composing the Pecos formation and is therefore designated herein the Seven Rivers tongue of the Pecos formation. The strata belonging to the Seven Rivers tongue in the No. 3 reservoir site of the Carlsbad irrigation project were described and designated the Seven Rivers gypsiferous member of the Chupadera formation by Meinzer, Renick, and Bryan. ${ }^{43}$ The name Seven Rivers tongue is applied only where strata of the Pecos formation are overlain by the Carlsbad limestone tongue. (See fig. 8.)

The bluffs paralleling the Pecos River on the east are formed by strata of the Pecos formation. The upper part of the Pecos formation is exposed in an irregular belt several miles wide east of the bluffs. East of this belt the Pecos formation is overlain by purplishred shale and sandstone tentatively assigned to the Triassic ${ }^{44}$ and by loose sands known as the "Mescalero sands." 45 The upper part of the Pecos formation has been removed by erosion west of the Pecos River, but the lower part extends a few miles west of the river. Except in parts of Tps. 10 and 11 S., R. 24 E., in the vicinity of Roswell, where the alluvial deposits rest directly upon the Picacho limestone, the lower part of the Pecos formation underlies nearly all of the alluvial basin. The most extensive exposures of the Pecos formation on the west side of the river are north of Roswell in the vicinity of Salt Creek, in the upper drainage basins of Cottonwood Creek and Walnut Draw, and in the lower drainage basins of the North and South Seven Rivers. (See pl. 3.) There are small outcrops of the Pecos formation in sec. 23, T. 13 S., R. 23 E., on the north side of Eagle Draw northeast of Hope, and along Fourmile Draw southeast of Hope. The Seven Rivers tongue, which does not differ greatly in lithology from other parts of the Pecos formation, is exposed in the bluffs on the southeast side of Lake McMillan, in the Seven Rivers cuesta (see pl. 9, $C$ ), and in the northern part of the No. 3 reservoir site of the Carlsbad irrigation project. According to the geologic maps of Darton ${ }^{46}$ and Blanchard and Davis, ${ }^{47}$ the Seven Rivers tongue extends south as far as the SW. 1/4 T. 24 S., R. 23 E.

${ }^{43}$ Meinzer, O. E., Renick, B. C., and Bryan, Kirk, Geology of the No. 3 reservoir site of the Carlsbad irrigation project, N. Mex., with respect to water-tightness: U. S. Geol. Survey Water-Supply Paper 580, pp. 6, 13-15, 1926.

${ }^{44}$ Darton, N. H., "Red Beds" and associated formations in New Mexico, with an outline of the geology of the State: U. S. Geol. Survey Bull. 794, pp. 32, 234, 1928.

45 Idem, p. 59.

46 Idem, pl. 49.

${ }^{4 \pi}$ Blanchard, W. G., jr., and Davis, M. J., Permian stratigraphy and structure of parts of southeastern New Mexico and southwestern Texas: Am. Assoc. Petroleum Geologists Bull., vol. 13, No. 8, nl. 10, 1929. 
Within the Roswell artesian basin the Pecos formation consists chiefly of red beds, gypsum, anhydrite, impure limestone, lightcolored fine sand, and intercalated thin beds of magnesian or dolomitic limestone and dolomite. Wells drilled for oil east of the Pecos River are reported to have encountered salt in this formation, but according to the available information salt has not been found in this formation on the west side of the river. However, analyses of water in the artesian area indicate that small quantities of salt may be present in these sediments west of the river. In the northern and central parts of the artesian basin the lower strata of the Pecos formation consist dominantly of red shale and sand with a few lenses of impure limestone and light-colored fine sand, but the upper strata, as exposed east of the river, contain a large proportion of gypsum interbedded with the red beds. In the southern part of the artesian basin both the lower and upper strata of the Pecos formation consist chiefly of alternating beds of gypsum and red shale with intercalated thin beds of dolomitic limestone and dolomite. In most places the gypsum predominates. Partial sections of the bluffs along the east side of the Pecos River were measured by Fisher. ${ }^{48}$ In the following section by Fisher the 35 feet of " massive gray limestone" at the top is a part of the Carlsbad limestone tongue of the Capitan limestone. The gypsiferous strata beneath the Carlsbad limestone are assigned in this report to the Seven Rivers tongue of the Pecos formation.

Section about 2 miles southeast of the mouth of the South Seven Rivers, near the east end of the Seven Rivers cuesta

Feet

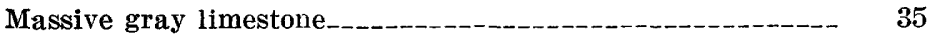

Gypsum and red sandstone in alternating layers, with an occasional limestone ledge.

Gypsum, thin-bedded porous limestone, and red sandstone

arranged alternately, the gypsum predominating

Gypsum, with thin layers of gray limestone_......- 50

285

The following section was measured by the writer:

Section of bluffs on the southeast side of Lake McMillan, in sec. 1, T. 20 S., R. 26 E.

Carlsbad limestone tongue of the Capitan limestone:

Feet

Limestone, light gray, dense to slightly porous, in beds ranging from 2 inches to $1 \frac{1}{2}$ feet in thickness_.....-.-

Seven Rivers tongue of the Pecos formation:

Gypsum and intercalated thin beds of limestone, largely concealed by talus 
Seven Rivers tongue of the Pecos formation-Continued

Limestone, dark gray, thin bedded. Weathered surface is light gray and has a "worm-eaten" appearance.-.

Gypsum, white

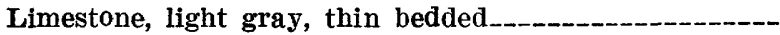

Gypsum, red and white

Feet

Limestone, light gray, dense to porous, thin bedded. Forms a bench. Weathered surface of some of the beds has a "worm-eaten" appearance.

Gypsum, white and red, with a few intercalated thin beds of light-gray limestone

Limestone, light gray, dense to porous, thin bedded. Forms a bench. Porous beds have a "worm-eaten" appearance

Gypsum, white

Limestone, light gray, thin bedded. Forms a bench...-

Gypsum, white

Limestone, light gray, very porous, thin bedded; weathered surface is white. Forms a bench. High porosity is due to numerous large holes and irregular open spaces probably formed by solution, which gives the limestone a "worm-eaten" appearance. Holes are lined with platy and crystalline calcite and earthy gypsum (?). Rock weathers to a white powder which is found along joint planes. Unweathered surface difficult to find

Gypsum, white and red; red color appears to be result of mixture of red shale with white gypsum

Limestone, light gray, dense, thin bedded. Forms a bench

Gypsum, white, with 1-inch bed of limestone near middle

Limestone, light gray, dense, containing a few small irregular patches of gypsum (?) ; weathered surface is white and comparatively smooth. Beds range in thickness from 6 inches to 1 foot. Bedding is distorted, owing to slumping. Forms a ledge and bench

Gypsum, white

Limestone, light gray, dense to porous. Beds range in thickness from 1 inch at the top to 4 inches at the bottom. Weathered surface is white and in places has a "worm-eaten" appearance. Some of the small open spaces contain powdered lime, which effervesces quickly in acid

Gypsum, white, with a few intercalated thin lenses of light-gray, dense limestone

Nearly all of the limestone in the last two sections given above is more or less dolomitic, and some may more nearly approximate a true 
dolomite. The base of the Seven Rivers tongue is not exposed in either of these sections.

The following log shows the character and thickness of the formations a few miles east of Roswell:

Driller's log of the New State Petroleum Oo.'s well 1, in the center of the SW. $1 / 4$ NE. $1 / 4$ sec. 27, T. 10 S., R. $26 \quad E$.

[Altitude, 3,695 feet]

Pecos formation :

Feet Pecos formation-Continued. F'eet

\begin{tabular}{|c|c|}
\hline $\begin{array}{l}\text { Red beds } \\
\text { Gypsum }\end{array}$ & $\begin{array}{r}0-90 \\
90-100\end{array}$ \\
\hline Red beds__-_ & $100-104$ \\
\hline Gypsum_-_-_- & 104-105 \\
\hline Red beds & $105-112$ \\
\hline Gypsum_- & $112-135$ \\
\hline Red beds_-_- & $135-141$ \\
\hline 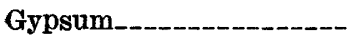 & $141-156$ \\
\hline Red beds____ & $156-220$ \\
\hline Gypsum___________ & $220-245$ \\
\hline Red beds & $245-255$ \\
\hline Gypsum__-_. & 255-265 \\
\hline Red beds & $265-290$ \\
\hline Gypsum_______-_ & $290-297$ \\
\hline Sand, hole full of water. & 297-305 \\
\hline Red beds____- & $305-425$ \\
\hline Gypsum__-_-_. & $425-430$ \\
\hline Red beds__- & $430-470$ \\
\hline Shale, blue____ & $470-474$ \\
\hline Gypsum_________ & $474-550$ \\
\hline Sand, red _ & $550-565$ \\
\hline Red beds___ & $565-582$ \\
\hline Shale, blue________ & $582-630$ \\
\hline $\begin{array}{l}\text { Li mest one, b rown, } \\
\text { sandy; show of gas.. }\end{array}$ & $630-656$ \\
\hline Red beds, some sandy & $656-730$ \\
\hline Sand, red_-_-__- & $730-760$ \\
\hline Rock, & 770 \\
\hline
\end{tabular}

Sand, red________ $770-800$

Red beds__.___._-_._._. $800-805$

Sand, red_________-_ 805-865

Rock, red____________ 865-970

Sand, red_________._._. 970-975

Red beds_____________ 975-978

Limestone, gray _...-..- 978-994

Red beds and gypsum_- 994-999

Gypsum, hard, white_- 999-1,066

Picacho limestone:

Limestone, brown_-- 1, 066-1, 140

Limestone, sandy _... 1, 140-1, 224

Limestone, gray_-..-- 1, 224-1, 265

Limestone, brown_-- 1, 265-1, 430

Limestone, broken_.-- 1, 430-1, 445

Limestone, s a n d y, brown_-_._._._._. 1, 445-1, 545

Limestone, brown; oil show at 1,545 to 1,590 feet; 1 bailer of water at 1,590 to

1,610 feet_._._._._. 1,545-1,610

Limestone__._._._._- 1, 610-2, 131

Sandstone, hard, dry - 2, 131-2, 161

Limestone_._._._._-_ 2, 161-2, 200

Nogal formation:

Shale__._._-_____-_ 2, 200-2, 213

Sand, red_._._-_._-_ 2, 213-2, 250

There is a small outcrop of the Pecos formation on the south side of a wash in the western part of sec. 23, T. 13 S., R. 23 E. The strata exposed here consist of red shale overlain by a 2 -foot bed of brecciated sandy limestone containing solution cavities. Parts of the rock are spongelike. The color of the rock is mottled red, brown, and white. It is overlain by a thin bed of dense greenish-gray limestone about 2 inches thick, which in turn is overlain by coarse gravel.

In the upper drainage basins of Cottonwood Creek and Walnut Draw the lower part of the Pecos formation consists dominantly of brick-red shale and sandy shale, which are well exposed in the slopes of the gravel and conglomerate-capped mesas. In this area 2 to 4 feet of granular and highly altered limestone occurs in the 
midst of the red beds. It generally forms a prominent ledge, which in places is visible for miles. It appears to be a continuous stratum, but it may consist of lenses at approximately the same stratigraphic horizon. In some places the limestone is thin bedded, but in others it is a single massive bed 2 to 3 feet thick. In many places the bedding planes are irregular and poorly defined, and the joints are also irregular. In large part the weathered surface of the limestone is irregularly pitted, but in some places it is comparatively smooth. As a rule it has a mottled color ranging from light and dark gray through yellowish red to light brown. The fresh surface is usually tan. In many places the limestone has a dense, coarsely crystalline texture; in most places, however, it is granular and crumbles easily when broken, like a poorly cemented coarse-grained sandstone. In fact, in many places it appears at first glance to be a limy sandstone, but when examined closely it is seen to be composed of poorly cemented rounded grains and interlocking crystals of calcite. The limestone contains numerous irregular cavities, and much of it is highly altered. In places the cavities are so numerous that the interior of the rock has a honeycombed or cellular appearance: Many of the cavities are lined with minute crystals of calcite. As a rule nearly all the cavities are lined with an earthy limonitic substance ranging in color from yellow to red. In the SW. 1/4 sec. 5, T. 16 S., R. 24 E., the limestone occurs as a bed 2 to 3 feet thick underlain and overlain by red sandy shale. This limestone weathers light brown and has a platy structure, apparently because of the varying degrees of hardness or resistance to erosion of the laminae of which it is composed. Resistant seams of a white calcareous and argillaceous material in the joints give the rock a cellular appearance. Parts of the limestone cropping out along the sides of a dry wash near the southeast corner of T. 15 S., R. 22 E., are altered to a very fine grayish-white calcareous powder resembling powdered chalk. Various stages of this alteration were seen. A few intercalated thin beds of dark-gray dense limestone, ranging in thickness from a fraction of an inch to 6 inches, were observed here. The character of these beds changes along the strike in one or two places. Firmly cemented brecciated limestone with angular fragments of light-gray limestone in a dark-colored matrix was also observed in several places. The limestone at this locality forms a ledge that is notably distorted, probably because of slumping. (See pl. 9, A.) In one place the limestone is almost on end, forming small hogbacks which from a distance have the appearance of igneous dikes. In the SE. $1 / 4$ sec. 18 , T. 16 S., R. 23 E., the limestone forms a ledge about a third of the way up the slope of a small gravel-capped mesa. The limestone, which is thin bedded and weathers dark gray, is underlain by 
green, red, and purple shale and shaly mudstone. The shale and mudstone are underlain by fine-grained red sandstones, mottled with white, reddish purple, and greenish gray, resting upon green shale and mottled red and green shaly mudstone. Most of the slope, however, is composed of brick-red shale and fine sand. Nearly all of the red shale and sand in the lower part of the Pecos formation is calcareous.

The outcrop of the Pecos formation in the bluff on the south side of Fourmile Draw, near the center of sec. 12, T. 19 S., R. 24 E., consists of 15 to 20 feet of yellowish sand and poorly cemented sandstone overlain by about 20 feet of red sand. The sand and sandstone are fine grained. The bedding is poorly defined and in places indistinct. The bluff is capped by 10 to 15 feet of limestone conglomerate and coarse gravel.

The outcrops of the Pecos formation in the southern part of the area covered by the geologic map (pl. 3) consist dominantly of gypsum with intercalated partings and relatively thin lenses of red shale, dolomitic limestone, and dolomite. Thin lenses of intimately associated red shale and gypsum are common. All gradations from gypsum containing small lumps of red shale to red shale containing small lumps of dense gypsum are present in these sediments. The red shale, some of it sandy, usually contains many seams of selenite, some of which are 1 inch or more thick. The bedding of the gypsum and red shale is usually distorted and indistinct. Characteristic outcrops of gypsum and red shale with intercalated thinbedded dolomitic limestone are shown in Plate 10. As a rule the dolomitic limestone and dolomite in the Pecos formation in this part of the area are thin bedded and in places shaly, the laminae rarely exceeding 2 inches in thickness. Here and there, however, beds of limestone 4 inches to 1 foot thick are found. Nearly all of the limestone is more or less dolomitic, and most of it is extremely fine grained and very dense. Some, however, contains numerous small holes about the size of a large pinhead, especially on the weathered surface, which give the rock a characteristic "wormeaten" appearance. Some of the holes are filled with powdered gypsum, a part of which looks as if it might be syngenetic, as many of the holes appear to be entirely disconnected. Most of the gypsum, however, is plainly epigenetic. Some holes are filled with powdered lime. Some of the dolomitic limestone capping a hill near the southeast corner of T. 20 S., R. 21 E., has the appearance of a firmly cemented limestone breccia, which when fractured is seen to consist of angular fragments of dark-gray dense dolomitic limestone in a white calcareous powder that effervesces rapidly in dilute hydrochloric acid. Fossils are rarely found in these limestones. 
In the southeastern part of the artesian basin limestone breccia is found in the Pecos formation. Very firmly cemented and very hard limestone breccia is exposed in a ravine southwest of Lake McMillan. It consists of fragments of yellowish to tan granular limestone and gray limestone irregularly distributed and cemented in a gray calcareous matrix. The fragments vary greatly in size, shape, and distribution. Some are as much as $21 / 2$ feet long and 8 inches thick. The matrix, in many places, contains numerous cavities and is very porous. Many of the fragments have been partly removed by solution, leaving an outer shell; this gives the breccia a large-scale cellular appearance. The breccia, as a whole, is heterogeneous. Limestone breccia is also exposed in the railroad cut west of the railroad bridge over the Pecos River and in many places in the lower drainage basin of the Seven Rivers. Limestone breccia in the Seven Rivers tongue of the Pecos formation is well described by Meinzer, Renick, and Bryan. ${ }^{49}$

No complete section of the Pecos formation is exposed at any place within this area. In fact, even the contact between the Pecos formation and the underlying Picacho limestone was found by the writer at only one place. In the W. $1 / 2$ sec. 19, T. 20 S., R. 23 E., on the east side of a road from Hope to the Guadalupe Mountains, on the north bank of a dry wash, there is a small exposure of gypsum and red shale resting upon fine-grained dense dolomitic limestone. (See pl. 9, B.) The strata east of the Pecos River that are believed to be of Triassic age have a characteristic purplish-red color uncommon in the Pecos formation, and they contain little if any gypsum. The red beds of the Pecos formation have a brick-red color. However, the differences between the Triassic red beds and the underlying Permian red beds are so slight that the precise upper limit of the Permian in this region is not known.

The strata of the Pecos formation are notably poor in fossils. The few fossils that have been collected indicate a Permian age, and this formation has been tentatively correlated with formations cropping out in Texas east of the Llano Estacado that have been proved to be Permian. ${ }^{50}$

As a general rule the strata of the Pecos formation are extremely lenticular and vary greatly in character from place to place. The persistent red sand used as a key bed in the Artesia oil field ${ }^{51}$ is a notable exception. In most places where the Pecos formation crops out the attitude of the beds does not reveal the broad structural

49 Meinzer, O. E., Renick, B. C., and Bryan, Kirk, Geology of the No. 3 reservoir site of the Carlsbad irrigation project, N. Mex., with respect to water-tightness: U. S. Geol. Survey Water-Supply Paper 580, pp. 13-15, 1926.

${ }_{50}$ Hoots, H. W., Geology of a part of western Texas and southeastern New Mexico, with special reference to salt and potash: U. S. Geol. Survey Bull. 780, pp. 74-76, 1925.

51 Davis, M. J., Artesia field, Eddy County, N. Mex. : Structure of typical American oil fields, vol. 1,. pp. 114-118, 1929. 


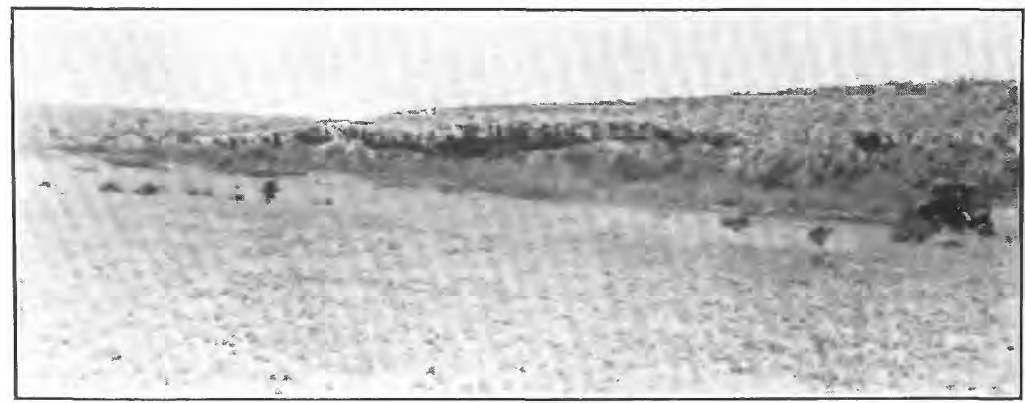

A. IMPURE LIMESTONE IN THE PECOS FORMATION EXPOSED NEAR THE SOUTHEAST CORNER OF T. 15 S., R. 22 E.

Note distortion of bedding, which appears to be due to slumping. Photograph by S. S. Nye.

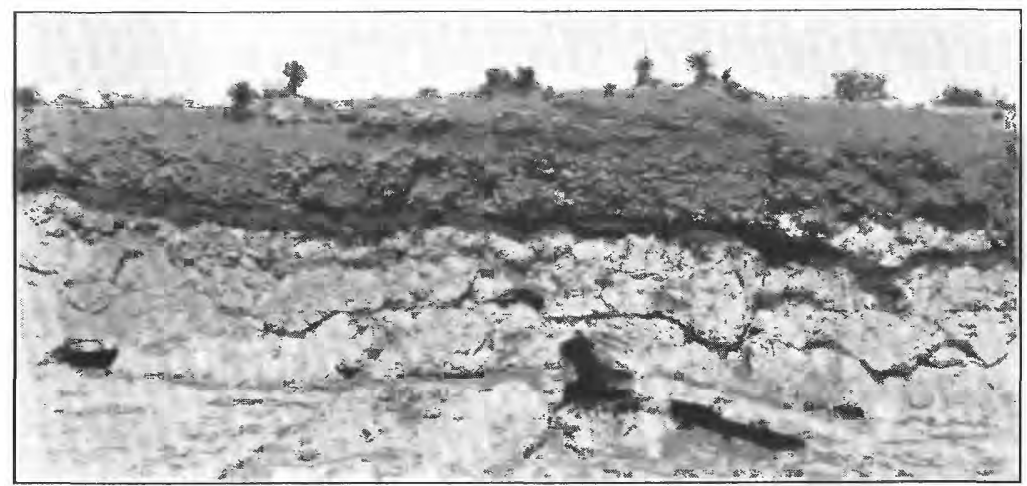

B. GYPSUM AND RED SHALE OF PECOS FORMATION RESTING UPON PICACHO I.IMESTONE IN THE W. 1/5 SEC. 19, T. 20 S., R. 23 E.

Photograph by S. S. Nye.

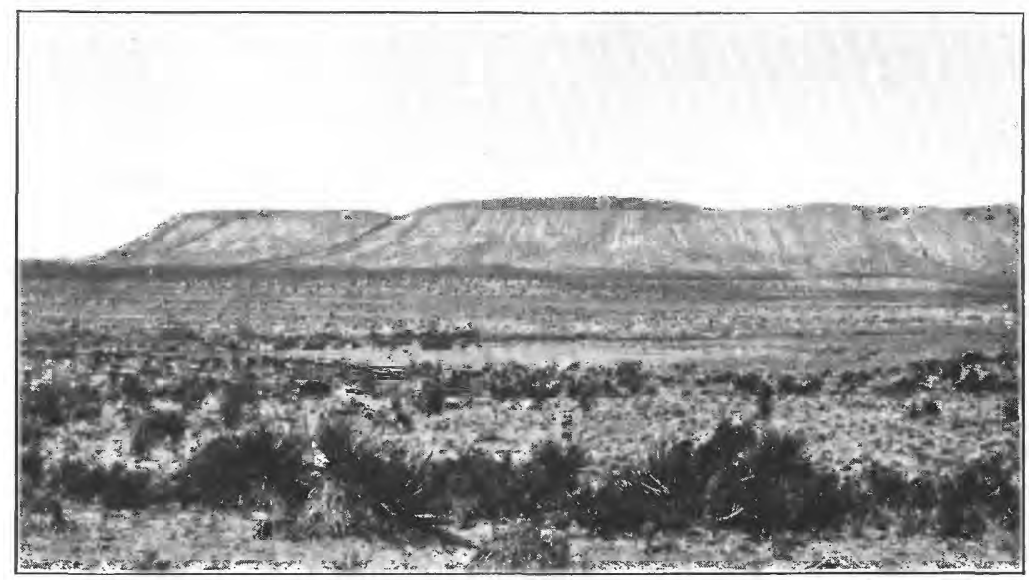

C. SEVEN RIVERS CUESTA, SEC. 23, T. 21 S., R. 24 E.

Looking north across the valley. Shows Seven Rivers tongue of Pecos formation overlain by Carlsbad limestone tongue of Capitan limestone. Photograph by S. S. Nye. 


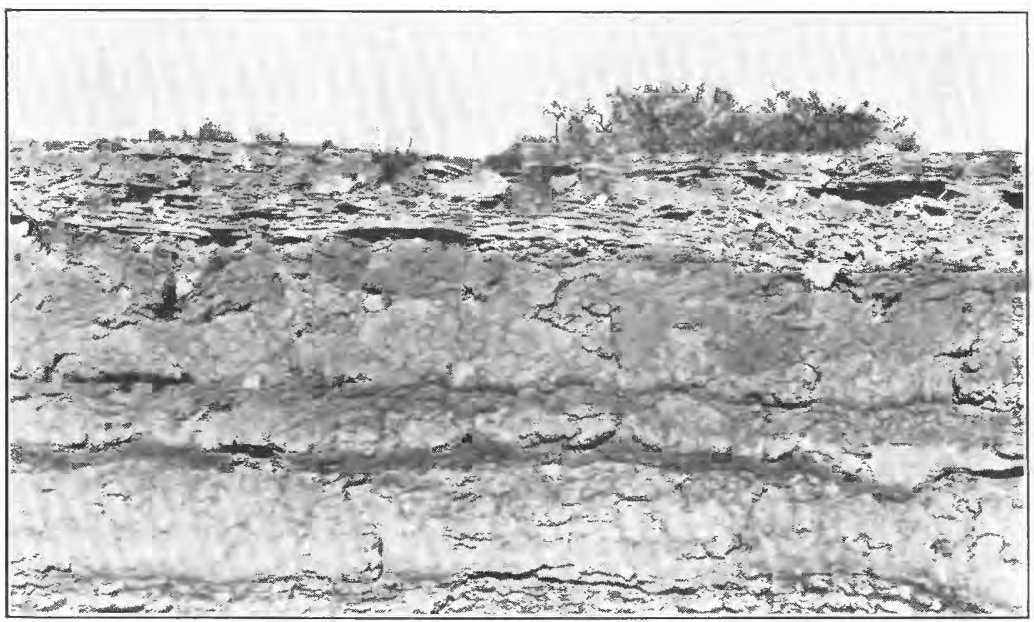

A. OUTCROP OF PECOS FORMATION NEAR THE CENTER OF T. 19 S., R. 23 E. Photograph by S. S. Nye.

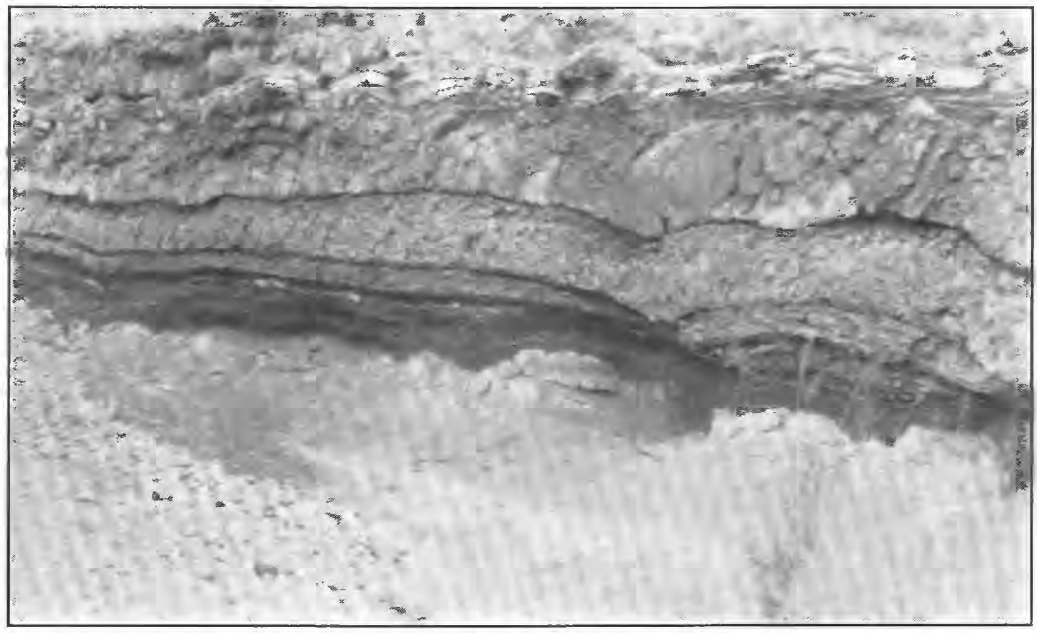

B. OUTCROP OF THE PECOS FORMATION IN THE NORTHERN PART OF T. $21 \mathrm{~S}$, R. $21 \mathrm{E}$.

Photograph by S. S. Nye. 
features of the Permian rocks, because there has been a great deal of what Lee" termed "solution and fill" in the Pecos formation, owing to the presence of large quantities of gypsum and other soluble rocks. Numerous sink holes and undrained depressions and highly deformed strata characterize the outcrops of the Pecos formation, especially in the southern part of the area, where gypsum predominates.

CARLSBAD IIMESTONE TONGUE OF THE CAPITAN LIMESTONE

The constriction of the Pecos Valley below the mouth of the Seven Rivers is caused by the outcropping of resistant limestone, which caps the Seven Rivers cuesta, crosses the Pecos River, and caps the bluffs extending northeastward along the southeast side of the Pecos River to the southeast side of Lake McMillan. The limestone projects into the upper red-bed and gypsum series (Pecos formation) in the vicinity of Lake McMillan and thins out in the outcrop due east of Lakewood. As this limestone crops out extensively west and northwest of Carlsbad, it has been called the Carlsbad limestone for many years by oil geologists working in this part of New Mexico. In 1926 it was described by Meinzer, Renick, and Bryan, ${ }^{53}$ and on Darton's recommendation ${ }^{54}$ it was assigned by them to the Chupadera formation and designated the Carlsbad limestone member of the Chupadera formation. It has been described also by Darton, ${ }_{2}^{55}$ Crandall, ${ }^{56}$ and Blanchard and Davis. ${ }^{57}$ According to these writers the limestone thickens greatly to the southwest and extends nearly to Guadalupe Point. Darton ${ }^{58}$ says that it "constitutes the higher part of the mountain at El Capitan." As it is a part of the Capitan limestone, it is designated in this report the Carlsbad limestone tongue of the Capitan limestone.

The Carlsbad limestone where it caps the Seven Rivers cuesta (see pl. 9, $C$ ) and the bluffs along the southeast side of the Pecos River as far as the south end of Lake McMillan is 35 to 40 feet thick. Northeastward from the dam at Lake McMillan it thins gradually to a few inches and finally disappears entirely in the outcrop due east of Lakewood. The Carlsbad limestone is well exposed in the canyon walls of Rocky Arroyo, which is a few miles south of the area cov-

${ }^{62}$ Lee, W. T., Erosion by solution and fill: U. S. Geol. Survey Bull. 760, pp. 107$121,1925$.

ss Meinzer, O. E., Renick, B. C., and Bryan, Kirk, op. cit., pp. 6, 12-13.

s Darton, N. H., and Reeside, J. B., jr., Guadalupe group: Geol. Soc. America Bull., vol. 37, p. $419,1926$.

s Darton, N. H., "Red Beds" and associated formations in New Mexico, with an outline of the geology of the State: U. S. Geol. Survey Bull. 794, p. 224, 1928.

brandall, K. H., Permian stratigraphy of southeastern New Mexico and adjacent parts of western Texas: Am. Assoc. Petroleum Geologista Bull., vol. 13, p. 938, 1929.

* Blanchard, W. G., Jr., and Davis, M. J., Permian stratigraphy and structure of parts of southeastern New Mexico and southwestern Texas: Am. Assoc. Petroleum Geologists Bull., vol. 13, pp. 983-985, 1929.

Darton, N. H., op. cit. (Bull. 794), p. 224. $135252-33-5$ 
ered by Plate 3. In the eastern part of T. 21 S., R. 24 E., the Carlsbad limestone is several hundred feet thick, but within less than a mile to the west over 400 feet of it gives place to white and red gypsum with intercalated lenses of red shale and sand and thinly laminated dolomitic limestone (Seven Rivers tongue of the Pecos formation). This change from limestone to gypsum is strikingly revealed along the north wall of Rocky Arroyo and can be viewed from a point on the south side of the canyon. The gypsum rests upon sandstone and limestone and is overlain by limestone. The limestone overlying and underlying the gypsum is exposed continuously from west to east along the canyon wall. As the gypsum slopes are covered with talus in most places the precise relationship of the gypsum to the limestone has not been determined. It is the opinion of Blanchard and Davis ${ }^{59}$ that "the dolomite overlying the gypsum may represent a transgressional overlap, in which case the gypsum would be older than the dolomite." However, the possibility of lateral gradation from dolomitic limestone to gypsum has not been eliminated. Positive evidence has not been obtained to prove or disprove either of the two hypotheses. In any case, the Carlsbad limestone tongue is in part the stratigraphic equivalent if not the time equivalent of the Seven Rivers tongue of the Pecos formation.

In this area the Carlsbad limestone tongue consists almost entirely of thin-bedded dolomitic limestone. The beds are generally less than a foot thick, although on the southeast side of Lake McMillan they are as much as 2 feet thick in places. Most of the beds consist of extremely fine-grained very dense gray dolomitic limestone whose weathered surface is relatively smooth and light tan to buff. The rock weathers into angular blocks. It breaks with a subconchoidal fracture with sharp edges, like flint. Some of the dolomitic limestone has a light tan or cream-colored fresh surface. In one or two places beds of dolomitic limestone containing a few solution cavities were observed. The weathered surfaces of these rocks were pitted, which is rather unusual in the Carlsbad limestone.

In this area the Carlsbad limestone contains few fossils. However, in the limestone capping the Seven Rivers cuesta Beede ${ }^{60}$ found some in beds "about 10 feet below the crest of the escarpment and a little west of its eastern end." Beede ${ }^{61}$ stated

At the locality south of Lakewood $* * *$ fossils of some five or six species were found. They consist of Cyrtodontarcal parallellidentata?, ${ }^{\circ 0} 0.8$ sp., another pelecypod, the cast of an ostracode, and some minute gastropods from 1 to 3 millimeters in length badly preserved as molds. The Cyrtodontarcae

59 Blanchard, w. G., jr., and Davis, M. J., op. cit., p. 983.

$\infty$ Beede, J. W., The correlation of the Guadalupian and the Kangas sections: $\mathbf{\Delta m}$. Jour. Sci., 4th ser., vol. 30, p. 134.1910.

62 Idem, p. 136.

2e "Identical with a Quartermaster form doubtfully referred to this genus." 
appear, though poorly preserved, to be specifically identical with one of the species from the Whitehorse and Quartermaster beds of Oklahoma and the Panhandle of Texas. Like them, these shells are by far the most abundant fossils in the collection.

The Whitehorse and Quartermaster formations are Permian in age.

\section{PICACHO LIMESTONE}

The Sacramento cuesta is capped by limestone belonging to a thick limestone series that plunges beneath the surface along or near the western edge of the alluvial basin and extends underground far to the east. The limestone series consists dominantly of limestone and dolomitic limestone but includes minor amounts of dolomite, gypsum, anhydrite, sandstone, and shale. It is believed by geologists working in this region to be the stratigraphic equivalent of the San Andres limestone of Lee and Girty ${ }^{63}$ and has been referred to by that name for years. In 1922 Darton assigned it to the Chupadera formation. ${ }^{64}$ In the report ${ }^{65}$ on the artesian basin made in 1928 it is referred to as the limestone member of the Chupadera formation. In this report, it is designated as the Picacho limestone. The name is taken from the town of Picacho, in the valley of the Rio Hondo, in the vicinity of which the lower part of the limestone series is well exposed. The upper 700 to 800 feet has been removed by erosion. Two sections measured about 4 miles east of Picacho are given below. At the place where section 1 was measured the base of the Picacho limestone is not exposed. Section 2 was therefore measured in order to define the base, but the upper beds are omitted from this section, as they are essentially the same as those in the upper part of section 1. The two sections can be correlated with respect to the sandstone beds present in both, which are given as Nos. 22 and 34 in section 1 and as Nos. 4 and 8 in section 2.

Partial sections of the Picacho limestone 3.9 miles by highway east of Picacho

1. About 150 yards north of the Roswell-Alamogordo highway on the east side of a ravine entering Rio Hondo Valley opposite Sunset ranch

Picacho limestone:

Ft. in.

1. Limestone, light to dark gray, very fine grained; breaks with a semiconchoidal fracture. Appears to be thin bedded, although the bedding is not clearly exposed. Forms a comparatively gentle slope. Fractured surfaces of some of the limestone are rough, and weathered surfaces are pitted and hackly

${ }^{6}$ Lee, W. T., and Girty, G. H., The Manzano group of the Rio Grande Valley, N. Mex. : U. S. Geol. Survey Bull. 389, p. 12, 1909.

e Darton, N. H., Geologic structure of parts of New Mexico: U. S. Geol. Survey Bull. 726, pp. 181-182, 207-208, 210, 1922.

Fiedler, A. G., and Nye, S. S., Ground-water investigation of the Roswell artesian basin, N. Mex. : New Mexico State Engineer Eighth Bienn. Rept., pp. 81-107, 1928. 
Picacho limestone-Continued.

2. Limestone, concealed by talus

Ft. in.

3. Dolomitic limestone, dark gray, massive. Beds ties about the size of a pinhead. Weathered surface is rough and hackly. Contains solution cavities lined with calcite crystals, many of which are coated with a limonitic substance Forms steep slopes. Fairly well exposed...-.-

4. Limestone, dark gray, massive. Texture is crystalline to granular. Contains many small cavities about the size of a pin head. Weathered surface is very rough and hackly. Beds range in thickness from 2 to 4 feet. Bedding planes are indistinct. Forms a ledge

5. Limestone, dark gray, dense, in beds 6 inches to 2 feet thick. Weathered surface is generally rough and hackly. Contains solution cavities lined with calcite crystals, which are covered with a yellow limonitic coating. Most of the limestone has a crystalline texture

6. Limestone, gray to $\tan$, texture crystalline to powdery. Contains many solution cavities lined with irregular masses of calcite crystals. In some of the cavities the calcite crystals are coated with an orange-colored limonitic substance. Weathered surface is rough and distinctly different from other limestone beds. In places weathered surface has a violet hue...-

7. Limestone, dark gray, massive, in beds 6 inches to 2 feet thick. Crystalline texture. Some is fine grained, dense, and light gray. Most of it contains irregular solution cavities, many of which are lined with calcite crystals. Fossiliferous in places. Fossils are locally replaced by crystalline calcite. Weathered surface is hackly. Some of the limestone breaks with a semiconchoidal fracture, but most of it has a rough fractured surface

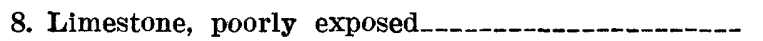

9. Limestone, light gray, earthy. Contains small irregular masses of crystalline calcite and a few scattered irregular solution cavities lined with calcite crystals. In some places the weathered surface is hackly, in others it is smooth

10. Dolomitic limestone, dark gray, massive, in beds 1 to 3 feet thick. Most of the limestone is fine grained and dense, but some has a coarsely crystalline texture. Weathered surface is hackly. Most of the limestone is poorly ex-

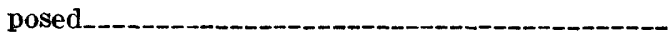


Picacho limestone-Continued.

Ft. in.

11. Limestone, dark gray, massive. Weathered surface is somewhat hackly and grooved. Formas a ledge at this point

12. Limestone, dark gray, crystalline to earthy, in beds 2 to 3 inches thick. Contains a few cavities about a quarter of an inch in diameter lined with calcite crystals, which are coated with a yellow to orange-colored limonitic substance. Weathered surfaces are hackly

13. Limestone, dark gray, massive, crystalline. Bedding is indistinct. Weathered surface is rough

14. Limestone, light gray, earthy, massive. Contains numerous cavities from the size of a pin point to that of a pin head, lined with calcite crystals. Weathered surface is white to light gray. The bedding is very indistinct

15. Limestone, light to dark gray, some of which contains small irregular cavities lined with calcite crystals. Poorly exposed.

16. Limestone, dark gray, dense. Weathered surface is pitted, grooved, and hackly. Forms a ledge at this place

17. Limestone, dark gray to nearly black, in beds averaging 2 to 3 inches in thickness. Bedding becomes indistinct a few feet away along the strike. Lower part forms a ledge, but the upper part consists of thin indistinct beds and forms a slope. Some of the limestone contains casts of small fragments of fossils replaced by calcite. Some of the nearly black limestone has a slight petroliferous odor when struck with a hammer.

18. Limestone, dark gray. Weathered surface is somewhat hackly, and fractured surface is rough

19. Limestone, gray, very fine grained and dense. Fractured surface is semiconchoidal and smooth

20. Limestone, lower part gray and upper part brownish gray. Cavernous. Weathered surface of the lower part is hackly and very rough, but that of the upper part is much smoother. Forms a ledge

21. Calcareous breccia, yellow to tan, resembling a mud-ball conglomerate. Consists of granular limestone, hard sandy clay, and lumps of sandstone. Its upper surface is very irregular, and in places the upper part appears to grade laterally into limestone. 
Picacho limestone-Continued.

22. Sandstone, white to light yellow, medium to coarse grained, granular, massive, with indistinct bedding. Weathered surface is covered at many places with small nodules, usually an eighth to a quarter of an inch in diameter, which have the appearance of concretions and stand out prominently. Same as No. 4 in section 2

23. Concealed.

24. Limestone, gray, earthy, dense. In places contains a few scattered solution cavities lined with calcite crystals. Weathered surface is light gray and slightly pitted.-...-

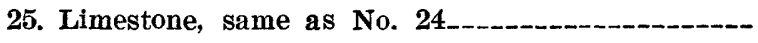

26. Limestone, light to dark gray, earthy, dense. Con.tains irregular masses of white calcite, roughly parallel to the bedding, which are an eighth to a quarter of an inch thick, weather a rusty brown, and, being more resistant to erosion than the limestone matrix, stand out prominently. Some of the calcite masses are concretionary. The limestone also contains chert masses which are generally less than 3 inches long

27. Limestone, light gray, granular, arenaceous in places. Weathered surface of arenaceous portions is brownish gray, pitted, and rough. Other portions are light gray, are comparatively smooth, and have a more earthy appearance.-

Ft. in.

28. Limestone, light gray, earthy, very fine grained. Contains scattered cavities the size of a pinhead, which are lined with calcite crystals. Weathered surface is pitted, grooved, and hackly in places. Contains small concretions of chert, which weather a rusty brown

29. Limestone, olive-gray mottled with white, granular, massive Contains solution cavities lined with calcite crystals, which in places are coated with a rust-colored substance. Weathered surface of upper part is hackly and rough. Lower part changes laterally to a dark-gray, finegrained, dolomitic limestone, which appears to consist of beds not more than 2 to 3 inches thick

30. Dolomitic limestone, dark gray, very fine grained. Weathered surface is light gray and smooth.--

31. Dolomitic limestone, dark gray, overlain by brownish-tan calcareous shale 2 inches thick, which does not appear to be continuous along the strike. The dolomitic limestone weathers light gray 
Picacho limestone-Continued.

Ft. in.

32. Dolomitic limestone, dark gray. Weathered surface lighter colored and hackly in places.

33. Limestone, gray, arenaceous. Weathers light brownish gray, yellowish in places

34. Sandstone, calcareous and ferruginous, composed of subangular grains of quartz, many of which are frosted. Weathers yellow and rusty brown. Base not exposed here. Probably same as No. 8 in section 2

Base of Picacho limestone is concealed at this place. Interval to bottom of ravine, covered by material slumped down from above

2. Slope on north side of Rio Hondo, northeast of Sunset ranch

[This section is a short distance south of section 1]

Picacho limestone:

1. Dolomitic limestone, light to dark gray, in beds 1 to 3 feet thick. Upper 3 to 4 feet forms a prominent ledge which is continuous for some distance laterally

2. Limestone, light gray, crystalline. Contains many solution openings. Weathered surface is light tan, pitted, and hackly. Lower 10 to 15 feet is massive and forms a prominent ledge at this place

3. Dolomite and dolomitic limestone, light to dark gray and olive-gray, very fine grained, in beds 6 inches to 2 feet thick. Most of the limestone weathers light gray. The weathered surfaces of some of the beds are smooth and others are hackly. Beds are poorly exposed. Forms a slope

4. Sandstone, white to light jellow, medium to coarse grained. Weathers dark gray, white, and light yellow. Same as No. 22 in section 1.-

5. Dolomite and dolomitic limestone, gray, very fine grained and dense, in beds 1 to 2 feet thick. Upper part appears to be somewhat sandy and to grade into No. 4

6. Limestone, light gray, arenaceous. Forms a ledge

7. Dolomite and dolomitic limestone, light gray, very fine grained to earthy. Weathers light tan. Beds in lower 10 feet are 1 to 3 inches thick. In upper part beds are 1 to 5 feet thick, and weathered surfaces of beds are hackly and rough. Bedding planes are poorly defined...--- 
Picacho limestone-Continued.

Ft. in.

8. Sandstone, white to light yellow, fine grained, massive. Composed of subangular to wellrounded quartz grains cemented by lime. Very even grained. Sugary texture. Weathers yellow to ocher-yellow. Similar in texture to No.

4. Probably same as No. 34 in section 1....-

9. Limestone and dolomitic limestone, light gray to light yellowish gray, earthy to crystalline, some slightly arenaceous. Beds are 6 inches to 4 feet thick. Top bed is 4 feet thick and forms a ledge in places. Beds below are poorly exposed and form a slope. Weathers light gray to light tan

10. Limestone and shaly limestone, light gray to light yellowish gray. Lower part grades from shaly limestone to limestone in beds 1 or 2 feet thick. Upper part consists of massive limestone with indistinct bedding and hackly weathered surfaces. Upper part forms a ledge at this place. All weathers a light tan.

Nogal formation:

11. Shale and sandy shale, red, yellow, and greenish gray, poorly exposed.

The thick sandstone member in the above sections (No. 22 in section 1 and No. 4 in section 2) is called Glorieta sandstone by geologists working in this region, the limestone series above the sandstone is called San Andreas limestone, and the strata below the sandstone are assigned to the Yeso formation. Some geologists apply the name Glorieta sandstone to both the upper and the lower sandstones (Nos. 22 and 34 in section 1 and Nos. 4 and 8 in section 2), thereby including the intervening limestone under that name. It is not at all improbable that these two sandstones may be lenticular and may represent a sandstone zone rather than continuous stratigraphic horizons.

The Picacho limestone is defined in this report as a lithologic unit in the Roswell artesian basin, consisting dominantly of limestone and dolomitic limestone but including minor amounts of sandstone, shale, gypsum, and anhydrite, whose upper and lower limits are variable with respect to stratigraphic position and time. The base of the Picacho limestone, as indicated in section 2 , is defined as the base of the limestone series, the so-called Glorieta sandstone being included in and considered a member of the Picacho. Likewise, the top of the Picacho limestone is defined as the upper limit of the limestone series. It appears probable, for reasons that will be discussed later, 
that within and perhaps east of the artesian area the top of the Picacho limestone is defined by a local erosional unconformity which in places appears to be pronounced and which probably played an important part in the formation of the artesian aquifers atd the reservoir rocks in the adjacent oil fields.

Throughout most of the artesian basin the Picacho limestone is underlain by the thick series of red beds, gypsum, and salt designated in this report the Nogal formation, which in the sortheastern part of the artesian basin gives place to a thick section consisting dominantly of limestone. After the deep wells drilled for oil in the southern part of the artesian area entered the Picacho limestone they continued almost entirely in limestone or dolomitic limestone. So far no wells have passed through the limestone series in this part of the artesian basin. This thick limestone series may be both the stratigraphic and the time equivalent of the lower red-bed series (Nogal formation) but is tentatively included, within the artesian basin, in the Picacho limestone. (See fig. 8.)

Where the Picacho limestone is overlain by the Pecos formation . and underlain by the Nogal formation it is 800 to 1,200 feet thick, but beneath the southeastern part of the artesian basin, where the Nogal formation is absent, the thickness of the Picacho is not known. The Midwest-Terry well, in the SW. 1/4 NW. $1 / 4$ sec. 15, T. 18 S., R. 26 E., penetrated about 2,590 feet of limestone, dolomitic limestone, and dolomite. The log of this well is given below:

Condensed log of Mothoest-Terry well in sec. 15, T. 18 S., R. 26 Et.

[Well is 2,010 feet south of north line and 150 feet east of west line of sec. 15; altitude, 3,349 feet. Drilled in 1927 with rotary rig to 835 feet and with cable tool rig from 835 to 3,156 feet]

Soil and gravel

Feet

Clay

0-20

$20 \div 90$

Clay and sand.

$90 \div 140$

Clay, cream-colored, tough

140-205

Gypsum, shelly

205-230

Clay, red, and gypsum

$230-350$

Shale, sandy

$350-370$

Shale, blue

$370-385$

"Chalk" (gypsum ?)' with' shehy limestone streaks_-

Gypsum

$380^{2}-407$

$407-430$

"Chalk" (gypsum ?)

Limestone

$430-445$

Gypsum and shale

$445-450$

Shale, blue-

$450-457$

$457-485$

Gypsum

$485-500$

Shale; blue; sandy:

$500=530$

Sandstone

$530-532$ 


\begin{tabular}{|c|c|}
\hline & \\
\hline lay and sand, red.- & \\
\hline imestone, " shelly" & $555-563$ \\
\hline $\begin{array}{l}300 \text { gallons a minute. Set } 121 / 2 \text {-inch casing at } 569 \\
\text { feet. }\end{array}$ & $567-635$ \\
\hline and, red. & 35-637 \\
\hline $\begin{array}{l}\text { imestone. Artesian water, } 100 \text { gallons a minute, } \\
\text { at } 665 \text { feet }\end{array}$ & $637-686$ \\
\hline $\begin{array}{l}\text { Imestone, gray, hard. Small seep of sulphur water } \\
\text { at } 715 \text { feet. }\end{array}$ & 686-753 \\
\hline hal & 753-758 \\
\hline Lim & $758-783$ \\
\hline aite_-.. & $783-788$ \\
\hline Sandstone, red, calcareous_....... & $788-791$ \\
\hline Limestone. Show of oil and gas at 808 to 810 feet.-- & 791-812 \\
\hline Limestone, gray. Sulphur water at 830 & 812-835 \\
\hline imestone. Set $10-\mathbf{i}$ & $835-880$ \\
\hline 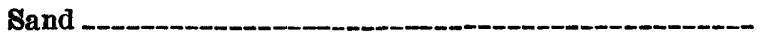 & $880-891$ \\
\hline Limestone, bro & $891-1,054$ \\
\hline ian water at 1,063 to 1,100 & \\
\hline Limestone... & $-1,132$ \\
\hline $\begin{array}{l}\text { Limestone, sandy. Artesian water } \\
\text { Limestone, gray }\end{array}$ & $\begin{array}{l}\mid 32-1,140 \\
440-1,157\end{array}$ \\
\hline $\begin{array}{l}\text { Limestone; brown. Oil show at } 1,176 \text { to } 1,182 \text { feet. } \\
\text { Flow of salt water at } 1,182 \text { to } 1,234 \text { feet. Set } \\
81 / 4 \text {-inch casing at } 1,247 \text { feet-a. }\end{array}$ & \\
\hline Limestone, mostly gray, some sandy- & $-1,440$ \\
\hline Sand. Gas burned & $(40-1$ \\
\hline $\begin{array}{l}\text { Limestone, mostly gray and brown. Small show of oil } \\
\text { at } 1,567 \text { to } 1,570 \text { and } 1,643 \text { to } 1,648 \text { feet. A little } \\
\text { salt water at } 2,125 \text { to } 2,130 \text { feet- }\end{array}$ & \\
\hline
\end{tabular}

This well appears to have penetrated 205 feet of valley fill and to have encountered the Picacho limestone at 567 feet. It is reported that much of the limestone below the top of the Picacho is dolomitic and anhydritic. West of the alluvial basin in places the Picacho is 700 to 800 feet thick.

There are fossiliferous beds in all parts of the Picacho limestone from which numerous fossils have been collected. Most of these fossils have come from the lower part of the Picacho, in which they are most numerous, but some are from the middle and upper parts.

In regard to fossils from the Picacho, Girty ${ }^{86}$ states:

The data for comparing the fauna of the Picacho limestone with the faunas of the Manzano group are not at hand in amount and precision sufficient to lead to reliable conclusions. The forms that are known in either region are too few

Written communication, May, 1930. 
and their specific relation in many cases too uncertain. It is true that in the Manzano fauna over 60 species have been distinguished among the collections from the Yeso and San Andres and in the Picacho fauna species to about the same number; but many of these forms have not been definitely identified or have been identified only generically. Only the Yeso and San Andres formations are here considered because the paleontologic evidence, so far as we have any, suggests a natural division of the Manzano beds into the Yeso and San Andres on one side and the underlying Abo on the other and because the probable stratigraphic relations suggest that the Abo would be of little interest in the proposed faunal comparisons.

If the faunal lists of the Picacho limestone and the faunal list of the two Manzano formations are compared, it becomes evident at once that each contains a large percentage of species not yet known in the other, so that the ground common to both is greatly narrowed. Of the species that are identical or at least comparable in the Picacho and Manzano faunas, the Picacho fauna contains a certain number that are known only in the Yeso fauna and a certain number that are known only in the San Andres fauna, also a certain number of species that are common to both the Yeso and San Andres faunas. The evidence afforded by comparing the species is thus somewhat conflicting as is also the evidence of a more general character. For instance, the Picacho fauna is rather rich in nautiloid types and in pelecypods of the Pleurophorus group, both of which are much more abundant in the Yeso formation than in the San Andres limestone. Nevertheless, the Picacho species that are actually restricted to one formation or the other indicate both by their number and by their significance a closer alliance with the San Andres fauna than with the Yeso fauna. Consequently, given identical boundaries to the units, one would hardly hesitate in saying that as between the Yeso formation and the San Andres limestone the Picacho should be tentatively correlated with the San Andres. There is, however, no assurance, at least on the evidence furnished by paleontology, that the boundaries of the units are the same. The large number of species common to both the Yeso and San Andres faunas would make a decision difficult without a goodly representation of critical species from critical horizons, a condition that does not exist, and the presence in the Picacho limestone of numerous species not known in either the Yeso Iormation or the San Andres limestone, together with the somewhat conflicting evidence of the species that are known in one but not in both, adds to the uncertainty.

Throughout most of the artesian basin the Picacho eonsists almost entirely of limestone and dolomitic limestone with a small proportion of dolomite, and as a whole it has remarkably uniform characteristics. The characteristics of the individual beds of which it is composed, however, are variable. The carbonate rocks vary in color from light tan to black, but most of them are dark gray; their texture is very fine to coarse grained, and the thickness of the beds ranges from a fraction of an inch to about 5 feet. The very fine grained carbonate rocks are generally argillaceous or dolomitic limestone and dolomite, and as a rule are very dense, containing few, if any, open spaces visible megascopically. They are usually very light gray to light tan, although some are dark gray to nearly black. Their weathered surfaces are often lighter colored and 
nearly always comparatively smooth. Nearly all break with a characteristic smooth semiconchoidal, sharp-edged fracture. The joints are small and rather tight. With few exceptions, the rocks are notably poor in fossils. The coarse-grained rocks, as a rule, are limestone or limestone that is only slightly dolomitic. They are usually in massive beds 1 to 5 feet thick and are characteristieally. dark gray, although some are black, or nearly so, and others are light gray. Some of the rocks are oolitic on a very small scale, and others are arenaceous. Many are fossiliferous, and some of those that are nearly black have a petroliferous odor when struck with a hammer. Most of the limestone is more or less cavernous and contains solution cavities and openings, which vary greatly in number, size, shape, and distribution in different beds and often in the same bed. Some of the limestone is extremely cavernous, especially that which is fossiliferous. It weathers into very jagged, pitted surfaces and contains irregular openings. The fractured surfaces are rough. The joints are large and irregular. Many of the spaces between the joints have been enlarged by solution and in places are 6 inches to a foot or more wide. Very large cavernous openings are common, especially in the thick beds.

Some of the limestone contains numerous small holes formed by solution which give the rock a "worm-eaten" or "honeycombed" appearance. In some of the coarse-grained types there are innumerable holes about the size of a pin point and some the size of a pinhead or larger. In others there are holes of all sizes and shapes irregularly distributed. Plate $11, A$, shows one type of "wormeaten" limestone obtained from the upper 50 feet of the Picacho limestone at a depth of 490 to 495 feet in the J. R. Farrell well, in the SE. $1 / 4$ NW. $1 / 4$ NW. $1 / 4$ sec. 18, T. 11 S., R. 25 E., about 5 miles south of Roswell. Plate $11, B$, shows another type of cavernous limestone obtained at an outcrop of the Picacho limestone about 9 miles south of Hope. In thin section (pl. 12), it is seen to be an oolitic limestone with cavities that are irregular in shape. Apparently solution started between some of the oolites or with the coarser and more soluble ones. Both specimens. indicate a very active solution of the limestone. Many of the cavities in the various types of cavernous limestone are lined with small calcite crystals, and others are coated with an orange to rust colored powdery substance. In some cavities this substance is found as a coating on the calcite crystals that line the cavities.

The most characteristic "worm-eaten" type of limestone is fine grained and contains numerous cavities about the size of a pinhead or larger. The cavities are much more regularly distributed, as a rule, than those in the other types. Many of the cavities havo a 
rectengular outline, and on the weathered surface of the rock many appear not to be connected with one another. The fresh surface shows that the interior of the rock contains numerous inclusions of gypsum, many of which have a rectangular outline, and that the cavities are primarily the result of the solution and removal of the gypsum. The rectangular outline suggests that the gypsum was originally deposited as anhydrite, which was essentially contemporaneous with the formation of the limestone. Apparently during the deposition of the limestone there were at times "showers" of crystals and small nodules of anhydrite. Subsequently the anhydrite was changed to gypsum. This involved an expansion which may have rounded or modified the original shape of the anhydrite crystal or nodule. An intimate association of anhydrite and dolomite or dolomitic limestone in cuttings obtained from deep wells in this region is very common. This type of "worm-eaten" limestone usually occurs in beds a few inches thick or less, very commonly in the gypsiferous portions of the Pecos formation, especially where the formation consists mainly of gypsum with intercalated thin beds or lenses of dolomitic limestone and dolomite. It is also commonly associated with gypsiferous portions of the Picacho limestone. However, it is not confined to gypsiferous strata, for it occurs not uncommonly in the upper part of the Picacho limestone, where it consists of thin-bedded limestone, dolomitic limestone, and dolomite. Plate 13 shows a typical specimen of this limestone obtained from the lower part of the Pecos formation in an outcrop about 12 miles south-southeast of Hope. The cavities in this rock are now filled with coarsely crystalline calcite, which is clearly secondary. In thin section it is seen that in many places the calcite has replaced the wall rock. The rectangular shape of some of the cavities is well shown in Plate $13, B$. Plate 14 is a photomicrograph of a thin section of a part of the rock and shows coarse-grained calcite spherules in cavities in a dense, fine-grained carbonate rock. The polished face of a specimen of this type of "worm-eaten" limestone, obtained from the upper 50 to 100 feet of the Picacho limestone at a depth of 515 feet in the J. P. White well, in the NE. $1 / 4$ SE. $1 / 4$ NW. $1 / 4$ sec. 7, T. 11 S., R. 25 E., is shown in Plate 15, $B$. The cavities in this rock are now lined with secondary calcite.

Plates $15, A$, and 16 show another type of cavernous limestone from the upper part of the Picacho limestone about 20 miles southsouthwest of Hope, in the northern part of T. 21 S., R. 21 E. Plate 17 shows photomicrographs of a thin section of this limestone.

One of the most striking features of all of the cavernous limestone in the Picacho is that much of it is directly overlain or underlain by very dense limestone that does not appear to differ greatly in texture 
or composition from the unaltered portions of the cavernous limestone. Another very striking feature commonly found is that the cavernous condition of the limestone is not confined to certain beds but changes laterally, even within a few feet, from one bed to another, without any other visible changes in the character or structure of the beds. This condition is well exhibited in an exposure in the northeastern part of T. 14 S., R. 22 E., on the south side of a drywash tributary to the Rio Felix. It doubtless explains to a great extent the discontinuity along definite stratigraphic horizons of the so-called "water rocks" beneath the artesian area.

Although the Picacho is not easily separable into smaller units, the lower part possesses some characteristics that are either uncommon or absent in the upper part. The terms "lower part" and "upper part" are used in a general sense and are, therefore, rather indefinite, for the differences between the "lower" and "upper" parts appear to be gradational. In the lower part of the Picacho most of the carbonate rocks are dark-gray, thick-bedded, massive limestone. Most of the beds are more than 1 foot thick, a large proportion are 2 to 3 feet thick, and many are 4 to 5 feet thick. Much of the limestone is coarse grained, although fine-grained, dense limestone is not uncommon. A view of limestone in the lower part of the Picacho is shown in Plate 18, $C$. Many of the beds are fossiliferous, and there are many beds of dark-gray to black limestone that have a petroliferous odor when struck with a hammer. In the upper part of the Picacho, especially near the top, most of the limestone is light tan to light gray and thin bedded. Much of it is dolomitic. There are few beds more than 2 feet thick and most of the beds are less than 1 foot thick. A large part of the limestone and dolomitic limestone is argillaceous, very fine grained, and very dense. Few of the beds are notably fossiliferous, and beds of black limestone having a petroliferous odor when struck with a hammer are either rare or absent. These statements apply only in a general way, for many exceptions can doubtless be found to all of them.

The sandstone zone in the lower part of the Picacho is absent in the southeastern and northwestern parts of the artesian basin and possibly throughout much of the southwestern part. Two sandstones were encountered near the base of the Picacho in the Dunken Dome well, in sec. 29, T. 17 S., R. 18 E., and it was reported that the Farnsworth well, in sec. 7, T. 21 S., R. 21 E., encountered water in sandstone at a depth somewhere between 1,100 and 1,250 feet. The latter, however, may be in the Nogal formation. The sandstones in the lower part of the Picacho near the town of Picacho must thin out within a relatively short distance westward, for no comparable sandstones were found in the lower part of the Picacho near the 
Bonnell ranch, 15 to 20 miles west-northwest of Picacho, nor along the west flank of the Sacramento Mountains east and northeast of Tularosa. According to geologists who have examined samples from wells drilled for oil in the northeastern part of the artesian basin the sandstone encountered in the lower part of the Picacho has remarkably uniform characteristics. It is generally medium to coarse grained and consists of subangular to rounded quartz grains, many of which are frosted. As a rule, the sandstone is light yellowish to cream-colored, although occasionally. it is rust-colored in places, owing to the presence of ferruginous cement.

According to the drillers' logs of many wells, thin beds of sandstone and red shale and sand are encountered in the upper few hundred feet of the Picacho limestone in the southeastern part of the artesian basin. In the central part of T. 20 S., R. 21 E., the writer observed red beds which appeared to be in the upper part of the Picacho. According to Renick, ",7 "thin beds or lentils of red sandy shale and yellow sandstone" occur in the lower part of the Picacho limestone in the upper drainage basin of the Rio Penasco. At the $\mathrm{Y}-\mathrm{O}$ crossing there is a 2 to 3 foot bed of bright-yellow sandy shale or shaly sandstone in the Picacho limestone. A bed similar to this was observed in the Picacho limestone in the canyon of the Rio Hondo above the Diamond $\mathbf{A}$ headquarters ranch.

Northwest of Roswell, in the vicinity of Salt Creek, thick beds of gypsum appear in the upper few hundred feet of the Picacho limestone. Many of the beds are 5 to 10 feet or more thick. Gypsum occurs in the upper part of the Picacho limestone west of Roswell, in the vicinity of Hope. On the north side of a tributary to Fourmile Draw, in the southeastern part of T. 18 S., R. 21 E., there is a very interesting exposure of intimately associated limestone and gypsum. Figure 9 is a somewhat generalized columnar section showing the stratigraphic sequence at one point along the bluff. The lower part of the bluff consists of thin-bedded dark-gray limestone in beds 6 inches thick or less, containing in places small irregular masses of white gypsum. This is overlain by an 8 -inch bed of irregularly mixed gypsum and greenish-gray limy shale. Above this bed there is 2 to 3 feet of fine-grained dark-gray limestone, some of which contains numerous small holes about half a millimeter in diameter, which give the rock a worm-eaten appearance. The lowest bed is about 9 inches thick, and the top bed is 2 to 3 inches thick. The upper surface of the top bed is irregular, with 1 to 3 inch masses of dense white gypsum filling the depression. This is overlain by a 4 -foot bed of

\footnotetext{
or Renick, B. C., Geology and ground-water resources of the drainage basin of the Rio Pefiasco above Hope, N. Mex.: New Mexico State Engineer Seventh Bienn. Rept, p. 119, 1926.
} 
very intimately associated dark-gray "worm-eaten" limestone and dense white gypsum. The lower 6 to 8 inches contains many large masses of gypsum, but the rest, except in spots where there is little gypsum, consists of gypsum and limestone in about equal proportions. There are many small seams of selenite in this mixture of gypsum and limestone. The limestone is gray and "worm-eaten." The gypsum appears to have replaced the limestone, for in places there are small irregular pieces of limestone surrounded by massive gypsum. Plate

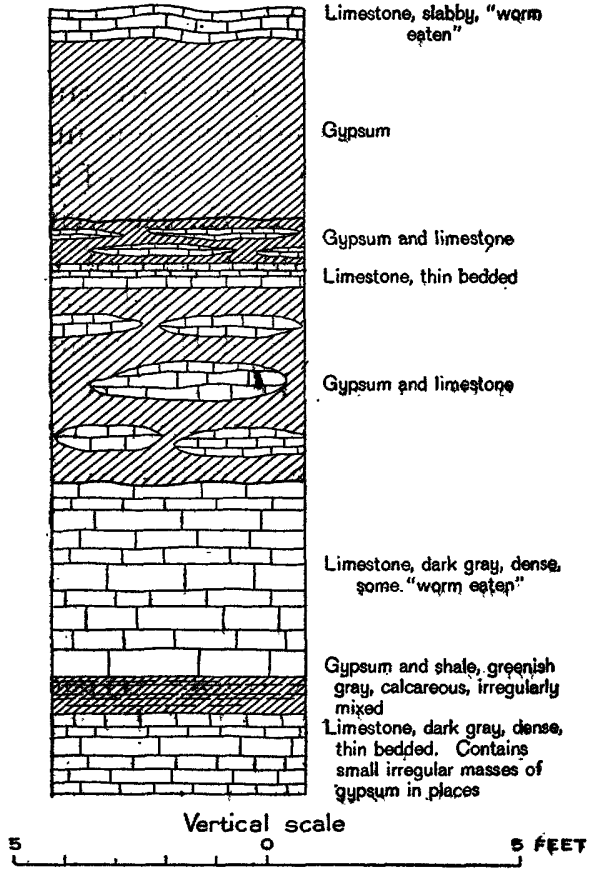

Figurb 9.-Generalized columnar section of an exposure of the upper part of the Picacho limestone at a point along the bluff in the southeastern part of T. 18 S., R. $21 \mathrm{E}$.
19 shows views of a specimen collected from this bed and clearly shows the intimate relations of the gypsum and limestone. A detailed study of this specimen was kindly made for the writer by Goldman, who states: ${ }^{68}$

The gypsum of the gypsified limestone consists of two partsmore or less spherular masses of fine-grained gypsum and roughly horizontal veins of coarser gypsum, the latter in places with a comb structure at right angles to the walls of the vein. (See pls. 20 to 22.) The spherules are full of grains of carbonate which appear to be exactly like that of the matrix ; these carbonate grains generally increase in amount toward the periphery of the spherule, and the contact of the spherule with the wall rock is very irregular. All of which indicates that the spherules were formed by replacement of the country rock. The veins evidently enter into or pass through the spherules but generally lose their coarseness of grain and much of their regularity and continuity in them, tending to become thinner, branched, and irregular in direction. In places they pass around the outside edge of the spherule. This, together with the way they break up inside the spherules, indicates that they are later than the spherules. From their general relation and the microscopic evidence it is quite possible that the spherules formed essentially contemporaneously with the limestone-that is, while it lay at the bottom of the body of water in which it was formed; but the definiteness and relative regularity of the veins indicate that the limestone was indurated at the time the veins were formed and that they are therefore epigenetic.

The gypsiferous limestone is overlain by fine-grained dark-gray limestone which breaks with a semiconohoidal fracture. Although

${ }^{68}$ Goldman, M. I., written communication. 


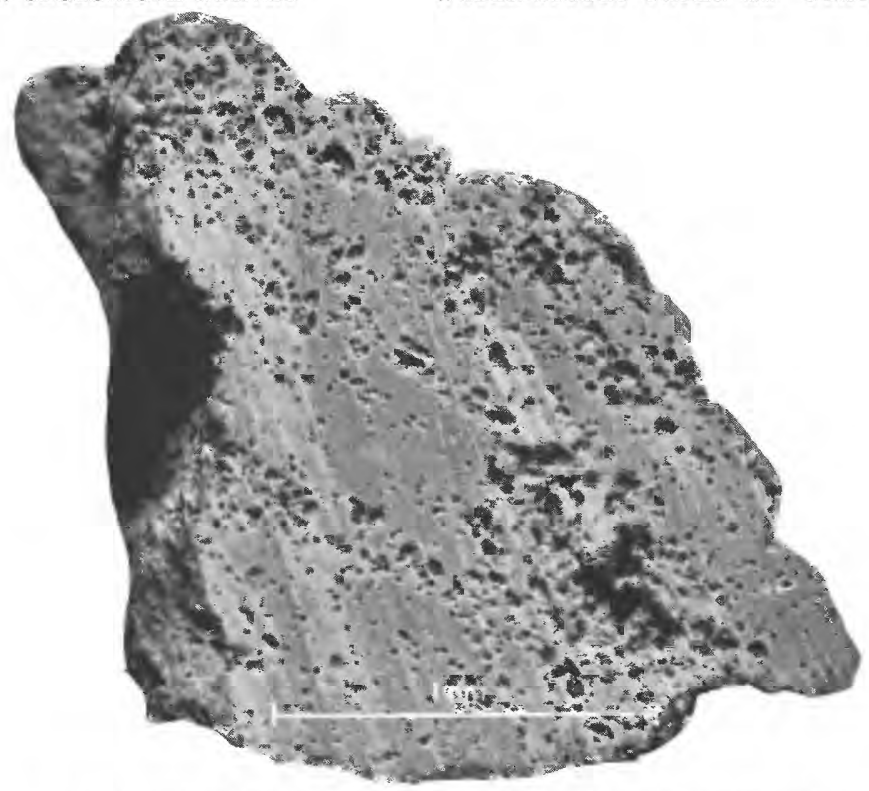

A. POLISHED FACE OF SPECIMEN OF "WORM-EATEN" LIMESTONE FROM THE UPPER PART OF THE PICACHO LIMESTONE

Obtained at a depth of 490 to 495 feet in a well in the SE. 1/4 NW. 1/4 NW. 1/4 sec. 18, T. 11 S., R. 25 E. Photograph by M. I. Goldman.

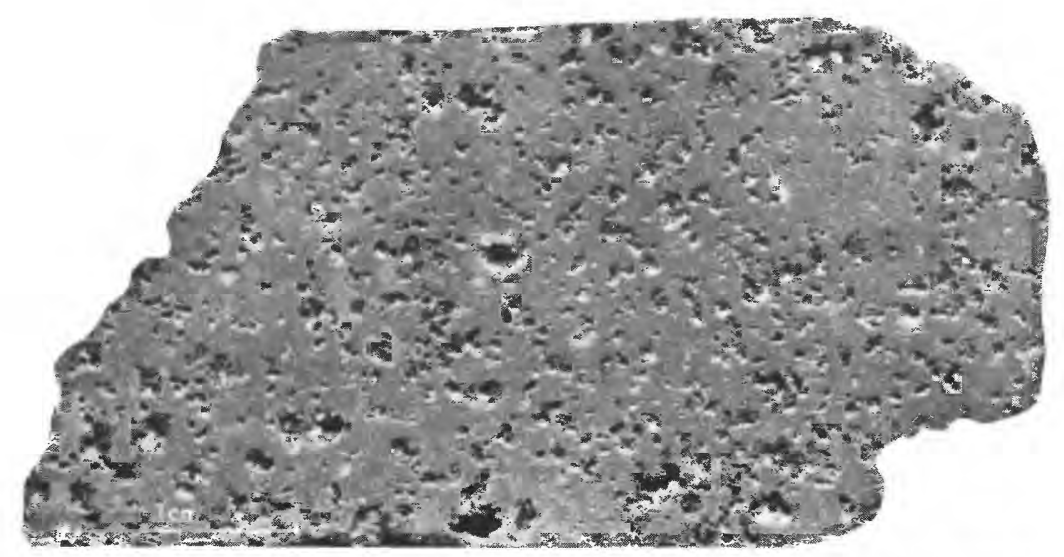

B. GROUND FACE OF SPECIMEN OF CAVERNOUS LIMESTONE FROM THE UPPER PART OF THE PICACHO LIMESTONE

Obtained about 9 miles south of Hope. Photograph by M. I. Goldman. 


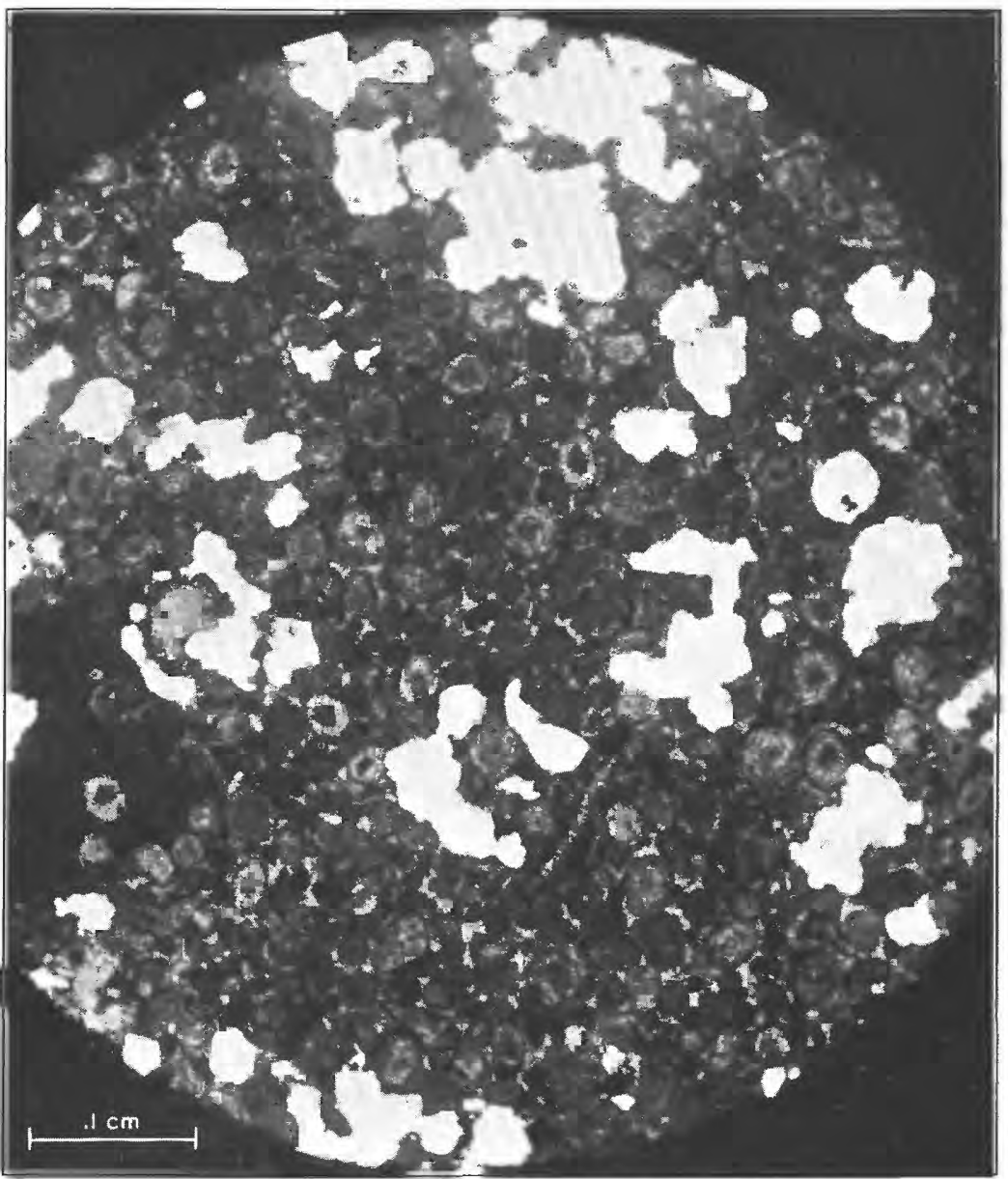

THIN SECTION OF SPECIMEN SHOWN IN PLATE 11, $B$

Photomicrograph hy M. I. Goldman. 


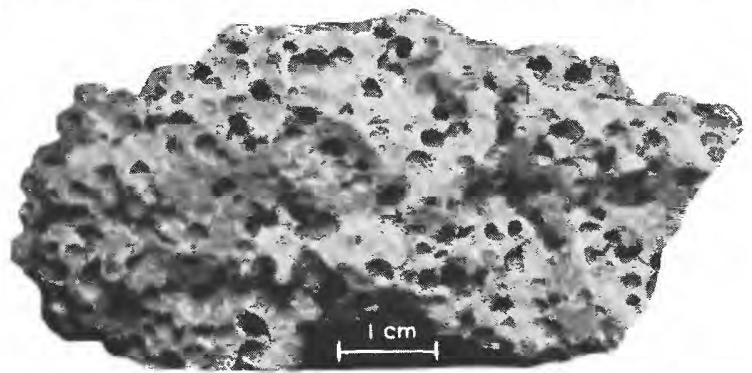

A. SPECIMEN OF "WORM-EATEN" LIMESTONE FROM THE LOWER PART OF THF PECOS FORMATION IN T. 19 S., R. 23 E.

Photograph by M. I. Goldman.

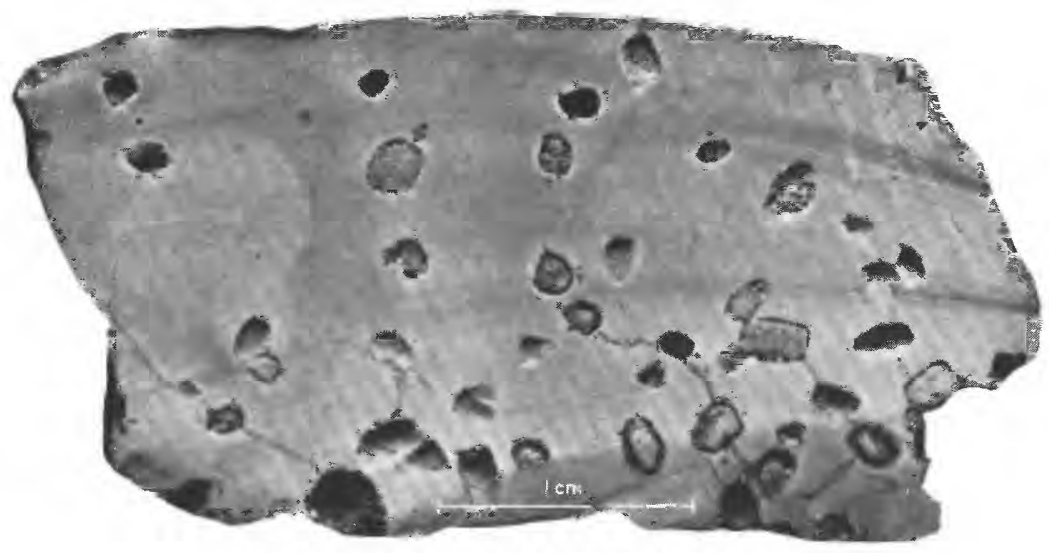

B. SAWFD FACE OF SPECIMEN SHOWN IN $A$.

Photograph by M. I. Goldman. 


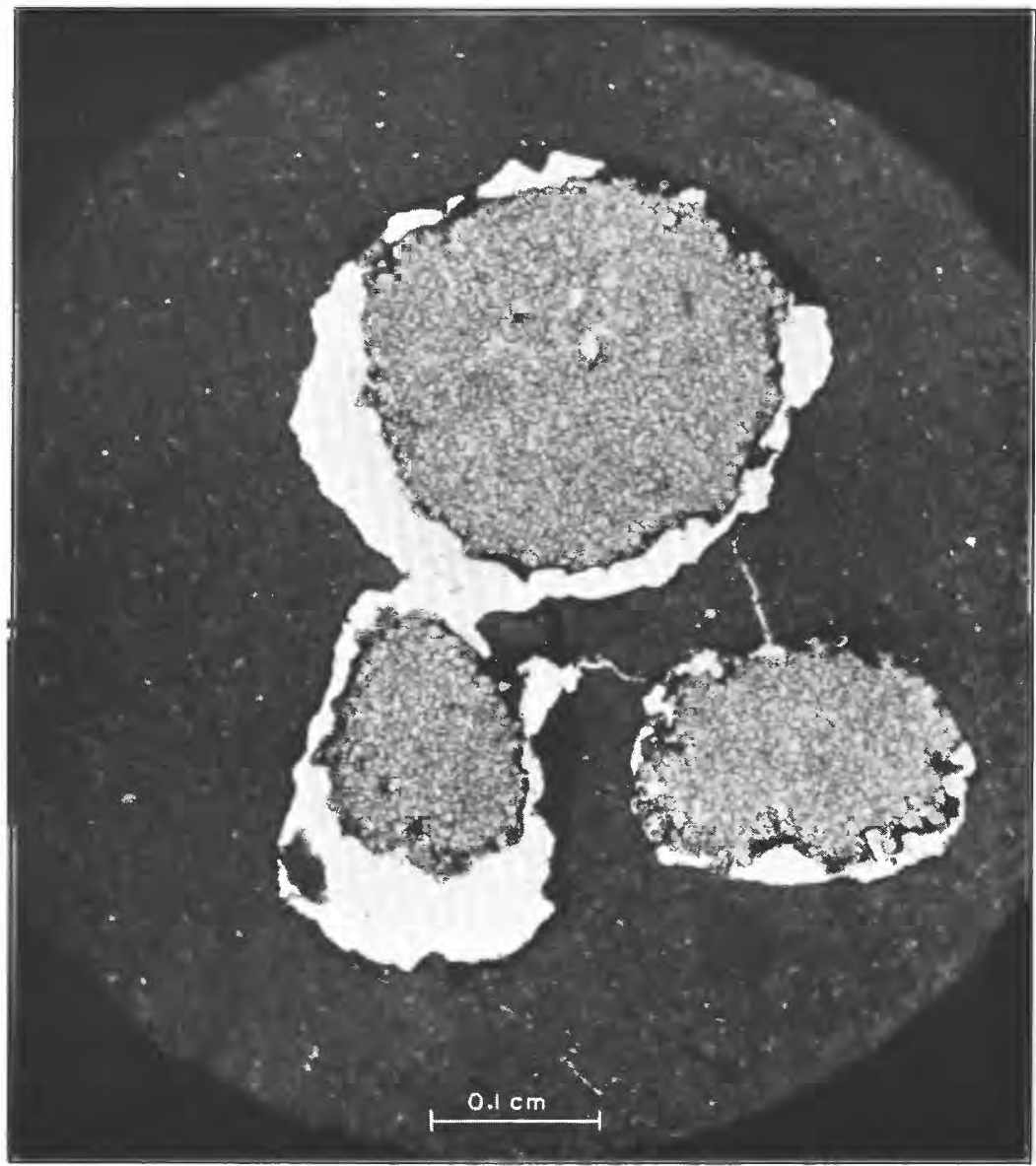

THIN SECTION OF SPECIMEN SHOWN IN PLATE 13, $A$

Showing dense, fine-grained groundmass and coarse-grained calcite spherules in cavities. Photomicrograph by M. I. Goldman. 


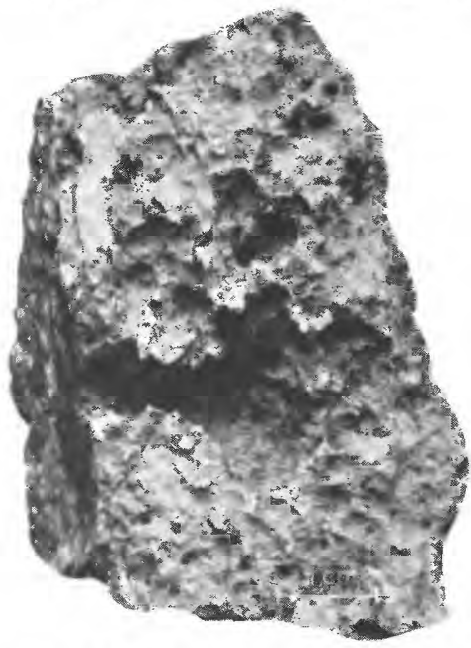

A. WEATHERED FACE OF CAYERNOUS LIMESTONE FROM THE UPPER PART OF THE PICACHO LIMESTONE IN THE NORTHERN PART OF T. 21 S., R. 21 E.

Photograph by M. I. Goldman.

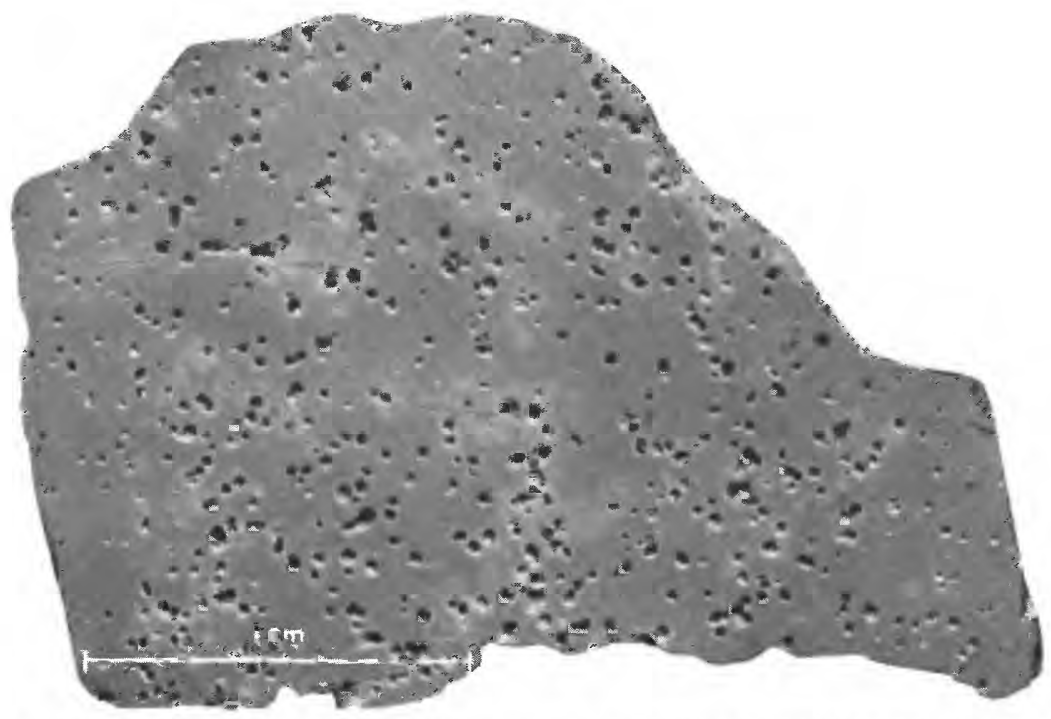

B. POLISHED FACE OF SPECIMEN OF "WORM-EATEN" LIMESTONE FROM THE UPPER PART OF THE PICACHO LIMESTONE

Obtained at a depth of 515 feet in a well in the NE. 1/4 SE. 1/4 NW. $1 / 4$ sec. 7, T. 11 S., R. 25 E. Photograph by M. I. Goldman. 


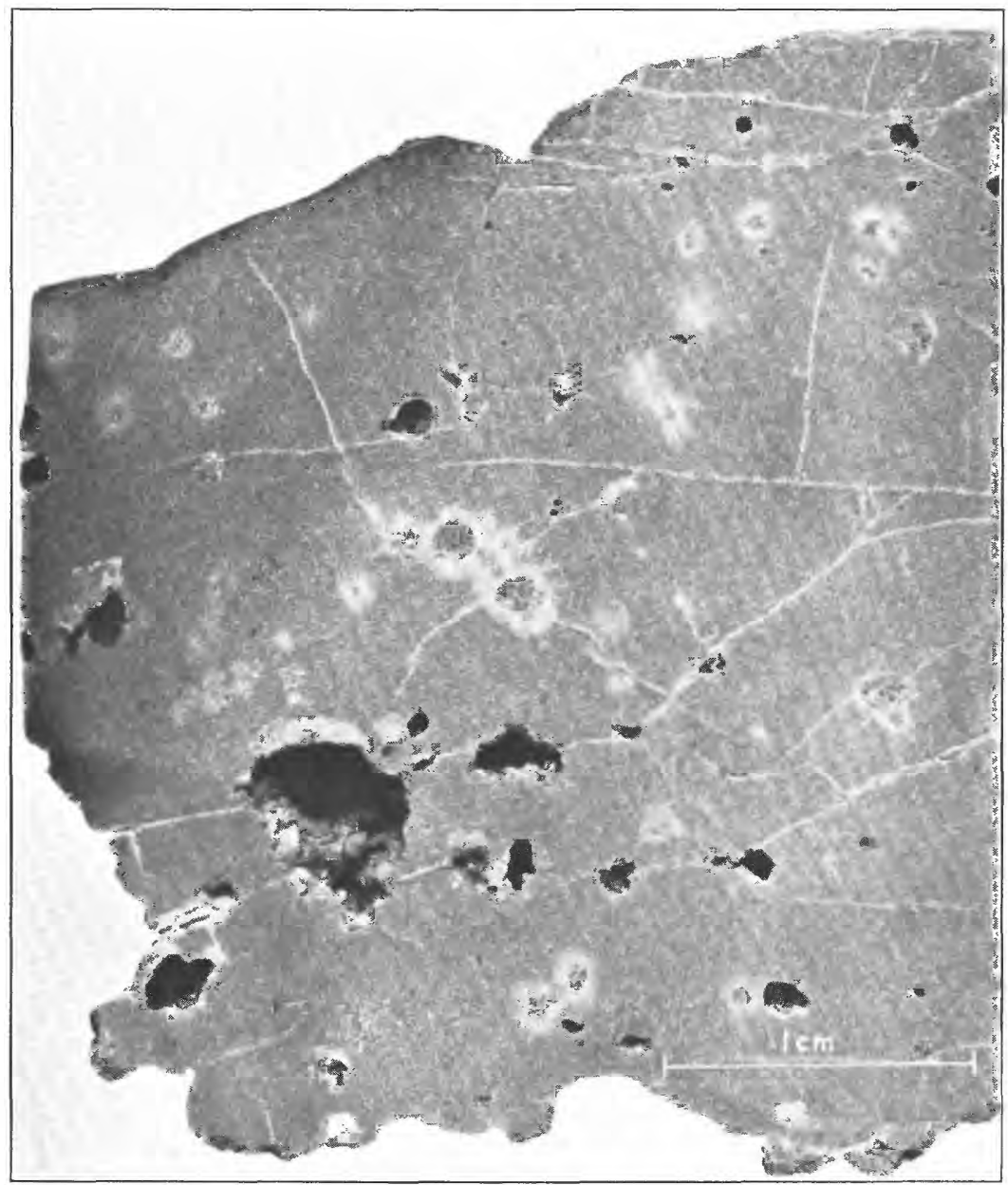

GROUND FACE OF SPECIMEN SHOWN IN PLATE 15, $A$ Photograph by M. I. Goldman. 


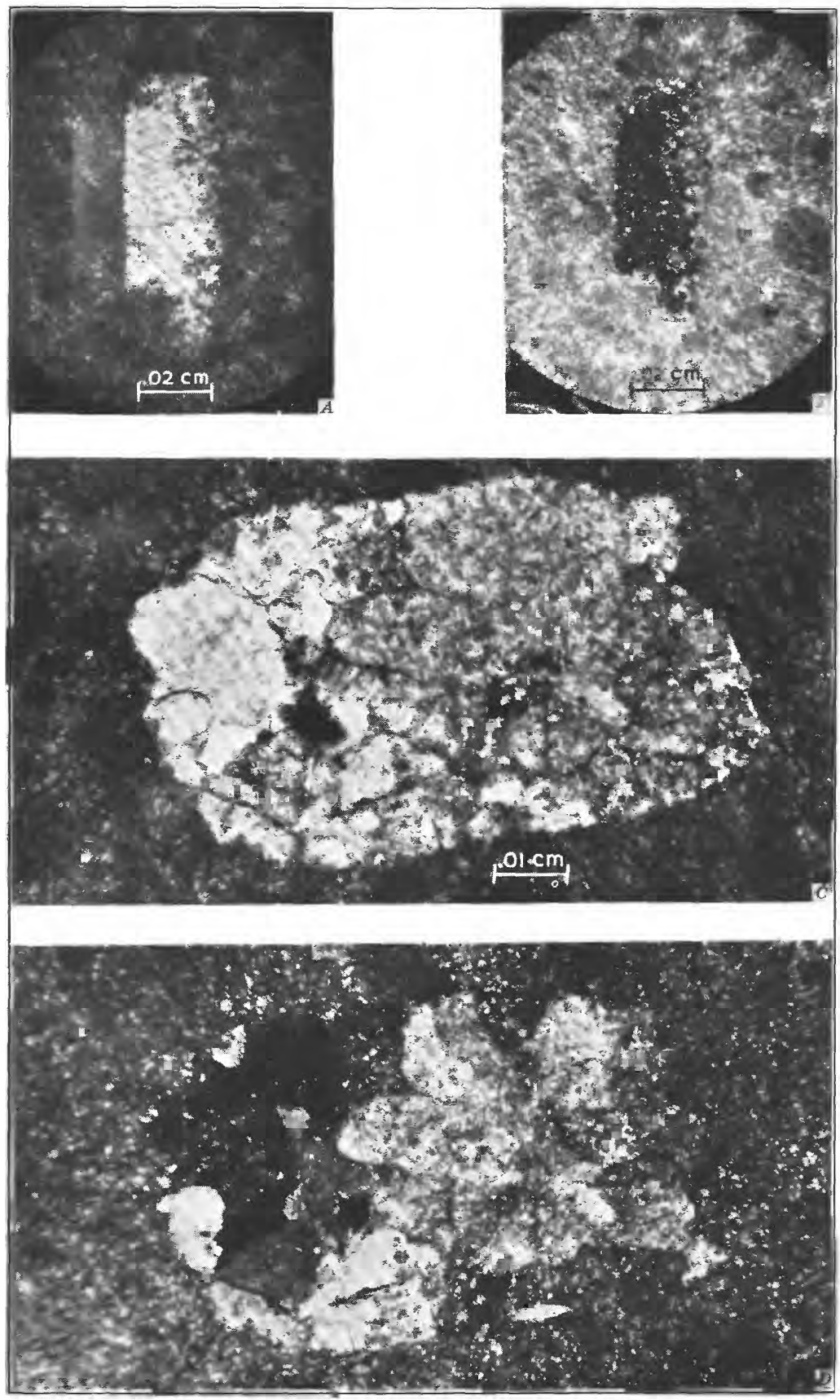

DETAILS OF THIN SECTIONS OF SPECIMEN SHOWN IN PLATE 15, $A$

$A, B$. Single large rectangular calcite crystal ( $A$, plain light; $B$, crossed nicols); $C, D$. Aggregate of coarse calcite with more or less rectilinear and rectangular boundaries ( $C$, plain light; $D$, cross nicols). Photomicrographs by M. I. Goldman. 


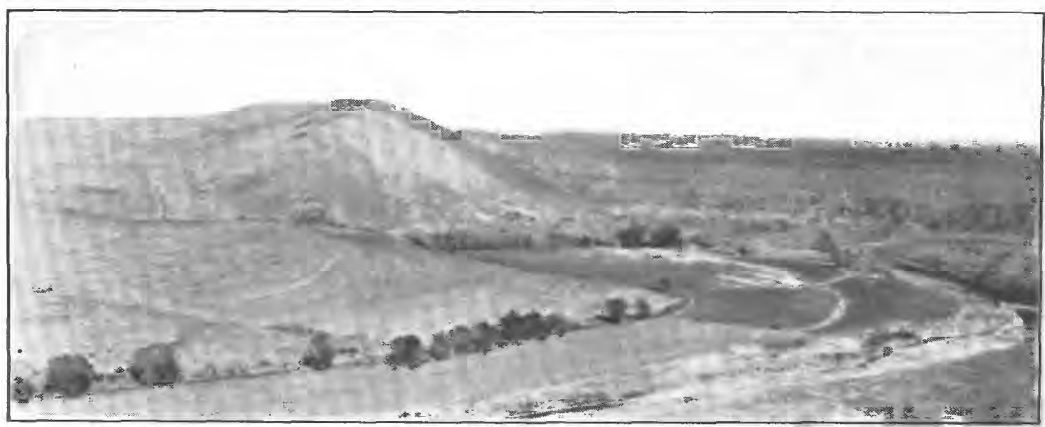

A. BORDER HILLS FROM A POINT ON THEIR SOUTHWESTERN CONTINUATION SOUTH OF THE RIO HONDO

Photograph by S. S. Nye.

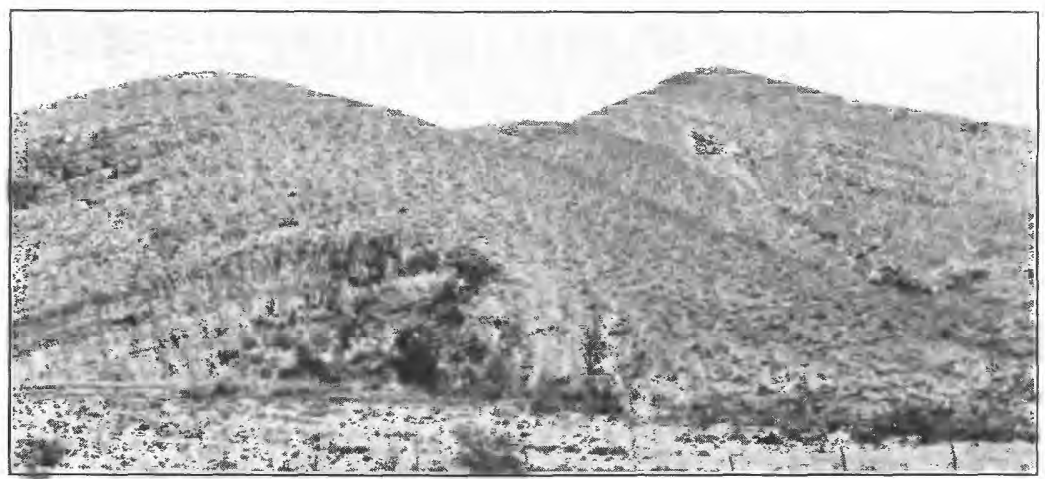

\section{B. BORDER HILLS FAULT}

Looking northeast from a point on the north side of the low ridge shown in the foreground of $A$. Photograph by S. S. Nye.

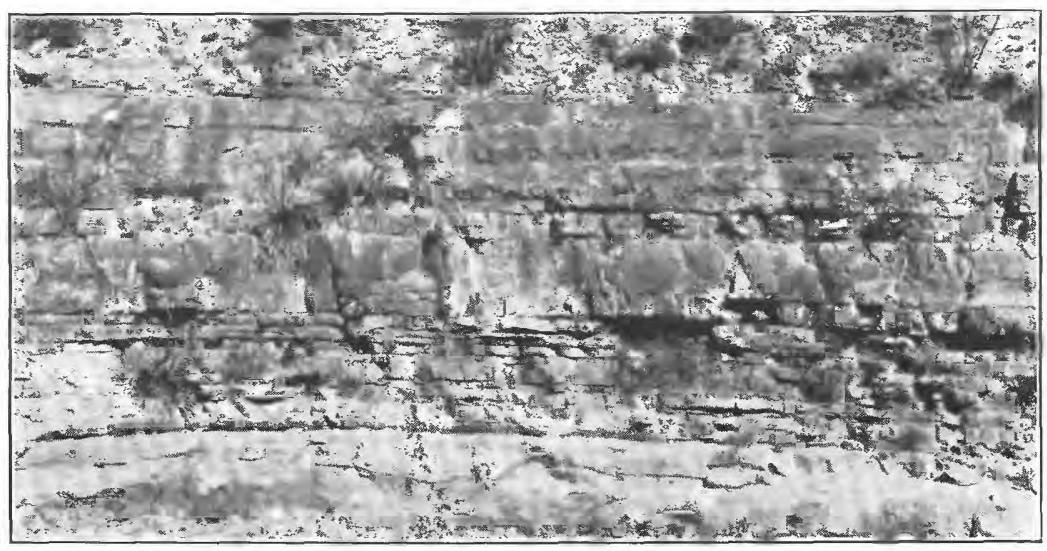

C. LIMESTONE IN THE LOWER PART OF THE PICACHO LIMESTONE EXPOSED IN T. 11 S., R. 20 E.

Photograph by S. S. Nye. 


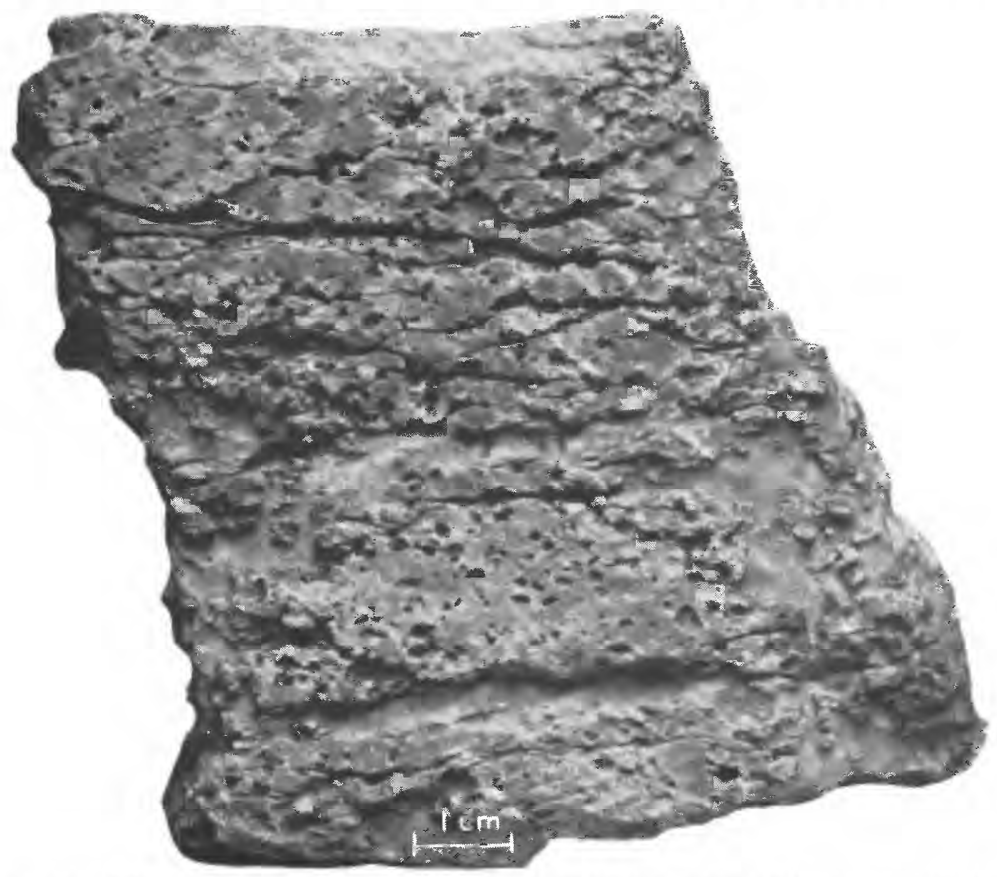

A. WEATHERED FACE OF SPECIMEN OF GYPSIFEROUS LIMESTONE FROM THE UPPER PART OF THE PICACHO LIMESTONE IN THE SOUTHEASTERN PART OF T. 18 S., R. 21 E.

Photograph by M. I. Goldman.

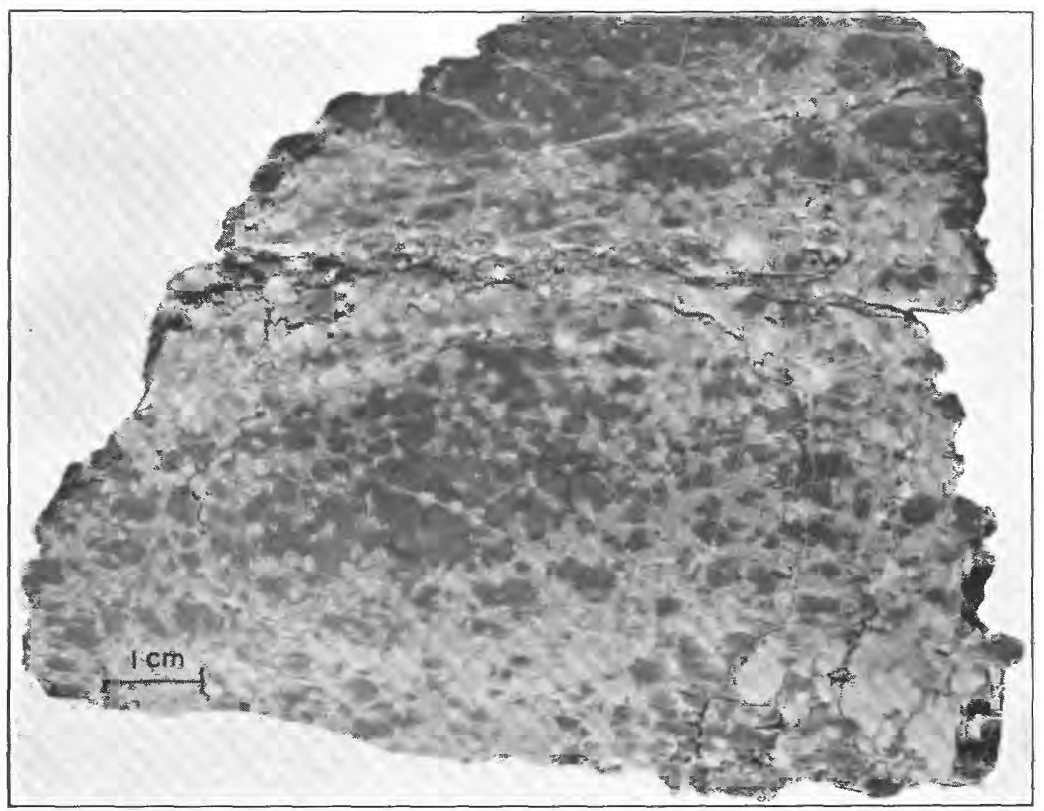

B. GROUND FACE OF SPECIMEN SHOWN IN $A$

Limestone dark gray; gypsnm light gray. Photograph by M. I. Goldman. 


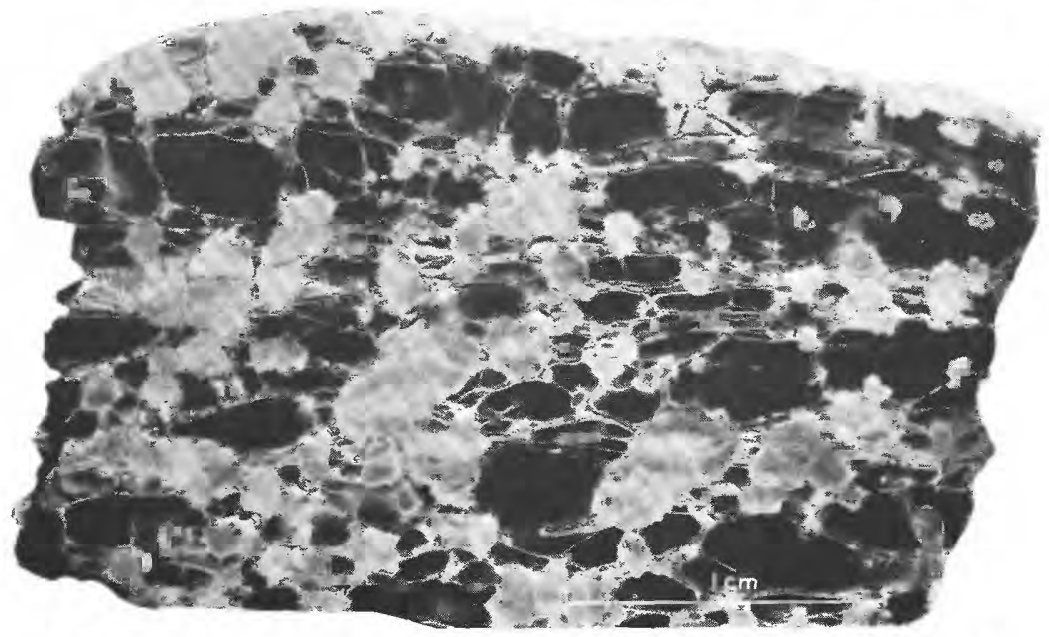

$A$. POLISHED FACE OF PART OF THE SPECIMEN SHOWN IN PLATE 19, $A$

Showing gypsum spherules and veins (light gray) in limestone (dark gray). Photograph by M. I. Goldman.

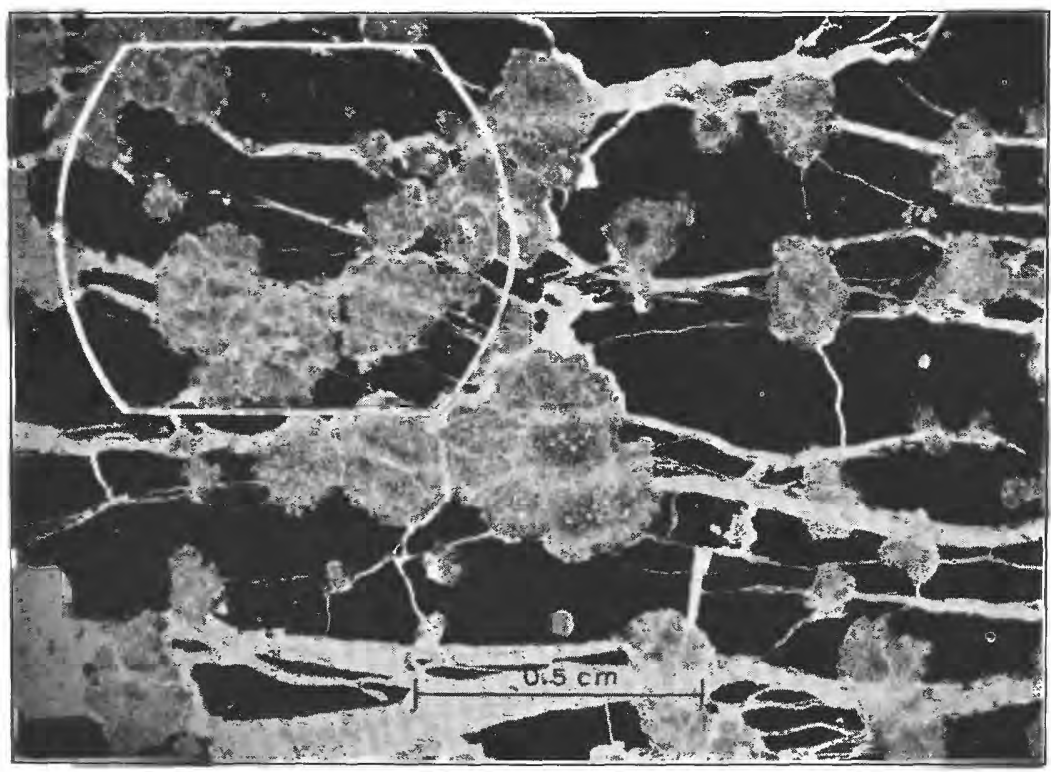

B. GENERAL VIEW OF THIN SECTION OF THE SPECIMEN SHOWN IN PLATE 19, $A$

Showing relations of gypsum veins and spherules. The white outline indicates the position of the more detailed views shown in Plate 21. Photograph by M. I. Goldman. 


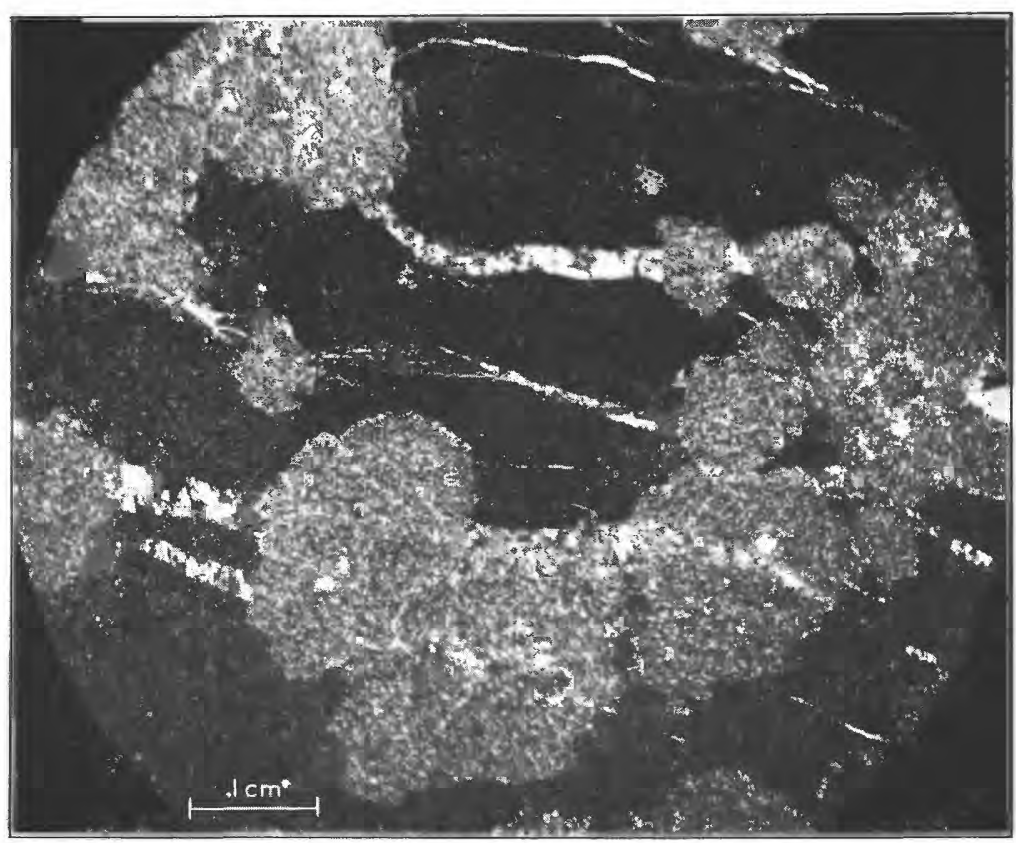

A

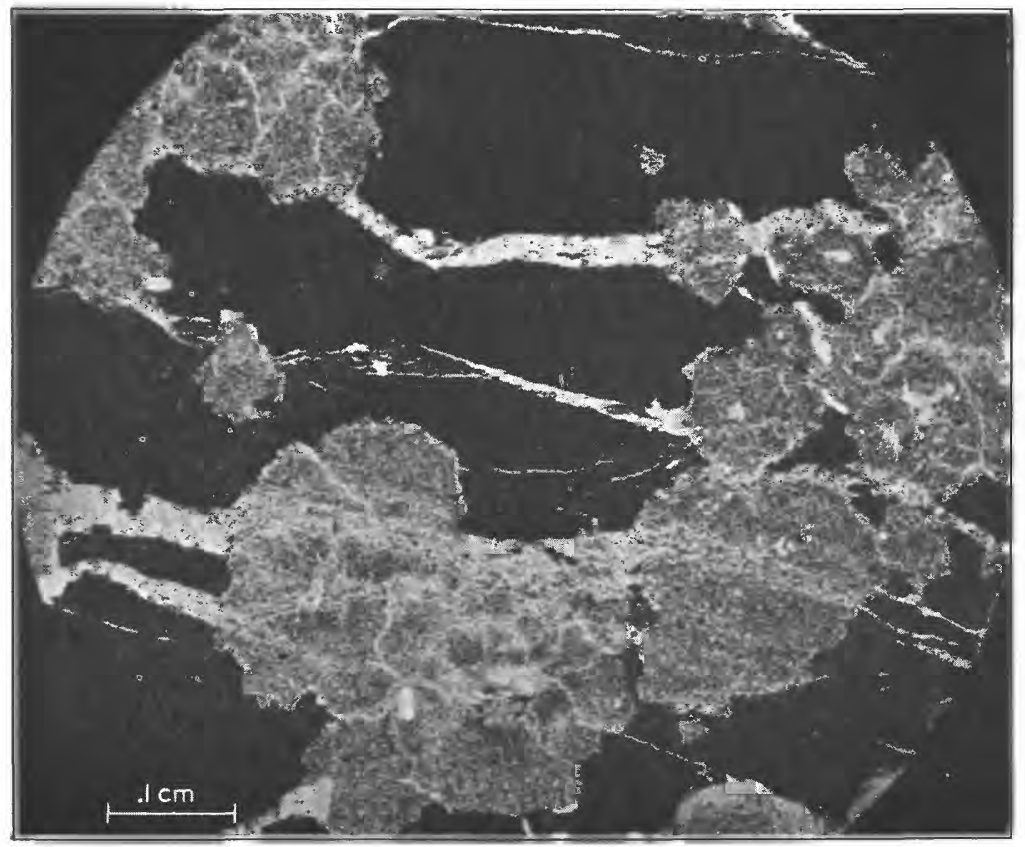

B

DETAIL OF PLATE 20, B

$A$, Plain light; $B$, crossed nicols Photographs by M. I. Goldman. 


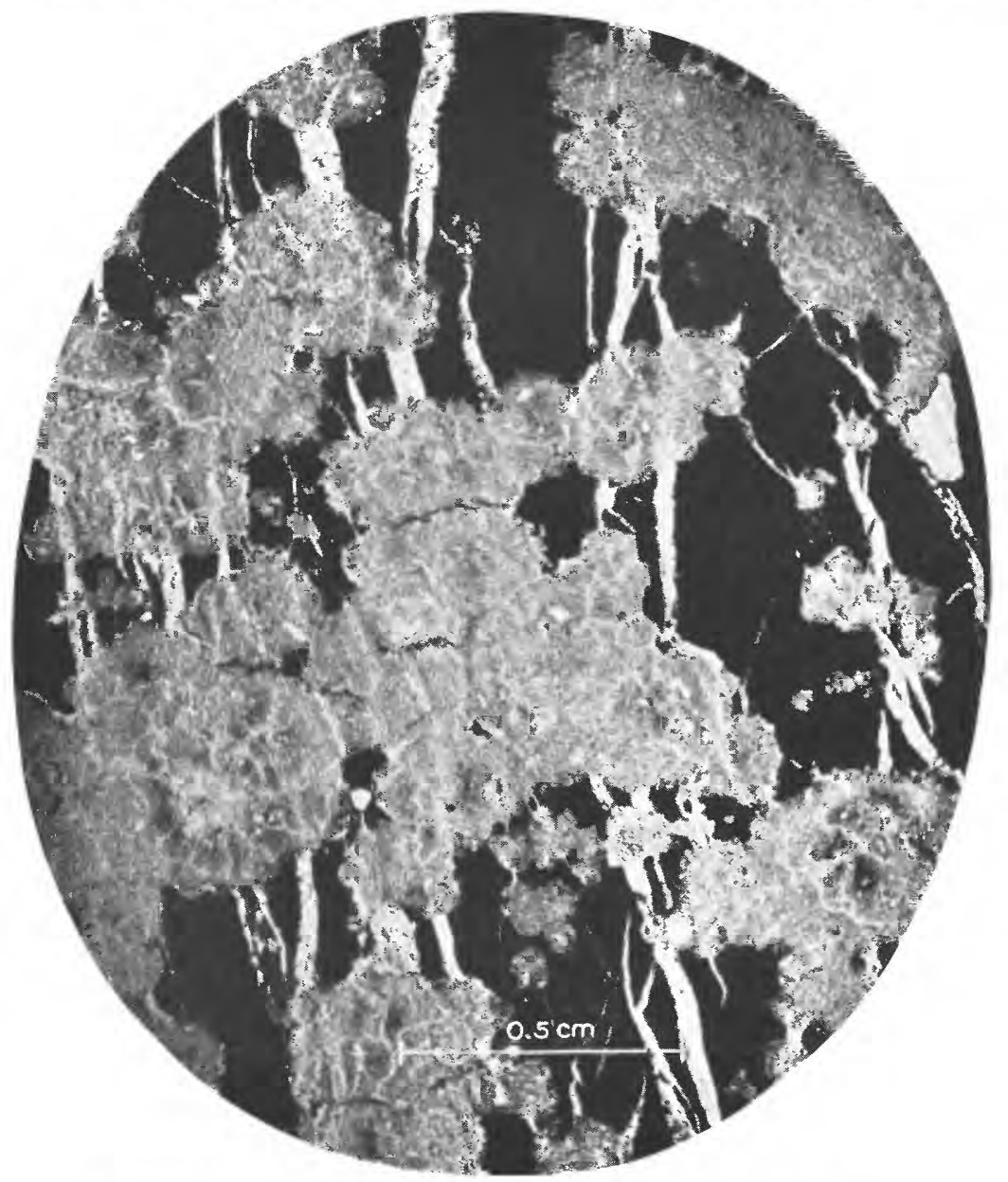

ANOTHER THIN SECTION OF SPECIMEN SHOWN IN PLATE 19, $A$

Photomicrograph by M. I. Goldman. 


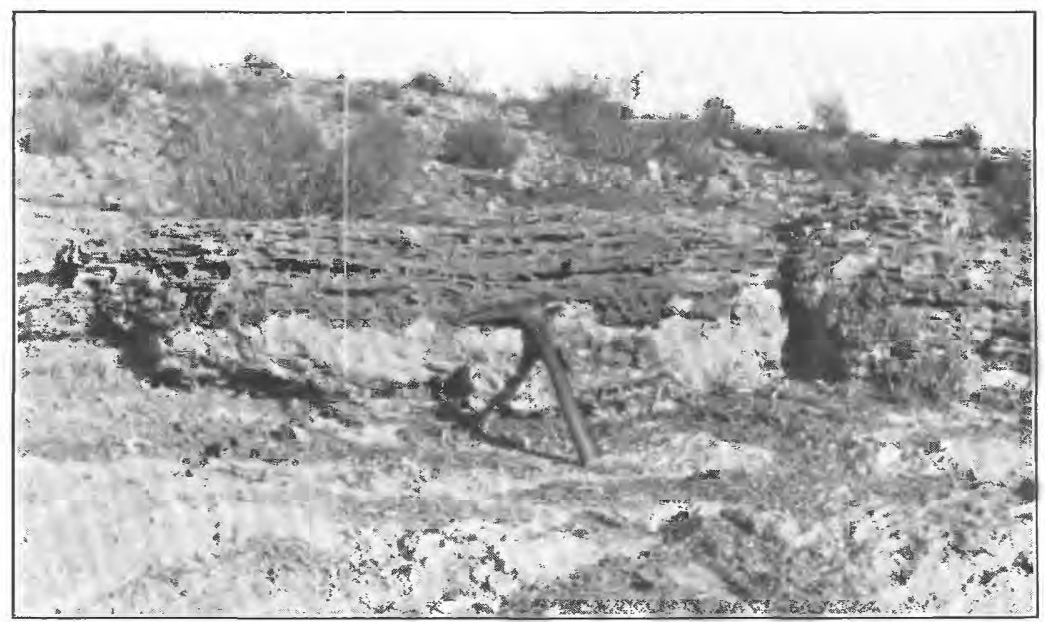

A. CELLULAR AND BRECCIATED LIMESTONE NEAR THE TOP OF THE PICACHO LIMESTONE IN SEC. 8, T. 14 S., R. 23 E.

Photograph by S. S. Nye.

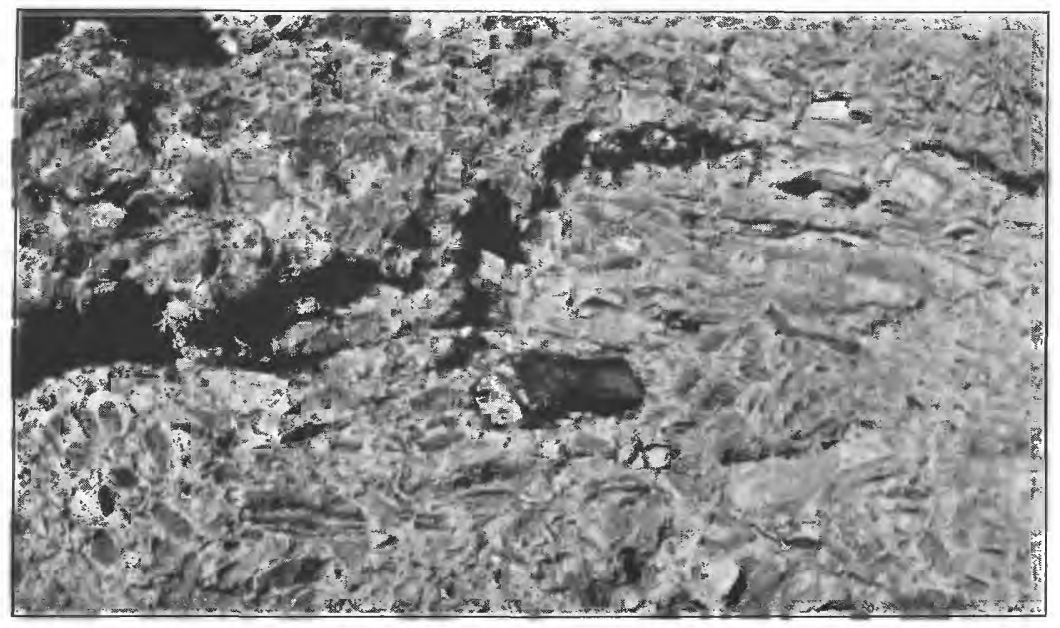

B. LIMESTONE BRECCIA NEAR THE TOP OF THE PICACHO LIMESTONE IN SEC. 25, T. 14 S., R. 22 E.

Exposed along the channel of the Rio Felix. Photograph by S. S. Nye. 
品

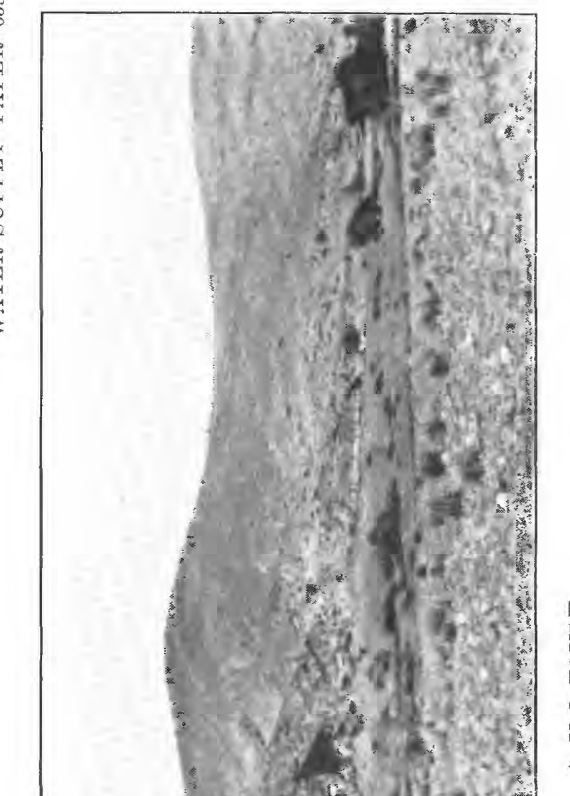

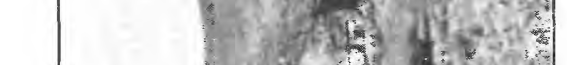

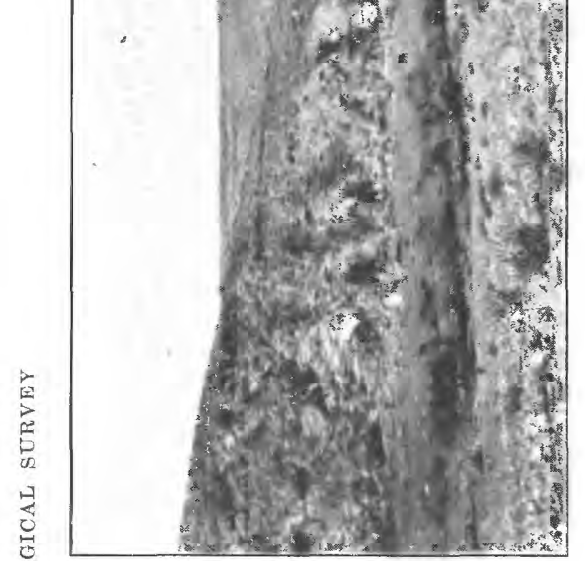

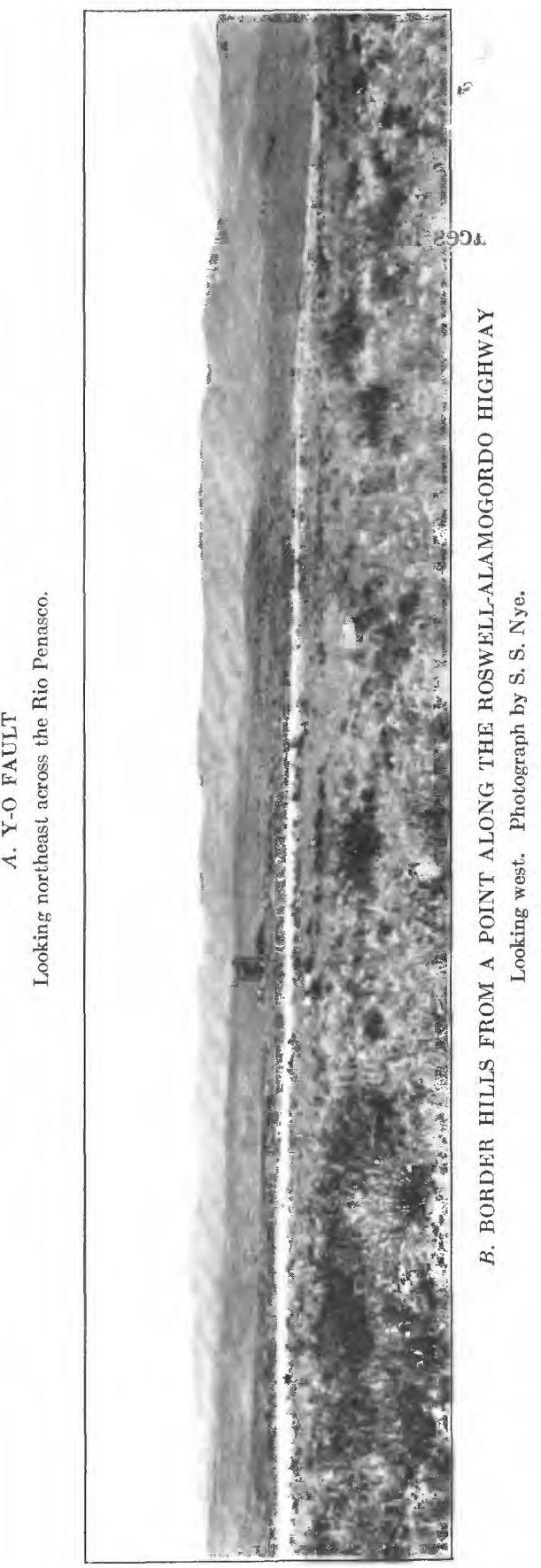


some of it is "worm-eaten," most of it is very dense. In other places there is a gradational change from the gypsiferous limestone to the next overlying bed, which consists of several feet of gypsum with lenses and blocks of limestone. In places alternating layers half an inch to 1 inch thick of gypsum and limestone were observed. Above thiis in 4 to 5 feet of granular to dense gypsum, which in turn is overlain by thin-bedded, slabby "worm-eaten" dark-gray limestone, in inlo ? ighly distorted. A short distance farther west the bluff consists dominantly of gypsum with a few intercalated thin beds and lenses of limestone. There is a similar exposure a little over 9 miles south of Hope, a short distance east of the road to the Whitaker ranch. At this place there is a bed of dark-gray "worm-eaten"

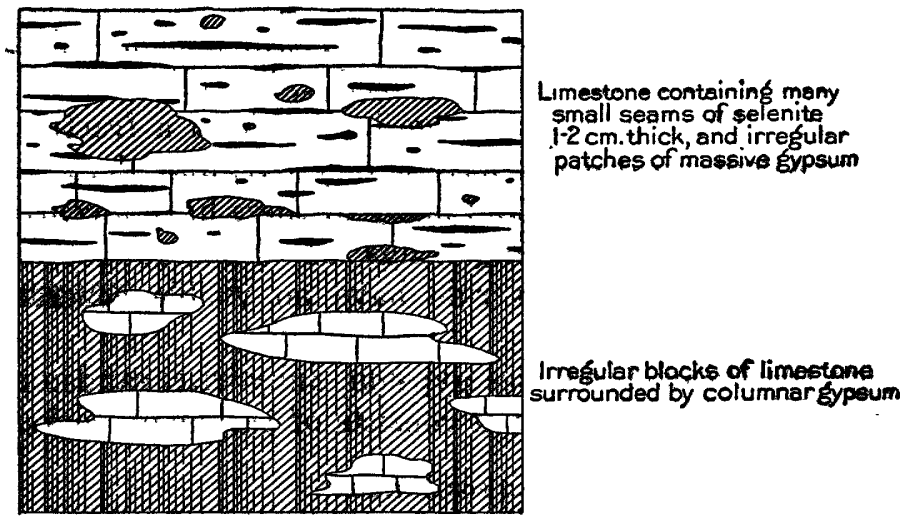

Frgurn 10.-Relations of gypsum and limestone in the uppex part of the Picacho limestone in an outcrop about 9 miles south of Hope

limestone containing selenite in small seams 1 to 2 centimeters thick and irregular patches of massive gypsum, below which are irregular blocks of limestone that appear to be supported by columnar and cellular gypsum. (See fig. 10.)

Limestone breccia at or very near the top of the Picacho limestone was observed in the NW. $1 / 4$ sec. 8 and the.SW. $1 / 4$ sec. $30, T$. 14 S., R. 23 E., in the S. $1 / 2$ sec. 25 , T. 14 S., R. 22 E., and at several stratigraphic horizons in the eastern part of T. $16 \mathrm{~S}$., R. $21 \mathrm{E}$. The breccia consists of angular blocks of limestone of all sizes irregularly distributed in a limy matrix. In the NW. 1/4 sec. 8, T. 14 S., R. $23 \mathrm{E}$., much of the breccia has a cellular appearance due to resistant seams of a white to pink calcareous material between blocks of limestone that have been largely removed by solution. (See pl. 23, A.) 'The breccia in the southern part of sec. 25, T. 14 S., R. 22 E., which is extensively and clearly exposed in the channel of Rio Felix, is very firmly cemented. (See pl. 23, B.) Limestone breceia occurs at several stratigraphic horizons in the upper 100 feet of the Picacho 135252-33-6 
limestone in the eastern part of T. 16 S., R. 21 E. At one place the relation of the breccia to overlying beds of limestone is clearly exposed. Blocks of limestone may be seen partly dislodged from the overlying limestone and firmly cemented in the breccia. This breccia is an excellent example of what Lee termed solution and fill. ${ }^{69}$ It is quite possible that the breccia may have been formed by solution and fill above the water table during Permian time and may therefore represent an unconformity at the top of the Picacho. However, no conclusive evidence as to its age was found.

Nodules and concretions of chert are commonly found in the limestone beds in all parts of the Picacho. They are usually in the top of a bed, and, owing to their superior resistance to erosion, they stand up prominently above the surrounding limestone. As a rule their weathered surfaces have a rust color which makes them conspicuous. The color of the chert is variable, but much of it is dark gray to black. The concretions range in size from a fraction of an inch to over a foot and usually have a very irregular shape. Some, however, are nearly spherical, and many of these have a central core surrounded by thin alternating rings of different colors. The nodular masses of chert as a rule have no visible concretionary structure.

Although the Picacho includes gypsum, anhydrite, sandstone, and shale, more than 95 per cent of it consists of carbonate rocks.

NOGAL FORMATION

Beneath the Picacho limestone there is a thick series of lenticular sediments, consisting chiefly of red beds, gypsum, and anhydrite, which may be seen to rest upon the Abo sandstone along the west side of the Sacramento Mountains. This series is considered by geologists working in southeastern New Mexico to be the Yeso formation of Lee and Girty. ${ }^{70}$ It is included by Darton ${ }^{71}$ in the Chupadera, forming the lower part in this region. In the preliminary report on the Roswell artesian basin published in $1928^{72}$ it is referred to as the "lowest member of the Chupadera formation." In this report it is designated the Nogal formation, because it is well exposed in the vicinity of Nogal Canyon, on the west side of

${ }^{\infty}$ Lee, W. T., Erosion by solution and fill : U. S. Geol. Survey Bull. 760, pp. 107-122, 1925.

${ }^{70}$ Lee, W. T., and Girty, G. H., The Manzano group of the Rio Grande Valley, N. Mex. : U. S. Geol. Survey Bull. 389, p. 12, 1909.

T1 Darton, N. H., Geologic structure of parts of New Mexico : U. S. Geol. Survey Bull. 726, p. 207, fig. 23, and pp. 210-211; "Red Beds" and associated formations in New Mexico, with an outline of the geology of the State: U. S. Geol. Survey Bull. 794, p. 205, 1928.

72 Fiedler, A. G., and Nye, S. S., Ground-water investigation of the Roswell artesian basin, N. Mex. : New Mexico State Engineer Efighth Bienn. Rept., pp. 81-107, 1928. 
the Sacramento Mountains. Nogal Canyon enters Tularosa Canyon about $1 \frac{1}{2}$ miles west of Bent, Otero County. The following sections were measured in the general vicinity of Nogal Canyon:

Section measured on the west side of a ridge separating Nogal Canyon from Tularosa Basin, about 10 miles east-northeast of Tularosa

Picacho limestone:

Feet

1. Dip slope formed by the slumping of gray to darkgray limestone.

Nogal formation:

2. Gypsum with intercalated red shale and yellow sandy shale, poorly exposed. Lower part consists mainly of gypsum

3. Gypsum and limestone, interbedded, with some red shale and yellow fine sandy silt. The yellow silt usually underlies the beds of limestone, and the stratigraphic succession is commonly limestone, gypsum, red shale, yellow sandy silt or shale, and limestone, although this succession does not prevail throughout this unit. Much of the limestone is fossiliferous, some is light gray and earthy, and some is nearly black. This entire unit is poorly exposed at this place, but to the north it forms ledges 10 to 15 feet thick, which are not continuous along the strike for any appreciable distance

4. Limestone, gray, crystalline to granular. Weathered surface is light tan and hackly

5. Gypsum, with some interbedded red shale and yellow fine sandy silt in the lower 50 feet

6. Limestone, black, in beds 6 inches to 1 foot thick.

7. Limestone, light gray, crystalline, massive. Bedding is indistinct. Weathered surface is hackly -

Units 6 and 7 are slumped toward the northwest and may not be in place.

8. Limestone, black, in beds 6 inches to 1 foot thick, whose weathered edges are rounded and stand out prominently

9. Gypsum, white, poorly exposed

10. Limestone, dark gray, crystalline, massive. Weathered surface is hackly. Slumped toward the northwest

11. Gypsum, white, poorly exposed.

12. Limestone, dark gray, massive, poorly exposed..-

13. Gypsum, white, poorly exposed

14. Gypsum, with some interbedded red shale and sandy shale, and a few thin beds of light-gray, fine-grained argillaceous limestone. The interbedded red shale and gypsum contain veins of selenite. 
Nogal formation-Continued.

Feet

15. Limestone, dark gray to black. Middle part is rather massive; lower and upper parts are thin bedded and grade laterally into the umderlying and overlying gypsum. Upper part weathers into plates and has the appearance of slate

16. Gypsum, white, with red shale in lower and upper parts. Red shale is lenticular and does not extend laterally more than 50 feet without interruption

17. Limestone, gray to buff, argillaceous, in beds 1 to 3 feet thick. Poorly exposed in places but in others forms a prominent ledge

18. Gypsum, with some interbedded red shale and a few thin beds of limestone. Poorly exposed. Intruded by several sills and dikes of igneous rock

Total Nogal formation

Abo sandstone:

19. Coarse arkosic grit, light gray speckled with red; weathers brick-red. Consists chiefly of angular to subangular quartz and red feldspar, with some subrounded pebbles of sandstone.

Partial section of mountain northrest of Bent, measured in a ravine $N .52^{\circ} \mathrm{W}$. of the mouth of Nogal Canyon

Picacho limestone:

Feet

1. Limestone, light gray to black, poorly exposed. Upper 300 feet consists chiefly of light-gray to gray limestone covered by detritus and poorly exposed. Lower part consists largely of darkgray to black fossiliferous limestone in beds 1 to 2 feet thick. Most of the black limestone has a petroliferous odor when struck with a hammer. At 30 to 38 feet and at 70 to 75 feet above the base there are zones of limestone similar to No. 2

2. Limestone, light gray, fine grained, argillaceous. Weathered surface has appearance of a limestone breccia. Weathers to a white calcareous powder having the appearance of powdered gypsum.

3. Limestone, dark gray to black, thick bedded, massive. The black limestone is carbonaceous and has a petroliferous odor when struck with a hammer

4. Timestone, similar to No. 2

5. Limestone, gray, fine grained, argillaceous, dense. Weathers light gray 
Picacho limestone-Continued.

Feet

6. Limestone, dark gray to black, thick bedded, massive. Many beds are tessiliferous and have a petroliferous odor when struck with a hammer.

7. Limestone, black, carbonaceous, dense, thin bedded, in beds 2 inches to $1 \frac{11}{2}$ feet thick, fossiliferous. Has a petroliferous odor when struck with a hammer. Breaks with a semiconchoidal fracture

8. Sandstone, white to yellow, fine grained, calcareous

10. Limestone, gxay, crystalline; containing a few solution cavities

11. Sandstone, white to light yellow; fine grained, calcareous. Sand grains are about 0.5 : millimeter in diameten, and many of them are well rounded and fnosted:

12. Dolomitic limestone and dolomite, dark gray; massive, in beds 1 to 7 feet thick, very, fine grained and dense. Breaks: with a semiconchoidal fracture. Vertical jointing is conspicuous

Total Picacho limestone

Nogal formation:

13. Gypsum. with intercalated shale, which decreases in amount toward the top. Poorly exposed..--

14. Limestone, gray; crystalline. Weathered surface is light gray and: rounded. Forms: a ledge' at this place, but is concealed by gypsum: on both sides of the ravine.

15. Gypsum; poorly exposed.

16. Shale; mostly red, some-greonish gray; with interbedded gypsum: Forms a prominent red rone in the upper part of the Nogal formatiom

17. Gypsum and dark greenish-gray shale, irregularly interbedded, in beds half an inch to 1 inch thick. In some places the gypsum andi shale are intimately mixed.

18. Limestone, shale, and anhydrite, interbedded in beds a few inches to 2 feet thick. Some of the beds are dark-colored. earthy limestone, some appear to be mixtures of olive-brown to black shale and anhydrite, and some appear to be mixtures of limestone and. olive-brown anhydrite. Top bed is fossiliferous limestone, which forms a ledge at this place; it is not prominent in adjoining ravines and appears to merge lat erally into gypsum: 
Nogal formation-Continued.

19. Chiefly gypsum, with intercalated dark greenishgray to black shale. In places the rock consists of shale with patches of gypsum a quarter to half an inch in diameter, which give the rock a mottled appearance. In other places the rock consists of gypsum with shale mixed in it. At the base is a bed $11 / 2$ feet thick of olive-brown earthy anhydrite or gypsum overlain by a mixture of gypsum and earthy gray limestone

20. Limestone, dark gray to black, crystalline to earthy, some carbonaceous and fossiliferous, with some black carbonaceous limy shale. Thickness of limestone beds ranges from a few inches to 2 feet. The black limestone and shale have a petroliferous odor when struck with a hammer. A small fault having a displacement of 2 feet occurs in the limestone beds. The entire unit forms a prominent ledge

21. Gypsum, with a small amount of shale. Lower 6 inches consists of greenish-gray shale with irregular masses of gypsum 2 to 3 inches in diameter. At 3 feet above the base there is a 6 -inch bed of red shale with veins of selenite half an inch thick.

22. Anhydrite (?), dark olive-brown, crystalline, massive

23. Gypsum, white, massive, with intercalated gray shale. In places the gray shale is mixed with the gypsum, giving the beds a mottled greenishgray to white color. Rests upon a sill of igneous rock about 5 feet thick, which forms a prominent ledge at this place

24. Gypsum, red beds, and thick beds of limestone interbedded, the gypsum predominating, intruded by sills and dikes of igneous rocks. The bedding is greatly distorted in places. Mostly concealed by talus and alluvial deposits. Underlain by Abo sandstone

Total Nogal formation

$996 \pm$

The Nogal formation is defined herein as a lithologic unit consisting chiefly of red beds, gypsum, and anhydrite, but including interbedded limestone, dolomitic limestone, sandstone, shale, and salt, which underlies the Picacho limestone and rests upon the Abo sandstone. Its upper limit and possibly its lower limit may be variable in stratigraphic position and time. It underlies the Picacho limestone with apparent conformity throughout most of the artesian basin. In the vicinity of Artesia, however, it gives place laterally 
to a thick limestone section which is tentatively included in the Picacho limestone.

The upper part of the Nogal formation is exposed in the canyons of the Rio Hondo near Picacho, the Rio Bonito near Lincoln, the Rio Ruidoso, and the Rio Penasco and in canyons tributary to these streams in and near the mountain region. The entire formation is exposed along the west flank of the Sacramento Mountains.

The Nogal formation is about 1,000 feet thick in the vicinity of Nogal Canyon, but it thickens greatly to the east and southeast. In the deep wells drilled for oil 13 miles northeast of Roswell, in sec. 31, T. 8 S., R. 24 E., and near Dunken, in sec. 29, T. 17 S., R. 18 E., it is more than 2,000 feet thick. In the southeastern part of the area the Nogal formation is absent, its place being taken by an unknown thickness of limestone.

As shown by the sections given above, the Nogal formation consists largely of gypsum and red beds with interbedded limestone and yellow sand and shale along the west slope of the Sacramento Mountains in the vicinity of Tularosa and Alamogordo. Where exposed in the canyons on the east slope of the mountains the upper part of the Nogal consists chiefly of red, yellow, and greenish-gray shale, sandy shale, and sandstone. According to information obtained in regard to wells drilled in various parts of the Mescalero Indian Reservation east of the crest of the Sacramento Mountains and east of the Capitan Mountains, the upper few hundred feet of the Nogal consists largely of red beds. According to well records, the Nogal formation contains large amounts of salt as well as gypsum and anhydrite. The strata of the Nogal formation are very lenticular, and the character of the formation as a whole is extremely variable from place to place. In this respect it is similar to the Pecos formation. It differs from the Pecos, however, in that it is much thicker bedded as a general rule and includes but a small proportion of red beds. Moreover, it includes thick beds of limestone, whereas in the Pecos formation the limestone beds as a rule are comparatively thin.

According to Semmes ${ }^{73}$ the strata of the Nogal formation are highly folded against the flanks of the Capitan intrusion at the eastern foot of the Capitan Mountains near Arabela.

The strata described by Semmes as San Andreas limestone and Yeso formation are the Picacho limestone and the Nogal formations, respectively, of this report. The writer has found no evidence of a pronounced angular or erosional unconformity between the Picacho limestone and the Nogal formation. It is possible, however, that

rs Semmes, D. R., Notes on the Tertiary intrusives of the lower Pecos Valley, N. Mex. : Am. Jour. Sci., 4th ser., vol. 50, pp. 426-427, 429-430, 1920. 
Iocal erosional unconformities of no regional significance may be found in places at the top of or even within the Nogal formation.

Few fossils have been collected from the Nogal formation, although it contains some beds of fossiliferous limestone. According to Girty, ${ }^{74}$ the fossils that have been collected are not diagnostic and do not differ markedly from those found in the Picacho limestone.

\section{IGNEOUS ROCKS}

The central parts of the Sierra Blanca and its outliers to the north and the Capitan Mountains are composed of large masses of igneous rocks, which as a whole have not been studied in detail. Numerous dikes and sills have been intruded into the sedimentary rocks in the general vicinity of the Sierra Blanca and of the Capitan Mountains, and east of the Pecos River northeast of Roswell are two nearly parallel dikes in the Permian and Triassic strata, which are known locally as the Railroad Mountain dike and the Devils Race Track dike. Part of the Devils Race Track dike is shown on Plate 3. Within most of the artesian basin, however, no bodies of igneous rocks have been found.

\section{STRUCTURE}

\section{GENERAL FEATURES}

The Roswell artesian basin is situated on the west limb of a broad, comparatively shallow structural besin or geosyneline formed chiefly by the Permian and Pennsylvanian rocks and occupying most of eastern New Mexico and western Texas and parts of Oklahoma and

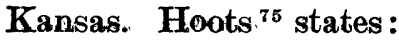

That $a$ basin of generally similar features was present in late Permian time is prowed by the presence and wide distribution of great thicknesses of satr; deposited from a sea which, in its stages of desiccation, must have occupied the lowest portion of a basin.

This: large structural basin or geosyncline is known as the Permian basin of the southwestern United States. According to Hoots, ${ }^{78}$ the deepest portion of the Permian basin is in southwestern Texas about 40 to 60 miles east of the New Mexico line and roughly between the latitudes of Roswell and the south line of Eddy: County, N. Mex.-that is, near the west sides of Midland, Martin, and Dawson. Counties and in central.Terry County, Tex. As dettermined by Hoots, ${ }^{77}$ the trend of the major axis of the geosyncline is nearly due north between the latitudes referred to; but north of the

"7urty, G. H., Oral communication.

To Hoots; H. W., Geology of a part of western Texas and southeastern New Hes; with. special reference to salt and potash: U. S. Geol. Survey Bull. 780; p. 119; 1926:

76 Idem, p. 113.

"7 Idem, pl. 17. 
latitude of Roswell it swings northeastward across the southern part of the Panhandle of Texas, and south of the latitude of the south line of Eddy County it swings southwestward. The east limb of the geosyncline in Texas is in the west-central part of the State, where the Permian and older strata crop out and dip west. The southern part of the Permian basin is approximately in eastern trans-Pecos Texas.

The geologic structure of the Roswell artesian basin as a whole, therefore, is relatively simple. In general, the Permian rocks dip gently to the east and southeast, forming a large monocline extending from the crest of the Sacramento Mountains on the west beyond the State line on the east. The oldest beds are exposed in the mountains, where the youngest beds have been removed by erosion. Toward the east successively younger beds appear at the surface. In the Pecos Valley the surficial deposits of clay, sand, and gravel rest upon the irregularly eroded surface of the Permian rocks.

The regional eastward dip of the Permian rocks is interrupted by several sharp anticlinal folds and faults, by many minor gentle folds due to regional earth movements, and by many small, irregular structural features resulting from the slumping and caving caused by the solution and removal by ground water of underlying rocks. The most prominent regional structural features are the Y-O, Border Hills, and Sixmile Hill anticlinal faults. These are described by Merritt ${ }^{78}$ simply as narrow anticlines, but they are notably faulted throughout much of their extent and are therefore described below in the section on faults. Renick ${ }^{79}$ has briefly described the more prominent geologic structures in the upper drainage basin of the Rio Penasco. All the large regional folds and faults in the artesian basin have a northeasterly trend.

\section{STRUCTURAL FEATURES RESULTING FROM REGIONAL GARTH MOVEMENTS}

FAUITS

The Border Hills, Y-O, and Sixmile Hill faults are very similar: Each is a combination of a remarkably narrow anticlinal fold and a fault of moderate displacement. According to Merritt, ${ }^{80}$ the width of the folds rarely exceeds a mile and generally is less than half a mile. In many places observed by the writer the width of the folds is less than 1,000 feet. Each is made prominent topographically by

re Merritt, J. W., Structures of western Chaves Connty, N. Mex. : Am. Assoc. Petroleum Geologists Bull., vol. 4, pp. 53-58, 1920.

70 Renick, B. C., Geology and ground-water resources of the drainage basin of the Rio Pefiasco above Hope, N. Mex. : New Mexico State Engineer Seventh Bienn. Rept., pp. 128-127, 1926.

- Merritt, J. W., op. cit., p. 56. 
straight, narrow ridges or a series of narrow ridges and hills in line. All three are comparatively straight and trend northeast. (See pl. 3.) They are roughly parallel, although the Y-O fault swings more to the east than the other two. The faults are most clearly revealed in the outcrop area of the Picacho limestone. The displacement does not appear to be more than 200 to 300 feet along any of the faults, and in many places it is certainly much less.

The Border Hills, Y-O, and Sixmile Hill faults appear to be the result of thrust movements. Both where the Rio Hondo cuts across the Border Hills and where the Rio Penasco cuts the ridge formed by the Y-O fault the strata on the upthrown side are steeply tilted and those on the downthrown side are notably less disturbed. (See pls. $18, A, B ; 24, A$.) Moreover, at neither place does the deformation have the appearance of extending to any great depth.

As the rocks younger than the Permian have been removed throughout the area affected by these faults, it is impossible to determine the age of the faults from the stratigraphic relations any closer than the end of the Permian. However, it is fairly well established that the igneous intrusions in the Sierra Blanca and the uplift of the mountains did not begin until the end of Cretaceous time. It appears probable, therefore, that the faults are younger than the Cretaceous. It is possible, if not probable, that the lines of weakness were developed during the orogenic movements at the end of the Cretaceous and that movements took place along those lines of weakness at intervals extending well into the Tertiary period and possibly into Pleistocene time.

Border Hills fault.-The Border Hills fault (see pl. 3) is one of the most conspicuous structural features in this region, for it is expressed topographically by a series of prominent narrow, unusually straight ridges in line with one another, which persist for many miles. They are known locally as the Border Hills, and it is said that they owe their name to the bitter feud between the cattlemen in the Pecos Valley and those in the vicinity of Lincoln, the hills being designated as the boundary line between the areas controlled by the two outfits. Plate $24, B$, is a view of the Border Hills from the Roswell-Alamogordo highway, which crosses them about 25 miles west of Roswell. The Border Hills are formed by a combination of a narrow anticlinal fold and a fault of moderate displacement, which in the canyon of the Rio Hondo appears to be a thrust fault. For several miles north of the Rio Hondo, at least, the beds on the west side are downthrown relative to those on the east side. According to K. H. Crandall, ${ }^{81}$ who made a detailed study of it, the fault reverses itself at several places, and for a few miles south of the Rio

8n Oral communication. 
Hondo the beds on the west side are upthrown relative to those on the east side. The attitude of the beds on the north and south sides of the Rio Hondo is shown in Figure 11 and Plate 18, A. As a topographic feature the Border Hills fault dies out in T. 9 S., R. 21 E., but evidence of its continuation northeastward beyond Salt Creek is said to have been found. According to Merritt, ${ }^{82}$ it extends southwestward as far as T. 16 S., R. 16 E. Paul McCune ${ }^{83}$ states that it changes into a narrow anticline and ends near the Manning dome, in T. 15 S., R. 17 E., which, together with the fact that it is not clearly seen to be a fault where the Roswell-Alamogordo road crosses it, may account for the fact that Merritt described it solely as an anticline.

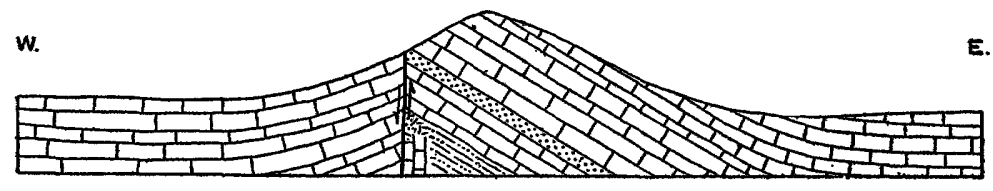

$a$

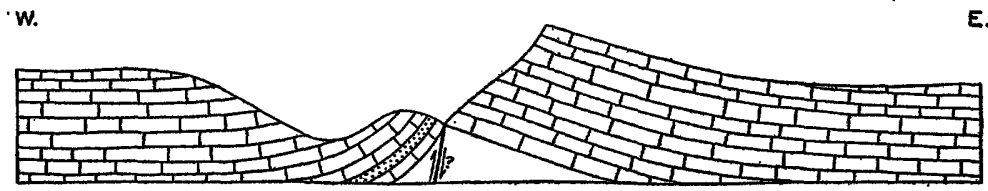

3

FIGURw 11.-Diagrammatic sections across the Border Hills in sec. 31, T. 11 S., R. $20 \mathrm{E}$., as exposed on the north $(a)$ and south $(b)$ sides of the valley of the Rio Hondo

Sixmile Hill fault.-The Sixmile Hill fault is also a combination of an anticlinal fold and a fault of slight displacement, but it is shorter and very much less prominent than either the $\mathrm{Y}-\mathrm{O}$ or the Border Hills fault. The fault is exposed at several places west and northwest of Roswell. The beds on the west side of the fault appear to be upthrown relative to those on the east side. The fracturing and brecciation of the Picacho limestone caused by the fault are most clearly seen where Berrendo Creek crosses it 4 or 5 miles northwest of Roswell. The fault dies out southwestward in Sixmile Hill, 5 or 6 miles due west of Roswell, from which it takes its name. The anticlinal structure of Sixmile Hill is clearly revealed along the road cuts of the main highway due west of Roswell, but the faulting is not. According to information obtained regarding the two Gibson wells drilled for oil on Sixmile Hill in sec. 8, T. 11 S., R. 23 E., the fault probably extends at least that far to the southwest. The first hole drilled was abandoned at a depth of about 600 feet, as it was too crooked, presumably because the drill was deflected along a fault surface. The second hole was drilled a few feet from the first and 
encountered the same difficulties. Moreover, the depth at which the sandstone near the base of the Picacho was reached in the second hole was notably at variance with the depth at which it was reached in the first. It was also reported that pyrite crystals were found in the drill cuttings. The displacement along the fault is probably less than 50 feet, although definite data as to the amount of displacement were not obtained. The fault appears to die out northeastward in the southwestern part of T. 9 S., R. 24 E., but there is some fragmentary evidence of its continuing still farther to the northeast as a gentle anticline and possibly as a fracture or slight fault. According to Merritt ${ }^{84}$ the Sixmile Hill anticline extends southwestward as far as T. 15 S., R. 19 E. The writer found little evidence of anticlinal structure in the canyon of the Rio Hondo in the vicinity of the Hondo reservoir site, nor in the canyon of Rocky Arroyo in the central part of T. $12 \mathrm{~S}$, R. $22 \mathrm{E}$. It is possible that the anticline trending northeastward from T. 15 S., R. 19 E., may not be continuous with the Sixmile Hill anticline but may be roughly in line with it.

$Y-O$ fault.-A cross section of the $\mathrm{Y}-\mathrm{O}$ fault is well exposed in the bluffs on the north side of the Rio Penasco at the Y-O crossing, in sec. 2, T. 17 S., R. 19 E. (See pl. 24, A.) At this place it is clearly seen that the beds on the west side have been folded in a narrow anticline, faulted, and thrust against those on the east side. The faulting is also revealed, although much less clearly than at the $\mathrm{Y}-\mathrm{O}$ crossing, at several places along the Rio Felix, in the southeastern part of T. 15 S., R. 21 E., and in the northwestern part of T. 15 S., R. 22 E. The Rio Felix has closely followed the course of the fault for 5 or 6 miles, although it crosses the fault at many places. The Y-O fault is made prominent by a series of disconnected rounded hills and narrow ridges that stand above the surrounding hills. The fault can be traced northeastward as far as the NW. $1 / 4$ sec. 8, T. 14 S., R. $23 \mathrm{E}$. Although there is no conclusive evidence of its continuation to the northeast beneath the alluvial deposits and into the Pecos formation east of the Pecos River, there are several lines of evidence indicating either that the Y-O fault extends at least as far as T. 10 S., R. 26 E., or that there are one or more faults of small displacement in line with the Y-O fault which extend to that point. Low hills in the northwestern part of T. 13 S., R. 24 E., appear to be elongated in a northeast-southwest direction, to rise above the Blackdom terrace, and to be in line with a continuation of the Y-O fault. The Shaffer well, drilled for oil in the NE. $1 / 4$ sec. 30, T. 10 S., R. 26 E., encountered considerable salt water in a sandstone near the base of the Picacho.

es Merritt, J. W., op. cit., p. 56. 
The Now State well, in the NW. 1/4 sec. 27 of the same township and only $2 \frac{1}{2}$ miles east of the Shaffer well, was said not to have encountered any water at all in a sandstone that was the same at approximately the same stratigraphic horizon as the one encountered by the Shaffer well. Presumably, therefore, there is a fault between the wells which effectively seals off the salt water in the sandstone oncountered by the Shaffer well, for even if the sandstone encountered in the New State well were not precisely the same stratum as the one encountered in the Shaffer well, it does not appear at all probable that the former would be dry if there were no fault between the wells. Furthermore, the peculiar hydrologic conditions existing in the northern part of T. 12 S., R. 25 E., and the southern part of T. 11 S., R. $25 \mathrm{E}$., suggest a fault or other structural feature roughly in line with the Y-O fault.

It is not improbable that the Y-O fault, like the Border Hills fault, may reverse itself along a series of fractures closely in line. Some evidence of this was seen in the field, but it was not conclusive. It is equally possible that there may be several lines of faulting extending northeastward, which are roughly in line with one another and with the Y-O fault. The Y-O fault, according to Renick, ${ }^{85}$ extends southwestward as far as section 31, T. 18 S., R. 18 E.

Other faults.-The location and description of a small fault in the Carlsbad limestone were obtained from F. S. Prout. The fault has a northwesterly trend, and the beds on the northeast side are upthrown with relation to those on the southwest side. According to Mr. Prout, the amount of displacement is less than 50 feet.

According to Campbell, ${ }^{86}$ Wegemann, ${ }^{87}$ and Boyer and Hansen, ${ }^{88}$ there is a tremendous amount of faulting in the Sierra Blanca region, and the displacement ranges from a few feet to over 1,000 feet. Boyer and Hansen state that horizontal thrust is indicated at several points by the offsetting of dikes. The longest fault described and mapped by them lies a short distance west of Capitan and extends several miles in a northeasterly direction. The strata on the west side are downthrown relative to those on the east. Many faults in this region are described by Wegemann.

TOLDS

The general monoclinal structure of the Picacho limestone is interrupted by numerous comparatively gentle folds, many of which have been mapped by geologists working in southeastern New

8 Renick, B. C., op. cit., pl. 1.

so Campbell, M. R., op. cit., pp. $432-433$.

Wegemann, C. H., op. cit., pp. 436-442.

ss Boyer, W. W., and Hansen, G. H., op. cit. 
Mexico. A few wells have been drilled on the larger ones. Most of the large folds have a general north or northeast trend, although Merritt ${ }^{89}$ found a few cross folds, and Renick's map ${ }^{90}$ shows a syncline west of Dunken whose axis has a northwest trend. Merritt ${ }^{91}$ mentions an anticline near Tinnie, and Darton ${ }^{92}$ states that there is a dome with a closure of about 300 feet west of Rock House, Lincoln County, the apex of which is in section 30, T. 12 S., R. $17 \mathrm{E}$. He also states there is another dome just west of Picacho which has a closure of about 600 feet and has its crest just west of the center of T. 11 S., R. 18 E. A well, 2,199 feet deep, was drilled for oil at Picacho and is said to have penetrated "granite" from a depth of 1,670 feet to the bottom. The well started in the upper part of the Nogal formation and remained in that formation until it reached the "granite." Many other anticlinal folds and domes have been found and mapped by geologists working for oil companies, only a few of which are mentioned below.

Black Hills antialine.-Concerning the Black Hills anticline Renick ${ }^{93}$ writes :

East of the Y-O overthrust, mostly in the southwest corner of $T$. $17 \mathrm{~N}$., R. $20 \mathrm{E}$., is an anticline known as the Black Hills or Cuevo anticline. Structural contour maps show that the axis of this anticline extends $\mathrm{N}$. $60^{\circ}$ E. from near the middle of the west line of sec. 31 beyond the Peñasco at least as far north as sec. 14, T. 17 S., R. 20 E.

The writer observed apparent anticlinal structure in the southeastern part of T. 16 S., R. 21 E., about 6 miles north-northwest of Hope, which seemed to be roughly in line with a continuation of the Black Hills anticline, but it was not definitely ascertained that the structural conditions were not due simply to slumping caused by solution and removal of underlying rocks.

Manning dome.-In 1925 the Arkansas Fuel Oil Co. drilled a well in the NW. $1 / 4$ sec. 14, T. 15 S., R. 17 E., on a dome known locally as the Manning dome. The well was drilled to a depth of 3,310 feet. It is said that the Border Hills fault ends at or near this dome.

Dunken dome.-A few miles east of Dunken there is a large dome whose axis lies near the east lines of secs. 19, 30, and 31, T. $17 \mathrm{~S}$, R. $18 \mathrm{E}$., and has a general north-south trend.93 A structure contour map of the dome is given by Darton.94 A well more than 4,000 feet deep was drilled for oil on top of this dome.

Merritt, J. W., op. cit., p. 56.

¿ Renick, B. C., op. cit., pl. 1.

21 Merritt, J. W., op. cit., fig. 2.

" Darton, N. H., " Red Beds" and associated formations in New Mexico, with an outline of the geology of the State: U. S. Geol. Survey Bull. 794, p. 213, 1928.

9a Renick, B. C., op. cit., p. 124.

os Darton, N. H., op. cit., p. 214. 


\section{LOCAL STRUCTURAT FEATURES RESULTING FROM GOLUTION}

All the Permian formations exposed in the Roswell artesian basin consist in large part of rocks that are more or less soluble in water. The most common and most extensive soluble rocks in this region are salt $(\mathrm{NaCl})$, gypsum $\left(\mathrm{CaSO}_{4} \cdot 2 \mathrm{H}_{2} \mathrm{O}\right)$, anhydrite $\left(\mathrm{CaSO}_{4}\right)$, limestone $\left(\mathrm{CaCO}_{3}\right)$, and dolomite $\left(\mathrm{CaMg}\left(\mathrm{CO}_{3}\right)_{2}\right)$. Salt, of course, is by far the most soluble and dissolves readily in water. Gypsum and anhydrite, although they are much less soluble than salt, are fairly soluble in water. Limestone and dolomite are relatively insoluble in pure water but are somewhat soluble in water containing carbon dioxide $\left(\mathrm{CO}_{2}\right)$. Surface waters acquire a certain amount of carbon dioxide from the air and in sinking into the ground are capable of dissolving limestone and dolomite as well as salt, gypsum, and anhydrite. Circulating ground water therefore dissolves and removes varying amounts of the soluble rocks through which it passes. This material is either carried into rivers and thence into the sea or is deposited in other places. The results accomplished over a long period of geologic time by the solution and removal of soluble rocks by circulating ground water are often very spectacular. The Carlsbad Cavern, in southern Eddy County, is a magnificent example of this process. If sufficient material is removed the overlying rocks are left unsupported and consequently cave in. This caving may be expressed at the surface by undrained depressions, open sink holes, and very erratic deformations of the overlying rocks that are entirely local and have no regional structural significance. The geologic features resulting from this process, however, are at many places difficult to distinguish from those formed by regional earth movements.

Both the Nogal and the Pecos formations within the Roswell artesian basin include large deposits of gypsum and anhydrite and moderate amounts of salt. As these rocks are dissolved rather easily by percolating water, sink holes, underground drainage channels, depressions, and highly deformed strata are numerous in the areas underlain by these rocks. They are especially common in the outcrop areas of the Pecos formation. In fact the strata are so much deformed by slumping that it is very difficult and at many places impossible to determine regional geologic structure in these areas. Sink holes are very common in the outcrop areas of the Pecos formation. In the southern part of T. 19 S., R. 23 E., a sink hole on the side of a small valley has captured the surface drainage of the ephemeral stream draining eastward into the Seven Rivers that carved out the valley. (See pl. 7, A.) Lee ${ }^{95}$ describes many ex-

${ }^{\infty 6}$ Lee, W. T., Frosion by solution and fll : U. S. Geol. Survey Bull. 760, pp. 107-122, 1825. 
amples of solution and removal of soluble rocks, with consequent slumping of overlying beds, in the Permian red beds of southern Eddy and Lea Counties and considers this to be the dominant process of erosion in the areas underlain by these rocks.

Although the Picacho limestone consists almost entirely of limestone and dolomite throughout most of the artesian basin, it contains thick deposits of gypsum and anhydrite northwest and west of Roswell and south of Hope. In these areas, especially northwest of Roswell and in the vicinity of Salt Creek, sink holes, depressions, and highly deformed strata caused by solution and slumping are almost as numerous as in the areas underlain by the Pecos formation. In the outcrop area of the Picacho limestone, where this formation contains very little or no gypsum, the spectacular solution phenomena mentioned above are surprisingly rare, although they are not entirely absent. A few sink holes and undrained depressions were observed, but they are much less common than one would expect in a limestone region. The strata are probably deformed in some places as a result of solution and slumping, but it is only where the deformation is very pronounced that it can be easily distinguished from regional . deformation. Such effects are not common, and where they are found they are not, as a rule, so spectacular as those in the areas underlain by thick beds of gypsum. Several structural features considered to be the result of slumping were observed in the Cactus Flat reservoir site, in secs. 5, 6, 7, and 8, in T. 17 S., R. 19 E., which is north of and parallel to the canyon of the Rio Penasco and is separated from it by a narrow ridge. A description of these structures is given in the writer's report on the reservoir site. ${ }^{97}$

\section{STRUCTURE OF THE ORIGINAL AREA OF ARTESIAN FLOW}

\section{SOURCIS OF THE DATA}

A contour map of the upper surface of the Picacho limestone within the original area of artesian flow is given as Plate 25. It is based almost entirely upon drillers' logs of artesian wells. The upper surface of the Picacho limestone was selected for contouring because it was the only lithologic break that could be ascertained with any degree of certainty in the drillers' logs. As the strata of the Pecos formation are lenticular and vary greatly from place to place, no satisfactory bed or series of beds in that formation can be identified in all the logs. A study of the logs soon revealed that the so-called "water rocks" in the Picacho limestone are not continuous strata but constitute irregular and very erratic solution zones. It was obvious, therefore, that none of the "water rocks" could be

\footnotetext{
${ }^{n}$ Nye, S. S., Geology of the Cactus Flat reservoir site, T. 17 S., R. 19 E., for the Hope Community, N. Mex.; New Mexico State Engineer Eighth Bienn. Rept., p. 184, 1928.
} 
used for contouring. As the Pecos formation consists very largely of soft materials whereas the Picacho limestone consists almost entirely of hard limestone, there is usually a distinct lithologic break between the two formations which can be easily identified in the logs of most of the wells, especially in the part of the artesian area that lies north of Artesia. The strata in the Pecos formation are recorded by the drillers chiefly as clay, shale, sand, and pack sand, and those of the Picacho limestone as "rock" and "hard rock." In many places, however, especially in the southern part of the artesian area, the lower part of the Pecos formation contains lenticular beds of hard limestone and is reported to contain beds of hard anhydrite, and the upper part of the Picacho limestone contains beds of sand and shale. The hard anhydrite and limestone are usually recorded simply as "rock" or "hard rock.". Consequently it is very difficult to determine the depth at which the Picacho limestone was encountered in many of the wells, and the writer's interpretation of many of these logs may be incorrect. Moreover, it is known that some of the water-well drillers wrote the logs of the wells they drilled from memory some time after the wells were completed, and a few are said to have submitted inaccurate logs. Nevertheless, a large proportion of the logs are essentially correct, and the contact between the Pecos formation and the Picacho limestone can be determined with a fair degree of accuracy.

Mr. Fiedler ran level lines to many of the wells and accurately determined the altitude of the surface at the wells and at many intervening points. The surface altitude at many other wells in the vicinity of Roswell, Dexter, and Lake Arthur was obtained from detailed topographic maps of these drainage districts. As the land surface in the artesian area is comparatively smooth and slopes gently to the east and east-southeast, the surface altitude of most of the other wells could be estimated within 10 or 15 feet from the many accurately known surface altitudes and bench marks scattered throughout nearly all of the artesian area. This is considered sufficiently correct for the contour interval of 50 feet used, the scale of the map, and the degree of accuracy with which the depth to the upper surface of the Picacho limestone could be determined from the drillers' logs. So few surface altitudes were known south of Dayton, however, that the contours on the upper surface of the Picacho limestone were not carried south of that point.

EROSION AND SOLUTION DURING PERMIAN TIME

Although the location of the contours shown in Plate 25 may be somewhat inaccurate in many places, they show the general character of the upper surface of the Picacho limestone. This surface is 135252-33-7 
irregular in many places, but if the minor irregularities are disregarded it is apparent that the broad general structure of the limestone is that of an eastward-sloping monocline, slightly downwarped in the area between Dexter and Artesia.

A close examination of the contour map shows that there are many hills, ridges, valleys, and undrained depressions in this surface which together bear a remarkable resemblance to karst topography developed in a limestone region and therefore strongly suggest that there is an erosional unconformity between the Picacho limestone and the overlying Pecos formation, at least within this area. It will be seen that in many places two or more valleys join and form a single valley; that many of the valleys are narrow and 100 to 150 feet deep; that many of the valleys and intervening ridges and hills are very irregular in shape and relation to one another; and that there are a number of deep depressions quite similar in appearance to surface depressions developed in a region underlain by soluble rocks. As the Picacho limestone is immediately overlain by alluvial deposits in many places in the central and western parts of T. $10 \mathrm{~S}$., R. 24 E., and the northwestern part of T. 11 S., R. 24 E., the extreme irregularity of its upper surface in the vicinity of Roswell is undoubtedly due in part to erosion during Quaternary time. In the artesian area southeast and south of Roswell, however, the Picacho limestone is overlain by 200 to 900 feet or more of strata of the Pecos formation. The upper surface of the Picacho in this part of the artesian area is almost as irregular in many places as it is in the vicinity of Roswell, and many of the irregularities are similar in character to those near Roswell. Although there can be little doubt that some of these features are the result of regional folding and deformation of the Permian strata, the shape, distribution, and relations of many of them are so irregular that it is difficult to conceive how they could be simply anticlines, synclines, domes, and structural basins produced by regional earth movements. The hypothesis that they are largely the result of erosion during Permian time is supported by the fact that in the northern part of the area the thickness of the Picacho limestone above the sandstone zone near its base varies as much as several hundred feet within relatively short distances, not only where the Picacho is overlain by Quaternary alluvial deposits but also where it is overlain by the Pecos formation. The thickness of the limestone above the sandstone zone (locally called Glorieta sandstone), according to the drillers' logs, is shown in the following table: 
Thickness of the Picacho limestone above the sandstone locally called the Glorieta sandstone

\begin{tabular}{|c|c|c|c|}
\hline Name of well & Location & $\begin{array}{l}\text { Thick- } \\
\text { ness } \\
\text { (feet) }\end{array}$ & Remarks \\
\hline Toltee Na, 2 & Sec. 17, T. 9 S., R. 24 E.- & 485 & May be overlain entirely by alluvia \\
\hline 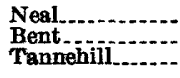 & $\begin{array}{l}\text { NW. } 1 / \text { NW. } 1 / 4 \text { sec. } 9, \text { T. } 9 \text { S., R. } 25 \text { E. } \\
\text { NW. } 1 / 1 \text { sec. } 17 \text {, T. } 9 \text { S., R. } 25 \text { E. } \\
\text { SE. } 1 / 4 \text { SE. } 1 / 4 \text { sec. } 2 \text {, T. } 10 \text { S., R. } 24 \text { E.. }\end{array}$ & $\begin{array}{l}813 \\
800 \\
710\end{array}$ & $\begin{array}{l}\text { Overlain by Pecos formation. } \\
\text { Do. } \\
\text { May be overlain entirely by alluvial }\end{array}$ \\
\hline $\begin{array}{l}\text { Roswell City... } \\
\text { Shaffer. } \\
\text { New State..... } \\
\text { Dresser } \\
\text { Orchard Park.. }\end{array}$ & $\begin{array}{l}\text { NW. 1/4 sec. } 4, \text { T. } 11 \text { S., R. } 24 \text { E... } \\
\text { NE. 1/ sec. 30, T. } 10 \text { S., R. } 26 \text { E. } \\
\text { SE. 1/ NE. 1/4 sec. } 27 \text {, T. } 10 \text { S., R. } 26 \text { E. } \\
\text { NW. 1/4 sec. } 24, \text { T. } 10 \text { S., R. } 27 \text { E. } \\
\text { Sec. 15, T. } 12 \text { S., R. } 25 \text { E. }\end{array}$ & $\begin{array}{r}750 \\
1,007 \\
1,065 \\
1,200 \\
1,000\end{array}$ & $\begin{array}{l}\text { Overlain by alluvial deposits. } \\
\text { Overlain by Pecos formation. } \\
\text { Do. } \\
\text { Do. } \\
\text { Do. }\end{array}$ \\
\hline
\end{tabular}

The relative thinness of the limestone at the Toltec, Tannehill, and Roswell City wells is doubtless due at least in part to erosion during Quaternary time, but its variation in thickness in the other wells can not be accounted for in this way.

The hypothesis that the variation in the thickness of the limestone where it is overlain by the Pecos formation is due to erosion during Permian time is also supported by the fact that the limestone east of the bluffs along the east side of the Pecos River, where it is overlain by 1,000 feet or more of the Pecos formation, contains cavernous zones. According to Davis, ${ }^{98}$ oil is encountered in cavernous zones in the upper part of the Picacho limestone in the Artesia oil field, which is about 6 miles east of the bluffs along the Pecos and 12 to 15 miles southeast of Artesia.

If the cavernous condition of the Picacho limestone within the artesian area was developed entirely by artesian circulation of ground water during Quaternary time, it is conceivable that some of the valleys and depressions in the upper surface of the Picacho may be the result of slumping caused by the solution and removal of soluble rocks. However, the relation of the valleys and depressions to one another are such that this explanation appears very improbable. Moreover, the solution openings in the limestone must have been filled with water under artesian pressure, which would have offered considerable support to the overlying rocks.

The evidence presented above certainly suggests an erosional unconformity at the top of the Picacho limestone, though it is by no means conclusive. The apparently abrupt change from conditions favorable for the deposition of limestone to those favorable for the deposition of red beds and gypsum also suggests though it does not prove the lapse of a considerable interval of time. On the other hand, if that interval of time was sufficiently long for a relief of

${ }^{8}$ Davis, M. J., Artesia fleld, Eddy County, N. Mex. : Structure of typical American oil fields, vol. 1, pp. 118-119, Am. Assoc. Petroleum Geologists, 1929. 
50 to 200 feet in the upper surface of the Picacho to be produced by erosion, evidence of so pronounced an erosional unconformity would be expected in its outcrop areas; and even if the formations change in character to the south and north of the artesian area, there should be some evidence of an erosional unconformity at a stratigraphic horizon approximately equivalent to the top of the Picacho limestone. So far as the writer knows, no such evidence has been found, but this may be due to the fact that the contact between the Picacho limestone and the Pecos formation is nearly everywhere concealed in the outcrop areas of these formations. The very small exposure of the contact found by the writer in the southern part of the artesion area is shown in Plate 9, $B$. At this place gypsum rests upon dense dolomitic limestone. The exposure is too small and the relations are not definite enough to prove or disprove that there is an unconformity at the top of the Picacho. Moreover, it does not necessarily follow that because an unconformity is pronounced it must be regional. The unconformity may be comparatively local and may not extend south of the artesian basin. The conditions of deposition were different south of the artesian basin, and the distance within which this change took place is surprisingly short. Consequently, it is not unreasonable to suppose that the unconformity did not extend even as far as the southern edge of the artesian area. The surface evidence found so far is therefore negative.

\section{POSSIBLE CHANGES IN CONDITIONS OF DEPOSITION}

It is possible that the irregularities in the upper surface of the Picacho and the variations ${ }^{\circ}$ in the thickness of limestone above the sandstone zone may be due in large part to rapid lithologic changes laterally from limestone to red beds and gypsum, caused by gradual, shifting, and unusual conditions of deposition-that is, the ridges and hills represented on the contour map may be tongues of limestone projecting into the lower strata of the Pecos formation. This possibility should be considered, for surprising lithologic changes within very short distances are not common in the Permian formations in this region. The exposure in the canyon walls of Rocky Arroyo, south of the artesian basin, where several hundred feet of limestone (Carlsbad limestone tongue) gives place within a mile to gypsum and red beds, is a striking example. According to the driller's logs of wells in the south end of the artesian area the upper part of the Picacho contains beds of sand, shale, and gypsum or anhydrite, and the lower part of the Pecos formation contains fairly thick beds or series of beds of limestone, indicating a gradational and shifting change in the conditions of deposition in that part of the area. Throughout most of the artesian area, however, 
there appears to be an abrupt change from the soft strata of the Pecos formation to the hard limestone beds of the Picacho. Furthermore, thick, narrow tongues of limestone, closely and irregularly spaced, would be necessary to account for many of the features shown by the contour map. Although it does not appear probable that the conditions of deposition required to produce these features could have existed, the hypothesis that the irregularities in the upper surface of the Picacho are due to interfingering of limestone, red beds, and gypsum can not be easily dismissed.

\section{REGIONAL EARTH MOVEMENTS}

There can be little doubt that regional earth movements have affected the structure of the Permian strata within the artesian area, but with one exception, the buried structural features can not be distinguished on the contour map with any degree of certainty from irregularities in the upper surface of the Picacho that may be the result of Permian erosion or of interfingering of limestone and red beds or gypsum. There are several lines of evidence, however, which indicate that the Y-O fault, or a fault roughly in line with it, continues northeastward across and beyond the artesian area. The contours in T. 11 S., R. 25 E., indicate a narrow anticlinal ridge extending from the southwestern to the northeastern part of the township. The contours south of this ridge are somewhat displaced to the west with respect to those north of the ridge, suggesting that the strata are also faulted a moderate amount, those on the south being downthrown with respect to those on the north; but the contour interval is too large to show the amount of displacement of the fault, if there is one. Faulting is also suggested by the facts revealed by the drilling of the Shaffer and the New State wells as described on pages 80-81. The configuration of the contours on the piezometric surface ${ }^{99}$ of the artesian water (see pl. 30) also indicates a pronounced northeast-southwest structural feature in T. 11 S., R. $25 \mathrm{E}$., which noticeably affects the direction of movement of the artesian water. No one of these lines of evidence is conclusive, but the three together indicate the existence of a narrow anticlinal fold with a fault that is either a continuation of the $\mathrm{Y}-\mathrm{O}$ fault or is approximately in line with it. The precise configuration and trend of this structural feature, however, may not be exactly as shown on Plate 25. The contours in the vicinity of Hagerman suggest. that the Black Hills anticline extends northeastward into the artesian area, but the data are too meager to permit a definite statement one way or the other.

"The term "piezometric" is applied to an imaginary surface to which the water from a water-bearing bed will rise under its full head, sometimes called a "pressure-indicating surface." 


\section{GEOLOGIC HISTORY}

By S. S. NYE

\section{PROTEROZOIC ERA}

Very little is known of the geologic history of this region during the Proterozoic era other than that the deposition of the Paleozoic sediments was preceded by a very long interval of erosion during which a great thickness of rocks was removed, exposing deep-seated granite, and the land was leveled to a rather smooth surface. Meinzer ${ }^{1}$ states:

The granite must have been originally covered by other rocks, because it can be formed only at great depths. There is nothing in this region to indicate the nature of the rocks that lay above the granite and were worn away during the period of erosion, but in the regions both north and south they appear to have consisted in part of clastic sediments now hardened into quartzite.

According to Darton, the underlying granite is exposed along the west front of the Sacramento Mountains for a short distance on both sides of Agua Chiquita Canyon, 18 miles south of Alamogordo. Contours drawn by Darton ${ }^{2}$ on the surface of the pre-Cambrian rocks indicate that in this region the surface slopes gently to the eastsoutheast and that in the artesian area the "bedrock" surface is roughly 4,000 to 5,000 feet below the present surface.

\section{PALEOZOIC ERA ${ }^{3}$}

In regard to the geologic history of southern New Mexico during the earlier part of the Paleozoic era, Darton ${ }^{4}$ states:

The sequence of events in southern New Mexico during the earlier part of the Paleozoic era can be known only in a most general way, for many long intervals of the time are not represented by deposits. It is probable that many beds were laid down that were subsequently removed. Doubtless some of the beds now remaining have been thinned by erosion, and possibly, also, they were formerly much more extensive. Some or all of the pre-Pennsylvanian formations

${ }^{1}$ Meinzer, O. E., and Hare, R. F., Geology and water resources of Tularosa Basin, N. Mex.: U. S. Geol. Survey Water-Supply Paper 343, p. 78, 1915.

"Darton, N. H., "Red Beds" and associated formations in New Mexico, with an outline of the geology of the State: U. S. Geol. Survey Bull. 794, pl. 60, 1928.

3 The Paleozoic history of this region is summarized in large part from information contained in the following reports : Darton, N. H., Comparison of Paleozoic sections in southern New Mexico: U. S. Geol. Survey Prof. Paper 108, 1917 ; "Red Beds" and associated formations in New Mexico, with an outline of the geology of the State: U. S. Geol. Survey Bull. 794, 1928. Meinzer, O. E., and Hare, R. F., Geology and water resources of Tularosa Basin, N. Mex. : U. S. Geol. Survey Water-Supply Paper 343, 1915. Lindgren, "Waldemar, Graton, L. C., and Gordon, C. H., The ore deposits of New Mexico: U. S. Geol. Survey Prof. Paper 68, 1910. Hoots, H. W., Geology of a part of western Texas and southeastern New Mexico, with special reference to salt and potash: U. S. Geol. Survey Bull. 780, pp. 33-126, 1926. Schuchert, Charles, Textbook of geology, pt. 2, Historical geology, New York, John Wiley \& Sons, 1924.

${ }^{4}$ Darton, N. H., Comparison of Paleozoic sections in southern New Mexico: U. S. Geol. Survey Prof. Paper 108, p. 55, 1917. 
may have covered all of New Mexico. Apparently the uplifts were widespread and not attended by folding, for the altitude of all of the Paleozoic formations is the same with a few slight local exceptions.

According to Darton ${ }^{5}$ there is a thin sandstone at the base of the Paleozoic section exposed near the mouth of Little Agua Chiquita Canyon, which he tentatively correlates with the Bliss sandstone, of Upper Cambrian age. Presumably, therefore, at least the southwestern part of the artesian basin was submerged beneath a shallow sea in which sands were deposited in Upper Cambrian time. As the Bliss sandstone is much thicker where it is exposed south and west of this region and as it probably does not extend north of latitude $33^{\circ} 40^{\prime}$ in the western part of the State ${ }^{\circ}$ the sea apparently advanced from the south and southwest, and the sands were probably derived from the rocks underlying the land mass to the north.

Although the evidence is not conclusive it is possible that sub. mergence of the land and sedimentation continued without a notable break into Lower Ordovician time (Beekmantown) when conditions were favorable for the deposition of a considerable thickness of limestone (El Paso limestone). This was followed by emergence of the land from the sea and an interval of erosion or nondeposition representing all of the Middle Ordovician and the early part of the Upper Ordovician. The land was again submerged beneath the sea in late Upper Ordovician time (Richmond). Sands were deposited in places, but throughout most of the time a considerable thickness of limestone and alternating beds of chert and limestone (Montoya limestone) was laid down. The Ordovician seas likewise appear to have advanced from the south and southwest, for the Ordovician formations thicken rapidly in that direction, and as the formations thin out to the north the seas apparently did not extend north of latitude $33^{\circ} 40^{\prime}$. The Ordovician formations are exposed along the west front of the Sacramento Mountains as far north as Alamogordo. The Ordovician seas, therefore, extended at least that far north in the western part of the artesian basin. Their eastward extent in the artesian basin, however, is not known.

Some time after the deposition of the Montoya limestone, southern New Mexico again emerged from the sea and was subjected to erosion until well into Silurian time. During a small part of Silurian time (late Niagara) a part of southern New Mexico was submerged beneath a sea which presumably advanced from the southwest, but it does not appear to have extended quite so far north as the previous seas. With the first advance of the sea, a conglomerate consisting of

"Darton, N. H., "Red Beds" and associated formations in New Mexico, with an outline of the geology of the State: U. S. Geol. Survey Bull. 794, p. 198, 1928.

Idem, pp. 9-10. 
pebbles derived from the underlying formation was deposited in places on the old land surface, and with a more complete submergence of the land, limestone (Fusselman limestone) was deposited.

The deposition of the Fusselman limestone was followed by a long break in sedimentation, representing late Silurian and early Devonian time, during which there was presumably a long emergence of the land. In late Devonian time the sea advanced from the southwest and west and extended into at least the western part of the artesian basin. Shale with thin beds of slabby and nodular limestone (Percha shale) was deposited at this time.

The early Paleozoic history is marked by successive advances and retreats of seas from the south, southwest, and west, which apparently did not extend farther north than latitude $33^{\circ} 40^{\prime}$. All extended into the western part of the artesian basin, and all except possibly the Cambrian sea extended at least as far north as the latitude of Alamogordo in this region. As all the formations appear to thin greatly toward the Sacramento Mountains it does not appear probable that the seas extended far east into the artesian basin. However, as the rocks older than the Permian are deeply buried east of the Sacramento Mountains and as no wells have yet been drilled in the artesian basin that are deep enough to reach the rocks older than the Pennsylvanian, it is not known how far east the pre-Carboniferous rocks extend underground. The pre-Carboniferous seas appear to have been comparatively small arms of slight extent, which successively advanced into this region and each time submerged approximately the same areas in southern New Mexico. Apparently most of northern New Mexico was never submerged by these seas. During a large part of Carboniferous time, however, most of New Mexico, including all of the southern part, was submerged beneath the sea at one time or another. The Mississippian sea covered most of southwestern New Mexico, and although it was probably more widespread than any of the earlier Paleozoic seas, it does not appear to have been nearly so extensive in New Mexico as the Pennsylvanian and Permian seas.

During the Mississippian epoch at least the western part of the artesian basin as far north as the latitude of Alamogordo was submerged beneath a sea in which shale and limestone (Lake Valley limestone) were deposited on the Devonian sediments. The eastern limit of this sea is not known. There was apparently a considerable break in sedimentation throughout a long interval of late Mississippian time, when presumably this region emerged from the sea, although there does not appear to be any notable discordance in the attitude of the Percha shale and the Lake Valley sediments nor a striking erosional unconformity between the two formations. In 
the Pennsylvanian epoch all of southeastern New Mexico and possibly most of the State was submerged beneath a sea that was probably much more widespread in New Mexico than any of the previous Paleozoic seas. Great thicknesses of shale, limestone, and sand (Magdalena group) were deposited, and locally, where there were swampy areas, peat bogs now represented by thin seams of coal were formed. ${ }^{7}$ According to Darton ${ }^{8}$ at least 1,500 feet of Pennsylvanian sediments are exposed all along the western part of the Sacramento Mountains.

The Permian epoch is represented by a very thick series of sediments, which underlie all of southeastern New Mexico and crop out through an enormous area in the east-central part of the State. These sediments are characterized by great diversity in lithology from place to place, indicating notably dissimilar conditions of deposition in adjoining areas, as contrasted with the relatively uniform sedimentation in the previous Paleozoic seas. While limestone and dolomite were being deposited in one place, anhydrite or gypsum and red beds were being deposited in another near by. Although in some places the conditions of deposition remained relatively constant for very long periods of time, in other places they were variable.

In places near the south boundary of New Mexico the deposition of limestone appears to have continued without a notable interval between Pennsylvanian and Permian time, but in the western and northwestern parts of the Roswell artesian basin, red beds and coarse arkosic materials (Abo sandstone) were deposited upon the Pennsylvanian limestone and shale. This was followed by the accumulation of a great thickness of anhydrite or gypsum and salt with interstratified limestone, dolomite, and red beds (Nogal formation), deposited in a shallow sea in which evaporation of the sea water generally exceeded the influx of fresh water from streams and rain, although at times the water became fresh enough for the existence of marine life and the deposition of limestone. In the southeastern part of the artesian basin, however, the sea was apparently deeper and conditions were favorable for the deposition of limestone during this time. Toward the end of Nogal time conditions became more and more favorable for the deposition of limestone and dolomite in the artesian area, until finally only limestone and dolomite were laid down, except for a time when sands were deposited in the northern part of the artesian basin. This resulted in the formation of the Picacho limestone. Toward the later part of Picacho time conditions became favorable for the deposition of thick beds of anhydrite

Meinzer, O. E., and Hare, R. F., Geology and water resources of Tularosa Basin, N. Mex. : U. S. Geol. Survey Water-Supply Paper 343, p. 78, 1915.

${ }^{8}$ Darton, N. H., "Red Beds" and associated formations in New Mexico, with an outline of the geology of the State: U. S. Geol. Survey Bull. 794, p. 19, 1928. 
or gypsum in the northeastern part of the artesian basin and to a less extent in the southeastern part, where sands were also deposited at times. It appears probable that after the formation of the Picacho limestone the artesian area and possibly an area to the east of unknown extent were elevated several hundred feet above sea level for an interval of time long enough for the development of an erosion surface with a maximum relief of 200 feet or more and of extensive solution passages in the upper part of the limestone. This may have been due to differential uplift and warping that resuited in raising the artesian area and depressing the central part of the Permian basin. Sedimentation may have been uninterrupted south of the southern end of the artesian basin, for there the conditions of sedimentation, as proved by the marked differences in the lithologic character and fauna of the formations, differed notably from those in this area. After the long interval of uplift and erosion, the artesian basin was submerged beneath a shallow sea in which red sand and clay were laid down. Shortly afterward anhydrite or gypsum with intercalated thin lenses of magnesian limestone and dolomite were deposited in the southern part of the artesian area, although in the northern part deposition of red beds with a few thin lenses of impure limestone continued for a much longer time. During a part of this time magnesian limestone and dolomite (Carlsbad limestone tongue) were being deposited near the southeast corner of the artesian basin and in the area to the south. Finally, red beds with some anhydrite and gypsum were deposited over the whole area. During the deposition of the strata in this area the region to the east was being downwarped. This resulted in the accumulation of great thicknesses of anhydrite and salts before the closing stage of red-bed deposition throughout most of the Permian basin. It is quite possible that the deposition of the Pecos formation was not continuous everywhere. In many places sedimentation may have been interrupted at times, resulting in local erosional unconformities.

The great accumulations of anhydrite, gypsum, and salt indicate that the climate in this region was arid throughout most of the time when the Permian sediments were being deposited.

\section{MESOZOIC ERA}

At the end of the Paleozoic era all of New Mexico was uplifted and possibly gently folded. The artesian basin was subjected to erosion during Lower and Middle Triassic time. In Upper Triassic time coarse sand, gravel, and red beds were deposited over most if not all of the artesian basin, probably by swiftly flowing streams from the north and west. Hoots ${ }^{9}$ states that the downwarping of

\footnotetext{
- Hoots, H. W., Geology of a part of western Texas and southeastern New Mexico, with special reference to salt and potash: U. S. Geol. Survey Bull. 780, pp. 125-126, 1925.
} 
the Permian basin to the east of this area was probably mildly accentuated at this time, for about 1,200 feet of Triassic sediments accumulated in the central part of the basin.

This region was apparently subjected to erosion throughout the Jurassic period, but during Cretaceous time the northwestern part and possibly all of the artesian basin was submerged beneath a shallow sea, and a great thickness of sediments, consisting mostly of mud and sand, was deposited. According to Baker ${ }^{10}$ a few scattered remnants of sediments of Lower Cretaceous age have been found underlying the later Tertiary materials forming the Llano Estacado. It is probable, therefore, that the early Cretaceous seas, at least, covered all of southeastern New Mexico. At times conditions were favorable for the deposition of limestone. Toward the end of the Cretaceous period there were many swamps and peat bogs, which later became coal. The climate was mild and humid, and there was a large amount of vegetation.

\section{CENOZOIC ERA}

The end of the Cretaceous period was marked by orogenic movements, volcanic activity, and uplift, which continued at intervals well into Tertiary time and resulted in the formation of the Rocky Mountains to the north and the mountain ranges in southern New Mexico. After Cretaceous time this region was never again submerged beneath the sea. The first part of the Cenozoic era in this region was characterized by the folding and faulting of the strata and intrusions and extrusions of tremendous masses of igneous rocks. The geologic history since mid-Tertiary time is chiefly that of successive intervals of erosion and sedimentation by streams, which have resulted in the removal of a thick series of sediments and the sculpturing of the mountains and the other land forms of the present time.

\section{TERTIARY PERIOD}

The deposition of the Cretaceous coal measures was followed by a marked uplift of the entire region, probably accompanied by gentle warping, igneous intrusions, and folding and faulting of the strata. Much of the igneous material forming the central core of the Sierra Blanca and the Capitan Mountains was probably intruded at this time. Its porphyritic texture indicates that the rocks solidified at no great distance beneath the surface, but the groundmass is noticeably crystalline, indicating that the rocks must have been covered by a moderate thickness of Cretaceous sediments at the time they were intruded and became solidified. Streams were rejuvenated and began to erode the surface actively. In the Sierra Blanca region

10 Baker, C. L., Geology and underground waters of the northern Llano Bstacado: Texas Univ. Bull. 57, pp. 20-21, 1915. 
and possibly in the other parts of the artesian basin streams deposited a thick series of coarse sand and gravel on the Cretaceous coal measures. This series is tentatively considered by Boyer and Hansen ${ }^{11}$ to be of Eocene age, although no fossils were found in the beds.

After the deposition of the sand and gravel there was renewed igneous activity accompanied by intense folding and faulting of the strata in the vicinity of the igneous intrusions. Large quantities of lava were poured out on the surface in places, and the mountains were again uplifted. The ore deposits in the vicinity of the Sierra Blanca appear to have been formed about this time.

Other than the probable sequence of events given above little is known of the detailed geologic history of this region during the first half of Tertiary time. It appears probable that there were several periods of igneous activity and of faulting and folding of the strata in the vicinity of the Sierra Blanca and Capitan Mountains, accompanied by uplifts of all the mountain ranges. During all of this time erosion was doubtless very active, removing a great thickness of Cretaceous and possibly Triassic sediments and exposing the igneous masses that formed the Sierra Blanca and Capitan Mountains, large parts of which were eroded in turn. The character of the unconformity between the Miocene and later materials that form the Llano Estacado and the underlying Cretaceous and Triassic rocks indicates that the land was worn down to a low undulating surface having a rather low gradient.

The High Plains are remnants of a constructional surface formed by a vast débris apron that once extended continuously from southeastern New Mexico northward all along the east flank of the Rocky Mountains. The deposits consist of clay, sand, and gravel and were spread out chiefly by intermittent and ephemeral streams flowing eastward and southeastward from the Rocky Mountains during Tertiary time.

The Llano Estacado is a remnant of the southern extension of the High Plains and was doubtless built up in part by streams flowing southeastward from the south end of the Rocky Mountains but probably in part by streams flowing eastward and east-southeastward from the mountain ranges in central and southern New Mexico. Between the artesian basin and the south end of the Rocky Mountains there are large remnants of the western extension of the Llano Estacado. The surfaces of these remnants slope to the east and east-southeast, indicating that the streams that built them had their sources to the west, probably in the mountains east of Albuquerque.

" Boyer, W. W., and Hansen, G. H., Eastern part of the Sierra Blanca coal fleld, N. Mex.: U. S. Geol. Survey unpublished report. 
If the deposits had been built up entirely by streams from the Rocky Mountains, the surfaces should slope toward the south-southeast or ${ }^{\text {* }}$ southeast. Moreover, the surface of the southern part of the Llano Estacado slopes rather uniformly toward the east-southeast. In the western third of the artesian basin, between the mountains and the western edge of the Diamond A plain, there are interstream remnants of a rock-cut plain, the Sacramento plain, which, if projected eastward, appears to merge with the surface of the Llano Estacado. No gravel has been found by the writer on remnants of this plain, but opportunities for examination were few, and it is not to be expected that many gravel deposits would have remained on this ancient surface. Wegemann ${ }^{12}$ states that there are high gravel terraces on the east flank of the Sierra Blanca in the vicinity of Fort Stanton. It is quite possible that these terraces may correspond to the surface of the Llano Estacado.

As the alluvial deposits underlying the Llano Estacado are probably of Miocene and Pliocene age, the mountains along the west side of the artesian basin were probably uplifted again in mid-Tertiary time. With renewed uplift the streams were rejuvenated, and erosion of the rocks in and near the mountains was speeded up. There was doubtless considerable rainfall in the mountains; and as the slopes were steep, the streams were able not only to erode their channels actively but to transport the eroded materials away from the mountains. In the plains east of the mountains, however, the climate was apparently arid or semiarid and the stream gradients were much less steep. Consequently the streams, as a result of decreased gradient and of rapid evaporation and seepage losses, lost their carrying power and deposited their loads of gravel, sand, and clay in the form of alluvial fans. Gradually the alluvial fans coalesced to form a single débris apron. This mantle of clay, sand, and gravel probably covered most if not all of the eastern half of the artesian basin. During the construction of the débris apron the western half was worn down to a fairly smooth rocky plain. At the end of the Tertiary period, therefore, the artesian basin, except along the mountains, was a smooth plain. The eastern half was an alluvial slope formed by a mantle of clay, sand, and gravel, and the western half was a rock-cut plain covered in places with a thin veneer of gravel and coarse sand.

The construction of the vast débris apron in eastern New Mexico appears to have continued into early Pleistocene time in the northern part of the Llano Estacado, for according to Baker ${ }^{13}$ early Pleisto-

\footnotetext{
t2 Wegemann, C. H., Geology and coal resources of the Sierra Blanca coal field, Lincoln and Otero Counties, N. Mex.: U. S. Geol. Survey Bull. 541, p. 434, 1915.

${ }^{23}$ Baker, C. L., Geology and underground waters of the northern Llano Estacado: Texas Univ. Bull. 57, pp. 34-35, 1915.
} 
cene fossils have been found in these deposits in a few places in that -area. From the description given by Baker of the deposits in which the fossils were found it appears quite possible that the Pleistocene deposits do not represent the uppermost materials of the Llano Estacado but simply the filling of canyons and channels that were incised in it. Baker states that at one place the Pleistocene deposits rest directly on the Triassic. However, sufficiently detailed studies of the deposits underlying the Llano Estacado have not been made to permit any definite statement as to the date of completion of its present surface. It is possible that the uppermost materials are not all of exactly the same age, for it is known that the uppermost materials underlying the High Plains are not everywhere of the same age. Few, if any, fossils have been found in the deposits along the west and south sides of the Llano, and the age of the uppermost materials underlying the southern part in southeastern New Mexico therefore is not definitely known. Presumably, however, they are late Pliocene or early Pleistocene.

\section{QUATERNARY PERIOD}

The geologic history of the artesian basin during the Quaternary period is largely one of nearly continuous erosion by streams in the mountains and of successive cycles of erosion and sedimentation by streams in and near the alluvial basin. It is assumed that the final trenching of the vast débris apron formed during the later half of Tertiary time did not begin until the end of the Pliocene or early in the Pleistocene epoch. The primary cause of this trenching of the ancient High Plains surface appears to have been either a marked uplift of the land, or a pronounced change in climate, or both. The beginning of the Pleistocene was marked by a very pronounced climatic change, which resulted in the formation of huge continental glaciers in the northern United States and in Canada. It is generally believed that this change in climate was accompanied by uplift, but it is not definitely known that this region was uplifted at that time. However, according to Lovering ${ }^{14}$ there is evidence of a considerable uplift in and near the Front Range in Colorado at the end of the Pliocene or early in the Pleistocene, and it seems reasonable to suppose that this region was also affected by the uplift. Whether or not the destruction of the High Plains began everywhere at the same time is not definitely known. A more precise dating of the major trenching of the streams and the removal of the deposits of the Llano Estacado in this region can not be made without more detailed studies of

${ }^{14}$ Lovering, T. S., Geologic history of the Front Range, Colo.: Colorado Sci. Soc. Proc., vol. 12 , No. 4 , p. 104, 1929. 
the alluvial deposits underlying the southern and western parts of the plain.

The available evidence used for the interpretation of the physiographic history of this region is given below.

\section{HISTORY OT THE PECOS RIVER AND CHANGES IN THE OHANNELS ON ITS MAJOR TRIBUTARIES IN THE ARTESIAN BASIN}

Many changes in drainage have occurred in this area during Pleistocene time, and stream piracy has played an important part in determining the present drainage lines. Much more field work aided by detailed topographic maps would be required to determine all or 'even a large part of the changes in drainage that have occurred since the beginning of the Pleistocene epoch.

Pecos River.-The Pecos River now originates in the south end of the Rocky Mountains northeast of Santa Fe and flows southeastward as far as Fort Sumner, where it turns and flows southward until it reaches Lake McMillan; below Lake McMillan it again flows southeastward into Texas.

The town of Portales is situated in a broad, $U$-shaped valley, cut about 250 feet below the surface of the Llano Estacado ${ }^{15}$ and bordered by caliche-capped bluffs. The valley extends from the west edge of the Llano Estacado near Krider, about 25 miles east of Fort Sumner, in a southeasterly direction across the east boundary of New Mexico into Texas. It is evident that such a broad, deep valley could not have been excavated by the present streams and that it must have been excavated by a southeastward-flowing stream of considerable size before the Llano Estacado was cut off from its western extension by the present Pecos River. It is probable that the part of the present Pecos River above Fort Sumner once continued southeastward across the Llano Estacado through the Portales Valley and that it was established before the beginning of the Pleistocene and was instrumental in the construction of the northern part of the Llano Estacado.

If, as seems probable, the deposits of the Llano Estacado once extended westward across the artesian basin to the east side of the Sacramento Mountains and the Sierra Blanca, it is evident that the part of the present Pecos River between the southern boundary of the State and Fort Sumner is younger than the Llano Estacado. The lower part of the stream probably extended itself northward by headward erosion and captured the drainage from the south end

\footnotetext{
15 Meinzer, O. E., Reconnaissance of ground-water conditions in Portales Basin, N. Mex. (unpublished manuscript, 1907) ; Underground water resources in Portales Valley, N. Mex. : U. S. Geol. Survey Press Bull. 406, October. 1909; The occurrence of ground water in the United States, with a discussion of principles: U. S. Geol. Survey Water-Supply Paper 489 , pp. 305-306, 1923. Baker, C. L., op. cit., pp. 52-54.
} 
of the Rocky Mountains which had flowed southeastward across the Llano Estacado through the Portales Valley. The present valley of the Pecos River, therefore, has probably been established since early Pleistocene time.

Rio Hondo.-Although most of the streams in this area flow east and east-southeast into the Pecos River, the Rio Hondo turns northeast at the west edge of the alluvial basin and flows in that direction until it is joined by the Berrendo River. There is a short, broad, $U$-shaped valley cut in the hard Picacho limestone and floored with recent alluvium on the west side of an "island" of Picacho limestone in the northeast quarter of T. 12 S., R. 22 E. The valley is not now occupied by any stream, but at times of high floods it is overflowed by waters from the Rio Hondo which flow into the present valley of Rocky Arroyo on the south side of the "island."

It is evident that there have been several changes in the lower course of the Rio Hondo and Rocky Arroyo since the trenching of the Diamond A plain, and it is also evident that some of these changes have occurred since the trenching and partial destruction of the Blackdom terrace began. This terrace has been completely removed in a wide area south and north of Roswell. (See fig. 1.) It is difficult to determine precisely the changes that have taken place. It is fairly certain that the Rio Hondo and Rocky Arroyo once joined west of the "island" and flowed eastward either through the present valley of Rocky Arroyo on the south side of the "island" or in the present valley of the Rio Hondo on the north side. Each may have occurred at different times; but the fact that the valley on the south side is the broader and better developed, indicates that this was the earlier course or perhaps that it was followed for a longer time. In either case there can be little doubt that the destruction of the Blackdom terrace and the construction of the Orchard Park terrace south of Roswell were accomplished largely by the Rio Hondo and Rocky Arroyo. The present courses of these streams below the northwest quarter of T. 12 S., R. 24 E., were established during or immediately before the recent epoch, and were probably due to a more rapid lowering of the surface east of Roswell by the large streams issuing from the big springs in the vicinity of Roswell. It is probable that other changes in the courses of the Rio Hondo and its tributaries have occurred in the limestone uplands since the beginning of Pleistocene time.

Rio Felix and Cottonwood Creek.-It is evident that the gravel capping the mesas at the west edge of the present drainage basin of Cottonwood Creek (see pl. 4) was deposited by eastward-flowing streams before the streams trenched their channels below the level of these mesas. During the last stages of the erosion cycle that 
resulted in the formation of the Diamond A plain the streams probably shifted many times over the smooth surface. There is evidence, however, that for some time after the trenching of this plain began the part of the Rio Felix above the south-central part of T. 15 S., R. 21 E., or perhaps streams now tributary to it, formed part of the drainage system of Cottonwood Creek. Near the head of the largest branch of Cottonwood Creek the present channel is a narrow V-shaped trench cut 65 to 70 feet below a prominent rock-cut bench. Above the bench the valley is very wide, $U$ shaped, and bounded by the high gravel-covered mesas whose surfaces are 140 to 150 feet above the bench. (See fig. 12.) It is entirely improbable that the present stream could have carved so wide a valley, for the head of Cottonwood Creek is only 3 or 4 miles farther west, and the drainage basin of that stretch of the valley is very small. The divides between the present tributaries to Cottonwood Creek and to the Rio Felix are well below the level of the gravelcapped mesas. Similar conditions-a narrow V-shaped trench cut below a wide bench that forms the floor of an ancient U-shaped valley bounded by high gravel-capped mesas-exist near the heads of several tributaries of Cottonwood Creek north and south of the locality described above. In each place the broad alluvial-fill surface common to all the large streams in the eastern half of the limestone uplands is conspicuously absent. The narrow V-shaped trenches of the upper parts of the tributaries of Cottonwood

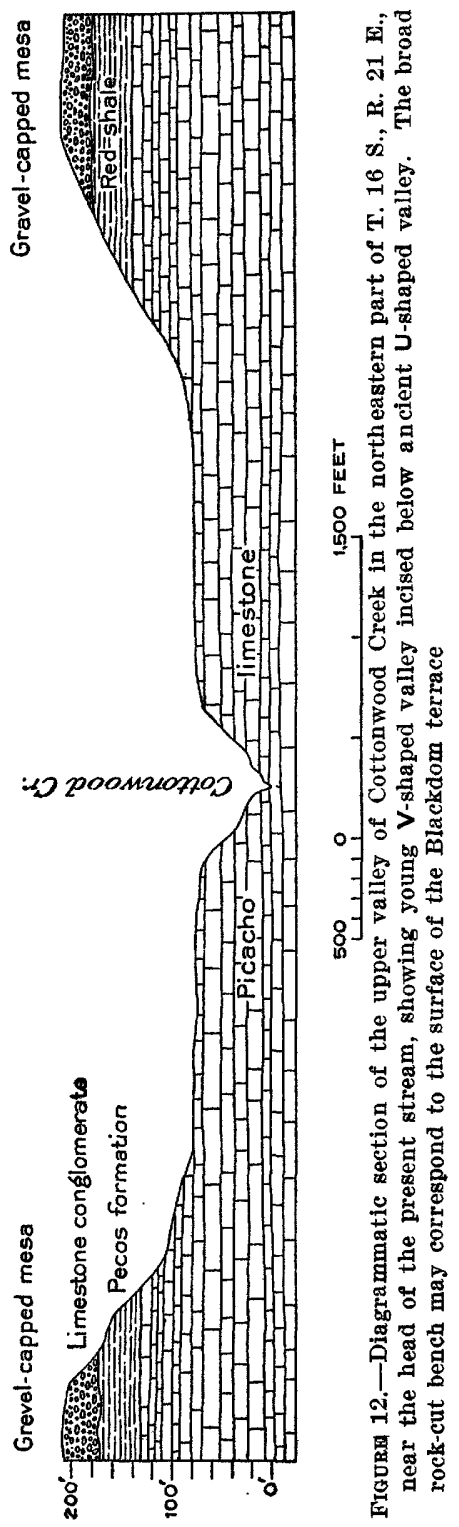
Creek are typical of the short youthful tributaries of the major streams and also of the heads of the major streams in the mountain region; it is obvious that they are in a very youthful stage of the erosional cycle and have been carved out by the present streams. 
It is also evident that the wide benches and the broad $U$-shaped valleys above the benches were developed by streams that extended much farther west than the present ones and had large drainage basins. The wide benches appear to correspond approximately to the surface of the Blackdom terrace, and it is not unlikely that they were developed at about the time of the completion of the terrace.

The upper half of the Rio Felix has the normal east and eastsoutheast direction characteristic of the artesian basin, but near the south-central part of T. 15 S., R. 21 E., the river turns sharply to the northeast and closely follows the $\mathrm{Y}-\mathrm{O}$ fault until it reaches the southeastern part of T. 14 S., R. 22 E., where it turns east again. It appears probable that the upper part of the Felix, which had drained eastward into the Cottonwood during a long period preceding or following the completion of the Blackdom terrace, was captured after the trenching of the Blackdom terrace began by a stream that had developed along the line of weakness formed by the $\mathrm{Y}-\mathrm{O}$ fault and flowed into the lower part of the present Rio Felix.

Rio Penasco.- Near the west edge of the Diamond A plain, in the southeastern part of T. 16 S., R. 17 E., there is a rather low, narrow divide between the present canyon of the Rio Penasco and a canyon tributary to the Rio Felix. The divide is 200 to 300 feet above the present channel of the Penasco but is perhaps 50 to 100 feet lower than the general surface of the Diamond A plain. The divide is now somewhat dissected by short streams tributary to the Felix and to the Penasco, but in a number of places there are large deposits of coarse gravel and cobbles which were evidently laid down by the Rio Penasco in an earlier stage of erosion, probably a short time after the trenching of the streams below the Diamond A plain began. The relations of the drainage lines suggest that the Rio Penasco during and for a relatively short time after Diamond $\mathrm{A}$ time was a part of the upper Rio Felix-Cottonwood Creek drainage system. More detailed work would be required to prove this hypothesis.

\section{ORIGIN OF THE DIAMOND A PLAIN}

The Diamond A plain is a comparatively smooth rock-cut surface developed in a north-south belt 20 to 25 miles wide in approximately the eastern third of the limestone uplands. It is east of and 200 to 300 feet lower than the Sacramento plain and is clearly younger. It has an eastward gradient of 60 to 80 feet to the mile, possibly more near its western edge. In many places it is veneered with deposits of coarse gravel, as much as 10 or 15 feet thick. Within the drainage basin of the Rio Hondo the gravel consists largely of limestone and igneous pebbles with a few quartzose pebbles. The igneous and quartzose pebbles are derived from the igneous rocks in the 
Sierra Blanca region. The limestone pebbles are derived from the Picacho limestone. Near the Rio Penasco the gravel consists almost entirely of such limestone pebbles.

There can be little doubt that the Diamond A plain is a surface formed by stream erosion. The fact that its eastward gradient is slightly less than the regional eastward dip of the Picacho, together with the fact that it is well below the Sacramento plain and is veneered with gravel in many places, eliminates the possibility of its being simply a dip slope. It is conceivable that it may have been carved out by the Pecos River and later tilted eastward. However, it appears improbable that so large an area would be uniformly tilted eastward at a very low angle. Moreover, the general absence of igneous pebbles in its gravel in the drainage basin of the Rio Penasco and the westward slope of the plains between the Pecos and the Llano Estacado strongly indicate that these plains have been developed largely by streams tributary to the Pecos. It is probable that the Diamond A plain has been formed entirely by the corrasion of streams tributary to the Pecos from the west. Even in this case it might be argued that the development of so smooth a plain required a much lower gradient than the present one and therefore that there has been tilting. The Permian and older rocks in the artesian basin have obviously been tilted eastward, but most of this tilting probably occurred during early Tertiary time, although it is possible that there may have been a small amount of additional tilting during the Pleistocene. Tilting, however, is not necessary to explain the present gradient of the Diamond A plain. Bryan ${ }^{16}$ has shown that smooth rock-cut plains, which he refers to as mountain pediments, with gradients as much as 200 feet to the mile have been developed by stream erosion along the flanks of mountains in southern Arizona. In regard to their origin, he states:

Davis ${ }^{17}$ recognizes that in the closing stages of an erosion cycle in desert regions graded rock floors will intervene between the alluvial slopes and the mountain slopes of an intermontane basin, just as he had previously recognized and shown these plains in a diagram in his discussion of the basin ranges. ${ }^{18}$ Under conditions of extreme aridity the development of plains cut on rock does not necessarily indicate old age, but such plains may be produced earlier in the cycle and are dependent for their position on the upper limit of alluvial deposition in the intermontane valleys. Rock plains or pediments develop at or above the edges of the valley fill and are limited in size only by the available area and the factor of time.

\footnotetext{
16 Bryan, Kirk, Erosion and sedimentation in the Papago country, Ariz., with a sketch of the geology: U. S. Geol. Survey Bull. 730, pp. 52-65, 1922.

${ }^{17}$ Davis, W. M., The geographical cycle in an arid climate: Jour. Geology, vol. 13, pp. 381-407, 1905; reprinted in Geographical essays, pp. 296-322, Ginn \& Co., 1909.

${ }^{1 s}$ Davis, W. M., Mountain ranges of the Great Basin : Harvard Coll. Mus. Comp. Zoology Bull., vol. 42, pp. 129-177, 1903 ; reprinted in Geographical essays, pp. 725-772, Ginn \& Co., 1909.
} 
The angle of slope of the mountain is controlled by the resistance of the rock to the dislodgment of joint blocks and the rate at which these blocks disintegrate. The angle of slope of the pediment, however, is due to corrasion by the streams, and this corrasion is controlled by the ab:lity of water to transport débris, for the pediment is a slope of transportation intervening between the mountain slopes and the alluvial plain in the middle of the valley.

Both the Sacramento and Diamond A plains may be considered pediments that are now deeply dissected. The development of the Sacramento plain was very similar to that of the pediments described by Bryan, for its position, form, and eastward extent were controlled by the successive positions of the upper edge of the débris apron forming the High Plains. The dominant factor in the development of the Diamond A plain, however, was the position of the Pecos River, although the position of the upper edge of the alluvial apron deposited near the Pecos doubtless exerted some control. It appears probable that the initial excavation of the Diamond A plain was coincident with the deepening of the channel of the Pecos River below the surface of the debris apron forming the Llano Estacado and that the final development of the plain is due to a long pause or to a very marked decrease in the rate of the downcutting of the Pecos River after it reached a level not much below that of the gravel-capped mesas near Melena and of the 150-foot terraces south of Lake McMillan.

The pediments described by Bryan normally have V-shaped reentrants which extend far up the canyons. In the artesian basin such reentrants of the Diamond A plain are not clearly defined, but there are rock-cut benches and benches veneered with gravel in the canyons of the Rio Hondo and the Rio Penasco west of the Diamond A plain that may correspond to the plain. As subsequent erosion has removed or greatly modified most of the benches in the canyons, it is difficult to identify definitely the benches that correspond to the Diamond A plain without the aid of a detailed topographic map.

In many parts of the area where the Diamond A plain is extensively developed there is a lower rock-cut surface which appears to correspond to the Blackdom terrace, but it is not so prominent as the Diamond A plain. Both have been greatly modified by subsequent erosion.

\section{ORIGIN OF THE ALIUVIAL BASIN}

The alluvial basin (see pl. 4) was obviously excavated by the Pecos River and its tributaries from the west. The primary cause of the excavation was the deepening of the channel of the Pecos, but the dominant factors affecting its width were the presence of soft rocks west of the river and the relatively large amount of pre- 
cipitation in the drainage basins of the streams tributary to it from the west within the artesian basin. The precise conditions that determined the limits of the alluvial basin are not so obvious.

The eastern limit of the alluvial basin is formed by the bluffs along the Pecos River and was determined chiefly by the course of the Pecos itself. The streams tributary to it from the east are comparatively short and have small drainage basins. The area drained by them receives little precipitation, and as that area is underlain by soluble rocks and as the water table is far below the surface a large part of the precipitation is carried off in underground drainage channels. Consequently the streams rarely convey much water into the Pecos and are incapable of any considerable erosion and planation. Hence they were unable to carve out a broad surface sloping toward and merging with the level of the Pecos, as was done by the streams from the west.

The western limit of the alluvial basin was apparently determined by the ability of the tributaries to widen their valleys and by the position and character of the Pecos River. The competency of the tributaries was controlled by their gradient, the amount of water carried, the hardness of the rocks, and the length of time involved. The character and position of the Pecos River were determined in part by the amount of water contributed to it north of the alluvial basin and in part by the contributions of water and sediment by the alluvial basin. The length of time involved in the excavation of the alluvial basin was apparently too short for the streams and their tributaries formed by local precipitation to plane off the divides in and near the outcrop of the hard Picacho limestone. The western limit of the present surface of the alluvial basin was determined largely by the position of the upper edge of the alluvial slope at the time of the completion of the Blackdom terrace.

The north and south limits of the alluvial basin correspond very closely with the north and south limits of the streams tributary to the Pecos River from the latitude of the Capitan Mountains to the south end of the Sacramento Mountains or, in other words, within the artesian basin. (See pl. 2.) This relationship certainly indicates that the alluvial basin is dominantly the result of drainage from the Sierra Blanca and Sacramento Mountains. The reason for this is not hard to find. The northern continuation of the Sierra Blanca dies out a few miles north of the latitude of the Capitan Mountains. Farther north there are no mountains of any consequence in the drainage basin of the Pecos River until the south end of the Rocky Mountains is reached. The area west of the Pecos River between the latitude of the Capitan Mountains and the south end of the Rocky Mountains is comparatively low and therefore 
receives much less precipitation than the Sierra Blanca and Sacramento Mountains. Consequently the few streams tributary to the Pecos in that area are all ephemeral or intermittent and carry little water into the river. Hence they are incompetent and are unable notably to widen their valleys and lower the general surface.

The southern limit of the alluvial basin was determined by several factors, the chief of which is the relative incompetency of the streams originating in the Guadalupe Mountains. The Guadalupe Mountains as a whole are considerably lower than the Sacramento Mountains and doubtless receive less precipitation. Because of their much shorter east slope, the streams originating in and near them are considerably shorter and have much smaller drainage basins than those originating on the east flank of the Sacramento Mountains, and as the gradients of the streams are greater they are less able on that account alone to widen their valleys near the Pecos River. Furthermore, the outcropping of the resistant Carlsbad limestone near Lake McMillan prevented the Pecos River from swinging widely and caused the constriction of the valley south of that place.

As the depth to bedrock near the Pecos is 250 to 300 feet in the vicinity of Roswell but only 50 to 60 feet a few miles south of Lake McMillan, there may have been a moderate amount of warping after the excavation of the alluvial basin, for obviously the river could not have eroded its channel between Roswell and Artesia much below the level of its channel south of Lake McMillan. However, a downwarping of only 200 feet near the north end of the alluvial basin would be required for the river to have had a sufficient gradient at the time the alluvial basin was excavated. It is also possible that for some distance south from Lake McMillan the Pecos may have flowed in an underground channel at that time.

The present surface of the alluvial basin is the result of several stages of sedimentation and erosion by the streams in their lower courses.

\section{ORIGIN OF THE TERRACES}

The Lakewood, Orchard Park, and Blackdom terraces are all generally underlain by a considerable thickness of alluvial materials consisting of coarse gravel, boulders, sand, and clay derived from the limestone uplands and the mountains to the west. All three terraces slope toward the Pecos River. The Blackdom terrace, which is the highest, has the greatest gradient, and the Lakewood terrace, which is the lowest, has the least.

The Lakewood terrace is definitely a constructional surface. This is clearly shown in many places within and near the artesian basin. The materials forming it differ in many ways from the materials of the older terraces and may be seen to rest unconformably upon 
them. Numerous exposures show that the formation of the Orchard Park terrace was followed by an interval of downcutting during which the streams lowered their channels at least 10 to 30 feet, probably more near the Pecos. The downcutting was in turn followed by an interval of filling, during which the streams deposited silt, sand, and gravel in the channels previously carved, filling them nearly to the surface of the Orchard Park terrace and forming the present Lakewood terrace. Since that time, the streams have again cut rather narrow channels 10 to 30 feet below the Lakewood terrace.

The relationships of the materials forming the Orchard Park and the Blackdom terraces are not clearly revealed in this area. The formation of the Orchard Park terrace was obviously preceded by the dissection of the Blackdom terrace, and in many places it is clear that the Orchard Park terrace is a cut terrace. Small ephemeral streams originating on the Blackdom terrace have dissected it approximately to the surface of the Orchard Park terrace, leaving a few small, low remnants projecting prominently above the surrounding surface of the Orchard Park terrace. This condition is clearly shown near the edge of the Blackdom terrace between Cottonwood Creek and the Rio Felix, where there are many remnants of the Blackdom terrace at various distances from its edge. Near the Pecos River and along the major tributary streams from the west, however, the present surface of the Orchard Park terrace appears to be a constructional feature. It is remarkably smooth and generally has a rather uniform gradient toward the east. The materials forming the terrace are, as a rule, poorly consolidated or loose, although in places the gravel is cemented by calcium carbonate into a firm conglomerate. In many places in the $U$-shaped valleys cut in the Blackdom terrace the deposits of the Orchard Park terrace differ noticeably from adjacent deposits of the Blackdom terrace. This is especially true where the Blackdom terrace consists of very coarse and very firmly cemented conglomerate, as the materials of the Orchard Park terrace a few feet away are generally loose or poorly cemented and the gravel is composed of much smaller pebbles. In fact, the gravel of the Orchard Park terrace generally consists of pebbles less than 2 or 3 inches in diameter, whereas the gravel and conglomerate of the Blackdom terrace in many places consist chiefly of much larger pebbles, cobbles, and boulders as much as 1 to 2 feet in diameter. If the Orchard Park terrace were entirely a cut terrace, it might reasonably be expected that the surface would be somewhat uneven and gently undulating in many places, that remnants of the Blackdom terrace would be found even where the Orchard Park terrace is extensively developed, and that in places the Orchard Park terrace 
would be immediately underlain by dissected conglomerate of the deposits of the Blackdom terrace. The absence of these features along the major streams and the general character of the Orchard Park terrace indicate that its formation, except near the edges of the Blackdom terrace between the major streams, was similar to that of the Lakewood terrace and that it is a constructional feature. The thickness of the deposits of the Orchard Park terrace, however, does not appear to be more than 10 to 20 feet.

The materials forming the Blackdom terrace were derived from the limestone uplands and the mountains and were deposited by streams flowing eastward into the Pecos River. The undissected portions of the terrace are smooth grassy plains sloping gently to the east and appear to be constructional. It is conceivable that the alluvial basin was filled to a surface higher than the Blackdom terrace and that this terrace was formed by the downcutting of streams, but if this hypothesis were correct one would expect to find hills composed of alluvial materials projecting above it in places. The absence of such hills and the smooth surface of the undissected portions of the Blackdom terrace indicate that the terrace is entirely a constructional feature, built up by streams from the limestone uplands and the mountains in much the same manner that the Llano Estacado was constructed. The alluvial slope was once continuous from north to south in the alluvial basin and extended eastward to the Pecos River. The construction of the Blackdom terrace was a slow process, as indicated by successive layers of solution-faceted limestone pebbles ${ }^{19}$ in many places, and indicates an arid climate at the time the deposits were built up. Since its completion the Blackdom terrace has been carved out into broad remnants between the major streams, and these remnants have been dissected by streams originating on the terrace or near its west side.

All three terraces, therefore, appear to be largely or entirely constructional features resulting from the deposition of alluvial materials by the Pecos River and its tributaries from the west during three distinct stages separated by stages of downcutting and trenching of the streams. The Blackdom terrace appears to have been a débris apron constructed almost entirely by the tributary streams from the west. The Orchard Park terrace appears to be largely the result of the filling of stream channels, trenches, and wide valleys excavated during a preceding interval by the Pecos River and its major tributaries, though in parts of the areas between the major tributary streams this terrace appears to be largely the result of dissection of the Blackdom terrace by short ephemeral 1929.

${ }^{10}$ Bryan, Kirk, Solution-faceted pebbles : Am. Jour. Sci., 5th ser., vol. 18, pp. 193-208, 
streams with little if any filling. The Lakewood terrace is entirely the result of the partial filling of the trenches and channels carved out by the Pecos River and its tributaries after the construction of the Orchard Park terrace. The possible causes of the successive intervals of erosion and filling are discussed in connection with the physiographic history.

\section{AGE OF THE QUARTZOSE CONGIOMERATE}

The interpretation of the physiographic history in the artesian basin and, therefore, the dating of the excavation of the deepest parts of the alluvial basin depend to a large extent upon the age of the quartzose conglomerate. The conglomerate is unquestionably older than the deposits of the Blackdom terrace, and it may also be older than the limestone conglomerate capping the high mesas and, therefore, older than the Diamond A plain.

Along the Pecos River, just below Lake McMillan, are two terraces approximately 75 and 150 feet above the river, both of which are underlain by limestone conglomerate. The 75-foot terrace corresponds to the Blackdom terrace, and the 150-foot terrace corresponds to the gravel-capped mesas and the Diamond A plain. Meinzer, Renick, and Bryan, ${ }^{20}$ in their report on a reservoir site just below Lake McMillan, describe the conglomerates as follows:

These terraces are underlain by very similar limestone conglomerates deposited by Pecos River in the two periods when it flowed at these higher levels. On the geologic map these two conglomerates have been mapped together as limestone conglomerate, although the conglomerate in the higher terrace is obviously older than that in the lower. ***

Although the boundary between the quartzose and limestone conglomerates is indefinite in many outcrops, there are indications of a distinct unconformity between them. At a number of places in the east bluff of the Pecos, south of the mouth of Rocky Arroyo, the quartzose conglomerate is tilted and otherwise deformed, whereas nowhere within the area examined was the limestone conglomerate found to be deformed. The existing remnants of the two terraces underlain by the limestone conglomerate are smooth and have gentle slopes characteristic of terraces. These slopes are accordant with each other, sloping from north to south, parallel to the course of the river, and from each side toward the river, parallel to the tributary streams. The limestone conglomerate thus appears to be wholly undeformed, whereas the underlying quartzose conglomerate has been broken and tilted. The deformation of the quartzose conglomerate appears to be due to fracture and slumping caused by the removal of soluble material from the underlying Castile formation.

The outcrops of quartzose conglomerate observed by the writer in the artesian basin substantiate the conclusion of Meinzer, Renick, and Bryan that the deformation of the quartzose conglomerate is

\footnotetext{
${ }^{20}$ Meinzer, O. E., Renick, B. C., and Bryan, Kirk, Geology of No. 3 reservoir site of the Carlsbad irrigation project, N. Mex., with respect to water-tightness: U. S. Geol. Survey Water-Supply Paper 580, pp. 8-10, 1926.
} 
due to solution and removal of underlying soluble rocks with consequent slumping of the overlying strata.

The quartzose conglomerate and its related alluvial materials were deposited on Permian rocks in or close to the channels of the Pecos River. Underground drainage and therefore solution and slumping of overlying beds would probably be more active beneath the channel of the river than at some distance away from it. Consequently, slumping of the strata beneath the channel of the river would not necessarily affect the high terraces some distance away. Nowhere was any evidence found that the deformation of the quartzose conglomerate is due to regional earth movements. Consequently, the fact that the conglomerate underlying the 150-foot terrace and capping the mesas in the artesian basin is not deformed does not necessarily mean that it is younger than the quartzose conglomerate, unless, of course, the quartzose conglomerate underlies the materials forming the 150-foot terrace, in which case there could be no question as to its age. In the repurt by Meinzer, Renick, and Bryan it is implied, but not definitely stated, that the quartzose conglomerate underlies the limestone conglomerate of the 150 -foot terrace as well as that of the 75-foot terrace. If this is true, the Pecos River and its tributaries must have carved out deep canyons and then filled them up with alluvial materials before the formation of the Diamond $\mathbf{A}$ plain. Somewhere, therefore, there should exist surfaces or remnants of surfaces corresponding to the 150-foot terrace which are underlain entirely by alluvial materials. The conglomerate and related materials capping the high mesas near Melena are not more than 20 feet thick and rest upon Permian red beds. Similar conditions exist in the high mesas north of Hope and near the west edge of the drainage basin of Cottonwood Creek, except that in their western parts the conglomerates and related alluvial materials rest upon the Picacho limestone. The conglomerate capping the mesa in the northwestern part of sec. 28 , T. 15 S., R. 23 E., is 10 to 15 feet thick and rests upon Permian red beds. In many places north of the artesian basin conglomerate and related alluvial materials corresponding to the 150-foot terrace are relatively thin and rest upon Permian rocks. A section across the valley of El Macho Creek about 18 miles north of Roswell showing the relation of alluvial materials corresponding to the 150 -foot terrace, to the underlying red beds, and to the younger alluvial deposits is shown in Figure 6. At no place within the artesian basin or in localities to the north were surfaces or remnants of surfaces corresponding to the 150-foot terrace and the Diamond A plain found by the writer to be underlain entirely by alluvial materials. At all places observed by the writer the alluvial materials corresponding to the 150 -foot terrace are rela- 
tively thin and rest upon Permian rocks, suggesting that the limestone conglomerate of the 150 -foot terrace is not younger than the quartzose conglomerate.

\section{RELATION OF PHYSTOGRAPHIC HISTORY TO GLACTAL STAGES}

A stream may erode as a result of earth movements or of increase in its volume of water or decrease in its load. It may deposit as a result of earth movements that lower its gradient or of decrease in its volume or increase in its load. The close accordance of the surfaces that have resulted from the several cycles of erosion and sedimentation in this region would have required a series of singularly harmonious uplifts and depressions. The fact that the eastward gradient of the terraces increases from the lowest, or youngest, to the highest, or oldest, does not necessarily indicate progressive tilting of the artesian basin; for, other things being equal, a stream will lower its channel less rapidly near its lower end than in the central part, and hence the difference in height between its successive profiles is likely to increase upstream. For these reasons it does not seem probable that the cycles are due primarily to oscillations of the land surface. It seems more probable that they are the result of climatic changes. During a relatively humid period the flow of the streams would be increased. At the same time there would be more vegetation in and near the mountains and a lower limit of timber, and hence less erosion of the mountain slopes and less material contributed to the streams. Therefore, the streams would erode, especially in the soft materials of the alluvial basin. The trenching would be most rapid at the beginning of the humid period and would gradually decrease with lowering gradient. Later the streams would tend to widen their channels, especially in the lower parts of their courses. With change to more arid conditions the vegetation would decrease, the lower edge of the timber would retreat upward, and the partial loss of the protective mat of vegetation would permit increased erosion of the upland slopes. With increase in load and decrease in the volume of water the streams would be unable to transport all the material supplied to them, and would aggrade, especially in the arid alluvial basin. Thus the almost continuous downcutting of the streams in the mountains and the alternate periods of erosion and sedimentation by the streams in and nèar the alluvial basin may well have been the result of climatic changes.

The five stages of downcutting by the streams after the completion of the Llano Estacado may perhaps be correlated with the five glacial stages recognized in the United States. The first two continental ice sheets advanced farthest south and presumably lasted longest, 


\section{and similarly the first two downcuttings in this region were much} greater than any of the following ones. A possible correlation of these events with those occurring in the glacial history in the northern United States are given in the following table:

Probable succession of events in the geologic history of Rosnoell artesian basin. during the Quaternary period and possible correlation of these events with glacial history of the northern United States

\begin{tabular}{|c|c|c|c|}
\hline Epoch & Deposition & Erosion & $\begin{array}{l}\text { Postulated age and } \\
\text { climate }\end{array}$ \\
\hline Pleistocene. & 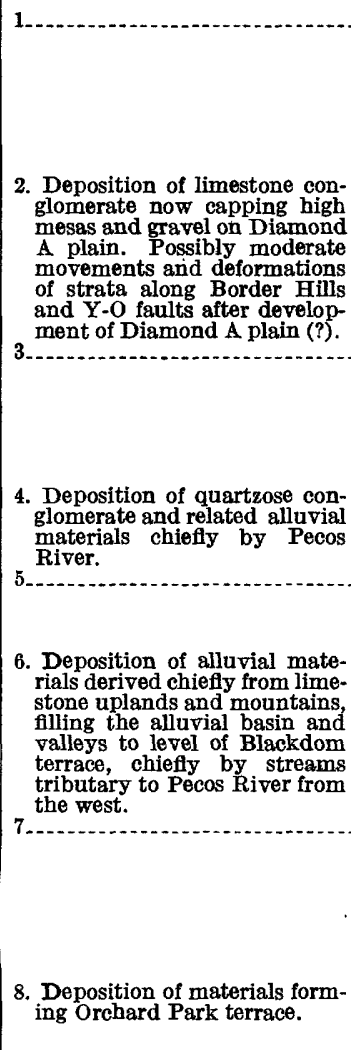 & $\begin{array}{l}\text { Trenching of streams } 200 \text { to } 300 \\
\text { feet or more below gravel- } \\
\text { capped mesa and Diamond A } \\
\text { plain, and excavation of allu- } \\
\text { vial basin by streams tributary } \\
\text { to Pecos River within the arte- } \\
\text { sian basin. } \\
\text { Deformation (due to under- } \\
\text { ground solution and removal } \\
\text { of soluble rocks) and erosion } \\
\text { of quartzose conglomerate. }\end{array}$ & $\begin{array}{l}\text { Yarmouth interglacial } \\
\text { stage. } \\
\text { Aridity. } \\
\text { mlinoian glacial stage. } \\
\text { Humidity. } \\
\text { Sangamon interglacial } \\
\text { stage. } \\
\text { Aridity. }\end{array}$ \\
\hline Recent. & $\begin{array}{l}\text { 10. Deposition of alluvial ma- } \\
\text { terials forming Lakewood ter- } \\
\text { race to levels } 10 \text { to } 30 \text { feet } \\
\text { above present stream channels. } \\
11 .\end{array}$ & $\begin{array}{l}\text { Erosion of present stream } \\
\text { trenches, possibly due to de- } \\
\text { struction of vegetation by } \\
\text { grazing. }\end{array}$ & $\begin{array}{l}\text { Wisconsin glacial stage. } \\
\text { Humidity. } \\
\text { Postglacial aridity. }\end{array}$ \\
\hline
\end{tabular}

Several objections to this correlation suggest themselves. First, the dating of the first downcutting by the streams is based upon the 
assumption that the final trenching of the streams below the Llano Estacado and the establishment of the Pecos River occurred at the beginning of the Pleistocene. Although this appears most probable, further detailed studies of the deposits underlying the southern and western parts of the Llano Estacado would be required to prove it. Second, the length of time required for the development of the Diamond A plain, which was carved out of hard rocks, was probably much greater than that required for the excavation of the alluvial basin, which was carved out of much softer rocks, whereas there does not appear to have been a similar difference in the length of the Nebraskan and Kansan glacial stages. However, this probability is based on the assumption that the rate of erosion and of downcutting by the streams was the same during both stages, and this is not necessarily true. Furthermore, there is little evidence upon which to base an estimate of the relative duration of the maximum advance of the Nebraskan and Kansan ice sheets. Third, there does not appear to have been a distinct stage of valley filling after the development of the Diamond A plain such as occurred after the later stages of downcutting. However, it does not follow that the geologic processes were the same during each interglacial stage, and although the development of the Diamond A plain may have begun during the Nebraskan glacial stage, its final planation and the formation of the comparatively smooth surface may have occurred during the succeeding Aftonian interglacial stage.

It is difficult to prove that the several stages of downcutting and valley filling by the streams are chiefly the result of climatic changes, and it is obviously impossible to prove the suggested correlation of the events in the physiographic history of this region with those in the glacial history of the northern United States on the basis of the evidence in this region alone. Detailed geologic and physiographic studies of a very large part of the western United States by many workers would be required to correlate the Pleistocene history of the unglaciated regions with that of the glaciated regions. Nevertheless the writer offers this climatic hypothesis for further consideration.

\section{GROUND-WATER CONDITIONS}

By S. S. Nre

\section{GENERAI RELATIONS}

\section{OCCURRENCE OF THE GROUND WATER IN THE ARTESIAN BASIN}

Beneath a certain depth, which varies greatly in different localities, there is, as a rule, a zone in the crust of the earth in which all the pores, cracks, and crevices in the rocks are filled with water under hydrostatic pressure. This zone is called the zone of satura- 
tion. ${ }^{21}$ A large part of the water that enters the rocks beneath the surface of the earth is drawn down by gravity to the zone of saturation. The water in the zone of saturation is called ground water, and the upper surface of the zone of saturation is known as the water table. In restricted areas water is suspended above the main water table because of the presence of a relatively impervious bed which hinders the downward movement of the water to such an extent that it forms an upper zone of saturation. The water in such an upper zone is called perched ground water, and its upper surface is called a perched water table. (See fig. 13.)

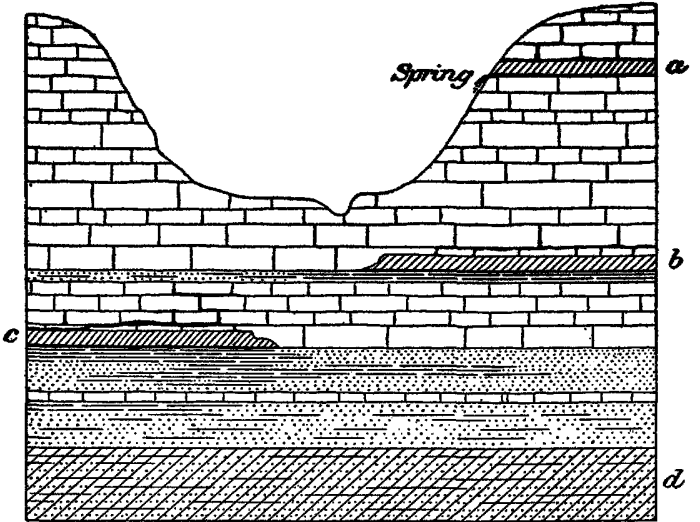

Figure 13.-Three perched zones of saturation $(a, b, c)$ above the main zone of saturation $(d)$

The ground water in the Roswell artesian area occurs in four formations-the valley fill, the Pecos formation, the Picacho limestone, and the Nogal formation - which differ greatly in lithology, structure, and origin, and therefore in waterbearing properties. The character and structure of these formations are described in detail on preceding pages. The areal distribution of the first three in the eastern part of the artesian basin is shown on Plate 3.

The aquifers ${ }^{22}$ in the valley fill and in the Picacho limestone have only one similarity-they do not represent continuous stratigraphic horizons over broad areas. The aquifers in the valley fill vary greatly in character and distribution from place to place. They are composed of unconsolidated sand and gravel in the zone of saturation. The water in these aquifers is under hydrostatic pressure but not, except perhaps locally, under artesian pressure. The aquifers in the Picacho limestone are not definite beds extending over broad areas but are extremely erratic cavernous zones formed by the solution and removal of the more soluble portions of the limestone by percolating water. The water in them is under hydrostatic pressure in the outcrop area of the limestone, but beneath the alluvial basin

21 For a discussion and definition of terms used in ground-water hydrology, see Meinzer, o. E., The occurrence of ground water in the United States, with a discussion of principles: U. S. Geol. Survey Water-Supply Paper 489, 1923 ; Outline of ground-water hydrology, with definitions: U. S. Geol. Survey Water-Supply Paper 494, 1923.

${ }_{22}$ An aquifer is a formation, group of formations, or part of a formation that yields water to wells and springs in sufficient quantity to be of consequence as a source of supply. 
it is confined by impermeable beds overlying the Picacho limestone and is under sufficient pressure to rise above the zone of saturation. In the alluvial basin the water in the Picacho limestone is therefore under artesian pressure. The interstices of the aquifers in the valley fill (the sand and gravel) are open spaces between the pebbles and grains of sand and are original-that is, they are the result of the geologic processes by which the materials were deposited. The interstices of the aquifers in the Picacho limestone are solution passages developed long after the limestone was formed and are therefore secondary.

The parts of the Pecos and Nogal formations underlying the area treated in this report are similar in many respects, lithologically and structurally. Both consist of very lenticular beds of red shale and sand, gypsum or anhydrite, and limestone, although the detailed character and the relative proportions of the beds in the two formations differ somewhat. However, these two formations may be considered a single type, at least in so far as the characteristics of the aquifers and of the water in them are concerned. Both contain aquifers of fine red sand, which are discontinuous and yield relatively small amounts of water, and both contain beds of gypsum and anhydrite from which in many places the ground water dissolves large quantities of calcium sulphate. The two differ, however, in that the Pecos formation contains lenticular beds of cavernous limestone that are artesian aquifers within the artesian area, whereas the Nogal formation, so far as the available data show, does not contain aquifers of that type. The Pecos formation, therefore, contains artesian aquifers very similar to those in the Picacho limestone. Both the Pecos and the Nogal formations contain aquifers whose interstices are similar in origin and character to those of the aquifers in the valley fill. The different types of interstices characterizing the aquifers in the artesian basin are shown in Figure 14.

The water in the Pecos formation, like that in the Picacho limestone, as a rule, has a water table in the outcrop area and is under artesian pressure beneath the artesian area. The water in the Nogal formation is recovered only in and near the mountains, at places where there are bodies of perched ground water.

\section{SOURCE OF THE GROUND WATER}

Most of the ground water is derived from precipitation. In the Roswell artesian basin essentially all of the water that is recovered through springs and wells is derived from rain and snow that fall on the extensive drainage basins of the streams that are tributary to the Pecos River, mostly, if not entirely, within the north-south limits of the alluvial basin. The structure of the rocks is such as to 
preclude any important contribution to the ground-water supply in the artesian basin from precipitation and stream losses outside of the basin. Not all of the precipitation in the artesian basin contributes to the ground-water supply. A large part runs off in surface channels to the Pecos River, much of it evaporates, and some is utilized by plants. The rest sinks into the ground, and eventually most of it is drawn down by gravity to the main zone of saturation, which, in the upland region west of the alluvial basin, furnishes most of the water supplying the wells in the artesian area. The sources of the ground water are discussed in detail in connection with the waterbearing formations.
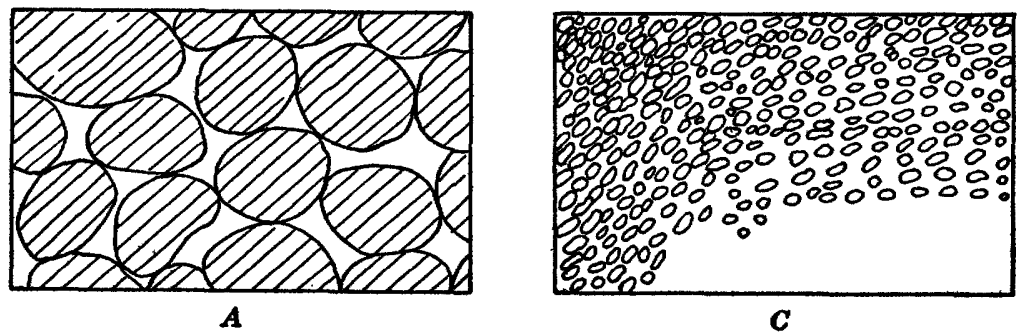

$\boldsymbol{C}$

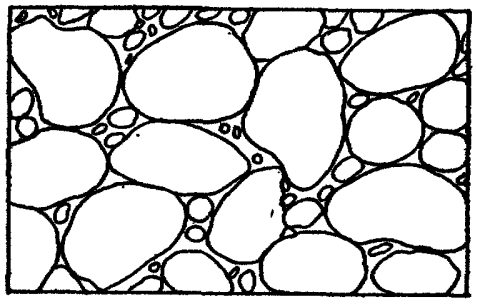

$B$

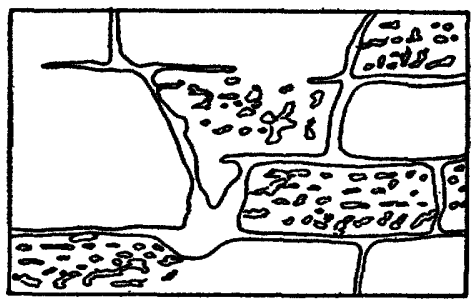

D

FIgUR 14.-Types of interstices characterizing aquifers in the Roswell artesian basin. After Meinzer. $A$, Coarse clean gravel; $B$, mixture of coarse gravel and sand; $C$, coarse sand; $D$, solution openings in limestone. $D$ shows two types of openings developed within the limestone, resulting in "worm-eaten" and " honeycombed" limestone

\section{THE WATER TABLE}

In the artesian basin the main water table, or the upper surface of the main zone of saturation, slopes eastward from the upland region on the west to the Pecos River, where it is at or near the surface. The eastward slope of the land surface in this area is greater than that of the water table. Therefore, the depth to the water table increases westward from the Pecos River. Near the mountains the main water table is 1,000 to 1,500 feet or more below the surface. In the higher parts of the limestone uplands and in the mountains, however, there are many perched water tables that are relatively near the surface. These perched zones of saturation are not exten- 
sive over large areas but are entirely local and are highly erratic in distribution and depth. The eastward dip of the formations and the eastward slope of the ancient land surface upon which the valley fill rests are also greater than the eastward slope of the main water table. Consequently, the water table passes out of the valley fill a few miles west of the Pecos River, extends diagonally across the Pecos formation and the Picacho limestone, and in the central part of the limestone upland enters the Nogal formation. The relation of the water table to the slope of the land and the structure of the rocks is shown in the sections on Plate 2.

\section{MOVEMENT AND DISPOSAL OF THE GROUND WATHR}

The movement of ground water depends upon two factors: (1) The interstices in the rocks must be connected with one another so that the water can percolate from one interstice to another. Obviously, if the interstices in the rocks are isolated, or largely so, there can be little movement of the water in them. (2) There must be a difference in pressure from point to point; otherwise there will be no tendency for the water to move. This difference in pressure is called the hydraulic gradient and the direction of the movement of the ground water is, of course, determined by the direction of the hydraulic gradient.

The rate of movement of the ground water depends, according to Slichter, ${ }^{23}$ upon

(1) the size of the pores in the water-bearing medium, the capacity to transmit water being enormously greater for large pores than for small pores; (2) the porosity of the material, the flow being much greater for high porosity than for low porosity, other things being equal; (3) the pressure gradient, or the change in pressure, or head, per unit of length measured in the direction of the motion, the flow being greater, of course, for high gradients than for low gradients; and (4) the temperature of the water, the flow being noticeably greater for high temperatures than for low temperatures.

So far as the size of the pores is concerned, the rate of the movement of the water depends largely upon the size of the smallest connecting interstices rather than upon the size of the largest ones, for obviously if two large interstices are connected by a small one the water can not percolate from one large interstice to the other any faster than the size of the connecting interstice will permit.

The rate of movement in the aquifers differs, of course, according to the size and character of the interstices. For instance, the rate of movement of the water in the aquifers in the Nogal formation, which are chiefly fine sand, is probably rather slow, whereas in the cavernous

es Slichter, C. S., The motions of underground waters: U. S. Geol. Survey Water-Supply Paper 67, pp. 17-18, 1902.

$135252-33-9$ 
aquifers of the Picacho limestone, which are highly permeable, it is comparatively rapid. It was not found practicable to measure the rates of movement of the ground water in the different types of aquifers in the artesian basin.

The general direction of movement of ground water is toward points of discharge, whether springs, wells, or areas of ground-water evaporation. The natural points of discharge are ordinarily determined by the relation of the land surface to the water table. In low places where the land surface intersects the water table ground water is discharged at the surface along the line of intersection, as along streams that have cut their channels below the water table. When a well is pumped or allowed to flow the ground water moves toward it. The water in the artesian basin moves eastward and southeastward from the high land on the west to the Pecos Valley, where it is discharged at the surface through wells or springs.

Some of the water never appears at the surface, but discharges into the Pecos River through underground channels or by upward percolation from the underlying permeable strata, through which it is forced by the strong artesian pressure. Much of the water in the valley fill doubtless discharges into the Pecos River, as well as at the surface through wells. The large gain in the flow of the Pecos River (see p. 126) as it crosses the artesian basin is proof that ground water is being discharged into it. Before the artesian wells were drilled artesian water was discharged at the surface through the large springs in the vicinity of Roswell and probably through the many smaller springs in the valleys of the Pecos River and the Seven Rivers. There is little reason to believe that there is any considerable eastward movement of the water in the artesian basin east of the bluffs on the Pecos River. (See also pp. 129, 132, 140, 155, 156.)

\section{ARTESIAN CONDITIONS}

The Roswell artesian basin is not a structural basin such as is commonly shown in textbooks to illustrate the simpler conditions of artesian flow (see fig. 15); instead, it simulates more nearly what has been called an "artesian slope." ${ }^{24}$ An artesian basin as here defined does not necessarily imply a structural basin.

The structure of the Roswell artesian basin is fully described on pages 76-88 and is shown by the sections on Plate 2. With the exception of the valley fill, the rocks in the artesian basin consist of regularly bedded permeable and impermeable strata dipping east at a low angle. In the western part of the artesian basin the Pecos formation and some of the Picacho limestone have been removed by

24 Fuller, M. L., Summary of the controlling factors of artesian flows; U. S. Geol. Survey Bull. 319, p. 38, 1908. 
erosion, and in the eastern part, where the lower part of the Pecos formation still remains in all but the north end, a heterogeneous mass of alluvial materials (the valley fill) has been deposited upon the eroded surfaces of the Pecos formation and the Picacho limestone. The Picacho limestone and the underlying Nogal formation rise toward the west, forming a gentle slope which extends to the Sacramento Mountains and Sierra Blanca. To the east they dip beneath the valley fill and the Pecos formation.

The general artesian conditions in this area are essentially as follows: Part of the precipitation that falls in the mountains and limestone uplands sinks beneath the surface and is drawn down by gravity to the main zone of saturation in the Picacho limestone. Ground water has a tendency to move from higher to lower levels and in the direction of the dip of the strata, where the dip is in general accordance with the slope of the land surface, as in this region. Therefore the ground water in at least the upper part of the main zone of saturation moves eastward through solution passages, fractures, and joints diagonally across but in the general direction of the dip of the limestone strata until it reaches the western edge of the alluvial basin, where the relatively impermeable cover formed by the Pecos formation and the valley fill prevents most of the water from passing into the overlying formations and confines it in the Picacho
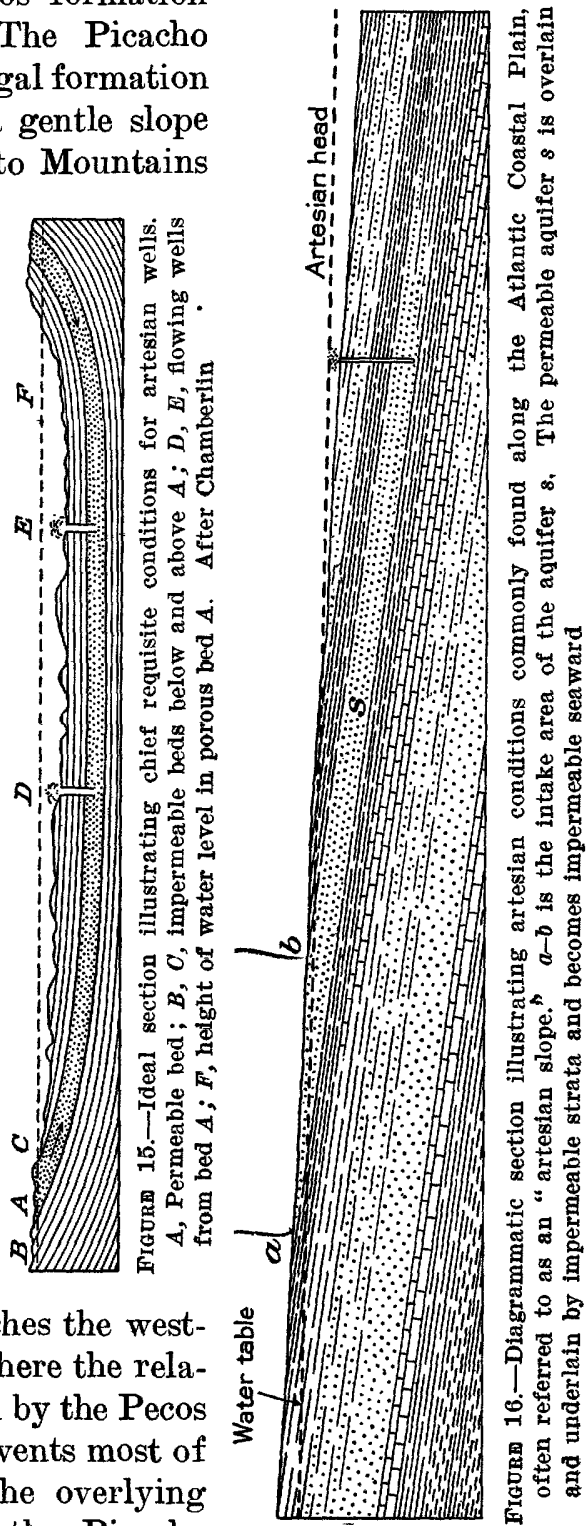
limestone. Some of the water in the Picacho limestone, because of the great hydraulic pressure behind it, is forced upward through devious paths into the beds of cavernous limestone and permeable sand in the Pecos formation. Some ultimately finds its way to the 
surface and appears as springs. When a tightly cased well is drilled to a cavernous zone in the Picacho limestone or to an aquifer in the Pecos formation the water from the aquifer rises nearly but not quite to the level at which it is confined in the aquifer by overlying impermeable beds, a level higher than the water table outside the well. If the land surface is below the static level of the water, or the height to which the water would rise in a pipe, the well flows.

\section{WATER IN THE VALLEY FILL}

\section{OCCURRENCE}

A large number of windmill wells and a few pump wells in the alluvial basin are supplied with water from sand and gravel in the valley fill. The valley fill includes the Recent and the undifferentiated alluvial deposits which are described on pages 25-29. The areal distribution of these deposits is shown on Plate 3.

The deposits are thickest along the Pecos River, where the water table is at or very near the surface. Westward from the Pecos the valley fill thins out and the depth to the water table increases. Therefore, the area in which the valley fill contains ground water is very much less than the area covered by these deposits. The region in which ground water can be obtained from the valley fill is, in general, a narrow, irregular strip bordering the Pecos River. The eastern limit of this strip is near the base of the bluffs on the east side of the river. The western limit is very indefinite but is probably from 5 to 15 miles west of the Pecos. The area in which it is profitable to develop the ground water in the valley fill for irrigation is smaller still. The western limit of this area is probably a short distance east of or in places may roughly coincide with the line along which the water table is 50 feet below the surface. (See pl. 26.) This area is generally not much more than 2 or 3 miles wider than the present area of artesian flow, as may be seen by a comparison of Plates 26 and 39 .

Although the main body of ground water in the valley fill occurs in a comparatively narrow strip along the Pecos River, there are a few bodies of perched ground water in the alluvial deposits west of this strip, especially in the valleys of the Rio Hondo, the Rio Felix, the Rio Penasco, and other major streams, which are held above the main water table by impervious beds. The well near the north bank of the Rio Hondo at the Diamond A ranch, in sec. 20, T. 11 S., R. 21 E., draws from a perched body of ground water in the alluvial deposits, which is held above the main water table by limestone whose joints and fractures are cemented with calcium carbonate or by caliche deposited on top of the limestone. This perched body of ground water is apparently fed largely by underground seepage from the Rio Hondo. Several shallow wells drilled in the valley of the Rio 
Hondo half a mile to a mile from this well failed to encounter any water in the alluvial deposits. The perched bodies of ground water in the alluvial deposits are erratically distributed and can rarely be located without drilling.

The thickness of the valley fill generally ranges from less than an inch to 250 feet; in some places it appears to be 350 feet or more, but in most places it is probably less than 150 feet. The variations in thickness are due largely to irregularities in the topography of the ancient land surface upon which it was deposited. It is, of course, thicker above the valleys than above the hills of the old land surface and is thickest above the ancient valley of the Pecos River. The valley fill thins out westward because the old surface sloped toward the east, and the eastward gradient of the present surface of the valley fill is less than that of the old land surface upon which it rests.

The water-bearing beds in the valley fill are the unconsolidated coarse materials that lie below the water table, usually fine to coarse sand but including gravel also, varying mixtures of sand and gravel, and possibly cavernous caliche. Water-bearing beds of coarse clean gravel are comparatively rare in the valley fill, but beds of coarse well-assorted sand are not uncommon. The gravel deposits are usually a heterogeneous mixture of sand and gravel. The fine sand generally contains a certain amount of silt or clay mixed with it. The character, degree of assortment, distribution, and depth of the water-bearing beds are extremely variable from place to place. This is to be expected from the fact that the valley fill consists not of regularly bedded and extensive strata of clay, sand, and gravel but of a mass of poorly assorted alluvial materials, chiefly clay, silt, and fine sand, penetrated by a complicated network of interlacing trains of comparatively well-assorted coarse sand and gravel. The network is probably elongated in a general east-west direction. (See fig. 17.)

\section{SOURCES}

The water in the valley fill is derived from surface drainage, local precipitation, artesian water that has worked its way upward from the underlying permeable strata, leaky artesian wells, and irrigation losses.

Surface drainage.-Surface drainage from the mountains and from the western uplands that reaches the alluvial basin is probably one of the principal sources of the ground water in the valley fill. This source is very intermittent, for although the Rio Hondo and the Rio Penasco, which receive most of the drainage from the Sacramento Mountains and Sierra Blanca, are perennial streams in the upland region, none of the water in these streams ordinarily reaches the alluvial basin. Most of it is diverted for irrigation before it 
reaches the alluvial basin; the rest sinks into the ground or evaporates in the upland region. However, after periods of heavy precipitation in the mountains and western uplands, a large amount of the surface drainage received by these streams reaches the alluvial basin. There are occasional periods of exceptional rainfall after which all the major streams carry huge volumes of water, as is shown by the large boulders and cobbles in their beds. At such times large areas in the alluvial basin are flooded, especially in the valley of the Rio Hondo. It was reported that the central part of Roswell was under several feet of water at one time.

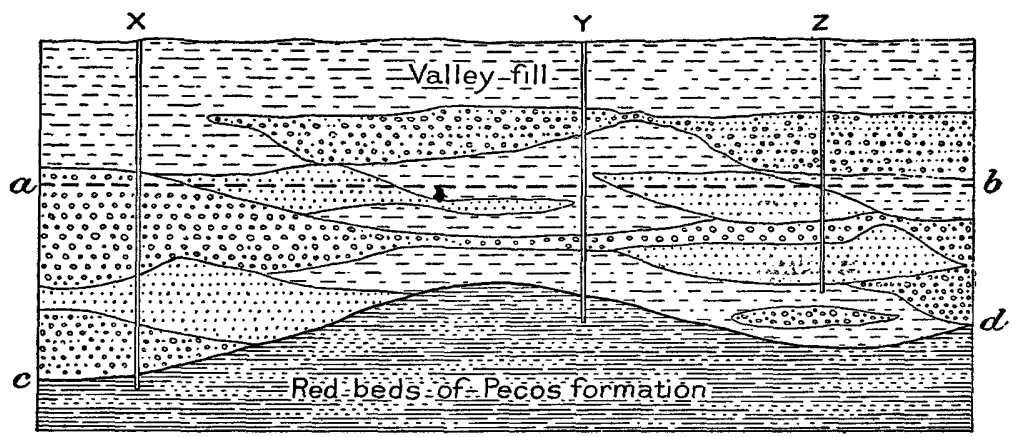

FIGUR 17.-Frratic character and distribution of aquifers in the valley fill and variation in thickness of the valley fill due to irregularities in the old erosion surface $(a-d)$ upon which it was deposited. The abrupt change in groundwater conditions within short distances is shown by hypothetical wells at $X$, $\mathbf{Y}$, and $\mathbf{Z}$. $A$ well at $\mathbf{X}$ encounters a large amount of coarse sand and gravel below the water table $(a-b)$ and has a large yield. At $Y$ there is little permeable material below the water table and a well there yields very little water. At $\mathrm{Z}$ there is considerable permeable material below the water table but not so much as at $\mathbf{X}$

Although most of the water from the large floods is doubtless discharged into the Pecos River, a part of it is quickly absorbed by the dry, porous materials in the alluvial basin. Not all of the water so absorbed reaches the zone of saturation. Much of it is held in the interstices of the alluvial materials, especially in those of the silt and clay, and either evaporates or is used by plants. It is not until the materials are thoroughly moistened that considerable amounts of water reach the water table. The heavy floods of short duration are probably less effective sources of ground water than intermediate floods of longer duration, as their water rushes into the Pecos River too quickly to allow much to sink into the ground. Likewise, not much water is contributed by small floods because most of the water that sinks into the ground is used to moisten the materials. In general, however, the floods from the upland region at long intervals contribute large amounts to the ground-water supply in the valley fill. 
Local precipitation.-Most of the local precipitation in the alluvial basin falls in the form of thunder showers during the summer. The thunder showers and the ordinary rains at other times of the year probably contribute little, if any, to the ground water. Although the run-off is not especially rapid and a large part of the water sinks into the ground, the rains are so infrequent in this area that the ground becomes very dry and light rains are hardly sufficient to moisten it. As a rule, comparatively little snow falls in the winter. Occasionally there are long, soaking rains, which doubtless contribute moderate amounts of water to the zone of saturation.

Artesian water.-The Berrendo Springs, the North and South Springs, and other springs in the alluvial basin, whose flow declined markedly or ceased entirely in response to the decline in the artesian head, prove that large amounts of artesian water find their way to the surface from the artesian horizons. The beds overlying the Picacho limestone, which contains most of the artesian water, are not everywhere impermeable, and it is likely that a certain amount of artesian water, although it may be only a small proportion of the total, slowly works its way upward into the permeable materials in the valley fill, even in the central part of the district, where the cover of Pecos red beds on the Picacho limestone is thickest. The red shales in the Pecos formation are relatively impermeable but not absolutely so. Hence, water under sufficient pressure can force its way across them, although at a very slow rate. Moreover, these beds are very lenticular and may be replaced laterally by more permeable beds. The largest contribution of artesian water to the valley fill takes place in the northern part of the alluvial basin, where the cover on the Picacho limestone is relatively thin. Artesian water that escapes from the Picacho limestone and from the Pecos formation is probably one of the important sources of the ground water in the valley fill.

Leaky artesian wells.-A considerable proportion of the leakage from artesian wells undoubtedly finds its way into the valley fill. This is suggested by the fact that the point at which the lower Cottonwood Creek began flowing advanced successively westward as artesian wells were drilled farther and farther up its valley. Just what proportion of the leakage from the artesian wells is contributed to the ground-water supply of the valley fill is, however, problematic.

Irrigation losses.-A large amount of artesian water used for irrigation is wasted through seepage losses in reservoirs and irrigation ditches, improper use of water, and wells that are allowed to flow continuously. This phase of the subject is more fully discussed on pages 229-231. Some of this water doubtless runs off into the Pecos River through surface channels, evaporates, and is utilized by plants, 
but a large proportion of it joins the ground water in the valley fill. In the area in which most of the irrigation losses occur the water table is comparatively near the surface and the materials between it and the surface are probably kept fairly moist most of the time by ordinary irrigation and by these losses. Consequently, a large proportion of the water lost in irrigation continually reaches the zone of saturation and is probably one of the chief sources of the ground water in the valley fill.

Summary.-The available data are insufficient to evaluate the relative importance of each of the sources of the ground water in the valley fill. However, from the remarkably close relationship between the area of shallow ground water, in which the water table ranges from the surface to 50 feet below the surface, and the area of artesian flow (see pls. 26 and 39), it appears that the artesian water, both directly and indirectly, is the main source of the ground water in the valley fill-that is, the combined contributions of water from leaky artesian wells, artesian water that works its way upward into the valley fill from the Picacho limestone and the Pecos formation, and irrigation losses surpass those from surface drainage and local precipitation.

\section{WATER TABLE}

The regional slope of the water table in the valley fill is eastward, but the eastward gradient of the upper surface of the valley fill (the land surface) is greater. Consequently the depth to the water table increases westward from the Pecos River, where it is at or very near the surface. Plate 26, a map of the eastern portion of the valley fill, shows the areas in which the water table is at depths of 0 to 10 feet, 10 to 25 feet, 25 to 50 feet, and 50 to 100 feet, representing roughly the depth at which the water stands in wells drawing from the valley fill. In general, these areas are narrow belts roughly parallel to the Pecos River, and except in a few isolated tracts the depth at which the water stands in the wells increases westward from the river.

The regional eastward slope of the water table is modified by local conditions. Near the valleys of the streams it slopes toward the stream channels, especially where the channels have been cut below the water table and the ground water is discharging into the streams. The effect of the topography and drainage lines upon the depth to the water table is conspicuously shown by the configuration of the various belts and isolated areas depicted in Plate 26 and Figures 35 to 37 . The surface of the water table is probably much more uniform, however, than might be inferred from these maps. Time did not permit the making of a contour map of the water table-that is, a map showing lines drawn through points of equal altitude above sea level or any assumed datum plane-except in the 
small area along the Rio Felix, shown in Figure 35, where Mr. Fiedler made a detailed study of the ground water in the valley fill.

The height to which the ground water in the valley fill rises in wells does not everywhere coincide with the height of the main water table outside the wells. The reason for this is that the valley fill is made up of both permeable and relatively impermeable materials, and where the upper surface of the zone of saturation is formed by a relatively impermeable bed there is no water table. At such a place any difference between the height to which the ground water from the underlying permeable material would rise in a well drilled at that place and the height of the water table in permeable material surrounding the impermeable bed depends upon the thickness and extent of the impermeable bed. ${ }^{25}$ Again, the water may be perched or semiperched. ${ }^{26}$

Although the structure of the valley fill is such that flows are not ordinarily to be expected from it, light flows have been obtained from permeable beds in a few isolated places. They are the result of special conditions and may be due to a relatively isolated train of sand and gravel incased in less permeable materials, in which ground water is confined at a slightly higher level than that of the mouth of the well. As a rule, however, the depth to water in wells drawing from aquifers in the valley fill may be considered the depth to the main water table.

\section{MOVEMENT AND DISPOSAL}

The Pecos River has cut its channel below the water table, and consequently ground water in the valley fill is discharging into the river along the entire length of the alluvial basin. Hence the regional movement of the ground water and therefore the regional slope of the water table are toward the Pecos River, but they are modified locally by the larger tributary streams from the west, which in their lower courses near the Pecos River have also cut their channels below the water table. At such places the ground water moves northeastward or southeastward toward the channels of these tributary streams and discharges into them. This is well shown by the contour map of the water table in a small area along the Rio Felix. (See fig. 35.) Other local variations in the direction of movement are caused by springs and by heavy pumping from wells.

\footnotetext{
${ }^{25}$ See Meinzer, O. E., The occurrence of ground water in the United States, with a discussion of principles: U. S. Geol. Survey Water-Supply Paper 489, p. 30, 1923.

2 Meinzer, O. E., Outline of ground-water hydrology, with definitions: U. S. Geol. Survey Water-Supply Paper 494, p. 41, 1923. "Ground water may be said to be semiperched if it has greater pressure head than an underlying body of ground water, from which it is, however, not separated by any unsaturated rock. Semiperched water belongs to the same zone of saturation as the underlying water, and therefore where it occurs there is only one water table, which may be called a semiperched water table. Semiperched water, like perched water, is underlain by a negative confining bed of either permeable or impermeable type. The underlying water has subnormal head."
} 
Most of the ground water in the valley fill is being disposed of through springs, through surface channels cut below the water table, and through wells that are in use. That the amount removed in this way is considerable may be inferred from the fact that the flow of the Pecos River increases about 50 second-feet, or 35,000 acre-feet a year (see p. 118), as it flows from the north to the south end of the alluvial basin. Although some of this gain in flow may be the result of direct losses from the artesian reservoir, undoubtedly a large proportion is derived from ground water in the valley fill. Large quantities of the ground water in the valley fill are also being disposed of by evaporation and by the transpiration of plants ${ }^{27}$ in large areas on the Lakewood terrace along the Pecos River and in other places where the water table is at or very near the surface.

If there were no points of discharge or if the amount of water contributed each year to the zone of saturation in the valley fill were greater than the amount of ground water removed from it, the zone of saturation would gradually be built up until it reached the land surface and overflowed the ground-water reservoir. This is practically what happened in large areas in the northern part of the alluvial basin. The zone of saturation in the valley fill was built up so high that in several large areas it was found necessary to install extensive subsurface drainage systems at great expense in order to reclaim the land for farming.

\section{WELLS}

Partial or complete records were obtained of 212 wells (see table, pp. 346-353), which represented practically all the wells drawing from the valley fill in the artesian area outside of T. 14 S., R. 26 E., in which Hagerman is situated, and most of the wells in that township. The distribution of the wells is shown in Plate 26. In the part of the area of artesian flow where the artesian aquifers are encountered at relatively shallow depths and yield large amounts of artesian water there are few wells drawing from the valley fill-only 5 or 6 northeast and east of Roswell, 2 southeast of Roswell, and 5 southeast of South Spring. Practically all the remaining wells drawing from the valley fill in the vicinity of Roswell, South Spring, and Orchard Park are west of the area of artesian flow. The wells drawing from the valley fill are most numerous in the vicinity of Hagerman, Greenfield, and Dexter, where the depth to the artesian aquifers is much greater and where the artesian aquifers are apparently less permeable and yield relatively small amounts of water.

${ }^{27}$ See Meinzer, O. E., Plants as indicators of ground water : U. S. Geol. Survey WaterSupply Paper 577, 1927. 
(See pp. 223-224 and pl. 41.) All the remaining wells in the valley fill except the few near Lakewood are scattered along Cottonwood Creek and in the vicinity of Artesia and Dayton. The table given below shows the distribution of the wells of which records were obtained according to townships and counties. Most of the wells are in Chaves County, and of the total number, including those not recorded, there are more than twice as many in T. 14 S., R. 26 E., as in any other township.

Distribution of wells of which records were obtained that draw from the valley fill

\begin{tabular}{|c|c|c|c|c|c|}
\hline \multicolumn{3}{|c|}{ Chaves County } & \multicolumn{3}{|c|}{ Eddy County } \\
\hline \multicolumn{2}{|c|}{ Location } & \multirow{2}{*}{$\begin{array}{l}\text { Number } \\
\text { of wells }\end{array}$} & \multicolumn{2}{|c|}{ Location } & \multirow{2}{*}{$\begin{array}{l}\text { Number } \\
\text { of wells }\end{array}$} \\
\hline T. S. & R. E. & & T. S. & R. E. & \\
\hline \multirow{3}{*}{$\begin{array}{r}9 \\
10 \\
11 \\
11 \\
12 \\
12 \\
13 \\
13 \\
14 \\
14 \\
15 \\
15\end{array}$} & \multirow{3}{*}{$\begin{array}{l}24 \\
24 \\
24 \\
25 \\
24 \\
25 \\
25 \\
26 \\
25 \\
26 \\
25 \\
26\end{array}$} & \multirow{2}{*}{$\begin{array}{r}1 \\
13 \\
22 \\
5 \\
5 \\
18 \\
13 \\
16 \\
13 \\
47 \\
8 \\
6\end{array}$} & $\begin{array}{l}16 \\
16 \\
16 \\
17 \\
17 \\
18 \\
19\end{array}$ & $\begin{array}{l}24 \\
25 \\
26 \\
25 \\
26 \\
26 \\
26\end{array}$ & $\begin{array}{r}3 \\
5 \\
4 \\
8 \\
9 \\
11 \\
5\end{array}$ \\
\hline & & & $\ldots$ & ....... & 45 \\
\hline & & 167 & & & \\
\hline
\end{tabular}

The depth of 154 wells drawing from the valley fill ranged from 10 to 185 feet. Of these wells, 23 were 10 to 25 feet deep, 44 were 25 to 50 feet deep, 64 were 50 to 100 feet deep, and 23 were over 100 feet deep. The water level in the wells of which records were obtained ranged from $41 / 2$ to 119 feet below the surface.

Nearly all the wells were equipped with windmills or hand pumps, and the water was used for domestic purposes and stock and in a few places for irrigating small gardens. There were only about 10 wells equipped with motor-driven pumps. Of these, two were used to supply the city of Hagerman, and the other eight were used for irrigation.

The wells equipped with windmills are, of course, pumped at only a few gallons a minute, but the reported yield of the wells equipped with motor-driven pumps ranged from 150 to about 1,000 gallons a minute. Two wells east of Dayton were reported to have a combined yield of 1,900 gallons a minute. This great range in yield is due to variations in the number, thickness, and water-yielding capacity of the aquifers penetrated and in the construction and equipment of the wells. 


\section{FUTURE DEVELOPMENT}

The ground water in the valley fill is a valuable but relatively undeveloped resource which merits more serious consideration than it has thus far been accorded by the farmers in the Pecos Valley. The reason for this is quite understandable, for obviously it was far more desirable to have a flowing well than one which had to be pumped. It was, therefore, not until recent years, after the area of artesian flow had decreased greatly in size and pumps had to be installed over many wells which had formerly flowed, that serious efforts were made to develop the ground water in the valley fill.

In view of the urgent need of prohibiting any additional development of the artesian water, the possibility of developing the shallow ground water in the valley fill for irrigation should certainly not be overlooked. A large part of the ground water in the valley fill is derived directly and indirectly from artesian water, and a large proportion of it is escaping into the Pecos River. It therefore represents a great waste which could easily be reclaimed in many parts of the artesian area. It is not everywhere possible to obtain adequate supplies of ground water from the valley fill, and in many places the quality of the water is poor. Moreover, it is often difficult to cope with the aquifers consisting of fine loose sand. However, methods have been devised to develop successfully large quantities of water from aquifers consisting of loose sand, and the cost of drilling test holes 50 to 150 feet deep is not excessive. In the central part of the artesian area, where the depth to the better artesian aquifers is relatively great, the cost of developing adequate supplies of shallow ground water for irrigation would probably be much less than the cost of drilling and equipping an artesian well, especially toward the western part, where an artesian well would have to be pumped. Although the shallow ground water in many places is not suitable for domestic purposes most of it could probably be used for irrigation if the land is well drained and proper care is taken in using the water. There are many large tracts of land within the artesian area, especially in Chaves County, that could probably be irrigated profitably with shallow ground water. There are also many farms on which the flows of the artesian wells have diminished greatly or ceased entirely where attempts might be made to develop supplies of the shallow ground water for irrigation.

The thickness of the valley fill ranges, as a general rule, from 50 to 200 feet and in most places is less than 150 feet. Test holes or wells intended to develop the ground water in the valley fill should not be drilled below the base of these deposits, which is easily determined because of the distinct character of the red beds in the underlying Pecos formation. If suitable aquifers are not encountered above 
the red beds the drilling rig should be moved to a different site, not necessarily very far away, and another test hole drilled. It is practically impossible to predict without previous test drilling the yield of a well drilled into the valley fill, for the number, character, thickness, and water-yielding capacity of aquifers in the fill are too variable.

Although the possibility of overdeveloping the ground-water supply in the valley fill seems rather remote at present, it should not be entirely disregarded. The supply is certainly not inexhaustible. It is possible to withdraw by pumping more water than is being contributed to the zone of saturation in the valley fill and to lower the water table excessively. Therefore, if there is any considerable development of the shallow ground water in the valley fill, records should be kept of the depth to the water level in the wells, so that developments may not proceed to the point of exceeding the safe yield.

\section{WATER IN THE PECOS FORMATION}

IN THE OUTCROP AREAS

\section{GENERAL GROUND-WATER CONDITIONS}

The sand strata in the lower part of the Pecos formation, which lie below the water table, yield small or moderate amounts of water to wells. In the drainage basin of Cottonwood Creek, where only the lowest part of the formation is present, there are few if any beds of gypsum in the Pecos formation, and the water, although hard and appreciably mineralized, is used generally for domestic purposes, but in the outcrop area south of the alluvial basin the formation contains large amounts of gypsum, and the water is therefore generally too highly mineralized to be suitable for domestic purposes and in places even for stock.

No detailed study was made of the ground-water conditions east of the bluffs along the Pecos River, but the water table in that area probably slopes westward toward the river. What little information was obtained in regard to the wells in the outcrop area of the Pecos formation between the bluffs and the east edge of the area shown on Plate 3 indicates that the water table in that part of the area lies 100 to 300 feet below the surface and that water is obtained chiefly from beds of fine sand. In that area the Pecos formation contains many beds of gypsum, anhydrite, and salt. Consequently the water is as a rule too highly mineralized to be used for domestic purposes, but cattle drink it.

In a few places near the bluffs there are artesian aquifers of fine sand and cavernous limestone considerably below the level of the Pecos River and extending westward, but of course the land surface 
is too high for the water to flow. The eastern limit of the artesian aquifers in the Pecos formation is not definitely known.

WELLS

Information was obtained in regard to nine wells drawing from aquifers in the Pecos formation in the outcrop areas west of the Pecos River. The wells are 100 to 250 feet deep, and the water levels in them are 65 to 220 feet below the surface. All the wells are pumped by windmills except two or three near Cottonwood Creek from which the water is lifted by hand. The water from the wells near Cottonwood Creek is hard and appreciably mineralized but is used for domestic purposes and stock. The water from the wells near the Seven Rivers is very highly mineralized and is used only for stock.

There are nine or more wells in the outcrop area east of the Pecos River in R. 27 E., belonging to the Diamond A Cattle Co., which range in depth from 60 to 168 feet. No information was obtained as to the depth to water in the wells. The water is very highly mineralized and is used only for stock. The water from several of the wells was reported to be so salty that even stock would not drink it.

\section{UNDERLYING THE ALLUVIAL BASIN}

\section{GROUND-WATER CONDITIONS WEST OF THE ARTESIAN AREA}

The lower part of the Pecos formation lies beneath the valley fill in all but a few parts of the alluvial basin. In most of the central part of the alluvial basin the water table is above the base of the formation and below the base of the valley fill. The beds of sand and cavernous limestone within the zone of saturation yield small to moderate amounts of water to wells. Information was obtained in regard to about 25 wells drawing from the Pecos formation in the central part of the alluvial basin. The depth of the wells ranged from 100 to 400 feet and the water level in the wells was 80 to 325 feet below the surface. The water from the aquifers in the Pecos formation in this part of the area can generally be used for all ordinary purposes, although it is all noticeably mineralized. In some places, however, the water is of poor quality for domestic purposes and is used only for stock.

\section{ARTESIAN CONDITIONS}

Artesian aquifers and confining beds.-Part of the Pecos formation underlying the alluvial basin includes permeable beds, chiefly cavernous limestone and red sand or sandstone, which contain water under artesian pressure. Many of the beds of cavernous limestone are 10 to 50 feet thick, and some are more than 50 feet thick. They 
are very similar in appearance and in water-bearing properties to some of the cavernous beds in the Picacho limestone, but they are not continuous over large areas. They are variable in character and thickness, and both their vertical and lateral distribution are very erratic. Consequently, they are not everywhere encountered by the wells in the artesian area. The beds of sand and sandstone are comparatively uniform in character and extend over much larger areas, but they are also lenticular and variable in both vertical and lateral distribution; and being much less permeable than the lenses of cavernous limestone, they yield water less freely. Not all the beds of sand in the Pecos formation yield flows, and in many places none of them do. Flows are reported also from red clay or shale and gypsum in the Pecos formation. It is very unlikely that any of the beds of clay or shale yield artesian water. The flows reported to come from clay or shale are probably from beds of sand in the shale which were not noticed by the drillers. The water is confined in these aquifers by the overlying and underlying beds of relatively impermeable clay or shale, which are lenticular and doubtless merge laterally into sand in many places. Consequently, they do not form a continuous coyer, and some of the water in the aquifers probably escapes upward.

Head of the artesian water.-Definite information in regard to the difference in head between the artesian water in the Pecos formation and that in the Picacho limestone was obtained only at one place. Mr. Bruning, a well driller, stated that in a well drilled by him in the SW. 1/4 NW. 1/4 NW. 1/4 sec. 16, T. 17 S., R. 26 E. (see fig. 18), artesian water was encountered at a depth of 720 feet in a cavernous limestone about 40 feet thick in the lower part of the Pecos formation and that the water rose within 18 feet of the surface. This water was then effectively sealed off and the well was drilled into the Picacho limestone, the top of which was at a depth of 910 feet, where a strong flow of artesian water was obtained from a cavernous zone about 115 feet below the top of the limestone. At this place, therefore, the difference in head between the artesian water encountered in the Pecos formation and that in the Picacho limestone was at least 18 feet and was probably considerably more. The differences in head between the artesian water in the shallower aquifers in the Pecos formation and the deeper ones in the Picacho limestone are probably considerably greater. As a rule the water from the lower artesian aquifers in the Pecos formation has a higher head than that from the upper artesian aquifers. The lower head of the artesian water from the aquifers in the Pecos formation is probably due largely to losses in artesian pressure caused by the greater resistance offered to the movement of the water by the much 
lower permeability of the strata composing this formation. The head of the artesian water in the Pecos formation, especially that from the lower aquifers, is high enough to produce flows in much of the eastern part of the area of artesian flow.

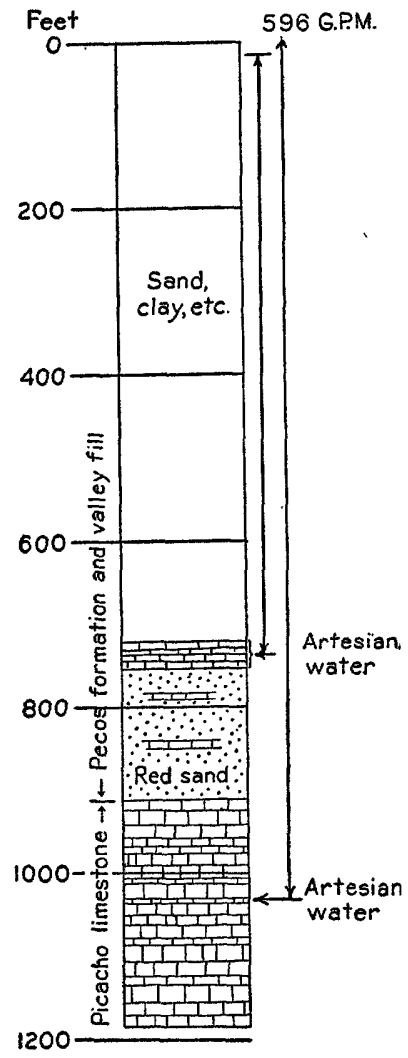

Figurn 18.-Driller's $\log$ of well in $\mathrm{SW} .1 / 4 \mathrm{NW} .1 / 4 \mathrm{NW}$. $1 / 4$ sec. 16, T. 17 S., R. 26 E. Water encountered in limestone in the Pecos formation rose within 18 feet of the surface. This aquifer was cased off, and the well was drilled into the Picacho limestone. Water encountered in the Picacho limestone was reported to have flowed at the rate of 596 gallons a minute

Movement and disposal of the artesian water.-The character of the Pecos formation and the general hydrologic conditions are such that there is very little likelihood of there being a general eastward movement of the artesian water in the Pecos formation beyond the limits of the Roswell artesian basin. In the first place, there are no outlets of any consequence for the artesian water in the Pecos formation east of the bluffs parallel to the Pecos River, except in western Texas (see p. 155). In the second place, the eastward movement of the artesian water beyond the artesian basin would be impeded greatly by the lensing out or the gradation of the artesian aquifers into relatively impermeable strata, and it is not likely that the artesian pressure is sufficient to overcome effectively this resistance. In the third place, some of the water would be consumed by entering into chemical combination with the anhydrite with which it came into contact, to form gypsum. ${ }^{28}$

As the tendency of water is to move along the paths of least resistance and toward the nearest outlets, the general movement of the artesian water is slowly eastward towa'd the Pecos River, and locally it moves more rapidly toward the wells drawing from aquifers in the Pecos formation. Some water leaks from lower to higher aquifers and finally through devious paths into the Pecos River. At the south end of the area of artesian flow some of the artesian water in the Pecos formation may be escaping southward through underground solution passages in gypsum and

28 The chemical composition of anhydrite is $\mathrm{CaSO}_{4}$; of gypsum, $\mathrm{CaSO}_{4} .2 \mathrm{H}_{2} \mathrm{O}$. A molecule of anhydrite is converted into a molecule of gypsum by the addition of 2 molecules of water. 
through other permeable strata in the valley of the Pecos River. There are no. apparent structural or stratigraphic conditions in the vicinity of the Seven Rivers to prevent the southward escape of artesian water from the Pecos formation.

Utilization of the artesian water.-There are a few artesian wells that are supplied with water entirely from the Pecos formation; but because of the lower head of the water and the lower yield of the aquifers in the Pecos formation, most of the artesian wells are drilled to the Picacho limestone, and the artesian water encountered in the Pecos formation is cased off. As a general rule the water from the Pecos formation is of poorer quality than that from the Picacho limestone, except in some parts of the artesian area where the water from the Picacho limestone is sulphurous or salty.

\section{SOURCE}

The possible sources of the water in the Pecos formation west of the Pecos River are local precipitation, seepage losses in the streams from floods originating chiefly in the mountains and in the limestone uplands, movement of the ground water near the water table from the Picacho limestone into permeable strata in the Pecos formation, and upward percolation of some of the artesian water in the Picacho limestone into permeable strata in the Pecos formation.

The only places where local rainfall could contribute appreciable quantities of water to the ground water in the Pecos formation are in the outcrop areas, which are relatively small, and in the western part of the alluvial basin, where the water table is beneath the base of the valley fill and the cover of valley fill is thin. In those areas some of the water from local precipitation doubtless reaches the zone of saturation in the Pecos formation, but the relative amount is probably small in the Pecos formation as in the valley fill.

Seepage losses in the streams from floods originating chiefly in the mountains and in the limestone uplands undoubtedly contribute considerable amounts of water to the permeable strata in the Pecos formation, especially in the outcrop areas in the drainage basins of Cottonwood Creek and the Seven Rivers, but the floods are very infrequent and the amount of ground water annually derived from this source is probably a minor proportion of the total annual recharge. Most of the seepage from flood waters probably enters the Picacho limestone or the valley fill.

The writer believes that most of the ground water in the Pecos formation is derived from ground water in the Picacho limestone which moves into permeable strata in the Pecos formation along the zone where the water table crosses the contact between the two formations and from artesian water in the Picacho limestone that 
escapes upward into the Pecos formation where its lowest strata are permeable. The lowest strata in the Pecos formation are variable in character-even the clay and shale are not absolutely impermeable-and there are doubtless many places where they are sufficiently permeable to receive some of the artesian water from the Picacho limestone, even though, being less permeable than the Picacho, they serve to confine most of the artesian water in it. In the northern part of the area, especially, the lowest strata in the Pecos formation consist of fine sand and are doubtless incapable of confining all of the artesian water in the Picacho limestone.

\section{WATER IN THE PICACHO IIMESTONE}

\section{OCCURRENCE}

The water in the Picacho limestone occurs chiefly in two distinct types of openings-those formed by mechanical processes and those formed by chemical processes. The first type includes joints, bedding planes, and irregular fractures. Limestone strata are generally broken up by two sets of joints, which are roughly at right angles to each other and also to the bedding planes. As a rule these joints are irregularly spaced and are not continuous from one bed to another, but there may be also numerous irregular fractures cutting across many beds in any direction.

Openings formed by chemical processes are the result of the solution and removal of limestone by percolating waters and are extremely irregular in character and distribution. They may be developed by the enlargement of joints, bedding planes, and irregular fractures or by solution within the individual beds of limestone. The first process results in fairly continuous and definite, although irregular solution channels; the second results in beds of honeycombed and spongelike limestone.

In most limestone regions the solution channels developed by the enlargement of openings along bedding planes and fractures of all kinds are much more common and contain more ground water than beds of honeycombed limestone. Solution channels of this type often result in huge caverns and large underground rivers, such as the Carlsbad Cavern, in southeastern New Mexico. In limestone regions where definite solution channels are the sole or prevailing type of solution openings there is a very large element of chance in prospecting for ground-water supplies, for although there may be an extensive network of connected solution channels containing water, they are erratically distributed. (See fig. 19.)

The water in the Picacho limestone occurs largely in solution openings. In the Roswell artesian basin the solution openings formed within individual beds of limestone are at least as common as the 
solution channels formed along joints, fractures, and bedding planes. Probably more so, for the reason that many of the beds in the Picacho limestone, especially in the central and lower parts, are not relatively homogeneous, dense, and impervious but are somewhat variable in texture and in composition. Many have an earthy texture, some are granular, oolitic, or crystalline, and some are sandy. Such beds contain pores which, although they are minute, allow the entrance of water. Where these beds have been subjected to the solvent action of percolating waters the minute pores in the limestone have been greatly enlarged, thus forming very porous and permeable beds. (See pls. 11-17). Some of the limestone appears to have contained crystals and nodules of anhydrite or gypsum which, being more soluble than the limestone matrix, have been dissolved out, giving the rock a wormeaten appearance. Solution openings originating within the individual limestone masses of course may merge with those originating along bedding planes and fractures and become indistinguishable from them. The Picacho limestone as a whole is very cavernous, and few if any

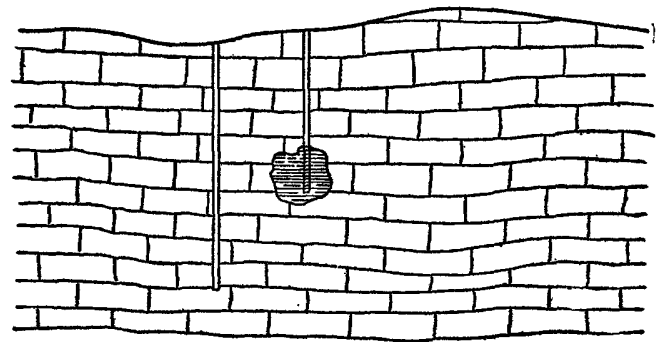

Fig URD 19.-Difference in conditions in wells in limestone not far apart. After Matson, G. C., Water resources of the Blue Grass region, Ky.: U. S. Geol. Survey Water-Supply Paper 233, p. 47, 1909

wells drilled below the main water table, where it is appreciably above the base of the formation, have failed to encounter adequate supplies of water in the limestone.

The cavernous condition of the limestone is also exemplified by the many wells in and near the limestone uplands that blow or suck air. At times the blowing or suction at the mouths of these wells is very strong and can be heard several hundred yards away from them. Phenomena of this sort are not uncommon in limestone regions and are probably due to changes in atmospheric pressure. Many of the inhabitants have believed that the air rushing out of the wells was gas escaping from the rock formations penetrated by the wells, but all attempts to ignite the blast from the wells failed. Oil and gas are encountered in parts of this region, but they have not been found in the limestone uplands, although some of the limestone beds in the lower part of the Picacho limestone are petroliferous. It is very improbable that any of the blowing water wells in the limestone region yield gas. Additional evidence is afforded by the fact that, so far as known, all the wells which blow at times suck air at other times. 
Water occurs also in beds of sand and gypsum in the Picacho limestone. There are a number of thin beds of sandstone in different parts of the Picacho limestone, and in the northern part of the artesian basin there are one or two thick beds of sandstone near the base of the Picacho (called Glorieta sandstone by local geologists). The wells that have been drilled to the sandstones near the base of the Picacho near or east of the eastern edge of the outcrop area encountered salt or highly mineralized water. It is possible that farther west these sandstones may yield better water. The Farnsworth well, in SE. $1 / 4$ SE. $1 / 4$ sec. 7, T. 21 S., R. 21 E., is reported to draw from a sandstone at a depth of 1,100 or 1,200 feet below the surface. The sandstone is probably in the Picacho limestone, but this can not be stated definitely. The water from this well has no noticeable taste and is softer than the water from many of the wells drawing from limestone. Northwest of Roswell and possibly southwest of Lakewood near the eastern edge of the outcrop area of the Picacho limestone, where gypsum is interbedded with the limestone, some of the wells encountered highly mineralized water in gypsum. West of the artesian area, however, most of the wells drawing from the Picacho limestone are supplied with water from cavernous zones in the limestone. In many wells the cavernous zones are encountered considerably below the water table, but in such wells the water rises approximately to the level of the water table.

\section{WEST OF THE ARTESIAN AREA}

MAIN WATER TABLE

The main water table in the Picacho limestone slopes eastward, but the eastward gradient of the land surface is greater. Consequently the depth to the main water table increases westward from about 75 feet near Roswell to more than 1,000 feet in the limestone uplands. The regional eastward dip of the Picacho limestone is also much greater than the eastward gradient of the main water table, and therefore the main water table passes into the underlying Nogal formation in the central part of the limestone uplands. The main water table in the Picacho limestone is so far beneath the surface that its configuration bears little if any relation to the topography, and probably it is comparatively smooth. Its eastward gradient is between 10 and 15 feet to the mile. The relation of the main water table to the land surface and to the dip of the strata is shown in the sections on Plate 2.

Throughout most of the outcrop area of the Picacho limestone shown on the geologic map (pl. 3) the main water table is more than 300 feet below the surface. Along the eastern edge of the outcrop area the main water table is shallowest west and northwest of 
Roswell, where it is 75 or 100 feet to about 350 feet below the surface, and deepest at the south end, south of Hope, where it is 500 to 800 feet or more below the bottoms of the valleys.

West of the artesian area there were very few wells as compared with the number in the artesian area, and the depth to the water level in many of these wells was not known by the owners and could not be measured without removing the pumping equipment. Few of the wells in the limestone uplands (see pl. 3) are drilled more than 50 to 80 feet below the water table. Consequently, where only the depth of the well is given the depth to the water table can be estimated roughly. However, many of the wells in the limestone uplands, especially in the western part, are supplied with water from perched bodies of ground water (see below), and therefore the depth to the water level in those wells does not represent the depth to the main water table. It should also be noted that most of the wells in the limestone uplands are in canyons or valleys and that the depth to the main water table is several hundred feet greater in the intercanyon areas than on the bottoms of the canyons and is, of course, greater on the bottoms of the shallow canyons than on those of the deep canyons and valleys.

\section{PERCHED GROUND WATER}

There are numerous bodies of ground water in the Picacho limestone perched high above the main water table of the limestone uplands. These perched bodies are probably held above the main water table by impervious beds of shale, shaly limestone, or perhaps even dense dolomite, dolomitic limestone, or limestone whose fractures have been firmly cemented by calcium carbonate. The water that sinks into the ground in the limestone uplands moves downward as a general rule until it reaches the main water table. In places, however, its downward progress is hindered or stopped by an impervious bed, and it forms a perched body of ground water. The perched water moves in a general easterly direction along the impervious bed until that bed ends or is interrupted in one way or another. If the interruption is beneath the surface the water sinks underground until it reaches another impervious bed or the main water table. The downward progress of the water may be hindered several times by impervious beds, forming in succession several bodies of perched water, but its ultimate goal is the main water table. If the impervious bed is interrupted by the land surface the perched water may appear as a spring and may never reach the main water table, although in the limestone uplands, where the main water table is far below the surface, at least a part of the spring water sinks into the ground again and ultimately joins the main body of ground 
water. A small spring emerging from the south wall of the canyon of the Rio Hondo above the Diamond A headquarters ranch, in $\mathrm{T}$. $11 \mathrm{~S}$., R. $20 \mathrm{E}$., is an example of perched water appearing at the surface. The spring emerges from limestone in a small cave nearly 200 feet above the channel of the Rio Hondo. (See fig. 20.) The perched water is probably held up by impervious beds of shale or shaly limestone. The spring is reported to have a fairly constant yield of about 1 barrel in 24 hours, even during droughts. Apparently there is a rather large underground reservoir with a small outlet that controls the flow of the spring.

The character and distribution of the perched bodies of ground water in the Picacho limestone are very erratic, and it is therefore ordinarily impossible to predict the location, extent, depth, and number of such bodies or the amount of perched water, except where the water discharges at the surface in the form of springs. Even

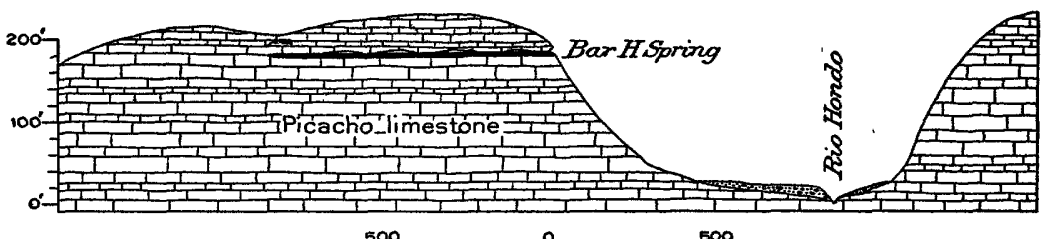

500

500

Figorn 20.-Diagrammatic section of valley of Rio Hondo between Diamond A headquarters ranch and Border ranch, in eastern part of T. 11 S., R. 20 E., showing position of spring fed by a perched body of ground water. The main water table is probably at least 500 feet below the channel of the Rio Hondo, which flows at this place and is also perched

there it is rarely possible to predict the amount of perched water available to wells. Hence, anyone seeking an adequate supply of water in the limestone uplands must be prepared to drill to the main water table. Because a plentiful supply of water has been obtained from one well at a depth of only 200 or 300 feet it does not follow that another well near by will encounter the same body of ground water. The main water table may be 1,000 feet or more below the surface.

\section{WELLS}

Information was obtained in regard to 85 wells drawing from the Picacho limestone west of the artesian area. The location of the wells, their depth, and the depth to water level in them are shown on Plate 3. The descriptions of the wells are given in the table on pages $354-367$. Of the 85 wells 50 are in the limestone uplands, and only about 15 are in Eddy County. There are very few wells in the vicinity of Hope. It was reported that many attempts to obtain adequate supplies of ground water near Hope failed, implying that 
the limestone is not so cavernous in this part of the area as in the other parts. However, no definite records were obtained of wells drilled appreciably below the water table that failed to encounter adequate supplies of water in the Picacho limestone. There is no apparent reason why the limestone should not be cavernous in the vicinity of Hope. There are probably few if any places in that vicinity where a well will fail to encounter water in the Picacho limestone if it is drilled deep enough, although the limestone may not be cavernous at or near the water table. The people in Hope obtain water for domestic purposes from cisterns and from the Hope Community irrigation ditch, which diverts the water from the Rio Penasco at the Hope diversion dam, in the SE. $1 / 4$ sec. 14, T. $17 \mathrm{~S}$., R. $20 \mathrm{E}$.

The wells drawing from the Picacho limestone in regard to which information was obtained range in depth from 100 to 1,200 feet, and the water level in them is from 75 to about 1,100 feet below the surface. Most of the wells are between 300 and 600 feet deep. The depth of the wells in Tps. 13 and 14 S., R. 20 E., is from 180 to 430 feet. These wells are undoubtedly drawing from perched bodies of ground water, for the main water table in those townships is at least 500 feet, and probably more than 600 feet, below the surface.

Very few of the wells in the limestone uplands have more than one joint of casing in them. The wells drawing from the Picacho limestone in the western part of the alluvial basin and in the outcrop areas of the Pecos formation are cased only to the top of the limestone.

Practically all the wells are equipped with windmills except the deepest ones, which are pumped by gasoline engines. The wells equipped with windmills yield between 3 and 10 gallons a minute; those pumped by gasoline engines are reported to yield 15 to 20 gallons a minute. Many of the wells would doubtless yield more if they were equipped with larger pumps. The variations in yield are due to variations in the diameter and equipment of the wells and to variations in the water-yielding capacity of the aquifers supplying them. In many of the wells the water level is only 5 to 10 feet above the bottom, and in such wells the yield is limited by moderate drawdown. The yield of a well drawing from the Picacho limestone can rarely be predicted, but the limestone is generally so cavernous that few wells fail to obtain sufficient water for domestic purposes and stock.

The water from at least half of the wells visited is used solely for stock, although few of the wells yielded water unsuitable for domestic purposes. 


\section{IN THE ARTESIAN AREA}

\section{GENERAL ARTESIAN CONDITIONS}

The general factors that have produced the artesian conditions in this area are discussed on pages 118-120. It is intended here to point out the specific factors to which the presence of artesian water in the Picacho limestone is due.

The Picacho limestone forms the eastern slope of the Sacramento Mountains and the Sierra Blanca, dips beneath the surface along the western edge of the alluvial basin and the Pecos formation west of the Pecos River, and underlies the entire artesian area. The upper part of this thick limestone series is very cavernous beneath practically all of the alluvial basin and is saturated with water. Most of the water in the upper part of the limestone is confined in it by the overlying less pervious Pecos formation and valley fill and by the underlying less pervious beds of limestone in the Picacho, which apparently are not cavernous or only slightly so beneath the alluvial basin, and by the relatively impervious Nogal formation underlying the Picacho limestone. Being under artesian pressure, the water has a tendency to rise approximately to the level at which it is first confined by the overlying beds, but it will not rise exactly to that level, because as it moves toward a well or other opening it loses head through friction. As the altitude at which the impervious beds in the Pecos formation and valley fill confine the water in the Picacho limestone is higher than that of the land surface in the eastern part of the alluvial basin, the water rises above the surface in tightly cased wells.

The Picacho limestone is at the surface over a vast area west of the alluvial basin and receives a very large share of the drainage from the Sacramento Mountains and the Sierra Blanca. The low angle of dip of the Picacho limestone and its tremendous outcrop area on a comparatively gentle slope are also very favorable to its gathering in a large amount of water from rainfall. The intake area of the Picacho limestone and the annual recharge of the artesian water in it are discussed more fully on pages 148-152.

The artesian aquifers in the Picacho limestone do not appear at the surface east of the artesian basin, and there is probably little leakage of the artesian water in that direction. (See p. 155.) There may be some leakage at the southeast corner of the artesian basin, but the quantity is probably small. The possibility of the artesian water escaping north of the artesian basin is slight because of the structure of the Permian strata and the general hydrologic conditions in that area. Consequently, as the water can not escape readily at horizons lower than those of the artesian aquifers beneath the alluvial basin, 
it is practically, though not absolutely, confined in the Picacho limestone within the limits of the artesian basin, which forms an underground reservoir containing water under artesian pressure.

\section{ARTESIAN AQUTFERS}

The artesian aquifers in the Picacho limestone are not definite beds continuous over large areas, as many suppose, but are highly erratic and irregular cavernous zones in the limestone, comprising definite and continuous solution channels and beds of honeycombed, spongelike, and "worm-eaten" limestone. The latter are locally called "water rock" and, according to the well logs, are more frequently encountered by wells than the open channels. However, the open solution channels are not uncommon, for many drillers reported "caves" through which the drill dropped several feet or more and the drill cuttings were washed away. The "water rocks" are extremely variable; some are mere skeletons of limestone and are very highly porous and permeable; others contain smaller and fewer solution openings. Because of the extreme variability in the character of the rocks and the impossibility of obtaining large enough specimens, it is very difficult to determine the porosity or to assign any definite limits to the porosity of any given zone or even of the upper cavernous portion of the Picacho limestone as a whole. In some parts of the area the upper part of the Picacho limestone is very cavernous and therefore very porous and permeable. In other parts of the area it is locally said to be "tight"that is, the limestone is less cavernous and does not yield the artesian water as readily or as generously as it does elsewhere. Considered as a whole, however, the upper part of the Picacho limestone beneath the artesian area is remarkably cavernous throughout the area; few if any wells have failed to encounter water in it. The Picacho limestone in the Roswell artesian basin, therefore, is a very trustworthy source of water supply. It is interesting to note that some wells are locally said to be "dry" if they are supposed to be within the area of artesian flow and do not flow, although they may be filled with water to a level within a few feet of the surface. It is also interesting to note that in the Roswell area of artesian flow, where flowing wells of very large yield are the rule, a well flowing only 200 or 300 gallons a minute is considered disappointing, whereas in many other regions a well yielding that amount of water is exceptional and is bragged about for miles around.

The depth, number, and thickness of the cavernous zones below the top of the Picacho limestone are not constant, but vary greatly from place to place. Likewise, the individual cavernous zones are not extensive beneath the entire artesian area, nor even beneath 
large parts of it. The "water rocks," therefore, can not be used as stratigraphic horizon markers. Some wells encountered a cavernous zone near the top of the limestone, and many did not encounter a cavernous zone until they had penetrated 100 to 200 feet or more of the limestone. Most of the wells encountered three "water rocks" or cavernous zones, and consequently the terms "first flow," "second flow," and "third flow" are commonly used by the inhabitants of the artesian area. These terms are misleading, for the number and depth of the "water rocks" beneath the top of the Picacho limestone and the intervals between them are variable, and three "water rocks" are not everywhere encountered; many wells encountered five or six "flows," and some only one, although they penetrated several hun. dred feet of the limestone.

A large number of wells in many parts of the artesian area encountered cavernous zones, and therefore artesian water, as much as 400 to 500 feet below the top of the Picacho limestone. According to the writer's interpretation of the logs, one well encountered an artesian aquifer 636 feet below the top of the Picacho, and another well encountered an aquifer 740 feet below the top. Although several deep wells have been drilled within the artesian area, so far as the writer knows none were reported to encounter artesian water at a depth greater than 750 feet below the top of the Picacho limestone, and all but three or four wells encountered artesian aquifers only in the upper 500 feet of the limestone. Consequently, within the artesian area the cavernous condition of the Picacho limestone does not generally extend more than 500 feet below the top of the limestone. There is no way of definitely forecasting the number, depth, character, and water-yielding capacity of the artesian aquifers that will be encountered in the Picacho limestone at any one place. In some places there may be only one artesian aquifer in the upper 500 feet of the limestone, and in others there may be as many as seven or eight. However, if most of the wells in a locality have encountered three artesian aquifers within a given depth, the chances are that a new well will encounter the same number. It is fairly safe to say that at least one artesian aquifer will be encountered within the upper 500 feet of the Picacho limestone. As a general rule, most of the artesian aquifers are within the upper 200 or 300 feet of the Picacho limestone, but the possibility of encountering additional artesian aquifers between depths of 300 and 500 feet below the top of the limestone should not be overlooked.

Beneath the northern part of the artesian area there is near the base of the Picacho limestone a thick bed of sandstone (called "Glorieta sandstone" by local geologists), which contains water under artesian pressure. The water from this sandstone, however, 
was found to be "salty" or very highly mineralized in all the deep wells that penetrated it in and east of the artesian area, although the well drilled for oil on Sixmile Hill, in the NE. $1 / 4$ sec. 8, T. 11 S., R. $23 \mathrm{E}$., was reported to have encountered fresh water in this sandstone. This sandstone is absent beneath the southern part of the artesian area. For most purposes, therefore, this sandstone may be disregarded as a source of artesian water.

\section{CONFINING BEDS}

Upper confining beds. - The upper confining beds constitute one of the chief factors governing the presence of the artesian water and are much more important in this area than the lower confining beds, because the water in the artesian aquifers, being under pressure, tends to rise through the overlying beds. If the overlying beds were more permeable than they are, the pressure of the artesian water might be less and might not be sufficient to produce flowing wells. ${ }^{29}$

The upper confining beds of the artesian aquifers in the Picacho limestone are the lower strata of the Pecos formation, which underlie the eastern part of the artesian basin, and the valley fill. Neither the Pecos formation nor the valley fill is absolutely impermeable under the existing artesian pressures, for both contain permeable materials that yield water readily to wells. Both the Pecos formation and the valley fill are dominantly composed of impermeable materials, but the impermeable materials are not continuous over the entire artesian area. The impermeable materials, however, are interspersed with permeable materials. The permeable materials in the Pecos formation and in places those in the valley fill are artesian aquifers, but although they allow the escape of some artesian water from the Picacho limestone, they are very much less permeable than the upper cavernous part of the Picacho, as is indicated by the strong pressure of the artesian water in it.

The most effective confining beds in the Pecos formation and the valley fill are the clays and shales. Soft clays are considered the best confining beds because they are both impervious and as a rule free from joints, fractures, or other large openings. Shales are considered second best. There are many beds of soft clay and shale in both the Pecos formation and the valley fill.

The clays and shales in the Pecos formation in many places grade laterally into beds of argillaceous fine sand and beds of fine sand which, though somewhat permeable and therefore less effective than the clays and shales, also serve as confining beds, partly because they

${ }^{29}$ See Chamberlin, T. C., The requisite and qualifying conditions of artesian wells: U. S. Geol. Survey Fifth Ann. Rept., p. 138, 1885. 
are much less permeable than the artesian aquifers and partly because they are stratified and offer more resistance to the passage of water across them than along the planes of stratification..$^{30}$

Beds of limestone and dolomite in the Pecos formation and caliche and firmly cemented gravel in the valley fill may also help to retard the upward passage of the artesian water, but they are not as effective confining agents as the clay and shale.

Lower confining beds.-Beneath the artesian area the lower few hundred feet of the Picacho limestone does not appear to be cavernous, at least not to an appreciable extent, but consists of massive beds of limestone and dolomite. Beneath the northern part of the artesian area the Picacho limestone is underlain by the Nogal formation, but beneath the southern part of the artesian area the Nogal gives place to a thick series of limestones. All the strata underlying the cavernous upper part of the Picacho limestone are very much less porous and permeable and constitute the lower confining beds. The massive limestone strata underlying the cavernous portion of the Picacho limestone may be broken up by joints and fractures of various kinds; but as the rocks are deeply buried in all but the north end of the artesian area, most of these openings are probably very small, and many of them may be cemented by calcium carbonate. The Nogal formation is composed, at least in its upper part, largely of shale, and although it may contain permeable strata it is as a whole relatively impervious.

Even if the strata underlying the artesian aquifers are somewhat permeable, they have doubtless become saturated with water that is probably under greater head than the water in the artesian aquifers, for there is apparently no means of escape other than upward. The tendency then would be for the water in the underlying confining beds to escape upward into the artesian aquifers in the Picacho limestone rather than for the artesian water in the Picacho to escape downward.

West of the artesian area the Picacho limestone is nearly everywhere underlain by the Nogal formation and there are cavernous zones in all parts of the limestone except perhaps near the artesian area, where the lowest limestone strata may not have been extensively subjected to the solvent action of percolating water. The Nogal formation is certainly very much less permeable than the cavernous Picacho limestone, and in many places its upper part is relatively impervious. Where the water table is above or only slightly below the base of the Picacho limestone, the permeable strata in the Nogal formation are therefore saturated with water and serve effectively

${ }^{30}$ See Fuller, M. L., Summary of the controlling factors of artesian fiows: U. S. Geol. Survey Bull. 319, p. 22, 1908. 
as lower confining beds. In the western part of the limestone uplands and in the mountains the water table is far below the base of the Picacho limestone; and as the shale beds in the upper part of the Nogal formation are somewhat lenticular and do not everywhere underlie the Picacho limestone, they do not prevent the downward percolation of water from the Picacho, though they retard it.

\section{DIFFERENCES IN THE HEAD OF THE ARTESIAN WATER}

As a general rule the head of the artesian water increases in successively lower artesian aquifers in both the Picacho limestone and the Pecos formation. The lower head of the artesian water in the Pecos formation is probably due largely to the lower permeability of the artesian aquifers in this formation and to losses in head incurred through friction as the artesian water moves from lower to higher aquifers. The increase in the artesian head of the water in successively lower aquifers in the Picacho limestone, however, is not so easy to explain. No specific data were obtained in regard to the exact differences in head between the water in lower and higher artesian aquifers in the Picacho limestone, but the differences do not appear to be great. (See also pp. 206-207.) Such differences in head are probably due to differences in the permeability of the artesian aquifers in the Picacho limestone; this hypothesis is supported by the general experience that the lower aquifers yield larger flows. On the other hand, it might be maintained that the larger flows are the result solely of the greater head of the artesian water in the lower artesian aquifers, that the cavernous zones in the Picacho limestone are not connected with one another, and that the artesian water in the lower aquifers enters at higher levels than the water in the higher aquifers. However, as the artesian aquifers are cavernous zones in the limestone and not continuous permeable beds, it is inconceivable that they are not connected with one another in many places. The cavernous zones in the limestone were formed by active circulation of subsurface water, and it is obvious that water could not circulate in the lower beds without passing through the upper ones.

\section{AREAS OF LARGE AND SMALL YIELD}

There are four irregular segments in the artesian area in which most of the wells have a low yield as compared with the yield of most of the wells in the other parts of the artesian area. The location and boundaries of these segments, which were determined by Mr. Fiedler, are shown in Plate 41. There is no evidence to support a hypothesis that these segments are separated from the adjoining ones, in which the average yields of the artesian wells are much greater, by faults, dikes, or in other ways. All the evidence indicates that these rela- 
tively poor segments are the result simply of variations in the porosity and permeability of the artesian aquifers in the Picacho lime-

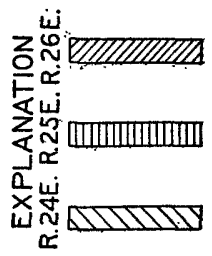
stone. The probable causes of these variations are discussed on pages 183-185.

\section{WELLS}

The artesian wells of which logs were obtained and which are known to be drawing from the Picacho limestone range in depth from 156 to
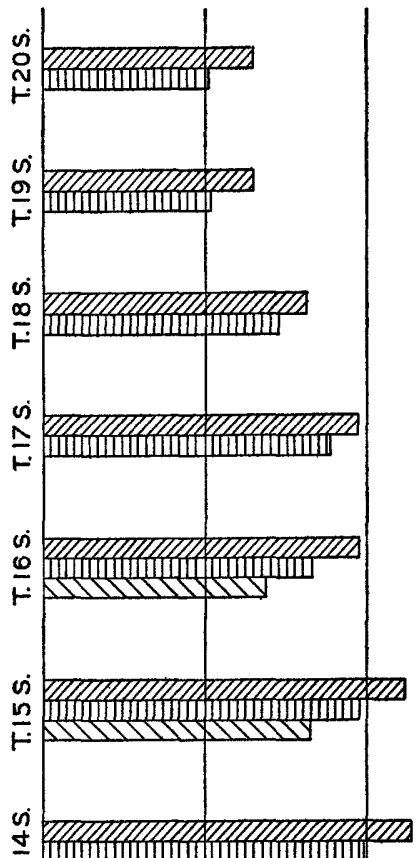
1,563 feet. This statement does not apply to the many deep wells drilled primarily for oil and later converted into artesian wells for irrigation and other purposes but applies only to wells drilled primarily for artesian water in the Picacho limestone. Most of these wells are between 200 and 1,200 feet deep; very few are less than 200 feet or more than 1,400 feet. The

wells are shallowest in the vicinity of Roswell, and as a rule they are deepest in the central part of the artesian area. The average depth of the wells in each tier of townships increases from west to east, for the eastward dip of the Picacho limestone is greater than that of the land surface. In each range the average depth of the wells increases southward from the townships north of Roswell, where they are shallowest, to the central part of the artesian area and thence decreases southward to the south end of the artesian area, where they are almost as shallow as in the vicinity of Roswell. These conditions are clearly shown in the table given below and in Figure 21. In interpreting the table it should be clearly borne in mind that many of the wells were drilled only to the first artesian aquifer encountered in the Picacho limestone, which in many places was very near 
the top of the limestone, and others were drilled 600 to 700 feet or more below the top of the Picacho limestone and 100 to 200 feet or more below the lowest artesian aquifer encountered in the limestone. It should also be noted that in each township the depth of most of the wells is less than the average depth in the western and northern parts of the township and greater in the eastern and southern parts of the township.

Depth of artesion wells known to be drawing from the Picacho limestone in successive rows of townships

\begin{tabular}{|c|c|c|c|c|c|c|c|c|c|c|c|}
\hline \multirow{3}{*}{$\begin{array}{l}\text { Town } \\
\text { ship }\end{array}$} & \multicolumn{3}{|c|}{ R. $24 \mathrm{E}$. } & \multicolumn{3}{|c|}{ R. $25 \mathrm{E}$. } & \multicolumn{3}{|c|}{ R. $26 \mathrm{E}$. } & \multicolumn{2}{|c|}{$\begin{array}{l}\text { Total in tier } \\
\text { of townships }\end{array}$} \\
\hline & \multirow{2}{*}{$\begin{array}{l}\text { Num- } \\
\text { ber of } \\
\text { wells } \\
\text { aver- } \\
\text { aged }\end{array}$} & \multicolumn{2}{|c|}{$\begin{array}{c}\text { Depth of wells } \\
\text { (feet) }\end{array}$} & \multirow{2}{*}{$\begin{array}{l}\text { Num- } \\
\text { ber of } \\
\text { wells } \\
\text { aver- } \\
\text { aged }\end{array}$} & \multicolumn{2}{|c|}{$\begin{array}{c}\text { Depth of wells } \\
\text { (feet) }\end{array}$} & \multirow{2}{*}{$\begin{array}{l}\text { Num- } \\
\text { ber of } \\
\text { wells } \\
\text { aver- } \\
\text { aged }\end{array}$} & \multicolumn{2}{|c|}{$\begin{array}{c}\text { Depth of wells } \\
\text { (feet) }\end{array}$} & \multirow{2}{*}{$\begin{array}{l}\text { Total } \\
\text { num- } \\
\text { ber of } \\
\text { wells } \\
\text { aver- } \\
\text { aged }\end{array}$} & \multirow{2}{*}{$\begin{array}{l}\text { A ver- } \\
\text { age } \\
\text { depth } \\
\text { of all } \\
\text { wells } \\
\text { (feet) }\end{array}$} \\
\hline & & Range & $\begin{array}{c}\text { Aver- } \\
\text { age }\end{array}$ & & Range & $\begin{array}{l}\text { Aver- } \\
\text { age }\end{array}$ & & Range & $\begin{array}{l}\text { Aver- } \\
\text { age }\end{array}$ & & \\
\hline & 176 & $175-635$ & $\begin{array}{l}326 \\
409\end{array}$ & \multirow{8}{*}{$\begin{array}{r}11 \\
67 \\
19 \\
37 \\
5 \\
43 \\
48 \\
4 \\
3 \\
7 \\
5\end{array}$} & $\begin{array}{l}418-558 \\
374-960\end{array}$ & $\begin{array}{l}485 \\
6653\end{array}$ & \multirow{8}{*}{$\begin{array}{r}9 \\
42 \\
5 \\
18 \\
46 \\
81 \\
56 \\
16 \\
9\end{array}$} & & & \multirow{8}{*}{$\begin{array}{r}176 \\
178 \\
28 \\
79 \\
10 \\
68 \\
114 \\
89 \\
59 \\
23 \\
14\end{array}$} & \multirow{8}{*}{$\begin{array}{r}405 \\
530 \\
968 \\
1,004 \\
1,062 \\
954 \\
828 \\
950 \\
770 \\
681 \\
600\end{array}$} \\
\hline & & & & & $727-1,330$ & 914 & & $970-1,057$ & 1,023 & & \\
\hline & & & & & & 963 & & $944-1,302$ & & & \\
\hline & 7 & $701=$ & & & $972-1,015$ & $\begin{array}{l}989 \\
916\end{array}$ & & $1,065-1,225$ & 1,135 & & \\
\hline & 20 & $350-850$ & 60 & & $566-1,000$ & 828 & & $687-1,350$ & 964 & & \\
\hline & & & & & $\begin{array}{l}825-953 \\
688-800\end{array}$ & $\begin{array}{l}888 \\
730\end{array}$ & & $\begin{array}{l}756-1,563 \\
551-1,450\end{array}$ & 971 & & \\
\hline & & & & & & 513 & & $666-1,140$ & 849 & & \\
\hline & & & ..... & & $330-617$ & 510 & & $561-900$ & 650 & & \\
\hline
\end{tabular}

Most of the wells penetrate two or three artesian aquifers in the Picacho limestone and are drilled less than 250 feet below the top of the limestone. A few penetrate only one aquifer, but many penetrate four or more. A few deep wells encountered as many as seven or eight artesian aquifers in the Picacho limestone.

Nearly all the artesian wells are cased only to the top of the Picacho limestone, which in some parts of the artesian area is locally referred to as the "cap rock," the artesian aquifers encountered in the Pecos formation being generally cased off. In most of the wells the casing is set only a few feet below the top of the Picacho, and from there down the hole in the limestone is left open.

\section{LOCAL ARTESTAN CONDITIONS}

The many good artesian wells drilled to the Picacho limestone indicate that the artesian reservoir in this limestone is continuous throughout the artesian area; but the number, depth, and yield of the aquifers and the head, the amount of decline in head, and the local source and direction of movement of the artesian water vary considerably in different parts of the artesian area, owing to local structural features and to differences in the relative permeability of the limestone beneath different parts of the artesian area. 
The artesian area may be divided into five segments in which the artesian water is most extensively developed. (See pls. 39 and 45.) They correspond in a general way to the five areas shown in Plate 41 in which the yield of most of the wells is relatively large. These five good segments of the artesian area will hereafter be referred to as the Roswell, Dexter, Cottonwood, Artesia, and Seven Rivers segments. The Roswell segment includes all of Tps. 10 and $11 \mathrm{~S}$. The Dexter segment comprises T. 13 S. The Cottonwood segment is rather indefinite but includes most of the south half of T. $15 \mathrm{~S}$. and the northern part of T. $16 \mathrm{~S}$., an irregular area adjoining Cottonwood Creek and Lake Arthur. The Artesia segment is the area between Artesia and Dayton, which includes most of T. $17 \mathrm{~S}$. and the north half of T. $18 \mathrm{~S}$. The Seven Rivers segment comprises the south half of T. $19 \mathrm{~S}$. and the north half of T. $20 \mathrm{~S}$. There is no conclusive evidence to support a common belief that these seg: ments are definitely separated from one another by "dikes" or in any other way. In fact, the evidence strongly indicates that the five good segments are all integral parts of one artesian basin and that they are merely parts in which the artesian conditions are more favorable than elsewhere.

In all five segments most of the artesian water is obtained from aquifers in the Picacho limestone, which underlies the entire artesian area. The variations in the artesian conditions from one end of the artesian area to the other are gradational, but as the five good segments are separated by large areas beneath which the limestone is less permeable and in which there are but few developments of the artesian water, there is a marked difference between the detailed artesian conditions in one segment and those in another.

\section{SOURCE AND QUANTITY OF THE WATER}

The water in the Picacho limestone is derived from the rain and snow that fall upon its outcrop area in the drainage basins of the streams tributary to the Pecos River within the alluvial basin, and possibly also from the precipitation on a narrow strip adjoining the east edge of the outcrop area of the Picacho limestone. The artesian water is derived from the main body of ground water in the Picacho limestone.

The chief streams tributary to the Pecos River within the artesian basin are the Rio Hondo, the Rio Felix, the Rio Penasco, and the Seven Rivers. In the upland region the Rio Hondo and Rio Penasco are perennial streams fed by springs, which in turn are fed by perched ground water derived from precipitation on the slopes of the mountains. Ordinarily most of the water in these streams 
either is diverted for irrigation in the upland region or sinks into the ground before it reaches the alluvial basin. The Rio Felix and the Seven Rivers are ephemeral streams in the upland region and flow only after heavy rains; usually most of their water sinks into the ground before it reaches the Pecos River. It is only at times of exceptional floods that the surface drainage received by the tributary streams reaches the Pecos River; consequently a large proportion of the surface run-off from the mountains and the limestone uplands sinks into the ground and joins the main body of ground water in the Nogal formation, the Picacho limestone, and the valley fill.

The rain and snow disposed of by evaporation and by the transpiration of plants represent a total loss so far as the recharge of the ground water is concerned. The evaporation is least in the mountains, where the average annual temperature is lowest and the rainfall is greatest, and greatest in the Pecos Valley, where the average annual temperature is highest and the rainfall is least. The amount of precipitation utilized by plants, however, is large in the mountains, which are heavily timbered, but relatively small in the catchment area east of the mountains, where the vegetation is scanty. In the aggregate the amount of precipitation disposed of by evaporation and transpiration is probably large.

A large part of the water that sinks into the ground in the mountains and in the limestone uplands ultimately reaches the main body of the ground water in that region, but not all of it is contributed to the ground water in the Picacho limestone. In the mountains and in the western part of the limestone uplands the base of the Picacho is relatively near the bottoms of the deeper canyons, in many places only 100 to 200 feet below the deepest canyons. Near the town of Picacho, in the valley of the Rio Hondo; near Lincoln, in the valley of the Rio Bonito; and southwest and west of Mayhill, in the valley of the Rio Penasco, the base of the Picacho limestone is above the bottoms of the valleys and the upper strata of the underlying Nogal formation are at the surface. Furthermore, the water table is a considerable distance below the upper surface of the Nogal formation, for several wells drilled to depths of 600 to 700 feet below the surface and 400 to 500 feet below the base of the Picacho limestone in and near the Mescalero Apache Indian Reservation failed to encounter any water. All the successful wells in or near the Indian reservation draw from perched water in the Nogal formation.

The slope of the main water table in the Nogal formation is doubtless considerably steeper than it is in the Picacho limestone, and its eastward slope is certainly much less than that of the surface and hence less than that of the upper surface of the Nogal formation. 
As indicated by the numerous springs in the mountains and as brought out by Renick, ${ }^{31}$ shallow ground water perched high above the main water table is found in the Nogal formation and in the Picacho limestone for a certain distance east of the summits of the Sacramento Mountains and the Sierra Blanca. The perched water in the mountains either discharges at the surface through springs or sinks underground to the main water table. East of this shallowwater area in the mountains there is a broad belt, the western part of the limestone uplands, in which the main water table is hundreds of feet below the surface and in which there are comparatively few wells. Most of the wells in this belt draw from perched water in the Nogal formation, the Picacho limestone, or the alluvial sand and gravel in the larger canyons. The main water table in the western part of the limestone uplands is in the Nogal formation and is 800 to 1,000 feet or more below the deepest valleys. Consequently most of the water received by the Picacho limestone, both directly and indirectly, in the western part of the limestone uplands and in the mountains, probably sinks to the main water table in the Nogal formation east of the shallow-water area in the mountains. The main water table crosses the contact between the Picacho limestone and the Nogal formation and passes into the Nogal in the central part of the limestone uplands.

The lower part of the Picacho limestone in the mountains is probably as cavernous as the upper part is beneath the alluvial basin, and as the top of the Nogal formation consists of shale in many places, some of the water received by the Picacho limestone may be held in the limestone by the shale and form a perched water body. This condition undoubtedly exists in many places.

Some of the ground water in the Nogal formation may percolate across the strata into the Picacho limestone. Most of that percolation must take place in the zone where the main water table crosses the contact between the Picacho and Nogal, because farther east the lower strata of the Picacho limestone are relatively impermeable and act as lower confining beds for the artesian water in the upper part of the Picacho. As the upper part of the Nogal formation in many places consists of shale, the relative amount of ground water percolating across the strata from the Nogal into the Picacho probably is not large.

Most of the water in the Picacho limestone, therefore, and hence the artesian water supplying the wells in the Pecos Valley, is derived from water that sinks into the rocks in the outcrop area of

\footnotetext{
${ }^{34}$ Renick, B. C., Geology and ground-water resources of the drainage basin of the Rio Penasco above Hope, N. Mex.: New Mexico State Engineer Seventh Bienn. Rept., pp. 109-138, 1926.
} 
the Picacho limestone east of the line where the main water table crosses the contact between the Nogal formation and the Picacho. This belt will hereafter be referred to as the principal intake area of the artesian water supplying the wells in the Pecos Valley. It is shown on Plate 2 and illustrated by the section across the artesian basin. The principal intake area includes a narrow irregular strip adjoining on the west the line where the main water table crosses the contact between the Nogal formation and the Picacho limestone because the water sinking into the ground from the surface will not percolate straight downward to the main water table but will percolate along the dip of the limestone beds for some distance, drop to a lower level, and so on until it reaches the main water table. The principal intake area includes also another much narrower, irregular, and somewhat indefinite strip adjoining the east edge of the outcrop area of the Picacho limestone, where the cover of valley fill and Pecos formation is thin and where the main water table is considerably below the top of the Picacho limestone.

The conception of the principal intake area just outlined is substantiated by several lines of evidence. The ratio of the amount of artesian water withdrawn annually through wells and natural outlets (or the estimated annual recharge to the artesian reservoir) to the amount of annual precipitation in the catchment area (the limestone uplands and the mountains) is small, whereas its ratio to the amount of annual precipitation and stream losses in the principal intake area is much more nearly what one would expect. Although a close relationship between the amount of annual precipitation in the mountains and the fluctuation in artesian head in the Pecos Valley is not to be expected, no apparent relationship was found over a long period of time, whereas a close relationship was found between the amount of annual precipitation in the principal intake area outlined above and the fluctuations in the head of the artesian water. Another significant bit of evidence is found in the fact that most of the stream losses in the Rio Hondo and the Rio Penasco occur in the stretches of these streams that are within the principal intake area. The relation of precipitation to recharge is discussed further on pages 245-250.

The principal intake area, chiefly the eastern part of the limestone uplands, receives water from rain and snow that fall upon it, from the normal perennial flows of the Rio Hondo and the Rio Penasco that reach it, and from flood waters in all the streams that cross it. The amount of the annual precipitation on the principal intake area bears a close relationship to and is comparable in magnitude to that in the Pecos Valley, although it may be slightly greater, for the principal intake area is considerably higher than the Pecos Valley. 
However, the difference is not great enough to invalidate any estimates of the recharge of the artesian water based upon precipitation records in the Pecos Valley. Such estimates are much more nearly correct than any based upon precipitation records in the mountains or even in the artesian basin as a whole, for the annual precipitation in the mountains is not only considerably greater than that in the Pecos Valley and in the principal intake area but bears no close relationship to it. The amount of precipitation in the mountains is important only in so far as it affects the flow of the Rio Hondo and Rio Penasco and gives rise to floods in the streams crossing the principal intake area. The amount of surface water reaching the principal intake area from the mountains can best be determined by stream measurements within the area. Such measurements have been made at different times along the Rio Hondo and Rio Penasco. (See pp. 239-242.)

\section{MOVEMENT OF THE WATER}

The main water table in the Picacho limestone slopes eastward and east-southeastward about 10 to 15 feet to the mile, and the movement of the water is in the same general direction. The permeability of the cavernous portion of the Picacho is probably high, and the rate of movement of the water relatively rapid. The general direction of movement of the artesian water in the Picacho is eastward and eastsoutheastward in the artesian area as a whole, but the direction varies considerably in different parts of the area. This is illustrated by Plate 30, the direction of movement of the artesian water being roughly at right angles to the contour lines shown on this map. In the vicinity of Orchard Park there is a marked steepening of the hydraulic gradient. This appears to be caused by the Y-O fault or by a fault of small displacement in line with the Y-O fault across the artesian area. (See also pl. 3 and pp. 80-81.) This structural feature will hereafter be referred to as the Orchard Park barrier.

The definite southward trend of the artesian water in the Hagerman segment strongly indicates that the water comes chiefly from a source to the north and northwest. It appears probable that west of Hagerman and Dexter the northern part of the Y-O fault and the Orchard Park barrier deflect a large proportion of the water in the Picacho limestone north of the line between Tps. 15 and $16 \mathrm{~S}$., which would normally move east and east-southeast, so that most of it moves northeastward into the Roswell segment (Tps. 10 and 11 S.) and in the vicinity of South Spring and west of Orchard Park spills over the Orchard Park barrier. Part of the water may find its way into the Roswell and Dexter segments.

The catchment area contributing to the principal intake area of the Picacho limestone north of the line between Tps. 15 and $16 \mathrm{~S}$. 
(see pl. 2) is much larger and probably receives much more precipitation than the catchment area south of that line. Therefore, if this hypothesis is correct, it explains in large measure the more favorable artesian conditions in the Roswell segment and the less favorable artesian conditions in the southern part of the artesian area, for if most of the water in the Picacho limestone north of the line between Tps. 15 and $16 \mathrm{~S}$. is deflected toward the Roswell segment by the Y-O fault and the Orchard Park barrier, it becomes apparent that a very large proportion of the artesian water is concentrated in the northern part of the artesian area. With this relative abundance of artesian water one would expect to find in the northern part a relatively small decline in the head of the artesian water and a relatively small annual fluctuation. These are exactly the conditions found in the Roswell segment. In the southern part of the artesian area one would expect a considerably smaller amount of artesian water and a much smaller annual recharge. This also appears to be true, for the greatest decline in the head of the artesian water has occurred at the south end of the artesian area and the greatest annual fluctuation in head is found there. This hypothesis is further supported by the progressive increase in the amount of decline in head and in the amount of annual fluctuation in head of the artesian water from the north end to the south end of the artesian area, except in the middle and upper parts of the Cottonwood segment.

The artesian conditions in the middle and upper parts of the Cottonwood segment, which are discussed on pages 203-204, differ markedly from those in the Hagerman segment. However, the eastward movement of the artesian water as indicated by the hydraulic gradient (see pl. 30), the high head, the relatively small decline in head, and the relatively small annual fluctuations in the head of the artesian water in the upper and middle parts of the Cottonwood segment suggest that this segment also constitutes one of the main arteries of the artesian area. Apparently a large amount of the water in the Picacho limestone in the principal intake area south of the line between Tps. 15 and $16 \mathrm{~S}$. moves eastward toward the Cottonwood segment. Farther south the general direction of movement of the artesian water is east-southeast.

The artesian water in the Roswell segment is believed to come from the northwest, west, and southwest. The water in the area between Dexter and the Roswell segment comes partly from the west and northwest and partly from the Roswell segment. Between Dexter and Lake Arthur it comes almost wholly by percolation from the limestone in the area north of Dexter, although probably some comes also from the west. In the middle and upper parts of the Cotton- 
wood segment it comes entirely from the west, but in the lower part of the Cottonwood segment from both the west and the northwest. South of the Cottonwood segment it comes from the west-northwest.

\section{DISPOSAL OF THE WATMR}

The water in the Picacho limestone is disposed of through wells and through natural avenues of escape. The artesian wells, both those that are pumped and those that flow, make the largest draft upon the artesian reservoir. Considerable water escapes through underground leakage from abandoned artesian wells that were either improperly cased or improperly plugged. The disposal of the artesian water through artesian wells and through underground leakage from artesian wells is discussed on pages 231, 235. West of the artesian area some water in the Picacho limestone is withdrawn by wells pumped with windmills, but the total amount is probably only about 150 acre-feet a year.

A moderate amount of the artesian water escapes through springs in the Berrendo River. Though practically all the other springs in the artesian area have gone dry, some of the artesian water doubtless still escapes upward from the Picacho limestone through the overlying Pecos formation and the valley fill and finds its way underground into the Pecos River.

An appreciable amount of the artesian water in the Picacho limestone probably escapes underground at the southeast corner of the artesian basin. According to L. E. Foster and J. R. Yates, ${ }^{32}$ of the United States Bureau of Reclamation, the flow of the Major Johnson Springs, which are in the channel of the Pecos River a short distance below the mouth of the Seven Rivers, was about 40 second-feet before the construction of the McMillan Reservoir and the flow never falls below 40 second-feet, even during the times when the McMillan Reservoir is empty. They therefore consider 40 second-feet to be the basic flow of the springs. It has been proved ${ }^{3 s}$ that the flow of the springs in excess of 40 second-feet is derived from underground leakage from the McMillan Reservoir, but it is very probable that most if not all of the minimum flow of 40 second-feet is derived from artesian water escaping from aquifers at the southeast corner of the artesian basin. In addition, it is not improbable that some artesian water escapes underground at the southeast corner of the artesian basin and does not reach the surface until it has moved so far south or southeast that its source is not apparent.

\footnotetext{
s2 Personal communication, September, 1929.

${ }^{a z}$ Meinzer, O. E., Renick, B. C., and Bryan, Kirk, Geology of the No. 3 reservoir site of the Carlsbad irrigation project, N. Mex., with respect to water-tightness : U. S. Geol. Survey Water-Supply Paper 580, p. 23, 1927.
} 
There is probably very little if any escape of the artesian water north and east of the artesian area. There are no surface outlets, except possibly in western Texas, as in both directions the land surface rises above the static level of the artesian water.

It is improbable that there is any underground leakage toward the north, for if the Picacho limestone is cavernous north of the alluvial basin, the water in it would tend to move south, inasmuch as the direction of the hydraulic gradient is in that direction. It also appears improbable that there is any appreciable underground leakage toward the east. The Roswell artesian basin is situated on the west flank of a broad structural basin formed chiefly by the Permian rocks. The land surface in the central part of the basin is higher than the static head of the artesian water. Consequently the only possible outlets for the artesian water in the Permian rocks are in western Texas along the east and southeast sides of the basin where the Permian rocks reappear at the surface.

It appears that the Permian formations in this area change in character toward the east and southeast and that they are not continuous as lithologic and stratigraphic units across the basin. ${ }^{34}$ Records of numerous wells drilled for oil in southeastern New Mexico show that there are pronounced changes in the character of the Permian formations between this area and the southeast corner of the State. The well records also indicate that the Picacho limestone gives place to gypsum, anhydrite, salt, and red beds east of this area and does not crop out along the east and southeast sides of the Permian basin. The great thickness of relatively impermeable red beds and of anhydrite east of this area undoubtedly offer considerable resistance to the eastward movement of the artesian water from the Picacho limestone as well as that from the Pecos formation, and it appears improbable that the artesian pressure is sufficient to force appreciable quantities of artesian water through these beds to the east side of the Permian basin. If the artesian water were escaping eastward, oil found in the limestone would probably have been flushed out long ago. Consequently, it appears improbable that there is much escape of artesian water from this area along the east and southeast sides of the Permian basin.

\section{LIMITS OF THE ARTESIAN BASIN}

The available information indicates that the cavernous condition of the Picacho limestone extends a few miles east of the bluffs along

st Hoots, H. W., Geology of a part of western Texas and southeastern New Mexico, with special reference to salt and potash : U. S. Geol. Survey Bull. 780, p. 33-126. Gould, C. H., and Willis, Robin, Tentative correlation of the Permian formations of the southern Great Plains: Geol. Soc. America Bull., vol. 38, pp. 431-442, 1927. 
the Pecos River, but there are no data upon which to determine its precise east limits. However, the artesian water is not under sufficient pressure east of the bluffs to rise to the surface nor even within an economic pumping distance. Moreover, most of the land east of the bluffs is unfit for cultivation. Hence for all practical purposes the bluffs along the east side of the Pecos River may be considered the east limit of the artesian basin. However, wells drilled to the Picacho limestone east of the bluffs should be plugged at or below the top of the limestone and above the highest aquifer encountered in the limestone before being abandoned.

The north limit of the artesian basin is not definitely known, for very few deep wells have been drilled north of the original area of artesian flow, and no definite information was obtained in regard to the ground-water conditions north of the area. North of the alluvial basin the land surface rises and is too high, except perhaps in the valley of the Pecos River, which is comparatively narrow, to obtain flowing artesian water. Hence the north limit of the alluvial basin, approximately the north line of T. 9 S., may be considered for all practical purposes the north limit of the artesian basin.

The Seven'Rivers cuesta marks the south limit of the artesian basin. South of the cuesta the stratigraphy changes rapidly, and although the structure of the rocks is favorable for artesian circulation, the stratigraphic relations and the topography are unfavorable. The strata forming the Seven Rivers tongue of the Pecos formation merge into the Carlsbad limestone tongue of the Capitan limestone, and the requisite upper confining beds are either absent or incompetent to confine the water in the limestone under sufficient artesian pressure. The Carlsbad limestone tongue, which caps the Seven Rivers cuesta, thickens southward and has resisted erosion in the interstream areas. Consequently the country south of the Seven Rivers cuesta consists of rocky, barren limestone uplands and is too high, except perhaps locally in the narrow valleys, to obtain flowing artesian water. It is possible though not probable that deep wells drilled near the Pecos River in the valleys of tributary streams from the west and in the valley of the Pecos may encounter flowing artesian water, but as no deep wells have been drilled in those places, no definite information in regard to the ground-water conditions is available.

\section{WATER IN THE NOGAL FORMATION}

\section{OCCURRENCE}

West of the intake area of the Picacho limestone (see pl. 2) the upper part of the Nogal formation contains beds of fine sand and cavernous limestone, which in many places yield potable water. Here the water in the upper part of the Nogal is perched high above the 
main water table, which is probably more than 1,000 feet beneath the surface in the mountain region. The bodies of perched water in the Nogal formation are held above the main water table by shale and other impervious beds. As neither the beds of water-bearing sand nor the impervious strata beneath them are continuous over the entire region nor even over wide areas, these bodies of perched water are highly erratic in size, distribution, and depth. Consequently it is generally impossible to forecast the location and depth of the perched bodies of ground water except where their presence is revealed by springs, and even there it may be impossible to determine their extent. The lower part of the Nogal contains in places thick beds of gypsum and anhydrite and some salt. Therefore it is generally inadvisable to drill to the main water table in search of water, as the water in the lower part of the formation is probably highly mineralized and unfit for most purposes.

Most of the wells in the Mescalero Apache Indian Reservation that are within the artesian basin, many wells in adjoining areas east of the reservation, and many wells in the vicinity of the Capitan Mountains draw from perched bodies of water in the upper part of the Nogal formation. Renick describes an interesting occurrence of such perched water encountered by the well drilled for oil in the NE. $1 / 4$ sec. 14, T. 15 S., R. 17 E., on the Manning dome. ${ }^{85}$ According to a $\log$ of this well flows encountered in sand at 275 and 310 feet were lost in cavernous limestone beneath a bed of blue shale. The well started at or near the top of the Nogal formation.

The Dunken dome well, in the SW. 1/4 SW. 1/4 sec. 29, T. 17 S., R. $18 \mathrm{E}$., according to information obtained from Mr. William C. Kneale and from the driller's log, encountered fresh water in the Nogal formation at 855 to 860 feet in "soft red gravel" and at 1,160 to 1,165 feet in "gray lime." Mr. Kneale stated that water encountered at 855 to 860 feet rose 150 feet, and that at 1,160 to 1,165 feet rose 300 feet, or approximately to the level at which the first water was struck. Salt water was encountered at 2,510 to 2,515 feet in "white sand" in the lower part of the Nogal formation and is said to have risen 1,000 feet. According to the log, water was also encountered at 4,373 to 4,385 feet in "brown sandy lime" and at 4,894 to 4,900 feet in "hard white sand." These two water-bearing beds are probably in the Magdalena group (Pennsylvanian). Mr. Kneale stated that the water encountered at the bottom of the well, at 4,894 to 4,900 feet, rose 4,100 feet. This well penetrated more than 800 feet of Picacho limestone and apparently encountered no water in it.

${ }^{20}$ Renick, B. C., Geology and ground-water resources of the drainage basin of the Rio Peñasco above Hope, N. Mex.: New Mexico State Engineer Seventh Bienn. Rept., p. $129,1926$. 
The well drilled for oil near Picacho, in sec. 21, T. 11 S., R. 18 E., is reported to have struck water at 113 feet either in the alluvial deposits or in a sand near the top of the Nogal formation, and at 778 to 789 feet in sand in the Nogal. Water encountered at 778 to 789 feet is said to have risen within 190 feet of the top of the well, but no information is available as to the quality of the water.

\section{SOURCE}

The only possible sources of the water in the Nogal formation are the rain and snow that fall upon the broad area between the crests of the Sacramento and Capitan Mountains and the Sierra Blanca and the west edge of the intake area of the Picacho limestone. In this area the upper part of the Nogal formation is exposed in the deeper canyons, and in large parts of the area the base of the Picacho is less than 200 or 300 feet below the bottoms of the canyons and several hundred feet above the main water table; consequently a 1 large part if not most of the water that sinks into the ground gets into the Nogal formation. However, as the upper part of the Nogal contains many impermeable strata that tend to hold up most of the water, it appears probable that only a very small proportion of the total precipitation sinks to great depths. Much of the water that sinks into the Nogal formation reappears at the surface in the form of springs and is contributed to the streams that cross the intake area of the Picacho limestone.

\section{MOVEMENT AND DISPOSAL}

Little study was made of the water in the Nogal formation, and therefore few data are available in regard to its movement and disposal. The perched water in the upper part of the formation undoubtedly moves eastward, at least in the mountain region, as is proved by many springs in and adjacent to the mountains. Some of the perched water reappears at the surface as springs, runs into the streams, and sinks into the Picacho limestone farther east, although much of it evaporates before it reaches the intake area of the Picacho, and some probably sinks back into the Nogal formation. The perched water that does not reappear at the surface probably moves eastward slowly and sinks to lower and lower levels until it reaches the main zone of saturation. Near the west edge of the intake area of the Picacho limestone some of the water in the Nogal formation near the top of the main zone of saturation doubtless moves diagonally across the strata and gets into the Picacho limestone, thus contributing to the artesian supply.

The water in the lower part of the Nogal formation and below the main water table, if it moves at all, doubtless moves eastward at 
a comparatively slow. rate. Although no definite information is available, it appears highly improbable that the Nogal formation continues eastward as a lithologic unit and crops out east of the Llano Estacado. It is possible that as the strata change in character eastward some water from the Nogal formation slowly works its way upward into successive younger strata and appears at the surface in western Texas.

The geologic structure and the stratigraphy preclude any lateral movement of the water in the Nogal formation other than eastward and southeastward. However, in the eastern part of the artesian basin the water in the Nogal is under considerable artesian pressure and may be forced upward into the Picacho limestone along joints and bedding planes in the limestone and along large fractures and faults, such as the Border Hills and Y-O faults. The entrance of water from the Nogal may account for the salt water encountered in the lower part of the Picacho in the southern part of the artesian area and for the salt water in the vicinity of Roswell. Moreover, some of the water in the Nogal formation may be slowly combining with anhydrite to form gypsum.

\section{PERCHED-WATER CONDITIONS}

\section{GROUND WATER}

In the region west of the intake area of the Picacho limestone the main water table is 500 to 1,000 feet or more below the bottoms of the deep canyons. Throughout most of this region the Nogal formation is at or near the surface. The top of the formation is exposed in many parts of the canyons of the Rio Bonito, Rio Ruidoso, Rio Hondo, Rio Felix, and Rio Penasco and in some of the deeper canyons tributary to them. In large portions of the area where the Nogal formation is not exposed its top is only 200 to 300 feet below the bottoms of the canyons. Throughout this region there are beds of impervious shale in the upper part of the Nogal formation, which locally prevent or greatly retard the downward percolation of water that sinks into the ground. Consequently, local zones of saturation are formed which are perched high above the main zone of saturation. There are also bodies of perched water in the Picacho limestone, which are held up by thin impervious beds of shale and shaly limestone. As the impervious beds of shale are not continuous over the entire area but occur at different horizons, the development of ground-water supplies within reasonable depths in this region involves many uncertainties.

In the canyons of the Rio Hondo, Rio Felix, and Rio Penasco and their tributaries there are many wells less than 150 feet deep which draw from perched bodies of water in the alluvial deposits or in 
the upper part of the Nogal formation. The well at the Bonnell ranch, in the canyon of the Rio Ruidoso, about 65 miles from Roswell on the main highway to Alamogordo, is reported to be between 40 and 50 feet deep and to draw from sand and gravel in the alluvial deposits. The main water table at this place is hundreds of feet below the surface. The dug well at the Diamond $\mathrm{A}$ headquarters ranch, in the canyon of the Rio Hondo, in the NE. $1 / 4$ NE. $1 / 4$ sec. 20 , T. 11 S., R. 21 E., is reported to be 37 feet deep and to draw from a gravel bed between the depths of 20 and 34 feet. The main water table at this place is several hundred feet below the surface. Renick ${ }^{36}$ describes many wells 30 to 60 feet deep drawing from shallow bodies of perched water in the canyon of the Rio Felix, in T. $15 \mathrm{~S}$., R. $17 \mathrm{E}$., and in the canyon of Bluewater Creek in Tps. 17 and $18 \mathrm{~S}$., R. $16 \mathrm{E}$., where the main water table is 500 to 1,000 feet below the surface.

\section{SPRINGS}

There are numerous springs in the upper drainage basins of the Rio Hondo and Rio Penasco, especially in the mountain region. All these springs are fed by bodies of perched ground water, most of which are held high above the main water table by impervious beds in the upper part of the Nogal formation and, in the Sierra Blanca region, by igneous rocks. All the perennial streams in the mountain region are fed by these springs. Renick ${ }^{37}$ describes many springs in the upper drainage basin of the Rio Penasco and gives a detailed description of the perched-water conditions in the drainage basins of the Rio Penasco and Rio Felix. Many springs may be seen issuing along the steep slopes near the roads in the Sacramento Mountains, and springs are numerous in the Sierra Blanca. Practically all the communities and ranches in the Sacramento Mountains and Sierra Blanca depend upon springs for their water supplies. It is reported that many springs issue in the bed of the Rio Ruidoso and along its banks in the stretch between Hondo and a point a few miles above the Bonnell ranch, also along the Rio Bonito above Hondo.

A small spring half a mile east of the Diamond $\mathbf{A}$ dam across the Rio Hondo, in T. 11 S., R. 20 E., was examined by the writer. It is known as the Bar $H$ Spring and issues from small joints in cavernous limestone on the south side of the canyon of the Rio Hondo, nearly 200 feet above the channel of the river. (See fig. 20.) The flow is reported to be about 50 gallons in 24 hours and is said to be relatively constant even during dry years. The spring is fed from

\footnotetext{
* Renick, B. C., Geology and ground-water resources of the drainage basin of the Rio Penasco above Hope, N. Mex.: New Mexico State Engineer Seventh Bienn. Rept., pp. 129, 135-136, 1926.

* Idem, pp. 130-133.
} 
a small body of perched water, which is probably held up by a thin bed of limy shale or shaly limestone. Its constant flow may be attributed to small openings, which regulate the flow.

\section{STRFAMS}

The Rio Bonito, Rio Ruidoso, and Rio Penasco and many of their larger tributaries are perennial streams in the mountains, where they are fed by many springs. The Rio Penasco is a perennial stream as far as the Hope diversion dam, in the SE. 1/4 sec. 14, T. 17 S., R. 20 E., where all of the flow is taken out. The Rio Hondo ordinarily flows below the Diamond $A$ headquarters ranch. All these streams are perched from 250 to more than 1,000 feet above the main water table. In and adjacent to the mountain region they are held up chiefly by impervious beds in the Nogal formation and are fed by many springs along their course. East of the region of shallow perched ground water, however, the Rio Hondo and Rio Penasco are probably held up by partly cemented silt and by calcium carbonate deposited in the joints and small fractures of the limestones above which the streams flow. Both streams lose water by seepage in stretches where their beds are not impervious, and between the Diamond $\mathrm{A}$ headquarters ranch and the Hondo Reservoir the entire flow of the Rio Hondo sinks into the Picacho limestone.

\section{CHEMICAI CHARACTER OF THE GROUND WATER}

\section{SOURCE AND SIGNIFICANCE OF THE MINERAL CONSTITUENTS}

By Margaret D. Foster

The amount and kind of mineral matter dissolved in a natural water depends upon the chemical composition and physical structure of the rocks with which the water has been in contact, the temperature, the pressure, the duration of the contact, and the materials already in solution. The dissolved mineral matter in most natural waters consists chiefly of the carbonates, sulphates, and chlorides of the alkalies and alkaline earths. Waters of low mineral content contain the same substances in solution as those containing larger quantities of dissolved mineral matter, but the amounts and proportions of the different constituents may not be the same.

The total quantity of mineral matter dissolved in waters used for private and public supplies throughout the United States is generally less than 500 parts per million. The waters of the Roswell artesian basin are, as a rule, more highly mineralized than this, those analyzed containing from 402 to 5,668 parts per million of dissolved mineral matter, with the exception of the water encountered at a depth of about 1,200 feet in the Roswell city well, which contained 17,535 parts 
per million. More than two-thirds of the samples, however, contained between 600 and 2,000 parts per million of dissolved mineral matter. Only three samples contained less than 600 parts.

Calcium is dissolved to some extent from practically all rocks and may be dissolved in large quantities from limestone, dolomite, and gypsum. Calcium carbonate, the essential mineral of limestone, is but slightly soluble in pure water but dissolves readily in water containing carbon dioxide. In the Roswell artesian basin, where the formations consist of dolomitic limestones containing beds of gypsum and anhydrite, calcium sulphate is the predominating mineral constituent in most of the waters from these formations.

Water from dolomite or dolomitic limestone usually contains considerable magnesium. Other rocks furnish smaller quantities of magnesium. It is one of the abundant constituents of sea water and is found in appreciable quantities in water contaminated with sea water or with salts or brines embedded in deposits laid down in the sea in past ages.

Calcium and magnesium are the chief cause of hardness in water. They are also the principal basic constituents of the scale formed in boilers or other vessels in which water is heated or evaporated.

Sodium is a normal constituent of all natural waters, as traces of sodium are found in practically all rocks. It may also be present in waters as a result of pollution by sewage, of contamination with sea water, or of the presence of salts or brines inclosed in marine sediments. The quantity in solution may range from a few parts per million in normal waters in humid regions to several thousand parts in waters from the alkali rocks and soils of the semiarid regions of the Southwest. Some of the waters of the Roswell basin contain large amounts of sodium chloride dissolved from the beds of salt found at some places in the formations underlying the basin. Moderate quantities of sodium have little effect upon the suitability of a water for ordinary uses. If sodium is present much in excess of 100 parts per million, however, foaming may occur in steam boilers unless precautions are taken to prevent it. Waters that contain large quantities of sodium injure crops, and some waters contain so much sodium that they are unfit for nearly all uses.

Potassium is usually present in waters in smaller quantities than sodium, although many rocks contain more potassium than sodium. Approximately equal quantities of sodium and potassium are frequently found in waters in which the quantities of these two constituents together amount to less than 10 parts per million. With larger amounts of sodium, however, the proportion of potassium is less. Few waters contain more than 100 parts per million of potas- 
sium. In many analyses the sodium and potassium are reported together as sodium. The two elements have practically the same effect in the use of the water.

Carbonate is not present in appreciable amounts in most natural waters. The carbonate of the rocks, through the action of carbon dioxide in the water, is held in solution as bicarbonate. Waters that come from relatively insoluble rocks may contain less than 10 parts per million of bicarbonate. Waters from limestone or dolomite generally contain from 100 to 500 parts per million of bicarbonate. Calcium and magnesium bicarbonate make up the greater part of the dissolved mineral matter of many natural waters. The waters examined from the Roswell basin contained only moderate amounts of bicarbonate-from 132 to 285 parts per million. The bicarbonate as such has comparatively little effect upon the use of a water.

Sulphate is derived from various sources in the soil and rocks and from materials added by human agencies-from gypsum, from sulphates resulting from the oxidation of metallic sulphides or organic compounds, or from fertilizers containing sulphates. The waters of some public supplies contain additional sulphate from the aluminum sulphate used in treating the water. In mines, where pyrite (iron sulphide) is exposed to the action of air and water, the oxidation of sulphide and the formation of sulphuric acid may be so extensive that serious damage results. Hardness due to calcium or magnesium sulphate may increase the cost of softening and makes the scale formed in boilers much more troublesome. If present in sufficient quantity sulphate may impart a bitter taste to the water. In most of the waters of this area calcium sulphate is the predominating constituent.

Chloride is dissolved in smail quantities from rock materials. Waters that are contaminated with sea water or come from deep wells that penetrate brines or salt deposits inclosed in the old marine sediments contain large quantities of chloride. Sodium chloride is a characteristic constituent of sewage, and any appreciable pollution of a water is accompanied by a measurable increase in chloride. The presence of chloride in more than "normal quantities" can not, however, be taken as a definite indication of pollution, because of the many other sources from which chloride may be derived. Chloride may be detected by a salty taste in water containing over 300 parts per million. The large quantities of sodium chloride in some of the waters in this basin make them unfit for drinking because of the disagreeable taste.

Nitrate may be leached from the rocks, although few rocks contain appreciable amounts of nitrate except in regions where there 
are nitrate deposits. It may be washed from the soil, especially in areas where nitrate fertilizer is used. Many waters contain less than 1 part per million of nitrate, but as much as 100 parts per million is sometimes found. Although the quantity of nitrate has sometimes been taken as an indication of the extent of pollution, the interpretation of the presence of abnormal amounts with reference to the sanitary condition of a water should be made with extreme caution and only after due consideration of various factors-the chloride content, the sanitary surroundings of the source of the water, and the nature of the rock formation from which it is derived. The quantities of nitrate usually found in water have no effect upon the value of the water for ordinary uses.

The mineral constituents that have been considered above are those which are in chemical equilibrium in water. The mineral matter dissolved in a natural water is not a collection of random quantities of several constituents. In practically all waters the quantities of the basic radicles-calcium, magnesium, sodium, and potassiumare together chemically equivalent to the sum of the acid radiclesbicarbonate, sulphate, chloride, and nitrate. If the quantities of all but one constituent are known, the quantity of the missing radicle may be calculated to complete the analysis. Where one basic and one acidic constituent make up the greater part of the dissolved mineral matter it is convenient and customary to characterize the water by the name of the compound which these two constituents form. For example, most natural waters are calcium bicarbonate watersthat is, calcium and bicarbonate make up the greater part of the dissolved mineral matter. But where two or more acidic radicles or bases are present in a water in practically equivalent amounts it is misleading and unjustifiable to refer to the water by the name of a single compound.

In addition to these constituents that are in chemical equilibrium with each other all waters contain iron, aluminum, and silica, which are generally supposed to be present in the colloidal state as oxides.

Iron is dissolved from many rocks and may be dissolved from water pipes in sufficient quantities to be objectionable. Some of the waters of the Roswell Basin contain enough iron in solution to cause difficulty if the water is used for some purposes. Small quantities of iron in a water are more objectionable than much larger quantities of other constituents. If iron is in solution in excess of 1 part per million some of it may separate out as the reddish hydrated oxide when the water is exposed to air. It is this precipitated oxide which forms the reddish sediment in many spring and well waters and which causes the reddish stain on white enameled or porcelain 
plumbing fixtures. A water that contains more than 0.5 part per million of iron is objectionable for laundry work. The excess of iron may be removed from most waters by simple aeration and sedimentation or filtration, but a few require the addition of lime or some other substance.

Aluminum is usually present in waters in quantities decidedly less than 1 part per million. It appears to have no particular effect on the use of the water when only normal quantities are present. Its determination was omitted in the analyses made for this report.

Silica is dissolved from practically all rocks. In most waters it is found in quantities ranging from 10 to 30 parts per million. The silica separates with other scale-forming constituents in steam boilers and not only adds to the amount of the scale but makes the scale harder. Otherwise silica is of no significance in regard to the use of a water.

Hardness, or soap-consuming power, of a water is chiefly due to the salts of calcium and magnesium. A few waters contain enough iron, aluminum, zinc or other metal to produce measurable hardness, but such waters are rare. Hardness was formerly differentiated as "temporary" and "permanent." Temporary hardness was that part of the hardness removed by boiling and was approximately the hardness caused by the carbonate and bicarbonate of calcium and magnesium. Permanent hardness was not removed by boiling and was caused by sulphate or other strong acid salt of calcium and magnesium. These terms were not definite and have been replaced by the definite terms "carbonate" and "noncarbonate" hardness. Hardness in general is expressed as the quantity of calcium carbonate equivalent to the calcium and magnesium present. Water having a hardness of less than 50 parts per million is considered soft, and its treatment for the removal of the hardness is rarely justified. Hardness between 50 and 150 parts per million does not seriously interfere with the use of the water for most purposes, but it does increase the consumption of soap. Its removal by softening processes. is profitable for laundries and other industries using large quantities of soap, and treatment of such water for the prevention of scale is also necessary for the successful operation of steam boilers. More than 150 parts per million of hardness is noticed by everyone. If the water contains more than 200 parts per million of hardness it is common practice to soften the water for household use or to. install a cistern to collect rain water. All the waters in this area are much harder than is generally considered desirable for domestic use, the hardness ranging from 340 to more than 2,400 parts per million. 
Ground waters are, as a rule, practically colorless, although in some parts of the country colored waters are obtained from deep wells that encounter beds of lignite or other deeply buried organic material. Surface waters may be noticeably colored even when quite free of suspended matter.

The analysis of a water for its mineral constituents gives little indication of the sanitary condition of the water, which depends upon its freedom from disease-producing organisms.

The chemical character of the ground waters of the Roswell artesian basin is shown by the analyses of 55 samples chosen to represent the water yielded by the geologic formations underlying the basin. The analyses were made by Margaret D. Foster and S. K. Love in the water-resources laboratory of the United States Geological Survey by the usual methods for the analysis of water. ${ }^{88}$ The results, reported in parts per million, are given in the following tables and are represented graphically in Figures 22 to 25 and in Plate 27. These analyses are grouped according to the formation from which the waters are derived. Other analyses of surface and ground water in the Roswell artesian basin are given by Fisher, ${ }^{39}$ Renick, ${ }^{40}$ and Collins and Riffenburg. ${ }^{41}$ In addition to the information gained from the analyses a number of general statements are available from reports of those using the waters and from the field experience of Mr. Nye throughout the investigation of the area.

The ground waters of the Roswell artesian basin, in their mineral content, reflect the character of the geologic formations underlying the basin, which consist of dolomitic limestones containing beds of gypsum, anhydrite, and, at some places, salt. Most of the waters are calcium sulphate waters of high mineral content, with moderate amounts of bicarbonate. There is, as a rule, a rather uniform ratio between the calcium and magnesium. In most of the waters analyzed the magnesium is approximately equivalent to half the calcium. Most of these waters contain small amounts of sodium chloride, but some, particularly those containing more than 3,000 parts per million of dissolved mineral matter, contain sodium chloride as the predominating constituent. These sodium-chloride waters contain about the same amounts of the other constituents as the waters of lower

\footnotetext{
${ }^{38}$ Collins, W. D., Notes on practical water analysis: U. S. Geol. Survey Water-Supply Paper 596, pp. 235-266, 1928.

${ }^{39}$ Fisher, C. A., Preliminary report on the geology and underground waters of the Roswell artesian area, N. Mex.: U. S. Geol. Survey Water-Supply Paper 158, pp. 22-23, 1906.

40 Renick, B. C., Geology and ground-water resources of the drainage basin of the Rio Penasco above Hope, N. Mex. : New Mexico State Engineer Seventh Bienn. Rept., p. 137, 1926.

41 Collins, W. D., and Riffenburg, H. B., Quality of water of Pecos River in Texas: U. S. Geol. Survey Water-Supply Paper 596, pp. 73, 75, 1928.
} 
mineral content, with more or less sodium chloride added. Apparently they are calcium sulphate waters that have come into contact with beds of salt. Only two calcium carbonate waters were analyzed, and these were the least concentrated of the waters examined, containing only 402 and 406 parts per million of dissolved mineral matter.

\section{WATER FROM THE VALLEY FILL}

The valley fill yields hard waters that differ widely in mineral content. The predominating constituents in the five samples which were analyzed were calcium and sulphate. Analyses of water from the valley fill are given in the following table and are shown graphically in Figure 22.

\section{Analyses of waters from the valley fill}

[Parts per million. Analyses 1 to 4 by Margaret D. Foster; analysis 5 by S. K. Love]

\begin{tabular}{|c|c|c|c|c|c|}
\hline & 1 & 2 & 3 & 4 & 5 \\
\hline 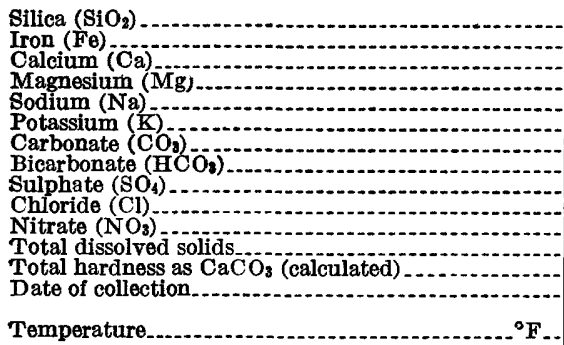 & $\begin{array}{l}15 \\
156 \\
51 \\
72 \\
4.5 \\
0 \\
237 \\
432 \\
78 \\
1.9 \\
975 \\
599 \\
\text { Dec. } 28 \\
1926 \\
60\end{array}$ & $\begin{array}{c}15 \\
5.6 \\
126 \\
40 \\
16 \\
0 \\
214 \\
291 \\
21 \\
2.2 \\
648 \\
479 \\
\text { Oct. } 13 \\
1926 . \\
65\end{array}$ & $\begin{array}{c}25 \\
220 \\
.12 \\
84 \\
55 \\
4.8 \\
0 \\
195 \\
617 \\
126 \\
29 \\
1,302 \\
894 \\
\text { May } 13, \\
1927 . \\
66\end{array}$ & \begin{tabular}{|c|}
18 \\
145 \\
5.52 \\
59 \\
29 \\
5.4 \\
0 \\
138 \\
494 \\
24 \\
7.5 \\
887 \\
604 \\
May 6 \\
1927. \\
\\
\end{tabular} & $\begin{array}{c}24 \\
536 \\
50 \\
201 \\
120 \\
7.2 \\
0 \\
217 \\
1,611 \\
408 \\
2.2 \\
3,084 \\
2,164 \\
\mathrm{M}^{2} 21, \\
1928 . \\
64\end{array}$ \\
\hline
\end{tabular}

1. Dug well (No. 1429), 24 feet deep, in SE. 1/4 sec. 31, T. 10 S., R. 24 E., owned by Chas. Alston, Roswell, N. Mex. Water is considered "good."

2. Drilled well (No. 1462), 115 feet deep, in SE. $1 / 4$ sec. 23 , T. 12 S., R. 24 E., owned by F. E. Burrows, Roswell, N. Mex. W ater is considered "good."

3. Two drilled wells (No. 1513), 106 feet deep, connected to one pump, in SW. $1 / 4$ sec. 1, T. 14 S., R. 25 E., owned by Herman Steffen, Hagerman, N. Mex. Water is considered "good."

4. Head of lower flowing portion of Rio Felix, in NW.1/4 NE. 1/4 sec. 7, T. 14 S., R. 26 E. Water is con. sidered "good."

5. Combination dug and drilled well (No. 1616), 48 feet deep, in SW. 1/4 NW. 1/4 NE. 1/4 sec. 23, T. 18 S., R. 26 E., owned by Tom Lattion. Water is very poor for domestic use and has a "gypy" or salty taste. It has been used for irrigation for many years without damage to the soil.

In many parts of the artesian area "bad" water in the valley fill occurs near the surface and "good" water is encountered in the deeper aquifers. If the first water found in the valley fill is highly mineralized it should be cased off and the well drilled to the base of the deposits, near which "good" water may be obtained. Most of the well water in the vicinity of Hagerman is reported to be "bad" and is used only for stock. Two wells east of Dayton, however, yield "bad" water that has been used for irrigation for many years. So far as is known, none of the water from the valley fill is unfit for stock. 


\section{WATER FROM THE PECOS FORMATYON}

Only two analyses were made of waters from the Pecos formation. These analyses are shown graphically in Figure 23.

In the central part of the alluvial basin the waters from the Pecos formation are noticeably mineralized but are generally used for

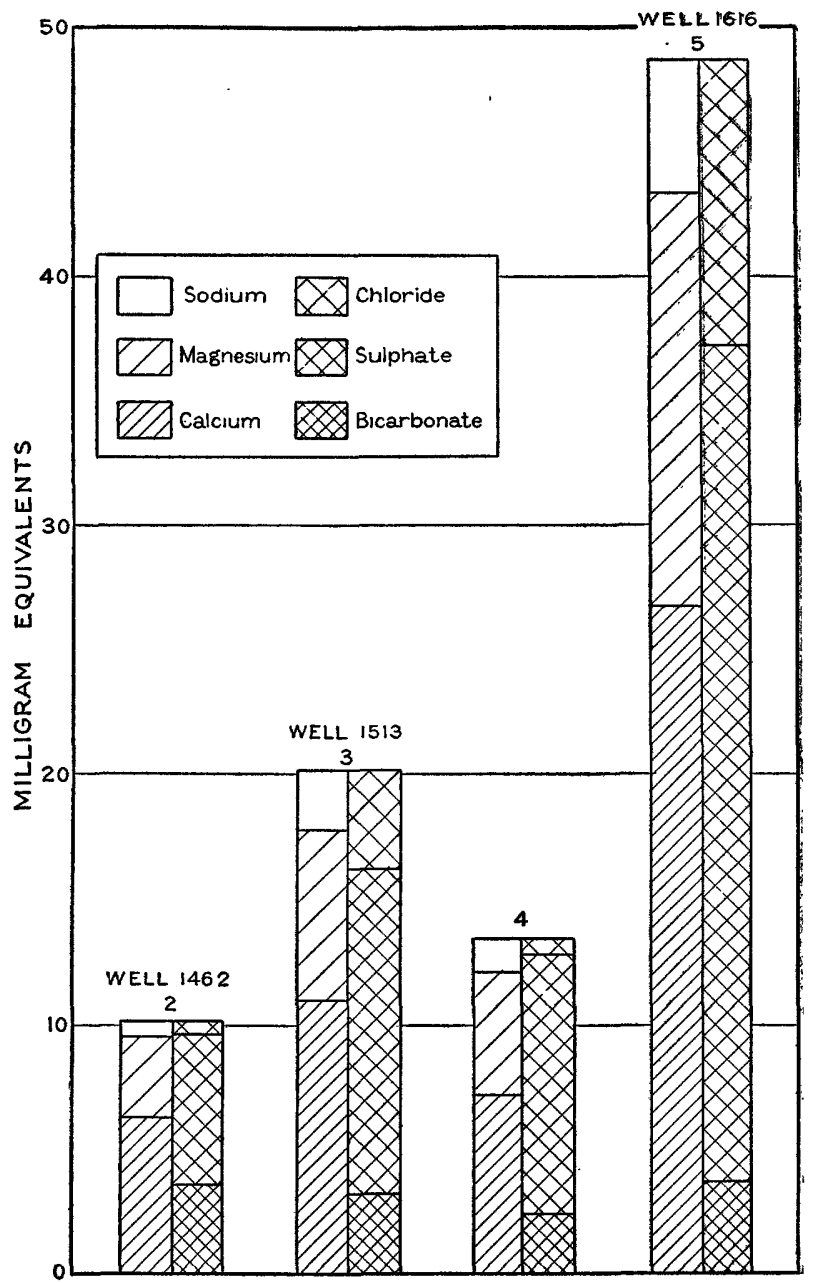

FiguRe 22.-Graphic representation of analyses of water from the valley fill. (See table in text)

domestic purposes, although in some places the water is used only for stock. In the outcrop areas of the Pecos formation south of the alluvial basin and between the bluffs along the Pecos River and the east edge of the area shown on Plate 2 the water is, as a rule, too highly mineralized to be used for domestic purposes and, in some places, even for stock. In the drainage basin of Cottonwoodl 
Creek, where only the lowest part of the formation is present, the water, although hard and appreciably mineralized, is used for domestic purposes.

\section{Analyses of waters from the Pecos formation}

[Parts per miltion. Analyses by Margaret D. Foster]

\begin{tabular}{|c|c|c|}
\hline & 6 & 7 \\
\hline 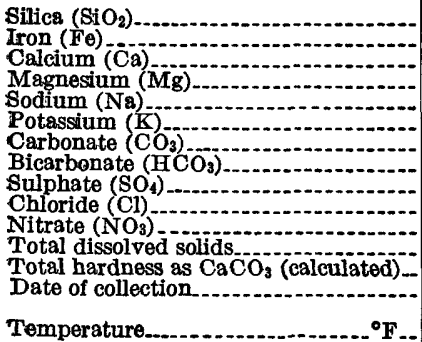 & \begin{tabular}{|c|}
9.5 \\
264 \\
87 \\
1,703 \\
13 \\
0 \\
176 \\
787 \\
2,682 \\
5,668 \\
1,017 \\
May 10 \\
1928. \\
67
\end{tabular} & $\begin{array}{c}20 \\
2.5 \\
129 \\
42 \\
9.4 \\
2.0 \\
0 \\
240 \\
273 \\
14 \\
3.8 \\
639 \\
495 \\
\text { Jan. } 21, \\
1927 . \\
70\end{array}$ \\
\hline
\end{tabular}

6. Drilled flowing artesian well (No, 284), 327 feet deep, in W. $1 / 2$ NW. $1 / 4$ sec. 25 , T. 10 S., R. 24 E., owned by J. A. Garrod. A sodium-chloride water of high mineral content from an artesian aquifer near the base of the formation in the vicinity of Roswell.

7. Drilled nonartesian well (No. 1743), 140 feet deep, in NE. $1 / 4$ SE. $1 / 4$ sec. 7, T. 15 S., R. 24 E., known as "Hackberry Mill" and owned by Diamond A Cattle Co., Roswell, N. Mex. A calcium sulphate water from the lower part of the formation in an area where the formation consists chiefly of calcareous red beds and lenticular beds of impure limestone with practically no gypsum or salt. This water compares favorably with the best waters in the artesian area.

\section{WATER FROM THE PICACHO IIMESTONE}

The waters of the Picacho limestone differ widely in chemical composition. (See tables, pp. 172, 174 and fig. 24.) The analyses indicate the quality of water that may be obtained from the formation, but they do not give a true picture of the character of the water generally obtained, because a disproportionate number of samples were collected from wells in the artesian area yielding salty and sulphurous water, in order to make a special study of the water of this type. Most of the waters from the Picacho limestone can be used for domestic purposes, and practically all, including the salty and sulphurous waters, are suitable for irrigation.

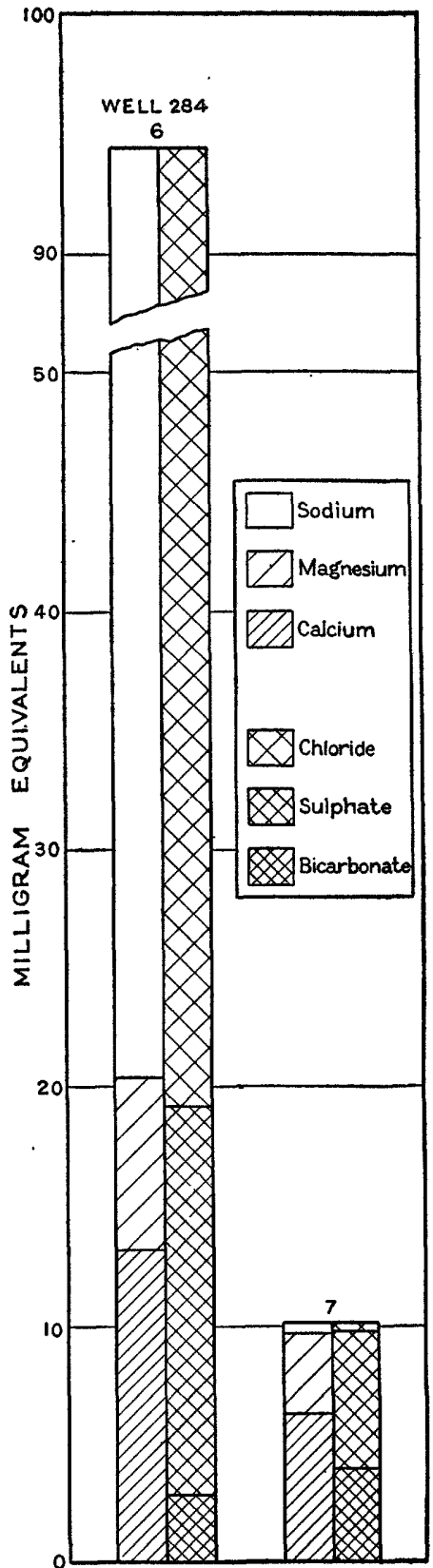

FradR 23.-Graphic representation of analyses of water from the Pecos formation. (See table in text) 
The chemical character of the waters from the Picacho limestone within the artesian area is shown by analyses 17 to 52. Representative analyses are shown graphically in Plate 27.

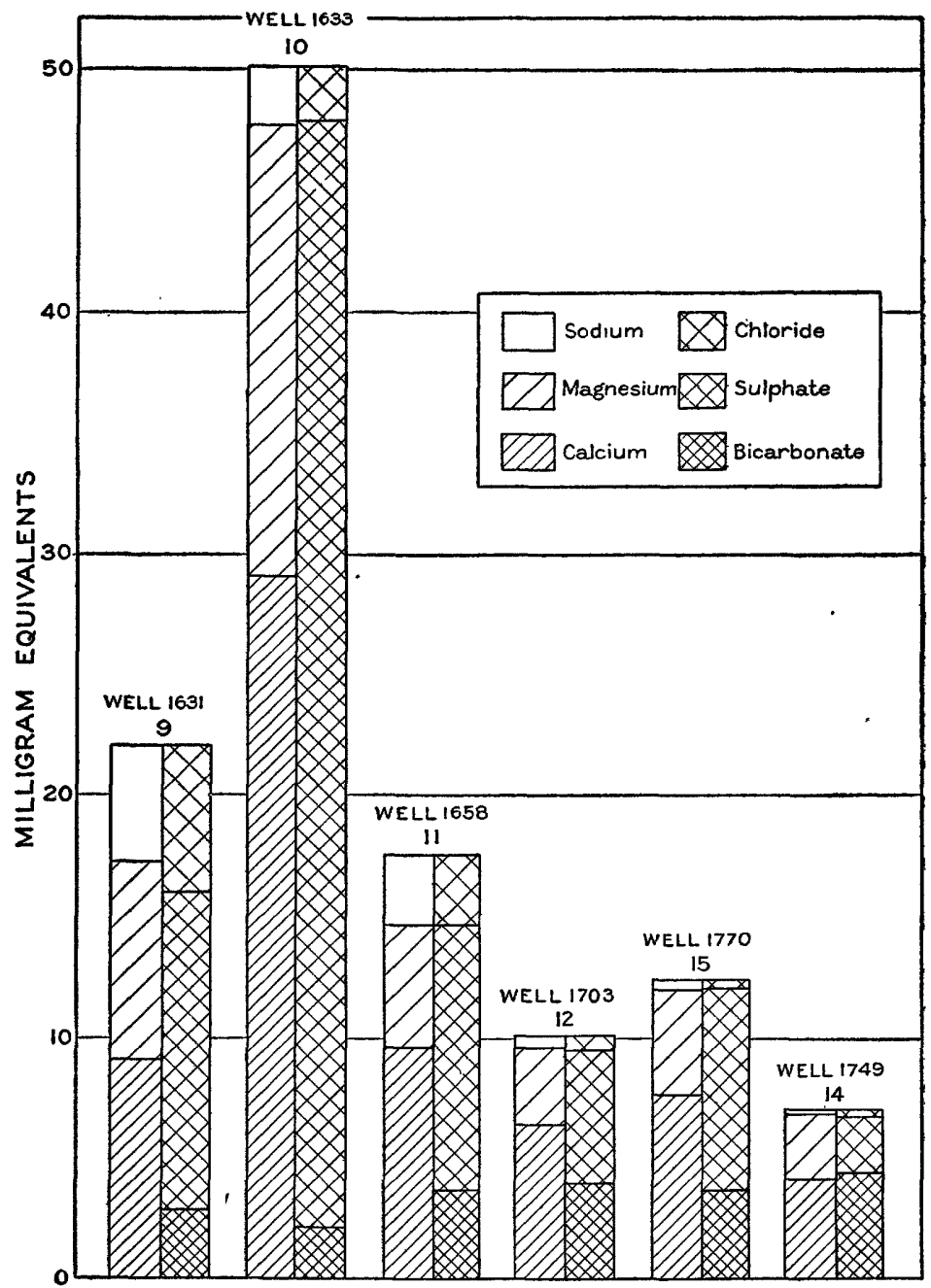

Figdre 24.-Graphic representation of analyses of water from the Picacho limestone in and near the outcrop area. See table in text

The analyses indicate that in the artesian area the Picacho yields calcium sulphate waters of variable mineral content, except in a relatively small area northeast of Roswell (samples 17-20, 22, and 23), where the predominating mineral constituent of the water is sodium chloride. The analyses of four samples collected during the construction of the deep test well drilled for the city of Roswell are represented graphically in Figure 25. 


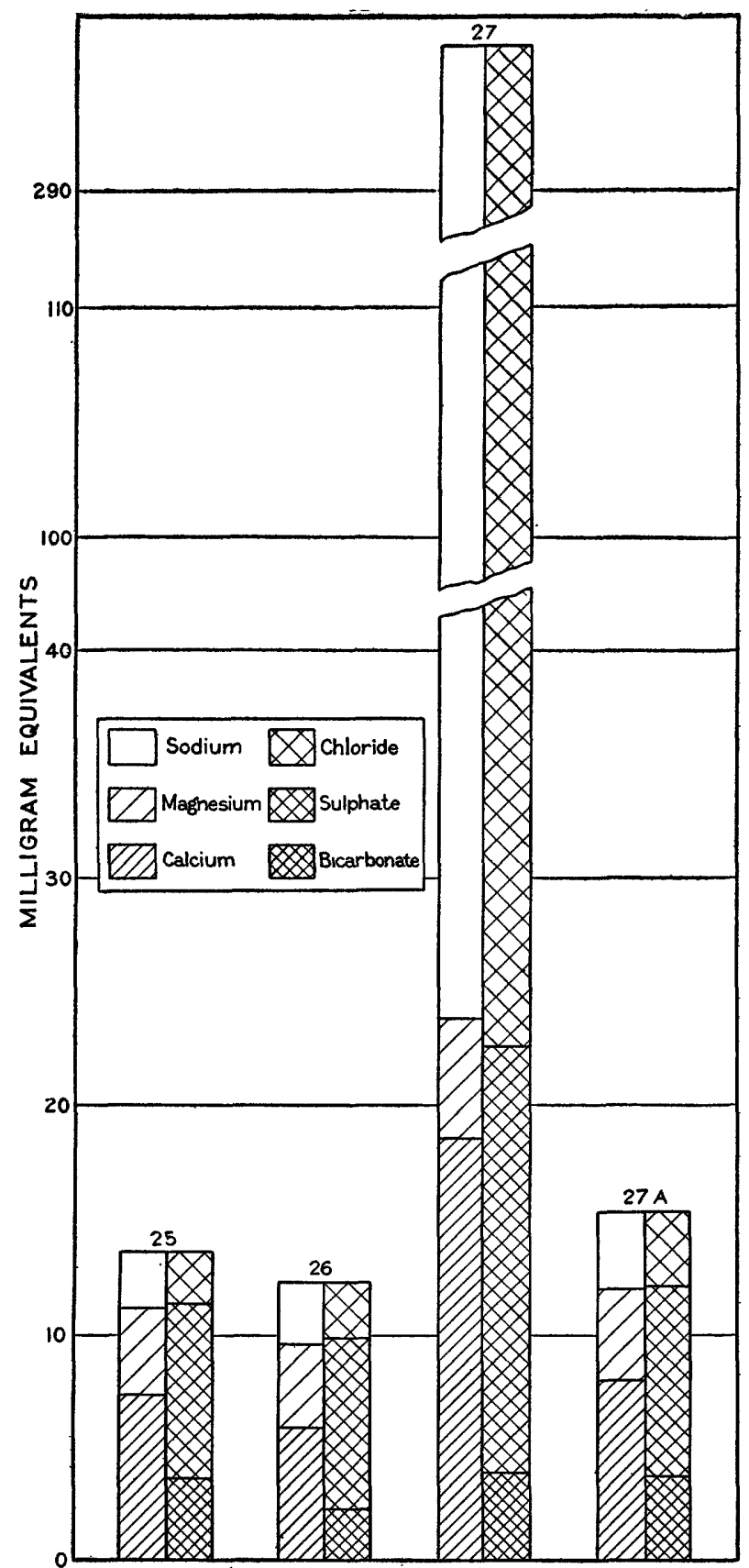

Frgurm 25.-Graphic representation of analyses of water from the deep Roswell city well. (See table in text) 


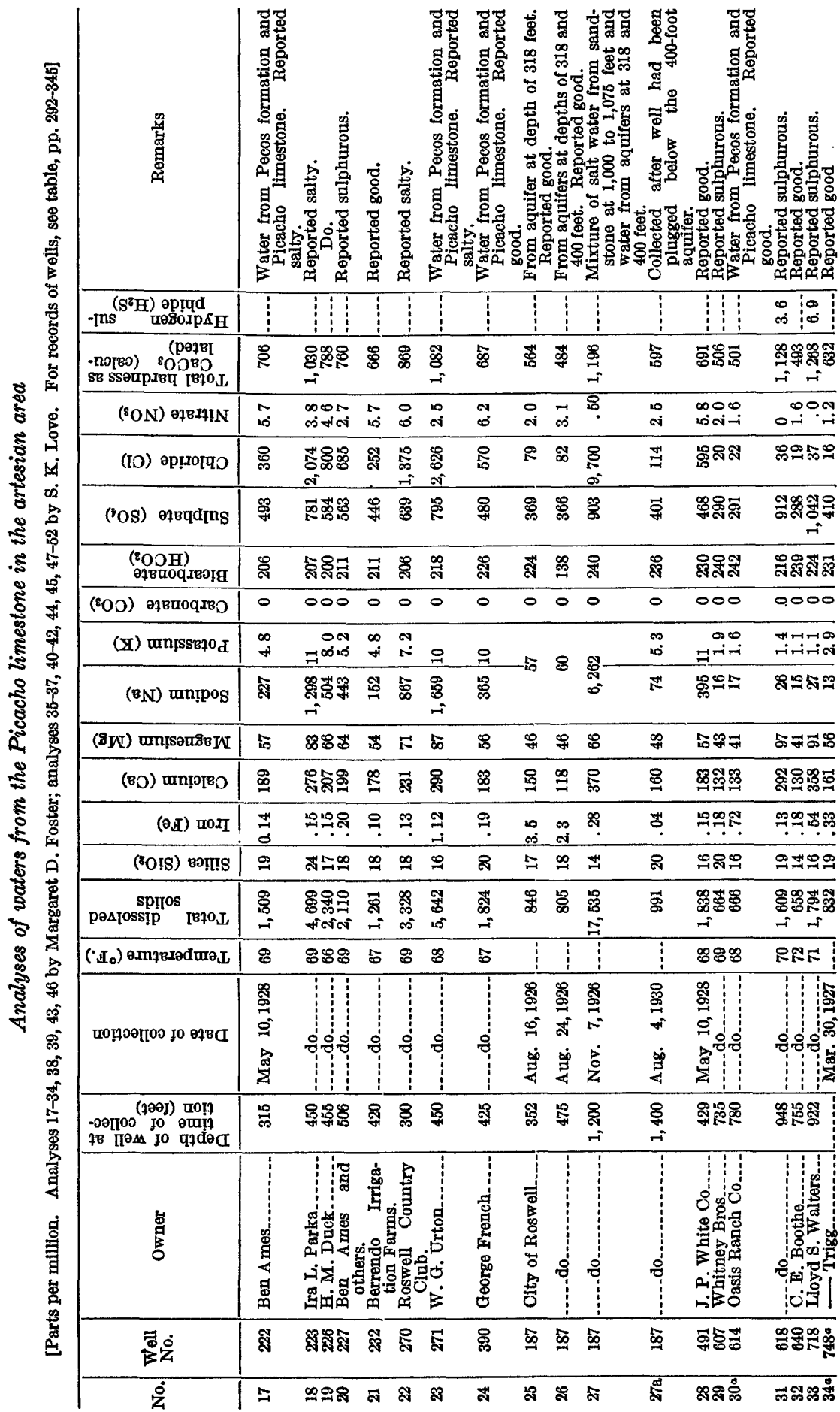




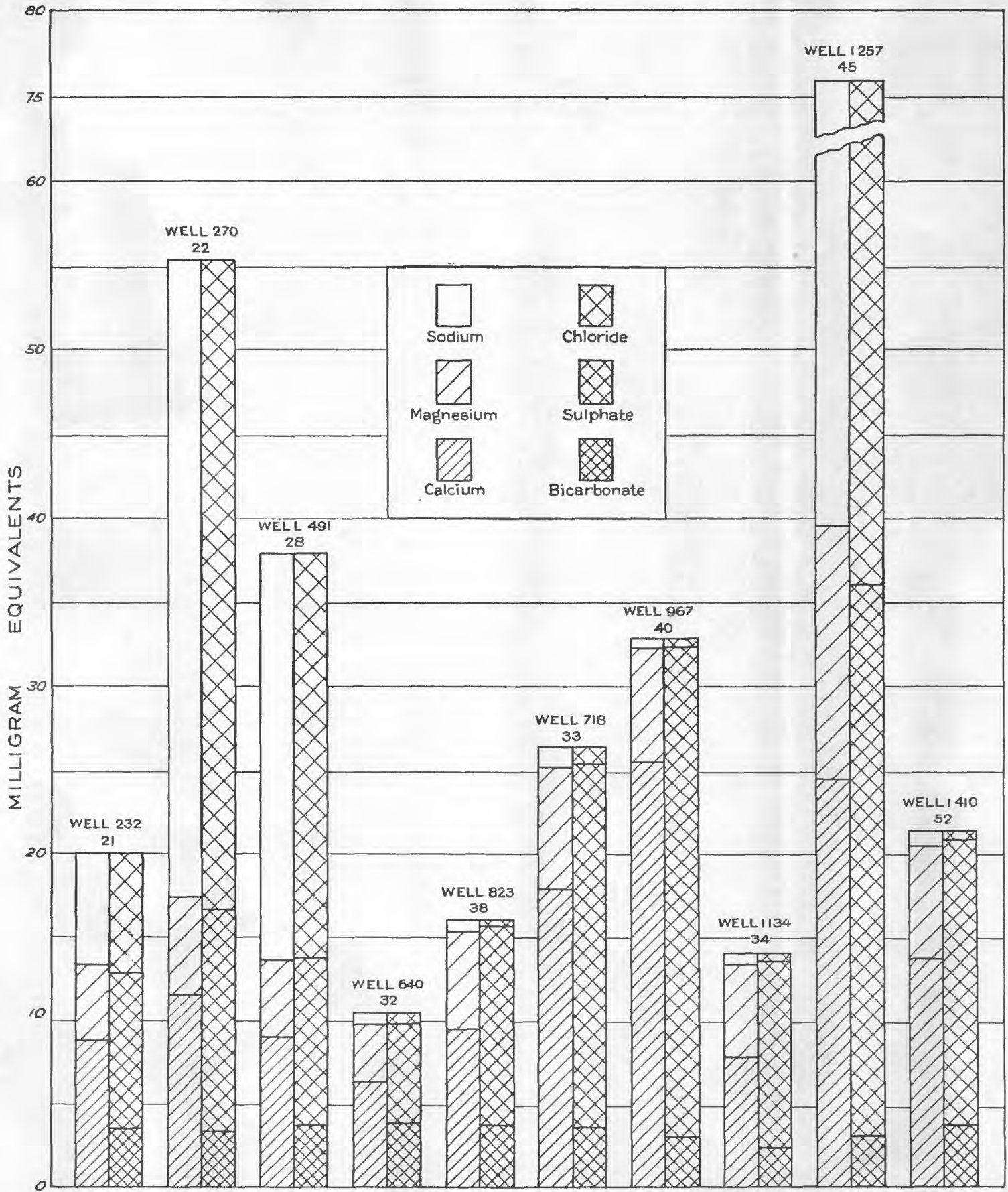

GRAPHIC REPRESENTATION OF ANALYSES OF WATER FROM THE PICACHO LIMESTONE WITHIN THE ROSWELL ARTESIAN AREA 


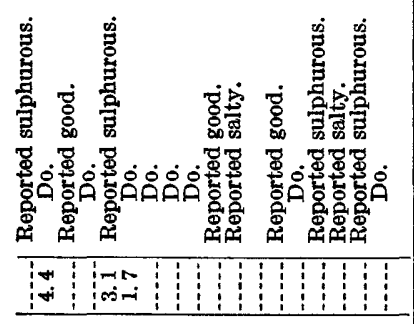

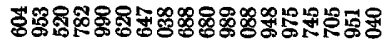

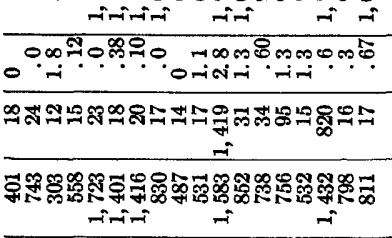

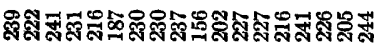

000000000000000000

कN⿻上丨तn

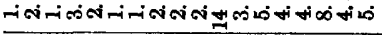

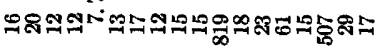

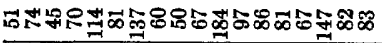

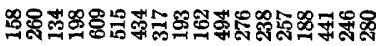

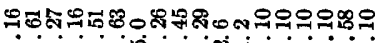

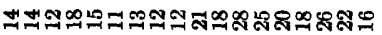

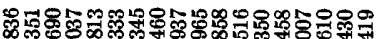

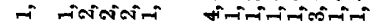
"กกล : ใด 密 휵히웡 -ini-i

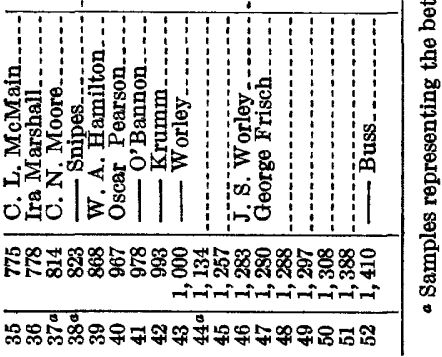


Analyses of waters from the Picacho limestone west of the artesian area

[Parts per million. Analyses by Margaret D. Foster]

\begin{tabular}{|c|c|c|c|c|c|}
\hline & $8^{a}$ & $9^{a}$ & $10^{\circ}$ & 116 & $12^{b}$ \\
\hline 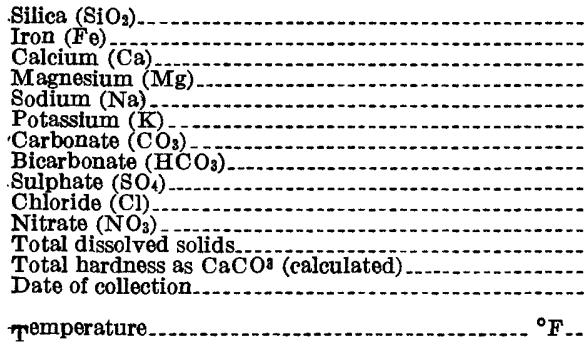 & \begin{tabular}{|c|}
20 \\
1.0 \\
119 \\
37 \\
178 \\
8.0 \\
4.8 \\
176 \\
272 \\
285 \\
3.2 \\
1,038 \\
449 \\
Jan. 10 \\
1927. \\
60
\end{tabular} & \begin{tabular}{|c|c|}
15 \\
2.5 \\
183 \\
99 \\
111 \\
5.2 \\
0 \\
173 \\
618 \\
196 \\
42 \\
1,421 \\
863 \\
Jan. 26, \\
1927.
\end{tabular} & $\begin{array}{l}34 \\
0.15 \\
588 \\
229 \\
52 \\
6.0 \\
0 \\
132 \\
2,178 \\
75 \\
1.5 \\
3,530 \\
2,409 \\
\text { Nov. } 12 \\
1926 .\end{array}$ & \begin{tabular}{|c|}
14 \\
2.4 \\
194 \\
62 \\
63 \\
2.8 \\
0 \\
221 \\
523 \\
96 \\
6.8 \\
1,121 \\
739 \\
Dec. 28 \\
1926.
\end{tabular} & \begin{tabular}{|c}
13 \\
0.44 \\
130 \\
41 \\
7.1 \\
4.0 \\
9.6 \\
222 \\
265 \\
16 \\
1.6 \\
616 \\
493 \\
Jan. 5 \\
1927. \\
64
\end{tabular} \\
\hline & & $13^{b}$ & $14^{b}$ & $15^{b}$ & 16 \\
\hline 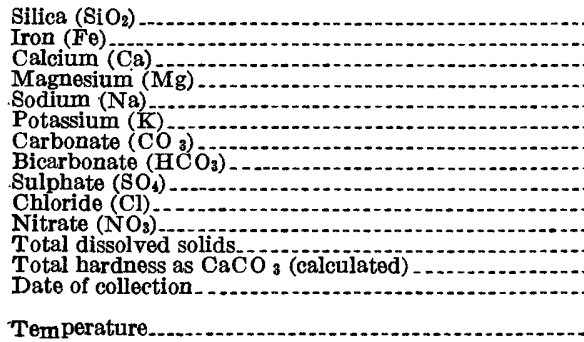 & --1 & $\begin{array}{l}11 \\
0.08 \\
111 \\
39 \\
7.2 \\
3.8 \\
0 \\
255 \\
213 \\
14 \\
2.0 \\
554 \\
437 \\
\text { Jan. } 4 \text {, } \\
1927 \text {. }\end{array}$ & $\begin{array}{l}20 \\
0.74 \\
86 \\
34 \\
1.6 \\
1.9 \\
0 \\
264 \\
112 \\
7.2 \\
2.9 \\
406 \\
354 \\
\text { Jan. } 28 \\
1927 .\end{array}$ & $\begin{array}{c}15 \\
12.3 \\
157 \\
52 \\
8.5 \\
2.2 \\
0 \\
217 \\
395 \\
7.0 \\
6.7 \\
782 \\
606 \\
\text { Mar. } 26, \\
1927 . \\
67\end{array}$ & $\begin{array}{c}16 \\
4.8 \\
529 \\
187 \\
10 \\
2.4 \\
0 \\
283 \\
1,747 \\
15 \\
0.08 \\
2,834 \\
2,089 \\
\text { Apr. 16, } \\
1927 .\end{array}$ \\
\hline
\end{tabular}

- Representative sample from Picacho limestone west and north of Roswell.

- Representative sample from Picacho limestone in the outcrop area.

8. Drilled well on Salt Creek about 15 miles northwest of Roswell, owned by George Corn, Roswell, N. Mex.

9. Drilled well (No. 1631), 364 feet deep, in SE. $1 / 4$ NW. 1/4 sec. 20, T. 9 S., R. 23 E., owned by C. A. Morley, Roswell, N. Mex. The high nitrate of this sample may possibly be due to surface drainage that is washed into sink holes and reaches the zone of saturation.

10. Erilled well (No. 1633), 263 feet deep, in SW. 1/4 NW. 1/4 sec. 35, T. 9 S., R. 23 E., owned by C. Ai Morley, Roswell, N. Mex. Water reported to be "gypy." Well encountered a large amount of gypsum. 11. Drilled weil (No. 1658), 327 feet deep, in SW. 1/4 NW. 1/4 sec. 2, T. 11 S., R. 22 E., owned by J. F. Barry, Roswell, N. Mex.

12. Drilled well (No. 1703), 180 feet deep, in NE. 1/4 SW. 1/4 sec. 33, T. 13 S., R. 20 E., known as "Maddox well" and owned by Diamond A Cattle Co., Roswell, N. Mex.

13. Drilled well (No. 1704), 515 feet deep, in SE.1/4 NE. 1/4 sec. 18, T. 13 S., R. 21 E., known as "Crow Flat well" and owned by Diamond A Cattle Co., Roswell, N. Mex.

14. Drilled well (No. 1749), about 450 feet deep, in SE. 1/4 SW. 1/4 sec. 12, T. 16 S., R. 21 E., owned by D. W. Runyan, Artesia, N. Mex.

i5. Drilled well (No. 1770), more than 800 feet deep, in NE. 1/4 SW. 1/4 sec. 32, T. 19 S., R. 21 E., known as "Whitaker well" and owned by Mr. Glasscock, Hope, N. Mex.

16. Drilled well (No. 1785), 525 feet deep, in NW.1/4 NW. 1/4 sec. 12, T. 20 S., R. 23 E., owned by J. F. Joyce, Carlsbad, N. Mex. Well is uncased through gypsiferous strata in the Pecos formation and yields "gypy" water, which is probably a mixed water from the Pecos and Picacho formations.

Many artesian wells in the vicinity of Dexter and Cottonwood Creek, a few near Dayton and the Seven Rivers, and a few scattered wells in other parts of the artesian area yield sulphur water. Several of the wells from which samples were collected (Nos. 20, 29, 31, $33,35,36,39-43,49,51$, and 52) are reported to yield sulphur water. The hydrogen sulphide in the water at the time of analysis was determined in a few samples, but this gives little indication of the amount present at the time of collection. The source of the hydrogen 
sulphide is not clear. Most of the wells that yield hydrogen sulphide water encounter, according to the logs, black carbonaceous limestone and shale, referred to by many of the well drillers as "sulphur rock," which has a petroliferous odor when struck by a hammer. In the southern part of the artesian area many wells have encountered small amounts of oil and gas in the Picacho, and much of the oil in the Artesia field, a few miles east of the Pecos River, is apparently obtained from the Picacho limestone. ${ }^{42}$

This close association of waters containing hydrogen sulphide with carbonaceous rocks in the Picacho limestone suggests that the carbonaceous material has been a factor in the formation of the hydrogen sulphide in the waters. The literature with reference to the formation of hydrogen sulphide by reduction of sulphate in the ground waters by hydrocarbons derived from carbonaceous material is summarized and discussed by Renick.43 Recent studies indicate that hydrogen sulphide in oil-field waters may also be formed by the reduction of sulphate by microorganisms in the presence of carbonaceous material. ${ }^{44}$

The analyses show that the hydrogen sulphide waters are similar in chemical composition to other waters of the area and furnish no positive evidence in support of these two hypotheses, according to which the formation of hydrogen sulphide is accompanied by the reduction of sulphate and the formation of an equivalent amount of carbonate. Hydrogen sulphide may likewise be formed by the decomposition of carbonaceous material containing sulphur by microorganisms, without involving reaction with constituents present in the ground waters. ${ }^{45}$

\section{WATER FROM THE NOGAL FORMATION}

The chemical character of the water in different parts of the Nogal formation and in different places probably varies considerably. In and east of the artesian area all the water that has been encountered in the Nogal formation is reported to be very salty and too highly mineralized for most purposes. This is to be expected, for deep borings reveal that in that part of the area the formation contains thick deposits of gypsum, anhydrite, and salt. Within the alluvial

\footnotetext{
42 Davis, M. J., Artesia field, Eddy County, N. Mex. : Structure of typical American oil fields, vol. 1, p. 119, 1929.

${ }^{43}$ Renick, B. C., Some geochemical relations of ground waters and associated natural gas in the Lance formation, Montana: Jour. Geology, vol. 32, pp. 668-684, 1924.

4 Ginter, R. L., Causative agents of sulphate reduction in oil fields: Am. Assoc. Petroleum Geologists Bull., vol. 14, pp. 139, 1930. Bastin, E. S., and Greer, F. E., Additional data on sulphate-reducing bacteria in soils and waters of Illinois oil fields: Idem, pp. 153-159. Gahl, R., and Anderson, B., Sulphate-reducing bacteria in California oil-field waters : Centralbl. Bakt. Parasitenk., Abt. 2, Band 73, pp. 331-338, 1928.

« Waksman, S. A., Principles of soll microbiology, p. 612, Baltimore, Williams \& Wilkins Co., 1927.
} 
basin; therefore, the Nogal formation is useless as a source of water for domestic purposes or for stock or irrigation. West of the alluvial basin the water from the upper part of the Nogal can be used for most ordinary purposes, but the water encountered in the lower part of the formation is reported to be salty or otherwise highly mineralized.

Only one sample of water, No. 53, known to be from the Nogal formation was collected. This is a calcium sulphate water which is very similar in chemical composition to many waters from the Picacho limestone. Sample 54 represents a water reported to be from sandstone that may be either in the Picacho limestone or in the Nogal formation; it is similar in chemical content to sample 14 (see table, p. 174) from the Picacho in the outcrop area. Samples 53 and 54 contain less dissolved mineral matter than any other samples collected in this area. Sample 27 (see table, p. 172) represents a mixture of very salty waters from a sandstone near the base of the Picacho and from sands in the upper part of the Nogal formation with comparatively fresh waters from the upper part of the Picacho.

Analyses of waters from the Nogal formation

[Parts per million. Analyses by Margaret D. Foster]

\begin{tabular}{|c|c|c|c|c|c|}
\hline & 53 & 54 & & 53 & 54 \\
\hline $\begin{array}{l}\text { Silica }\left(\mathrm{SiO}_{2}\right) \\
\text { Iron }(\mathrm{Fe}) \\
\text { Calcium }(\mathrm{Ca}) \\
\text { Magnesium }(\mathrm{Mg}) \\
\text { Sodium potassium } \\
\text { (Na+K) and } \\
\text { Carbonate }\left(\mathrm{CO}_{2}\right) \\
\text { Bicarbonate }\left(\mathrm{HCO}_{2}\right) \\
\text { Sulphate }\left(\mathrm{SO}_{4}\right)^{2}\end{array}$ & $\begin{array}{c}14 \\
1.2 \\
279 \\
90 \\
59 \\
0 \\
285 \\
822\end{array}$ & 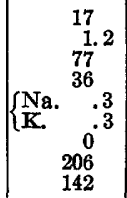 & $\begin{array}{l}\text { Chloride }(\mathrm{Cl}) \\
\text { Nitrate (NO}) \\
\text { Total dissolved solids } \\
\text { Total hardness as } \mathrm{CaCO}_{2} \\
\text { (calculated) } \\
\text { Date of collection. } \\
\text { Temperature........... }\end{array}$ & $\begin{array}{c}66 \\
4.8 \\
1,532 \\
1,066 \\
\text { Nov. } 8 \\
1926 \\
0\end{array}$ & $\begin{array}{r}6.0 \\
4.1 \\
402 \\
340 \\
\text { Mar. }_{1927} \\
70\end{array}$ \\
\hline
\end{tabular}

53. Drilled well (No. 1633a), 108 feet deep, at Hondo, N. Mex., about 100 yards east of crossroads and on north side of highway, owned by Titsworth Co., Capitan, N. Mex.

54. Drilled well (No. 1791), 1,240 feet deep, in SE. 1/4 SE. 1/4 Sec. 7, T. 21 S., R. 21 E., known as the Deep well and owned by $C$. M. Farnsworth, Roswell, N. Mex. Water reported to be from a sandstone, which may be in the Nogal formation or in the Picacho limestone.

\section{UTHITY OF THE GROUND WATER}

The usefulness of a water for any purpose depends, aside from sanitary considerations, upon the amount and character of the dissolved mineral matter. Waters having a mineral content of more than 2,500 parts per million are, as a rule, not satisfactory for domestic purposes. Waters containing chiefly magnesium and sodium sulphate or sodium chloride may be objectionable for drinking if the mineral content is greater than 1,500 parts per million. Many waters that are objectionable to human beings because of their mineral content can be used for watering stock, but waters containing more than 10,000 parts per million of dissolved solids are not satisfactory even for stock and may have a harmful effect. 
The usefulness of a water for irrigation depends upon the drainage and nature of the soil as well as on the character and amount of the mineral matter dissolved in the water. The more soluble salts (the alkalies) cause the most damage. The following discussion by Collins and Riffenburg ${ }^{46}$ in regard to the quality of the water of the Pecos River for irrigation is applicable also to the ground water in the Roswell artesian basin, inasmuch as the river water and the ground water are similar in chemical character:

The water generally carries more dissolved mineral matter than is considered desirable in irrigation, but this condition is offset by the porous character of the soil, which favors prompt drainage after the use of large volumes of water, and by the high proportion of calcium in the water, which helps the physical condition of the soil.

In a paper on the movement of water in irrigated soils Scofield " notes chemical reactions between soils and waters as determining factors in the movement of the waters. These reactions are also referred to by Harris ${ }^{48}$ in his discussion of soil alkali. Both of the authors named emphasize the importance of drainage as a primary requisite for successful irrigation, regardless of the quality of the water used. Natural drainage may be sufficient to prevent the accumulation of harmful quantities of alkali, but many irrigated areas require artificial drainage. Scofield and Harris give many references to articles dealing with specific instances of irrigation practice and with laboratory experiments.

It is not possible to set any close limits for permissible concentration of salts in water to be used for irrigation. Reports of experiences on irrigation projects referred to by Scofield and by Harris suggest that 1,000 parts per million of dissolved solids is near the limit for satisfactory irrigation water and that water with 3,000 parts per million of dissolved solids requires the greatest care in its use to prevent accumulation of alkali in the soil. Scofield $^{\text {to }}$ states :

"While many crop plants may obtain water from a soil solution which contains more than 1 per cent of dissolved mineral matter, it would appear to be advisable generally to keep the solution below that degree of concentration. In order to do this it follows that in applying irrigation water it should be the aim to use enough so that the proportion lost by percolation is large enough to offset the concentration due to evaporation and transpiration. Thus if the irrigation water contains 1,000 parts per million of salt, enough should be used so that 10 per cent of the quantity applied may percolate below the root zone."

On this principle a water with 3,000 parts per million of dissolved solids should be used in sufficient quantity to permit 30 per cent to percolate below the root zone, and with water containing 5,000 parts per million 50 per cent should be drained away.

The effect of the proportions of the different basic constituents in irrigation waters has been noted by many writers and has been emphasized by Scofield

4 Collins, W. D., and Riffenburg, H. B., Quality of water of Pecos River in Texas : U. S. Geol. Survey Water-Supply Paper 596, pp. 70-71, 1928.

* Scofield, C. S., Jour. Agr. Research, vol. 27, pp. 617-694, 1924.

Harris, F. S., Soil alkali, its origin, nature, and treatment, New York, John Wiley \& Sons, 1820.

4s Scofield, C. S., op, cit., pp. 681-682. 
in his discussion of the permeability of soils. From field studies and experiments and from the results reported by other workers he concludes: ${ }^{50}$

"The injurious effects that have been ascribed to sodium carbonate, or 'black alkali' in irrigated soils appear to be due to the sodium rather than to the carbonate, and sodium in solution, even when associated with the stronger acids, combines with the soil and ultimately causes deflocculation and impermeability.

"The readjustment of the relative proportions of sodium and other bases in an impermeable soil, to the end of improving the physical condition, depends upon replacing the sodium with another base, such as calcium or aluminum, which when combined with the soil brings about a flocculated and permeable condition."

Gypsum has long been recognized as beneflcial in the treatment of soils injured or likely to be injured by alkali. Its application has not been so generally recognized as serving to prevent the replacement of calcium in the soil by sodium in the applied water that occurs when the ratio of calcium to sodium in the soil solution drops too low. Obviously the prevention of this reaction in the soil is much easier than its reversal, because before the replacement the soil is permeable, whereas after it the soil is relatively impermeable and therefore not so easily acted on by solutions that will give up calcium for the sodium.

\section{ORIGIN OF THE SOLUTION OPENINGS IN THE PERMIAN LIME- STONE OF THE ROSWELL ARTESIAN BASIN}

REQUISITE CONDITIONS FOR THE FORMATION OF SOLUTION OPENINGS IN ROCKS BY SUBSURFACE WATER

There are only two general conditions requisite for the formation of solution openings in rocks by subsurface water-the water must contain a solvent of the rocks, and there must be circulation of the water in the rocks. All conditions may be grouped under one of these two headings.

\section{SOLVENTS IN SUBSURFACE WATER}

Salt, gypsum, and anhydrite are readily soluble in pure water, but limestone and dolomite are only slightly soluble. However, when carbon dioxide $\left(\mathrm{CO}_{2}\right)$ is dissolved in water, carbonic acid $\left(\mathrm{HCO}_{3}\right)$ is formed, and this acid converts calcium carbonate (limestone) into the readily soluble calcium bicarbonate $\left(\mathrm{Ca}\left(\mathrm{HCO}_{3}\right)_{2}\right)$. The water that sinks into the ground acquires a certain amount of carbon dioxjde from the air before it percolates into the ground, from the air in the openings in the rocks above the water table, and from decaying vegetation, and it is therefore capable of dissolving limestone. Murray and Love ${ }^{51}$ state that under certain conditions organic acids formed by the action of soil bacteria on decaying vegetation may be very effective solvents of limestone.

so Scofield, C. S., op. cit., p. 692.

61 Murray, A. N., and Love, W. W., Action of organic acids upon limestone : Am. Assoc. Petroleum Geologists Bull., vol. 13, pp. 1467-1475, 1929. 
Carbonic acid is generally the only effective solvent of limestone commonly found in ordinary subsurface waters. The amount of limestone that any given quantity of subsurface water can take into solution, therefore, depends largely upon the amount of carbonic acid in the water. This is strikingly shown by the chemical analyses of waters from the various formations in the Roswell artesian basin. (See pl. 27 and figs. 22-25.) All the formations are calcareous, but some contain much more calcareous material than others. Moreover, the calcareous material in some of the formations, because of its texture and composition, is more easily soluble than that in others. Nevertheless the bicarbonate content of all the waters analyzed, regardless of the formation from which they were obtained, is remarkably constant.

Aside from the amount of carbon dioxide picked up by the water from air above and below the surface, which is small and in general relatively constant, and regardless of the climate, the carbonic acid content of subsurface waters depends largely on the amount of decaying vegetation in the region. This factor may be fully as important in determining the relative amounts of limestone taken into solution by surface and subsurface waters in arid and in humid regions as the relative amounts of these waters in the two regions. Both the amount of vegetation and the amount of available water, of course, are largely determined by the amount of rainfall, but there is probably no direct relation between the carbonic acid con. tent of surface and subsurface waters and the amount of rainfall. About all that can be said in the absence of pertinent data is that during any given interval of time the amount of limestone taken into solution, other things being equal, is generally less in arid or semiarid regions than in humid regions, because in the former both the amount of water and the amount of carbonic acid in the water are less than in the latter.

\section{CIRCULATION OF sUBSURFACE WATER}

OPENINGS IN THE ROCKS

Most limestone is compact and dense, and the interstitial openings in it are generally so minute that they can be disregarded as effective conduits for initial ground-water circulation. Hence, before solution openings are developed in limestone the only connected openings of sufficient size to allow considerable movement of water through the rock are those along joints, irregular fractures, and bedding planes. These openings, however, vary greatly in size and continuity from place to place. In the Roswell artesian basin some of the limestone is moderately coarse grained, and probably the 
interstitial openings in it were sufficiently large to permit slow percolation of water under favorable circumstances.

OUTLETS FOR THE ESCAPE OF THE WATER IN THE ROCKS

It is obvious that if there are no outlets through which the water can escape there can be no circulation of the water in a formation, regardless of the size and continuity of the openings in the rocks and the amount of water entering them. The size of an outlet, other things being equal, controls the rate of movement, and its location largely determines the direction, areal extent, and depth of circulation of the water in any given body of rocks. Hence, the size, number, and location of the outlets through which the water can escape are effective factors in the formation of solution openings in the rocks by subsurface water.

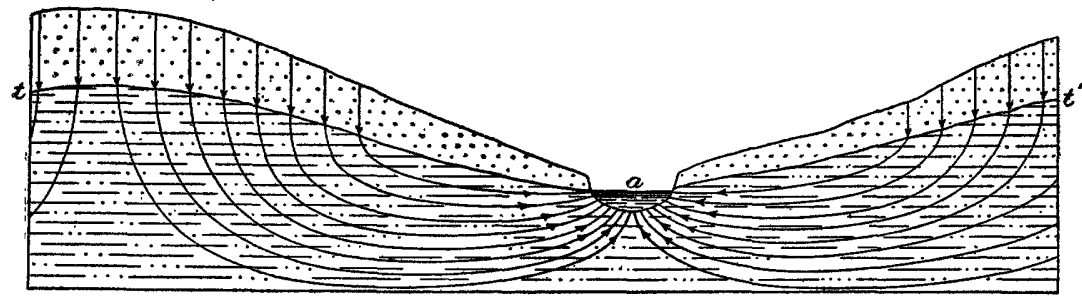

Frgurn 26.-Lines of flow of ground water. After King, F. H., Principles and conditions of the movements of ground water: U. S. Geol. Survey Nineteenth Ann. Rept., pt. 2, p. 99, 1899. $t$ - $t^{\prime}$, Water table; $a$, outlet; lines with arrows are lines of flow

\section{DEPTH OF CIRCULATION OF GROUND WATER}

The depth of circulation of water below the water table depends upon the geologic and hydrologic conditions, and the depth below the water table to which the solution of limestone may extend may be very much greater under artesian conditions than under watertable conditions. Under water-table conditions some of the water follows the paths shown in Figure 26, and the depth of circulation is limited only by the depth of the permeable material. However, in a formation of uniform permeability the rate of movement of the water is greatest along the water table, which affords the shortest path between the intake and the outlet and therefore the least loss in head through friction. Furthermore, the rate of movement of the water in the zone of saturation toward the outlet decreases with depth below the water table.

\section{HYPOTHESES OF THE ORIGIN OF THE SOLUTION OPENINGS}

It is evident that in the aggregate a great amount of solution has taken place in the Picacho limestone. This solution could have been effected only by active circulation of subsurface water in the upper 
half of he Picacho within the artesian area throughout a long interval of gologic time. Furthermore, there must have been circulation of subsurface water in the limestone east of the artesian area. Hence, the hydrologic conditions under which active circulation of subsurface waters in the Picacho and in the limestone east of this area began form the basis for any explanation of the origin and age of the solution openings.

Before solution openings were extensively developed the only connected openings that could have served as effective conduits for the circulation of subsurface water were the joints, fractures, and bedding planes. These openings were small, and they were not all connected with one another. Hence, under any conditions the solution of the limestone must have proceeded very slowly at first.

Artesian circulation probably did not occur in the Picacho limestone until mid-Tertiary time, for prior to Tertiary time the strata were generally flat lying, and therefore effective circulation could not have taken place. The stripping of the Picacho did not occur to any great extent until the later half of the Tertiary period and then only in the western part of the artesian basin. In the eastern half the Triassic and Permian rocks were probably buried beneath a thick mantle of late Tertiary sediments derived largely from the mountains to the west and north. The removal of these sediments and the formation of the Diamond $\mathbf{A}$ plain consumed a large part of Pleistocene time. It appears improbable that the alluvial basin was excavated until after the formation of the Diamond $\mathbf{A}$ plain. As this plain is $\mathbf{1 0 0}$ to 150 feet higher than the present land surface in the artesian area and as the artesian pressure was probably not great enough to force the water above that level, it is not likely that there could have been active circulation of ground water in the Picacho limestone at any time prior to the excavation of the alluvial basin except during the Permian epoch.

There appear to be only two ways, therefore, in which the extensive cavernous zones could have been produced-by artesian circulation during the Pleistocene epoch or by circulation of subsurface waters above and near a water table during the Permian epoch. The writer believes that both have been effective in producing the conditions now found in the Roswell artesian basin.

\section{EVIDENCE OF ARTESIAN CIRCULATION AND OF SOLUTION DURING THE PIEISTOCENE AND RECENT EPOCHS}

SPRINGS

There is little reason to doubt that the Berrendo Springs and North and South Springs in the vicinity of Roswell were fed by artesian water from the Picacho limestone, for the flow of these 
springs nearly or entirely ceased with the marked decline in the head of the artesian water. It is reported that before many artesian wells were drilled there were many small springs along the valley of the Seven Rivers near the west edge of the area of artesian flow and many along the Pecos River. These springs also dried up after the great decline in the head of the artesian water. The springs in the vicinity of Roswell discharged large quantities of water, and there was probably a fairly rapid artesian circulation in this vicinity. These springs, however, and those in the valley of the Seven Rivers were along or near the west edge of the area of artesian flow, where the Permian and Quaternary deposits overlying the Picacho are thin. Throughout most of the artesian area, especially in the central part, the Picacho limestone is deeply buried and the artesian circulation that caused the small springs along the Pecos River was doubtless slow.

The large masses of travertine near the east edge of the upper part of the Cottonwood segment appear to have been formed by springs. If so, the springs were probably supplied with artesian water derived directly or indirectly from the Picacho limestone and there was probably fairly rapid artesian circulation in.that vicinity. In the upper part of the Cottonwood segment, however, the Pecos formation and the Quaternary deposits overlying the Picacho are comparatively thin.

REOHARGE OF WATER IN THE PECOS FORMATION AND THE VALLEY FTL

It is probable that much of the water in the Pecos formation and in the valley fill is derived from the underlying Picacho limestone by upward percolation (see pp. 123, 133) and that much of this water escapes into the Pecos River, thus causing a small amount of artesian circulation. But as there are many thick impermeable beds in the overlying Permian and Quaternary deposits, the rate of this circulation is very slow, though it was doubtless greater before the drilling of the artesian wells than at present.

CAVERNOUS LIMESTONE IN THE PBCOS FORMation

Beneath the artesian area there are many lenticular beds of cavernous limestone in the Pecos formation, most of which do not crop out. These beds are now and probably have been since Permian time far below the water table. If there are local unconformities in the Pecos formation, it is possible that the solution openings in these lenticular beds of limestone are the result of ground-water circulation during the Permian. However, no definite evidence of local unconformities within the Pecos formation was found, and it appears more probable that the solution openings are the result of artesian circulation during Pleistocene and later time. 
The absence of highly saline water in the Picacho limestone beneath the artesian area definitely indicates that there has been a large amount of circulation of fresh water in the Picacho since Permian time. Inasmuch as there was little opportunity for the circulation of fresh water in the limestone prior to the Pleistocene epoch and as the waters encountered in the limestone in the oil fields east of the artesian basin are highly saline, it appears very probable that the saline water has been flushed out of the Picacho by artesian circulation within the artesian basin since the beginning of the Pleistocene.

REILATION OF AREAS OF GREAT PGRMEABILITY TO MAJOR DRAINAGE IINES

Each of the five segments of large artesian yield is traversed by one of the major surface drainage lines from the west. This remarkable relationship suggests that the higher permeability of the cavernous zones in the limestone beneath these segments is the result of more active ground-water circulation close to the large surface drainage lines than in the intervening areas. As most of the surface run-off from rainfall over large areas is eventually concentrated along the major drainage lines, more water will, as a general rule, sink into the limestone along them than in the intervening parts of the intake area. Although the major lines of underground drainage do not everywhere coincide with those of surface drainage, the correspondence is in many places fairly close.

Inasmuch as there is upward leakage of artesian water from the Picacho limestone through the overlying Pecos formation and Quaternary deposits at the present time, there was probably much greater leakage when the land surface in the alluvial basin was lowest-after the dissection of the Diamond A plain and before the deposition of the quartzose conglomerate. At that time the pressure head of the artesian water with respect to the land surface was very much greater. It was greatest beneath the channels of the Pecos River and its major tributaries. Consequently, it is not unreasonable to assume that the maximum discharge of the artesian water generally occurred along these streams. Inasmuch as the circulation of ground water is controlled by the outlets, the artesian water doubtless moved from all sides toward these points of discharge, and its rate of movement was probably greater in the vicinity of the streams than beneath the intervening areas. Although no evidence of springs was found, it is not reasonable to expect any; travertine or other evidence of the springs would, of course, be concealed by the thick mantle of alluvial deposits. 
With the exception of Cottonwood Creek all the larger streams crossing the five good segments have large drainage basins in the mountains and in the limestone uplands. The greater amount of water sinking into the ground along these drainage lines in the intake area and the greater discharge of water along them in the artesian area would tend to increase the amount of solution of the limestone in their vicinity in the artesian area. The solution openings in these areas would therefore increase in size more rapidly than those in the intervening areas, and with increase in the size of the openings the rate of artesian circulation would also increase, which in turn would further increase the rate of solution of the limestone.

It has been suggested that the five areas of greater permeability may be related to surface drainage established during Permian time after the deposition of the Picacho limestone but before the deposition of the Pecos formation. A comparison of Plates 25 and 41 shows no apparent relationship between these five areas and the drainage lines indicated by the contours on the top of the Picacho. Furthermore, it would be a most remarkable coincidence if the present major drainage lines coincided with those formed during the Permian. Hence, it seems more probable that these areas of greater permeability are related to the present surface drainage and that they are the result of artesian circulation during the Pleistocene and Recent epochs.

The unusual hydrologic conditions in the Cottonwood segment (see pp. 203-204) appear to be due solely to differences in the cavernous condition of the limestone, for there is no evidence of faulting or of any unusual structural conditions that might account for them. The rather uniform hydrologic conditions within each of the three parts of this segment, the marked changes in these conditions within narrow limits between the three parts, and the fact that the conditions are most favorable in the upper part and least favorable in the lower part suggest that the progressive differences in the cavernous condition of the limestone are the result of artesian circulation which was controlled by outlets to the surface at the east edges of the upper and intermediate parts of the Cottonwood segment. The upper part benefited from all of the artesian water reaching it; and as the thickness of red beds overlying the Picacho was least there, conditions were most favorable for active artesian circulation and solution of the limestone beneath that part of the segment. As some of the artesian water from the west escaped at the surface through outlets at the east edge of the upper part, the intermediate part of the Cottonwood segment received less water; the water reaching it, being farther from the source, had less solvent power; and, as the limestone was 
more deeply buried, there was less active artesian circulation and solution of the limestone. Similarly the conditions were still less favorable for active artesian circulation and solution of the limestone beneath the lower part of the Cottonwood segment.

The presence of outlets for the artesian water near the east edge of the upper part of the Cottonwood segment is inferred from the large masses of travertine, which appear to have been formed by springs supplied with artesian water derived directly or indirectly from the Picacho limestone. Although the red beds overlying the Picacho here are relatively thin, the conditions to which the presence of the springs is due are not apparent. There is no evidence of faulting at this place, but it is possible that there were open fractures in the rocks through which the water in the limestone found easy access to the surface and that these openings have since become filled or covered by impermeable materials. No evidence of former outlets near the east edge of the intermediate part were found, though it is possible that there may have been outlets which have since been covered by the valley fill. It is conceivable that in the narrow belt near the east edge of the intermediate part of the Cottonwood segment, where the hydraulic gradient is unusually steep, the limestone was less permeable than elsewhere and, consequently, the water was not able to percolate eastward easily but escaped at the surface in the form of springs. Such springs, once established, would have controlled the artesian circulation in the limestone between them and the upper part of the Cottonwood segment. Similar conditions may have determined the location of the springs that formed the travertine near the east edge of the upper part of the Cottonwood segment, but no evidence to support this suggestion was found.

The apparently anomalous fact that although the present drainage basin of Cottonwood Creek is small the Cottonwood segment is one of the best in the artesian area suggests that the underground drainage tributary to the Cottonwood segment is much greater than might be inferred from the size of the present surface drainage basin. It is possible that after the dissection of the Diamond A plain began, but prior to the final excavation of the alluvial basin, the lower Rio Penasco, the part of the Rio Felix west of the heads of Cottonwood Creek, and the upper part of Eagle Draw may have drained eastward into the Pecos River along the present valley of Cottonwood Creek, and that the underground drainage channels then formed have persisted in spite of the subsequent capture of the surface drainage and the diversion of the Rio Penasco, the Rio Felix, and Eagle Draw into their present channels. This hypothesis is suggested by the present surface drainage pattern and by the topography in the vicinity of these streams, but no conclusive evidence was found. 


\section{EVIDEXOE}

\section{OF GROUND-WATER CIRCULATION AND OF SOLUTION UNDER} WATER-TABLE CONDITIONS DURING PERMIAN TIME

The conditions described above indicate that a notable amount of solution has been effected by artesian circulation during Pleistocene and Recent time. However, they do not necessarily prove that the cavernous condition of the Picacho limestone has been produced entirely by artesian circulation since early Pleistocene time. There is strong evidence that a large part if not most of the solution was effected under water-table conditions during the Permian epoch.

UNCONFORMITT BETWEEN THE PIOACHO LIMESTONE AND THE PECOS FORMATION

Evidence of an erosional unconformity between the Picacho limestone and the Pecos formation has been presented on pages 86-87. The presence of an erosional unconformity at the top of the Picacho definitely suggests that solution openings were formed in the limestone by the circulation of subsurface water above and near a water table during the Permian epoch. An examination of Plate 25 shows that there are many depressions in that ancient land surface which have the appearance of sink holes formed by the solution and removal of soluble beds. Several of the depressions are very large, indicating that a large amount of solution was required for their formation.

The production of an erosion surface with a maximum relief of more than 200 feet on the Picacho limestone probably required a long time and suggests that the land surface was several hundred feet.above sea level. If the upper few hundred feet of the limestone was above the water table it is not unreasonable to assume that extensive solution openings were formed by the circulation of subsurface water above and near the water table throughout the artesian area.

CAVGRNOUS ZONES IN THE IIMESTONE EABT OF THE PECOS RIVER

The bluffs along the east side of the Pecos probably marked the eastern limit of active artesian circulation, as the lowest outlets for the artesian water were doubtless close to the Pecos River. It is not improbable that the artesian circulation controlled by the outlets along the Pecos may have been sufficiently active to form solution openings in the limestone a short distance east of the bluffs, but it does not seem probable that the solution openings in the limestone beneath the oil fields far to the east could have been formed in this way. The artesian head was probably never great enough to force the water to the surface east of the bluffs. Moreover, it does not seem at all likely that artesian circulation effective enough to form extensive cavernous zones extended to the east and southeast limits of the Permian basin. If there had been artesian circulation across the 
Permian basin the oil and salt water now found in the limestone beneath the oil fields would probably have been flushed out.

The writer believes that the only satisfactory explanation for the presence of extensive solution openings in the limestone east of the Pecos is that the limestone was raised above the sea and subjected to erosion during the Permian epoch and that the solution openings were formed by the circulation of subsurface water above and near the water table at that time.

HIGHER PERMEABILITY OF THE LOWER CAVERNOUS ZONES AND SCARCTTY OF CAVERNoUs zoNES IN THE LOWER HALF OF THE PICACHO

If the cavernous zones in the limestone were produced entirely by artesian circulation, the upper ones might reasonably be expected to be more permeable than the lower ones, for, other things being equal, the circulation would be more active near the top than farther down, though there might be some circulation of water and therefore some solution of the limestone even in the lowest part. The fact that the lower cavernous zones in the upper half of the Picacho are generally more permeable than the upper zones and the further fact that there do not appear to be any extensive cavernous zones in the lower half of the limestone are difficult to account for if it is held that the cavernous condition of the limestone is entirely the result of artesian circulation. It is possible that the scarcity of cavernous zones in the lower half of the Picacho may be due to differences in the character of the limestone, but this does not appear to be the case. In the outcrop area, where the base of the limestone is above or near the water table, the lower half of the Picacho is almost as cavernous as the upper half is beneath the artesian area. This indicates that the character of the limestone in the lower half is not unfavorable for the formation of solution channels under suitable conditions.

If in the Permian epoch, when the Picacho was above the sea, the length of time during which the main water table was at the position of the lower cavernous zones was greater than that during which it was near the upper zones, the lower zones would have become more permeable than the upper ones. And if the lower half of the limestone was always well below the main water table, it is improbable that extensive solution channels would have been formed in this half.

HIGH PERMEABIIITY OF THE CAVERNOUS ZONES IN, ALL PARTS OF THE ARTESIAN AREA

The permeability of the cavernous zones in the Picacho is high in all parts of the artesian area, even -in the areas between the good segments. So great an amount of solution required active circulation of subsurface water throughout the artesian area during a very long period. 
It is questionable whether all of the solution that has taken place could have been accomplished if the limestone had not been made cavernous during the Permian epoch, because the rate of movement of the water would have been controlled not only by the small interstitial openings in the sand and clay of the overlying Pecos formation but also by the small size of the mechanical openings in the limestone. The pressure available for establishing artesian circulation by forcing the water upward through the small interstitial openings in the overlying fine sand and clay of the Pecos formation would have been much less than if the openings in the limestone were large. Hence the amount of water and the rate of movement of the water in the limestone beneath the artesian area would have been very small. 'As a result, most of the carbonic acid in the water would have been consumed near the source. The length of time that would have been required for the crevicing of the upper part of the limestone throughout the artesian area would have been much less under water-table conditions during Permian time than under the conditions of generally slow artesian circulation that existed during Pleistocene time.

\section{CONCLUSTONS}

The evidence presented above indicates that there has been considerable artesian circulation in the Picacho limestone since the beginning of the Pleistocene epoch. The remarkable relationship of the areas of relatively great permeability of the limestone to the major lines of surface drainage and the presence of cavernous limestone in the Pecos formation indicate that a large amount of solution was effected by artesian circulation. The hypothesis of Pleistocene artesian circulation, however, does not satisfactorily account for the presence of cavernous zones in the limestone many miles east of the bluffs along the Pecos River, the higher permeability of the lower cavernous zones, the scarcity of solution channels in the lower half of the Picacho beneath the artesian area, and the high permeability of the cavernous zones throughout the artesian area. Furthermore, the contours on the upper surface of the Picacho (see pl. 25) indicate an erosional unconformity and give evidence that considerable solution of the limestone occurred during the Permian epoch. These conditions are all better accounted for by the hypothesis that a large part of the solution of the limestone was accomplished by circulation of subsurface water under water-table conditions through a long interval in the Permian epoch before the deposition of the Pecos formation, during which the Picacho limestone was above the sea and exposed to erosion, and that the high permeability in the segments traversed by the major tributary streams is the result of additional solution accomplished by artesian circulation in 
the Quaternary period. The many apparently anomalous artesian conditions that exist in the Roswell artesian basin are probably due to erratic solution channels produced under these two widely different sets of conditions and modified by structural features.

\section{GROUND-WATER DEVELOPMENT}

\section{By A. G. FredLer}

\section{EARLY IRRIGATION DEVELOPMENT}

In 1880 irrigation in this section of the Pecos Valley was confined to a few small farms. The first white men to enter the valley were cattlemen, who tried to prevent extensive irrigation development. The original irrigation systems in the vicinity of Roswell derived their water supply from the North and South Spring Rivers and the Berrendo Creeks. (See fig. 27.) The ditches from these streams were gradually extended by the landowners until most of the water from these sources was diverted for irrigation farming. The water was not utilized at a very high duty, and in view of the quantity of water available the size of the irrigated area was not nearly so large as it doubtless would have been under modern irrigation practice. With the development of artesian water the flow of the North and South Spring Rivers and the Berrendo Creeks gradually declined, and as a result most of the early ditches have been abandoned because of inadequate water supply.

The Northern Canal was part of a very extensive irrigation scheme that was planned for the irrigation of a large part of the Pecos Valley extending from Roswell to the Texas State line. The Northern Canal system is described in a report ${ }^{52}$ by the Department of Agriculture as follows:

The Northern Canal system receives the unused waste and drainage water from the Roswell district, together with water from the Hondo when that stream is flowing. The Northern Canal flows from 90 to 125 cubic feet of water per second. The canal starts at a dam in the Hondo directly east from Roswell. This diverting dam collects the various waters of the Berrendos, North Spring River, and the Hondo River, and where the canal crosses South Spring River a second dam is constructed, which diverts the water of the South Spring River. For a distance of nearly 20 miles below South Spring River no water is taken out from the canal. On both sides of the Felix, level farming land is watered from the Northern Canal. The canal extends to a distance of about 5 miles beyond the Felix River.

Though the present system of the Northern Canal is essentially the same as that just described, the character of its water supply has changed in some particulars. The present water supply for the canal is derived chiefly from return flow from irrigation, water reclaimed

Fa Field operations of the Division of Soils, 1899 : U. S. Dept. Agr. Rept. 64, p. 42, 1900. 
by drainage, the water from eight artesian wells, and relatively small amounts of water from the tributary streams that are diverted.

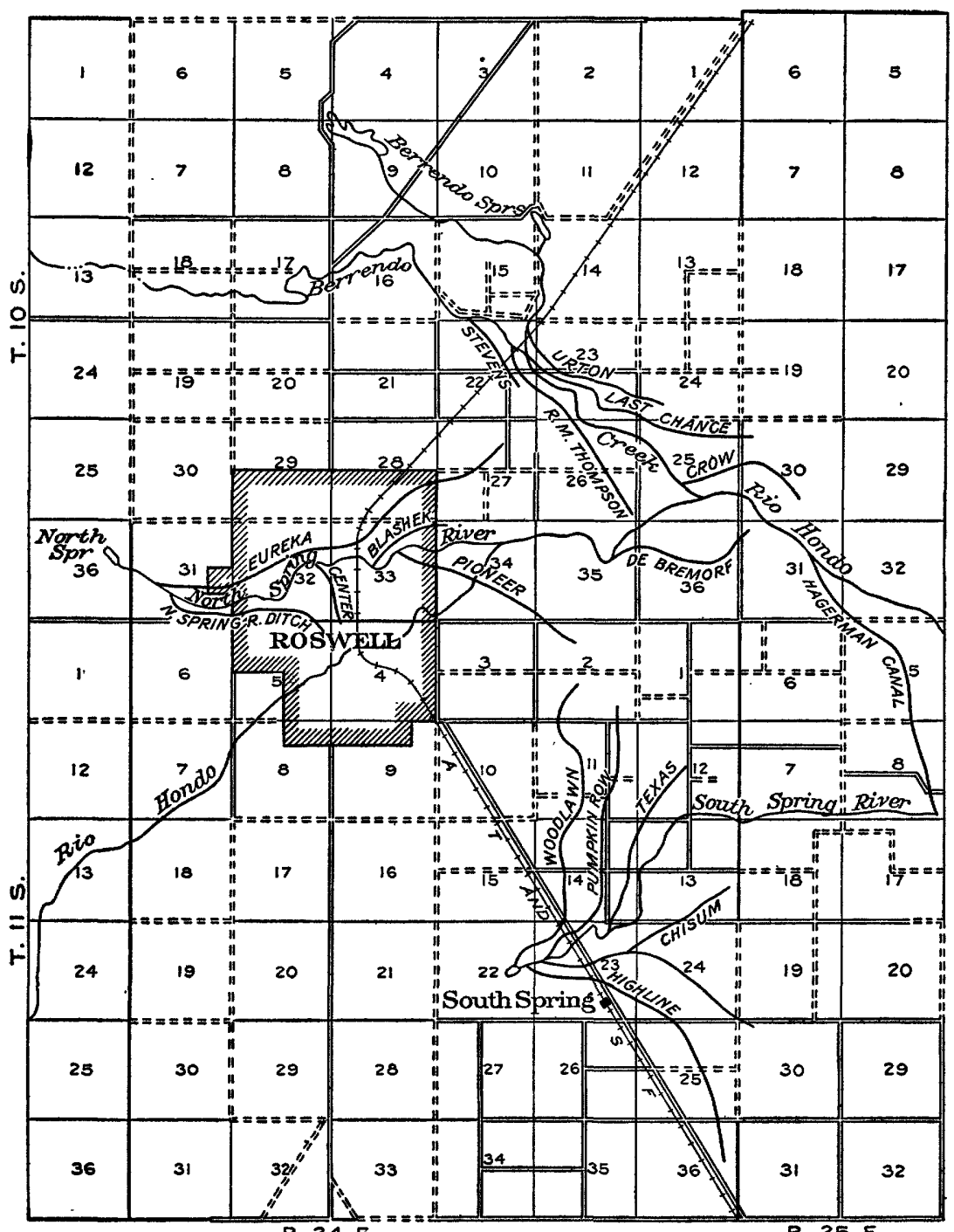

R. 24 E.

$1 / 20$

3 MILES

R. 25 E.

- Figdri 27.-Map showing location of early irrigation ditches in the vicinity of Roswell

DEVELOPMENT OF THE ARTESIAN WATER ${ }^{\text {s }}$

The first flowing well of which there is a definite record was drilled in the city of Roswell in the spring of 1891 and flowed only about 1

GB For deflnitions of terms see pp. 114-115. 
gallon a minute. During the next few years drilling gradually increased, and by 1900 there were 153 wells in the area. Most of the early wells were drilled in Roswell and its vicinity and were used chiefly for domestic supplies and the watering of gardens and lawns. As the quantity of water diverted for irrigation from the tributary streams was only sufficient to irrigate a small portion of the arable land, wells to obtain irrigation supplies were drilled, beginning about 1903 in Chaves County and 1904 in Eddy County. Many of the early wells drilled for irrigation flowed between 500 and 1,000 gailons a minute, and a few were reported to flow as much as 1,500 gallons a minute. In many of the wells, however, the opening was constricted so as to enhance the spectacular effect of the flowing water and give the appearance of a large yield.

Although 485 artesian wells had been drilled by the end of 1905 , there had been no noticeable decline in artesian head, except in the vicinity of Artesia. In view of the high initial artesian head in Eddy County, together with the greater depth of the wells and the nature of the formations overlying the artesian aquifers, it was much more difficult to drill a perfect well in this area than in the vicinity of Roswell. New drillers were constantly coming into the area because of the demand for wells, and though the operators were skilled in the art of drilling, many of them were entirely unfamiliar with the locality. It can readily be seen that under such circumstances imperfect construction was likely to result and that such construction probably was a contributing cause of the decline in head noted in that segment of the area.

The large yield of the wells created much interest, and though some decline in head had occurred prior to 1905 , as shown by measurements made by Fisher, ${ }^{54}$ the decline was unnoticed or was disregarded by the inhabitants, and the supply was considered inexhaustible.

Prior to 1905 most of the wells drilled were 6 inches or less in diameter. From 1905 to 1910 approximately an equal number of 6-inch and 8-inch wells were drilled. After 1910 most of the wells drilled were 8 inches in diameter or larger. Since 1920 the preference has been for 10-inch wells, and approximately 65 per cent of the 10-inch wells were constructed during the period 1920 to 1927. The total number of artesian wells drilled in the artesian basin from 1891 to 1927 , by periods and by counties, is shown in the following tables and in Plate 28. Of the total number of wells drilled, 66 per cent are in Chaves County and 34 per cent in Eddy County.

\footnotetext{
64 Fisher, C. A., Preliminary report on the geology and underground waters of the Roswell artesian area, N.Mex.; U. S. Geol. Survey Water-Supply Paper 158, p. 20, 1906.
} 


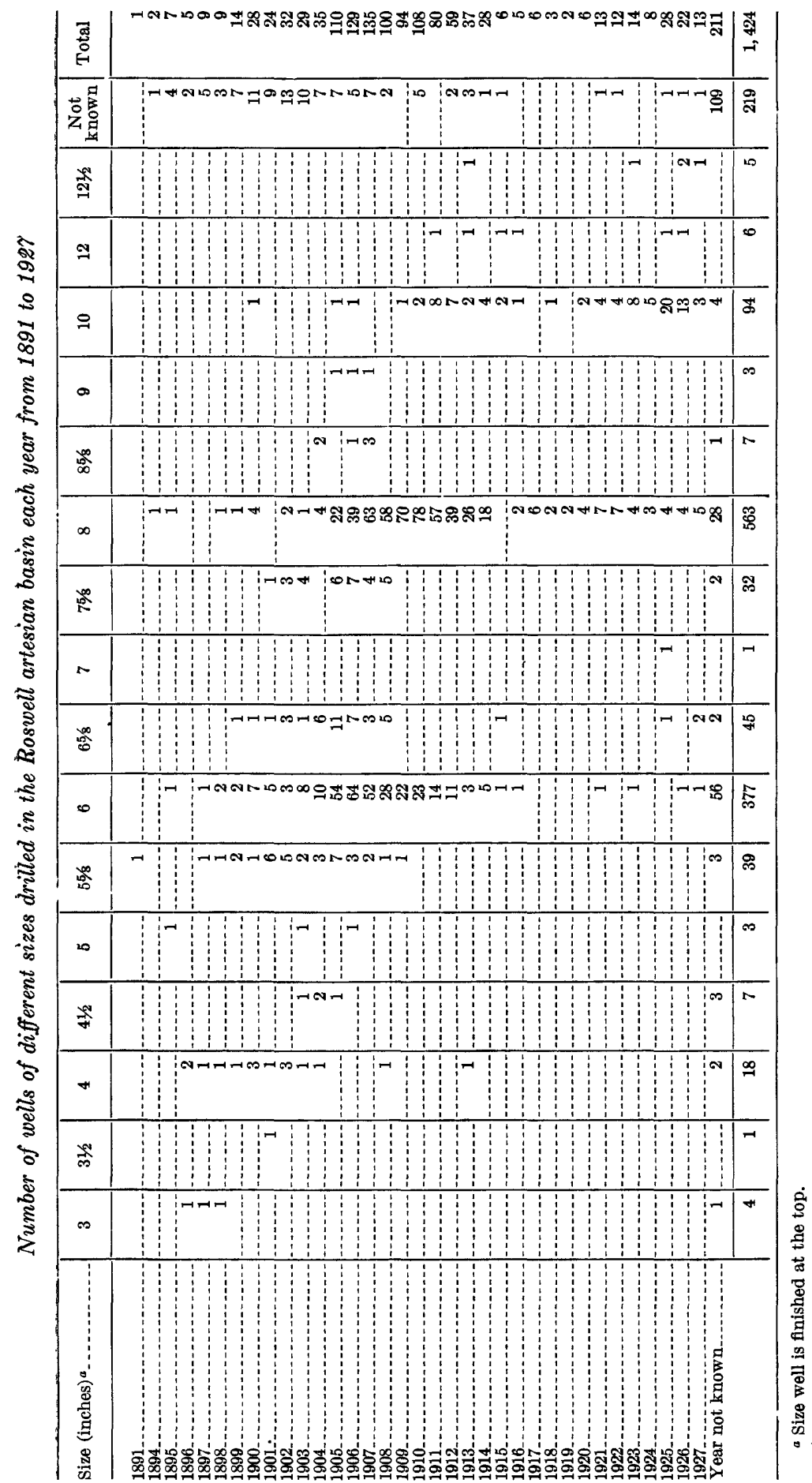


Number of artesian wells arilled in the Roswell artesian basin to the end of 1927, with the percentage of wells in each county

\begin{tabular}{|c|c|c|c|c|c|c|}
\hline \multirow{2}{*}{ Period } & \multicolumn{2}{|c|}{ Chaves County } & \multicolumn{2}{|c|}{ Eddy County } & \multicolumn{2}{|c|}{ Total } \\
\hline & Number & Per cent & Number & Per cent & Number & Per cent \\
\hline $\begin{array}{l}\text { Prior to } 1901 \\
1901-1905 \\
1906-1910 \\
1911-1915 \\
19161920 \\
1921-1925 \\
1926-1927\end{array}$ & $\begin{array}{r}134 \\
196 \\
345 \\
171 \\
13 \\
52 \\
29\end{array}$ & \begin{tabular}{r|}
14.2 \\
20.9 \\
36.7 \\
18.2 \\
1.4 \\
5.5 \\
3.1
\end{tabular} & $\begin{array}{r}19 \\
136 \\
252 \\
39 \\
9 \\
23 \\
6\end{array}$ & \begin{tabular}{r|}
3.9 \\
28.1 \\
52.1 \\
8.0 \\
1.9 \\
4.8 \\
1.2
\end{tabular} & $\begin{array}{rl}a & 153 \\
a & 332 \\
a & 337 \\
210 \\
210 \\
22 \\
75 \\
35\end{array}$ & $\begin{array}{r}10.7 \\
23.3 \\
41.9 \\
14.8 \\
1.5 \\
5.3 \\
2.5\end{array}$ \\
\hline & 940 & 100.0 & 484 & 100.0 & 1,424 & 100.0 \\
\hline
\end{tabular}

- Includes wells listed in the preceding table under the heading "Year not known."

During the 5-year period 1905 to 1909 there were 620 wells drilled. This number represents 43.5 per cent of the total number drilled and covers the most active 5-year period of drilling in the history of the area. During the 10-year period 1905 to 1914 there were 938. wells drilled, or 65.8 per cent of the total. Such a marked increasein the number of wells and the consequent rapid increase in the draft on the artesian reservoir caused a very noticeable change in the artesian head. This condition became most evident along the west. side of the valley, where a belt of land had been developed by pumping from nonflowing artesian wells and from wells that yielded only small quantities of water by natural flow because of their small heads. As the head declined at about the same rate in the pumped wells as in the flowing wells with the rapid increase in drilling during the period 1905 to 1914 , many pumping plants previously operated were abandoned, and farms at somewhat lower levels could continue irrigation only by the installation of expensive pumping equipment.

According to a survey made in connection with the present investigation, in 1926 and 1927 there were 54 wells that yielded between 1,000 and 1,500 gallons a minute, 24 wells that yielded between 1,500 and 2,000 galions a minute, 5 wells that yielded between 2,000 and 3,000 gallons a minute, and 2 wells that yielded more than 3,000 . gallons a minute, either by natural flow or by pumping.

An artesian well that created great interest by reason of its large yield was completed in the Roswell Basin during the course of the present investigation. This well, which was drilled for the Oasis Cotton Co., had a measured flow of 5,710 gallons a minute on April 21,1926 , and the water issued from the 121/2-inch casing to a height of 5 feet. (See pl. 29, A.) The artesian head was several feet higher at the time the well was completed, in March, 1926, than on the date that the flow was measured. The flow at the time of comple- 
tion is estimated to have been about 6,000 gallons a minute and, according to the best information available, this well yielded more water by artesian pressure than any other well in the United States and probably in the world. Because this well yielded so much more water than any other well that had previously been drilled in the Roswell basin, it was assumed by many of the local people to constitute additional evidence that the artesian supply was inexhaustible. Therefore, it is considered advisable to point out the fact that this well draws upon the same general source of supply as the other artesian wells of the basin.

\section{DEVELOPMENT OF THE WATER IN THE VALLEY FILL}

There has been very little development of the shallow ground water in this area, and it has only been in recent years that this source of water supply has begun to receive attention.

In some nonflowing artesian wells that are pumped, shallow wells have been drilled in the bottom of the pump pit and connected with the main pumping equipment. Because these wells only supplement the artesian wells, proper attention is not usually given to the drilling and development of the shallow well. In most of these wells the quantity of shallow ground water recovered is not very large.

A tract of 140 acres on the Rio Felix about 4 miles west of Hagerman has been successfully irrigated for about 12 years with water pumped from two shallow wells. Because of the gradual failure of an artesian flowing well, which ultimately was abandoned, a smaller tract in the same area was partly irrigated by water obtained from a shallow well for approximately the same period. The results obtained by these installations created some interest, and other shallow wells were drilled in this area in 1925, 1926, and 1927. At the end of 1927 there were five plants in operation for the irrigation of 580 acres in the Felix shallow-water district. In this locality shallow ground water is within 18 to 35 feet of the surface, and properly constructed wells yield from 600 to 800 gallons a minute. (See also pp. 260-263.)

\section{HEAD OF THE ARTESIAN WATER}

\section{ORIGINAL HEAD}

According to observations made by Fisher ${ }^{55}$ in 1904 , the pressure on several wells in the vieinity of Roswell was sufficient to raise the water to an altitude of 3,586 feet above sea level. This was the same as the altitude of the water surface at the head of the North Spring River, west of Roswell. During the present investigation these de-

\footnotetext{
55 Fisher, C. A., Preliminary report on the geology and underground waters of Roswell artesian area. N. Mex. : U. S. Geol. Survey Water-Supply Paper 158, pp. 9, 20, 1906.
} 
terminations were checked by running levels to several of the wells observed by Fisher. The exact point of reference used by him was not ascertained, but after allowance has been made for the maximum possible error due to this cause, the available information indicates that in 1904 the artesian water at the north end of the basin did not rise higher than 3,590 feet above sea level.

The fact that the initial pressure head of the wells was sufficient to raise the water to the same altitude as the water surface at the North Spring suggests that these springs acted effectually as controlling valves on the artesian reservoir and prevented the building up in this segment of the area of an artesian head higher than their level. A study of the geology of the region indicates that the water of the springs had probably the same origin as the artesian water, and the springs may, in a sense, be regarded as natural artesian wells of large capacity. They controlled the maximum head of the artesian water in the Berrendo tract, north of Roswell, by reason of the fact that they afforded a natural outlet for the artesian water. The Berrendo tract comprises T. 10 S., R. 24 E.. except the portion south of a line drawn through the north boundary of the city of Roswell. Although the artesian head may at times have been somewhat higher than the level of the springs, such increased head caused an increased discharge and thereby automatically prevented the building up of the artesian head.

In June, 1905, the pressure of a well in the SW. 1/4 NW. 1/4 sec. 25 , T. 10 S., R. 24 E., was sufficient to raise the water to an altitude of 3,581.8 feet above sea level. This well is about 5 miles east of North Spring, and the altitude to which the water rose was only about 4 feet lower than that of North Spring. The hydraulic gradient eastward from North Spring was therefore relatively flat, indicating that the discharge in this segment prior to 1905 was relatively small compared with the discharge during the period 1925 to 1928. The slope of the piezometric surface is toward the point of discharge, and it appears that prior to the drilling of wells the piezometric surface in the north end of the area must have been nearly horizontal below the level of the springs. Westward from the springs there was undoubtedly a hydraulic gradient of considerable magnitude, in view of the large discharge from these openings.

In 1904 Fisher made observations on certain wells in the south end of the artesian area and found that the artesian pressure in this section was sufficient to raise the water to an altitude of 3,563 feet above sea level. ${ }^{58}$ The altitude of several other wells ${ }^{87}$ upon which Fisher made observations was checked by a level line during the

* Fisher, C. A., Unpublished map made to define probable area of artesian fiow, 1904.

"7 Fisher, C. A., Preliminary report on the geology and underground waters of the Roswell artesian area, N. Mex. : U. S. Geol. Survey Water-Supply Paper 158, p. 20, 1906. 
present investigation, and it was found that the pressure of the wells, as measured in June, 1904, was sufficient to raise the water to altitudes of 3,555 to 3,560 feet. Unfortunately, observations for this period on wells in the extreme southeast corner of the basin are not available, though it would seem that the artesian pressure was sufficient to raise the water nearly to the same height as that indicated by the pressure of other wells in the southern part of the basin. As shown by measurements made during the period June, 1904, to May, 1905, on wells in the vicinity of Artesia some decline in head occurred in this segment of the area, and in view of the marked decline that has occurred since, it would seem that an appreciable decline in head had already occurred prior to the first observations made in 1904.

Some water doubtless escapes from the southeast corner of the artesian reservoir (see also p. 231) and because of this leakage the piezometric surface in this part would be somewhat lower than in the rest of the area, though apparently the level was not greatly below that at the north end. As the static level of the water in wells in the southern part of the area in 1904 was only from 23 to 31 feet below the water level of wells observed in the north end, and as it appears that some decline had occurred in the south end prior to the observations made in 1904, the conclusion is drawn that the head in the southern part of the area was nearly as high as that in the northern part prior to the drilling of wells.

Fisher ${ }^{68}$ suggested the possibility that the artesian head increases to the west and that artesian flows might be obtained higher up the slopes in the valleys of the Rio Felix, Cottonwood Creek, and the Rir Penasco than was indicated on his map of the area of artesian flow Subsequent drilling within the area has shown this to be true along Cottonwood Creek, in T. 16 S., R. 24 E. The first well drilled in the upper Cottonwood locality on which the original pressure was recorded is in lot 13, sec. 1, T. 16 S., R. 24 E. This well was drilled in April, 1906; and if the initial pressure as reported is correct, it was sufficient to raise the water to an altitude of 3,610 feet above sea level. Subsequent drilling throughout the artesian area indicates that it is only within the relatively small area on Cottonwood Creek that the head was originally higher than in the remainder of the artesian basin.

HEAD IN 1926, 1927, AND 1928

The artesian head has varied greatly according to the locality. When the artesian basin was first tapped the artesian water rose in tightly cased wells to nearly the same level in all of the artesian area east of and below the level of the outlet of the springs in the north

Fisher, C. A., op. cit., p. 8. 


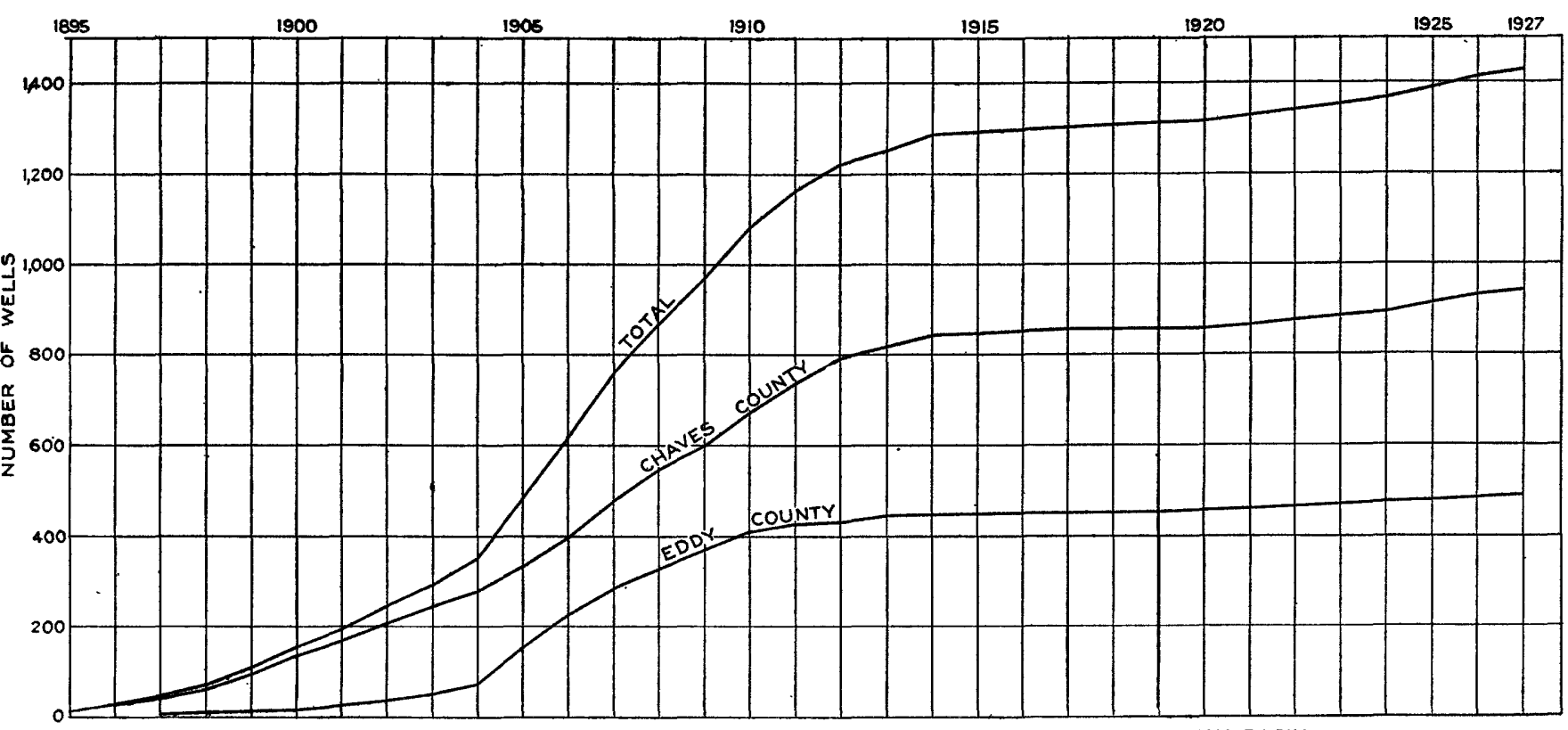

NUMBER OF WELLS DRILLED TO ARTESIAN HORIZONS IN ROSWELL ARTESIAN BASIN

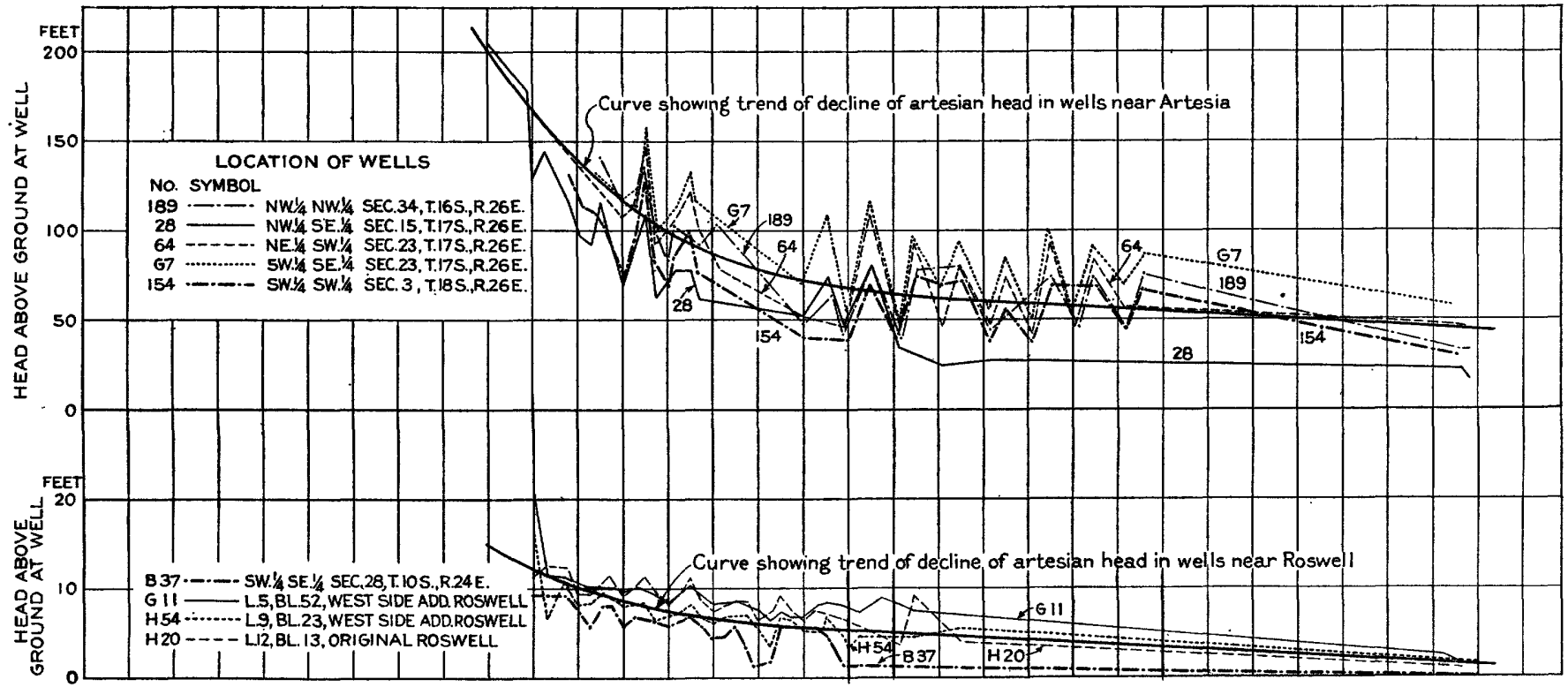
FLUCTUATIONS OF ARTESIAN HEAD IN TYPICAL WELLS

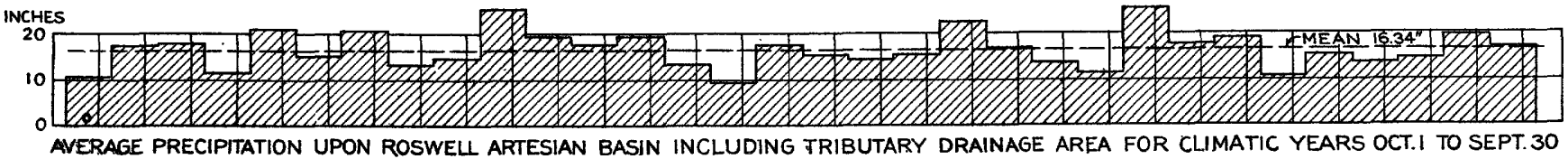
NUMBER OF ARTFSIAN WELLS DRILLED, FLUCTUATIONS OF ARTESIAN HEAD, AND AVERAGE ANNUAL PRECIPITATION IN THE ROSWELL ARTESIAN. BASIN, 1895 TO 1927 


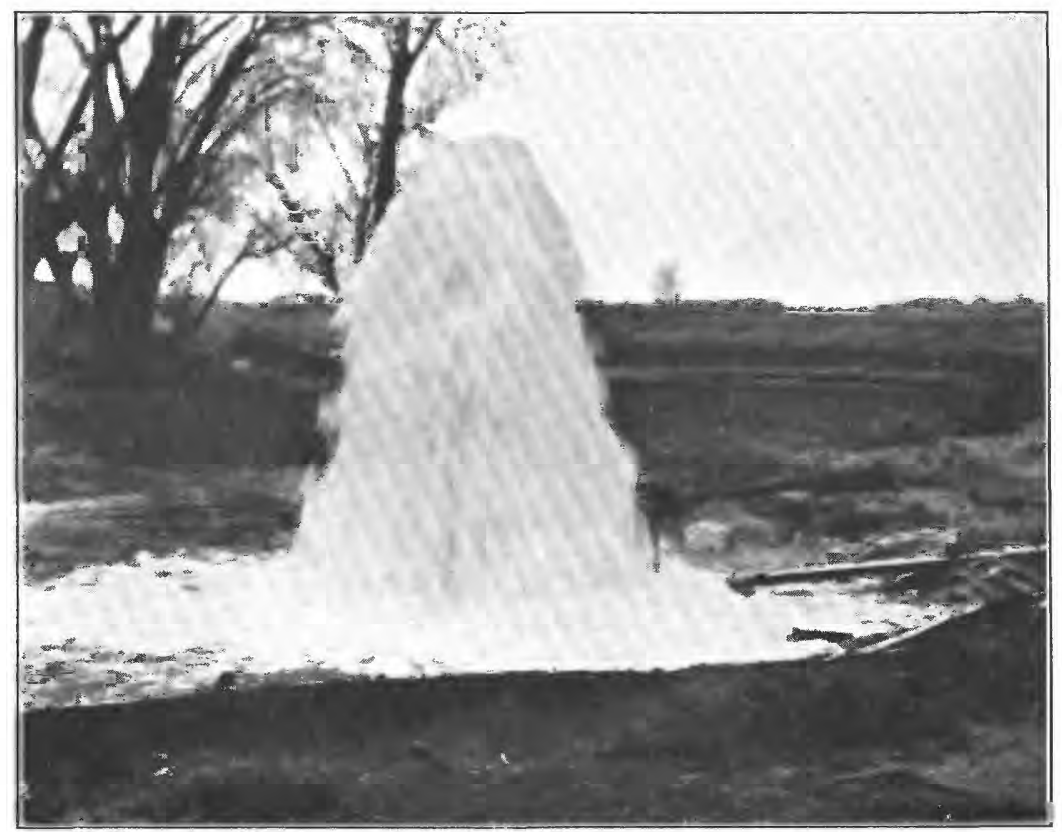

A. WELL OF UASIS COTTON CO., IN THE NW. 1/4 SEC. 22, T. 11 S., R. 25 E.

This well is 780 feet deep and 1216 inches in diameter. On April 21. 1926. it had a flow of 5,710 gallons a minute. Photograph by A. G. Fiedler.

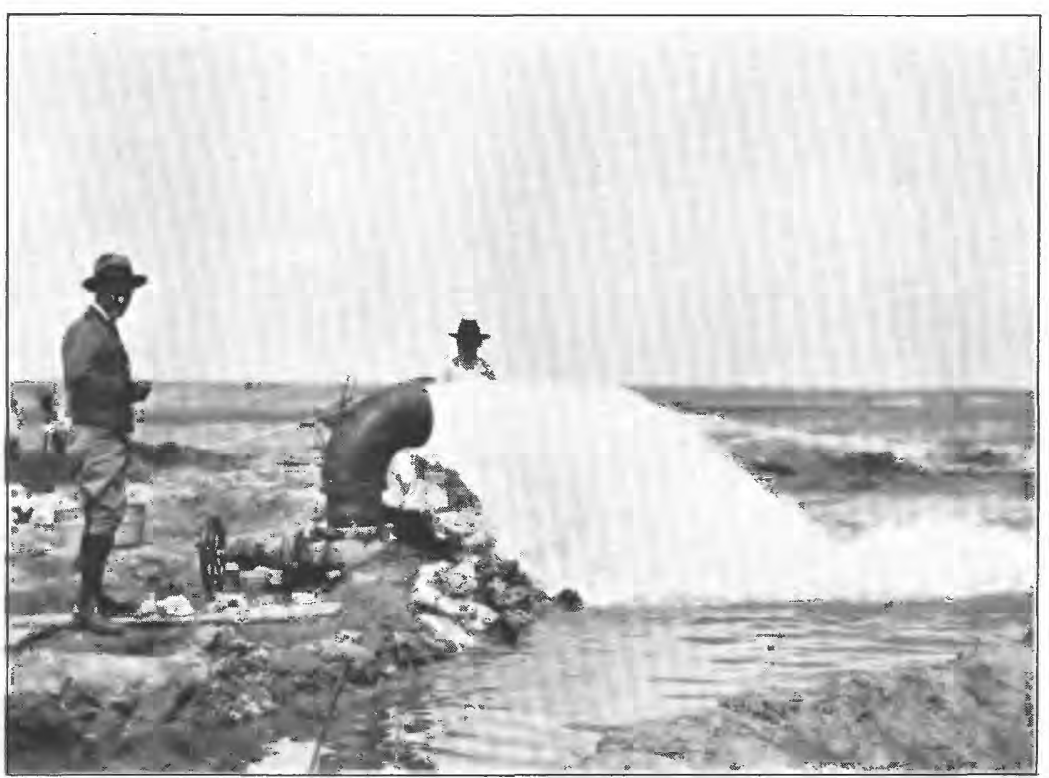

B. WELL OF H. D. KING, IN THE SW. $1 / 4$ SEC. 14, T. 11 S., R. 25 E.

This well is 845 feet deep and 10 inches in diameter. On April 21, 1926, it had a flow of 3,190 gallons a minute. Photograph by $\mathrm{A}$. G. Fiedler. 


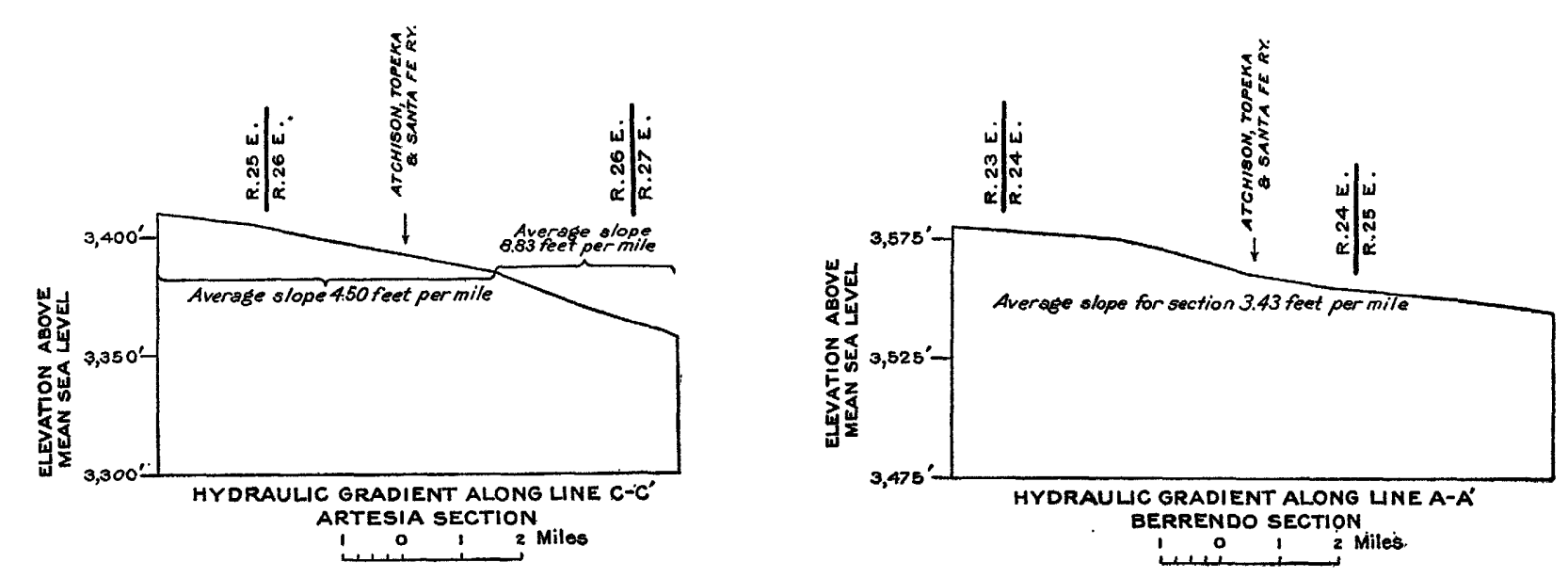

WATER-BTPPLY PAPER 639 PLATE 31:

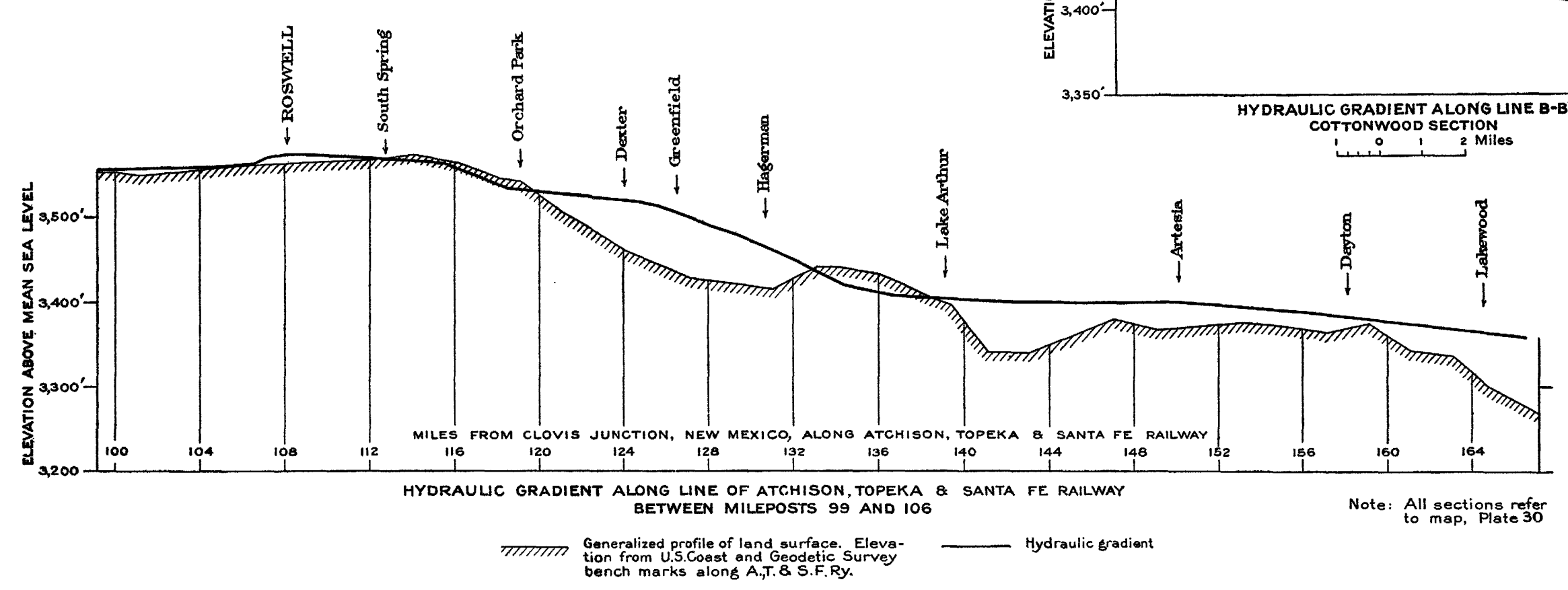

HYDRAULIC GRADIENT ALONG SECTIONS ACROSS THE ROSWELL AREA OF ARTESIAN FLOW 


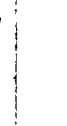


end of the area, except for a small tract along Cottonwood Creek. As the basin was developed and the draft upon the artesian reservoir increased, a much steeper hydraulic gradient was created, so that in 1926 to 1928 the water did not rise nearly so high on the east side of the area as on the west side.

During the present investigation detailed observations of the head were made on representative wells in the northern, central, and southern parts of the area, as listed below. These are nonflowing wells in the belt west of the area of artesian flow.

Observation wells in which the head was recorded, 1925-1928

\begin{tabular}{|c|c|c|c|}
\hline Name of well & Location & Recording instrument & Length of record e \\
\hline $\begin{array}{l}\text { Berrendo No. } 1 . \\
\text { Berrendo No. } 2 . \\
\text { Orehard Park.- } \\
\text { Artesia. }\end{array}$ & $\begin{array}{l}\text { SW. } 1 / 4 \text { NE. } 1 / 4 \text { sec. } 19, \text { T. } 10 \\
\text { S., R. 24 E. } \\
\text { SW. } 1 / 4 \text { SW. } 1 / 4 \text { sec. } 9, \text { T. } 10 \text { S., } \\
\text { R. } 24 \text { E. } \\
\text { NW. } 1 / 4 \text { NW. } 1 / 4 \text { sec. } 23, \text { T. } 12 \\
\text { S., R. } 25 \text { E. } \\
\text { sW. } 1 / 4 \text { NW. } 1 / 4 \text { sec. } 32 \text {, T. } 17 \\
\text { S., R. } 26 \text { E. }\end{array}$ & $\begin{array}{l}\text { Float gage } \\
\text { Stevens continuous water- } \\
\text { stage recorder. } \\
\text { Au drum-type water-stage } \\
\text { recorder. }\end{array}$ & $\begin{array}{l}\text { July, 1925, to June, } 1928 . \\
\text { June, 1926, to Nov., } 1928 . \\
\text { July, 1925, to Dec., } 1928 . \\
\text { July, 1925, to Dec., } 1928 .\end{array}$ \\
\hline
\end{tabular}

- For detailed record see pl. 32.

The table below gives, for the years 1926 to 1928, the altitude of the artesian head above sea level for the day of average lowest head and average highest head, also the average head for the year in the Berrendo No. 1, Orchard Park, and Artesia observation wells.

On the Berrendo well 1, equipped with float gage, single daily observations were made. For the wells equipped with automatic water-stage recorders the record is continuous, except as shown in Plate 36.

Artesian head in representative nonflowing wells, 1926 to 1928

[Datum plane is mean sea level]

Berrendo well 1

\begin{tabular}{|c|c|c|c|c|c|}
\hline & \multicolumn{2}{|c|}{ Lowest } & \multicolumn{2}{|c|}{ Highest } & \multirow{2}{*}{$\begin{array}{l}\text { Yearly } \\
\text { average } \\
\text { (feet) }\end{array}$} \\
\hline & Date & $\underset{\text { (feet) }}{\text { Head }}$ & Date & $\underset{\text { (feet) }}{\text { Head }}$ & \\
\hline $1926-1927-121$ & $\begin{array}{l}\text { Aug. } 13 \\
\text { Aug. } 10\end{array}$ & $\begin{array}{l}3,573.03 \\
3,572,06\end{array}$ & $\begin{array}{l}\operatorname{Jan} 7 \\
\operatorname{Jan} .16-19\end{array}$ & $\begin{array}{l}3,577.63 \\
3,577.49\end{array}$ & $\begin{array}{l}3,575.64 \\
3,574.31\end{array}$ \\
\hline Average & -......... & $3,572.5$ & $\ldots$ & $3,577.6$ &.- \\
\hline
\end{tabular}

Orehard Park well

\begin{tabular}{|c|c|c|c|c|c|}
\hline 1926 & $\begin{array}{lr}\text { July } & 3 \\
\text { June } & 10 \\
\text { July } & 13\end{array}$ & $\begin{array}{l}3,515.25 \\
3,515.20 \\
3,515.21\end{array}$ & $\begin{array}{l}\text { Dec. } 31 \\
\text { Jan. } 6 \\
\text { Dec. } 2\end{array}$ & $\begin{array}{l}3,534.82 \\
3,535.40 \\
3,532.90\end{array}$ & $\begin{array}{l}\mathbf{3}, \mathbf{5 2 5} .95 \\
\mathbf{3}, \mathbf{5 2 3} .96 \\
\mathbf{3}, \mathbf{5 2 4} . \mathbf{4}\end{array}$ \\
\hline A verage & $\ldots$ & $3,515.2$ & -....... & $3,534.4$ & -. \\
\hline
\end{tabular}

- Average for the day.

b Partly estimated.

$135252-33-14$ 
Artesian head in representative nonflowing wells, 1926 to 1928-Continued

Artesia well

\begin{tabular}{|c|c|c|c|c|c|}
\hline 1926 & $\begin{array}{lr}\text { July } & 9 \\
\text { Aug. } & 2 \\
\text { July } & 18\end{array}$ & $\begin{array}{l}3,376.84 \\
3,375.62 \\
3,372.86\end{array}$ & $\begin{array}{l}\text { Dec. } 28 \\
\text { Jan. } 2 \\
\text { Dec. } 26\end{array}$ & $\begin{array}{l}3,399.36 \\
3,399.38 \\
3,394.03\end{array}$ & $\begin{array}{l}3,387.49 \\
3,384.22 \\
\text { b } 383.4\end{array}$ \\
\hline Average. & - & $3,375.1$ & & $3,397.6$ & $\ldots$ \\
\hline
\end{tabular}

${ }^{b}$ Partly estimated.

The absolute minimum head recorded in the wells during the period was somewhat lower than the average head, and the absolute maximum head recorded was somewhat higher than the average head.

The artesian head is at its lowest stage during the summer, when the irrigation draft is greatest, and at its highest stage during the winter, when the draft is least. The average difference between the winter highs and summer lows in 1926 and 1927 was only a little more than 5 feet in the Berrendo well 1. During the 3-year period 1926 to 1928 the average difference between the high and low stages amounted to about 19 feet in the Orchard Park well and to about 22.5 feet in the Artesia well.

In the Berrendo well 1 the average head in 1927 was 1.3 feet lower than in 1926. In the Orchard Park well the average head in 1927 was 2.0 feet lower than in 1926, and in 1928 it was 1.5 feet lower than in 1926. In the Artesia well the average head in 1927 was 3.2 feet lower than in 1926, and in 1928 it was 4.0 feet lower than in 1926.

In the Cottonwood segment only occasional observations of the artesian head were made. The head in a well in lot 13, sec. 1, T. 16 S., R. 24 E., was sufficient to raise the water in August, 1926, to an altitude of 3,548.4 feet above sea level, but the absolute minimum was probably somewhat lower. An observation in the same well in December, 1926, indicated a head of 3,551.9 feet.

The maximum artesian head in the area at present, as in the early days of drilling, is found in the relatively small tract on upper Cottonwood Creek. The head in a well in the SE. $1 / 4$ SW. 1/4 sec. 11, T. 11 S., R. 24 E., was sufficient to raise the water to an altitude of 3,583.5 feet above sea level in 1926. In 1927 the highest level reached in this well was about 4.5 feet lower than that reached in 1926.

Plate 30 shows the piezometric surface during the period of maximum head in the winter of 1926-27. Originally this surface was probably more nearly level, but with the development of the basin it has assumed a slope from west to east, with a definite southeastward trend. Plate 31 gives the hydraulic gradient along sections across the piezometric surface indicated on Plate 30 . These sections show clearly the change in head from west to east across the basin and the relation of the head at the north end of the area to that at the south end. 
The profiles of the hydraulic gradient along lines $\mathrm{A}-\mathrm{A}^{\prime}$ and $\mathrm{B}-\mathrm{B}^{\prime}$ for the Berrendo and Cottonwood sections, respectively, as shown in Plate 31 , indicate that the slope becomes progressively flatter to the west of the artesian area. This would indicate that a cone of depression has been developed in the piezometric surface in the artesian area because of the draft from the wells. This cone of depression is considerably more pronounced during the summer, when the draft from the artesian wells is greatest. Owing to the wide variation in pressure of the artesian wells during the summer, both from day to day and at different times during the same day, it has not been feasible to draw a piezometric surface for the artesian area based on observations made during the summer. Changes would occur in the artesian pressure during the time required to make the observations necessary for plotting such a surface, and observations made in different parts of the area only a few days apart would be very inconsistent with one another. It is apparent that in view of the many corrections that would be necessary to allow for the changing conditions the result would be largely an estimate. As noted on page 205 , the observations on a well in the catchment area showed that the water table, as indicated by measurements of the water level in the well, declined only 1.15 feet during a period of 9 months and 8 days from June 7, 1927, to March 15, 1928. However, in the well near Artesia, which is in the same general east-west segment of the artesian basin, the mean monthly artesian head for July, 1927 (see pl. 34) was about 11 feet lower than the mean monthly artesian head for the same well in December, 1927. These observations indicate something of the amount of the depression which undoubtedly occurs in the piezometric surface in the artesian area during the summer.

\section{DECLINE IN HEAD}

\section{DECLINE IN THE ARTESIAN AREA}

Variations in the artesian head have been noticed for many years. It was part of the duty of the county well supervisors to visit the wells periodically and make observations as to the flow and pressure. Much information was gathered in this manner, and it soon became evident from the study of the records that the artesian head was declining. The decline, however, has not proceeded uniformly but has been least at the north end of the valley and on upper Cottonwood Creek and greatest south of Artesia.

The altitude of the springs at the head of the North Spring River largely controlled the original level of the artesian head at the north end of the area. It has been shown that the artesian head in the north end of the area rose nearly to the same level in all of the artesian area below the level of the outlet of the springs, except 
for the small tract on Cottonwood Creek. In the southern and southeastern parts of the artesian area the head was somewhat lower than that in the north end; but because no information is available regarding the exact level in this region prior to the drilling of wells, the altitude of the head of the North Spring River, 3,586 feet above sea level, will be used in making comparisons showing the amount of decline that has occurred. By assuming 3,586 feet as the original level, the decline indicated for the southern part of the area will probably be about 10 or 15 feet too high, but this is immaterial as far as the conclusions here drawn are concerned.

If the altitude to which the water would rise was originally 3,586 . feet, the artesian head in the vicinity of the Berrendo well 1 , in the SW. $1 / 4$ NE. $1 / 4$ sec. 19 , T. 10 S., R. 24 E., has declined only about 15 feet, if the minimum water level reached on August 10, 1927, is used for comparison; or if the average water level for the year 1927 is used the decline has been only 11.7 feet. (See table, p. 201.) The artesian head of a well farther east, in the SW. $1 / 4$ NW. 1/4 sec. 25, T. 10 S., R. 24 E., in June, 1905, was only 4.2 feet below the level of the water surface of North Spring, and the hydraulic gradient between these two points was therefore approximately 0.84 feet to the mile; but in the winter of 1926-27 there was a difference of about 26 . feet between these same points (see pl. 30), or a hydraulic gradient of approximately 5.2 feet to the mile. Thus with the development of the basin a steeper hydraulic gradient has been created as a result of increased draft upon the artesian reservoir. The north-south hydraulic gradient has also become steeper for the same reason, as is shown by observations of the pressure on a well in the north end and $a$ well in the south end of the area. In October, 1905, the water rose to an altitude of 3,577 feet in a well in the SE. $1 / 4$ NE. $1 / 4$ sec. 7 , T. 11 S., R. 25 E., and to 3,495 feet in a well in the NW. $1 / 4$ SE. $1 / 4$ sec. 15, T. 17 S., R. 26 E. The difference of artesian head in these wells was 82 feet, which is equivalent to a gradient of 2.02 feet to the mile for the distance between the two wells. In the winter of 1926-27 the difference in artesian head between the same points was 172 feet (see pl. 30), which is equivalent to a gradient of 4.25 feet to the mile. It is therefore evident that the hydraulic gradient has increased both from west to east across the area and from north to south.

As a result of the development of a steeper hydraulic gradient the decline on the east side of the Berrendo tract, north of Roswell, has been greater than on the west side and has amounted to about $\mathbf{4 0}$ feet. The average decline for the Berrendo tract is about 25 feet from the assumed original level. The decline has been much greater toward the south end of the artesian area. The conditions are illustrated in 
Plate 33, which shows the head in typical artesian wells, approximately one well in each tier of townships from T. 10 S. to T. $18 \mathrm{~S}$. All these wells are along the west side of the area of artesian flow, and they are fairly comparable with one another for indicating the decline of the water level in the successive tiers of townships.

The following table gives the minimum head recorded during 1926 and 1927 for the wells shown in Plate 33.

\section{Minimum altitude of water level during 1926 and 1927 in typical wells and decline from original level}

[Original altitude of water level in wells is assumed to have been 3,586 feet above sea level]

\begin{tabular}{|c|c|c||c|c|c|}
\hline $\begin{array}{c}\text { Town- } \\
\text { ship } \\
\text { south }\end{array}$ & $\begin{array}{c}\text { Minimum } \\
\text { water level } \\
\text { in well } \\
\text { (feet above } \\
\text { sea level) }\end{array}$ & $\begin{array}{c}\text { Decline } \\
\text { from } \\
\text { original } \\
\text { level } \\
\text { (feet) }\end{array}$ & $\begin{array}{c}\text { Town- } \\
\text { ship } \\
\text { south }\end{array}$ & $\begin{array}{c}\text { Minimum } \\
\text { water level } \\
\text { in well } \\
\text { (feet above } \\
\text { sea level) }\end{array}$ & $\begin{array}{c}\text { Decline } \\
\text { from } \\
\text { original } \\
\text { level } \\
\text { (feet) }\end{array}$ \\
\hline 10 & 3,554 & 32 & 14 & 3,441 & 145 \\
11 & 3,527 & 37 & 16 & 3,415 & 171 \\
12 & 3,547 & 39 & 17 & 3,368 & 218 \\
13 & 3,501 & 85 & 18 & 3,382 & 204 \\
\hline
\end{tabular}

Plate 28 shows two curves indicating the rate of decline for a group of wells in the southern part of the area, in the vicinity of Artesia, and for a group of wells in the northern part, in the vicinity of Roswell. The graph for each well shows considerable variation in head from season to season, with a maximum occurring during the winter and a minimum during the summer. The seasonal variation for the wells around Artesia is greater than that for wells in the vicinity of Roswell. The following table shows the amount of decline and the average rate of decline during various periods for the two groups of wells, based on the curves in Plate 28.

Amount and average rate of decline of artesian head for groups of wells in the vioinity of Artesia and Roswell

\begin{tabular}{|c|c|c|c|c|c|c|c|c|c|}
\hline \multirow[b]{2}{*}{ Period a } & \multicolumn{2}{|c|}{$\begin{array}{c}\text { Wells near } \\
\text { Artesia }\end{array}$} & \multicolumn{2}{|c|}{$\begin{array}{l}\text { Wells near } \\
\text { Roswell }\end{array}$} & \multirow[b]{2}{*}{ Period a } & \multicolumn{2}{|c|}{$\begin{array}{l}\text { Wells near } \\
\text { Artesia }\end{array}$} & \multicolumn{2}{|c|}{$\begin{array}{c}\text { Wells near } \\
\text { Roswell }\end{array}$} \\
\hline & $\begin{array}{l}\text { Amount } \\
\text { of de- } \\
\text { cline }\end{array}$ & $\begin{array}{l}\text { Average } \\
\text { annual } \\
\text { rate of } \\
\text { decline }\end{array}$ & $\begin{array}{l}\text { Amount } \\
\text { of de- } \\
\text { cline }\end{array}$ & $\begin{array}{l}\text { Average } \\
\text { annual } \\
\text { rate of } \\
\text { decline }\end{array}$ & & $\begin{array}{l}\text { Amount } \\
\text { of de- } \\
\text { cline }\end{array}$ & $\begin{array}{c}\text { A verage } \\
\text { annual } \\
\text { rate of } \\
\text { decline }\end{array}$ & $\begin{array}{l}\text { Amount } \\
\text { of de- } \\
\text { cline }\end{array}$ & $\begin{array}{l}\text { A verage } \\
\text { annual } \\
\text { rate of } \\
\text { decline }\end{array}$ \\
\hline $\begin{array}{l}1904-1906 \\
1906-1908 \ldots \\
1908-1910 \ldots \\
1910-1912 \\
1912-1914 \\
1914-1916 \\
1916-1918 \\
1918-1920 \\
1920-1922 \ldots\end{array}$ & $\begin{array}{c}\text { Feet } \\
59 \\
42 \\
21 \\
10 \\
4.5 \\
3.5 \\
3.5 \\
3.5 \\
3\end{array}$ & $\begin{array}{l}\text { Feet } \\
29.5 \\
21.0 \\
10.5 \\
5.0 \\
2.25 \\
1.75 \\
1.75 \\
1.75 \\
1.5\end{array}$ & $\begin{array}{r}\text { Feet } \\
4.6 \\
2.7 \\
1.4 \\
.7 \\
.6 \\
.6 \\
.6 \\
.5 \\
.5\end{array}$ & $\begin{array}{r}\text { Feet } \\
2.30 \\
1.35 \\
.70 \\
.35 \\
.30 \\
.30 \\
.30 \\
.25 \\
.25\end{array}$ & $\begin{array}{l}1922-1924 . . \\
1924-1926 .- \\
1904-1910 . \\
1910-1915 . \\
1915-1920 . \\
1920-1925 . . \\
1904-1926 . .\end{array}$ & $\begin{array}{l}\text { Feet } \\
3 \\
3 \\
122 \\
17 \\
8 \\
7 \\
156.0\end{array}$ & $\begin{array}{r}\text { Feet } \\
1.5 \\
1.5 \\
20.3 \\
3.4 \\
1.6 \\
1.4 \\
7.1\end{array}$ & $\begin{array}{r}\text { Feet } \\
0.5 \\
.5 \\
8.7 \\
1.6 \\
1.4 \\
1.3 \\
13.2\end{array}$ & $\begin{array}{r}\text { Feet } \\
0.25 \\
.25 \\
1.45 \\
.32 \\
.28 \\
.26 \\
.6\end{array}$ \\
\hline
\end{tabular}

a Years, July 1 to June 30. 
The greatest decline in both groups of wells occurred during the period 1904 to 1910, when it averaged 20.3 feet a year in the group of wells in the vicinity of Artesia and 1.45 feet a year in the wells around Roswell. The decline proceeded at a slower rate during the succeeding 5-year period and at a still slower rate in more recent years. Plate 28 shows that the greatest decline in head occurred during the period of greatest activity in drilling. The decline for the two groups of wells illustrated is typical of the entire area, and though there have been minor variations the trend in all has been the same.

The mean monthly and mean annual artesian head in the four observation wells during the period August, 1925, to December, 1928, are shown in Plate 34. (For detailed record see pl. 36.) The monthly mean for each well was obtained by averaging the daily mean. The mean monthly head is shown in the diagram as distance to the water surface in the well, measured from the bench mark at the top of the well casing. The mean monthly artesian head in reference to sea level for any well is obtained by subtracting the distance to the water surface from the altitude of the bench mark at the top of that well. For example, the average level of the artesian water in the Orchard Park well for January, 1926, was 16.4 feet below the bench mark, which is 3,547.3 feet above sea level; the mean monthly artesian head was, therefore, 3,530.9 feet above sea level. In comparing the head for the same month in the years shown it will be noted that the trend of head is generally downward. The mean monthly head ranged lower in 1927 than in the corresponding months in 1925 and 1926, except for January and February. The head for March was practically the same in 1926 and 1927. The mean annual head for 1927 was lower than that for 1926 in all the wells. For the Berrendo well 1 the head was 1.33 feet lower in 1927 than in 1926; at Orchard Park the head was 2 feet lower in 1927 than in 1926; and at Artesia it was 3.18 feet lower than in 1926. For 1928 the records of the two Berrendo wells are not complete. In 1928 the head in the Orchard Park and Artesia wells was lower for January to April, June, and July than for the corresponding months in 1926 and 1927. For May, 1928, the head was somewhat higher in both wells than for May, 1927, but lower than for May, 1926. For August, 1928, the artesian head in both wells was higher than for the same month in 1926 and 1927. During the rest of 1928 the artesian head was generally higher than for the corresponding months in 1927 but lower than for the same months in 1925 and 1926. The mean annual head in the Orchard Park well was slightly higher in 1928 than in 1927 but lower than the mean annual head in 1926. In the Artesia well the mean annual head in 1928 was somewhat 
lower than that in 1926 and 1927 . Thus it is seen that during 1926, 1927, and the first half of 1928 the artesian head was generally declining at a moderate rate, but during the last half of 1928 the head rose moderately and the average head for the year was practically the same as in 1927.

The year 1926 was marked by a deficiency of precipitation during the growing season, though the average precipitation for the year was slightly above normal. (See pls. 36 and 44.) The year 1927 was very deficient in precipitation throughout, and particularly because of the deficiency during the growing seasons of 1926 and 1927 the irrigation draft was considerably greater than normal. For these reasons the decline in head for 1926 and 1927 as shown in Plate 34 may likewise be greater than the average decline during a normal season with the present development of the basin. During 1928 the precipitation during the first half of the year was generally below normal, but beneficial rains occurred in July and August that materially reduced the irrigation draft during the remainder of the growing season, and the artesian head for the rest of the year was in consequence noticeably higher.

The conditions in the Cottonwood segment of the artesian area, though generally similar to those in the remainder of the basin, are different in some particulars. The map of the piezometric surface (pl. 30) shows that there are in the Cottonwood segment three distinct sections with different artesian heads and hydraulic gradients. In the upper section, which is a small area along the valley of Cottonwood Creek that extends from the west side of the area of artesian flow to a line drawn north and south through about the center of secs. 3 and 9, T. 16 S., R. 25 E., the head is at the highest level in the valley. The first recorded pressure of a well in this area is for the well in the SE. 1/4 NW. 1/4 sec. 11, T. 16 S., R. 24 E., which was drilled in 1915. The pressure in this well was sufficient to raise the water to an altitude of 3,600 feet above sea level in August, 1916, and to 3,579 feet in December, 1927. The decline therefore amounted to 21 feet in a period of 11 years, or an average decline of 1.91 feet a year. It is evident that, contrary to the general impression concerning the wells in this tract, there has been even here a measurable lowering of the artesian pressure.

A study of the initial head and the decline in other sections of the artesian area indicates that the initial head in the upper Cottonwood section was probably more than 3,615 feet in 1905 , before the drilling of many artesian wells. If such a conclusion is correct the decline during the 22 years 1906 to 1927 amounted to more than 36 feet, or an average of about 1.64 feet a year for the period. This conclusion is supported by a study of the adjacent area on the east, 
called here the intermediate section, concerning which more information is available.

For the intermediate section, which is bounded on the west by a line drawn north and south through about the center of secs. 3 and 9, T. 16 S., R. 25 E., and on the east by a line drawn north and south from a point about on the west line of sec. 2 , T. 16 S., R. 25 E., the well in lot 13, sec. 1, T. 16 S., R. 24 E., furnishes valuable information as to the rate of lowering. This well was drilled in April, 1906, and the recorded pressure at the time of completion was sufficient to raise the water to an altitude of 3,610 feet above sea level. An observation made on this well in December, 1927, showed that the water level stood at an altitude of 3,550 feet. This indicates a decline of 60 feet in a period of 21 years, or an average decline of about 2.85 feet a year. This average decline is somewhat greater than the decline in the upper Cottonwood section but it is considerably less than in the section at the lower end of the Cottonwood segment.

Detailed observations are not available to show the rate of decline by shorter periods for the upper and intermediate sections on Cottonwood Creek. The data are, however, sufficient to show that the decline has progressed in a manner similar to that of the other parts of the area that have been studied in detail.

The lower section along Cottonwood Creek comprises the east half of the Cottonwood segment as defined on page 148. It includes the southeast quarter of T. 15 S., R. 25 E., the south half of T. 15 S., R. $26 \mathrm{E}$., the northeast quarter of T. 16 S., R. $25 \mathrm{E}$., and the north half of T. 16 S., R. 26 E. The artesian head in this section is lower than that in the upper and intermediate sections and is comparable to that in the vicinity of Lake Arthur and Artesia; its characteristics, as to both the amount and the rate of lowering, are similar to those shown by the curve for the wells in the vicinity of Artesia (see pl. 28 and table on p. 201), though the amount and rate may not be quite so great.

Viewed as a whole, the data show conclusively that a decline in the artesian head has occurred in all parts of the artesian basin, although the amount of decline and the rate over a period of years have differed widely from one locality to another. The total decline and the rate of decline have been least near the north end of the area of artesian flow and have increased more or less uniformly southward to the lower end of the area, except as noted for the upper and intermediate Cottonwood sections. A comparison of the curves showing the trend in decline and the number of wells drilled (see pl. 28) affords conclusive evidence regarding the reason for the decline and indicates that with increased drilling and greater draft on the artesian reservoir further decline is to be expected. The lessening 
in the rato of decline from that during the earlier years of development to that of recent years is encouraging in that, though the lowering of the artesian head has not yet been completely arrested, the rate during the last few years has been very moderate. Owing to a marked deficiency in precipitation during the growing season in recent years and the resultant heavy irrigation draft the decline has been probably greater than it would have been during years of normal rainfall.

\section{DECLINE IN THE INTAKE AREA}

In order to obtain a record of the fluctuations of the level of the water table in the intake area an Au gage, which gave a continuous record, was installed over a well in the NW. $1 / 4$ NW. $1 / 4$ sec. $27, T$. $19 \mathrm{~S} .$, R. 23 E. This well was drilled as an oil prospect hole and reached a depth of 416 feet, when it was abandoned. A study of the $\log$ showed that it penetrated 355 feet of the Picacho limestone and that it was drilled a considerable depth below the main water table. The water surface in this well is therefore a true indication of the level of the water table of the main body of ground water, which farther east is under artesian pressure.

The gage was installed on June 7, 1927, and the water level at that time was 371.49 feet below the bench mark established at the top of the well. No marked fluctuations were recorded, and the record showed only a very gradual decline in the water level in the well during the period that the gage was in operation. The record was discontinued on March 15, 1928, when the water level was 372.64 feet below the bench mark. During the period of 9 months and 8 days that the gage was in operation the water level had therefore lowered 1.15 feet, or at the rate of 1.49 feet a year. This fact is of particular significance in relation to the safe yield of the artesian reservoir and will be considered further in connection with the quantity of recharge. (See pp. 253-254.)

\section{HEAD OF THE ARTESIAN AQUTFERS}

Prior to the drilling of large numbers of wells there was some difference in the head in aquifers in the Roswell artesian basin. Normally the head of water in the first aquifer encountered was the lowest and that in the deepest aquifer the highest. Very little information is available regarding the difference in head on the individual aquifers, for the reason that the wells are usually cased only a few feet below the top of the Picacho limestone, below which they are extended as uncased holes. As a result the artesian head of the water from several aquifers of the Picacho limestone was equalized. In most wells the aquifers in the Pecos formation are cased off, but 
it is quite probable that in many wells there is considerable leakage between these upper aquifers along the outside of the well casing, and as a result any differences in head between the aquifers in this formation would also tend to be equalized. However, according to the available information, the original differences in head were not large.

The deepest aquifers normally yield the largest quantities of water, and for this reason the impression has been created that they had a very much higher head than the upper aquifers, but the greater yield from the lower aquifers may be due to greater permeability rather than to higher head. (See also p. 145.)

Throughout most of the basin the artesian head on the different aquifers was equalized because of the drilling of so many wells. This is shown by the close agreement of the artesian head in wells in the same locality. This fact is rather remarkable in view of the marked differences in the character and occurrence of the aquifers from place to place. The measurements of artesian head which were made for the purpose of defining the piezometric surfaces shown on Plate 30 agreed very closely for wells in the same locality; and where marked differences in the head in the wells occurred it was generally evident that the well casing was defective. It has been pointed out in the discussion of the head during the period 1926 to 1928 (pp. 198-199) that in the upper sections of the Cottonwood segment the artesian head is higher than in the adjacent parts of the area. There are no data to show that this difference in head is caused by certain strata deriving their supply from separate bodies of water at different altitudes to the west of the artesian area. So far as is known, all the aquifers that are tapped in the area derive their supply from the same large body of ground water, the surface of which lies several hundred feet below the land surface in the intake area to the west, where the water-bearing strata are exposed. If it is true that the artesian aquifers derive their supply from the same body of ground water, the difference in head in the different sections of the Cottonwood segment must be largely due to differences in the permeability of the aquifers. However, in view of the fact that more specific information is not available, no definite conclusion can be drawn.

A noticeable difference in artesian head similar to that in the upper Cottonwood sections was found in sec. 15, T. 18 S., R. 26 E. Here an oil exploration well was drilled to a depth of 3,156 feet. In constructing the well the hole was cased below the bottom of the artesian aquifers that are tapped by the water wells in the vicinity. Drilling was then continued below the bottom of the casing. Additional water was encountered, and another string of casing was set to ex- 
clude the water from the hole. As oil was not obtained, the well was plugged to the bottom of the water-bearing formation, the strings of 8-inch and 10-inch casing, which excluded the water from the hole, were pulled, and the well was completed as a water well. The pressure in this well on July 22, 1927, measured 14 pounds to the square inch when the prevailing pressure of other artesian wells in the vicinity averaged about 8 pounds to the square inch, due allowance being made for difference in altitude between the wells. This higher pressure was probably derived from the water-bearing formation encountered at 1,063 to 1,140 feet, a level about 200 feet below the usual depth of water wells in this vicinity.

On pages 141-142 it has been pointed out that some of the artesian aquifers are more nearly water-bearing channels than continuous strata that may be traced from weil to well. There is, therefore, no definite assurance that the same deep aquifer would be penetrated if wells in the same vicinity were drilled deeper.

\section{FLUCTUATTONS IN HEAD}

\section{INTERFERENCE OF WELIS}

The static level of water in an artesian well drilled in the Roswell artesian area is dependent upon the hydrostatic pressure in the artesian aquifers tapped by the well. The pressure head or, as it is commonly called, the head in a well shows the pressure on the particular aquifer when the water is at rest. The pressure head is commonly expressed with reference to the land surface at the well or to some other convenient datum. Actually the water in any artesian aquifer in this area is never at rest but is always moving slowly toward the points of discharge. The difference in head due to the imperceptible movement of the water is so small that static conditions are considered to exist as long as the well is not appreciably affected by the operation of other wells tapping the same artesian aquifer.

The conditions of discharge are essentially the same in a pumped well as in a flowing well, hence the following discussion pertains chiefly to nonflowing wells, in which the effects of interference can be more readily discerned than in flowing wells. Whenever a well is permitted to flow under natural artesian pressure, there is a reduction in the pressure; and when a nonflowing well is pumped, the water level in the well drops, rapidly at first and then more and more slowly until, finally, there may be no further drop. The time required to reach a condition of essentially complete equilibrium is at least several hours and may be several days. This reduction in the water level of the well is extended to the level of the water in near-by wells tapping the stratum. 
The fluctuations in the water level of the Artesia observation well, in the SW. $1 / 4$ NW. $1 / 4$ sec. 32, T. 17 S., R. 26 E., are shown in Figure 28. The record was obtained by means of an automatic water-stage recorder, which gave a continuous record of the water level. The well is on the west side of the irrigated area and is influenced chiefly by the pumping of wells in the vicinity. The flowing wells east of this section are operated almost continuously during the irrigation season, and because of their distance from this well their effect on the water level is largely obscured by the operation of the pumps, which is intermittent. It will be noted from the graph that the water level is normally highest between 6 and $7 \mathrm{a} . \mathrm{m}$. and lowest between 6 and $7 \mathrm{p} . \mathrm{m}$. The pumps in this area are usually started between 6 and 7 a. m., and the water level declines during the day and reaches the lowest point in the evening just before the pumps are stopped. The water level then rises, reaching the maximum the following morning just before the pumps are again started. It is likely that, owing to a small amount of lag, the high and low points of the artesian head actually occur a short time after the pumps are started and stopped, but because of the small scale of the recorder graphs this slight interval can not be accurately determined.

It has been pointed out by Meinzer ${ }^{59}$ that the gradual recovery of the artesian head during the night, after the pumps are stopped, as indicated by the rise of the water level in the well, seems to show that the artesian aquifers may be compressed a small amount by the weight of the overlying formations when the head in the well is lowered by pumping. This phenomenon is discussed in greater detail on pages $242-245$.

The reduction in the water level of wells in the vicinity of a well that is being pumped is due to the fact that the pumping causes a cone of depression in the prevailing static level of the artesian formation. (See fig. 29.) The apex of this inverted cone is at the well that is being pumped, and its profile is a curve that is steepest at the well and gradually flattens out toward the base until it becomes essentially a horizontal line. Where several wells tapping the same strata are being operated at the same time their cones of depression coalesce and the piezometric surface in the vicinity consists of a series of irregular depressions.

The well upon which the graph shown in Figure 28 is based is within the cone of depression of several pumped wells, and the reduction in the water level in this well, due to the surrounding pumping, is clearly shown.

${ }^{50}$ Meinzer, O. E., Compressibility and elasticity of artesian aquifers : Econ. Geology, vol. 23, pp. 279-280, May, 1928. 


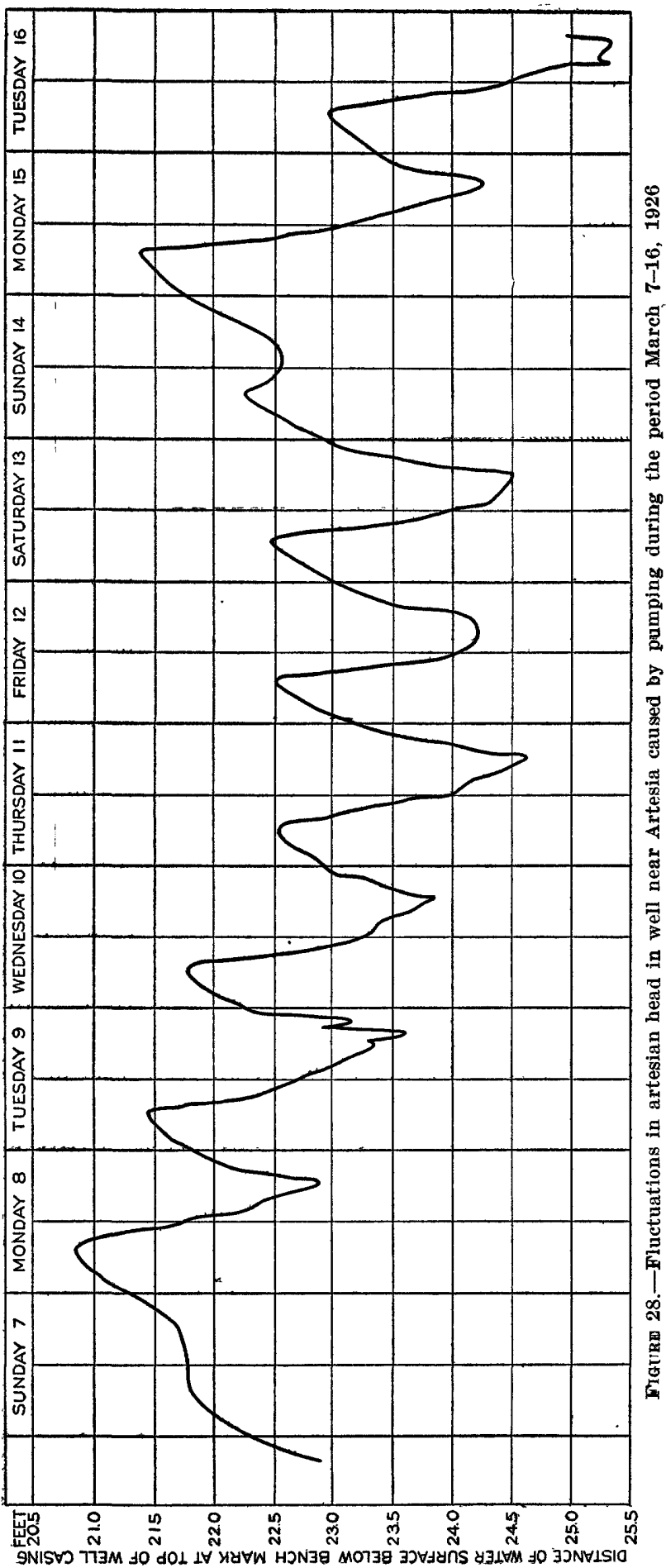


The quantity of water withdrawn from any particular well and its distance from other wells largely control its effects on their water levels. The operation of a near-by well yielding a small quantity of water may affect the water level to a much greater extent than the operation of a more distant well of considerably larger yield. This is illustrated by the character of the water-level fluctuations shown in Figure 28. The irregularity in the graph for the evening of March 9 , 1926, was caused by the breaking of the belt on the pump of a near-by well. The belt broke about $6 \mathrm{p}$. m., and this pump stopped. A noticeable rise in the water level occurred until about $6.45 \mathrm{p} . \mathrm{m}$., when the pump was again started. At about $8 \mathrm{p}$. m. most of the

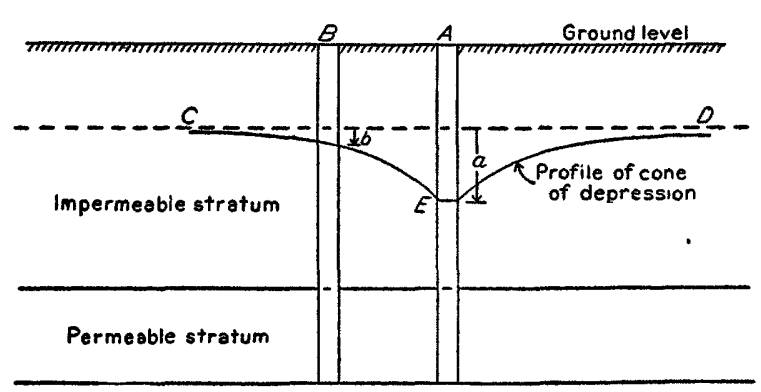

Frguri 29.--Effect of pumping on the piezometric surface and interference of wells. $A$, Nonflowing artesian well that is pumped. $B$, Nonflowing artesian well that is not pumped. $O D$, Profile of the normal piezometric surface, showing the height to which the artesian water will rise in the wells when neither is being pumped. $a$, Drawdown, or amount of lowering of the piezometric surface, at well $A$ caused by pumping this well. $b$, Drawdown at well $B$ due to pumping well $A$. $O E D$, Profle of the cone of depression in the piezometric surface caused by pumping well $A$; this profle shows the level at which the water would stand in wells located in the cone of depression while well $\boldsymbol{A}$ is being pumped wells were shut d ow $\mathrm{n}$, including the plant with the faulty belt. The water level immediately rose until about 8.45 p. m., when the faulty belt was repaired and that pump was again started. The water level then again declined until 9.45 p. m., when the plant was shut down for the night. The pumped well that caused these irregular fluctuations in the water level of the observation well was only about 175 feet distant; otherwise it is probable that the fluctuations caused by its intermittent operation would have been largely obliterated by the effects of pumping the other wells in the vicinity.

The effect of the curtailment of irrigation is clearly shown on the two Sundays, March 7 and 14, 1926. Practically no pumping was done on March 7, and on March 14 only part of the pumps were operated.

It is impossible to segregate the effects of the different wells in the vicinity upon the water level in the observation well. Within a radius of 1 mile of the well there are 10 pumping plants, all pumping different quantities of water. The effect of the operation of flowing wells is similar to that of the operation of pumping plants, and there is a corresponding reduction in the pressure of near-by 
flowing wells. The reduction in pressure due to flowing wells may be measured by means of a pressure gage and represents the same effect as the lowering of the water level in a nonflowing well. ${ }^{60}$

\section{FLUCTUATIONS CAUSED BY RATNFALI}

Fluctuations in the artesian head following periods of rainfall, as indicated by the changes of the water level in wells, have been generally noted throughout the area. Plate 32 shows for the period July 8 to 15, 1926, the water level in the Berrendo No. 2, Orchard Park, and Artesia observation wells and the amount of precipitation recorded by the United States Weather Bureau at Roswell and Artesia. The fluctuations in all these wells were recorded by automatic water-stage recorders. In the Berrendo well 2 the clockweight driving chain of the water-stage recorder broke on July 11, and the recorder was out of operation until July 14; the record for this period was partly estimated on the basis of an observation made July 12.

The graph of the Berrendo well 2 for July 8 to 10 indicates by the characteristic fluctuations that there was a normal irrigation draft on those days. Precipitation began at Roswell, according to the record, at $11 \mathrm{p}$. m. July 10 . It is not probable that there was a marked change in the irrigation draft in this segment at that hour of the night. The pronounced rise starting at 2 a. m. July 11, within two hours after the beginning of the precipitation at Roswell, appears to be the first direct effect of rainfall. From 1 to 10 a. m. July 11 the water level rose 0.58 foot. Though unfortunately a complete record was not obtained from July 11 to 14, the observation made at noon July 12 showed that the water level within a short time after the cessation of the rainfall was about 1 foot higher than it had been prior to July 11. It is impossible, for the period after about noon. July 11 to segregate the effect of curtailment in draft from the effect of rainfall. A study of other fluctuations during periods of intermittent well operation show, however, that such a pronounced rise in head is not produced by the shutting down of the wells. A rise due to curtailment of irrigation is illustrated by the graph of July 8 for the Berrendo well 2, which is considered typical of the normal fluctuations in this segment during the average irrigation period. It is evident that the marked rise in the artesian head starting at 1 a. $\mathrm{m}$. July 11 in this well was unquestionably the effect of precipitation.

\footnotetext{
For detailed discussion of hydraulics of wells and interference see Slichter, C. S., Theoretical investigation of the motion of ground waters: U. S. Geol. Survey Nineteenth Ann. Rept., pt. 2, pp. 368-369, 1899: Thompson, D. G., Ground water supplies in the Atlantic City region, New Jersey : New Jersey Geol. Survey Bull. 30, 1928.
} 
The graph for the Orchard Park well shows that there was no material draft in the vicinity of this well for several days prior to July 11. A marked rise in head began at about 1.30 a. m. July 11, and the rise continued at a rapid rate until late on the night of July 13. This increase in head was obviously caused by the precipitation; and in view of the practically uniform rate of the increase, it would indicate that the rise was unaffected by the intermittent operation of wells in the vicinity. The graph shows that the head in this well rose slightly more than 6 feet in a period of three days after the start of the precipitation as recorded at Roswell.

The record for the Artesia well during the period July 8 to 10 exhibits the characteristic fluctuation caused by the operation of other wells. The low point on July 8 and 9 occurred at about 7 p. m., when the shutting down of the pumped wells in the vicinity produced a gradual increase in head, which continued until the following morning. The irregularities on July 10 were probably caused by the starting and stopping of a pump in the nearest well, about 175 feet from the observation well. Though no definite proof is available, a study made of the effect of the operation of other wells in the vicinity upon the water level in the observation well (see also p. 210) indicated that only this nearest well was able to exert so pronounced an influence. It would therefore appear to be reasonable to attribute the fluctuations to this cause. There was considerable pumping in the vicinity of the Artesia well on July 11; and though the exact draft on July 11, as compared with that on July 10, is not known, the general trend of the artesian head was upward, and the low level on July 11 was 2.60 feet higher than that on July 10. There is normally a reduction of irrigation on Sundays during the irrigation season, and this is shown by the much smaller depression of the head on July 12 as compared with the depression caused by the probable average maximum irrigation draft on July 13. It should also be noted that although there was considerable irrigation draft in the vicinity of this well on July 13,14, and 15, the trend of the head was upward, as the peak reached on July 15 was about 0.42 foot higher than the high point on July 13 . There is no marked change in the character of the graph of the Artesia well after the rainfall, such as is evident in the Berrendo and Orchard Park wells. However, from the level at the time the precipitation began at Roswell the head rose 4.20 feet to the peak on July 15. Had it not been for the retarding effect of the heavy irrigation draft in the vicinity of the Artesia well it is probable that the rise in the artesian head in this segment would have been greater than that near Orchard Park. 


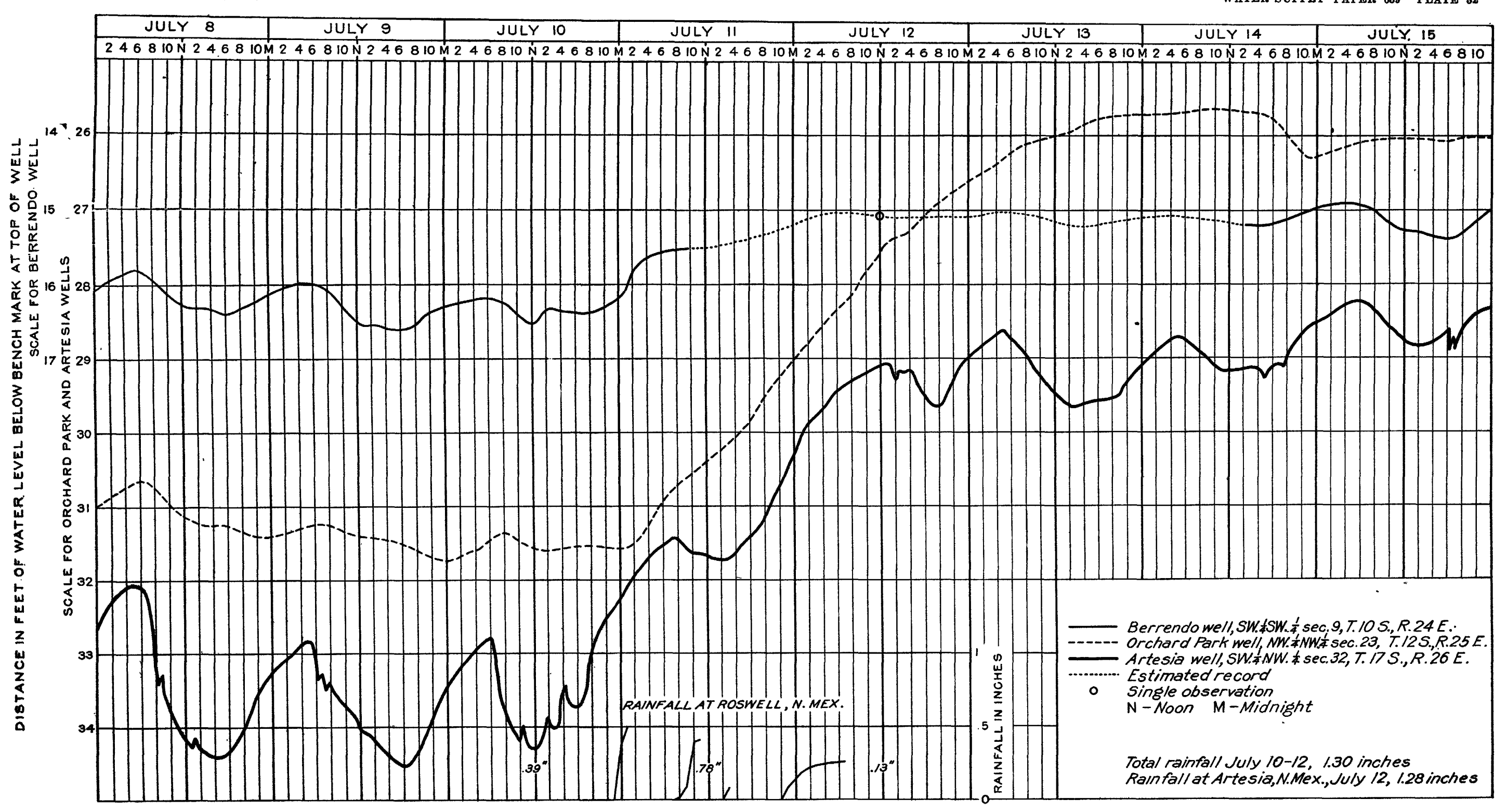

FLUCTUATIONS IN ARTESIAN HEAD IN THE BERRENDO, ORCHARD PARK, AND ARTESIA OBSERVATION WELLS CAUSED BY RAINFALL AND REDUCTION IN IRRIGATION DRAFT 
J. S. GROLOGICAL GURVEY

WATER-SUPPLY PAPER 639 PLATE 33

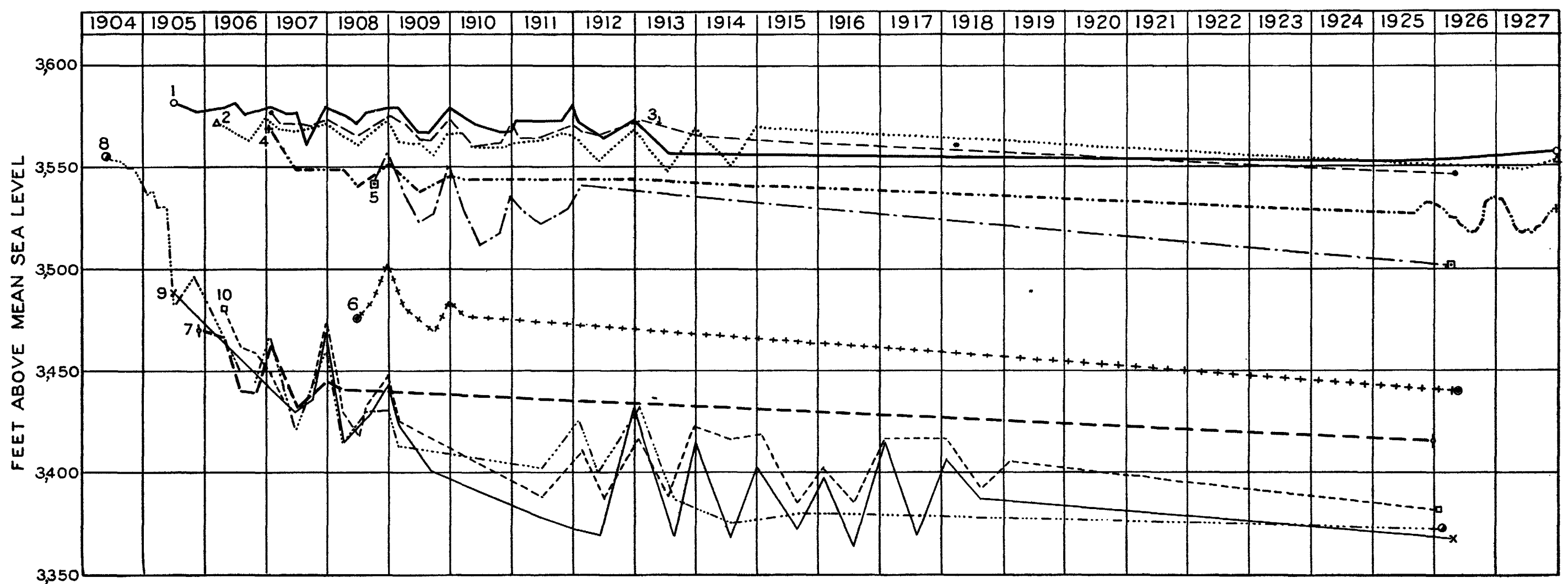

1 SW. $\frac{1}{4}$ NW. $\frac{1}{4}$ sec. 25,T.1OS.,R.24E.

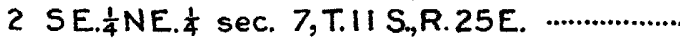

3 Lot I, sec. 3,T.12 S.R. 25E. - - -

4 NWI NW1

LOCATION OF WELLS

T SE.4 NW.4 Sec.30,T.16 S., R.26E. -

8 NW. 4 SE + sec. 15, T.17S, R.26E ....- ....

9 NE 1 SW 1 Sec.23, T.17S, R.26E.

SW. $\frac{1}{4}$ SW. $\frac{1}{4}$ sec. 3,T. 18 S, R.26E.

HEAD OF TYPICAL ARTESIAN WELLS, 1904-1926 
$\therefore \quad \therefore \quad \therefore \quad \div$

$\cdot$

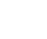



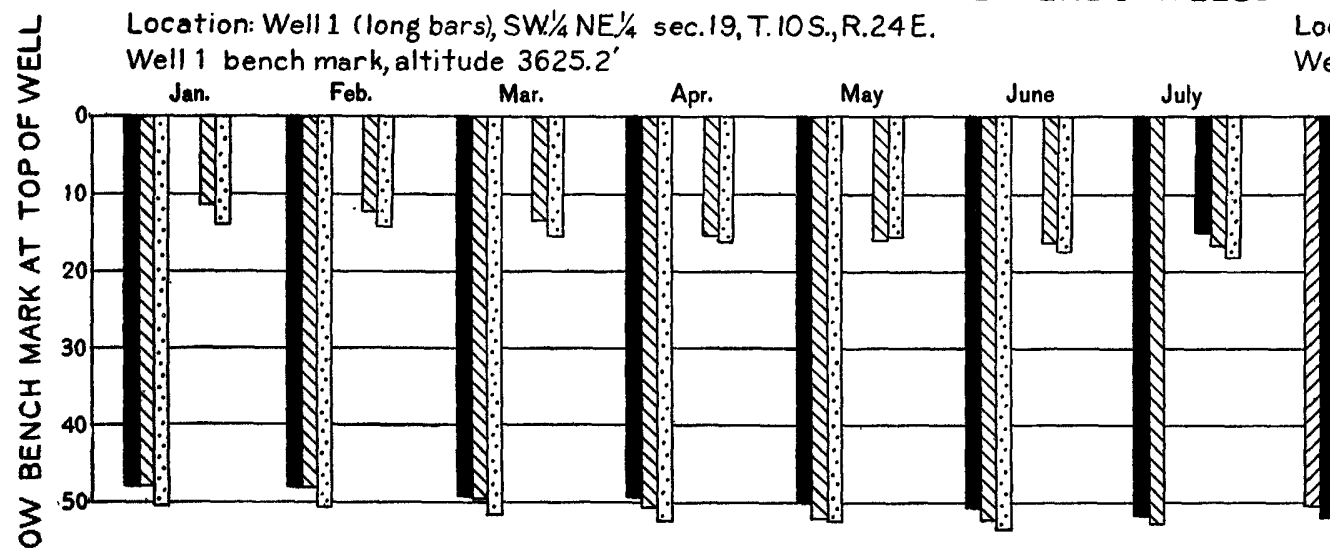

Location: Well 2 (short bars), SW.1/4 SW.1/4 sec.9. T. IOS., R.24E. Well 2 bench mark, altitude $3586.5^{\prime}$
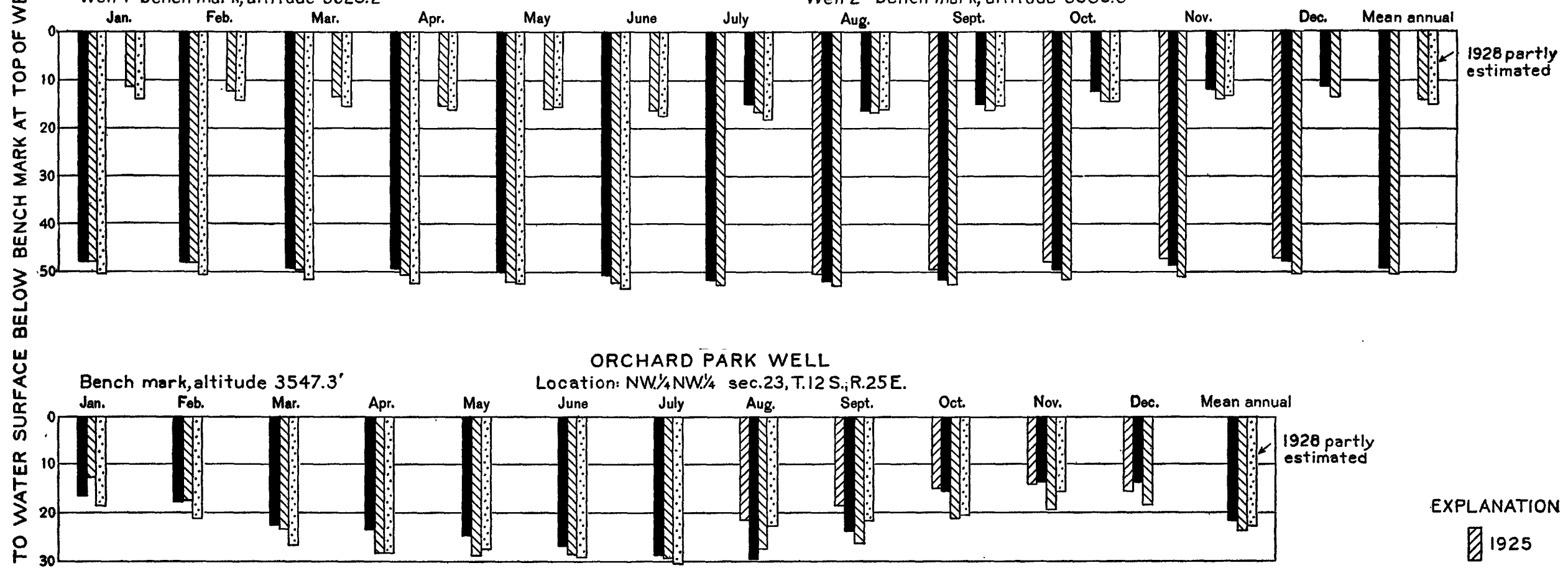

湈

ARTESIA WELL

Location: SW. $1 / 4$ NW. $1 / 4$ sec.32,T.17S., R.26E

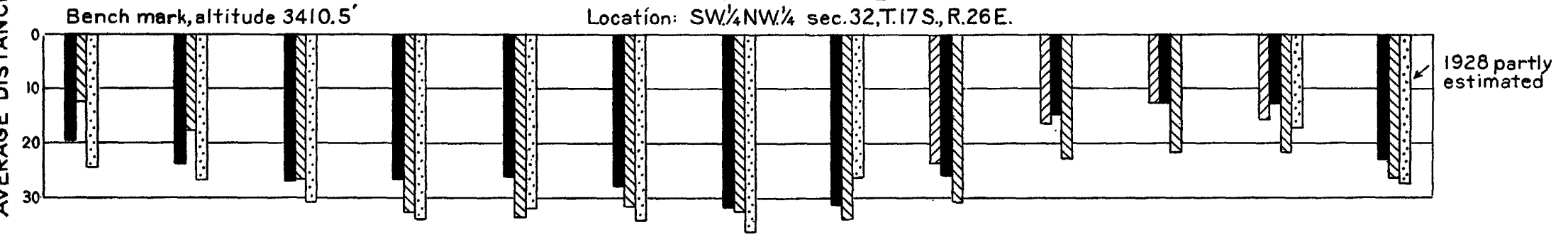

MEÁN MONTHLY AND MEAN ANNUẠL ARTESIẠN MEẠp IN REPRESENTATIVE WELLS, AUGUST, 1925, TO DECEMBER, 1928

EXPLANATION

目 1925

1926

81927

1928 


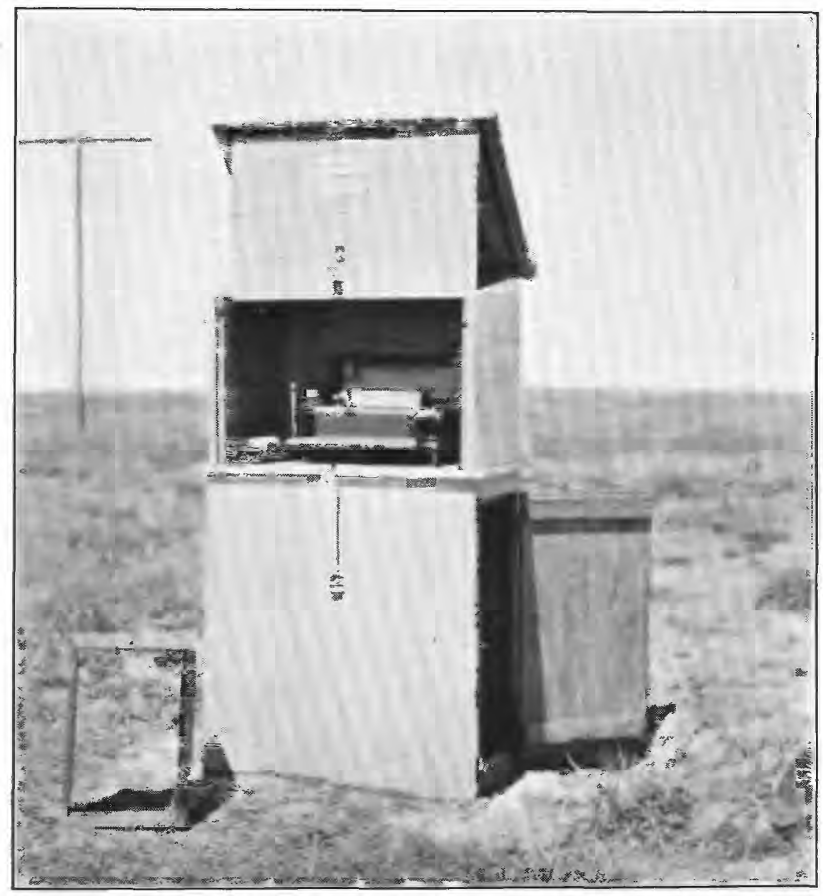

A. AUTOMATIC WATER-STAGE RECORDER INSTALLED OVER NONFLOWING ARTESIAN WELL

Photograph by A. G. Fiedler.

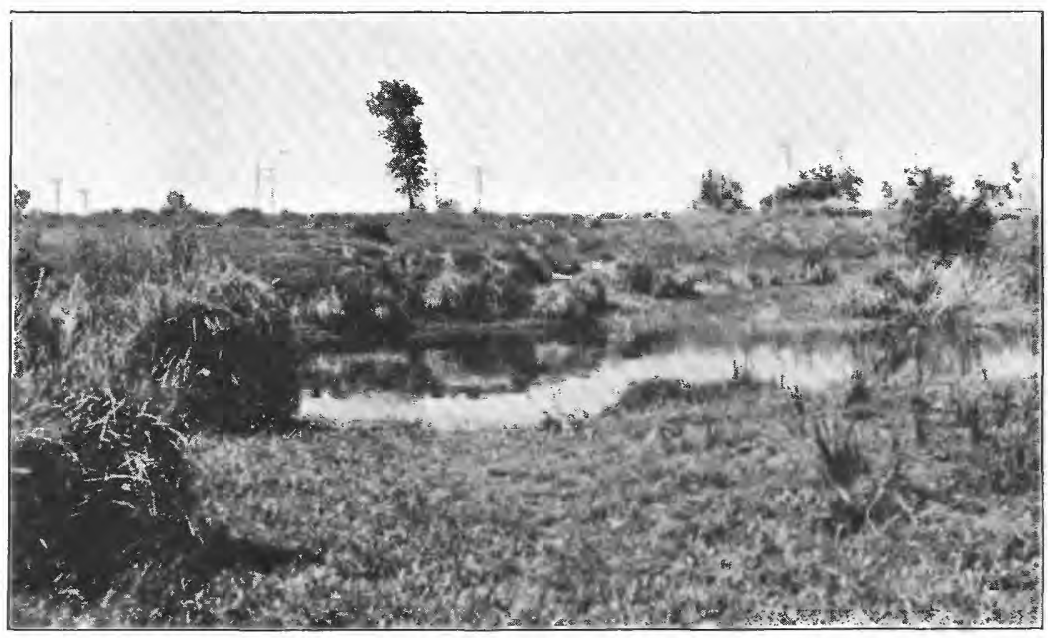

B. SOUTH SPRINGS, HEAD OF THE SOUTH SPRING RIVER

Photograph by A. G. Fiedler. 




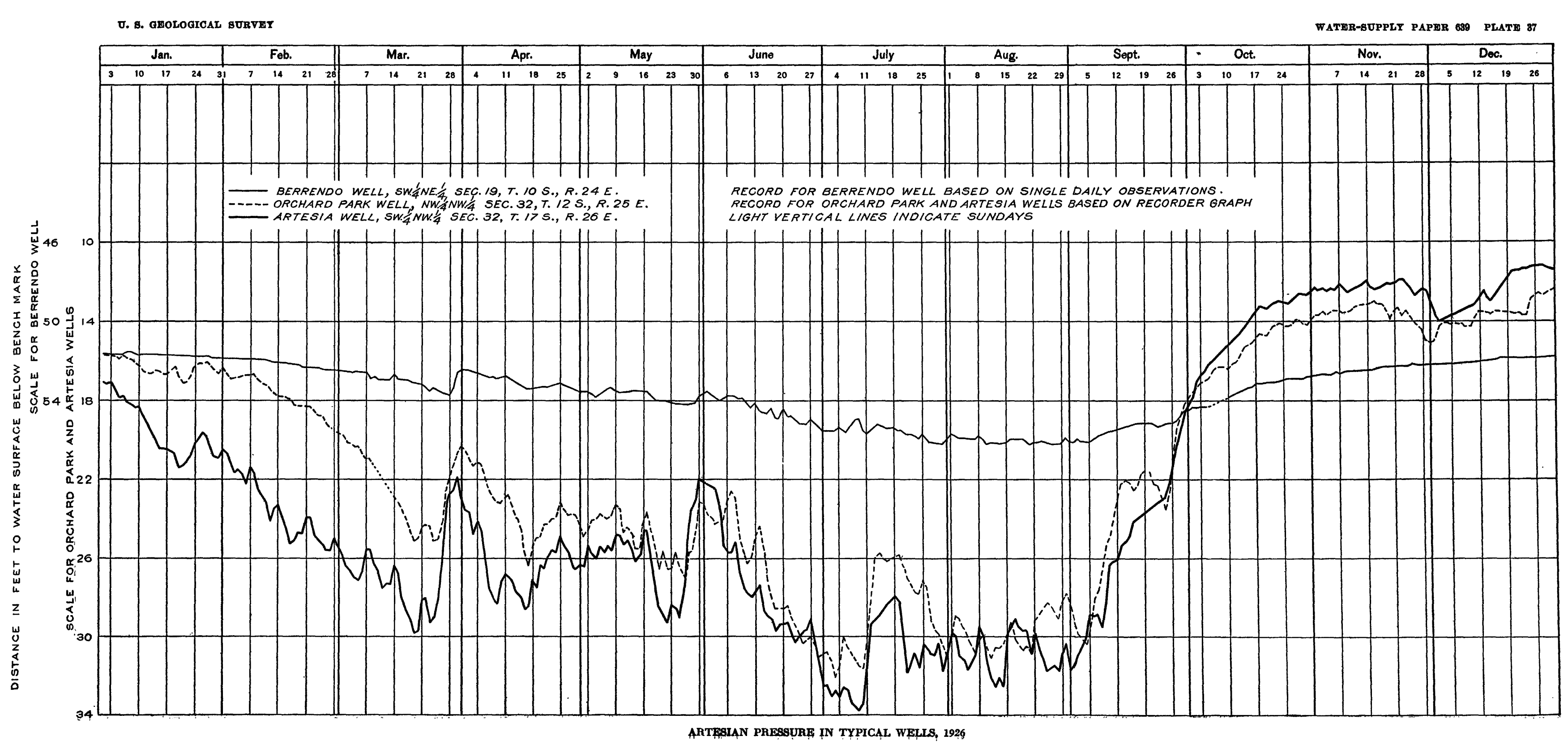



Roswell is the only station in the entire artesian basin at which a recording instrument is used for measuring the time of beginning and ending of rainfall. The precipitation during the period July 10 to 12 was, however, general throughout the valley and the tributary drainage area on the west, and the quantity recorded at the other stations in the valley varied but little from the quantity at Roswell, though in the tributary drainage area the rainfall was somewhat greater at the higher altitudes.

The characteristic fluctuations that follow periods of precipitation are plainly evident from a comparison of the records of precipitation at Roswell and Artesia with the graph of the water level of the wells in the different segments, as shown in Plate 36. The peak head is generally reached within about two days after the end of periods of moderate rainfall and within a shorter time for lesser rains. The effect of less than 0.10 inch of rainfall is rarely discernible.

It is generally impossible to differentiate between the rise in head caused by the curtailment in irrigation draft during a period of rainfall and the direct effect resulting from the precipitation. Usually during periods of only moderate precipitation the draft is not materially reduced, for the reason that irrigation proceeds more rapidly because of the wetting of the upper surface of the ground by the rain. The fluctuations shown in Plate 32 therefore represent the combined result caused by reduced draft and the effect of precipitation. The relative proportion due to each cause varies according to the location and the particular conditions existing in any segment at the time that the precipitation occurs. The relation of precipitation to rise in artesian head is considered further on pages $247-248$.

\section{SEASONAL FLUCTUATIONS}

Changes in artesian head from season to season have been noticed for many years. The fluctuations in the Berrendo, Orchard Park, and Artesia observation wells are shown in Plate 36. The mean daily level for the wells equipped with water-stage recorders is determined by inspection of the recorder graphs, or, for days of wide fluctuations, by averaging the level for hourly or other regular periods. The graphs for each year are plotted superimposed so that the difference in the altitude of the water level for the same date in different years is readily discernible.

The Berrendo well 2, which is equipped with a recorder, is about 2 miles northeast of the Berrendo well 1, which is equipped with a float gage. The marked similarity of the graphs of the two wells clearly illustrates how closely the artesian head fluctuates within different wells tapping the same aquifers in the same locality, even though the wells may be several miles apart. In the Berrendo well 1 
the maximum seasonal variation for the period of record during1925 , from the high point in the winter until the low point in the summer, was 5.66 feet; for 1926 it was 4.60 feet; and for 1927 it was 5.43 feet. (See also table, p. 215.) In this area most of the wells are operated by electric motors, and the fact that the head fluctuated only slightly in January and February indicates that comparatively little irrigation was done before the first of March. As there is a minimum power charge based on the demand horsepower, the farmers delay placing the pumps on the electric power line until such time as pumping for lenger periods becomes necessary. After the start of the irrigation season the artesian head normally declines till the end of the summer, except for short periods when rainfall and the consequent reduction in the irrigation draft may cause it to rise. The fluctuations common to all wells are discernible in the graphs for the wells in the Berrendo tract, but in view of the fact that the fluctuations are greater in the wells farther south, they will be discussed in reference to the wells at Orchard Park and at Artesia.

The initial observation on the Orchard Park well, July 23, 1925, was made at the beginning of the first rains of consequence in that year. The records of the United States Weather Bureau at Roswell show that no measurable quantity of rain had fallen during a period of 98 days prior to May 5, 1925, and only a total of 0.79 inch in scattered showers from May 5 to July 21 . In consequence of the heavy irrigation draft caused by the marked deficiency in precipitation the artesian head at the beginning of the period was at a very low level, probably the lowest level that had been reached in the history of the area, but the heavy precipitation on July 21 and 22 had probably already caused some rise in the water level by the time the first observation was made.

As a result of the copious rains in the latter part of July, 1925, and the consequent reduction in the irrigation draft, a rise of 7.4 feet occurred in the water level in the Orchard Park well during: the period of 21 days from July 23 to August 13. A similar increase in the artesian head doubtless occurred in the wells in the Artesia segment, but the observations made were not sufficient to define the rise in this segment. An increase in the irrigation draft caused the lowering of the head in the latter part of August. Owing to scattered rains throughout September in the northern part of the area and the decrease in irrigation draft, the artesian head maintained a level about equal to the high point reached during August. Eddy County did not experience rains that were particularly beneficial during September, and irrigation proceeded without interruption, as a result of which there was no marked increase in head 
during the month. The irrigation of crops is practically completed by the latter part of September, and the reduction in draft is reflected in the subsequent gradual rise in the artesian head, which reached a maximum in the latter part of November.

In the north end of the valley, as represented by the graphs of the Berrendo and Orchard Park wells, the head was maintained at a high level until the latter part of January, 1926. The early irrigation of alfalfa fields and orchards and of land that is to be plowed usually commences in January or earlier, and such draft is reflected in the gradual decline of head in the Berrendo and Orchard Park wells during the latter part of January and the more noticeable decline in the Artesia well early in January. The gradual decline in all the wells during the spring is, of course, the result of irrigation. Marked fluctuations follow periods of rainfall and reduction of draft, and the peak head usually occurs from one to two days after the precipitation stops. The minimum head usually occurs either in. June or early in July in normal years. As a rule there is considerable precipitation in July, August, and September.

The seasonal change from the high point in the winter to the low point in the summer appears to follow a very regular cycle, and the average head during the period April to August tends to reach a stable level similar to the apparent condition reached in the water level of an individual well after it has been in operation for a. period of time.

The following table shows the amount of seasonal variation from: the high to the low point for the period of record for the observation wells:

Seasonal fuctuation, in feet, in observation wells, 1925 to 1928

[For periods of record see graph, pl. 36]

\begin{tabular}{|c|c|c|c|c|}
\hline Woll & 1925 & 1926 & 1927 & 1928 \\
\hline $\begin{array}{l}\text { Berrendo No. } 1 \\
\text { Orchard Park- } \\
\text { Artesia }\end{array}$ & $\begin{array}{r}5.66 \\
10.82 \\
15.47\end{array}$ & $\begin{array}{r}4.60 \\
19.58 \\
22.52\end{array}$ & $\begin{array}{r}5.43 \\
20.20 \\
23.76\end{array}$ & $\begin{array}{r}3.87 \\
17.69 \\
21.17\end{array}$ \\
\hline
\end{tabular}

The fluctuation given in the above table is the difference between the average level of the day of lowest head and the average level of the day of highest head. The absolute maximum variation is somewhat greater than that shown, except for the Orchard Park and Artesia wells for the year 1925, when the full seasonal variation was not obtained during the period of record.

In the Berrendo well 1 the artesian head was higher during theperiod August to December, 1925, than for the same periods in 1926. and 1927. In the period January to March the head was practically. 
the same for both 1926 and 1927. The beneficial rains and the corresponding lower irrigation draft during the early part of the irrigation season of 1926 maintained the head at a comparatively high level, probably much higher than that for the same period in 1925 ; however, in the later part of the season the effect of increased draft is reflected in the head, for, despite the earlier beneficial rains, the head in August and September, 1926, was lower than at the corresponding time in 1925 . The year 1927 was marked by a great deficiency of precipitation and a resulting heavy draft for irrigation; after the end of February, the head exceeded that of 1926 only for a short period during the later part of June and early in July, and at the end of 1927 the water level in this well was 2.67 feet lower than at the end of 1925 and 2.50 feet lower than at the end of 1926 . The artesian head in the Berrendo tract and the Roswell segment of the area was therefore not nearly so favorable in 1927 as in preceding years. The observations on Berrendo well 1 , in SW. $1 / 4$ NE. $1 / 4$ sec. 19, T. 10 S., R. 24 E., were discontinued on June 30, 1928, but records are available for most of the remainder of the year for well 2 , in the SW. $1 / 4$ SW. $1 / 4$ sec. 9, T. 10 S., R. 24 E., where the automatic water-stage recorder was operated through November 18, 1928. Well 2 is in the eastern part of the Berrendo tract, and its fluctuations are practically the same as the fluctuations in well 1 , which is in the western part. The difference in head in well 2 at the beginning of 1928 below the head at the beginning of 1927 was approximately the same as the difference for the same periods in well 1. From January to April, 1928, the head in well 2 averaged about 2 to 2.5 feet below that of the same period in 1927 . Beneficial rains occurred during the early part of May, and the head rose to a level about equal to that at the end of May, 1927. During June and July the head declined to a new low level, probably the lowest that has ever occurred in the Berrendo tract. (A similar low level is noted in the head of well 1 during the later part of June, just prior to the discontinuance of the record.) Copious rains occurred during August, and as a result the late seasonal irrigation draft was materially reduced, with a consequent marked rise in head during the month. A more or less gradual rise in head occurred during the rest of the year, and the head was about 1 foot higher at the end of 1928 than at the end of 1927.

The conditions shown by the graphs for the wells at Orchard Park and Artesia are similar to those for the Berrendo tract. The effect of conservation of the water during the winter of 1926-27 is shown by the fact that the head for December, 1926, to February, 1927, was considerably higher than for December, 1925, to February, 1926. During 1928 the minimum head in the Orchard Park well was practically the same as that reached in 1927; but the mini- 
mum head in the Artesia well was 2.76 feet lower than the minimum head in 1927. At Orchard Park the head on December 31, 1927, was 2.03 feet lower than on the same date in 1925 and 5.27 feet lower than on the same date in 1926. The record of the Orchard Park well for 1928 is not complete, but observations made in the other wells indicate that the head was approximately the same on December 31, 1928, as on the same date in 1925. At Artesia the head on December 31, 1927, was 4.70 feet lower than on December 31,1926 ; and on December 31, 1928, the head was practically the same as on the same date in 1925. The records of the three wells for the year 1926 are shown in Plate 37. The graph illustrates in a very striking manner the rise due to the curtailment of irrigation. In the Artesia well during the period January 25 to March 10 a series of rises occurred at intervals of one week. These increases invariably occurred on Sunday, except where the result of precipitation and recharge to the artesian reservoir cause the rise to occur a day or so later. Similar fluctuations are recorded for all the observation wells and may be readily identified by noting the coincidence of the peaks with the dotted lines used to designate Sundays.

Plate 37 illustrates also the very marked relation between the fluctuations of the wells in the different segments of the area. Corresponding fluctuations are discernible in the curves of all three wells, though the magnitude of the fluctuations is not so great in the north end of the artesian area, represented by the Berrendo wells, as it is in the wells at Orchard Park and Artesia. This is good evidence that the basin is not separated into several units that act independently of one another, for if these wells were located in distinct basins it is not likely that there would be so marked a correspondence in the fluctuations of the artesian head as is shown by these graphs. It is true that there are minor differences in different localities in precipitation and draft. Such a condition is to be expected, and the reason is clearly evident by reference to the effect created by the operation of individual wells, as discussed on pages 207-211. In view of such minor variations and more particularly because of the varying conditions in the Cottonwood segment, it is frequently stated that the area in Eddy County is more or less independent of that in Chaves County and that the results of conservation in any particular segment will not benefit other segments. There is no evidence other than these minor differences which would support such a conclusion, and it can not be too definitely pointed out that the entire basin is largely one unit. It is therefore evident that greater draft or waste of water in any segment in the area will result in lowering the water level in the wells in other segments. 


\section{ATMOSPHERIC PRESSURE}

The effect of the changes of atmospheric pressure upon the water level in wells has been noted by many investigators. Plate 38 shows the atmospheric pressure at Roswell, from United States Weather Bureau records, and the level of the water in the observation well at Orchard Park, 12 miles south of Roswell. The barograph readings, which are recorded as inches of mercury, have been converted to equivalent feet of water, and the curve of atmospheric pressure and the curve of water level are therefore comparable. The specific gravity of mercury is 13.58 , and therefore a change in atmospheric pressure which produces a change of 1 inch in the mercury barometer would produce a change of 13.58 inches in a water barometer. The curve of atmospheric pressure is inverted so that the relation between the water level and the atmospheric pressure may be more readily apparent.

During the periods shown in Plate 38 there were no great fluctuations caused by pumping. The remarkable similarity between the two curves, therefore, gives ample evidence that an increase in the atmospheric pressure caused a lowering of the water level and a decrease in atmospheric pressure caused a rise in the water level. Except for November 23, the relation is consistent. On that day, a day of falling barometer, the water level also declined. It is believed that this decline was caused by the operation of distant wells. The periods shown in Plate 38 are typical of other periods during which there was no noticeable operation of wells to interfere with the normal water-level fluctuations.

The effect of changes in atmospheric pressure upon the water level in wells is summarized by Meinzer ${ }^{61}$ as follows:

If a shallow well ends in a formation that lies at the surface and is freely permeable throughbut, only slight barometric effects or none at all are to be expected, because any change in the atmospheric pressure is transmitted almost as freely upon the water table through the permeable material as upon the water level in the well. If a well ends in an artesian formation and this formation or the overlying confining beds have sufficient strength completely to resist deformation by slight changes in pressure at the surface, the well will act as a barometer. The fiuctuations of its water level will have virtually the same range of fiuctuations as would be shown by a water barometer, or 13.5 times the range in a mercury barometer. However, the movements of the water level in the well will always be in the opposite direction from those in the barometer. If this well is near the seashore its water level will not show any tidal infiuence.

If a well ends in a somewhat elastic artesian formation that is confined beneath beds, such as soft shale, that are impermeable but yield more or less

or Meinzer, O. E., Methods of estimating ground-water supplies, pt. 1, Outline of available methods (paper presented at annual technical session, Society of Bconomic Geologists, December, 1928), p. 23 ; also in U. S. Geol. Survey Water-Supply Paper 638, pp. 140-141, 1932. 
to even slight pressure, its water level will have smaller fluctuations resulting from atmospheric pressure changes than that of a water barometer, and the satio of the movements in the well to the corresponding movements in the barometer will give a measure of the resistance of the water-bearing and confining beds. If such a well is near the seashore its water level will fluctuate more or less with the tide.

If a well ends in a formation that is effectively covered by an impermeable bed but is unsaturated in its upper part, thus having an air chamber between the water table and the overlying impermeable bed, the water level in the well will behave like that in an artesian well in competent beds. It will fluctuate through about the same range as the water level in a water barometer, because, as in the other case, the counter pressure will remain nearly constant.

The records indicate that the confining beds overlying the artesian aquifer tapped by the observation wells are of sufficient strength to resist the changes in atmospheric pressure, as the fluctuations in the water level in the well are approximately equal to the fluctuations in pressure indicated by a water barometer. The fact should not be overlooked that the fluctuations in the water level in wells are the result produced by the operation of several forces operating simultaneously, and for this reason the fluctuation produced by the operation of a force of small magnitude is usually discernible only during periods when the other interacting forces are not great.

\section{AREA OF ARTESIAN FLOW}

The original area of artesian flow as mapped by Fisher ${ }^{62}$ comprised about 650 square miles. Since the time of Fisher's investigation it has been found that the area of artesian flow extended slightly farther north on the Berrendo tract north of Roswell and somewhat farther west on Cottonwood Creek in Eddy County. In the first preliminary report ${ }^{63}$ of the present investigation the original area of artesian flow was stated as being 670 square miles. Since the publication of this preliminary report the compilation of a new base map for this area has been completed, and according to the best information now available the original area of artesian flow (see pl. 39) has been determined as comprising 663 square miles.

With the decline in head the size of the area of artesian flow has decreased. In 1916 Meinzer ${ }^{64}$ mapped the boundaries of the area of artesian flow as it existed in August of that year. There had been a decrease of 164 square miles, of which 58 square miles were in Chaves County and 106 square miles in Eddy County. During the

\footnotetext{
Fisher, C. A., Preliminary report on the geology and underground waters of the Roswell artesian area, N. Mex.: U. S. Geol. Survey Water-Supply Paper 158, p. 9, 1906.

Fiedler, A. G., Report on investigations of the Roswell artesian basin, Chaves and Eddy Counties, N. Mex.: New Mexico State Engineer Seventh Bienn. Rept., p. 43, 1926.

64 Meinzer, O. E., memorandum regarding the Pecos Valley artesian basin (U. S. Geol. :Survey manuscript report), 1916.
} 
period 1916 to 1925 there was a further decrease of 74 square miles35 square miles in Chaves County and 39 square miles in Eddy County.

Figure 30 shows a hypothetical section which illustrates the relation of the decline in artesian head to the decrease in the width of the area of artesian flow for a basin of the Roswell type. As a result of the topography a decline in the artesian head during a certain period may cause a large shrinkage in the width of the area of artesian flow and hence in the total area of flow, whereas a decline of like amount during a succeeding period may cause only a very small shrinkage in the area of flow. It is evident that the nature

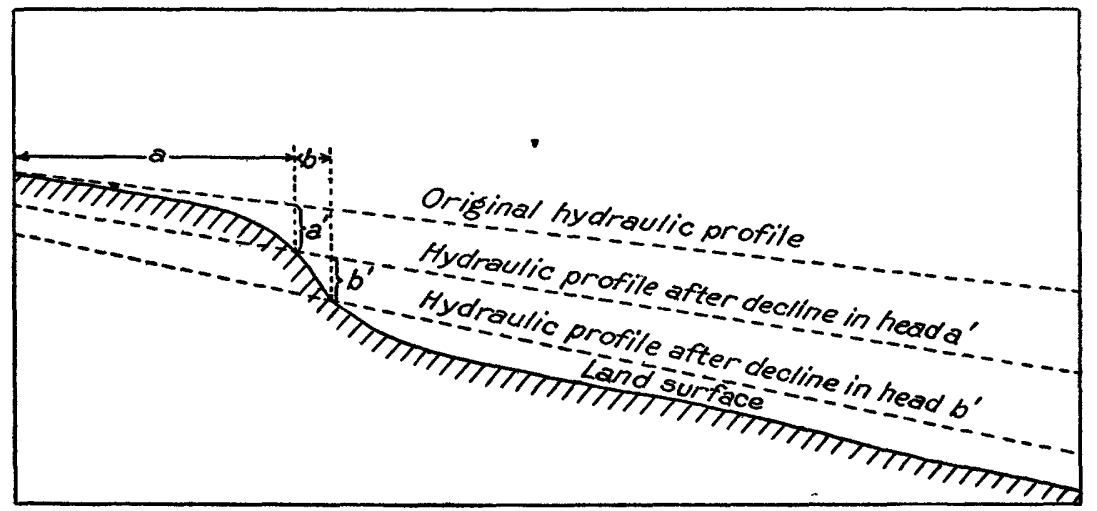

FradR 30.-Hypothetical section showing decrease in width of area of artesian flow with decline in artesian head. The hydraulic profile indicates the height to which the water would rise in artesian wells along the section. $a$, Decrease in width of area of flow due to decline in head $a^{\prime} ; b$, further decrease in width of area of flow due to decline in head $b^{\prime}$

of the topography along the western boundary of the area of flow in the Roswell artesian basin has a bearing upon the shrinkage that has already occurred. Unfortunately topographic maps covering the Roswell artesian basin are not available, and it is impossible to determine accurately the shrinkage in area of artesian flow that would occur as a result of further decline in the artesian head. However, in view of the fact that the eastward slope of the ground surface generally grows less toward the Pecos River it is evident that future decline in head of only a moderate amount may result in a considerable shrinkage in the area of artesian flow.

The decrease in the area of artesian flow has varied according to the relative location of the west boundary. At the north end the change in the boundary of the area of flow has been very small and has not been sufficient to affect greatly the size of the area. Up to 1916 the decline in Chaves County had been greatest west of Hager- 

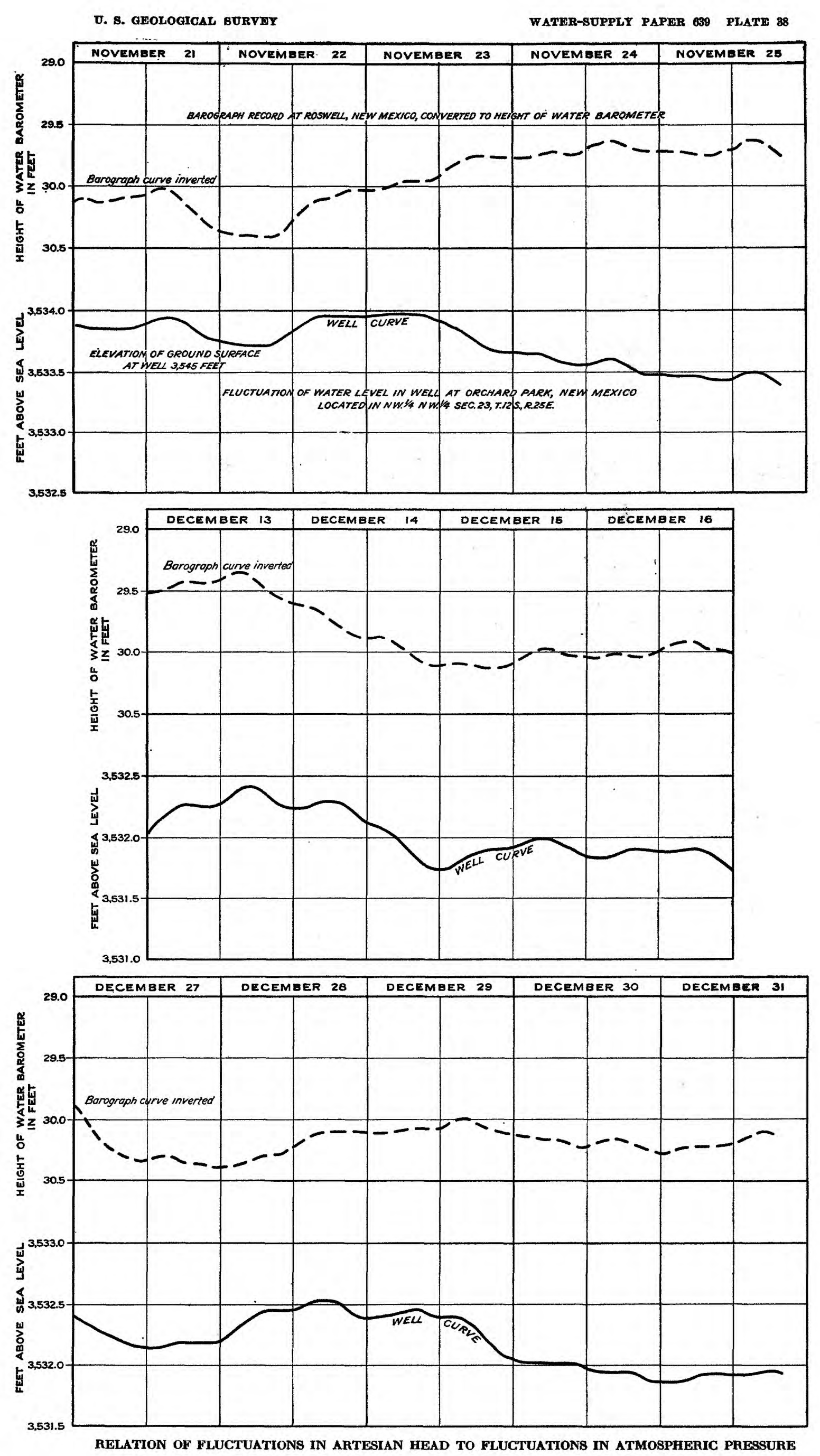

man and Lake Arthur. From 1916 to 1925 wells ceased flowing in an additional strip about $11 / 2$ miles wide along the west side of the area of flow from Roswell south to the county line. In Eddy County from 1905 to 1916 wells stopped flowing in a strip about 4 miles wide along the west side of the area from Cottonwood Creek southward. From 1916 to 1925 the area of artesian flow shrank by an additional strip about $11 / 4$ miles in width. (See pl. 39.)

The following table shows, according to counties and for the whole basin, the size of the original and present areas of artesian flow and the decrease in area up to 1916 and for the period 1916 to 1925.

Size, in square miles, of area of artesian flow and decrease during various periods

\begin{tabular}{|c|c|c|c|c|}
\hline & $\underset{\text { area }}{\text { Original }}$ & $\begin{array}{l}\text { Decrease } \\
\text { to } 1916\end{array}$ & \begin{tabular}{|l} 
Decrease \\
$1916-1925$
\end{tabular} & $\begin{array}{c}\text { Area in } \\
\text { winter of } \\
1926-27\end{array}$ \\
\hline \multirow[t]{2}{*}{$\begin{array}{l}\text { Chaves County } \\
\text { Eddy County }\end{array}$} & $\begin{array}{l}376 \\
287\end{array}$ & $\begin{array}{r}58 \\
106\end{array}$ & $\begin{array}{l}35 \\
39\end{array}$ & $\begin{array}{l}283 \\
142\end{array}$ \\
\hline & 663 & 164 & 74 & 425 \\
\hline
\end{tabular}

Plate 39 shows a small shrinkage in the area of artesian flow on the upper part of the Cottonwood segment. There has been a definite decline in the head of the wells in this locality (see also pp. 203204) and hence some shrinkage in the area of artesian flow has undoubtedly occurred here. The prevailing general opinion to the contrary is probably due largely to the fact that at the time of Fisher's investigation wells had not been drilled far enough up the Cottonwood to define this area fully.

An irrigated area adjacent to the west side of the area of artesian flow has been developed by pumping water from nonflowing artesian wells. With the decline in head and the shrinkage of the area of artesian flow other wells that formerly flowed are now operated with pumps. A decline in artesian head lowers the level of the water in the nonflowing wells at about the same rate as in the flowing wells. This causes a higher pumping lift and may require the installation of larger power plants to produce the same quantity of water. With further decline the pumping lift may eventually become so great that it is no longer profitable to operate the farm, and the property may finally be abandoned. This slow but progressive change has persisted through many years and has added one farm after another to the belt of abandoned farms that are so conspicuous along the west side of the artesian area. Obviously, therefore, the aim in the present use of water should be to prevent further shrinkage in the area of artesian flow, which is still continuing, though at a considerably reduced rate. 


\section{SPECIFIC CAPACITY OF WELLS}

The specific capacity of a flowing well is the rate of discharge per unit of head. For a well that yields water by pumping the specific capacity is the rate of discharge per unit of drawdown. The discharge of a well is usually expressed in gallons a minute and the head in feet of water. In a flowing well the head is usually measured by a pressure gage that indicates the pressure in pounds to the square inch when the well is closed. Each pound of pressure to the square inch is equivalent to about 2.3 feet of head. The discharge is usually measured by means of a weir or a current meter. A well of large specific capacity is good and one of small specific capacity is poor, hence the specific capacity furnishes a convenient measure for comparing wells. Within certain limits the discharge of a well varies almost directly with the head. (See fig. 31.)

The observations upon which are based the graphs of the wells shown in Figure 31, were made by the artesian-well supervisors over a period of years, and a considerable range in pressure and discharge was therefore noted. As was to be expected, the individual observations deviate somewhat from the mean curve, owing probably to inaccuracies in the measurement of the discharge. The average specific capacity, or discharge per foot of head, is 8.5 gallons a minute for three 6-inch wells, 17.9 gallons a minute for four 8 -inch wells, and 55 gallons a minute for two 10-inch wells on which observations were made in 1926. The range in stage and discharge during the period of the investigation of the 10-inch wells was, however, insuffcient to develop curves of specific capacity for these wells. Observations on one $121 / 2$-inch well gave a specific capacity of 89 gallons a minute.

The specific capacity of 6 -inch wells appears to range from about 7 to 10 gallons a minute, that of 8-inch wells generally ranges from 13 to 22 gallons a minute, and that of most of the 10 -inch wells observed ranges from 50 to 55 gallons a minute. However, one 10-inch well, which was drilled in 1927 in the NE. 1/4 NE. 1/4 sec. 24, T. 15, S., R. $25 \mathrm{E}$., in a locality where wells of particularly large yields are obtained, has a specific capacity of 73 gallons a minute.

In some segments of the area the yield is low, and the specific capacity of wells drilled in these segments is considerably below the averages cited. These segments have been fairly well defined by drilling. With the decline in head the farms that were irrigated with water from wells of low specific capacity were usually abandoned because the yield of the wells became so small that operation of the farms was no longer profitable. As a result these wells were usually not maintained in proper condition, and measurements of pressure and discharge were not regularly obtained. Sufficient ob- 
servations are therefore not available to define properly the specific capacity curves for such wells. Single observations have indicated that the specific capacity of some 6-inch wells is as low as 2 to 3 gallons a minute, as compared with a specific capacity of 8.5 gallons a minute for an average 6 -inch well.

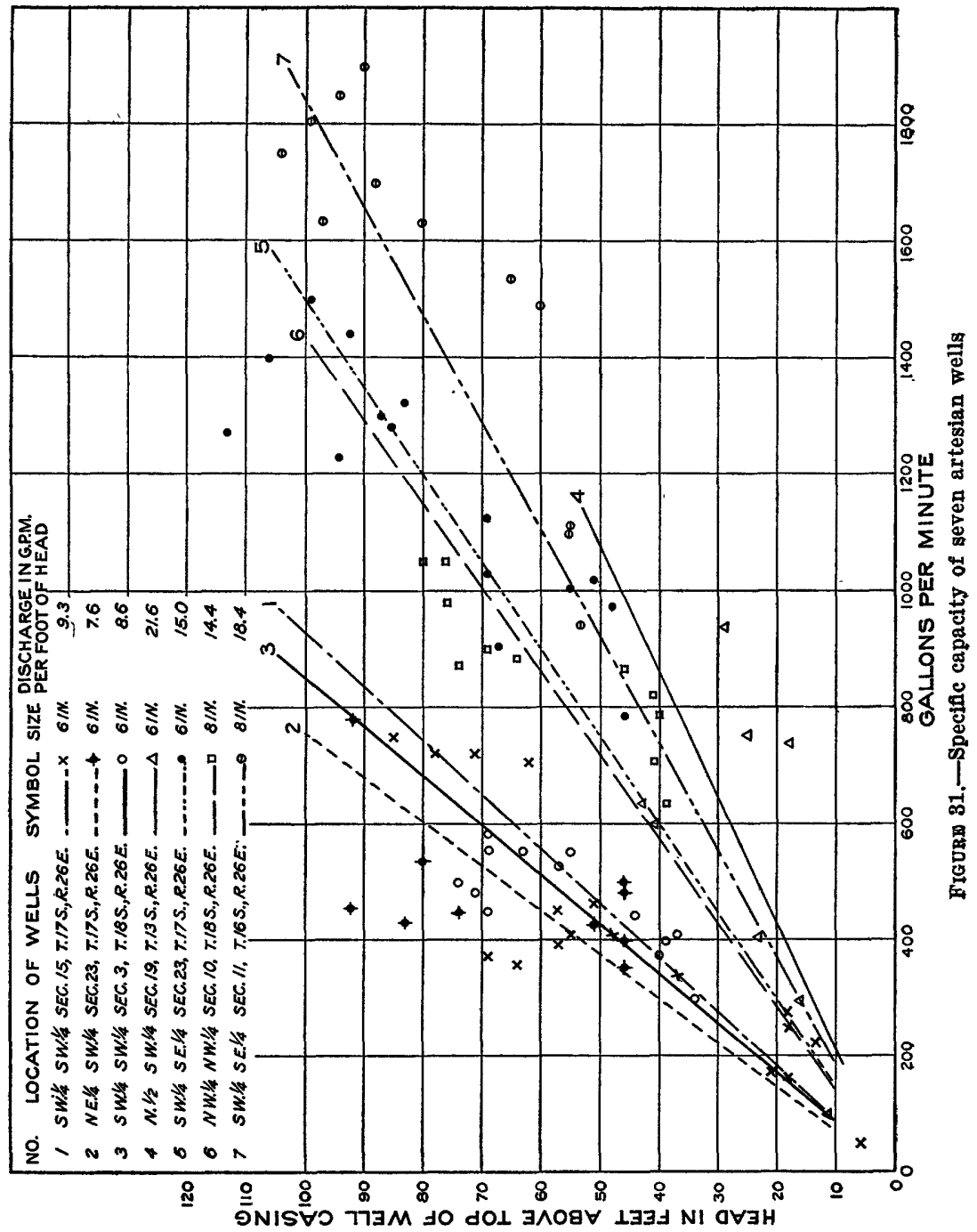

The approximate boundaries of the areas of wells of large yield and those of small yield are shown in Plate 41. These boundaries have been determined from a study of the specific capacity of the wells and are subject to some variation. The areas of low yield are more generally referred to by the drillers as " areas of tight forma- 
tion." As pointed out on page 184, the low yield of wells within these areas is due in all probability to appreciably lower porosity and permeability of the artesian aquifers tapped. The term "permeability," or "hydraulic permeability," is defined ${ }^{65}$ as the capacity for transmitting water under pressure. The designation of these areas as areas of low permeability would, therefore, be more properly descriptive of the existing conditions.

The fact that the wells of low yield appear to be confined to certain areas has been cited as evidence that these areas are separated from the adjoining areas where the wells have a higher specific capacity. The available evidence does not support such a conclusion but on the contrary indicates that these relatively poor segments are the result of difference in porosity and permeability, as just stated.

These differences in the yield of wells have markedly affected the development of the different sections of the artesian basin. In traveling north and south through the valley it is noticed that the irrigation development is not continuous but is confined to certain segments, whose boundaries coincide more or less closely with the boundaries of the area of low permeability. Though the segments of low yield had not been recognized during the early development of the basin, the drilling of wells gradually defined their limits, and the irrigation development in these segments was thereby greatly affected.

\section{QUANTITY OF WATER DISCHARGED BY ARTESIAN WELLS}

\section{AGGREGATE CAPACITY OF ARTESIAN WELLS}

In the preliminary report ${ }^{66}$ of this investigation estimates were made of the aggregate capacity of the artesian wells. Since the publication of that report much additional information has become available, and revised estimates were published in a later report. ${ }^{87}$ Information regarding many additional wells was obtained from the declarations of water rights that were filed in 1927 as a result of regulations issued by the State engineer of New Mexico in administering the provisions of an act ${ }^{68}$ governing the appropriation, use, and management of underground waters. Although the quantities involved have changed somewhat, the conclusions drawn from the preliminary data regarding the aggregate capacity of the artesian wells have not been altered.

\footnotetext{
*o Meinzer, O. E., Outline of ground-water hydrology, with definitions: U. S. Geol. Survey Water-Supply Paper 494, p. 44, 1923.

$\circledast$ Fiedler, A. G., op. cit., pp. 45, 47, and 48 .

niedler, A. G., and Nye, S. S., Ground-water investigations of the Roswell artesian basin, N. Mex. : New Mexico State Engineer Eighth Bienn. Rept., pp. 90, 99, 100, 1928.

${ }^{68}$ New Mexico State Legislature 8th sess., Laws, ch. 182, approved March 16, 1927.
} 
The total number of artesian wells, both flowing and pumped, used for irrigation was about 45 in 1900, 249 in 1905, 769 in 1910, 910 in 1915, 750 in 1920, 781 in 1925, and about 826 in 1927. (See fig. 32.) In 1927 about 60 wells used primarily for irrigation were pumped by electric motors and 211 by internal-combustion engines.
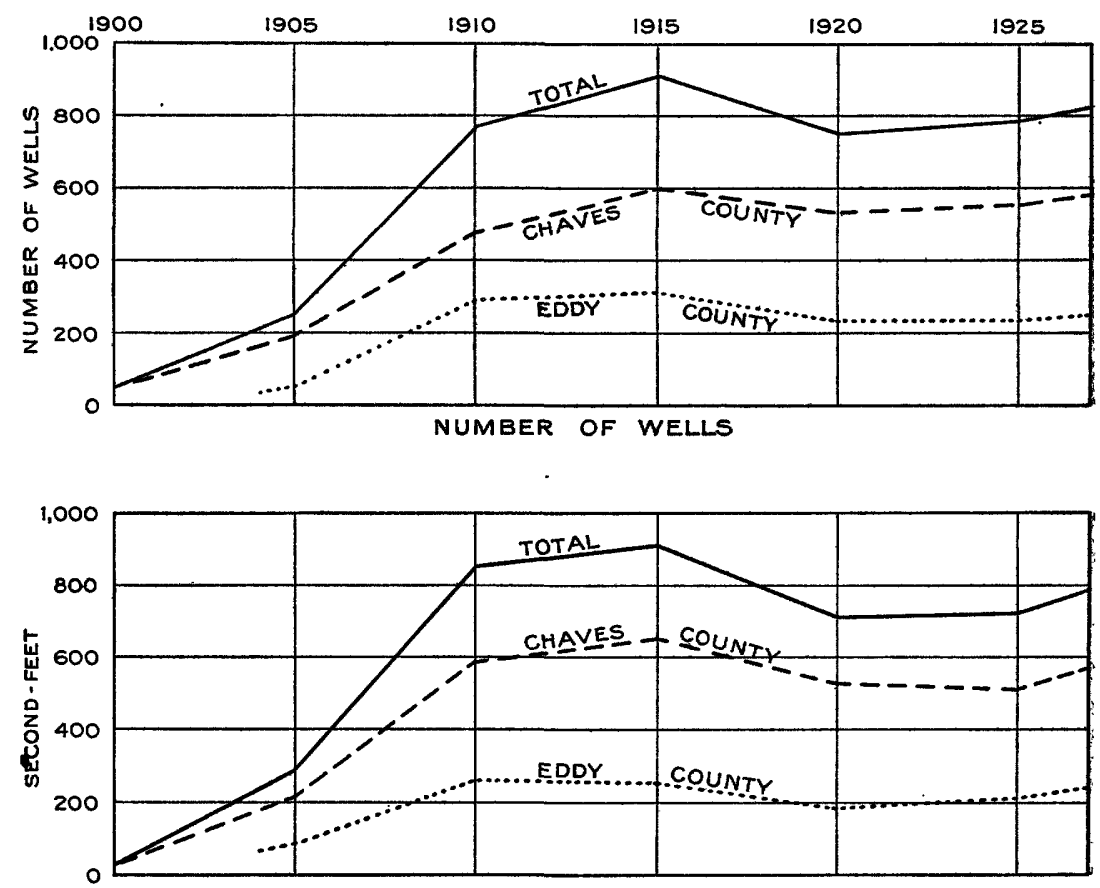

TOTAL AVERAGE DISCHARGE

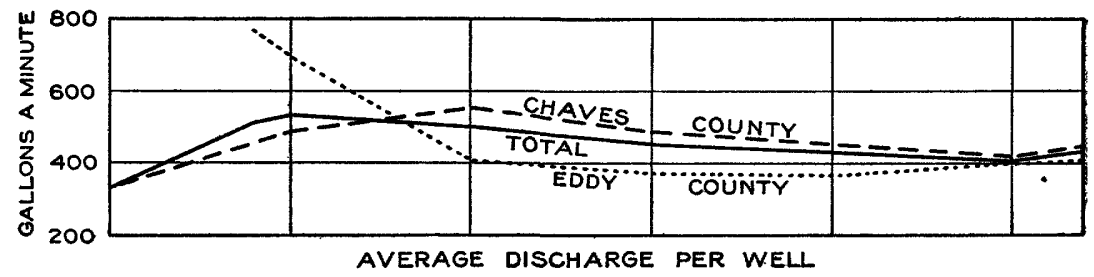

Figdre 32.-Number of flowing and pumped wells used for irrigation, 1900 to 1925, and total and average capacity of these wells

In Eddy County there were 56 pumped wells operated by internalcombustion engines. In the entire basin about 450 wells formerly used for irrigation have been abandoned, of which 244 are in Chaves County and 206 in Eddy County. Some of these wells, however, still furnish a small quantity of water which is used for domestic supplies and for watering stock. 
The estimates of capacity are based on a study of incomplete records of the county well supervisors, declarations of water rights filed with the State engineer, and a survey made during the present investigation. It should be noted that whereas Plate 28 shows the number of wells drilled during successive years, Figure 32 shows only those wells that were used for irrigation, and it does not include the large number of wells drilled within the city of Roswell and used chiefly for domestic purposes or wells that had been abandoned because of the drop in head or for other reasons.

In view of the fact that after 1905 most of the wells drilled were intended for irrigation the curves on Plate 28 and Figure 32 indicating total number of wells and wells used for irrigation show a marked similarity. The period 1904 to 1912 was the period of greatest drilling activity, and this activity is reflected in the curve showing the number of wells used for irrigation. As a result of this increase in draft upon the artesian reservoir a marked decline in head also occurred, and many wells ceased to flow or were abandoned because the pumping lift became too great for profitable farming. The curve of the number of wells used for irrigation therefore did not maintain a proportionate increase with the curve of wells drilled.

The wells drilled from 1916 to 1920 constitute only 1.5 per cent of the total (see table, p. 193), as compared with 14.8 per cent from 1910 to 1915 . The decline in drilling was probably due to war conditions, and for the same and other reasons many wells were abandoned. The curve of wells used for irrigation therefore declined during the period 1916 to 1920 . A slight increase occurred from 1920 to 1925 , probably owing to improvement in the drainage of portions of the irrigated area, the introduction of cotton, which had become a profitable crop, and the fact that the artesian head had not declined greatly. During 1926 and 1927 drilling increased, and the curve of the number of wells used for irrigation assumed a more definite upward trend.

In presenting these estimates of the number of wells used for irrigation it is realized that the figures may be subject to some error. Definite records were not maintained regarding the use of each well and the exact year that it may have been abandoned. For many wells the year of abandonment for irrigation was determined largely by the estimated discharge. However, though the estimates may be somewhat in error, it is believed that they indicate correctly the trend of the irrigation development and are therefore worth presenting.

The aggregate total discharge of the wells used for irrigation, based on a study of the records of the artesian well supervisors and a survey made in 1925 and 1927, is also shown in Figure 32. For the 
years prior to 1925 the estimates were partly made from records of discharge and partly computed from the more accurate records of head and from data or assumptions as to the specific capacity. The estimate for each well is an average of the estimated yield in the summer, when the head was low, and that in the winter, when the head was relatively high. For some years for which no records were available the records for preceding or following years were used.

The aggregate capacity of the wells amounted to about 33 secondfeet in 1900, 292 second-feet in 1905, 855 second-feet in 1910, 911 second-feet in 1915, 716 second-feet in 1920, 726 second-feet in 1925, and about 793 second-feet in 1927 . The peak capacity for the basin was doubtless reached before 1915 , probably in 1913, when the marked development occurred in the Berrendo tract north of Roswell. The peak in Chaves County occurred at about the same time as the peak for the area, but the peak in Eddy County was probably reached about 1908.

The average discharge of wells used for irrigation has not changed greatly during the last 20 years. Initially the wells were of small diameter and had a comparatively high head; hence their yields compared favorably with the yields of later wells that were larger in diameter but had lower heads because of the decline in the artesian pressure. The average capacity of the wells declined slightly from 1905 to 1925 . During 1926 and 1927 several wells of large yield were drilled, and the average discharge of 22 wells drilled in Chaves County during this period was over 1,300 gallons a minute. The addition of these wells of large yield was sufficient to give the curve for all the wells a definite upward trend for 1926 and 1927. It should be remembered that during the entire period shown on Figure 32 new wells were constantly being drilled while others were being abandoned. Hence, although the capacity of most wells declined from year to year, the average capacity of all the wells declined less rapidly and actually increased during parts of the period.

In 1927 the total number of wells in use for all purposes was 754 in Chaves County and 336 in Eddy County. The aggregate capacity of these wells was computed by estimating the average capacity of each well throughout the year and adding these averages. By this method it was computed that for 1927 the aggregate capacity of all the wells in Chaves County was about 607 second-feet, in Eddy County about 240 second-feet, and thus in the whole basin about 847 second-feet. In Chaves County the flowing wells had an aggregate capacity of 335 second-feet and the pumped wells 272 second-feet. In Eddy County the flowing wells had an aggregate capacity of 160 second-feet and the pumped wells 80 second-feet. The aggregate 
capacity of all flowing wells in the basin was 495 second-feet, and that of all pumped wells 352 second-feet.

\section{QUANTITY USFD FOR IRRIGATION}

The statistics presented in the preliminary report regarding the acreage irrigated by artesian water and the quantity of water used for irrigation remain practically unchanged. These statistics are based chiefly upon data furnished by the Roswell Chamber of Commerce, the Artesian Alfalfa Growers Association, and the county assessors. The data for Chaves County are the more complete because the Roswell Chamber of Commerce maintains a record for each farm in the whole county, showing the acreage planted in the various crops.

The following is quoted from the preliminary report: ${ }^{69}$

According to the available data, about 45,000 acres were irrigated in 1925 with water obtained directly from artesian wells, either by natural flow or by pumping. About two-thirds of this area lies in Chaves County and about onethird in Eddy County. In addition to this area of 45,000 acres irrigated directly by the artesian water about 13,200 acres within the artesian area were supplied by water from tributary streams, waste water from wells, and water reclaimed by drainage ditches. About 9,500 of the 13,200 acres thus irrigated are supplied by the Northern Canal, which directly or indirectly derives its water chiefiy from the artesian reservoir.

The artesian well law of 1925 permitted the use of 3.5 acre-feet to the acre. This provision was omitted in the amended act passed by the 1927 session of the New Mexico State Legislature. When the supervision of the waters of the Roswell artesian basin was assumed by the State engineer the following regulation ${ }^{70}$ was issued by his office:

It has been generally demonstrated by State, private, and Government tests to be reasonably conclusive that any claim for greater than an equivalent of a net duty of 3 acre-feet of water per acre is excessive and is therefore contrary to the constitution and laws of New Mexico, which limit all water rights to the extent and under the condition of actual useful or beneflcial purposes, so that in the issuance of permits or licenses to use water for such purposes the amount allowed should not be in excess of the equivalent of 3 acre-feet of water per acre delivered on the land. If in the opinion of the State engineer more than 3 acre-feet of water is being used from said well, the State engineer may require the user of water from said well to install an approved measuring device.

For the types of crops cultivated in the artesian area an average of 3 acre-feet to the acre delivered at the land is believed to be ample.

It has been roughly estimated that during the period of this investigation an average of 3.25 acre-feet to the acre, including losses,

60 Fiedler, A. G., op. cit., pp. 47, 49, 50.

${ }^{20} \mathrm{New}$ Mexico State Engineer, Manual of rules, regulations, requirements, and instructions under laws affecting underground waters of the State of New Mexico, sec. 25, 1927. 


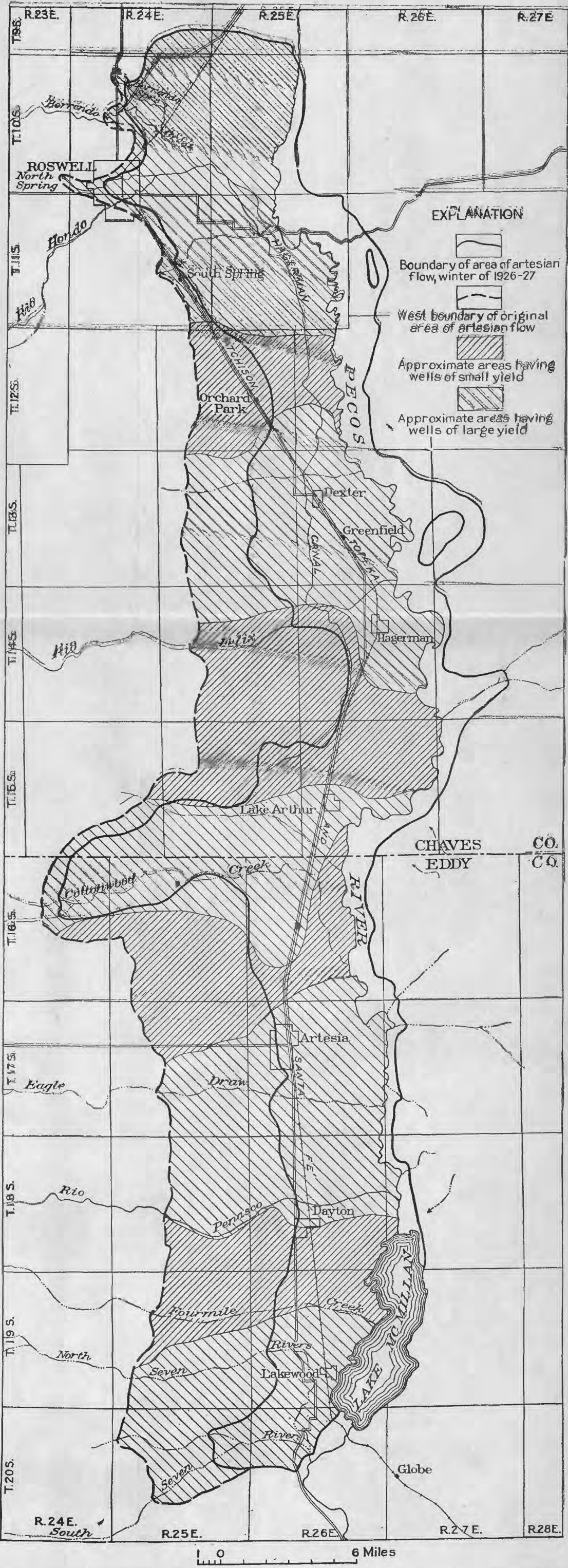

MAP SHOWING BOUNDARIES OF AREAS HAVING WELLS OF LARGE YIELD AND AREAS HAVING WELLS OF SMALI YIELD 


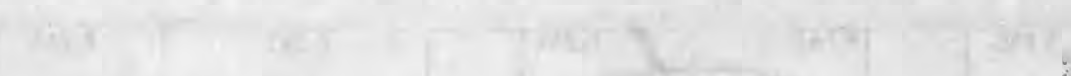


was used for the area directly irrigated from artesian wells either by pumping or natural flow. For the average area as shown for 1925 this would make a total of 146,250 acre-feet or in round numbers 150,000 acre-feet used for irrigation.

\section{SURFACE WASTE OF ARTESTAN WATER}

Fisher ${ }^{71}$ pointed out in his report the large waste of irrigation water throughout the Roswell Basin. No accurate measurements were ever made during the early years of the development of the basin; but according to the best information, it is estimated that nearly half of the water served no beneficial use. As a result of the enforcement of the artesian-well laws this condition was greatly improved, but probably the greatest corrective force was the decline in the yield of the wells and the water-logging of much low-lying land. Through the organization of drainage districts and the construction of drains the extension of the water-logged area was arrested, and large areas have been greatly benefited through a lowering of the water table.

From 1916 to 1925 the work of the well supervisors in curtailing waste was largely discontinued; and though the resulting condition was not nearly so serious as during the early years of development, there was a general spirit of laxness regarding the use of artesian water. In 1925 the waste of water during the irrigation season was probably no greater than that of the average irrigation project. Upon the farms where the water for irrigation is pumped the waste of water is at a minimum, though on some too much water is applied to the land. At the present time the largest loss of water during the irrigation season occurs through ditches which are in poor condition. The artesian-well law of $1927^{72}$ provides that the loss from the well to the point of use shall not exceed 20 per cent of the flow of the well. It is recommended that this provision be enforced as far as possible and that the irrigators be urged to improve their distribution systems by puddling ditches with clay, lining with concrete, or replacing with tile.

The largest waste of water occurs during the winter, when irrigation is at a minimum. In a survey made in the winter of 1925-26 it was estimated that 25,000 acre-feet of water was wasted from about 225 wells which had no valves or valves that were in poor condition and would not completely arrest the flow. These wells were about equally divided between the two counties, but the aggregate discharge of the wells in Chaves County was about 35 second-feet, whereas that of the wells in Eddy County was about 65 second-feet. The waste in pro-

${ }^{71}$ Fisher, C. A., op., cit. p. 25.

72 New Mexico State Legislature, 8th sess., Laws, ch. 149, sec. 7, 1927.

135252-33-16 
portion to the land irrigated was much greater in Eddy County than in Chaves County, for the irrigated area in Chaves County is nearly twice as large as that in Eddy County. Through the efforts of the county well supervisors the waste of water in Chaves County was materially curtailed during the winters of 1926-27 and 1927-28, but conditions in Eddy County have been only partly corrected. The waste in 1927 is estimated at about 15,000 acre-feet.

It is probably typical of irrigated regions to use large quantities of water prior to the major irrigation season whenever such water is available. The practice is not generally followed in the parts of this area where the water is pumped, but on lower-lying land where large flowing wells are obtained much water is used in this way. As a result the artesian head is seriously lowered, and at the start of the growing season the discharge of the wells has been greatly reduced. It is believed that the value of early irrigation is greatly overestimated in this area and that much benefit would be derived from a marked reduction in the winter irrigation, thereby saving water in the artesian reservoir until later in the season, when it may be used at a higher duty. The statement made in the preliminary report $^{73}$ regarding this practice is particularly applicable in this area and is repeated here:

Smith ${ }^{74}$ states in a discussion of winter irrigation of alfalfa that " 3 acre-feet of water applied in the months when alfalfa is dormant may be no more effective than 1 acre-foot in the growing season." Winter irrigation of crops in an area where the water would otherwise go to waste and where the irrigation does not produce water-logging may serve a beneficial purpose, but in the Roswell artesian area there is no reason why winter irrigation should be indiscriminately practiced. It would therefore be desirable to eliminate all winter irrigation, at least from November 15 to February 15, except for orchards which may be benefited by earlier irrigation. The results to be obtained by such a policy of conservation would be in the best interests of the area.

It is realized that in a few sections the type of soil is such that heavy irrigation is necessary for the proper preparation of the ground for crops, but these areas form but a small portion of the area on which large quantities of water are used prior to the major irrigation season. Without a complete measurement of the water used it is difficult to curtail this practice, but it is mentioned here for the reason that it may in the future become serious and ultimately require a complete metering of all the wells.

The noticeable recovery of head due to the curtailment of irrigation on Sundays shows that a closing of the artesian wells causes an increase in artesian head. The elimination of needless waste

\footnotetext{
${ }^{73}$ Fiedler, A. G., Report on investigations of the Roswell artesian basin, Chaves and Eddy Counties, N. Mex. : New Mexico State Engineer Seventh Bienn. Rept., p. 51, 1926.

${ }^{74}$ Smith, G. E. P., Ground-water supply and irrigation in Rillito Valley : Arizona Univ. Agr. Exper. Sta. Bull. 64, p. 97, 1910.
} 
would produce a like result, and the benefit from such conservation in Chaves County during 1926 and 1927 was definitely reflected in the artesian head, as shown on Plate 36. As stated in the preliminary report, ${ }^{75}$ conservation would largely arrest the progressive decline in head from year to year and might eliminate further decline altogether. Pumping costs would also be reduced, as the pumping lift would be lessened by the increase in the artesian head. In flowing wells the benefits of winter conservation would be derived through the increased discharge of the wells.

\section{DISCHARGE AT THE SURFACE}

According to the estimates made for the period 1925 to 1927 , about 150,000 acre-feet of water was used for irrigation directly from artesian wells. The surface waste of artesian water in 1927 was probably about 15,000 acre-feet more. The gain in the flow of the Pecos River between Acme and the mouth of the Rio Penasco (see also p. 252), estimated at about 35,000 acre-feet, is undoubtedly due to natural loss from the artesian reservoir. The basic flow of the Major Johnson Springs (see also p. 252), at the southeast corner of the artesian basin, is estimated at 29,000 acre-feet a year and is probably supplied from the artesian reservoir. Other losses from the artesian reservoir through springs and outlets in the tributary streams probably amount to about 5,000 acre-feet. The amount consumed for miscellaneous purposes, such as domestic use and watering stock, and for the city supplies of Roswell and Artesia is roughly estimated at 15,000 acre-feet. The total discharge at the surface from artesian wells and natural sources is therefore estimated at about 249,000 acrefeet a year, or, in round numbers, about 250,000 acre-feet.

\section{UNDERGROUND WASTE}

\section{IMPORTANCE OF THE PROBLEM}

It is evident that waste of water underground from a leaky artesian well reduces the amount of water available at the surface for irrigation. In some places a portion of the water that leaks out of the casing rises to the surface through a channel that has been eroded away along the casing and the water is utilized during the irrigation season. During the nonirrigation season this flow is wasted down the drainage ditches because it can not be controlled. The waste of water both above and below the ground surface from leaky wells tends to water-log low-lying lands and make them unfit for cultivation. The artesian head is greatest during the winter, when the irrigation draft is least. The greater head increases the amount of underground leakage, and the leaky wells therefore tend to prevent

35 Fledler, A. G., op. cit., p. 51. 
a rise in the artesian head in the same manner as the springs in the north end of the basin influenced the level of the artesian head prior to the development of the basin. Underground leakage from wells may in some sections form a major portion of the draft upon the artesian reservoir, and without proper steps to remedy such losses the artesian supply may be completely dissipated.

In the study of artesian basins the United States Geological Survey has long realized the importance of this problem, and considerable time has been devoted to the development of methods and instruments to determine the location and quantity of the underground leakage from wells.

\section{METHODS OF DETERMINING UNDERGROUND ILAKAGE}

Underground waste of artesian water caused by insufficient casing or defective casing may be determined by either the pressure method or the meter method. In the pressure method the pressure of a shutin well is obtained by means of a pressure gage. By comparing this pressure with that of similar wells in the vicinity, after due allowance has been made for the difference in altitude of the respective wells, it can be determined if the pressure of the well in question is up to the standard of the pressure of other wells in the locality. A pressure considerably lower than the prevailing level is usually indicative of a defective well. In the meter method of determining underground waste a specially constructed meter is inserted in the well and observations are made of the velocity of the water at different depths. Through the proper interpretation of the data obtained the location of the leak is determined and the quantity measured.

In the Roswell artesian basin the pressure method is satisfactory only for preliminary tests. The artesian head varies widely from place to place, and the artesian-pressure surface, or piezometric surface, is constantly changing. The pressure in the artesian reservoir changes from day to day and varies widely from season to season. There is also some difference in the head in different aquifers, and without complete up-to-date information on the prevailing artesian head for the section under consideration a low pressure may be interpreted erroneously. Because the operation of flowing or pumping wells in the vicinity may reduce the artesian head considerably, the pressure method is more reliable in the winter, when the draft for irrigation is the lowest, than in the summer, when most of the wells are in use. The meter method of determining underground waste is, however, the most reliable and during this investigation was used most generally.

The Price current meter, which is used by the United States Geological Survey in gaging streams, was the first current meter to be adapted for extensive use in exploring artesian wells. It has 
given valuable results when used in exploring wells in Hawaii, ${ }^{70}$. though it was not primarily designed for service of this type. A . new meter ${ }^{77}$ was designed and constructed especially for use in the wells of the Roswell artesian basin and has been successfully used in the exploration of numerous wells in the area.

The leaks usually occurring in wells may be classified as of four general types-(1) general disintegration of the casing, producing innumerable holes; (2) one or more large leaks; (3) improperly seated casing; (4) insufficient casing. The principles involved in the use of the meter method in determining these various types of leaks and the amount of underground waste and a description of the equipment are as follows: ${ }^{78}$

The fundamental hydraulic expression of water rising in a well is $Q$ equals $A \times \nabla$, where $Q$ equals the quantity of water per unit of time, $A$ equals the cross section area, and $\nabla$ equals the velocity of the water passing the section. It is apparent that for a given quantity of water flowing from a pipe in a unit of time the water has a certain mean velocity. Any increase in the quantity of water discharged per unit of time from a given pipe must be due to an increase in the velocity of the water. The water passing upward in an artesian well that is in good condition has a comparatively uniform velocity at all points along which the well casing is of the same nominal diameter, although minor variations are caused by slight irregularities in the cross-section area of the casing. Should a leak occur in the casing, the velocity of the water above this point will be decreased because a portion of the flow will be leaving the casing and wasting into permeable strata that are not filled with water or contain water under low head. The current meter is used to determine variations in velocity at different depths and thereby to locate underground leaks out of the well. The same principle is involved in the exploration of the uncased lower portion of the well to determine whether the casing has been inserted to a sufficient depth to prevent waste of water from the well into a permeable stratum that contains water under low head.

The Au deep-well current meter is essentially a turbine wheel mounted within a cylindrical brass case, which is suspended in a 3-inch pipe and is lowered and removed from the well by means of a cable and reel. The meter is provided with a mechanism for making and breaking an electric circuit either at every revolution or at every fifth revolution. When the meter is lowered into the well it is attached to an insulated electric cable so that the electric impulse made by interrupting the circuit may be recorded in a telephone receiver in a manner similar to that of an ordinary current meter. The meter is rated for different sizes of pipe and different velocities of water, and a table is prepared showing the number of revolutions per second corresponding to a certain velocity.

In exploring a well the meter is let down a little at a time and velocity observations are made at regular intervals to determine when a leak is passed. In a nonfiowing well no velocity will be noted until a leak is encountered,

76 McCombs, John, Methods of exploring and repairing leaky artesian wells on the island of Oahu, Hawaii : U. S. Geol. Survey Water-Supply Paper 596, pp. 4-24, 1927.

${ }^{77}$ Fiedler, A. G., The deep-well current meter and its use in the Roswell artesian basin, N. Mex., U. S. Geol. Survey Water-Supply Paper 596, pp. 24-32, 1927.

${ }^{78}$ Fiedler, A. G., Report on investigations of the Roswell artesian basin, Chaves and Eddy Counties, N. Mex.: New Mexico State Engineer Seventh Blenn. Rept., pp. 52-53, 1927. 
while in a flowing well a leak is indicated by an increase in velocity. If a water-bearing stratum which supplies water to the well is passed the speed of the turbine wheel will increase. After the meter has passed below the end of the casing variations in the velocity will occur due to the irregularities in the size of the hole. As long as no consistent change is noted these variations are disregarded.

Plate 42, A, shows the Au leakage meter, which was used in this investigation. Plate 43 shows two views of the complete equipment as mounted upon a truck for convenient use in moving from well to well. The motive power of the truck was also utilized in raising and lowering the current meter in the well.

\section{TEST OF SPECIMEN WELI}

Plate $42, B$, shows sections of defective casing removed from a leaky well during the course of the repairs that were made in 1927. This well was drilled in February, 1921, with a rotary rig and was 837 feet deep. The first 250 feet of the hole was drilled 12 inches in diameter, and the casing was first set at 430 feet. The seating of the casing was not successful, as sand was not completely cased off. The casing was then pulled, but the last two joints parted from the main string, and it was necessary to cut over these two joints with 10-inch pipe before they could be removed. The hole was therefore drilled about 12 inches in diameter down to 430 feet. The pipe was reset at 470 feet and the seating appeared to be successful. At the time the casing was reset the hole was approximately 650 feet deep. Drilling was then completed, and the original flow of the well was reported as about 1,500 gallons a minute. About 1924 some water started to appear around the outside of the casing. The quantity increased gradually, and in March, 1926, when the well was inspected with the leakage meter, all the water was issuing from a hole beside the casing. The record of the observations made during the examination is as follows:

Velocity record of leaky well

[Determined with Au leakage meter]

\begin{tabular}{|c|c|c|c|c|c|}
\hline $\begin{array}{l}\text { Depth } \\
\text { (feet) }\end{array}$ & $\begin{array}{l}\text { Velocity } \\
\text { (feet per } \\
\text { second) }\end{array}$ & $\begin{array}{l}\text { Depth } \\
\text { (feet) }\end{array}$ & $\begin{array}{l}\text { Velocity } \\
\text { (feet per } \\
\text { second) }\end{array}$ & $\begin{array}{l}\text { Depth } \\
\text { (feet) }\end{array}$ & $\begin{array}{l}\text { Velocity } \\
\text { (feet per } \\
\text { second) }\end{array}$ \\
\hline 5 & -0.00 & $180 \ldots$ & -4.60 & $465 \ldots$ & - 4.72 \\
\hline $10 \ldots$ & .00 & 200 & 5.10 & 495 & 2.88 \\
\hline 15 & -.07 & 225 . & - 4.96 & $520_{-}$ & 3. 84 \\
\hline $20 \ldots \ldots$ & -.48 & 260 & -460 & 54 & 3. 52 \\
\hline $25 \ldots$ & -2.24 & 285 & - 4.72 & $570_{-}$ & - 5. 24 \\
\hline 0 & -2.09 & 310 & -4.72 & 595 & 4. 72 \\
\hline $50 \ldots$ & -2.74 & 335 & 4. 60 & 625 & - 4.84 \\
\hline $75 \ldots$ & -3.72 & 360 & -4.60 & 650 & 5. 38 \\
\hline $100 \ldots$ & -3.72 & $390_{-}$ & -4.48 & 675 & 6. 34 \\
\hline $125 \ldots \ldots$ & -4.28 & 415 & -4.72 & $701 \ldots$ & -.42 \\
\hline $150 \ldots$ & -3.52 & 440 & -460 & & \\
\hline
\end{tabular}


The initial observations, made at depths of 5 and 10 feet, show that there was no water issuing from the casing at the time of the inspection. A marked increase in velocity was recorded at a depth of 25 feet. This increase in velocity was undoubtedly caused by the large hole in the top section of casing shown in Plate 42, $B$. A measurement of the defective casing after it was withdrawn from the well showed that this hole was about 23 feet below the ground surface. There was a gradual increase in velocity down to 200 feet, which indicated a gradual increase in leakage from the well. This interpretation was subsequently verified by an inspection of the casing that was pulled during the course of the repair work. Many small holes were found in all the joints of casing down to a depth of 190 feet. The end of the casing was at 470 feet, and the reduction in velocity at 495 feet was probably due to the enlargement of the hole. Minor variations in velocity occur in both the cased and the uncased portions of the well. These are due to irregularities within the casing and to variations in the size of the uncased hole caused largely by erosion. It was not possible to reach the bottom of the original hole because of an obstruction at 701 feet.

The results of the inspection of other artesian wells in the Roswell artesian basin with interpretations of the data are given in WaterSupply Paper 596, pages 29-32.

\section{QUANTITY OF UNDERGROUND WASTE}

During the present investigation several wells were examined for leakage with the Au leakage meter. For various reasons the large amount of time devoted to this phase of the work did not yield nearly as much information regarding the underground waste as was expected, largely because the work of examination was hindered by obstructions in the wells. Some wells were obstructed by foreign material that had been thrown in intentionally, others were obstructed by abandoned pumping equipment that could not be readily removed, and still others had probably collapsed. The pressure method could not be used on many flowing wells because the casing at the ground or the valve was in such condition that the well could not be shut in. Without the information afforded by tests or evidence of leakage as shown by water issuing from around the casing, it is almost impossible to determine definitely that a well is leaking underground, for the specific capacity varies so greatly that discharge alone is not a positive indication.

In the examinations for leakage practically all types of leaks were encountered. The data are insufficient to permit a classification of the quantity of leakage and waste according to the various types of leaks, but it would appear that, particularly in the older wells, about 
half of the leakage was caused by defective construction and half by the action of corrosive waters.

Out of a group of 65 wells examined 35 were found leaking and the rest showed no evidence of leakage. Of the wells examined 20 were found to be partly plugged or caved in and 17 were found partly obstructed so that a complete examination was not possible. The underground leakage was estimated at 16 second-feet, of which 4 second-feet has been stopped by repairs. An additional 2 secondfeet was coming to the surface around the casing and during the irrigation season was not wasted. The estimated total underground waste from these wells therefore amounted to about 10 second-feet, or 7,240 acre-feet a year.

In addition to the examinations noted, many others were attempted; but because of unfavorable conditions, due chiefly to obstructions, no definite information was obtained, and the results are not included in the above summary. It is probable, however, that most of these wells did not leak and that there was no material waste from them.

The individual owners of the artesian wells that were examined were informed as to the result of the examination, and the data regarding each inspection are filed with the well supervisors of the respective counties.

\section{CONCLUSIONS REGARDING UNDERGROUND WASTE}

A reliable estimate of the total underground waste can not be made because of insufficient data, but it is believed that enough information has been obtained to warrant the conclusion that in 1927 the amount of underground waste was not excessive. The information obtained would indicate that the underground waste is, at most, much smaller than is generally believed. In the mind of the average person the decline in flow of the wells is associated with huge quantities of underground leakage. The data regarding the decline in head show conclusively that the reduction in discharge has been due largely to the heavy draft upon the artesian reservoir. Underground waste has caused some of this draft but not the major part.

In considering the question of underground waste and leakage the fact should not be overlooked that during the next decade there may be a marked increase in the underground waste, due largely to the fact that many wells are probably nearing the end of their economic life. It is therefore recommended that the inspection of wells for determining leakage be continued by the county well supervisors. Should it appear that the underground waste is becoming greater, effective measures should be undertaken to remedy the situation. 


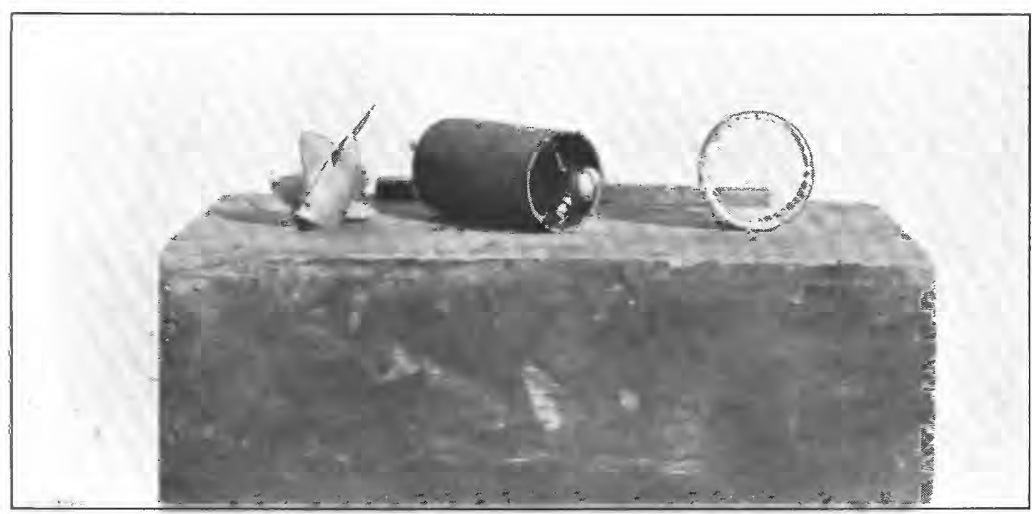

A. AU DEEP-WELL GURRENT METER

Photograph by A. G. Fiedler.

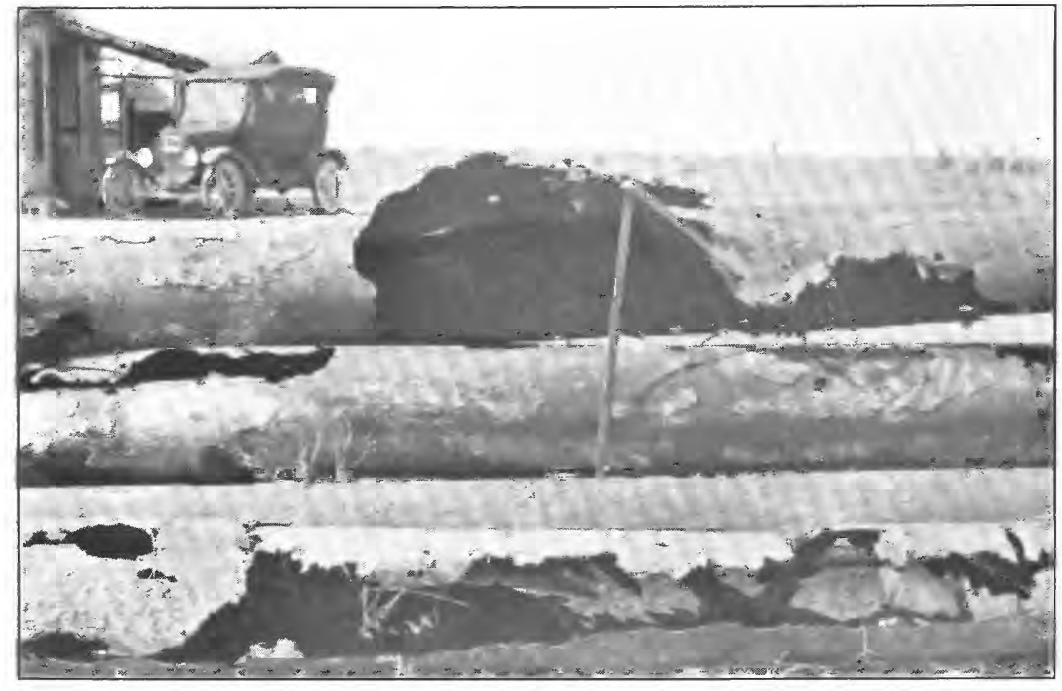

B. CASING REMOVED FROM DEFECTIVE WELL

Photograph by A. G. Fiedler. 


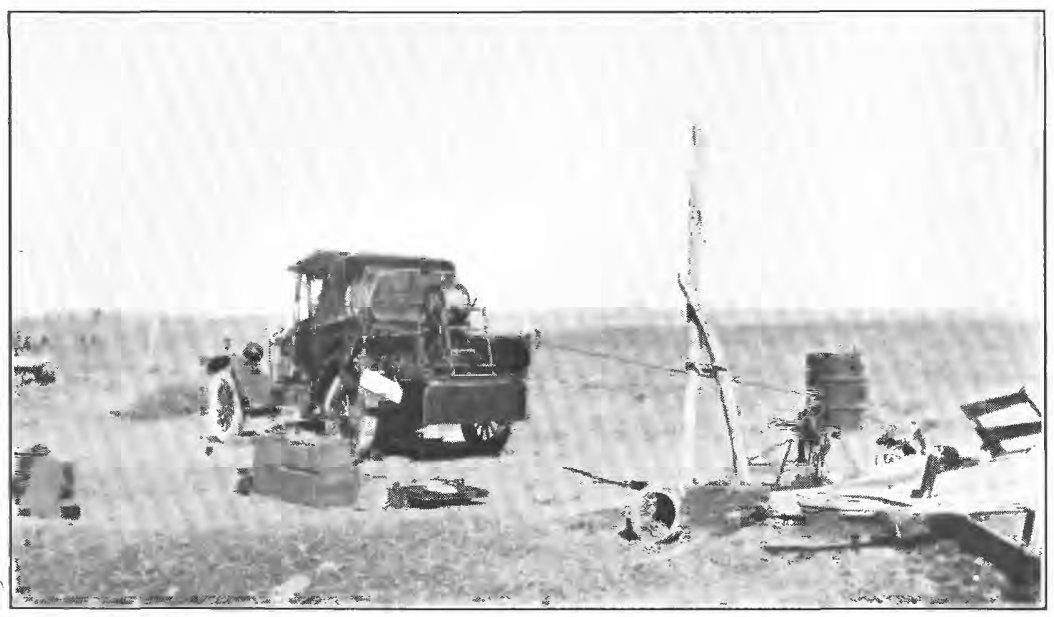

A. EQUIPMENT SET UP FOR LEAKAGE FXAMINATION

Photograph by A. G. Fiedler.

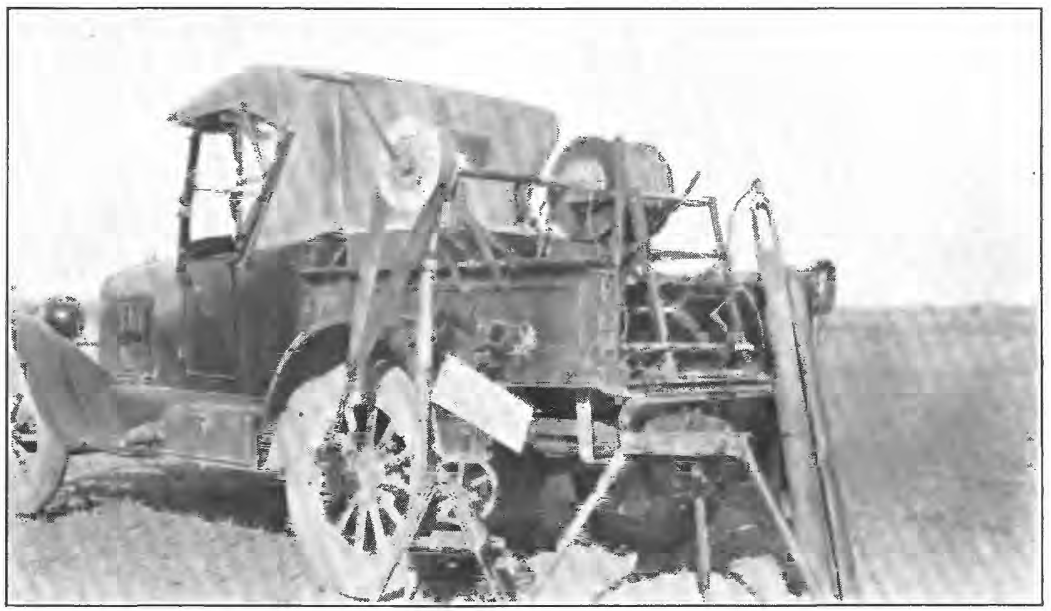

B. AUTOMOBILE TRUCK ON WHICH LEAKAGE EQUIPMENT IS MOUNTED Photograph by A. G. Fiedler. 
RECHARGE

\section{GENERAL CONDITIONS}

The water-bearing formations in the Roswell artesian basin crop out in successive zones on the high land west of the area of artesian flow. The two typical geologic sections across the artesian basin shown on Plate 2 indicate the relations of the formations to one another and the reason for the presence of flowing artesian wells in the valley. The character of the formations has been described in detail in the section on geology, and in a study of the recharge of the area it is merely necessary to point out that the area possesses all the requisite conditions for obtaining artesian flows. The precipitation that falls on the large drainage area west of the area of artesian flow furnishes the source of the water supply. The beds of the Pecos formation form the upper confining agent, and the denser portion of the lower beds of Picacho limestone in the artesian area and the upper beds of the underlying Nogal formation form the lower confining agent. The elevated body of ground water west of the area of artesian flow constitutes the source of pressure. By reason of the fact that the valley area lies considerably below the level of the water table, or ground-water surface, of the higher land to the west, deep wells that penetrate the permeable beds in the Picacho limestone encounter water under considerable artesian pressure.

\section{INTAKG AREA}

Though all of the drainage area shown on Plate 2 contributes to the artesian supply, some portions contribute considerably more than others. The lower part of the Picacho limestone at the higher levels and near the mountains is probably as permeable as the upper part of the same formation in the valley region. The Nogal formation, which underlies the Picacho limestone, is less permeable than the Picacho but is probably sufficiently permeable to permit some percolation of ground water down its slope. A study of the data from wells in the mountain region shows that shallow ground water is encountered for a certain distance east of the crest of the mountains and that perched water occurs in the Picacho limestone at the higher levels. East of this belt the main water table is several hundred feet below the surface and considerably below the top of the Nogal formation. There appears to be no evidence that the water table is near the line of contact of the Nogal formation and the Picacho limestone. Under such conditions the water derived from rain and snow that fall on that part of the drainage area lying west of the line where the water table crosses the contact between the Nogal formation and the Picacho limestone is largely contributed to the ground water in the Nogal or percolates down the dip of the 
Picacho limestone. It would appear, however, that the amount that percolates down the dip of the Picacho limestone could not be large, for in the mountains the Picacho limestone is rather permeable, and in the deeper canyons the Nogal is exposed. The conclusion is therefore drawn that contributions to the artesian reservoir from precipitation on the higher parts of the area can be derived only from the ground water in the Nogal which percolates across the bedding into the Picacho limestone and from water which percolates down the contact of the Picacho and the Nogal. Furthermore, east of the line where the water table crosses the contact of the Picacho limestone and the Nogal formation, the beds at the lower horizons of the Picacho limestone become relatively impervious and act as the lower confining beds of the artesian reservoir. The percolation from the Nogal would therefore have to occur near the line defined by the water table, and because the Nogal is relatively impervious as compared with the Picacho limestone it is believed that contributions from percolation down the dip of the Nogal can not be large.

The area of intake, or as it may more properly be called, the area of principal intake, is shown on Plate 2. The eastern boundary of this area is defined by the line of contact between the Pecos formation and the Picacho limestone. The western boundary is more or less defined by the line where the water table crosses the contact of the Picacho limestone and the Nogal formation, but on the map the western boundary has been placed a short distance west of this line; as the percolation would not be directly downward but would follow along the dip of the bed, this small additional strip is considered as productive as the part of the Picacho limestone somewhat farther east.

The precipitation in the mountainous region is largely beneficial to the artesian reservoir, as it is sufficient to produce run-off that reaches the principal intake area through the tributary streams. The precipitation in the principal intake area contributes to the ground-water supply that feeds the artesian reservoir. Because the Nogal formation is relatively impervious it would appear that the quantity of water that penetrates the Nogal to the water table is not large. Scant percolation in the Nogal is further indicated by the fact that the water table in the mountain region is several hundred feet below the surface and considerably below the top of the Nogal. It would therefore be expected that the water that percolates through the Picacho limestone in the high levels either contributes to the perched water in the Picacho or passes down the dip of the Picacho near its contact with the Nogal and contributes to the run-off of the streams, particularly in those sections where the Nogal is near the surface in the deeper canyons or is completely 
exposed. This conception of the structural conditions affecting recharge to the artesian reservoir is verified by a study of the records of flow of the tributary streams.

\section{SEEPAGE LOSSES ON TRIBUTARY STREAMS}

It was impossible during this investigation to make a complete survey of the seepage losses of the streams that cross the catchment area. Many complications are introduced into such a study because of diversions for irrigation and return flow, and it would be difficult to segregate original contributions to the stream flow from water that had been previously diverted and later returned to the stream.

Studies on seepage losses in the Rio Hondo were made in 1908 and 1909. The following table based on information obtained in this survey ${ }^{79}$ shows the gain and loss for various sections of the Rio Hondo in the vicinity of the intake area.

Discharge and gain or loss, in acre-feet, for various sections of the Rio Hondo from Picacho to Diamond A ranch for period June to August, 1928

\begin{tabular}{|c|c|c|c|c|c|c|c|c|}
\hline & $\begin{array}{c}\text { Discharge } \\
\text { at } \\
\text { Picacho }\end{array}$ & $\begin{array}{l}\text { Diversion } \\
\text { between } \\
\text { Picacho } \\
\text { and Bor- } \\
\text { der gage }\end{array}$ & $\begin{array}{c}\text { Discharge } \\
\text { at Border } \\
\text { gage }\end{array}$ & $\begin{array}{l}\text { Gain or } \\
\text { loss } \\
\text { between } \\
\text { Picacho } \\
\text { and Bor- } \\
\text { der gage }\end{array}$ & $\begin{array}{l}\text { Diversion } \\
\text { between } \\
\text { Border } \\
\text { gage and } \\
\text { Diamond } \\
\text { A ranch }\end{array}$ & $\begin{array}{l}\text { Discharge } \\
\text { at Dia- } \\
\text { mond A } \\
\text { ranch }\end{array}$ & $\begin{array}{c}\text { Gain or } \\
\text { loss } \\
\text { between } \\
\text { Border } \\
\text { gage and } \\
\text { Diamond } \\
\text { A ranch }\end{array}$ & Total loss \\
\hline \multirow[t]{2}{*}{$\begin{array}{l}\text { June_... } \\
\text { July } \\
\text { August............ }\end{array}$} & $\begin{array}{l}1,146 \\
4,908 \\
5,616\end{array}$ & $\begin{array}{r}751 \\
131 \\
16\end{array}$ & $\begin{array}{r}795 \\
3,537 \\
3,744\end{array}$ & $\begin{array}{r}+400 \\
-1,240 \\
-1,856\end{array}$ & $\begin{array}{r}225 \\
776 \\
81\end{array}$ & $\begin{array}{r}13 \\
2,188 \\
2,834\end{array}$ & $\begin{array}{l}-557 \\
-573 \\
-829\end{array}$ & $\begin{array}{r}-157 \\
-1,813 \\
-2,685\end{array}$ \\
\hline & 11,670 & 898 & 8,076 & $-2,696$ & 1,082 & 5,035 & $-1,959$ & $-4,655$ \\
\hline
\end{tabular}

During the period June to August, 1908, a total loss of 4,655 acre-feet occurred in the stretch of the Rio Hondo from Picacho to the Diamond A ranch. During periods of flood flow the Diamond $A$ ranch is unable to divert all the water that reaches its point of diversion, and the remainder of the flow is normally lost within 8 or 10 miles below that point. During the period June to August, 1908 , only 2,160 acre-feet ${ }^{80}$ of the 5,035 acre-feet that flowed past the Diamond A ranch reached the inlet canal of the Hondo Reservoir. Records of the diversions in the stretch of river below the Diamond $\mathbf{A}$ ranch are not available for this period, but it is known that only a small portion of the flow below the Diamond A ranch was diverted, and the difference in flow between the two stations is therefore largely seepage loss. The total loss during this period from Picacho down to the Hondo Reservoir probably exceeded 5,500

\footnotetext{
${ }^{79}$ Hondo hydrographic survey, sheets 1 to 8 , filed in office of New Mexico State engineer.

${ }^{30} \mathrm{New}$ Mexico State Engineer, Surface water supply of New Mexico, 1888-1925, p. 158, 1926.
} 
acre-feet. Measurements made by L. W. Bartholomew ${ }^{81}$ on December 1, 1909, showed a loss of 19.7 second-feet from a point about half a mile below the Diamond A ranch house to the mouth of the inlet canal of the Hondo Reservoir.

In a survey made by Follett ${ }^{82}$ the loss from the Mantando gage, in the NE. 1/4 SW. $1 / 4$ sec. 30 , T. 11 S., R. 19 E., down to the inlet canal of the Hondo Reservoir averaged 45.3 second-feet, or 90.5 acre-feet a day, for a period of 27 days from September 28 to October 24,1913 . The total loss during this period was therefore 2,443 acrefeet. Out of the 45.3 second-feet, 31.6 second-feet was lost in the last 19 miles of the stretch, and 22.2 second-feet was lost in the last 11 miles of the stretch.

On January 17, 1927, several discharge measurements were made by the writer on the Rio Hondo from the Border ranch to a point below the Diamond A ranch. The stretch above the Diamond A diversion showed a slight gain, probably because of return flow from ditches and irrigation. Below the Diamond $\mathbf{A}$ diversion a loss of 25.5 second-feet occurred in a distance of 8 miles.

Teeter ${ }^{83}$ determined that in the Rio Penasco a loss of 12.7 secondfeet, or 34.5 per cent of the total flow at the Laramore ranch, in sec. 35, T. 16 S., R. 17 E., occurred between the Laramore ranch and the Hope diversion dam, in sec. 14, T. 17 S., R. 20 E. Teeter also determined that the mean loss from Cady's ranch, in sec. 35, T. 16 S., R. 17 E., to the Y-O crossing, in sec. 2, T. 17 S., R. 19 E., over a period of 40 days during the irrigation season in 1923 was 25 per cent of the flow at Cady's ranch. As pointed out by Renick, ${ }^{84}$ this loss is in all probability due to seepage. Renick also makes the following statement in a discussion of the ground-water conditions in the vicinity of the upper Rio Penasco:

In this region the normal water table is generally between 500 and 1,000 feet below the surface, the depth gradually decreasing in the direction of the Pecos Valley. There are, however, several localities, as along Bluewater, west of Dunken, along the upper and lower Penasco, and in the vicinity of the head spring of the Rio Felix, where the water table is close to the surface and springs exist. This condition is brought about by the presence of impervious shale beds within this great thickness of limestones of the Chudapera formation. Melting snow and rain water seep into the limestones at the surface, but in some places its down progress is arrested by the presence of an impervious shale which holds the water closer to the surface and above the main body of

81 Bartholomew, L. W., memorandum from records of U. S. Reclamation Service.

8 Follett, W. W., Report on a hydrographic survey of the Bonita and Hondo Rivers and Bagle Creek in Lincoln County (made for El Paso \& Rock Island Railway Co.), 1913.

Teeter, E. E., Report on preliminary investigation for irrigation development on the Penasco River: U. S. Bureau of Reclamation, manuscript report, p. 74, 1924.

84 Renick, B. C., Geology and ground-water resources of the drainage basin of the Rio Penasco above Hope, N. Mex.: New Mexico State Engineer, Seventh Bienn. Rept., p. $127,1926$. 
ground water. This water is, therefore, said to be perched. It flows as an underground stream or sheet of water over this impervious bed. If the impervious bed crops out the perched ground water is likely to appear as a spring. If the impervious bed continues underground the ground water will remain perched until the impervious bed grades into limestone or is broken or otherwise interrupted, when the perched water will sink to a greater depth to join the main body of ground water. *** The streams in this region are also perched. They are held up by impervious beds and by the tightly packed and partly cemented silt in the stream channels. Wherever these perched streams cross a stretch where there is no impervious bed and where the channel is not waterproof it loses water by seepage.

The losses in the Rio Penasco are further substantiated by Black, ${ }^{85}$ who found similar losses during an investigation in 1927 conducted for the New Mexico State engineer.

The section in which the losses in the Rio Hondo and Rio Penasco occur coincides largely with the principal intake area. It is apparent, therefore, that the precipitation in the mountainous region is beneficial to the artesian aquifers, as such precipitation produces run-off that reaches the stretch of the tributary streams where large seepage losses occur.

The losses from the streams as they cross the principal intake area are so large that they can be accounted for only as being due to downward percolation, because evaporation from the water surface of the stream would account for only a very small percentage of the loss. By reason of the structure of the artesian basin it is reasonable to assume that this water percolating downward contributes to the water in the artesian reservoir. It would therefore be expected that if the losses by percolation could be increased, the supply in the artesian reservoir would be augmented accordingly. As a result of the increase in supply to the reservoir the artesian head would be increased, and the wells tapping the artesian aquifers would yield larger quantities of water. The seepage losses in the streams might be increased by impounding the flood waters in the mountainous area and permitting only such quantities of water to flow across the principal intake area as would be completely absorbed by downward percolation into the reservoir, or by constructing reservoirs on the principal intake area. It is questionable if the benefits to be derived would warrant the expense involved in the construction of suitable structures for impounding the flood water. However, the Hondo Reservoir is within the area of principal intake (see pl. 2), and because of its location would be well suited for this purpose.

The Hondo Reservoir was constructed by the United States Reclamation Service for use in impounding chiefly the flood waters of the Rio Hondo for irrigation of lands in the Hondo Valley. As exces-

s Black, R. F., oral communication. 
sive seepage loss of water occurred in the reservoir, it was never actually used, and the entire project was ultimately abandoned. Though the inlet canal, headgates, and diversion dam have been permitted to deteriorate through lack of use, it is believed that these structures might be repaired at relatively small expense so as to be suitable for diverting the flood waters into the old reservoir. The water impounded would seep into the artesian reservoir, and benefits would accrue to the artesian wells in proportion to the amount that the recharge into the artesian reservoir was increased. Some complications may arise in the execution of such a program of diversion because of water rights that have been granted to lands below the Hondo Reservoir. Within recent years very little water has been diverted under these old filings, and many have doubtless lapsed through lack of use. However, if such a program can be worked out so as to satisfy all the interests involved, there appears to be no question that the recharge into the reservoir would be increased and the yield of the artesian wells would be increased accordingly. The expense involved in such a plan of utilizing the Hondo Reservoir would be nominal, and the chief difficulties, which are largely of a legal nature in satisfying existing rights in the flow of the lower Hondo, are not insurmountable. In view of the benefits that would accrue to users of artesian water and the added advantage of affording a large measure of protection from floods for the city of Roswell, it is recommended that steps be taken to impound in the Hondo Reservoir all waters in excess of the amount required to satisfy existing rights in the streams.

\section{COMPRESSION OF ARTESIAN AQUTFERS}

The safe yield of an underground reservoir is defined by Meinzer ${ }^{86}$ as the rate at which water can be withdrawn from an aquifer without depleting the supply to such an extent that withdrawal at this rate is no longer economically feasible. In a perfectly rigid artesian system withdrawal of water from a well should result in an immediate readjustment of the hydraulic gradient all the way to the source of the water and should produce a somewhat more rapid percolation throughout the distance. When withdrawal of water has ceased the reverse process should occur and there should be a prompt readjustment of the gradient and a return to conditions similar to those which existed prior to the withdrawal.

The effect produced by pumping upon the artesian head in the aquifers in the vicinity of the observation well near Artesia is shown in Figure 28 and is further described on pages 208-210. The high

\footnotetext{
${ }^{80}$ Meinzer, O. E., Outline of ground-water hydrology : U. S. Geol. Survey Water-Supply Paper 494, p. 55, 1923.
} 
point usually occurs at about 7 a. m., just prior to the starting of the pumps. The low point is reached usually between 6.30 and $7 \mathrm{p}$. m., just prior to the stopping of the pumps. After pumping is stopped the recovery of the head is at first prompt and then more gradual until the high point of the following morning is reached. The gradual recovery of head indicates the existence of a cone of depression in the vicinity of the pumped artesian wells similar to that formed in the vicinity of heavily pumped wells drawing from ground water that is not under artesian pressure. The cone of depression in the artesian aquifer is not a cone of depletion of storage but a cone of depression in the piezometric surface, as the aquifer remains filled with water under pressure, but the pressure at the well is lowered. The presence of a hydraulic gradient always indicates a certain movement of water, and because the cone of depression around a well that has been pumped during the day persists to some extent during the night, the question arises as to what becomes of the water that must be moving toward the well throughout the night. The explanation seems to be that the beds have undergone a certain amount of compression due to the release of internal pressure through the withdrawal of water from the aquifer. Before the pressure in the well can again completely reach the prevailing pressure in the formation, sufficient time must elapse after the cessation of pumping to permit the water to percolate into the depleted parts of the formation surrounding the well and to expand the interstices that have been previously compressed. The rise in pressure in the formation to that which prevailed before the well was pumped is, however, not wholly due to the filling and reexpansion of the compressed parts of the formation. The reduction of pressure in the formation in the vicinity of the well while it is being pumped is due largely to consumption of energy in overcoming friction and maintaining the velocity of the water as it moves through the formation toward the well. Therefore, when the pumping is stopped a large part of the resultant rise in pressure is due to the fact that the water moves toward the well at a much slower rate than when the well is pumped and that a smaller quantity of water moving into depleted portions of the formation causes less friction. The only other theory which might account for the gradual recovery of head is that of gas accumulation. This theory would assume that the water withdrawn from the interstices is replaced with gas. However, gas is generally absent from the water issuing from the wells, and this explanation is not considered valid. In some places the same phenomenon might be due to leakage from wells, but it appears that this reason is likewise insufficient as a satisfactory explanation of the gradual return of pressure over so long a period. 
In so far as the writer is informed, the phenomenon of the compression and elasticity of the beds forming the aquifer in its relation to the problem of determining the safe yield of an artesian reservoir was first demonstrated by O. E. Meinzer, of the United States Geological Survey. For a further discussion of the subject the reader is referred to papers by Meinzer. ${ }^{87}$

The seasonal fluctuations of the artesian head in the Roswell artesian area (see pl. 37) shows a condition which is very similar to the gradual return of head in the vicinity of a pumped well. The head for the basin reaches the low point in the summer; and after the curtailment of irrigation in the fall, it gradually rises, reaching a high point in January or February. This broad general cycle may be due in part, at least, to a seasonal compression of the beds, resulting from the reduction in artesian pressure in summer, when much water is withdrawn from wells, and then the gradual building up of the pressure as the water percolates again into the compressed portions of the formation and the beds are expanded.

Near the south end of the basin the head returns more gradually after the closing of wells than near the north end. 'This may be partly explained by the greater release of pressure while the wells in this segment are operated, since they generally have a higher head and hence would suffer greater compression. The slower return is, however, more probably due to lower permeability of the artesian aquifers. The hydraulic permeability or perviousness of a rock is defined by Meinzer ${ }^{88}$ as its capacity for transmitting water under artesian pressure. As shown by Plate 31 the hydraulic gradient is steeper along certain sections across the southern part of the artesian area then in the northern part, in spite of the fact that the withdrawal from the artesian reservoir is greater in the northern part. Under the same conditions of permeability, the recovery of pressure in the formation after pumping would be most rapid when the difference in pressure before and after pumping was the greatest, for the greater pressure would cause the water to flow more rapidly toward the well. Conversely, if this difference in pressure were the same, the return to normal conditions would be most rapid where the aquifer was most permeable. It has been pointed out that the artesian aquifers are apparently less permeable in the southern part of the artesian area. As the difference in pressure in the aquifer before and after pumping is also greatest in this part of the artesian

${ }_{87}$ Meinzer, O. E., and Hard, H. A., The artesian-water supply of the Dakota sandstone in North Dakota, with special reference to the Edgeley quadrangle: U. S. Geol. Survey WaterSupply Paper 520, pp. 73-95, 1925. Meinzer, O. E., Compressibility and elasticity of artesian aquifers : Econ. Geology, vol. 23, pp. 263-291, 1928.

${ }^{88}$ Meinzer, O. E., Occurrence of ground water in the United States, with a discussion of principles : U. S. Geol. Survey Water-Supply Paper 489, p. 28, 1923. 


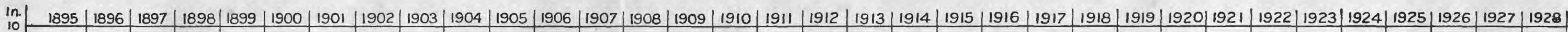

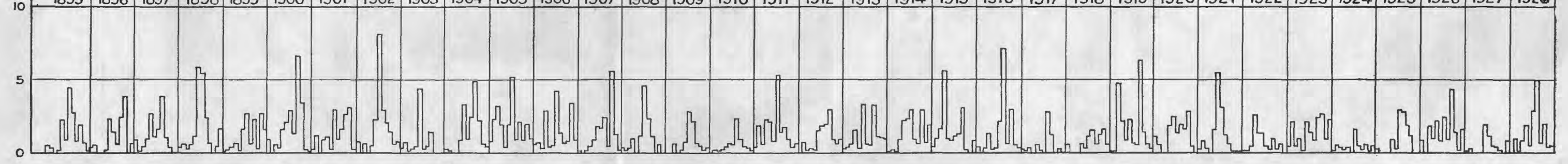

MONTHIY DEVIATION FROM AVERAGE MEAN PRECIPITATION ON THE ARTESIAN AREA

(n)

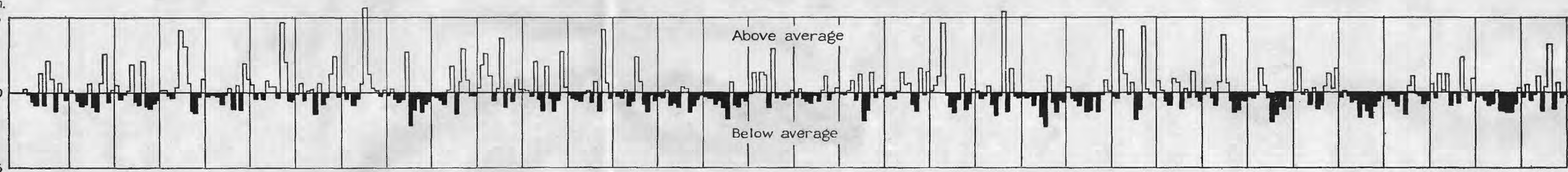

MEAN ANNUAL PRECIPITATION ON THE ARTESIAN AREA FOR CLIMATIC YEARS OCT. I TO SEPT. 30

Diagrams are based on records of US. Weather Bureau. Diagrams-represent average of the precipization at Roswell, Artesia, and Carlsbad and short records of precipitation at Hope

in

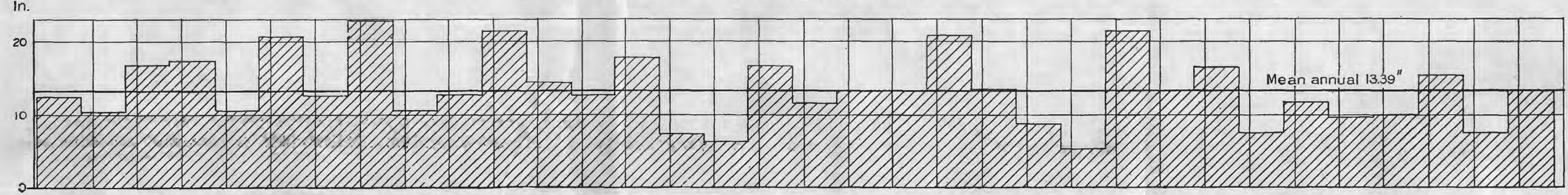
MEAN MONTHLY PRECIPITATION, MEAN MONTHLY DEVIATION FROM NORMAL PRECIPITATION, AND MEAN ANNUAL PRECIPITATION ON THE ROSWELL ARTESIAN AREA 


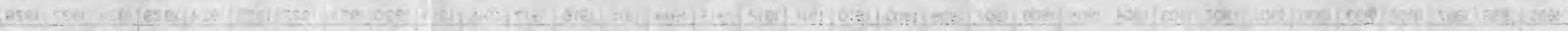

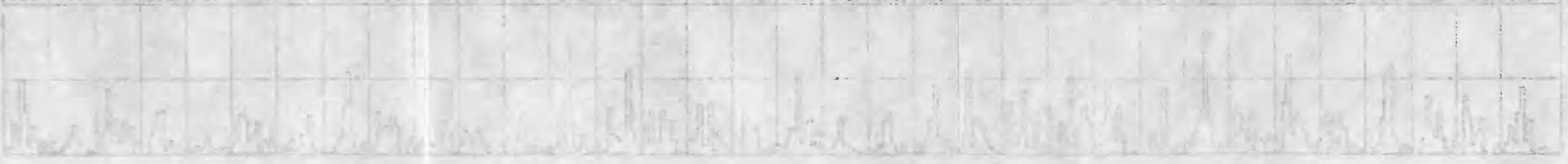

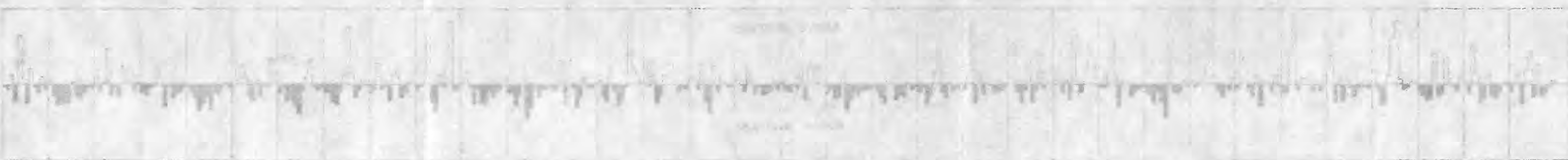

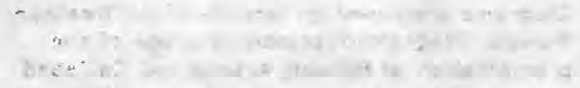

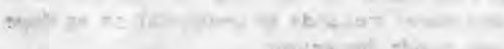

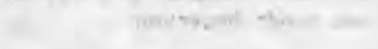


area, it would appear that the major factor accounting for the more gradual return of pressure in the southern part of the area is that of permeability.

In his study of the artesian water supply in North Dakota, Meinzer ${ }^{89}$ demonstrated that the Dakota sandstone has probably been compressed several inches and that a considerable portion of the water withdrawn in the past was derived from water stored in the sandstone before compression. In the Roswell area the total compression that may have occurred as a result of the decline in head since the initial development of the basin is small in comparison with the quantity of water that the artesian reservoir has yielded, and hence only a comparatively small quantity of the water can have been obtained from the portions of the formation that have since been compressed.

\section{RELATION OF PRECIPITATION TO RECHARGE}

Records have been obtained for a period of years by the United States Weather Bureau at several stations throughout the drainage area tributary to the artesian reservoir. (See p. 7.) A study of these records shows that precipitation is very unevenly distributed in this region but that over a period of years the average precipitation at any station maintains the same general relation to the average at other stations. The precipitation varies largely with the altitude, as is indicated by Figure 33.

A study of the precipitation records of all the stations seems to indicate that the fluctuations of artesian head are more nearly related to the precipitation in the artesian area than to that in the upper part of the Sacramento Mountains. This condition would appear to indicate that precipitation on the intake area is largely the same as that shown for the precipitation stations at Roswell, Artesia, and Carlsbad. The relation between fluctuations of precipitation and artesian head is marked for small quantities of precipitation occurring in the alluvial basin (see pp. 211-213 and pl. 32) ; but no relation is discernible between small quantities of precipitation in the mountain region and fluctuations of head. It is to be expected that normally there would be a considerable interval between the time of precipitation in the mountain region and the time its effect upon the artesian reservoir becomes evident. Large quantities of precipitation are normally distributed over a large area, and the records show that this is true in the Roswell Basin.

Meinzer, O. E. and Hard, H. A., The artesian water supply of the Dakota sandstone in North Dakota, with special reference to the Edgeley quadrangle: U. S. Geol. Survey Water-Supply Paper 520, pp. 90-93, 1925.

$135252-33-17$ 
The total area of the drainage basin that contributes to the artesian reservoir comprises about 4,000 square miles, and the average precipitation over this area (see pl. 28), based on an average of the precipitation recorded at the United States Weather Bureau precipitation stations in the artesian basin, is about 16 inches a year, which is equal to approximately $3,400,000$ acre-feet a year. The principal intake area (see pl. 2) comprises about 1,200 square miles, and its average annual precipitation (see pl. 44), based on records of pre-

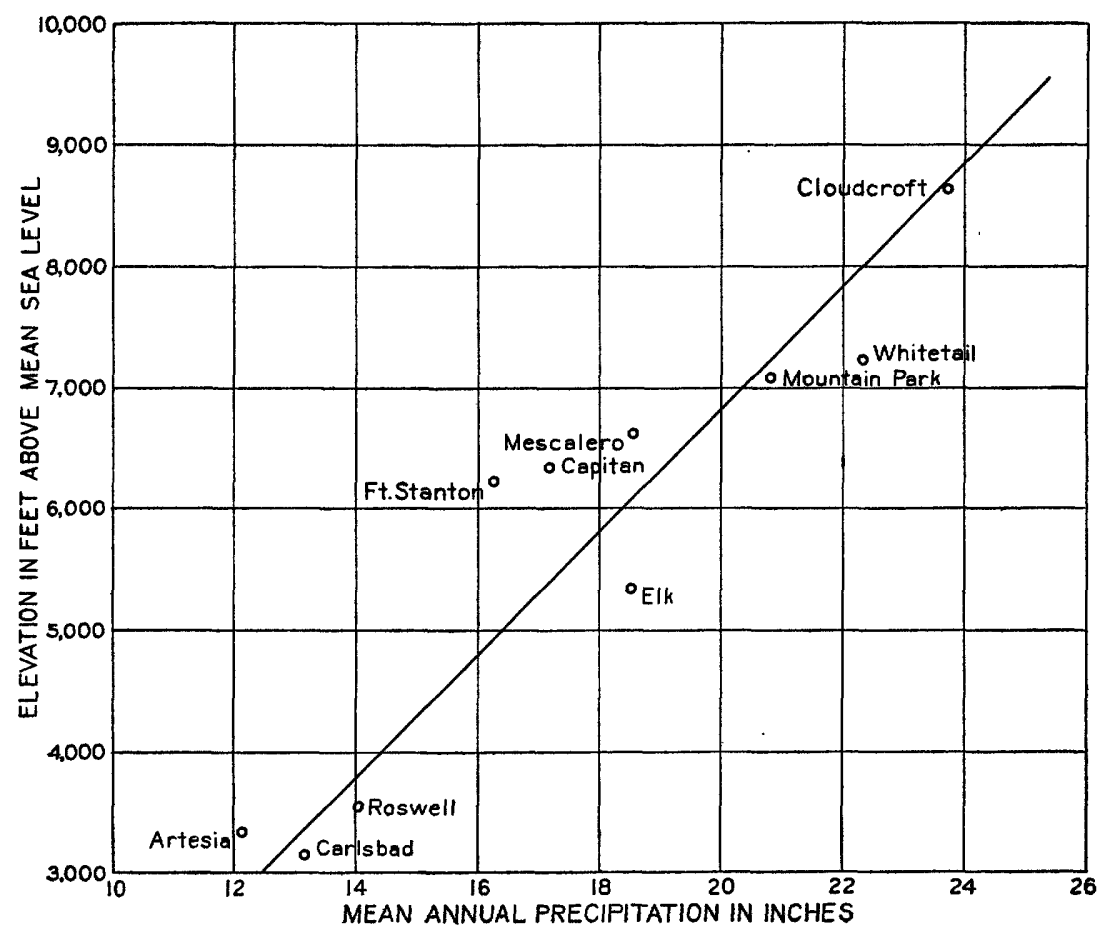

FIGURE 33.--Relation of precipitation to altitude in the Roswell artesian basin

cipitation at Roswell, Artesia, and Carlsbad and short records at Hope and Hondo Reservoir, is about 13 inches, or about 850,000 acre-feet.

The total discharge at the surface from the artesian reservoir has been estimated at 250,000 acre-feet a year. This quantity is only 7.3 per cent of the total average precipitation on the whole drainage area but is 29 per cent of the average precipitation upon the principal intake area. Because of the absence of complete records of the flow of the tributary streams, of the loss due to evaporation and transpiration, and of the precipitation, it has not been feasible during this investigation to determine what percentage of the precipitation that falls on the catchment area contributes to the 
artesian reservoir as recharge. It is probable, however, that less than 25 per cent of the precipitation on the principal intake area plus the run-off from the tributary streams that flow across that area percolates into the artesian reservoir and is available for the use of the artesian wells.

It has been shown that relatively small amounts of precipitation in the artesian area produce a noticeable rise in the artesian head in the wells. In view of the existence of impervious strata that overlie the artesian reservoir and hold the water under pressure, it is rather difficult to explain this phenomenon satisfactorily. The rise following rains is generally rather prompt, and for small amounts of rainfall it appears to be the result of change in pressure rather than of actual contributions of recharge to the artesian reservoir. The rise in artesian head following large amounts of rainfall is caused at least in part by the reduction in irrigation draft, but for rains of less than half an inch the draft upon the reservoir is not generally reduced, as irrigation proceeds more rapidly by reason of the previous slight moistening of the ground and the irrigators normally take full advantage of all moderate rains to facilitate their irrigation.

The effect of precipitation on the artesian head and recharge to the artesian reservoir is more noticeable in the south end of the artesian area than in the north end, as shown by Plate 32. A total precipitation of about 1.30 inches at Roswell and Artesia produced a rise in artesian head in the Berrendo well 2 only about one-fifth as great as that in the Orchard Park well. The difference in the amount of rise of the artesian head in the two wells is undoubtedly due to a readjustment of the hydraulic gradient and is explained as follows: The artesian basin possesses many features that are similar to those of a city water-supply system where an elevated reservoir is used to maintain the pressure in all parts of the system. One or more large distribution mains lead from the reservoir to different parts of the city, and these mains are tapped by smaller distribution pipes, which serve as street mains. The street mains are tapped by pipes 1 to 2 inches in diameter that lead to the individual houses. If no draft is made upon the system the pressure at the individual faucets would be sufficient to raise the water approximately to the altitude of the water surface in the elevated supply reservoir. As soon as a faucet is opened the pressure along the lines supplying the faucet is reduced by the amount necessary to overcome the friction as the water moves through the pipes and to give the water its velocity. For a small discharge the water moves very slowly through the large distributing mains and hence there is relatively little reduction in pressure, but for the same rate of discharge in the smaller 
pipes the water moves much more rapidly and hence the friction is greater and the reduction in pressure is also greater. With increased draft from many faucets the reduction in pressure along the lines becomes greater, and the pressure at a faucet at the end of a line is therefore considerably reduced. In the Roswell artesian basin the elevated body of ground water to the west of the area of artesian flow is the source of supply for the artesian wells, being similar to the elevated reservoir that is the source of supply for the individual faucets of a city water-supply system. The interstices and solution channels of the artesian aquifers conduct the water from the source of supply to the individual wells and are similar to the distribution mains and pipes leading to the faucets. When a flowing well is opened there is a considerable reduction in pressure in the vicinity of the well, because a portion of the available head is consumed in causing the water to move toward the well. Theoretically, there is some reduction in pressure in the formation for a great distance from the well, though actually the reduction becomes practically negligible within a few hundred or a few thousand feet of the well.

The piezometric surface shown on Plate 30 is similar to the surface that might be defined by the various pressures on the individual outlets of the city water-supply system for a given quantity of draft. In such a system the pressure would be lowest at the outlet most remote from the source of supply, and the hydraulic gradient would be more or less uniform, according to the distribution of draft from the reservoir to the discharge outlets. The prevailing slope of the piezometric surface in the Roswell basin is from west to east, with a definite southeasterly trend. This indicates that the area west of the north section of the basin is the area of largest contribution to the system and that in going southward down the valley there is a reduction of pressure due to an accumulation of draft, similar to the reduction of pressure near the ends of a city distribution system.

Plate 31 shows typical hydraulic gradients across various sections of the artesian area. They are profiles of the piezometric surface shown on Plate 30 . The principle of the hydraulic gradient is illustrated in Figure 34. With no discharge from the reservoir, the hydraulic gradient and the piezometric surface would be level, as shown at $\mathrm{X}-\mathrm{Y}$. With free discharge at the outlet the hydraulic gradient assumes the lower position. During periods of precipitation contributions are made to the artesian reservoir from percolation in the intake area, and with a reduction in draft on the artesian reservoir the hydraulic gradient assumes the upper position and rises an amount equal to $a^{\prime}$ and $a^{\prime \prime}$, respectively, at wells $\mathrm{A}$ and $\mathrm{B}$. Thus it is seen that the rise in head in the lower end of the artesian 
system is larger, as represented by the relation of $a^{\prime}$ and $a^{\prime \prime}$ in the diagram, and is similar to the rise in pressure at the end of the city distribution system when the intervening draft is curtailed. This analogy partly explains the probable reason for the much greater effect of precipitation in the lower portion of the basin, as illustrated by Plate 32. In this connection it must be remembered that with such a proportional change in head there may be a similar change in the probable proportional relation of the compression and expansion of the artesian aquifers.

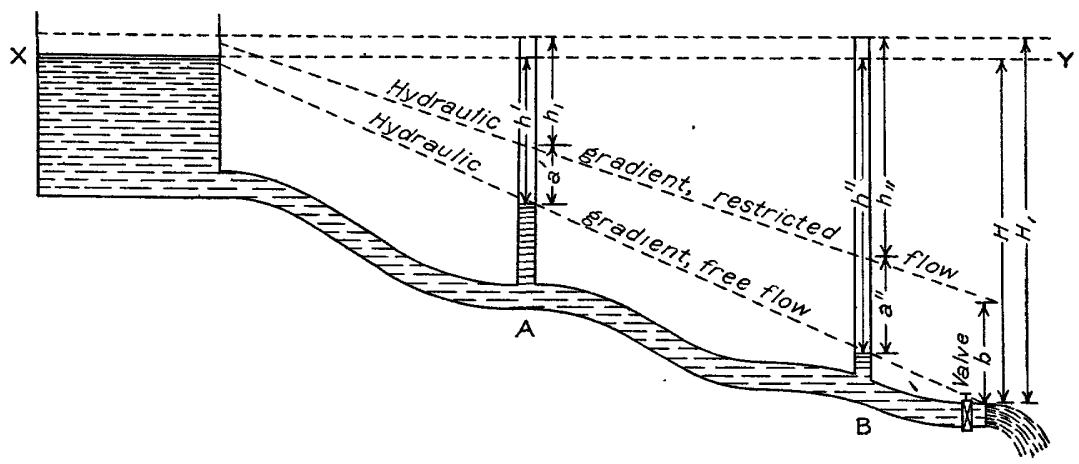

Figuri 34.-Effect of decrease in draft and increase of head in reservoir upon the hydraulic gradient. $h^{\prime}$ and $h^{\prime \prime}$, Loss of head at wells $\mathbf{A}$ and $\mathbf{B}$ due to free discharge with total head $H ; h$, and $h_{, \prime}$, loss of head at wells $\mathrm{A}$ and $\mathrm{B}$ due to reduced discharge with total head $H, ; a^{\prime}$ and $a^{\prime \prime}$, rise in hydraulle gradient at wells $\mathbf{A}$ and $\mathbf{B}$ due to reduction in discharge and increase-in head represented by $H,-H ; H$, loss of head at the discharge outlet due to free discharge with total head $H$; $b$, rise in hydraulic gradient at discharge outlet due to reduction of discharge and increase in head represented by $H,-H$

The difference in precipitation over various parts of the catchment area has a further bearing upon the problem of the greater decline in head in the southern part of the artesian area. The precipitation in the mountainous region along the west side of the drainage area is somewhat greater in the Sierra Blanca, at the north, than in the Sacramento Mountains, at the south. The recharge to the artesian reservoir received from the precipitation and run-off of the Sierra Blanca is also greater than that received from the Sacramento Mountains.

The permeability of the artesian aquifers varies considerably, and, as shown in Plate 41 , the less permeable areas appear to extend across the artesian area from west to east. These less permeable areas do not divide the artesian area into separate and distinct basins, for the artesian aquifers are more or less continuous and are connected by solution channels and fissures. The percolation of artesian water from north to south is, however, slowed up, across these zones of lower permeability, and as a result the more permeable zones, 
where most of the irrigation development has concentrated, are to a certain extent dependent for recharge upon the contributions from the catchment area to the west. As the southern part of the catchment area receives less precipitation than the northern part, a portion of the decline in head in the southern part of the artesian area is doubtless due to greater draft from storage in the southern section.

\section{QUANTITY OF RECHARGE}

In selecting methods for the determination of the safe yield of the Roswell artesian basin the essential character of the artesian reservoir should be kept in mind. In the Roswell Basin the water-bearing formations act as conduits which carry the water from the intake area to the wells and to the points of natural discharge, where the supply is recovered for irrigation and other uses. As there is considerable resistance to the flow of water on account of the small size of the interstices of the water-bearing formation, the safe yield of the artesian reservoir is controlled not only by the amount of water that reaches the intake area but also by the capacity of the formations to carry the water to the discharge outlets.

Before many wells were drilled the large springs in the north end of the artesian area largely controlled the level to which the artesian head would rise in that portion of the area. The initial hydraulic gradient which existed as a result of the flow at the springs had an eastward slope from the intake area to the natural spring outlets. The records of the pressure of the first wells that were drilled show that originally in the artesian area the piezometric surface was more nearly level than it is at present. The artesian reservoir is evidently not a tight basin, as shown by the gain in flow of the Pecos River as it crosses the artesian area, and the study of the geology of the region indicates that there must be some loss from the southeast corner of the reservoir. The available information indicates that prior to the drilling of wells the hydraulic gradient east and south of the springs was not as steep as that north and west of the springs. The present greater slope of the piezometric surface (see pl. 30), as shown by the hydraulic gradient at various sections across the artesian area (pl. 31), is largely the result of draft on the artesian reservoir caused by wells.

The initial marked decline in artesian head which occurred during the early period of drilling did not necessarily indicate depletion of the artesian reservior but was evidence of the large amount of pressure consumed in producing the flow from the wells. Likewise, a rapid decline of head during the development period does not indicate an overdevelopment of the artesian reservoir unless the decline is so great as to indicate the approach of pumping lifts that are be- 
yond the economic limit. The important question, therefore, is to determine a rate of withdrawal that will establish a drawdown within the permissible pumping lift. Unfortunately the question can not be definitely answered because the available data are insufficient for the successful application of the various methods of determining safe yield.90 However, they are sufficient to form a basis for certain conclusions.

Though the amount of discharge from the artesian reservoir prior to the drilling of wells can not be used as an accurate measure of the safe yield of the basin, it is an approximate indication of the amount that may safely be withdrawn by wells.

Information regarding the flow of the Berrendo Springs, North Spring, and South Spring is given by Meinzer ${ }^{91}$ as follows:

The combined flow of all the openings of the Berrendo springs prior to the drilling of the artesian wells was doubtless more than 100 second-feet, according to W. A. Wilson, county surveyor of Chaves County, and was estimated at 50 second-feet in February, 1889, according to Newell. In 1926, however, the North Berrendo Spring flowed only 5 second-feet and the Middle Berrendo Spring only 3 second-feet, while the South Berrendo Spring was entirely dry.

The North Springs had an estimated discharge of about 50 second-feet in February, 1889, according to Newell, and 77 second-feet November 6, 1901, according to a measurement made by Mr. Wilson. In 1901 a distribution of the water of North Spring River was made on a basis of 70 second-feet. Mr. Wilson estimated that prior to the drilling of any artesian wells, the discharge of these springs was between 100 and 150 second-feet. In 1926 the North Springs were entirely dry.

The original discharge of the South Springs was probably between 60 and 75 second-feet, according to the estimate of $\mathrm{Mr}$. Wilson. The discharge in February, 1889, was 73 second-feet according to Newell's report. The flow failed rapidly after the drilling of artesian wells had begun. A measurement made in February, 1902, showed a flow of only 28 second-feet, and the springs practically went dry between 1902 and 1904.

According to this information, a conservative estimate of the average original flow of the Berrendo Springs would appear to be 65 second-feet. The average flow of North Spring, at the head of the North Spring River, prior to the drilling of artesian wells is estimated at 85 second-feet, and that of South Spring at 60 secondfeet. Only meager information is available regarding the spring flow of the Rio Felix, Rio Penasco, and Seven Rivers, but it is believed that the total spring flow of the lower reaches of these streams probably averaged about 20 second-feet.

${ }^{90}$ See Meinzer, O. E., Methods of estimating ground-water supplies, pt. 1, Outline of available methods (paper delivered at annual technical session, Society of Economic Geologists, Dec., 1928) ; issued also as Outline of methods for estimating ground-water supplies: U. S. Geol. Survey Water-Supply Paper 638, pp. 99-144, 1932.

${ }^{91}$ Meinzer, O. E., Large springs in the United States: U. S. Geol. Survey Water-Supply Paper 557, p. 90, 1927. 
Records of the flow of the Pecos River ${ }^{92}$ indicate an unaccounted for gain from Acme to below the mouth of the Rio Penasco. This gain is estimated at 50 second-feet in 1927, and it undoubtedly represents natural leakage from the artesian reservoir, together with small contributions from ground water in the valley fill supplied by rainfall. It is quite probable that prior to the drilling of artesian wells this discharge was greater than at present, as the natural leakage from the artesian reservoir was undoubtedly greater because of the higher artesian head which existed at that time. The minimum flow of the Major Johnson Springs, at the southeast corner of the artesian basin, amounts to about 40 second-feet and undoubtedly represents natural leakage from the artesian reservoir additional to that which reaches the Pecos River above the Rio Penasco. The flow from springs and natural outlets in the tributary streams probably amounts to at least 5 second-feet.

The total original discharge from all sources is estimated at about 325 second-feet, or 235,200 acre-feet a year. Of this amount the river gain of 50 second-feet, the flow of 40 second-feet from the Major Johnson Springs, and the 5 second-feet from other natural outlets, or 68,700 acre-feet a year, constitute natural leakage from the artesian reservoir which can not be controlled and is not available for use for irrigation in the artesian area. The remaining 166,500 acrefeet a year, or in round numbers 165,000 acre-feet, formerly discharged by the springs at the north end of the area has apparently been completely diverted to the wells. As pointed out previously, these estimates may be considerably in error in view of the absence of complete records of the flow of the streams.

An underground reservoir possesses a number of features which are similar to that of a surface reservoir. Its storage capacity is not, however, so definitely limited as that of a surface reservoir, for after a period of heavy pumping its capacity may be greatly increased so that it can receive by percolation water which would otherwise, if the reservoir were full, be wasted by run-off in the surface streams. Prior to the drilling of wells in the Roswell area the available capacity of the reservoir may have been more or less completely utilized after long periods of rainfall, and a larger portion of the flow of the streams crossing the intake area may formerly have been lost by run-off to the Pecos, but unfortunately.information is not available upon which to base a definite statement. The natural leakage may be less now than formerly because of the lower artesian head caused by the draft from wells. For these reasons it would appear that the

\footnotetext{
${ }^{22} \mathrm{New}$ Mexico State Engineer, Surface water supply of New Mexico, 1888-1925, pp. 127-142, 1926. Pecos River hydrographic survey, 1921-22; records on flle in office of New Mexico State engineer; and unpublished records of $U$. S. Bureau of Reclamation, Carlsbad, N. Mex.
} 
previously determined quantity of 165,000 acre-feet a year is possibly slightly under the safe yield of the artesian reservoir.

It has been shown that the artesian head tends to seek lower levels each year (see pp. 199-205), and though the head at the end of 1926 and 1928 equaled or slightly exceeded that recorded at the end of 1925 , the average head for the year in the observation wells was somewhat lower each succeeding year in practically all sections of the artesian area. This indicates that the present rate of withdrawals is somewhat in excess of the recharge but that the recharge and withdrawal are tending to reach an equilibrium in which the artesian head will be somewhat below its present level. This conclusion is verified by the flattening of the curve of decline shown on Plate 28, and though the present rate of decline is moderate, some further decline is to be expected.

The total draft at the surface during the period 1925 to 1927 has been estimated at 250,000 acre-feet a year. (See p. 231.) Of this amount approximately 70,000 acre-feet is discharged from natural sources and is not available for use in the artesian area. This leaves a balance of 180,000 acre-feet. In addition to this draft, underground leakage of about 7,200 acre-feet was actually measured. The total draft, both above and below the ground, due to wells is therefore probably in excess of 200,000 acre-feet a year. A comparison with the 165,000 acre-feet of flow from springs and other natural outlets from the reservoir estimated as being available for use in the artesian area would seem to indicate that the present rate of withdrawal is probably not over 30,000 to 40,000 acre-feet in excess of the safe yield.

In considering the problem of the safe yield of the artesian reservoir the information furnished by records of the fluctuations of the water level in wells that penetrate the water-bearing formations in the intake area is of considerable value. In the intake area the water in the water-bearing formations is not under pressure, and the fluctuations of the water table, as indicated by the fluctuations in the water level in the wells, would furnish a measure of the storage in the artesian reservoir. A general downward trend of the water table would indicate a draft upon the artesian reservoir in excess of the recharge. Conversely, a rise in the water table would indicate that the recharge to the artesian reservoir was in excess of the withdrawal. A critical study of the fluctuations in artesian pressure in the aquifers underlying the artesian area and of the rate of withdrawal during a definite period and a comparison of these with the changes in the level of the water table in the intake area during various periods would furnish a basis for. a much more reliable determination of the safe yield than could be made with the data available. 
Unfortunately, it has not been possible to obtain complete information on the fluctuations of the water table in the intake area because of the absence of wells properly situated for the purpose. The safe yield of the artesian reservoir is a factor of great importance in the future regulation of the withdrawal of water, and in order that this factor may be more reliably determined, the drilling of an observation well in the intake area is considered highly desirable.

The only information available regarding the fluctuations of the water table in the intake area is supplied by a well in the NW. 1/4 NW. $1 / 4$ sec. 27, T. 19 S., R. 23 E. (See p. 205.) During the period of 9 months and 8 days from June 7, 1927, to March 15, 1928, the water level in this well lowered 1.15 feet, or at the rate of 1.49 feet a year. It is to be expected that there would be a considerable lag between the decline in head in the artesian area and that in the intake area, hence the decline in the intake area during this period would correspond to the decline in head in the artesian area that had occurred some time before.

The table on page 201 shows the amount and rate of decline of the artesian head during several periods for groups of wells in the vicinity of Artesia and Roswell. The well in the intake area on which the observations were made is in the same general east-west segment of the artesian basin as the group of wells in the vicinity of Artesia used in the table on page 201.

During the 5-year period July 1, 1920, to June 30, 1925, the rate of decline of the artesian head for the group of wells in the vicinity of Artesia was 1.4 feet a year. During the observation period 1927-28 the water table in the intake area declined at the rate of 1.49 feet a year. Though the periods of observation are not entirely comparable, yet the rates of decline are of about the same magnitude. This relatively close agreement appears to be rather significant, and it supports the conclusion that the present draft is somewhat in excess of the recharge and that there is still some withdrawal from storage.

\section{IRRIGATION}

\section{REQUIREMENTS OF ARTESTAN WATER FOR IRRIGATION}

The Roswell artesian basin is peculiarly situated in regard to the crops which may be grown. The region is about as far south as it is possible to raise apples profitably and about as far north as cotton can be grown successfully. The usual field crops of corn, wheat, oats, and truck appear to thrive here. At first extensive tracts were planted to apple orchards, but now only a few of the better tracts are still in orchard. Prior to 1920 alfalfa was a leading crop, but since that date the cotton acreage has gradually increased until, in recent years, about 50 per cent of the cultivated area is planted in cotton. 
During the last few years there has been comparatively little change in the size of the areas devoted to the crops that are irrigated directly from artesian wells. The following table, which is reprinted from the preliminary report, ${ }^{93}$ shows the acreage of the chief crops irrigated by water obtained directly from artesian wells in 1925 .

Area devoted to crops irrigated by water obtained directly from artesian wells in the Rosuell artesian basin during 1925

\begin{tabular}{|c|c|c|c|c|c|c|c|c|c|c|}
\hline & \multicolumn{2}{|c|}{$\begin{array}{c}\text { Area irrigated } \\
\text { by artesian } \\
\text { wells }\end{array}$} & \multicolumn{2}{|c|}{ Cotton } & \multicolumn{2}{|c|}{ Alfalfa } & \multicolumn{2}{|c|}{ Orchard } & \multicolumn{2}{|c|}{$\begin{array}{l}\text { Miscellane- } \\
\text { ous crops }\end{array}$} \\
\hline & Acres & $\begin{array}{c}\text { Per } \\
\text { cent }\end{array}$ & Acres & $\begin{array}{l}\text { Per } \\
\text { cent }\end{array}$ & Acres & $\begin{array}{l}\text { Per } \\
\text { cent }\end{array}$ & Acres & $\begin{array}{c}\text { Per } \\
\text { cent }\end{array}$ & Acres & $\begin{array}{l}\text { Per } \\
\text { cent }\end{array}$ \\
\hline \multirow[t]{2}{*}{$\begin{array}{l}\text { Chaves County } \\
\text { Eddy County }\end{array}$} & $\begin{array}{l}29,600 \\
15,400\end{array}$ & $\begin{array}{l}66 \\
34\end{array}$ & $\begin{array}{r}13,950 \\
7,610\end{array}$ & $\begin{array}{l}47 \\
49\end{array}$ & $\begin{array}{r}10,300 \\
5,490\end{array}$ & $\begin{array}{l}35 \\
36\end{array}$ & $\begin{array}{r}1,810 \\
530\end{array}$ & $\begin{array}{l}6 \\
3\end{array}$ & $\begin{array}{l}3,540 \\
1,770\end{array}$ & $\begin{array}{l}12 \\
12\end{array}$ \\
\hline & 45,000 & 100 & 21,560 & 48 & 15,790 & 35 & 2,340 & 5 & 5,310 & 12 \\
\hline
\end{tabular}

Detailed figures for the acreage of certain crops planted in Chaves County during the 5-year period 1923 to 1927 are shown in the following table. The figures given include an average of 1,600 acres irrigated from surface water and about 9,100 acres supplied by the Hagerman Canal, which derives its water supply directly or indirectly from the artesian reservoir. Similar detailed figures are not available for Eddy County, but it is believed that the relative proportions of the crops are about the same as in Chaves County.

Aoreage of crops planted in Chaves County, 1923 to 1927

\begin{tabular}{|c|c|c|c|c|c|c|}
\hline . & 1923 & 1924 & 1925 & 1926 & 1927 & $\begin{array}{l}\text { Average } \\
\text { for 5-year } \\
\text { period }\end{array}$ \\
\hline 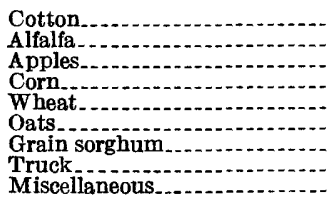 & $\begin{array}{r}10,199 \\
16,473 \\
3,717 \\
2,469 \\
221 \\
772 \\
1,611 \\
100 \\
750\end{array}$ & $\begin{array}{r}17,038 \\
14,922 \\
2,572 \\
1,923 \\
134 \\
886 \\
1,415 \\
100 \\
1,034\end{array}$ & $\begin{array}{r}19,212 \\
14,170 \\
2,492 \\
1,987 \\
56 \\
888 \\
1,327 \\
100 \\
516\end{array}$ & $\begin{array}{r}17,970 \\
15,306 \\
2,380 \\
3,814 \\
1,99 \\
1,282 \\
1,285 \\
1125 \\
625\end{array}$ & $\begin{array}{r}16,782 \\
15,637 \\
1,992 \\
3,557 \\
270 \\
1,429 \\
1,365 \\
\mathbf{1 2 5} \\
421\end{array}$ & $\begin{array}{r}16,240 \\
15,301 \\
2,631 \\
2,750 \\
156 \\
1,027 \\
1,401 \\
110 \\
669\end{array}$ \\
\hline & 36,272 & 40,024 & 40,748 & 42,816 & 41,578 & 40,285 \\
\hline
\end{tabular}

The farms that are irrigated with artesian water usually have one or more wells each, but in the Berrendo tract and the vicinity of Roswell, where a number of small tracts are irrigated, one well may supply several farms. The quantity of water applied to the land varies widely and depends on the discharge of the well, the head of water available for irrigation, the character of the soil, and the method of irrigation. On farms where the water is pumped it is generally used more economically than on farms with flowing wells.

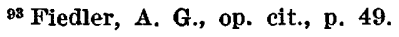


Under such varying conditions it is difficult to select representative farms on which accurate determinations of the use of water might be made. It is also quite beyond the scope of this investigation to determine the quantity of water drawn from each well by means of discharge measurements and a record of the number of hours that each well is in use. The requirements for irrigation in this area as here stated are therefore based on experiments by Bloodgood and Curry $^{94}$ at the agricultural experiment station near Mesilla Park, N. Mex.

The following table gives the net requirements of water for irrigation of certain crops on the basis of the acreage in cultivation in 1925 . The net requirement of water is the amount applied directly to a field and does not include losses by evaporation and seepage from reservoirs and ditches.

Net requirements of water, in acre-feet, for irrigation of different orops supplied direatly from artesian wells in the Roswell artesian basin during 1925

\begin{tabular}{|c|c|c|c|c|c|}
\hline & $\begin{array}{l}\text { Cotton } \\
\text { (12/3 acre- } \\
\text { feet per } \\
\text { acre) }\end{array}$ & $\begin{array}{l}\text { Alfalfa (3 } \\
\text { acre-feet } \\
\text { per acre) }\end{array}$ & $\begin{array}{c}\text { Orchard (3 } \\
\text { acre-feet } \\
\text { per acre) }\end{array}$ & $\begin{array}{l}\text { Miscel- } \\
\text { laneous } \\
\text { (21/2acre- } \\
\text { feet per } \\
\text { acre) }\end{array}$ & Total \\
\hline \multirow[t]{2}{*}{$\begin{array}{l}\text { Chaves County } \\
\text { Eddy County }\end{array}$} & $\begin{array}{l}23,160 \\
12,630\end{array}$ & $\begin{array}{l}30,900 \\
16,470\end{array}$ & $\begin{array}{l}5,430 \\
1,590\end{array}$ & $\begin{array}{l}8,850 \\
4,250\end{array}$ & $\begin{array}{l}68,340 \\
34,940\end{array}$ \\
\hline & 35,790 & 47,370 & 7,020 & 13,100 & 103,280 \\
\hline
\end{tabular}

The net requirement of water for all crops, based on the assumed duties, for land irrigated directly by artesian wells in 1925 was about $21 / 3$ acre-feet. If a loss of 20 per cent from the wells to the land is assumed, $27 / 8$ acre-feet to the acre, or a total of approximately 130,000 acre-feet, would be required to supply the area with the necessary amount of water. On the Carlsbad project, where conditions as to soil and climate are similar to those in the artesian area, an average of 2.44 acre-feet to the acre was delivered to the farms during a period of 13 years, but this quantity has not always been adequate for the requirements of the crops. The normal water right under the Hagerman Canal is $21 / 2$ acre-feet to the acre during the irrigation season. This quantity is sometimes supplemented, particularly during dry years, by additional water purchased prior to the main irrigation season, which begins about April 1, but the quantity of water used does not average over 3 acre-feet to the acre. In addition to the water used for irrigation, the area normally receives an average precipitation, according to the records of the United States Weather Bureau at Roswell over a period of 25 years, of 0.78 foot during the

${ }^{24}$ Bloodgood, D. W., and Curry, A. S., Net requirements for crops for irrigation water in Mesilla Valley, N. Mex. : New Mexico Agr. Bxper. Sta. Bull. 149, 1925. 
growing season, April 11 to October 26. (See table below.) It is believed that 3 acre-feet to the acre is generally ample for the farms in the artesian area. The principal irrigation season is considered to extend from April 1 to October 1. Many flowing wells, however, especially those with small discharge, are in operation continuously throughout the year. In sections where the discharge is larger the flowing wells are operated almost continuously for six to seven months. Pumped wells are operated from four to six months, and many are in use continuously day and night during the irrigation season.

Precipitation, in feet, during the growing season, April 11 to Ootober 26, for the years 1903 to 1927, with averages for 5-year periods

[Based on U. S. Weather Bureau records for Roswell, N. Mex.]

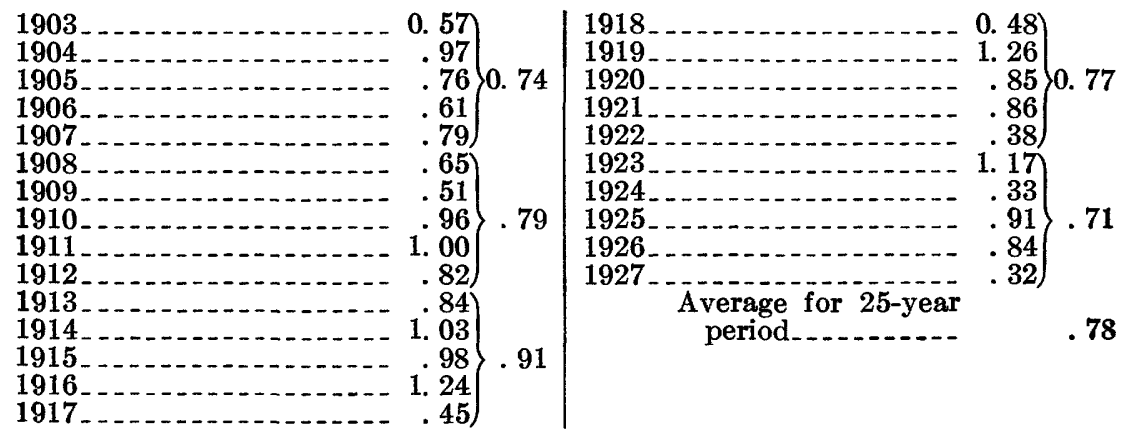

VALUE OF CROPS PRODUCWD FROM IRRIGATED ARFA

During the period 1923 to 1927 the Roswell Chamber of Commerce compiled each year records of the value of the crops produced in Chaves County. The records are based on individual records for each farm and are considered to be a reliable compilation of data. The following table gives the total value according to years and the value per acre of the crops produced in the entire county.

Dalue of crops produced in Chaves County, 1923 to 1927

\begin{tabular}{|c|c|c|c|c|c|c|}
\hline & \multicolumn{2}{|c|}{1923} & \multicolumn{2}{|c|}{$=1924$} & \multicolumn{2}{|l|}{1925} \\
\hline & Total & $\begin{array}{l}\text { Per } \\
\text { acre }\end{array}$ & Total & $\begin{array}{l}\text { Per } \\
\text { acre }\end{array}$ & Total & $\begin{array}{l}\text { Per } \\
\text { acre }\end{array}$ \\
\hline \multirow[t]{2}{*}{$\begin{array}{l}\text { Cotton } \\
\text { Alfalfa } \\
\text { Apples } \\
\text { Corn } \\
\text { Wheat. } \\
\text { Oats } \\
\text { Grain sorghum } \\
\text { Truck } \\
\text { Miscellanoous }\end{array}$} & $\begin{array}{r}\$ 906,070 \\
699,300 \\
210,800 \\
55,552 \\
5,525 \\
16,470 \\
24,000 \\
50,000 \\
18,250\end{array}$ & $\begin{array}{r}\$ 88.83 \\
42.45 \\
56.85 \\
22.82 \\
25.00 \\
22.50 \\
14.90 \\
500.00 \\
24.33\end{array}$ & $\begin{array}{r}\$ 1,491,915 \\
714,350 \\
337,800 \\
59,132 \\
4,422 \\
21,707 \\
23,400 \\
50,000 \\
20,680\end{array}$ & $\begin{array}{r}\$ 87.57 \\
47.87 \\
131.33 \\
30.75 \\
33.00 \\
24.50 \\
16.53 \\
500.00 \\
20.00\end{array}$ & $\begin{array}{r}\$ 1,487,430 \\
778,550 \\
260,000 \\
89,415 \\
1,680 \\
17,094 \\
23,800 \\
50,000 \\
10,320\end{array}$ & $\begin{array}{r}\$ 77.42 \\
54.94 \\
104.33 \\
45.00 \\
30.08 \\
19.25 \\
17.93 \\
500.06 \\
20.00\end{array}$ \\
\hline & $1,985,967$ & 54.75 & $2,723,406$ & 68.04 & $2,718,289$ & 66.71 \\
\hline
\end{tabular}


Value of crops produced in Chaves County, 1923 to 1927-Continued

\begin{tabular}{|c|c|c|c|c|c|c|}
\hline & \multicolumn{2}{|l|}{1926} & \multicolumn{2}{|c|}{1927} & \multicolumn{2}{|c|}{$\begin{array}{l}1923 \text { to } 1927 \text { (yearly } \\
\text { average) }\end{array}$} \\
\hline & Total & $\begin{array}{l}\text { Per } \\
\text { acre }\end{array}$ & Total & $\begin{array}{l}\text { Per } \\
\text { acre }\end{array}$ & Total & $\begin{array}{l}\text { Per } \\
\text { acre }\end{array}$ \\
\hline $\begin{array}{l}\text { Cotton } \\
\text { Alfalfa_- } \\
\text { Apples } \\
\text { Corn } \\
\text { Wheat_a } \\
\text { Oats } \\
\text { Grain sorghum } \\
\text { Truck } \\
\text { Miscellaneous }\end{array}$ & $\begin{array}{r}\$ 898,402 \\
609,800 \\
134,700 \\
133,490 \\
3,564 \\
23,452 \\
22,487 \\
62,500 \\
12,500\end{array}$ & $\begin{array}{r}\$ 49.43 \\
39.84 \\
56.59 \\
35.00 \\
36.00 \\
19.35 \\
17.50 \\
500.00 \\
20.00\end{array}$ & $\begin{array}{r}\$ 1,487,107 \\
731,256 \\
133,600 \\
118,270 \\
9,720 \\
38,583 \\
27,300 \\
50,000 \\
7,578\end{array}$ & $\begin{array}{r}\$ 88.61 \\
46.76 \\
67.06 \\
33.25 \\
36.00 \\
27.00 \\
20.00 \\
400.00 \\
18.00\end{array}$ & $\begin{array}{r}\$ 1,254,185 \\
706,651 \\
215,380 \\
91,172 \\
4,986 \\
23,461 \\
24,197 \\
52,500 \\
13,866\end{array}$ & $\begin{array}{r}\$ 78.37 \\
46.37 \\
83.23 \\
33.36 \\
32.00 \\
22.52 \\
17.37 \\
480.00 \\
20.47\end{array}$ \\
\hline & $1,900,895$ & 44. 40 & $2,603,414$ & 62.61 & $2,386,294$ & 59.30 \\
\hline
\end{tabular}

About 4 per cent of the total value of crops represented by the above figures is derived from about 1,600 acres irrigated with surface water. The remainder, or 96 per cent of the crop value shown, is derived from areas irrigated either directly or indirectly with water of artesian origin. The average yearly value of all crops for the 5-year period is more than $\$ 2,250,000$, and the average value of the yield per acre is $\$ 59.30$. The low average value per acre in 1926 was not due to poor yield but to the unusually low price for farm products in that year. A comparison of the value of crops produced in Chaves County with the corresponding figures for the entire State of New Mexico and for the United States is interesting and instructive. Figures for the value of the yield per acre are available for the years 1925 to 1927 through the Division of Crop Estimates of the Department of Agriculture. For this period the value per acre of the crops produced in Chaves County was $\$ 57.93$, as compared with only $\$ 27.36$ for the State of New Mexico and $\$ 23.44$ for the entire United States. The value of tame hay for the same period was $\$ 47.18$ for Chaves County, as compared with $\$ 30.76$ for the State of New Mexico and $\$ 20.24$ for the United States. The value per acre of the cotton crop is not given in the statistics of the Department of Agriculture, but the average yield of lint cotton per acre for Chaves County was 335 pounds, as compared with 316 pounds for New Mexico and 167 pounds for the United States.

The yield per acre and the value of crops per acre raised in the part of the artesian basin that lies in Eddy County is approximately the same as for the part in Chaves County. Unfortunately detailed data are not available, but incomplete data furnished by the Artesia Alfalfa Growers Association and the county assessor show that the average annual value of crops produced by irrigation from artesian water in Eddy County is approximately $\$ 1,000,000$.

The value of all crops produced in both counties by irrigation with artesian water is estimated at $\$ 3,250,000$ a year. The value of the 
poultry, dairy products, honey, and livestock produced on the farms is not included in the above figures.

\section{EXTENT OF IRRIGATED AREA AND RELATION TO ARTESIAN HEAD}

During the early years of irrigation with artesian water much land was irrigated along the west side of the original area of artesian flow. With the development of the basin and decline in artesian head the irrigated belt along the western boundary of the area was seriously affected by higher pumping lifts or greatly reduced yield from the flowing wells. Because of this condition much farm land in this part of the area was abandoned, and new development on lower lands was made. The land irrigated directly from artesian wells during 1926 and 1927 is shown on Plate 45, on which the outlines of the area are drawn chiefly from information obtained from the declarations of water rights filed with the State engineer, information furnished by the well supervisors, and field notes. The area irrigated by the Hagerman Canal, which derives its water supply directly or indirectly from the artesian reservoir is also shown. The data on acreage supplied by the Hagerman Canal were furnished by W. E. Bowen, of the Hagerman Irrigation Co.

Plate 45 also shows the relation of the artesian head to the ground surface and the location of the irrigated tracts. The area in which the artesian wells are pumped includes the part west of the area of artesian flow and a strip along the west side of that area where the artesian head is not great. The relation of the artesian head to the ground surface is shown for the winter of 1926-27. During the summer the head is 5 to 20 feet lower than that shown. To estimate the pumping lift in nonflowing wells a drawdown of 10 to 25 feet and an allowance of 5 to 20 feet for the decline in head during the irrigation season should be added to the depth to the water level as shown on the map. To estimate the pumping lift in flowing wells the head as shown on the map should be subtracted from the sum of the drawdown and decline in head during the irrigation season. The allowance to be made for the decline in head is least in the north end of the area and greatest in the south end. (See pls. 33 and 36.)

\section{IRRIGATION ALONG COTTONWOOD CREFK}

Prior to the development of the artesian basin Cottonwood Creek was practically dry except for the Noah Buck Spring, in sec. 1, T. 16 S., R. 25 E., which yielded a small flow used chiefly for watering stock. After the drilling of artesian wells in this segment springs appeared along the banks of the creek, and in the winter of 1926 the average flow of the stream where it crosses the west line of sec. 6 , T. 16 S., R. 26 E., amounted to about 18 to 20 second-feet. This 
water is derived from waste from artesian wells, leakage from wells, return flow from irrigation, and excess water used during the irrigation season. Through the construction of a small reservoir and a series of ditches the water is diverted and used for the irrigation of about 2,000 acres on both sides of the creek. Owing to the natural drainage into Cottonwood Creek, much of the water applied for irrigation in the upper reaches of the stream returns to the stream channel and is available for use in irrigating lower lands. Thus the original quantity of water available is used at a comparatively high duty.

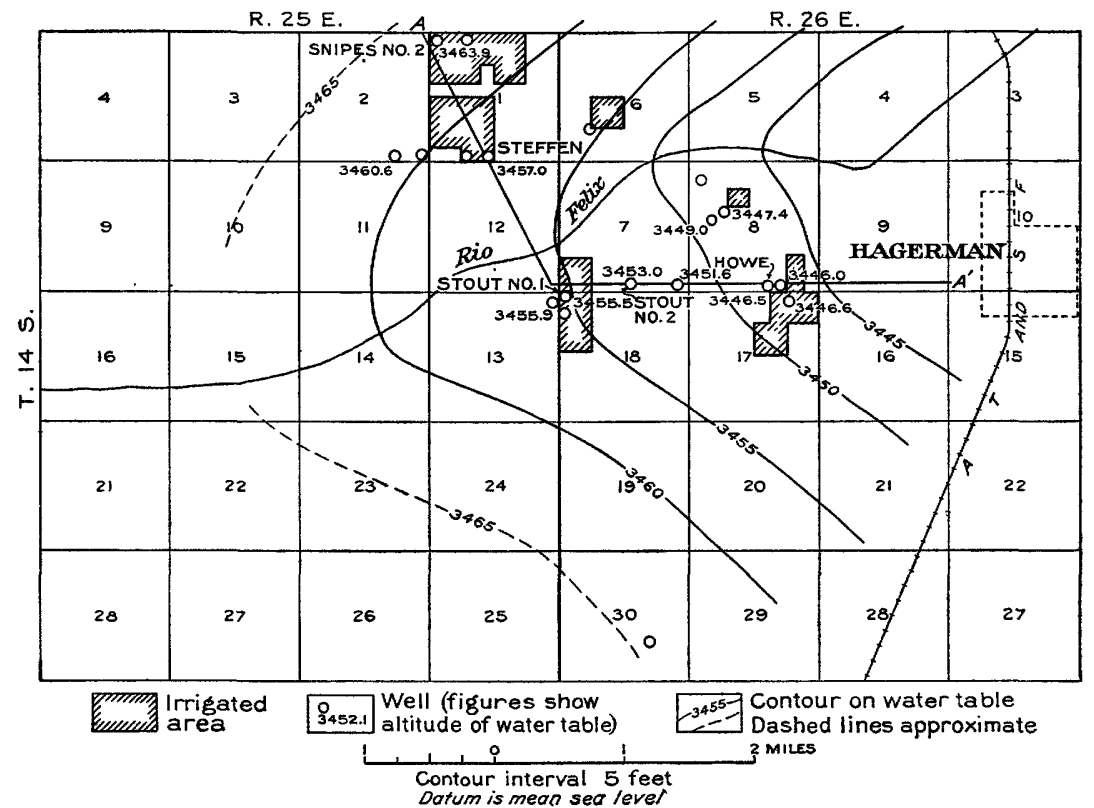

FIGURn 35.-Map of Felix shallow-water district, showing contours on the water table and area irrigated by pumping from shallow wells. $A-A^{\prime}$, Line of section in Figure 36

\section{FELIX SHALLOW GROUND-WATER DISTRICT}

In 1927 and 1928 a small area adjacent to the Rio Felix attained some prominence because it is the only area of consequence in the valley where the water supply for irrigation is derived by pumping shallow ground water. (See pl. 46, A.) As there are doubtless other shallow ground-water areas within the valley that would yield sufficient water for irrigation, some study has been devoted to the Felix area to determine its general characteristics.

A record of the fluctuations of the water table was obtained for the period March 19, 1927, to April 16, 1928, with a recording gage installed over a well that was not in use. The altitude of all wells in the area was determined by means of a level line, and observations were made on the level of the water table to determine its trend and 


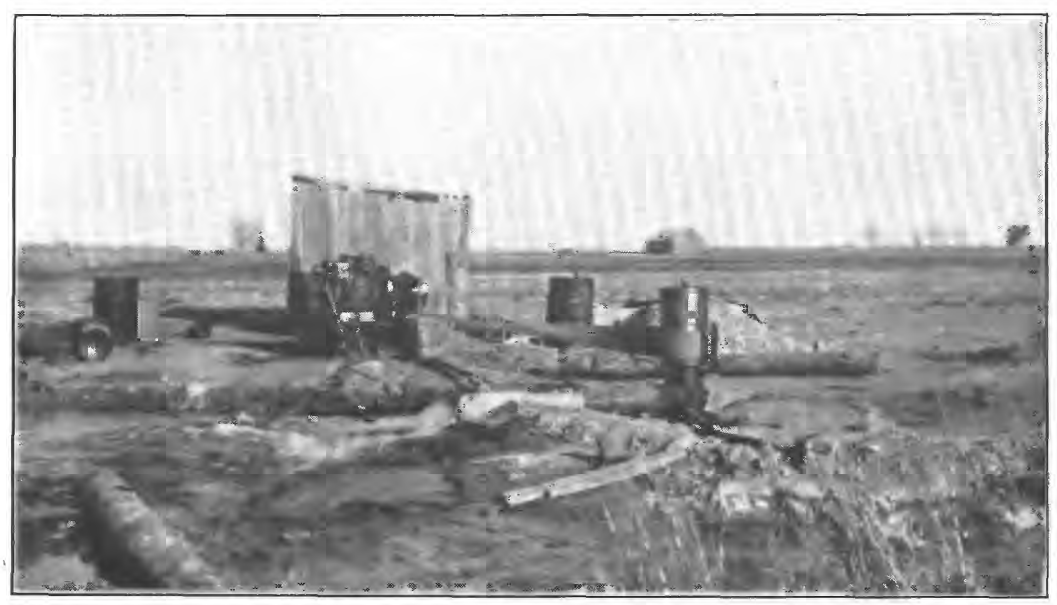

A. PUMPING WELL IN THE NW. $1 / 4$ NW. $1 / 4$ SEC. 1, T. 14 S., R. 25 E., IN THE FELIX SHALLOW GROUND-WATER DISTRICT

Photograph by A. G. Fiedler.

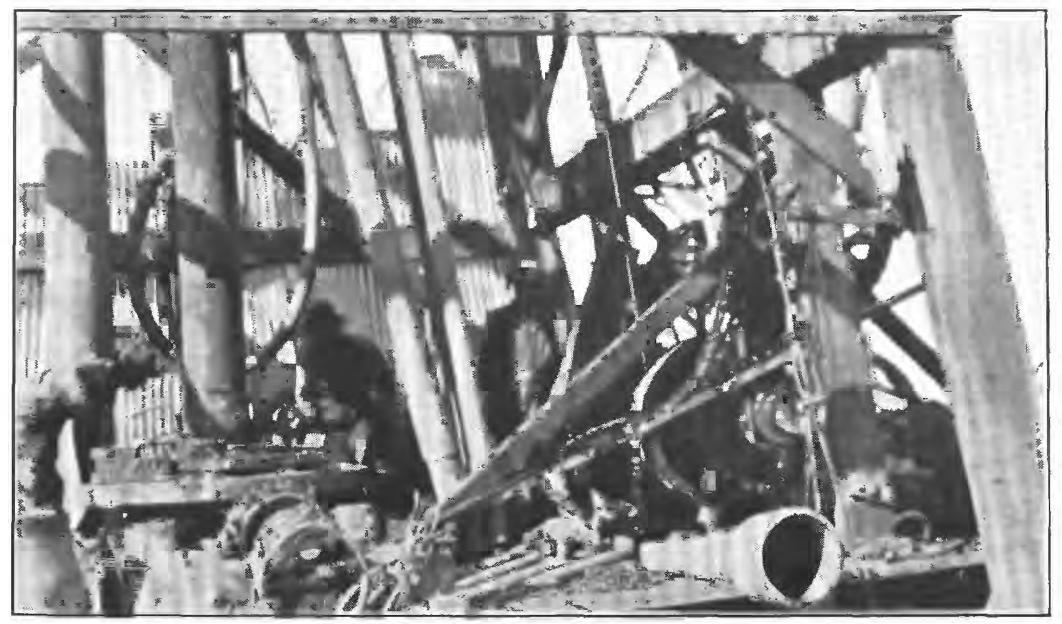

B. DRILLING WITH HYDRAULIC ROTARY PROCESS

Photograph by A. G. Fiedler. 

its relation to the land surface. Figure 35 is a map of the district with contours on the water table. The lines indicate that the water table slopes in general in the downstream direction of the Rio Felix and that the movement of ground water is therefore in the same

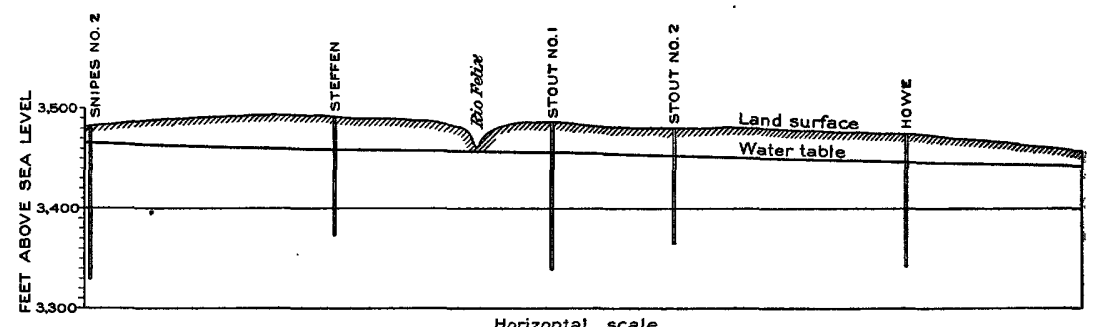

Horizontal scale

Figure 36.-Section along line $A-A^{\prime}$ shown in Figure 35

direction. Figure 36 is a section showing the relation of the land surface and the water table. Figure 37 is a map of the district showing the depth to the water table, which is least in the eastern part and adjacent to the Rio Felix and increases toward the west. Be-

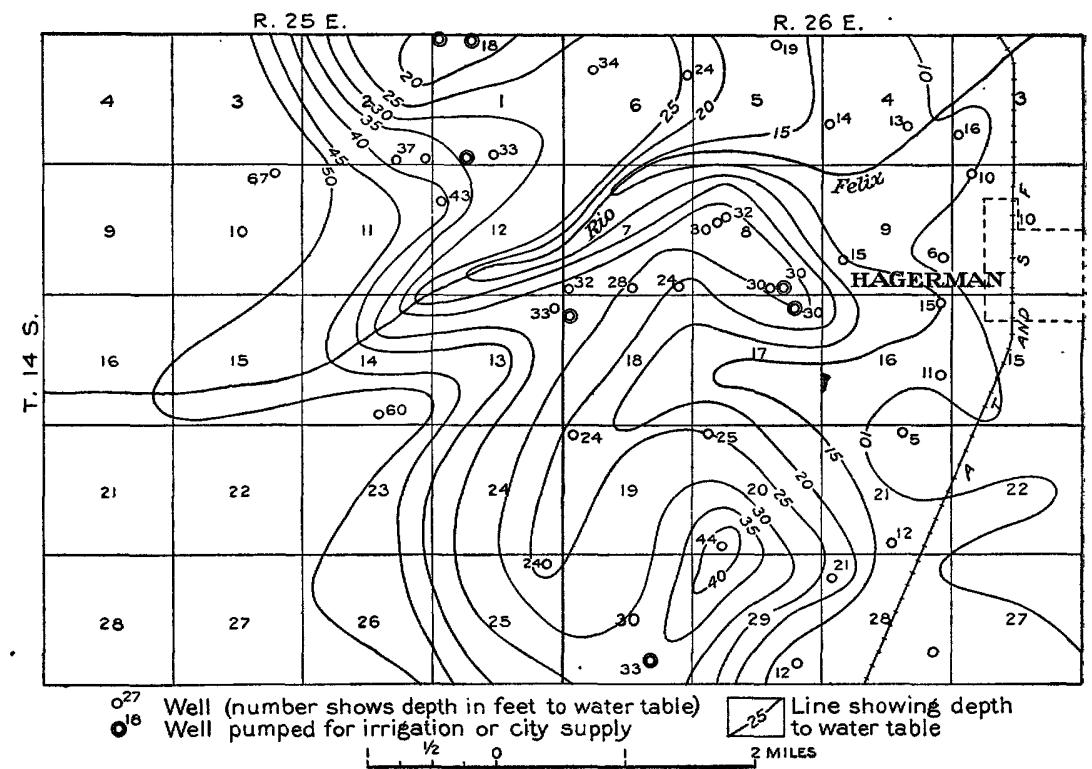

Frauke 37.-Map of Felix shallow-water district, showing depth of water table below the surface

cause of economic conditions it is generally not feasible in this area to pump water much more than 50 feet, and for this reason the development will be largely confined to the area east of the line shown in Figure 37 as indicating a depth to water of 50 feet. The total pumping lift will generally be from 12 to 18 feet more than the 135252-33-18 
depth to the water table, because of the drawdown that occurs while pumping. If there is much development there will also be some regional lowering of the water table.

At the time the record of the fluctuations of the water table was started, on March 19, 1927, the water level in the observation well was 28.29 feet below the bench mark at the top of the well. The water table gradually declined during the irrigation season, and on September 26, 1927, it reached the lowest point, which was 2.03 feet below the level at the start of the record. Between September 26, 1927, and February 12, 1928, the water table rose 1.14 feet. It then declined about 0.30 feet until April 16, 1928, when the recording gage had to be dismantled because the well was placed in use for irrigation.

Records on the pumping plant of Herman Steffen indicate that about 3.25 acre-feet of water to the acre was used for the irrigation of the land under this pump. Using 3.25 acre-feet to the acre as the average duty of water for the 580 acres irrigated by pumping from shallow wells gives a total of 1,885 acre-feet of water withdrawn during the season of 1927 . Some of the water from wells may return to the water table and hence again become available to the wells. Upon the basis of the assumed average available porosity, or specific yield, for the sand and gravel beds from which the water is obtained, a withdrawal of 1,885 acre-feet of water would lower the water table 1 foot over an area of 15,700 acres. Data are not available regarding the extent of the lowering of the water table over the whole area; but if the decline was the same as that shown by the observation well, the water table would have been lowered 2.03 feet over an area of 7,740 acres, or about 12 square miles. In addition to the lowering of the water table due to pumping, there may be seasonal lowering of the water table due to evaporation and transpiration.

The rise in the water table of 1.14 feet, which occurred between September 26, 1927, and February 12, 1928, replaced 56 per cent of the water withdrawn during the preceding season. The fact that the water table did not return to the high point recorded during the preceding year indicates a lowering of the water table for the year. During the year 1927 the precipitation in the region was greatly below normal, and the failure of the water table to rise to the previous high point may be largely attributed to this fact.

The study of the meager data available warrants the conclusion that during average years the shallow ground water will not be seriously depleted by the irrigation of the acreage now under cultivation. In view of the fact that development will be largely limited to the area east of the 50-foot line shown in Figure 37, it appears probable that the supply of shallow ground water is sufficient for 
the irrigation of all the land that is likely to be brought under cultivation along the Rio Felix in the vicinity of the present development. However, it must be remembered that this conclusion is based on scanty data, and the opportunity has not been afforded to observe the effect upon the water table during a year of normal precipitation. For this reason observations should be made from time to time to determine the level of the water table, and if a marked lowering should occur over several years, further development in this area should be halted.

\section{CONSTRUCTION AND REPAIR OF WELLS}

By A. G. FIEDLer

\section{CONSTRUCTION OF ARTESIAN WELLS}

\section{METHODS OF DRILLING ${ }^{95}$}

In the Roswell artesian area the two methods most commonly used in the drilling of artesian wells are the hydraulic rotary method and the cable-tool percussion method. In the sections where wells deeper than 500 to 600 feet are necessary to reach the artesian aquifers the rotary method is used almost exclusively, because larger strings of pipe must be handled and more rapid progress is generally made in penetrating the unconsolidated formations overlying the artesian aquifers.

\section{HYDRAULIC ROTARY METHOD}

In the hydraulic rotary method of drilling the practical operation consists of rapidly rotating a column of pipe, at the lower end of which is a cutting bit. In the bit are holes, through which water with clay in suspension is forced under pressure by pumps on the derrick floor. The mud fluid prevents caving of the uncased portion of the hole by "mudding up" or plastering the walls of the hole with mud. The fluid also permits the drill casing to rotate more readily, and by reason of its density it brings to the surface the cuttings that would not be removed by the use of clear water.

The derrick of the rotary rigs used in this area consists of a pyramidal framework from 70 to 90 feet high, erected over the well. At the top of the rig is mounted the crown block, which consists of a series of pulleys through which the steel cables operate in conjunction with tackle blocks used for the suspension of the drilling pipe and the raising and lowering of casing. The hoist is placed on the engine side of the derrick and consists of two parallel shafts, one of which contains a drum on which the cable is wound. Power is

\footnotetext{
95 For detailed description of drilling methods and tools used see Bowman, Isaiah, Welldrilling methods: U. S. Geol. Survey Water-Supply Paper 257, 1911 ; Ziegler, Victor, Oilwell drilling methods, John Wiley \& Sons, 1923 ; Jeffery, W. H., Deep-well drilling, Toledo, Ohio, W. H. Jeffery Co., 1921.
} 
usually supplied to the rig by means of a steam boiler and steam engine. The boilers in this locality are usually fired with fuel oil obtained locally. The hoist is driven by a chain and clutch. Power is also transmitted by means of a chain to the rotary table, or turntable, on the center of the drill floor. The rotary table is fitted with special clamps, spiders, and drive rings for holding the casing and turning the drill pipe. A fluted or square steel bar, called the grief stem, is held in the table by a grip ring drive or noncircular drive bushings, which transmit the rotating motion of the rotary table to the stem, which in turn rotates the drill pipe and cutting bit. The grief stem can be moved up and down through the rotary table about 25 feet by the hoist without interfering with the rotary motion. At the top of the grief stem is the rotary swivel, which supports the drill pipe and serves as a mud and water connection. It is suspended by a bail that supports the body of the swivel. The bail is hung on a $\mathbf{C}$ hook fastened to the tackle block. The hoisting cable is wound on the hoisting drum and passes through the crown block and tackle block; it is used to lower and raise the tools and casing into the well. A circulation of mud and water is supplied by a pump that forces the mud fluid through a hose connected to the swivel joint. The fluid is forced down the grief stem and the drilling pipe and issues from the holes in the drilling bit. This fluid then circulates up the drill hole, around the drill pipe, and carries with it the drill cuttings. In drilling unconsolidated materials a fishtail bit is used. For harder material, such as rock, a roller rock bit composed of a substantial frame with corrugated cone cutters at the base is substituted for the fishtail bit.

When drilling is started great care is used to maintain the drill pipe truly vertical, and as the rotating motion of the bit excavates the hole the drill pipe is slowly lowered by means of the hoist. When the bit has been lowered so that the top of the grief stem or drill pipe is near the table, another section of drill pipe is screwed on to the top of the section of drill pipe in the hole, the rotary swivel is reattached at the top, and drilling proceeds. In some sections in this area the caving of the upper formations can not be prevented, and it is then necessary to set one or more joints of casing called surface casing to keep the hole open to permit drilling. The surface casing is usually of light weight and is generally the size of casing next larger than the diameter of the finished well desired. This casing is lowered into the hole by the hoist and may or may not have a shoe at its lower end. After it rests upon the bottom of the hole it is seated either by slight driving or by a small amount of rotating. Drilling then proceeds inside this casing with a bit slightly smaller in diameter than the inside diameter of the casing. Where the exact 
depth of the artesian aquifers is not known with certainty it is common practice to drill or "rat-hole" ahead of the main hole with a bit of smaller diameter. In this way definite information is obtained regarding the underlying formations, and if the artesian aquifers are encountered unexpectedly the main hole is in such shape that a seat may properly be provided for the main casing. If the hole is drilled to the full diameter and the artesian aquifers are encountered unexpectedly, difficulty is experienced in seating the main casing and making a tight water shut-off. After the artesian aquifer is encountered in the small hole a decision is made as to the best location for seating the casing. In this area the casing is generally seated in rock or other solid formation. The hole is then reamed to a diameter sufficient to accommodate the main string of casing down to the depth where the casing is to be seated.

Before seating the main casing the hole is thoroughly mudded by circulating heavy mud behind the casing so as to prevent the circulation of corrosive waters around the casing and effectually seal off any water that might circulate with the water from the artesian aquifers and cause underground leakage. The casing is then lowered upon the seat prepared and is seated either by slight driving or rotating. After the casing has been seated drilling proceeds until the aquifers have been penetrated. The hole is normally drilled a short distance below the lowest aquifer to afford a settling basin to accommodate loose or caving material that is not removed by the natural flow of the well or by pumping. The hole when finally drilled to the full depth is then usually cleaned by bailing, unless the artesian flow is sufficiently great to remove the bottom cuttings by the discharge of the water. The well when completed is normally permitted to flow unchecked for several days to permit a thorough cleaning of the artesian aquifers and remove all loose material. After such a period of flow a valve is placed on the well to control the discharge.

\section{CABLE-TOOL PERCÚSSION METHOD}

The cable-tool percussion method of drilling is chiefly used in the northern part of the area, where the depth to the artesian aquifers does not exceed about 500 feet. Although progress is generally not so rapid with this method as with the rotary system, the expense of drilling is somewhat less, because lighter equipment may be used and may be readily transported from one location to another.

In drilling with the cable-tool system the hole is made by giving a string of tools an up-and-down motion, which causes the percussive action that crushes and pulverizes the formations. Water is added to the hole as drilling proceeds, so that the cuttings may be 
mixed into a sludge by the drilling bit, otherwise the drill would become ineffective by striking into its own cuttings. Sometimes sufficient water is encountered in the water-bearing strata that are penetrated; it is then unnecessary to pour water into the hole. After the drill has penetrated a certain distance the tools are withdrawn and the drill cuttings are bailed from the hole. The tools are then reinserted in the hole and drilling proceeds as before.

The portable rigs used in the cable-tool percussion method are essentially the same as the large standard rigs used for drilling deep wells, except that the high derrick is replaced by a mast supporting the sheave, and the entire equipment is much lighter and designed for portability. The power is usually derived from an engine mounted on the frame or from a tractor, which is also used to move the rig from one location to another. Within the frame two drums are mounted, one for the hoisting cable and the other for the sand reel, which is operated by a friction pulley from the band wheel. The sand reel is used for winding and unwinding the smaller cable used for handling the sand bucket or bailer. The up-and-down motion is imparted to the drill by means of a walking beam or a device called the spudder. In drilling with the larger machines, which are equipped with walking beams, only the first few feet of the hole is drilled with the spudder, and the rest of the drilling is done with the walking beam. The walking beam consists of a heavy timber, pivoted at the center, with one end connected to the pitman, which is fastened to the wrist pin of the bandwheel crank. The spudder is a device that jerks the drill cable back and forth between the crown sheave and the cable reel. In this manner the tools are alternately lifted and then permitted to drop by their own weight. In drilling with the spudder the cable is threaded over the crown sheave at the top of the mast, one end of the cable being attached to the cable reel and the other end to the tools. The spudder varies in design with different types and makes of outfit. In drilling relatively shallow water wells the drilling is done entirely by spudding.

The complete string of tools used consists of a drilling bit, stem, jars, sinker, and rope socket. Whether or not the complete string is used depends on the conditions under which the drilling is done. The drilling bits are of various patterns, and the type used depends upon the work to be done and the character of the formation to be penetrated. The drilling bit is essentially a heavy piece of steel at one end of which is a blunt chisel-blade cutting and crushing edge. The upper end is shaped into a threaded screw joint, which is screwed into the stem. The stem is a heavy bar used to give additional weight to the blows struck by the drill and assist in main- 
taining a straight hole. The jars consist of a pair of linked steel bars and are used to strike a sharp upward blow to the drill as the links of the jars are jerked together by the upward stroke of the walking beam. The sinker bar is another heavy bar used to add weight and length and assist in keeping the hole straight. The rope socket furnishes the means for attaching the end of the drilling cable to the string of tools. In drilling with the walking beam the drilling cable receives the up-and-down motion through the temper screw, which allows the cable to be fed downward as the drill hole is deepened.

A hole drilled by the cable-tool percussion method is generally started with a spudding bit, which is of the same general design as the regular bit except that it is much shorter. After a quantity of cuttings have been drilled loose, the bit is removed and the hole is cleaned out with the bailer. The process is then repeated. After the drill hole has penetrated to a depth of 25 to 75 feet, the spudding bit is removed and replaced by the regular string of tools. In drilling a small-diameter hole the spudding bit is usually omitted and drilling is started with the regular drill bit.

Where the formation is unconsolidated and the hole caves, it is necessary to follow the bit with casing, and in some places the casing is put down ahead of the drill by driving. When the hole has reached sufficient depth for setting the casing the drill hole is cleaned and the casing is lowered into the well by the hoist and seated in a solid formation by driving. Drilling then proceeds to the final depth and the well is completed as in the rotary method.

\section{COST OF DRILLING}

In this area a contract for the construction of a well calls for the well contractor to furnish all the equipment, material, and labor needed, or for the landowner to furnish the pipe and fittings and the contractor to furnish the drilling equipment and labor. Costs are subject to some variation, but the following are about average figures for drilling wells more than 500 feet deep by the rotary method, according to the prices that prevailed in 1927. The footage cost of shallower wells is somewhat higher.

\begin{tabular}{|c|c|}
\hline & Cost per foot \\
\hline -inch well & \\
\hline inch & $\$ 2.50$ to 2.75 \\
\hline . & 2.75 to 3.25 \\
\hline ell_... & 3.25 to 4.50 \\
\hline 1 & 4. 50 or more \\
\hline
\end{tabular}

The cost of drilling 6-inch and 8-inch wells with the cable-tool percussion method is generally $\$ 1$ a foot for the first 100 feet and 50 cents a foot additional for each 100 feet after the first 100 feet. The 
average price for 10 -inch wells under this method averages $\$ 1.50$ a foot for the first 100 feet and 50 cents a foot additional for each 100 feet after the first 100 feet.

The cost of casing averages as follows:

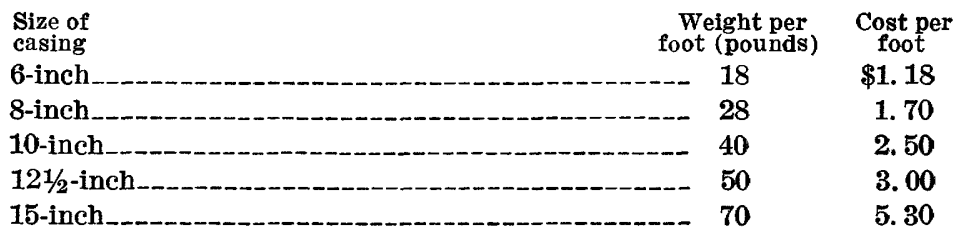

An 8-inch well, 800 feet deep, cased for 650 feet, costs about $\$ 3,500$; an 8-inch well, 1,000 feet deep, cased for 800 feet, costs about $\$ 4,200$; a 10-inch well, 800 feet deep, cased for 650 feet, costs about $\$ 4,500$; and a 10-inch well, 1,000 feet deep, cased for 800 feet, costs about $\$ 5,500$.

\section{CAUSES OF LEAKAGE}

The chief causes of underground leakage are initial defective construction and corrosion. Defective construction can, of course, be largely avoided by hiring competent drillers who have adequate equipment and a clear conception of the difficulties encountered in drilling artesian wells in this area. It is impossible to determine the exact proportion of the leaky wells that were caused by poor construction; but considering the lax methods of construction and scanty information regarding drilling during the period of early development, it is probably fairly accurate to assume that about 50 per cent of the present underground leakage is due to poor construction. In recent years the supervision of drilling has been somewhat stricter, and the drillers who are operating within the area have gained much experience in handling the problems that arise during construction. It is significant to note that many of the wells that leak were particularly difficult to construct and required more than the usual time necessary for drilling. So many wells have been drilled throughout the area that much information is now available regarding the depth to the artesian aquifers and the formations penetrated, and as a result the wells constructed during the last few years are generally of much better quality than those constructed during the early period of development.

The corrosion of well casing by mineral waters continues to be a serious problem; and though much good has resulted through the use of heavy casing, the life of the wells in the area where corrosive waters are encountered is greatly reduced by the disintegration of the casing. It is beyond the scope of this report to enter into a detailed discussion of the theories of corrosion. The two theories 
that appear to be most applicable to the conditions in this area and are largely substantiated by facts are quoted by Mills.96

\section{QARBONIO-ACID THEORY ${ }^{97}$}

Until recently the carbonic-acid theory has been considered to explain satisfactorily the phenomena of corrosion. As a matter of fact, it does express the truth to a certain degree, as will be shown later. It postulates that rusting is always started by an acid, even one as weak as carbonic acid sufficing to do this, the iron being first converted into a ferrous salt, with the escape of free hydrogen. Under the influence of oxygen and water the ferrous salt is oxidized to ferric hydroxide (which is insoluble and settles out) at the time that the carbonic acid which was required to form the ferrous salt is set free. This again attacks the metallic iron with the formation of more ferrous compound which is again decomposed, ferric hydroxide settling out and carbonic acid being set free to attack more iron and thus make the process a continuous one. The actions may be shown by these equations:

$$
\begin{aligned}
& \underset{\text { Iron }}{2 \mathrm{Fe}}+\underset{\substack{\text { carbonic } \\
\text { acid }}}{2 \mathrm{H}_{2} \mathrm{CO}_{3}}=\underset{\substack{\text { ferrous } \\
\text { carbonate }}}{\mathrm{FeCO}_{3}}+\underset{\text { hydrogen }}{2 \mathrm{H}_{2}} \\
& \underset{\substack{\text { ferrous } \\
\text { carbonate }}}{2 \mathrm{FeCO}_{3}}+\underset{\text { water }}{5 \mathrm{H}_{2} \mathrm{O}}+\underset{\text { oxygen }}{\mathrm{O}}=\underset{\substack{\text { ferric } \\
\text { hydroxide }}}{2 \mathrm{Fe}(\mathrm{OH})_{3}}+\underset{\substack{\text { carbonic } \\
\text { acid }}}{2 \mathrm{H}_{2} \mathrm{CO}_{3}}
\end{aligned}
$$

In order to prevent rusting, therefore, all we have to do is to neutralize the acid with an alkali, and those who held this to be the true explanation of the cause of corrosion pointed to the fact that iron does not rust in strongly alkaline solutions. It can be shown, however, that iron rusts very easily in dilute alkaline solutions, so that bit of evidence is thereby weakened.

Various investigators have lined up on both sides of the question and have defended their views with a series of ingenious and painstaking experiments, the object of which was to determine whether or not iron can rust in oxygen and water in the complete absence of carbonic acid. The result of this work seems to show that iron will corrode rapidly in the absence of this substance if oxygen and liquid water are present, and the experiments were so carefully made that no doubt remains that carbonic acid is only a slight factor in the corrosion of iron and that this process can go on very readily without it.

\section{ELECTROCHEMICAL THEORY ${ }^{98}$}

Every metal when placed in water is subjected to a certain fixed tendency to go into solution. This effect is wholly a matter of electrochemical activity and varies to a definite extent with each metal. The initial reaction in the process of corrosion of iron by water is exactly analogous to its solution in acid. Water exists in the liquid state not only in the form of its molecule but also as ions. These are formed by the breaking up or dissociation of the molecule, and some ions carry a charge of positive electricity and some a negative charge. * * *

All water is broken up in this way, although the proportion actually so dissociated is extremely minute. Acids, like water, are ionized, but to a far

\footnotetext{
Mills, R. Van A., Protection of oil and gas feld equipment against corrosion : U. $\mathbf{S}$. Bur. Mines Bull. 233, pp. 10-14, 1925.

or Wilson, L. C., The corrosion of iron, p. 25, 1915.

${ }^{28}$ Speller, F. N., and Knowland, R. G., Preservation of hot-water supply pipes in theory and practice: Am. Soc. Heating and Ventilating Eng. Proc., vol. 24, pp. 217-240, 1918.
} 
greater extent, into hydrogen ions and those formed from the remainder of the acid molecule. The net result of the presence of an acid in water is, therefore, to increase the amount of positively charged hydrogen ions present. It is the concentration of these hydrogen ions in water that determines its ability to attack iron; indeed, the initial speed of attack is proportional to the number of hydrogen ions in the water. It is thus easily understood that, while pure water with its very low concentration of acid ions is capable of inducing the corrosion of iron, water containing an acid will be proportionately more ruinous to the metal. It is, therefore, a fact that the tendency of iron to corrode depends to a certain degree upon the amount of acid present in the surrounding water. We shall show, however, that corrosion may be arrested even in a distinctly acid water. With this in view, too much emphasis can not be laid upon the fact that we must recognize two definite conditions, under one of which water acts as a corrosive liquid, whereas under the other it is harmless to metal.

If we place a piece of iron in water, a multitude of ting electrolytic cells are immediately established. The currents flow through the ionized water from point to point upon the surface of the metal, these points often being distinguished by the presence of surface impurities, an irregularity of finish, or some similar unusual condition. *** A positively charged ion will always be attracted toward a negative surface, while the negative ions move in an opposite direction.

The actual destruction of metal begins as *** the current previously established is removing metallic iron from the anode surface and sending it into solution in the form of its ions, each of these bearing two charges of positive electricity, which causes its passage toward the nearest negative surface or cathode. Its progress is soon arrested, however, as it meets the negatively charged hydroxyl ions moving in the opposite direction. These two ions combine, their charges neutralize each other, and ferrous hydrate is formed. The appearance of ferrous hydrate and hydrogen marks the first external evidence of corrosion.

Meanwhile, the positively charged hydrogen ions have reached a negative surface, being neutralized there and forming hydrogen gas molecules. These molecules unite with any oxygen present to form water, otherwise they collect over the cathodic surface, ultimately preventing further flow of current or "polarizing" it and ending the activity of corrosion by an actual congestion of its processes. It should be noted that the presence or absence of oxygen in this way determines the possibility for corrosion. Thus an inactive water may become extremely corrosive or active upon being aerated.

In * * * the final stage of rusting, where all the dissolved oxygen has disappeared from the water, *** the ferrous hydrate is partly oxidized to ferric hydrate or rust. The layer of hydrogen on the cathodic surface has flnally become so dense that the current is completely polarized and no further corrosion will be possible until it has been removed. It thus becomes apparent that the presence of dissolved oxygen in no sense causes corrosion but merely aids in its unimpeded operation. And this holds true whether the water is pure or acidic.

While dissolved oxygen is usually the factor determining the rate of corrosion, attention must be called to another phase of the problem. This involves a phenomenon called the discharge potential of hydrogen. Briefly stated, when water is decomposed by an electric current a certain difference of potential is required for the discharge of hydrogen upon the cathode, and this voltage depends upon the kind of cathode in question. If the potential required for the 
discharge of hydrogen is greater than that available, the gas will accumulate about the cathodic portions of the metal, and, unable to discharge, will soon polarize the process of electrolysis. Since the solution of iron in water is purely an electrochemical phenomenon, as has been demonstrated, these effects must be considered as applying strictly to every individual case of corrosion. Although the potential difference required for the discharge of hydrogen upon a metal is a very small quantity, a fraction of a volt, which may even be negative in value, the very low voltage obtained from the ionization of iron in water may not in every case be sufficient to compel such an effect. But if salts be present in the water, the metallic element of which can be plated on the cathodic surfaces by the current, it is evident that the nature of the metal deposited will raise or lower the discharge potential and hence determine whether electrolysis shall continue or shall cease-in other words, whether corrosion may occur.

As an extreme case, we may mention arsenic compounds which are well known to act in preventing the corrosion of iron. This effect is due to the fact that arsenic is deposited over the cathodic spots. The discharge potential of hydrogen on arsenic is too high to be overcome by the feeble current resulting from the corrosion process, hence this is retarded by the presence of an arsenic salt. Copper salts, on the other hand, promote corrosion owing to the low discharge potential of hydrogen upon this metal. The important point to be kept in mind is the fact that corrosion is purely a matter of electrolytic activity that is stopped by polarizing the cathode surfaces by any means available, and that the nature of the cathode surfaces is of itself able to aid or to hinder corrosion. These effects and their bearing upon the solution of metals in acids are admirably discussed in the paper by Watts and Whipple, ${ }^{90}$ which was presented in 1917 before the American Electrochemical Society.

The influence of the discharge potential upon corrosion is often of paramount importance; but in the majority of cases of severe corrosion inside pipe lines, with only iron in contact with water and no metallic salts present, the cause of the trouble is associated only with oxygen gas dissolved in the water. We have no positive proof that corrosion can be promoted by carbon dioxide or by any other similar gas if oxygen is not present. It is true that the presence of carbon dioxide, since it causes acidity, always implies a tendency toward corrosion; but if oxygen is not present also, the possibilities of corrosion are very slight. All our experimental evidence goes to show that the minute current involved in the rusting of iron is too feeble by itself to overcome the polarization resulting from this process. Hence, continued corrosion will be impossible unless oxygen or some metal or salt is present to take care of the hydrogen film that builds up in the path of the current. It is very evident that oxygen is the usual depolarizer met with in ordinary waters and that we must therefore consider the presence of this gas to be the key to the vast majority of cases of corrosion of iron and steel. If oxygen can be eliminated from water, with the effect of rendering the latter inactive, corrosion in pipes, tanks, boilers, and in other similar places may be practically prevented. We have no evidence on which to base a belief that the acidity of water modifies such a general conclusion.

The hydrogen sulphide $\left(\mathrm{H}_{2} \mathrm{~S}\right)$ that occurs in waters from some of the wells in the artesian basin is also a vigorous agent of corrosion. The corrosive effect of waters containing dissolved hydrogen sulphide

${ }^{90}$ Watts, O. P., and Whipple, N. D., The corrosion of metals in acids : Am. Electrochem. Soc. Proc., vol. 32, 1917, pp. 257-284. 
can readily be demonstrated by immersing iron lathe turnings in such water. As a result of the action that takes place black ferrous sulphide is deposited around the iron. The attack upon the iron may be stopped by inserting in the water a strip of zinc, which in turn will be attacked, yielding zinc sulphide as a product of corrosion. According to Mills, ${ }^{1}$ there is some uncertainty as to just what the corrosive action of this gas is, but the common occurrence of unoxidized ferrous sulphide, or possibly other iron sulphides, suggests that hydrogen sulphide may act directly on iron and steel.

In a number of oil fields where hydrogen sulphide occurs in the water considerable benefit has been derived from blocks of zinc cast around the oil-well tubing. Though the zinc does not completely stop the corrosive action of the water, the action is much less intense, and disintegration is slowed up considerably. Zinc-treated tubing appears to be much more resistant to the action of water containing hydrogen sulphide. As noted by Mills, ${ }^{2}$ protection by zinc appears to be one of the most practical methods by which to control the corrosion. However, the method should not be confused with the use of ordinary galvanized tubing, which does not materially retard corrosion of iron and steel equipment in oil and gas wells. It is presumed that this statement would apply with equal force to the use of galvanized casing, but without adequate field tests in wells which yield water of the type that occurs in some sections of the Roswell artesian basin it is inadvisable to make a definite statement that the slight additional cost of galvanized pipe would not be warranted.

Studies made on the corrosion of well casing in oil fields show that one of the chief contributing factors which starts corrosion is the scarring of the surface of the casing either by drill cables or rotary tools or abrasion of the casing as it is placed in the bore hole. The scarring of the casing tends to stimulate corrosion by causing local galvanic action at the marred area. The practice of leaving the threads at the collars exposed to corrosive waters is also a prolific cause of corrosion. Mill scale upon the surface of the casing has also been found to contribute to the progress of corrosion.

The effect of corrosion upon well casing is clearly shown in Plate $42, B$. An analysis of the corroded casing of this well indicated that the samples were almost entirely iron oxide together with 0.5 per cent of sulphate and about 0.1 per cent of chloride, showing a complete breaking down of the original material.

\section{PREVENTION OF CORROSION}

The United States Bureau of Mines has devoted much study to the problem of arresting corrosion and thereby extending the life of 
well equipment. ${ }^{3}$ Though complete prevention does not appear possible with present methods of well construction, several precautionary measures are recommended for this area, and their general adoption by water-well drillers would undoubtedly offer much protection.

As a preliminary step in preventing corrosion only perfect pipe, free from line cuts, scars, and accumulations of mill scale, should be used. Special care should be taken to leave no threads exposed at the collars when the pipe is made up. Where threads are exposed they should be thoroughly covered with waterproof bitumen, resin, or hydraulic paint adapted to well conditions. The use of heavy mud fluid behind the casing is especially recommended. Though this has been practiced to some extent under present methods of rotary drilling the use of mud has largely been confined to plastering the walls of the hole to prevent caving. Just prior to setting the pipe upon its final seat heavy mud should be circulated behind the pipe until some of it returns to the surface. The addition of oil to the mud fluid, or where acid attack is prevalent, the addition of alkalies to the mud fluid is beneficial.

A still further method of prevention that would be effective for all but a few of the types of water encountered here is to cement the casing from bottom to top. The cement may be placed behind the casing by any of several methods, but to be fully effective it should be carried for the full length of the casing. This process is strongly recommended for this area, as it will undoubtedly increase the life of the well, and future repairs or sealing may be more economically handled.

A process which has not been worked out in all its details but which offers possibilities for the prevention of corrosion is the use of asphalt behind the casing. The asphalt is heated by means of an electric heating element and forced into the hole under pressure. The process has been developed and successfully used for preventing leakage under dams (see p. 279); and if it can be adapted to waterwell drilling, it may offer a more effective protection than any other method thus far devised.

In the oil fields of the United States there is much divergence of opinion regarding the relative merits of wrought iron and steel for casing. Each material has stanch advocates, and under some conditions one material may be vastly superior to the other. In view of the fact that steel casing is cheaper than wrought-iron casing, it naturally has a much more widespread use, particularly in wildcat operations where production is uncertain. On the other hand, it has

${ }^{3}$ See Mills, R. Van. A., Protection of oil and gas field equipment against corrosion : U. S. Bur. Mines Bull. 233, 1925. 
been definitely proved that in some fields wrought iron is much superior to steel in preventing corrosion, and in spite of added initial cost its use has been demonstrated to be fully warranted.

In the Roswell area only steel casing and pipe have been used, and no first-hand data are available for making a comparison of wrought iron and steel under the conditions that exist here. In water-well construction one of the major objections to wrought iron is eliminated by reason of the fact that the casing is all of the same material, whereas in oil wells several strings of casing and tubing are used together with working barrels of different material, leading to the formation of galvanic couples which tend to stimulate corrosion. A large portion of the perforations from corrosion are the result of self-corrosion brought about by localized galvanic action due to the heterogeneous character of the metal. It appears that wrought iron withstands corrosion of this type much better than steel, and hence would be admirably adapted to local conditions. The use of wrought iron is therefore recommended in the areas of highly corrosive water, for it appears probable that the added cost would be warranted through the increased life of the well casing.

\section{REPAIR OF ARTESIAN WELLS}

\section{OUTLINE OF METHODS}

The chief processes of repair of wells are the inside recasing method, the outside recasing method, and the replacement of casing by new casing of the same diameter. Each system has advantages and disadvantages, and local conditions will normally determine the system that is the most applicable. All methods require the services of competent drillers with adequate equipment; otherwise failure will usually result.

\section{INSIDE RECASINA}

The inside recasing method consists of cleaning out the old well casing and inserting into the well the next smaller size of casing or pipe. This method of recasing has been in use for some years on the island of Oahu, Hawaii. The work has been carried on under the supervision of the United States Geological Survey, and uniform success has been experienced on all wells recased. None of the wells repaired by this method continued to leak, except a few in which it was impossible to carry the new casing deep enough. A detailed description of the process used is given by McCombs. ${ }^{4}$ The use of similar methods in the Roswell artesian area is considered applicable, particularly in recasing wells 8 inches in diameter or larger. Wells smaller than 8 inches in diameter are generally not considered worth

\footnotetext{
4 McCombs, John, Methods of exploring and repairing leaky artesian wells on the island of Oahu, Hawaii: U. S. Geol. Survey Water-Supply Paper 596, pp. 4-24, 1927.
} 
the cost of recasing and should be plugged. The equipment used for inside recasing is about the same as for drilling with the solid-tube percussion method.

The well is first cleaned by running a series of swedges, usually starting with a swedge about 2 inches smaller than the desired diameter and ending with the exact size. The swedges remove the scale and accumulation of extraneous material on the inside of the pipe and open the well to the full inside diameter if it is not too badly collapsed. Where the well is obstructed by plugs of débris or rock, these obstructions are first removed by using a jetting drill similar to that used in drilling test holes in unconsolidated material.

After the well has been thoroughly cleaned, the new casing is lowered into place a joint at a time. At the bottom of the string a coupling or steel shoe is usually provided. Clamps are provided around the casing to support the weight, and the casing normally is carried just to the end of the old casing or slightly below. In the recasing in Honolulu it has been found that there is little need of filling in the space between the two casings, as the couplings pick up scale and make a tight seal. However, thin cement grout is sometimes inserted between the two casings, and this undoubtedly helps in making a tight seal.

This process appears to be an unusually desirable method of recasing in this area, for the reason that the old casing is permitted to remain in the hole and the danger of serious caving, which is incident to the process of pulling old casing that is badly corroded, is thereby avoided.

\section{OUTSIDE RECASING}

The repair of wells by recasing on the outside is usually done with rotary-drill equipment, except where the leak is close to the surface. If the leak is close to the surface, it is sometimes possible to drive two or three joints of casing around the old casing and secure a shut-off in clay or other tight material. The driving of casing is not feasible for great depth in view of the danger of collapsing the old casing and ruining the well.

The repair of wells by this method, even with rotary-drill equipment, involves considerable hazard, for many wells are not drilled straight, and it is therefore difficult to follow the old well casing. In some wells the new casing has cut inside of the old casing and further progress is impossible. A rotary shoe is placed on the bottom of the new casing, which is either one or two sizes larger than the old casing. To prevent the old casing from being cut by the shoe and to assist in passing the collars, the inner edge of the shoe should be ground down to a blunt surface. This casing is rotated in the rotary table in a manner similar to that used in rotary drilling. The casing 
is carried down to the bottom of the old casing; or if the leaks are effectually sealed before reaching this depth, the casing is seated on a solid formation.

The use of this method has met with indifferent success in the Roswell area. Several failures have resulted because it was impossible to carry the new casing deep enough to seal off effectually all the leaks. The hazards are much greater than in recasing on the inside of the hole, but the method has the advantage of retaining the full diameter of the old hole for the flow of the well.

\section{REPLACEMENT OF OLD CASING}

The process of pulling the old casing and reinserting new casing in the drill hole is the most hazardous method of repair, and a number of serious failures have resulted. If it is possible to remove all of the old casing, the new casing is inserted down to the original depth; otherwise the new casing is threaded into the part of the old casing remaining in the well by means of a die nipple. This method is particularly hazardous for repairing large flowing wells because of the erosive action of the flowing water on that portion of the hole from which the casing is withdrawn. Hard, consolidated formations may withstand the erosion, but in unconsolidated material a cavity may be created in the drill hole, and, because the support is removed from the old casing, such casing may fall out of the line of the drill hole and resist all attempts at recovery. For this reason repair by this system should not be undertaken without having a casing of smaller size in the hole while the old casing is being withdrawn. With this precaution the work of withdrawing the old casing may be greatly retarded, but it furnishes the only means of preventing failure through caving and loss of contact with the old casing. The several failures that have been caused by this method of repair generally condemn it for this area, though in the hands of skilled drillers it may be successful.

The attempt to repair the Ditto well, in the NW. $1 / 4$ NE. 1/4 sec. 23 , T. 15 S., R. 25 E., by this method has been the most widely known failure within the area. According to court records in the case ${ }^{5}$ it is stated that in the attempt to repair this well 460 feet of 8-inch casing was withdrawn from the well and that the new casing was not coupled with the old casing in the well. It appears that the failure was caused by the old casing falling out of the line of the new casing, and that all attempts to bring it into the line of the hole were unsuccessful. The first few joints of old casing were withdrawn while a casing of smaller size was in the hole, but this precaution was later discontinued. Several joints of casing were then with-

Eccles vs. Ditto: 167 Pacific, p. 726. 
drawn, and after 460 feet had been removed it was impossible to connect with the old casing still in the hole. As the well was flowing between 1,500 and 1,800 gallons a minute, the water probably eroded a considerable cavity around the old pipe, and the upper section of the casing that was still in the well fell over into this cavity and resisted all attempts at recovery. The repair was finally completed by placing new casing in the well down to this level; and although most of the flow came up through the new casing, much water continued to rise to the surface around the outside of the casing.

During the summer of 1927 this well practically ceased flowing, and it was examined for leakage with the $\mathrm{Au}$ leakage meter. The hole was found to be caved at 467 feet, and the meter could not be carried to the bottom of the original hole. No leakage was found in the 460 feet of 8-inch pipe that was placed in the hole when the repair was attempted. This information therefore agrees with the information brought out in the suit.

\section{SEALING OF ARTESIAN WELLS}

\section{OUTLINE OF METHODS}

The methods formerly in use for sealing artesian wells in the Roswell area were largely makeshifts and, though no water may appear at the surface in the vicinity of the wells that have been sealed, many such wells may be leaking underground. The satisfactory sealing of wells is as vital a problem as the satisfactory construction or repair of wells; otherwise the community may labor under a sense of false security with the idea that leakage from a sealed well has been entirely arrested, when it has not.

A number of effectual methods of sealing wells has been devised through experience gained in the sealing of water wells and in handling the more difficult water problems that frequently occur in prospecting for oil. There appears to be no valid reason why similar methods should not meet with complete success in this area, though they may involve considerable expense.

Only a brief outline of the various methods used in sealing wells will be given here, as detailed descriptions have appeared in many other reports. ${ }^{6}$ The processes most frequently used are not distinct methods in themselves but are usually a combination of several methods, the choice depending upon the particular circumstances.

\footnotetext{
- MeCombs, John, op. cit., pp. 17-22. Lewis, J. O., and McMurray, W. F., The use of mud-laden fluid in oil and gas wells: U. S. Bur. Mines Bull. 134, 1916. Tough, F. B., Method of shutting off water in oil and gas wells: U. S. Bur. Mines Bull. 163, 1918. Swigart, T. E., and Beecher, C. E., Manual for oil and gas operations: U. S. Bur. Mines Bull. 232, 1923. Curtin, Thomas, Casing troubles and fishing methods in oil wells: U. $S$. Bur. Mines Bull. 182, 1920.
} 
The chief problem of sealing a water well consists in shutting off the water to permit the hardening of a cement cap. In the method devised by the United States Geological Survey that has been successfully used on the island of Oahu, Hawaii, ${ }^{7}$ the water is first shut off by means of iron turnings and filings placed by means of a dump bailer and tamped into the hole. In flowing wells of unusually high velocity, lead shot is used. The iron turnings may also be placed in tin canisters for insertion in the well, or lead wool packed in screen containers may be used. The well is next examined with the leakage meter to determine that no movement of the water exists that would prevent the cement from setting. Cement grout is then placed in the hole by means of a dump bailer and permitted to set, after which the hole is filled to the surface.

It has been frequently suggested that a bridge and cement cap down in the casing or at the place where the casing is set would be as effective as sealing the hole from the bottom. As a last resort in a well in which it is impossible to get to the bottom this method would serve, if the plug were placed down in the cap rock. It is evident that if the plug were placed in the casing corrosion might take place below the cement plug and leakage outside the casing would occur. An additional reason for plugging from the bottom to a level above the uppermost aquifer is to prevent circulation between the aquifers, thereby overcoming any possibility of a reduction in head on any particular aquifer due to heavy draft from wells in the vicinity which tap other aquifers. It can not be too strongly stressed that a satisfactory plugging job consists of plugging the hole from the bottom to a point above the uppermost aquifer. The firing of a heavy shot in the well opposite the level of caving formations has also been suggested as a means of shutting off the water. Such makeshift expedients can not be too strongly condemned, and they should not be tolerated in any program of conservation.

\section{OIL-WELL METHODS}

The use of cement in shutting off water in oil wells has been practiced for a long time, and in recent years the practice has become fairly general. Several methods have been devised, and their use has met with marked success in practically all oil fields where water conditions were formerly troublesome.

The use of cement under pressure, common in oil-well practice, is particularly adapted to plugging wells that are partly obstructed and can not be cleaned out to the bottom. If water is issuing at the surface from around the casing, such leakage is first confined by

McCombs, John, op. cit. 
placing several sections of large pipe and thoroughly cementing the pipe in place by the usual methods. Proper fittings are then attached to this section so that cement may be pumped into the well under pressure through tubing and forced out of the well into the aquifers. The pressure is then maintained on the well for several days to permit the cement to set thoroughly. There are several patented processes for introducing the cement into the well, and the process selected for any particular well would be governed by the existing conditions.

Under certain conditions mud-laden fluid, if properly applied, is an effective sealing agent that will prevent the circulation of artesian water from one aquifer to another or to porous horizons that contain no water. In order to be effective the mud must be free from sand and other coarse material that will tend to settle out. The effectiveness of the mud in overcoming the water pressure depends largely upon its specific gravity. According to Swigart and Beecher, ${ }^{8}$ the specific gravity of the average oil field mud fluid ranges from 1.05 to 1.30 , approximately 8.75 to 11.0 pounds a gallon, or 66 to 82 pounds a cubic foot. When used for plugging, the mud should normally be as heavy as can be handled satisfactorily by the pumps, but it must be a fluid and not a pasty clay.

Mud-laden fluid can be applied most effectively by the use of pumps. The well should preferably be opened to the bottom of the original hole and then thoronghly circulated with mud-laden fluid under pressure. The mud not only seals the interstices of the waterbearing formations, but the column of high-specific-gravity mud counterbalances the pressure of the water, thereby preventing circulation.

Nonflowing wells can be sealed by introducing the mud fluid into the hole with a dump bailer if mud-hog pumps are not available. Flowing wells can be sealed most satisfactorily by inserting the mud under pressure through tubing or by the Iubricator method, as described by Lewis and McMurray. ${ }^{9}$ After the hole has been thoroughly circulated with the fluid, it should be filled completely with clean mud of high specific gravity.

\section{ASPHALT SEALING}

In overcoming leakage through dams the use of asphalt applied under pressure has met with success. ${ }^{10}$ The details of the method

\footnotetext{
8 Swigart, L. E., and Beecher, C. E., Manual for oil and gas operations: U. S. Bur. Mines Bull. 232, p. 33, 1923.

${ }^{\circ}$ Lewis, J. O., and McMurray, W. F., The use of mud-laden fluid in oil and gas wells : U. S. Bur. Mines Bull. 134, pp. 19-23, 1916.

${ }^{10}$ Christians, G. W., Asphalt grouting under Hales Bar dam, a new method of sealing and its detailed operative procedure: Eng. News-Record, vol. 96, pp. 798-802, May 20, 1926.
} 
as applied to sealing water wells have not been worked out, but the process offers possibilities for use in preventing underground leakage. The essential operation in sealing leaks from reservoirs consists of placing asphalt in a hole through tubing which contains an electric heating element. The fluidity of the asphalt is controlled by regulating the temperature of the heating element. By adjusting the pressure furnished by the pumps the asphalt may be forced for long distances through a pervious formation. When the hot asphalt comes into contact with the water it congeals, and after complete hardening it will effectually resist the pressure of the water and furnish a tight seal. This material is particularly adapted to the open formations that are encountered in this area. Through the control of the temperature and pressure the asphalt inserted first is permitted to harden and fill up the large openings before additional quantities of asphalt are inserted to complete the water shut-off. In this respect the material is superior to mud fluid or cement, for it is probable that in some places the formations are so open that large quantities of mud fluid and cement would have to be forced into the aquifers before a complete shut-off would be obtained. Asphalt also possesses the advantage of being a permanent material not subject to deterioration under any conditions encountered in this area.

\section{CONSTRUCTION OF WELLS IN THE VALLEY FILI}

The development of ground water for irrigation in the Roswell area by pumping from relatively shallow wells that do not tap the artesian reservoir has been largely confined to the Felix shallowwater district. A study of the formations encountered while drilling the artesian wells indicates that in some sections where the water table is not too far below the surface there are excellent possibilities of developing water supplies for irrigation by pumping from shallow wells. Such development should be encouraged, for it would serve both to prevent a rise in the water table, which would injure the lands, and also to bring additional lands under cultivation.

In the Felix district the shallow wells that are pumped for irrigation were drilled by the cable-tool percussion method with portable rigs. Most of these wells are 10 inches in diameter and are cased with regular casing nearly to the bottom of the hole. Opposite the water-bearing beds the casing is perforated with $1 / 2$-inch holes. The well is normally drilled considerably larger than the outside diameter of the casing so that no difficulty is experienced in setting the casing. Should the hole cave badly while being drilled, casing of light weight is temporarily placed in it so that drilling may proceed. In the Felix district the wells have generally held up until 
the casing has been set, though in one or two wells difficulty was experienced in carrying the casing deep enough to bring the perforated sections of the pipe opposite the water-bearing beds. After the hole is completed the well is bailed clean and then the pump is operated until the water clears up. This method of finishing shallow wells has met with comparative success in the Felix district, for the water-bearing beds consist chiefly of gravel and coarse sand. Considerable trouble has been experienced in one well from sand issuing with the water, and it was necessary to replace the runner of the propeller pump after only a part of a season's use. After much sand had been removed from the well by continuous pumping, the condition was largely remedied by reducing the capacity of the pump. The experience on this well illustrates the difficulties encountered in developing water from water-bearing beds that are composed largely of very fine sand and demonstrates that the circular-hole type of perforations can not successfully exclude fine sand from a well.

In an endeavor to solve the problem of excluding sand from a well several different methods of construction have been devised. Though the methods are not all distinct types but more generally a combination of several methods, they may be classed generally as the stovepipe method, the well-screen method, and the gravel-pack method.

\section{STOVEPIPE METHOD}

The stovepipe method of well drilling has been used with excellent success where the water-bearing beds. contain some gravel in conjunction with the fine sand. The method as used in Arizona is described in detail by Schwalen. ${ }^{11}$ The well is drilled by the use of standard tools or with the mud scow, which is essentially a large bailer at the bottom of which is a plain flap valve and a heavy shoe. The mud scow is given an up-and-down motion similar to that used with solid tools. Water is used for mixing the material, which is drilled by the cutting shoe of the mud scow. The up stroke of the mud scow creates a suction, and the loose material is thereby pulled up from the bottom of the hole; on the down stroke the suspended material is forced into the mud scow through the valve. As the drilling proceeds the mud scow fills up and is then withdrawn and the material dumped.

Stovepipe casing is made of sheet steel in inside and outside joints from 2 to 4 feet in length. The inside and outside joints are put together, overlapping each other by half a joint. The casing is put into the hole and carried along with the drilling. Normally the

\footnotetext{
11 Schwalen, H. C., The stovepipe or California method of well drilling as practiced in Arizona : Arizona Univ. Agr. Exper. Sta. Bull. 112, 1925.
} 
weight of the casing is sufficient to carry it down the first 40 or 50 feet, after which it is driven down by the use of hydraulic jacks and driving with the drive clamps. After the casing has been carried through the water-bearing beds it is perforated with a casing perforator. Proper perforations made with the casing perforator are superior to circular drill-hole perforations because they are wedgeshaped openings with the largest side of the hole on the inside of the casing. This permits a particle that enters the casing to pass through readily, and therefore the perforations are not obstructed by an accumulation of fine material on the outside of the casing.

The most important operation in finishing is to open up the interstices of the water-bearing material so that the water will enter the casing readily. This operation is done either with a propeller or turbine deep-well pump or by compressed air. At first the pump is started and stopped repeatedly, a process known as "rawhiding." This process changes the direction of the water in the discharge column and tends to loosen up the finer material in the water-bearing formations and open up the interstices. After the pump has been operated in this manner for 10 or 12 hours, it is operated continuously for 3 or 4 days, except that during this time the process of rawhiding is occasionally used. The same result may be attained with the use of compressed air by alternately discharging from the well and then shutting the well in and backblowing the air into the well.

The importance of the proper finishing of a well can not be overestimated, for the capacity of the well is largely dependent upon the thoroughness with which this work has been done. In the Roswell area very little attention has been given to the process of developing, and wells are frequently pumped without any initial rawhiding to clear out the interstices of the water-bearing beds.

\section{WELL-SCREEN METHOD}

The well-screen method of construction differs from other methods chiefly in the use of a specially designed screen to prevent the continued entrance of fine sand and silt into the wells. Several types of screen are available on the market. The best results are generally obtained by first sending a sample of the water-bearing material to a reputable well-screen manufacturer, who will furnish a screen with openings of a size best adapted to the particular material. The chief purpose of the screen is not to prevent all the sand from entering the well but to admit a large percentage of the fine sand immediately surrounding the well and hold out the coarser material, which collects on the outside of the screen.

In finishing a well with a screen the well is drilled in the usual manner and is completed by inserting the screen opposite the water- 
bearing formation. The well is then developed by rawhiding, surging with compressed air, pumping beyond capacity, or a combination of these methods.

The screen method of construction may give the best results where sand is troublesome, but the larger quantity of water needed for irrigation generally limits the development of water supplies for this purpose to areas in which the water-bearing material is coarse, and hence fine screens are not required.

\section{GRA VEL-PACK METHOD}

The construction of a well to be finished by the gravel-pack method consists chiefly in drilling a large hole by the usual methods down to the water-bearing formation. The casing is then set at this level, and the hole is continued through the water-bearing formation with a casing of smaller size. As the casing is carried to the bottom the fine sand and silt are removed with a mud scow or sandpump bailer or pumped out by the use of compressed air. When the smaller casing reaches the bottom of the water-bearing bed, the well is pumped by compressed air or bailed at a slow rate until the water is nearly clear. If the formation does not yield sufficient water to permit the sand to be removed by the methods mentioned, additional water is supplied from the surface and poured into the well as needed. The pumping of the well creates a cavity around the lower section of the smaller casing. Pea-size gravel is then packed into the well between the small and large casings until the space is completely filled. While the gravel is being inserted the well is pumped at a rate sufficient to keep the water, fine sand, and silt in motion, and as the fine material is removed it is replaced with the graded gravel. Compressed air is generally the most satisfactory method of pumping the well while gravel is being inserted, as the pumping is continuous and the suspended sand does not cause excessive wear on the equipment and thereby interfere with its operation.

After the well has been packed with gravel, a screen is set in the bottom of the small casing. The small casing is then drawn back, and the upper end of the screen is swedged into place at the bottom of the casing. The well is then developed in the usual manner, and as the gravel settles around the screen additional gravel is added at the surface between the two casings. After the full quantity of water is obtained the large casing may be withdrawn, though it is considered better practice to leave both casings in the well, as future repairs are thereby greatly simplified.

The various operations involved in drilling the well and setting the screen may be varied according to the particular conditions encountered. In some cases the large outer casing is carried to the 
bottom of the water-bearing formation, the screen and inside casing placed, and gravel filled in between the inside and outside casing as the latter is withdrawn to the top of the screen.

This type of construction is admirably suited to fine sand and it has been used with great success in many sections. Several variations of this process are patented and possess features of merit under certain conditions.

\section{LEGAL PROVISIONS GOVERNING THE USE OF THE GROUND WATER}

\section{By A. G. FTEDLER}

Many of the problems and difficulties which confront the farmers and those dependent upon the productiveness of farm lands in the Roswell artesian area have arisen as the result of the increased diversion of water from the artesian reservoir. Ground-water supplies, in common with other sources of water supply, are not inexhaustible. Because of the increased demand for water for irrigation the safe yield of the artesian reservoir has been exceeded. As a result, the shortage of water for some lands affects adversely not only the individuals who have invested the labor and savings of a lifetime in developing a farm but also the growth of the villages and towns, which are dependent upon the productiveness of the agricultural areas surrounding them. That this has been the situation in the Roswell artesian area is clearly shown by a review of the history of the artesian development.

Initially, the artesian area was nonproductive except possibly for native grasses, which flourished for brief periods during seasons of abundant rainfall. It was ascertained that wells drilled to the artesian aquifers would furnish ground water in sufficient quantity to be valuable for irrigation, industrial, or domestic uses. Development of the area shortly followed, and the nonproductive areas were gradually converted into productive farms, which annually yield crops valued at several million dollars. Large sums of money were invested in the wells, pumping machinery, buildings, equipment, and labor in order that the land might produce a harvest. With the marked increase in the diversion of ground water the artesian head declined rapidly during the early period of development and more slowly in recent years. Many of the early flowing wells which at first yielded copious quantities of water ceased to flow, or their yield was reduced to such a point that the installation of expensive pumping machinery was required. Later such equipment had to be extended to take care of increased pumping lifts, and eventually the expense of obtaining the water became so great in some parts of the area that farming was no longer economically feasible and many farms were abandoned 
and reverted to their former state of nonproductiveness. Lack of foresight in the use of a valuable natural resource that should have been developed for the permanent prosperity and welfare of the people has resulted in heavy loss of investment in wells, equipment, farm lands, and industrial enterprises.

The studies made by the United States Geological Survey in 1904-5 and 1916 and those made in 1925-1928 in cooperation with the State of New Mexico have been directed largely toward formulating policies for the best use of the artesian water.

In 1905 the Legislative Assembly of the Territory of New Mexico, realizing the need of legal means to protect the water supply of the Roswell artesian basin, passed the first law to regulate the use of the artesian water. ${ }^{12}$ This law created the office of county well supervisor, whose duty it was to issue permits for the drilling of new wells, keep a record and $\log$ of each well drilled, and make measurements of the flow and pressure of the wells. The well supervisor was also empowered to file complaints for waste of water and to make regular inspections of all wells to determine that they were being maintained in good condition. This law was applied in Chaves and Eddy Counties, the only counties for which well supervisors were appointed. In 1909 the Legislative Assembly repealed the law of 1905 and passed a new law ${ }^{13}$ containing similar regulations and prescribing the weights of casing to be used in the construction of the artesian wells. In 1912 another law ${ }^{14}$ was passed placing the supervision of the wells in the hands of an artesian-well board in each county, the members of which were elected by the well owners of the respective counties. The artesian-well boards acted through well supervisors as previously.

In 1925 a law ${ }^{15}$ was enacted which repealed the law of 1912 , abolished the artesian-well boards, and delegated the supervision of the wells to the respective boards of county commissioners, who likewise acted through artesian-well supervisors. In 1927 the State Legislature repealed certain sections of the law of 1925 and by amendments transferred the supervision of the artesian wells to the State engineer. ${ }^{18}$ The intent of all these laws was to conserve the artesian water by regulating its use. New regulations were contained in each succeeding law as the changing conditions made new restrictions necessary.

At the end of the first year of the investigation covered by this report it became apparent that new wells to supply water for the

12 Territory of New Mexico 36th Legislative Assembly, Acts, ch. 17, approved Feb. 22, 1905.

13 Territory of New Mexico 38th Legislative Assembly, Acts, ch. 64, approved March 17, 1909.

14 New Mexico State Legislature, 1st sess., Laws, ch. 81, approved June 13, 1912.

15 New Mexico State Legislature, 7 th sess., Laws, ch. 101, approved March 17, 1925.

${ }^{16}$ New Mexico State Legislature, 8th sess., Laws, ch. 149, approved March 15, 1927. 
irrigation of additional tracts should not be drilled except where it could be demonstrated that such additional draft on the available supply would not affect the rights of the present water users. As a result of a recommendation made in the preliminary report published in $1926^{17}$ a law was passed in $1927^{18}$ declaring waters in underground streams, artesian basins, reservoirs, and lakes to be public waters and subject to appropriation under the existing laws of the State relating to appropriation and beneficial use of waters from surface streams, such appropriation to be made in accordance with the rules and regulations of the State engineer. The law recognized as valid all appropriations of water that was being beneficially utilized at the time of its passage.

In order to test the constitutionality of this legislation two suits were brought in the district court of Chaves County. These cases were combined into one appeal, which was taken to the Supreme Court of New Mexico. On April 12, 1929, the supreme court rendered a far-reaching opinion upholding certain sections of the law in principle, but declaring the law as a whole unconstitutional on technical grounds.

In its decision the Supreme Court held that chapter 182, Laws of 1927, was declaratory of existing law and that it did not take away vested rights that existed prior to the passage of the act; furthermore, that section 5 of the act did not delegate legislative power to petitioners who through a properly signed petition request the State engineer to proceed with the administration of the law as to any particular area but that this section was merely the statutory method of invoking a determination by the State engineer as to whether or not the ground-water area in question came under the jurisdiction of the act. The act was declared unconstitutional because it extended the power of the State engineer by title reference to existing statute, contrary to the constitution of New Mexico, which provides that "No law shall be revised or amended or the provisions thereof extended by reference to its title only; but each section thereof as revised, amended, or extended shall be set out in full."

A new act, ${ }^{19}$ so drawn as to overcome the objections advanced by the court, was passed in 1931 . The 1931 act recognizes as valid filings for the appropriation of ground water that had been made previously under the ground-water appropriation act of 1927. It authorizes the State engineer to issue permits for the appropriation of ground water in response to applications made in proper form if he finds that there is unappropriated water. Should objections to the

${ }^{17}$ Fief $/$ er, A. G., Report on investigations of the Roswell artesian basin, Chaves and Eddy Counties, N. Mex. : New Mexico State Engineer Seventh Bienn. Rept., p. 60, 1926. ${ }^{18}$ New Mexico State Legislature, 8th sess., Laws, ch. 182, approved March 16, 1927.

${ }^{19}$ New Mexico State Legislature, 10th sess., Laws, ch. 131, 1931. 
issuance of such a permit be filed, the State engineer is authorized to hold a hearing to determine if there are no unappropriated waters in the designated source or if the proposed appropriation would impair existing water rights, in which case the application shall be denied. The decision of the State engineer is final unless an appeal is taken to the district court within 30 days after the decision is rendered. The act also provides that whenever a water right in any of the waters described therein is not exercised for a period of four years, the water right shall be forfeited and such unused water shall revert to the public and be subject to further appropriation.

\section{FUTURE POLICY FOR THE CONSERVATION OF THE ARTESIAN WATER}

By A. G. FTRDLER

It is particularly difficult to outline a definite conservation policy for the Roswell area, for the reason that much depends upon the cooperation of the individual farmers and their willingness to make adequate financial provision for the consummation of any program that may be undertaken. The point can not be too strongly stressed that the area should be considered as a unit, for the rigid conservation of water in one section will result in benefits in adjoining sections, just as serious waste and misuse of water is detrimental beyond the bounds of the immediate area where it occurs.

The vital need at the present time is for a comprehensive organization of the area as an irrigation or conservancy district or for some similar arrangement whereby a program of conservation may be carried out through the organizied efforts of the water users themselves rather than through the enforcement of laws and regulations by a State officer. It is beyond the scope of this report to formulate plans for such an organization, but the need is a pressing one and should receive the serious attention of all water users. It is probable that some legislation will be required to give an organization of this type a legal status with definite authority and power under the law. The enactment of such legislation, if found necessary, is recommended.

As a basis for a program of conservation under such an organization the following policies are recommended:

Legislation.-Present statutes regarding the supervision of the artesian wells, the granting of drilling permits, the filing of wells, the methods of well construction, and the appropriation of ground water appear to be ample under existing conditions, and no further legislation for this purpose is recommended.

Reoord of fuotuations of head.-In order that timely data may be constantly available regarding the artesian head, continuous rec- 
ords of the fluctuations of the artesian head should be obtained by the operation of automatic water-stage recorders installed over representative wells. These instruments may be maintained either by the county well supervisors under the direction of the State engineer or by competent employees of a water users' organization.

Metering of wells.-The advisability of installing meters upon all artesian wells has been suggested frequently as a means of curtailing the draft upon the reservoir. This question is one which requires serious thought, and a decision to install meters should not be made before full consideration is given to all the factors of the problem. Unless an instrument is designed that may be installed at considerably less cost than those now in use the expense involved would cause much dissatisfaction. There appears to be no device now upon the market that could be installed at a reasonable cost and that would handle the quantity of water delivered by the average well. The installation of meters upon wells of small capacity might result in serious injustice, for the expense involved might exceed the value of the water obtained. It is recommended for the present that closer check be kept upon the water used through cooperation between the artesian-well supervisors and the farmers; and where it appears that wells are being permitted to run for a time greater than that necessary to deliver 3 acre-feet to the acre, the rules of the office of the State engineer should be invoked to reduce the draft.

Waste of water.-Surface waste has been materially curtailed during the period of this investigation, particularly in Chaves County. Considerable surface waste still occurs in the southern part of the basin and can be largely prevented by the installation of proper valves upon the wells. It is recommended that the laws regarding surface waste be rigidly enforced and useless withdrawal from the reservoir be prevented.

Underground leakage.-The problem of underground leakage involves the question of the cost and the benefits of a program of recasing and sealing of wells. According to the information available the present underground waste does not appear to be excessive. The prevention of this waste would benefit the basin, but, on the other hand, the recasing or plugging of wells is expensive. In many places it is questionable whether the expense of recasing or plugging a leaky well would be a profitable procedure for the individual landowner. As a rule the most economical way of preventing waste from a well is to seal the well effectually and abandon it. This plan, of course, would necessitate the drilling of a new well to irrigate the land formerly covered. Though such a program would be the least expensive, many farms are unable to bear this additional financial burden; and if the present law regarding under- 
ground waste is rigidly enforced, some farms would have to be abandoned, with resultant ruin to the farmers.

The leakage survey, particularly of abandoned wells, was seriously handicapped by obstructions in the wells which prevented the leakage meter from being inserted to the bottom of the well. Definite information regarding the underground leakage in wells that have already been abandoned is therefore scanty, but it appears that such waste is likewise not large. The fact can not be overlooked, however, that the underground leakage may increase unless a proper conservation program is followed. Further exploration of these wells is recommended, and in the event that considerable leakage is found the question of plugging these wells at the expense of present water users must be considered, for the owners of these properties generally consider them of little value and not worth additional expenditure.

The following policies covering the problem of underground leakage are recommended for guidance in this area :

1. A complete survey should be made to determine the condition of all the wells. The equipment should include a portable rig for opening up the obstructed wells so that the leakage meter can be used effectively. A reasonable appropriation is recommended for carrying out such a program over a period of several years until the survey is completed.

2. Especial care should be taken to explore those wells which have failed to the extent that their owners have applied for permits to drill new wells. If an old well is found to be leaking, it should be repaired or sealed at the expense of the owner.

3. If in the course of time the leakage survey shows that underground leakage is becoming a serious menace, an equitable policy should be adopted for spending a certain amount annually for repair or sealing of wells. If such a program becomes necessary, a moderate annual appropriation which would not prove burdensome to the well owners is recommended.

Well permits.-The policy of granting permits for new wells for tracts now under cultivation only on condition that all defective wells upon the property shall be effectually repaired or sealed should be continued.

Shallow wells.-The restrictions governing the drilling of artesian wells should not be extended to include the drilling of relatively shallow weils that do not tap the artesian aquifers. The development of shallow ground water by pumping from wells should be encouraged, for additional land may thereby be placed under cultivation without further draft on the artesian reservoir.

Hondo Reservoir.-In order to insure the maximum amount of recharge to the artesian reservoir it is desirable to construct impounding reservoirs on the tributary streams that cross the catchment area and release the impounded water only at such a rate as will assure its complete absorption by downward percolation inte 
the artesian reservoir as it flows across the principal intake area, ol to impound the waters of the tributary streams in reservoirs located on the principal intake area.

A construction program involving the building of impounding reservoirs is not considered advisable at the present time because of the great expense involved. However, the Hondo Reservoir is in the principal intake area, and waters impounded therein would undoubtedly increase the recharge to the artesian reservoir. It is therefore recommended that all water in excess of that required to take care of existing rights on the lower Rio Hondo be impounded in the Hondo Reservoir.

Further investigation.-Reliable results in any quantitative investigation of ground water can not be obtained if records covering only a short period are available. It is particularly important, therefore, that observations on the fluctuations of artesian pressure, the rate of withdrawal of water by wells, the fluctuations of the water table in the intake area, and other related factors be continued over a period of years. Further study should be made from time to time as this information becomes available, for only in this way is it possible to forecast the trend of the effect of the artesian development.

Because the fluctuations of the water table in the intake area have a vital bearing upon the determination of the safe yield of the artesian reservoir, it is recommended that observations be made on several wells located west of the artesian area, where the main water table is below the top of the Picacho limestone. Wells suitable for such observations may be existing wells that enter the Picacho limestone and are drilled 25 to 50 feet or more below the main water table, or, if such wells are not available, the drilling of several observation wells is recommended. In order to obtain the greatest amount of information these wells should be distributed near the east edge of the limestone uplands-one well west of the Roswell segment, one west of the Cottonwood segment, and a third west of the artesian area below Artesia. Periodic measurements should be made of the water level in such wells, or a record of the fluctuations of the water level should be obtained by the installation of automatic water-stage recorders.

General policy.-Further general draft upon the artesian reservoir should be prevented. However, it is recognized that the needs of the basin will be served by the granting of permits for the drilling of wells to supply water for tracts now under cultivation. Initially, most of the area supplied by artesian wells had a good water right sufficient to supply the average duty to the land under the wells. With the decline in head the wells no longer yielded their original 
quantity of water, and the full capacity of many of the wells became insufficient to supply the allowable quantity of water to the land. It is therefore urged that in granting applications to appropriate further water from the basin precedence be given, so far as possible, to those lands that have a marked deficiency of water, as shown by the declarations of water rights filed with the State engineer in 1927 and 1928 and those filed in 1931 in accordance with the provisions of the new appropriation act.

Additional appropriations of water for new land or for land that was formerly irrigated but has been abandoned because of insufficient water should not be granted. This expansion should not be permitted until such time as additional drafts upon the reservoir will not interfere with the rights of the present water users.

\section{WELL RECORDS}

Records of the wells in the Roswell area are given in the three tables following, which include, respectively, artesian wells (Nos. 1-1416, wells drawing from the valley fill (Nos. 1417-1628), and wells outside the area of artesian flow (Nos. 1629-1791). 


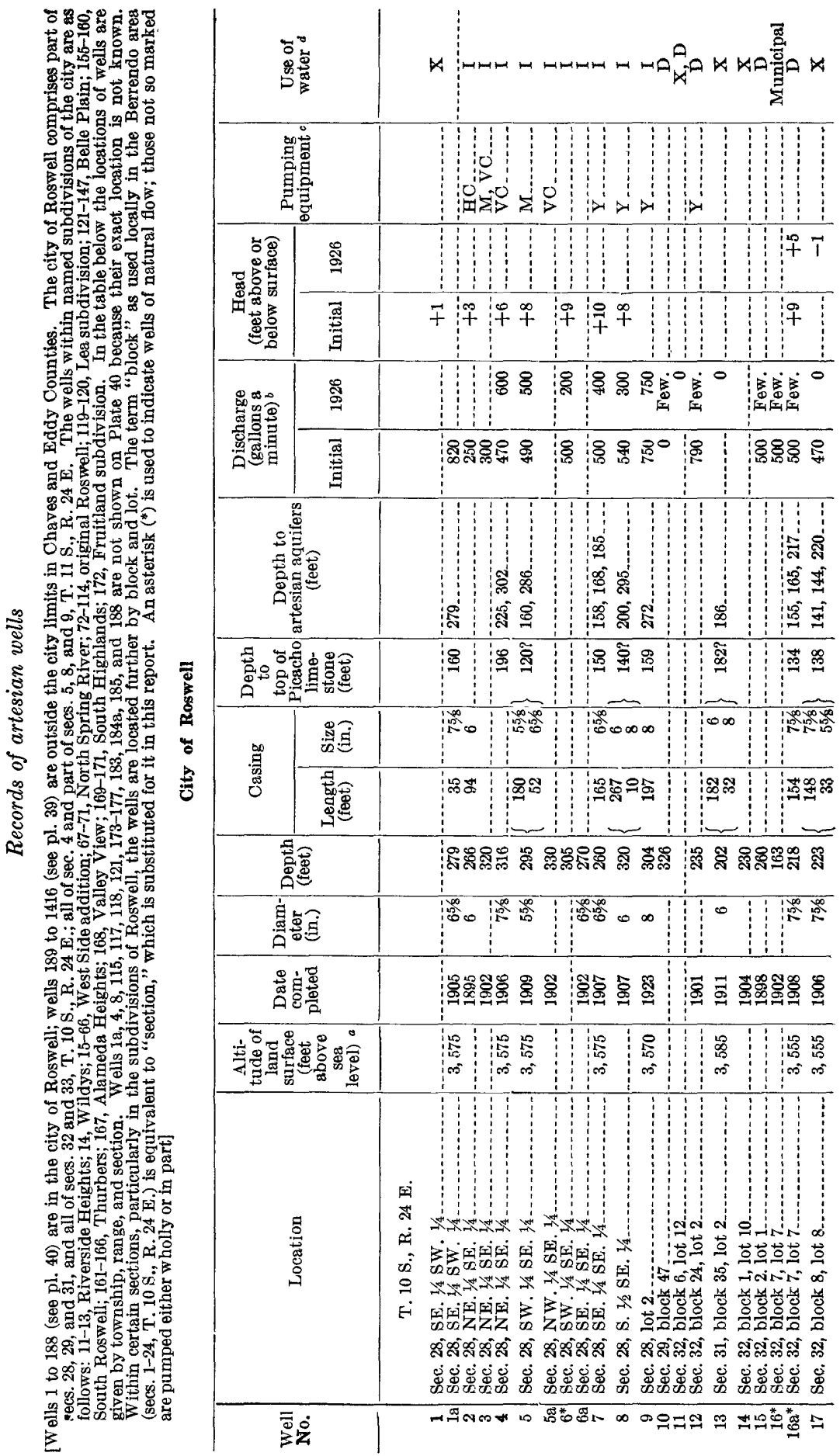




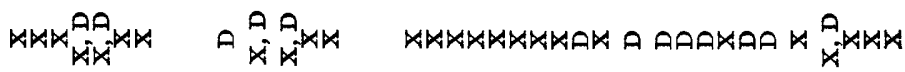

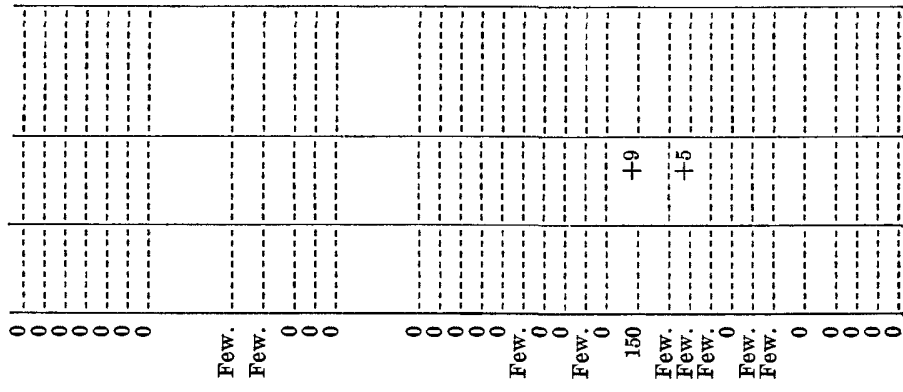

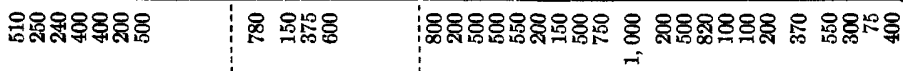

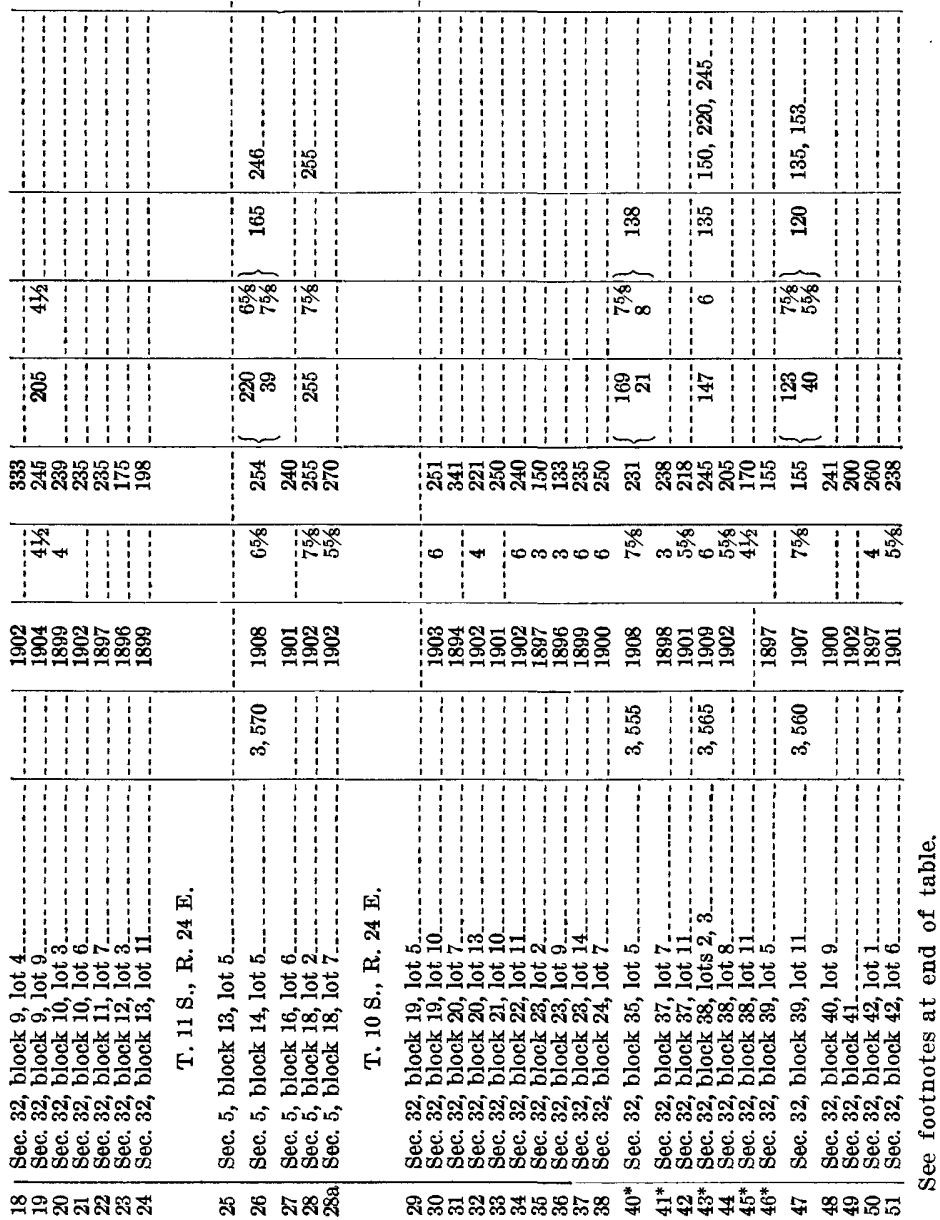




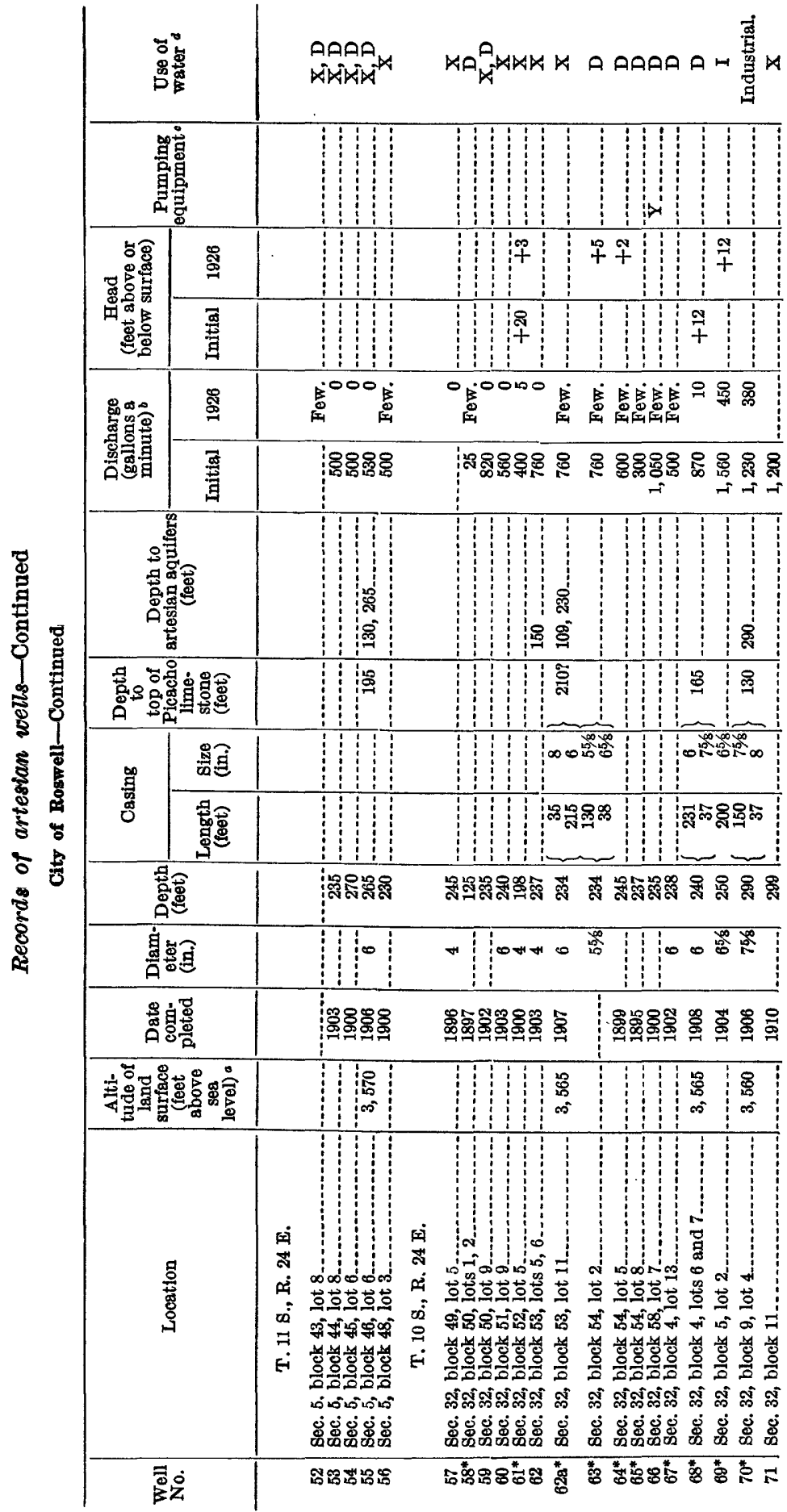




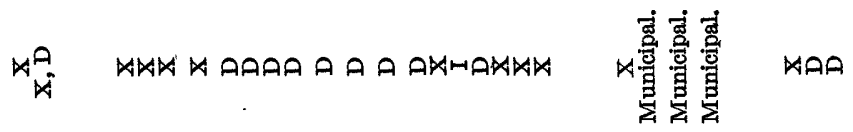

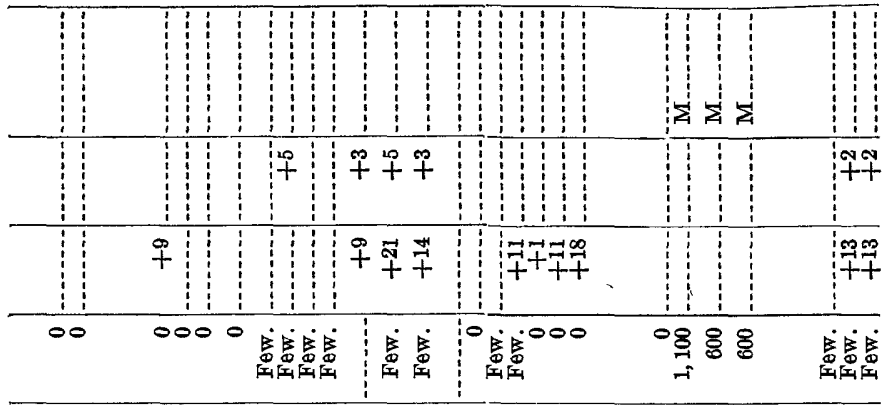

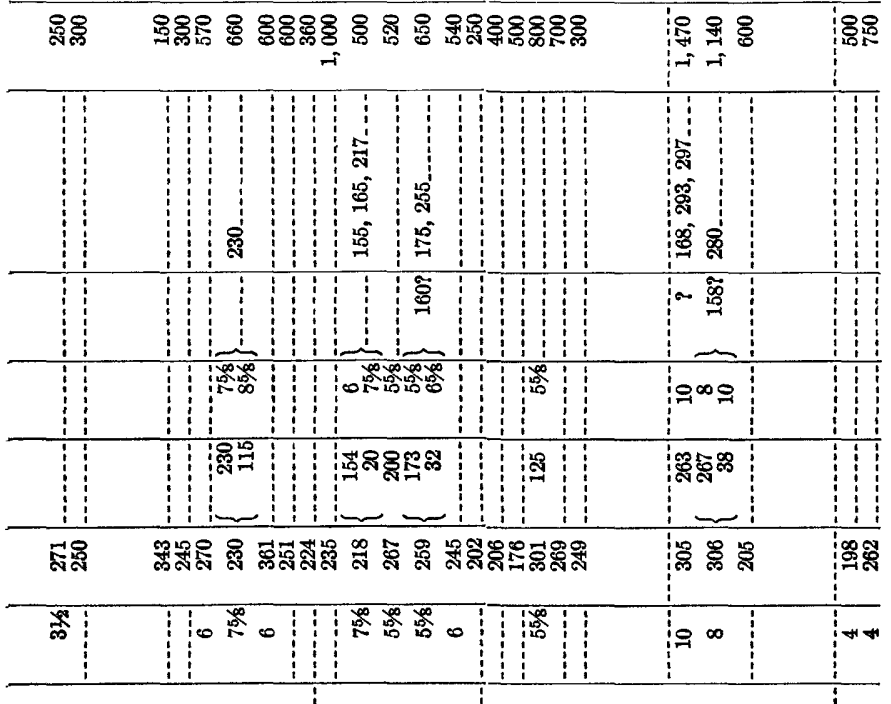

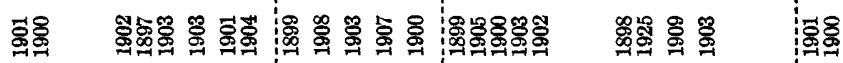

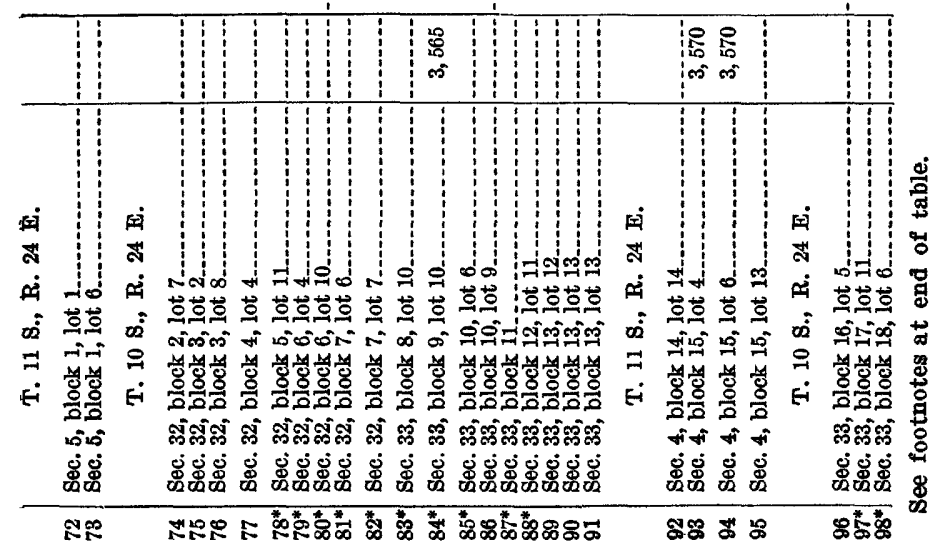




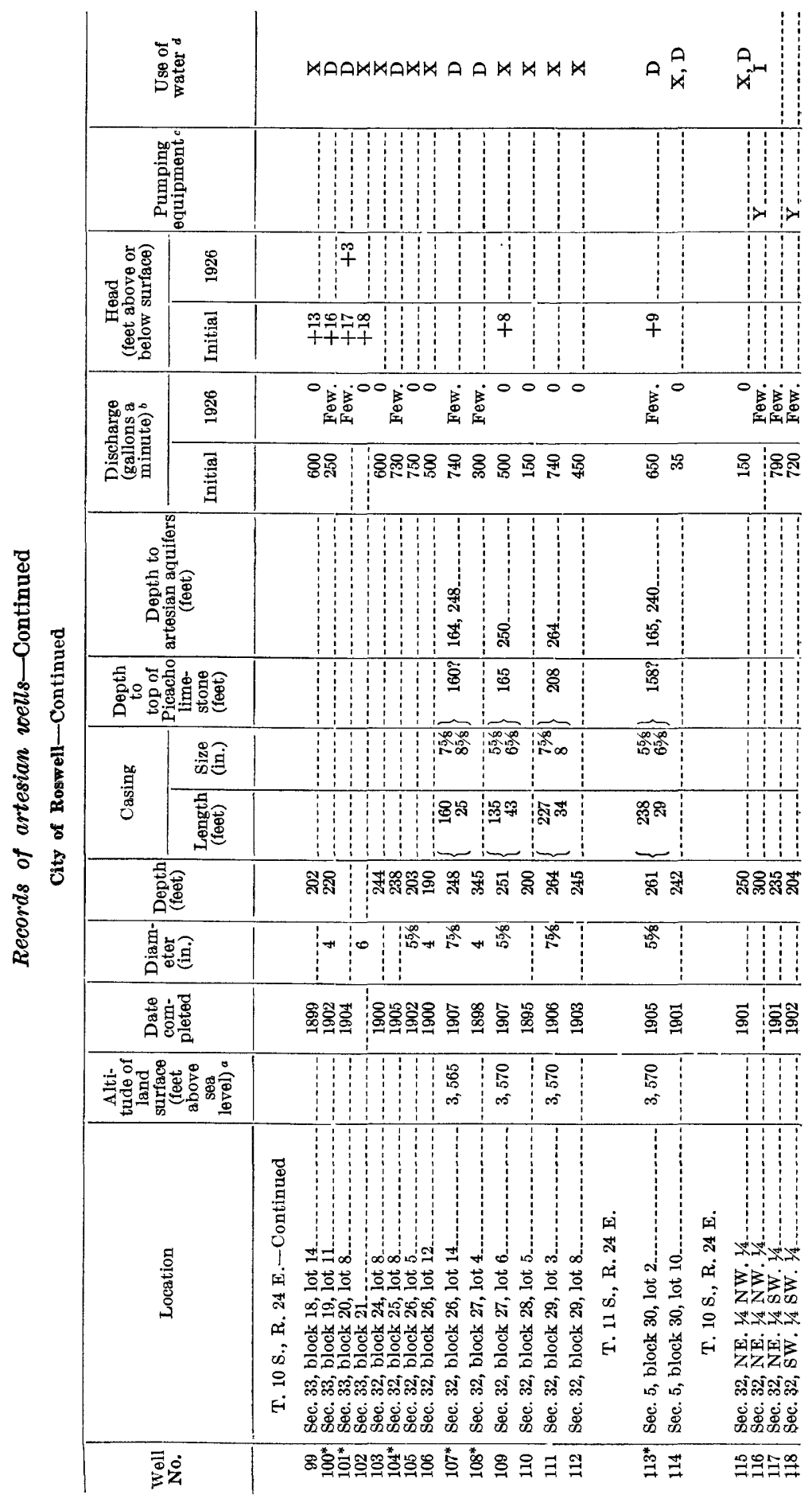




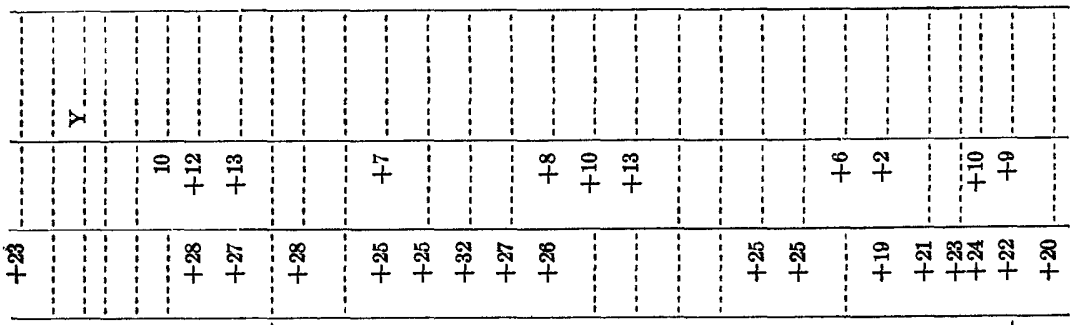

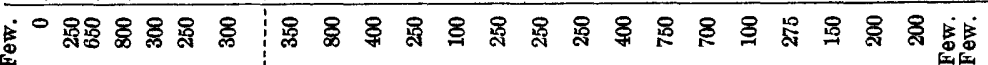

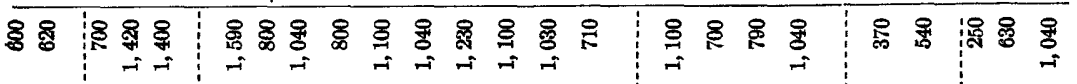

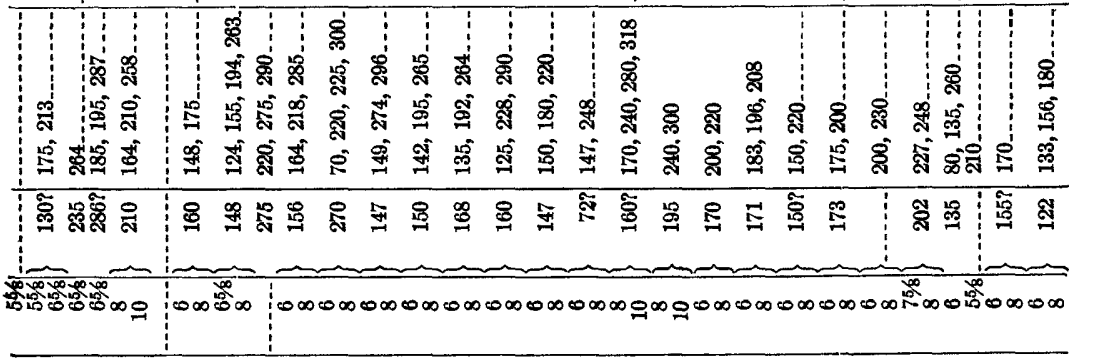

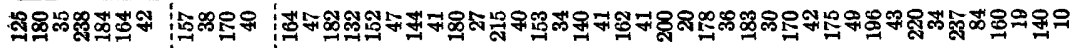

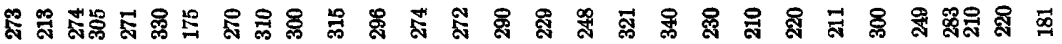

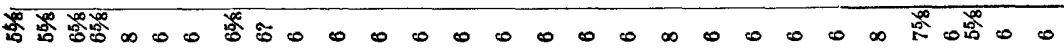

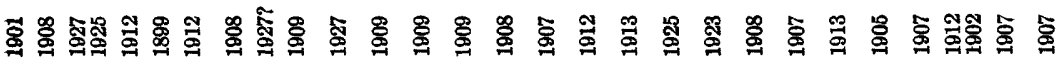

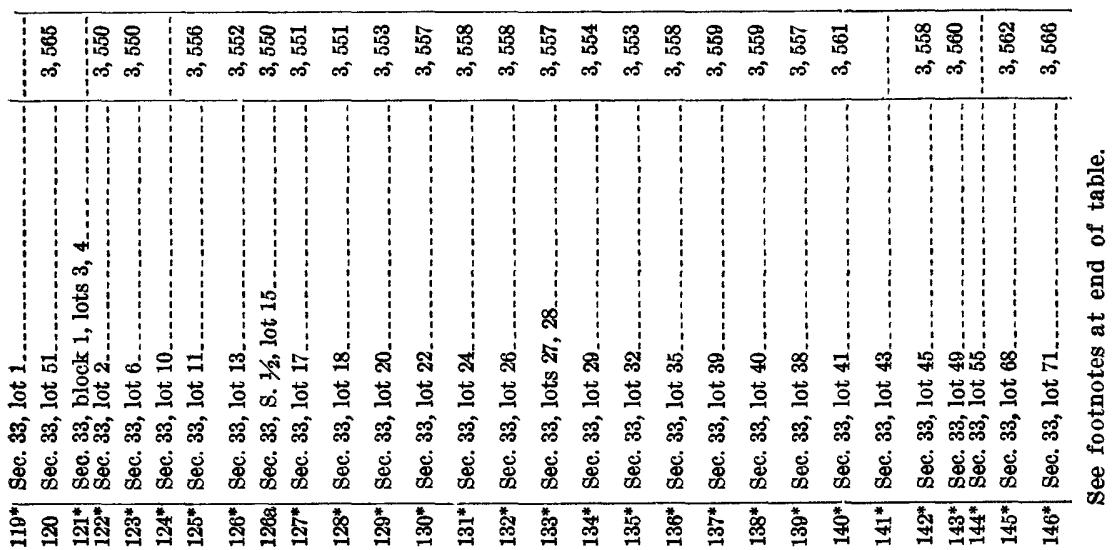




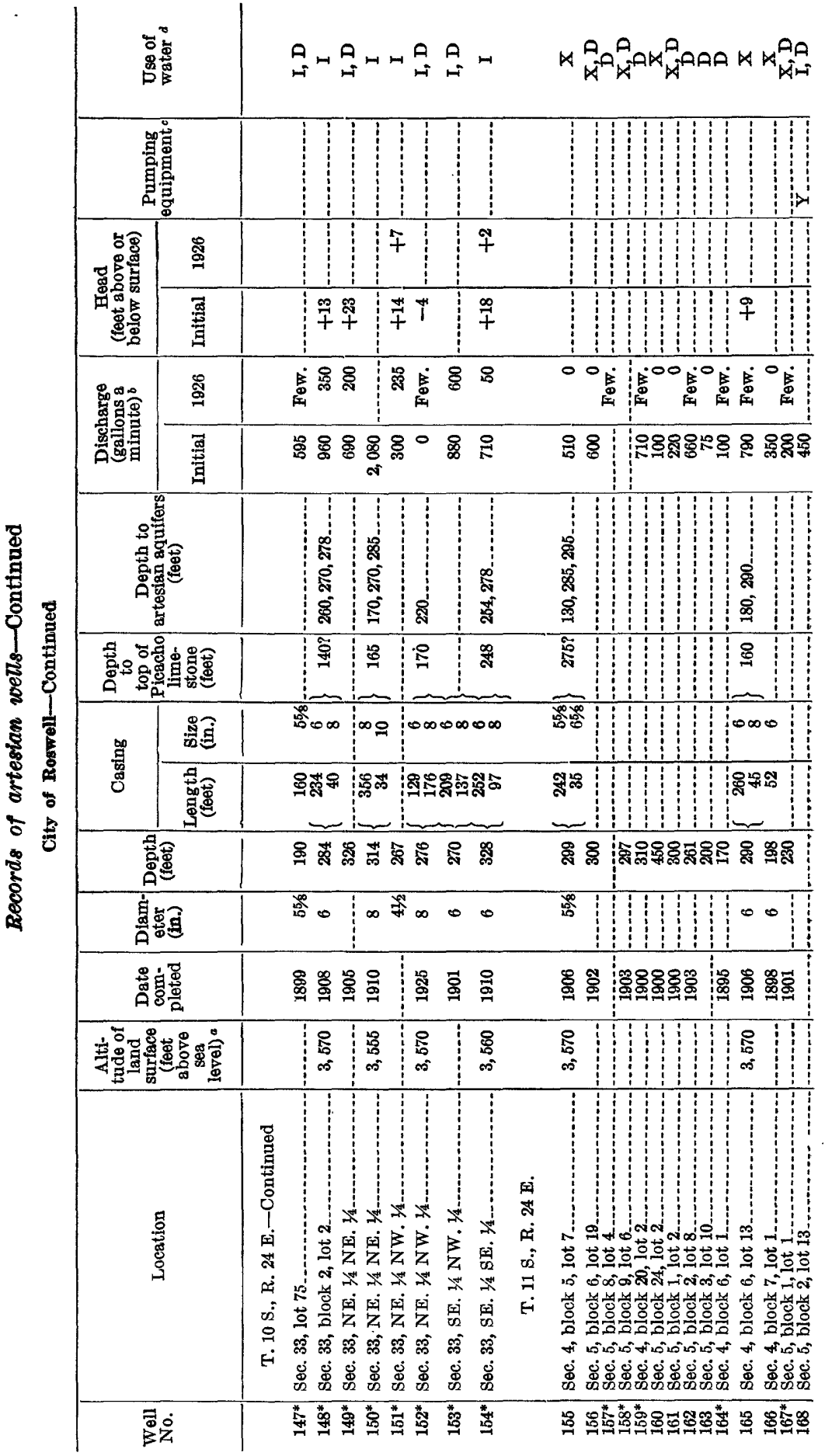


|

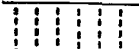

0

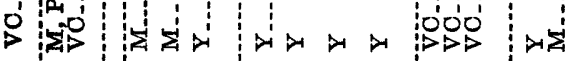

1!1

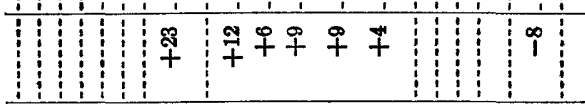

ం \%

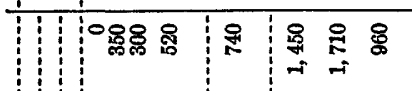

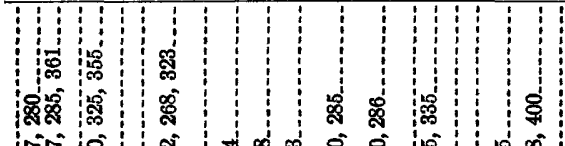

垥

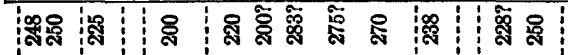

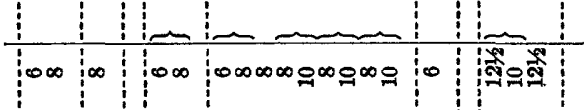

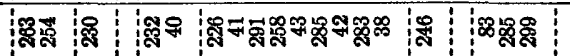

1: : : 1

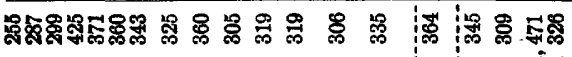

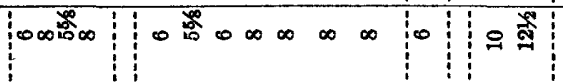

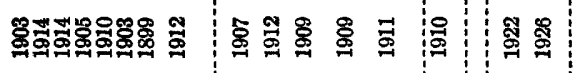

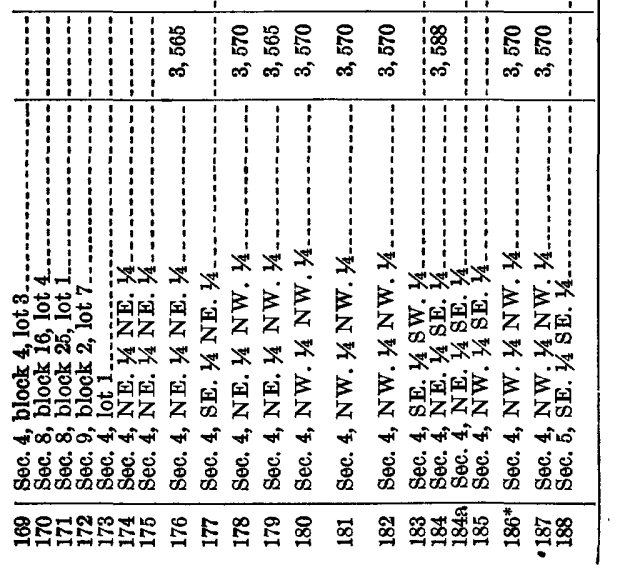

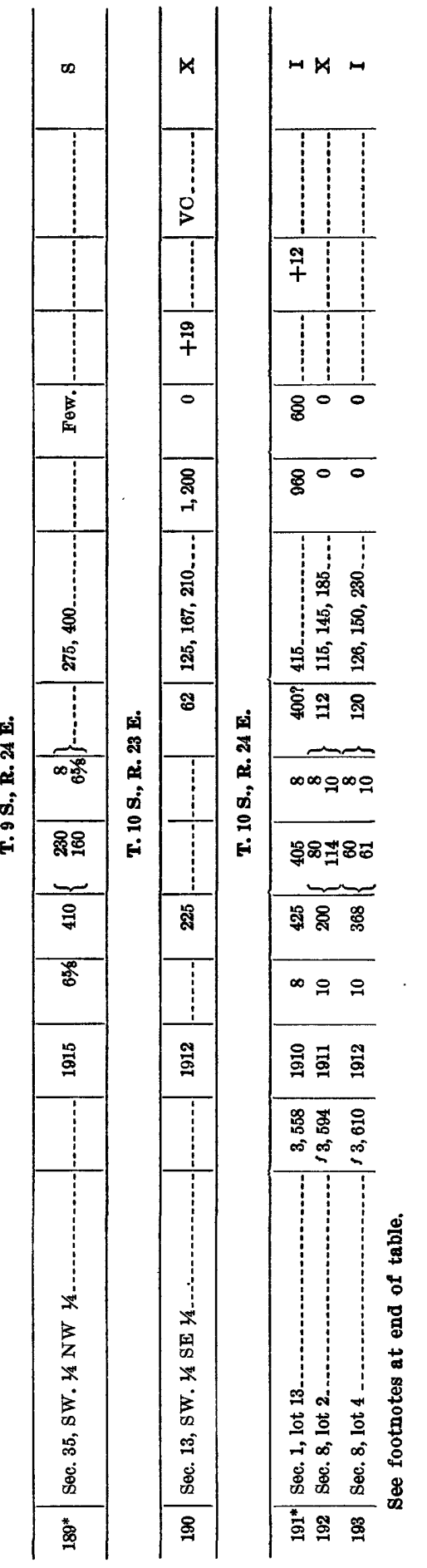




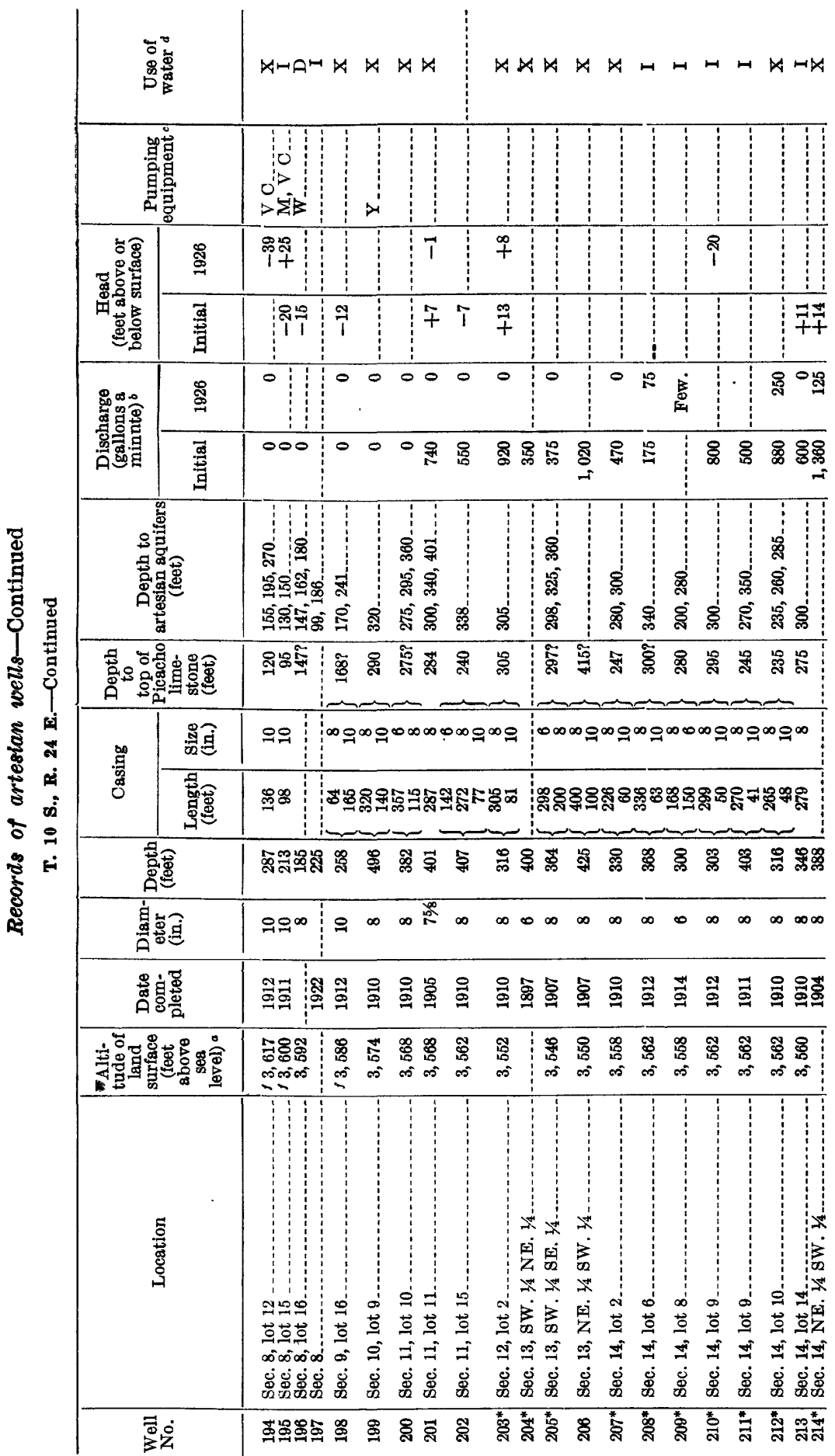




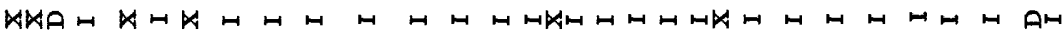

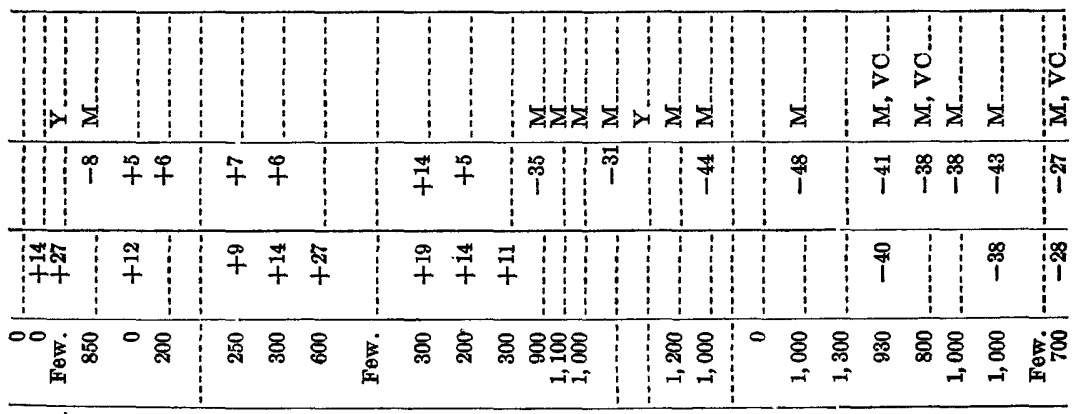

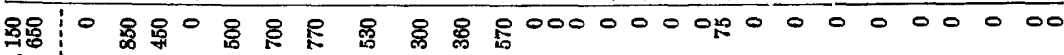
i

กิ

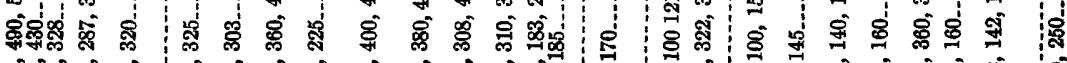

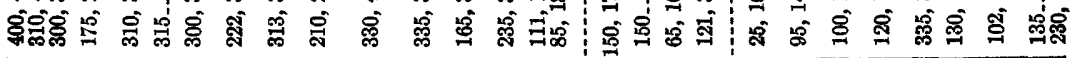

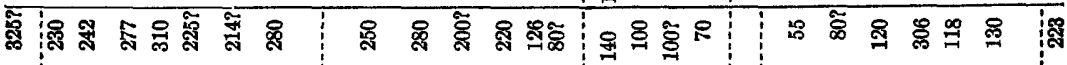
地 :

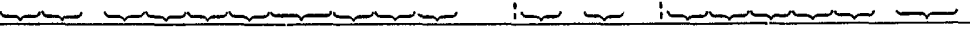

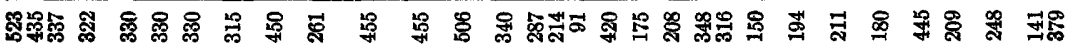

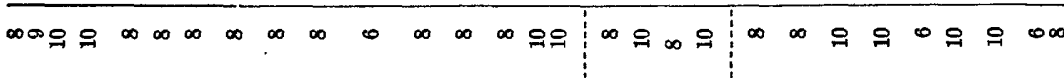

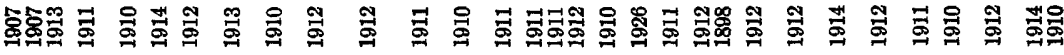
员 部

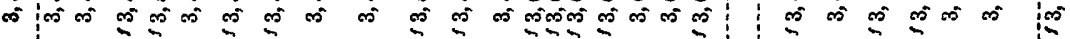

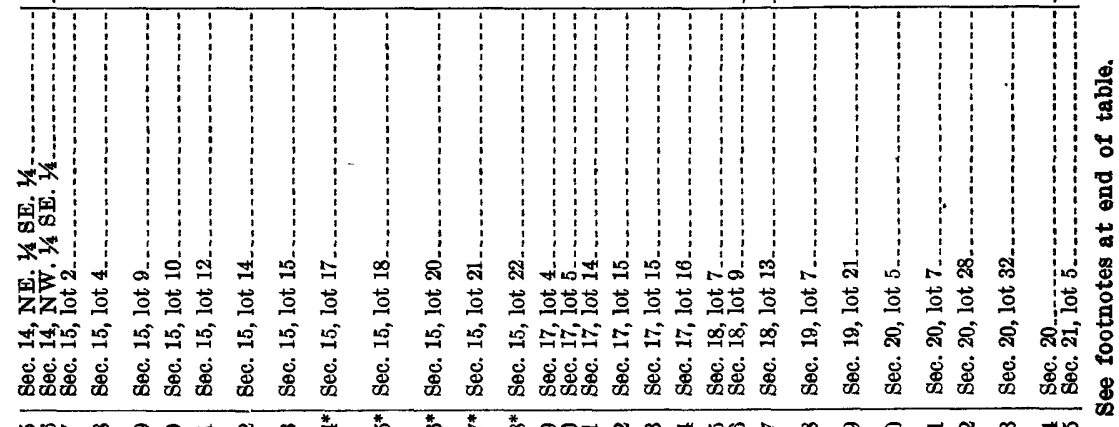

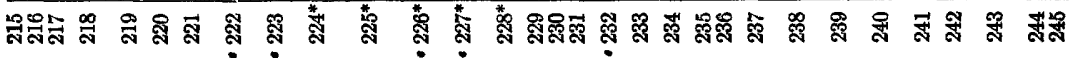




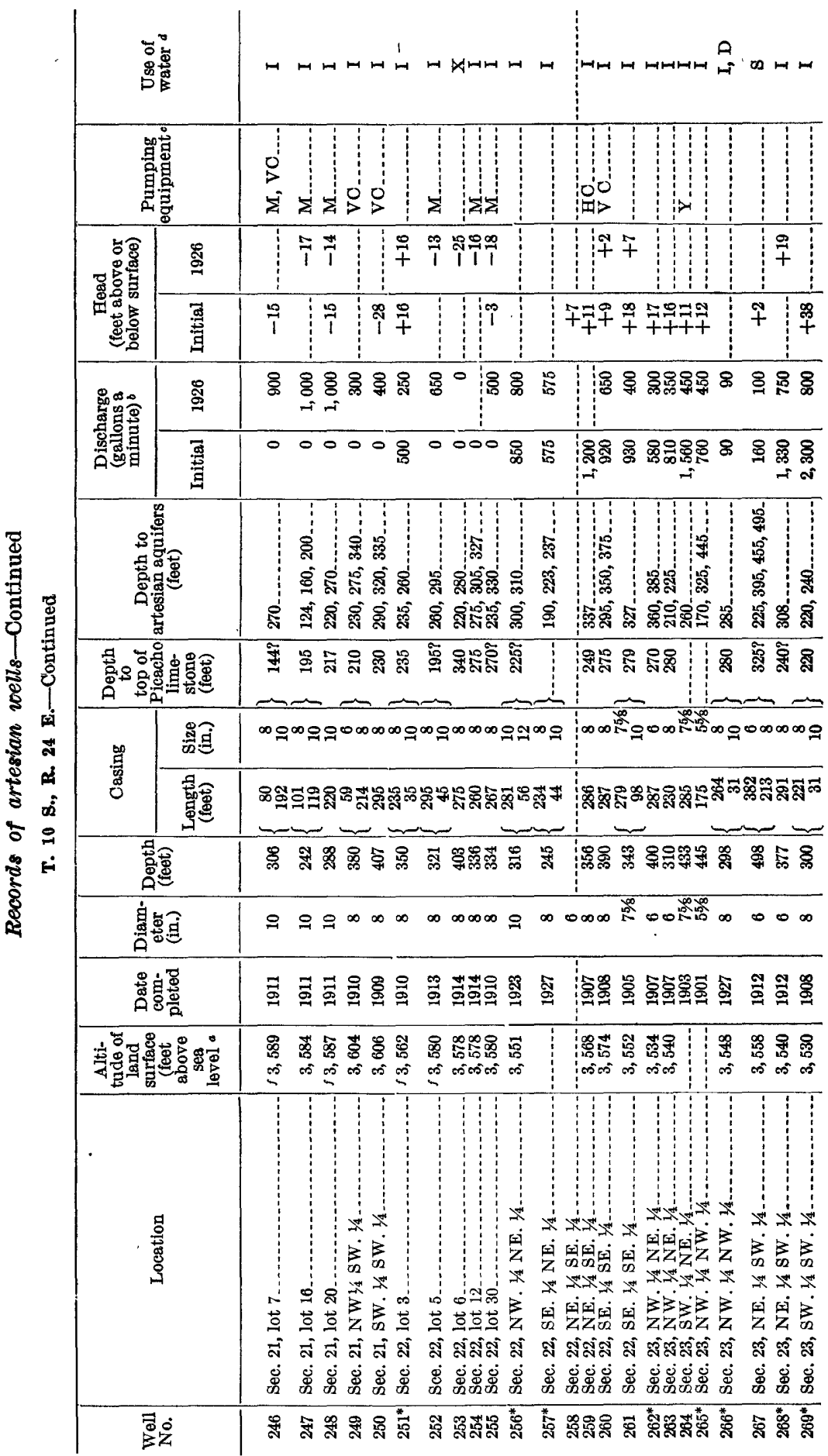




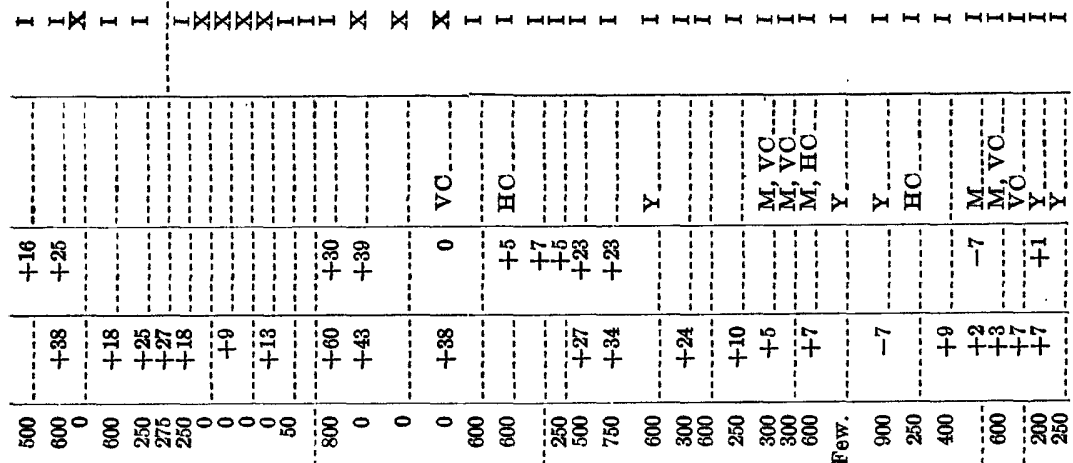

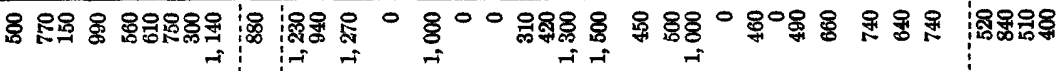

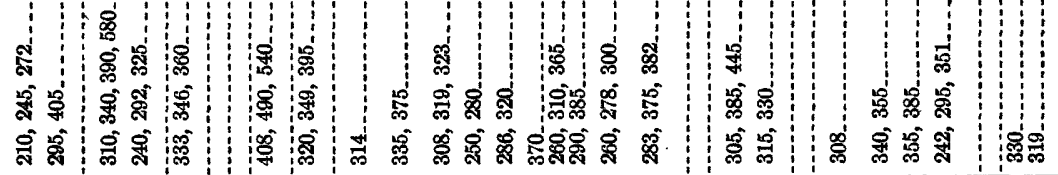
喿哭

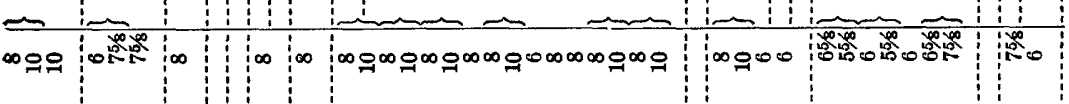

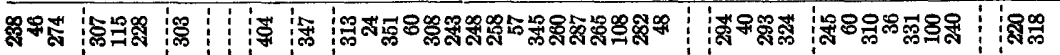

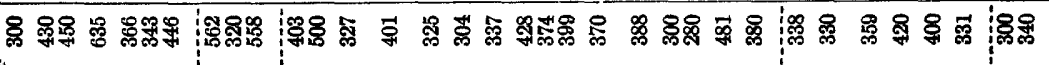

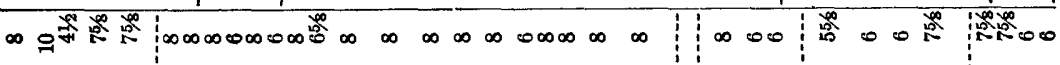

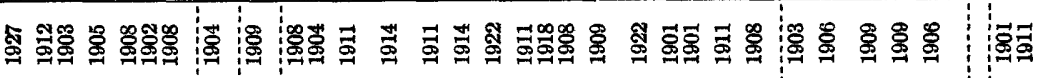

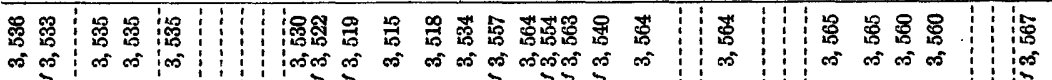

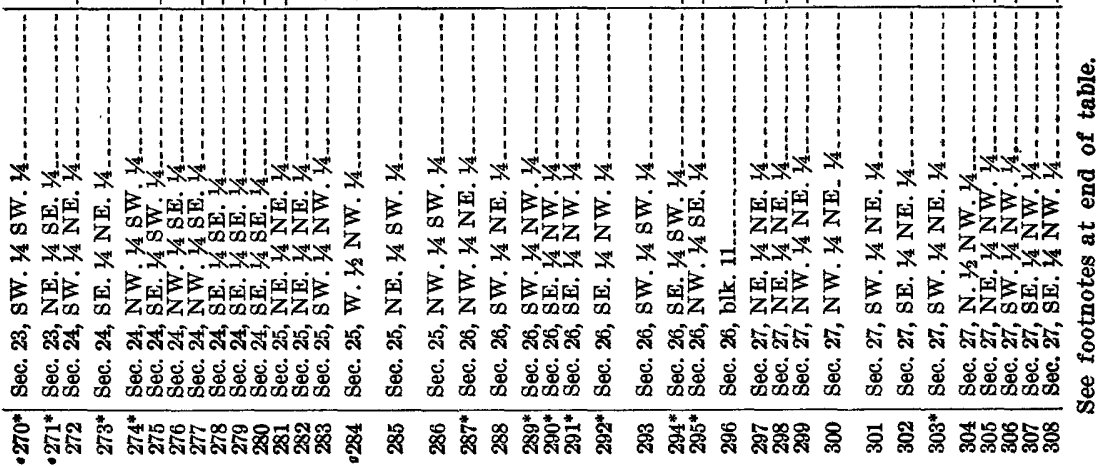




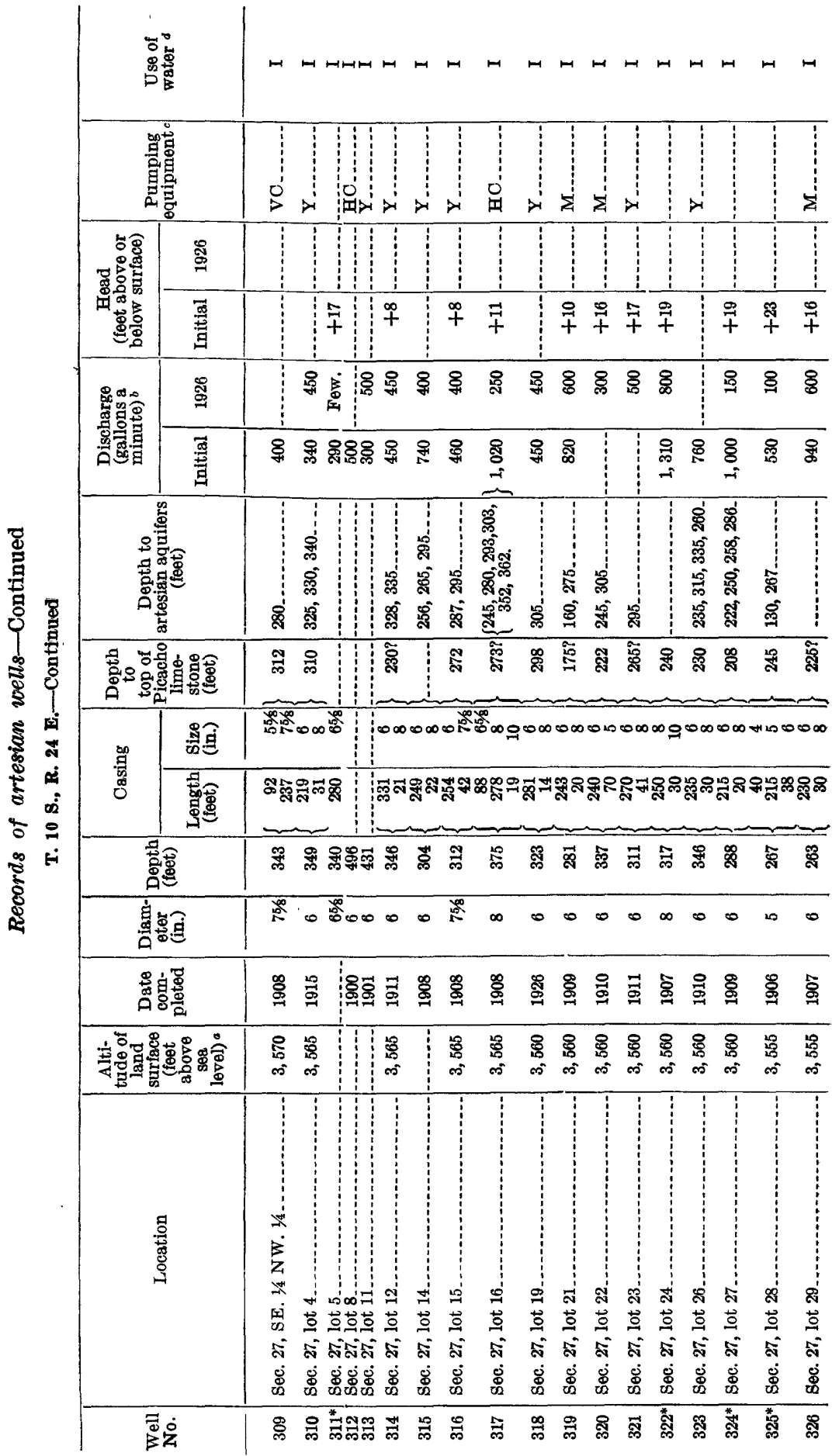




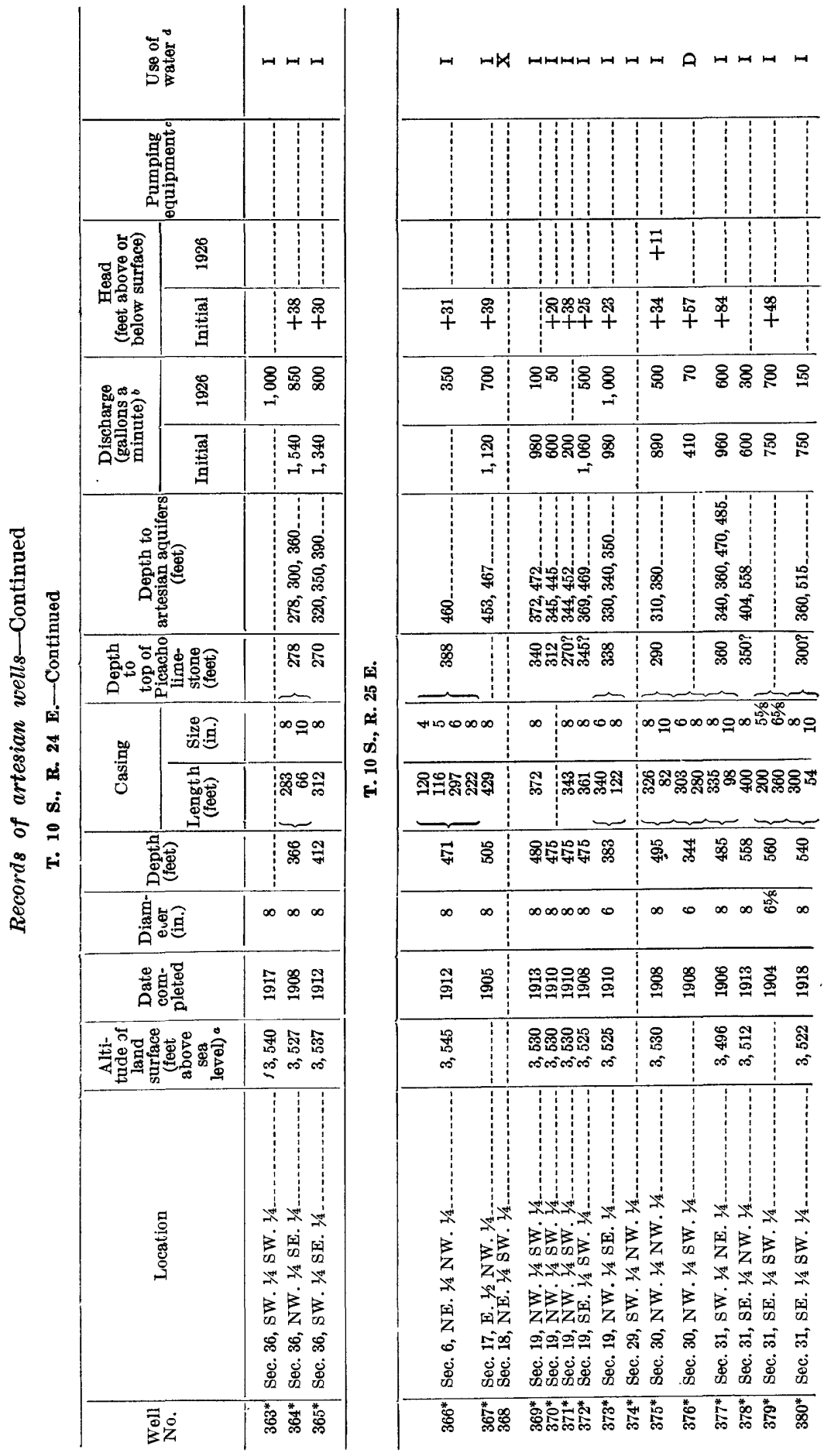




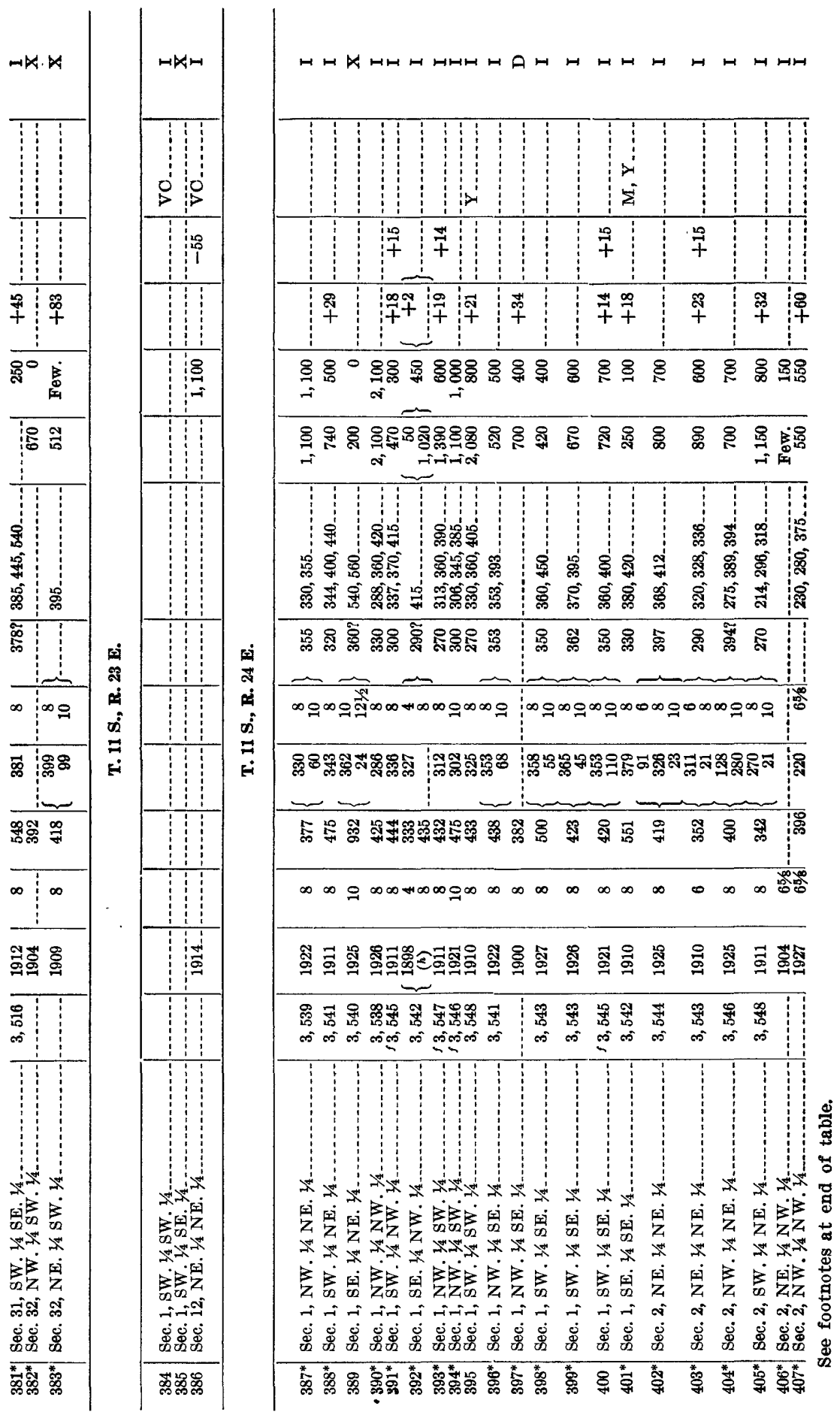




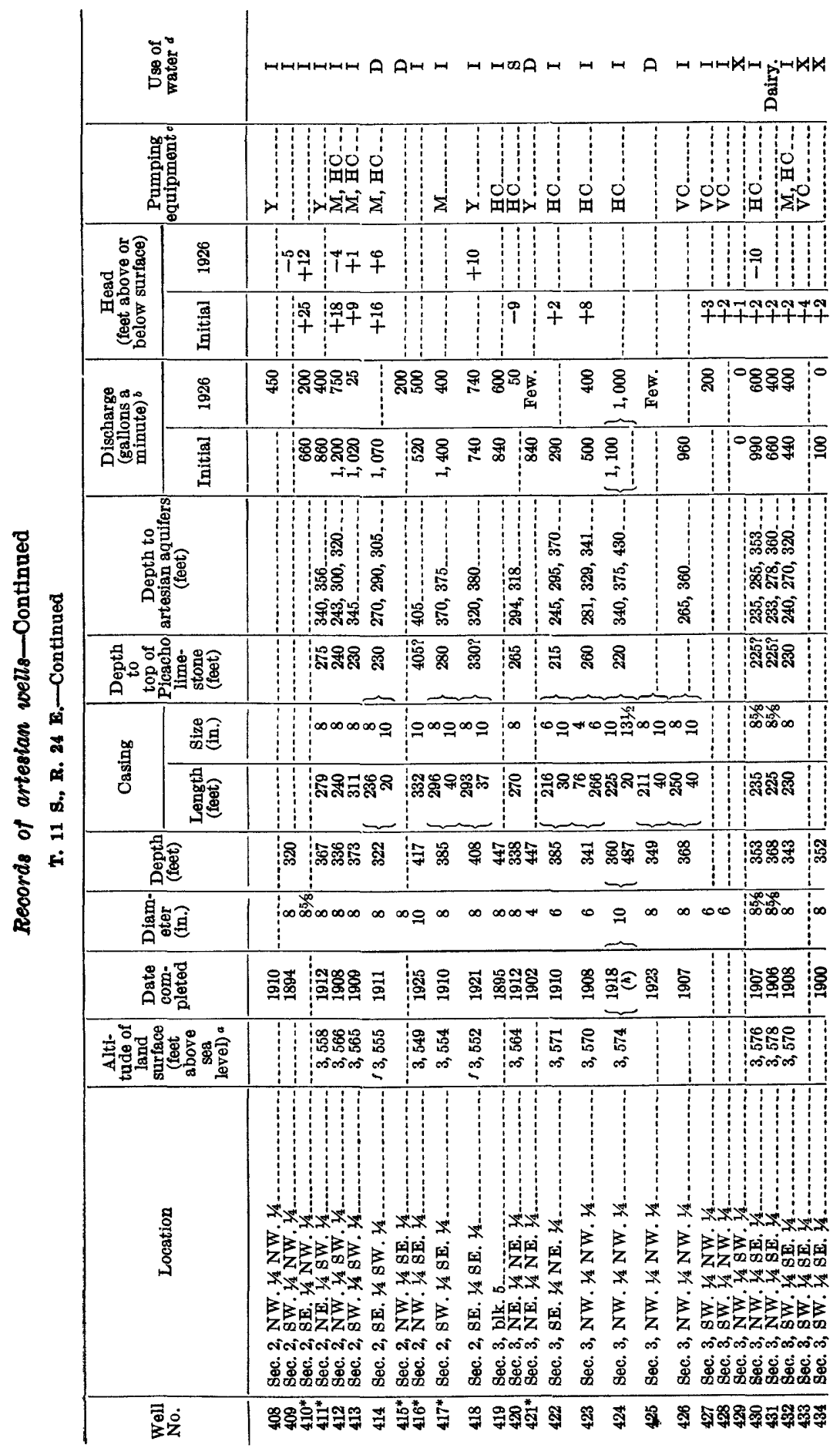




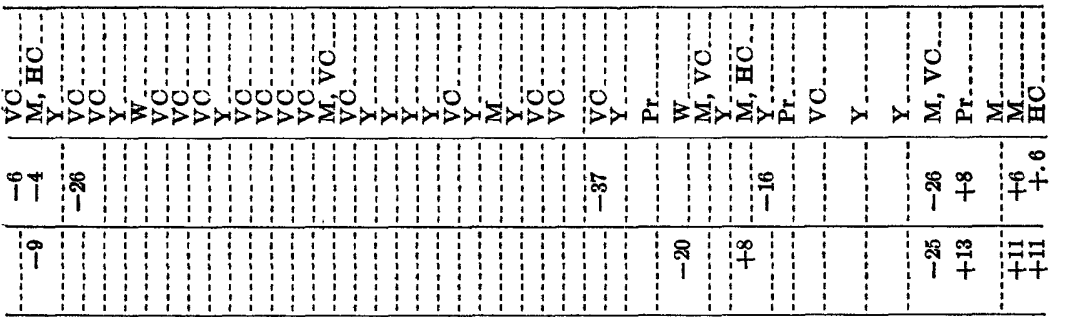

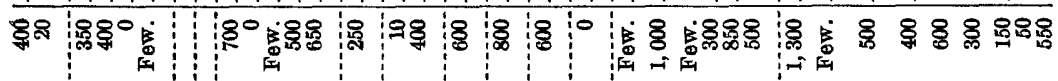
요요

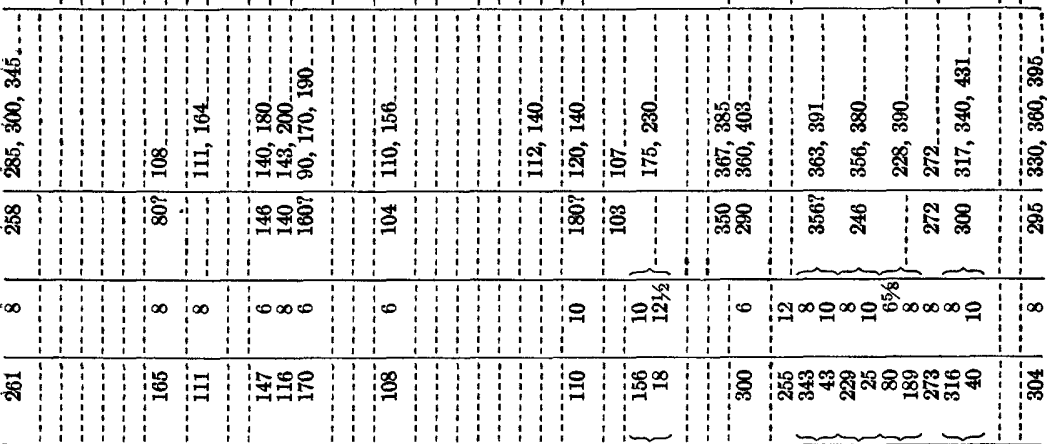

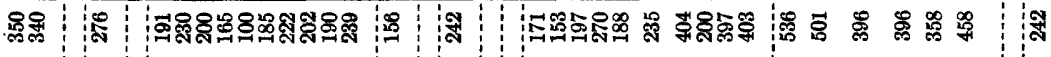

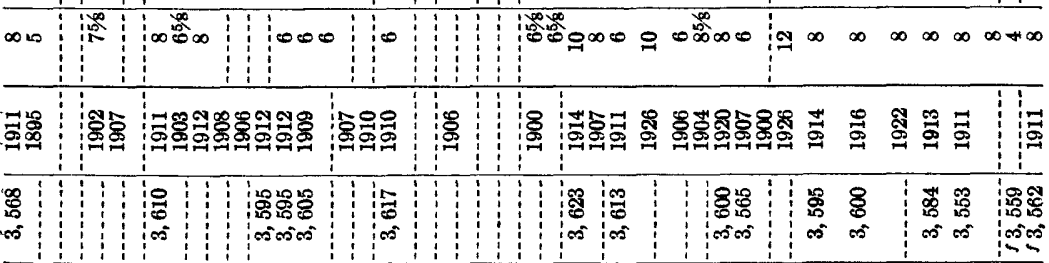

$\lim _{3 \rightarrow \infty}$

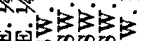

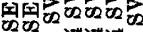

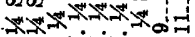

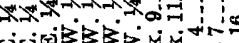

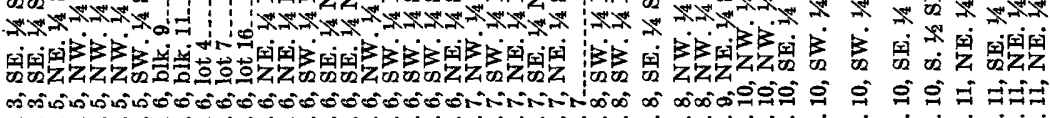

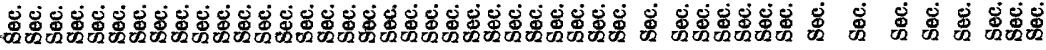

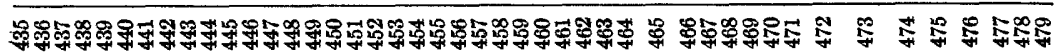

$$
\frac{2}{2}
$$
135252-33-21 


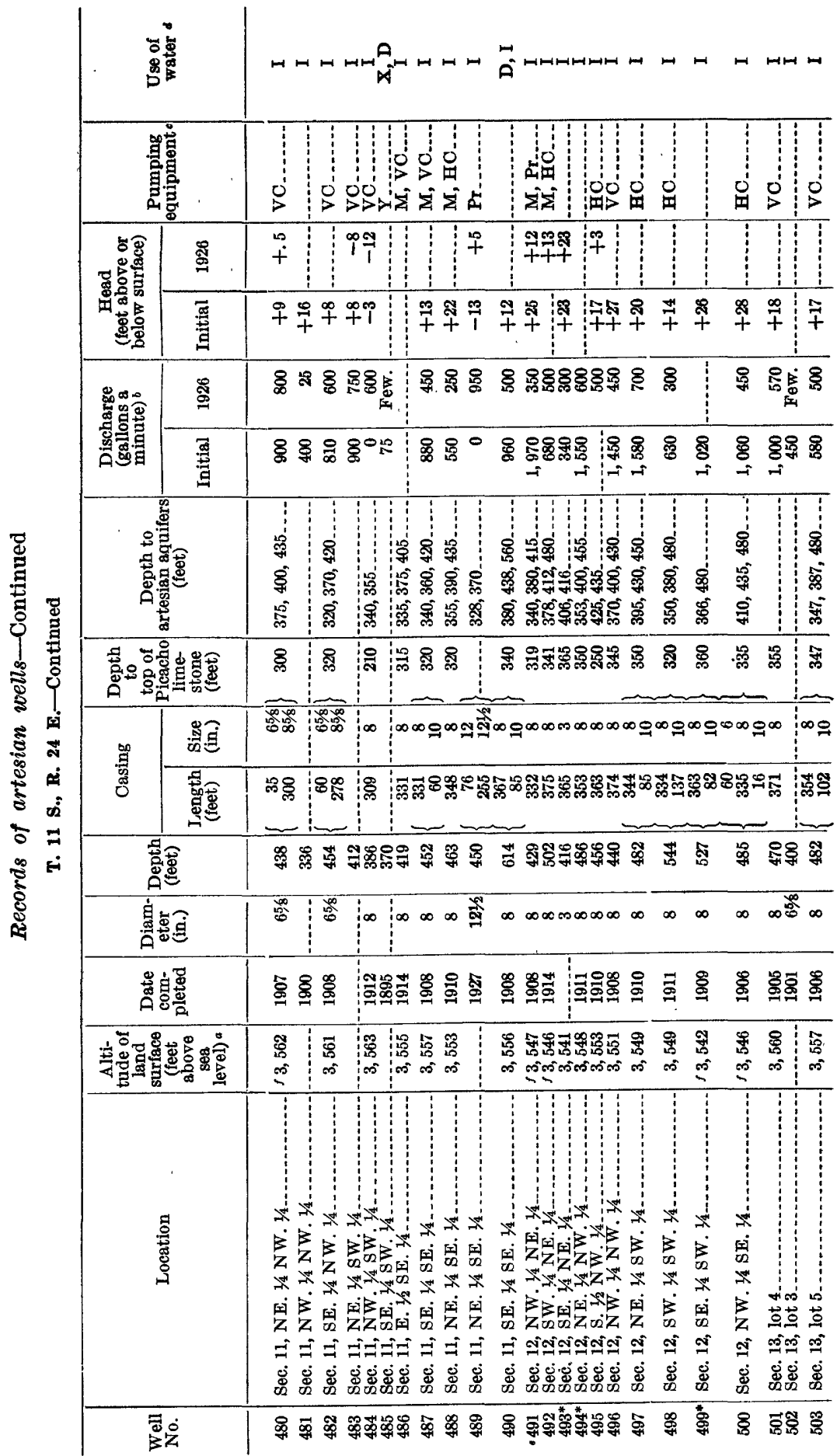




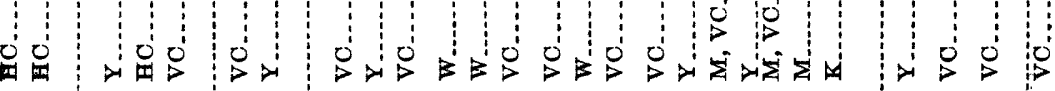

孛㔺芰条

辛

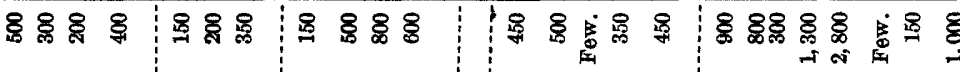

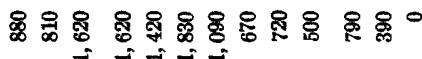

○08: 0 \%

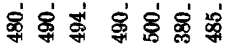

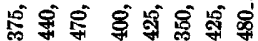

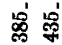

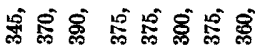

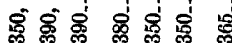

ষ্ণে

है

总唡

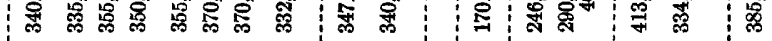

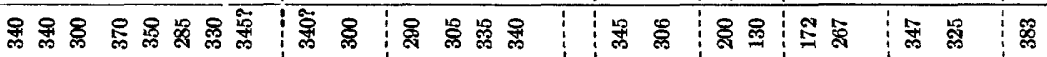

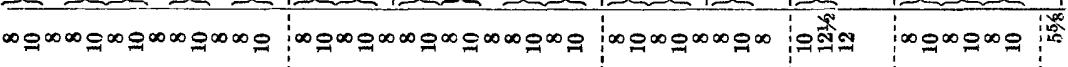

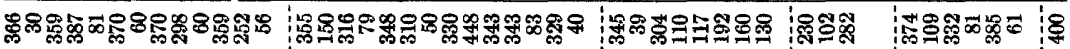

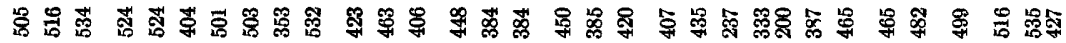

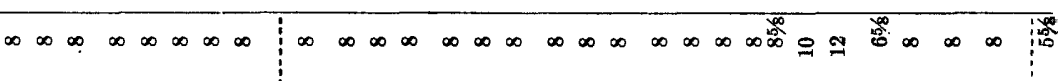

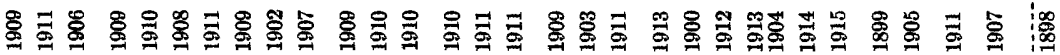

\begin{tabular}{|c|c|c|c|c|c|c|}
\hline 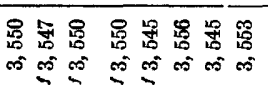 & $\begin{array}{ll}1 \\
0 \\
0\end{array}$ & 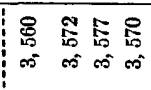 & 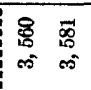 & 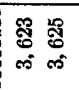 & $\begin{array}{l}\infty \\
0 \\
0 \\
0=0\end{array}$ & $\begin{array}{ll}0 \\
0 \\
0 \\
0 \\
0\end{array}$ \\
\hline
\end{tabular}

$x+2 x+2$

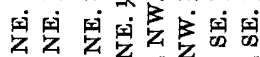

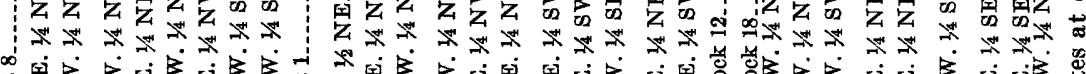

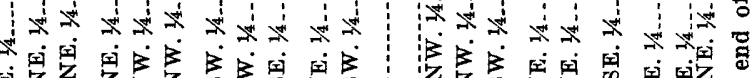

Nind

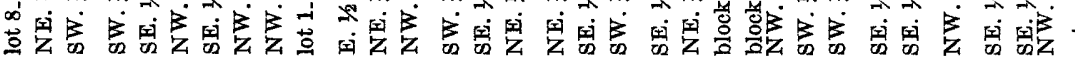

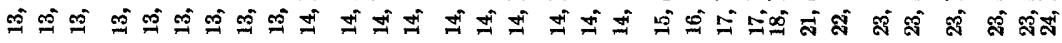

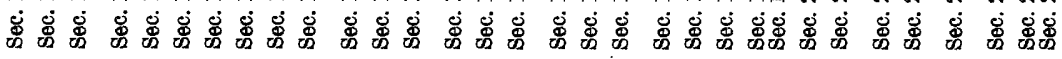

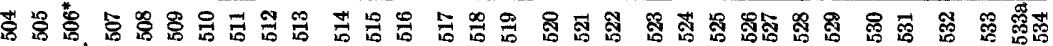




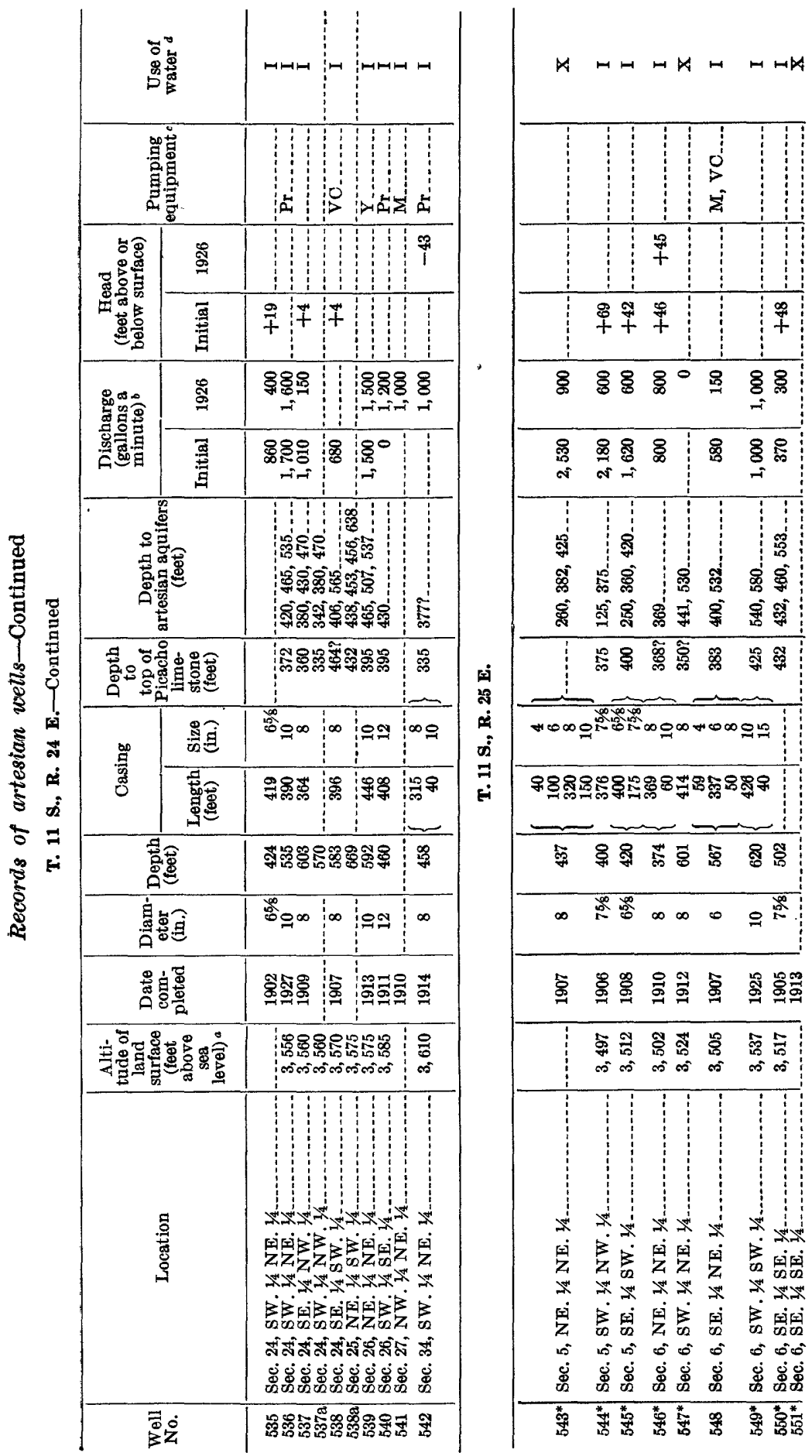




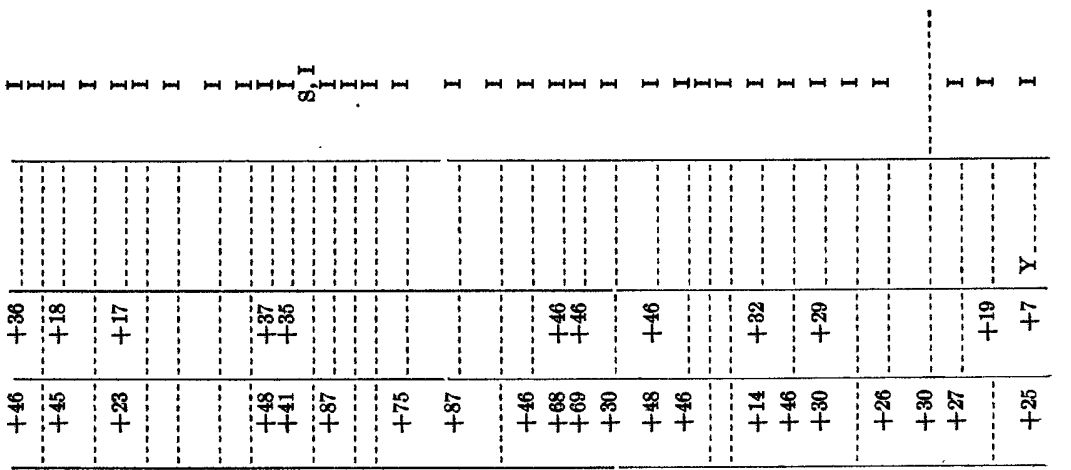

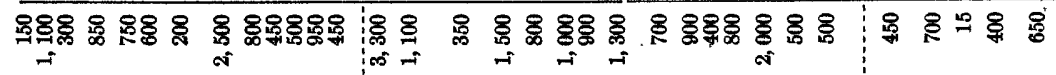

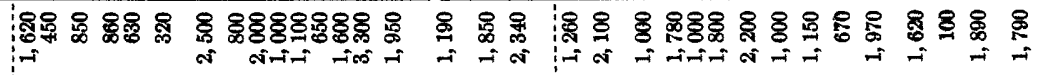

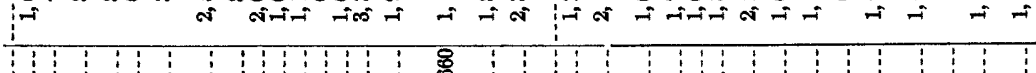

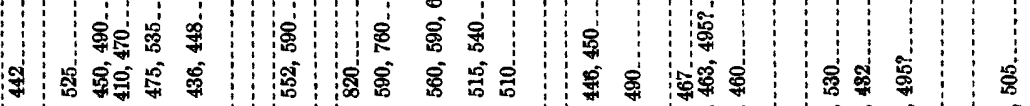

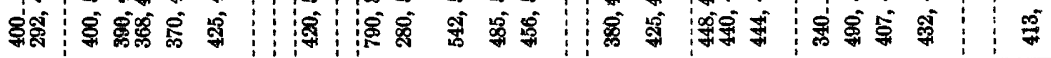
学

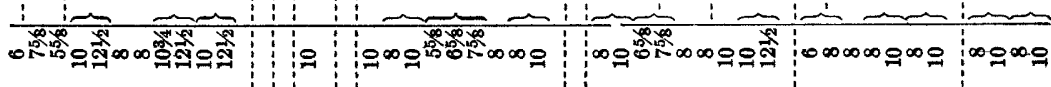

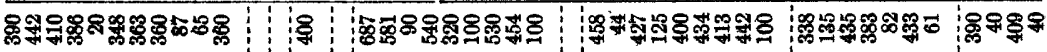

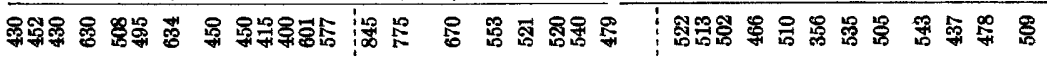

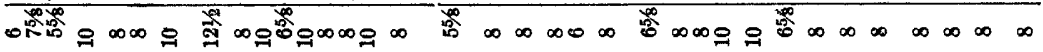

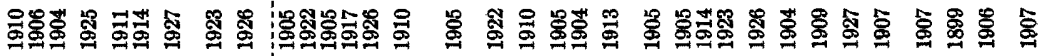

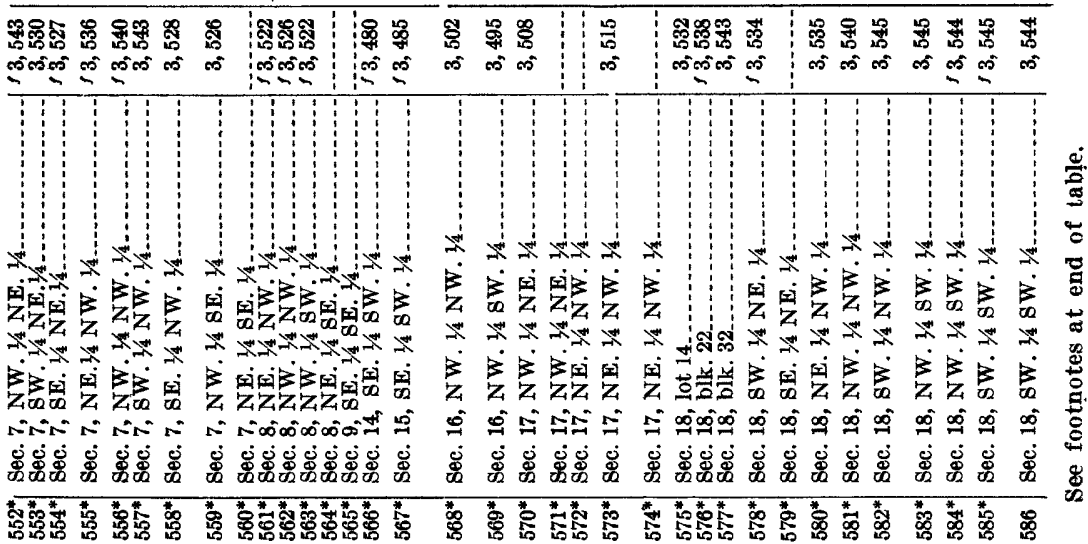




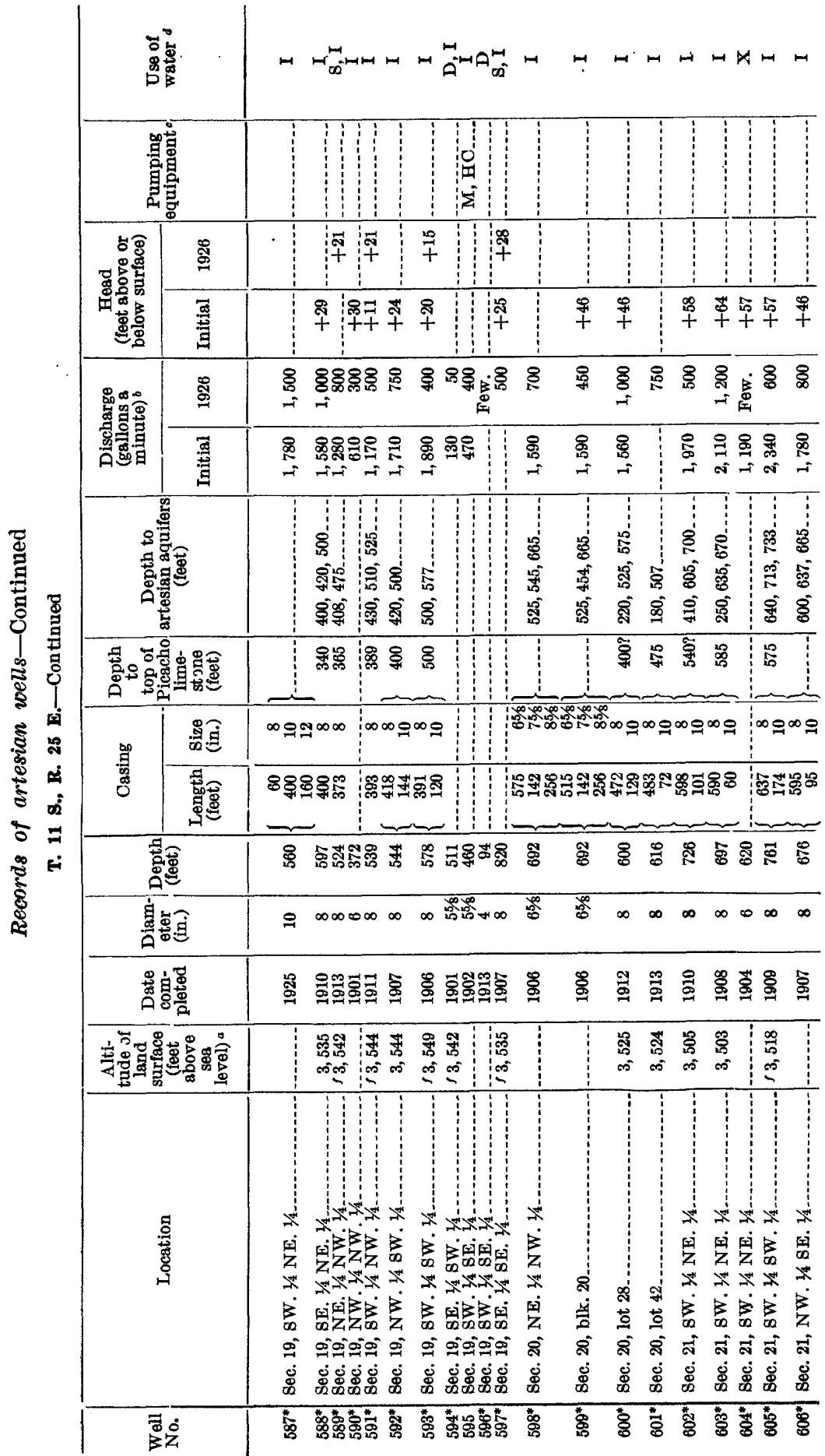




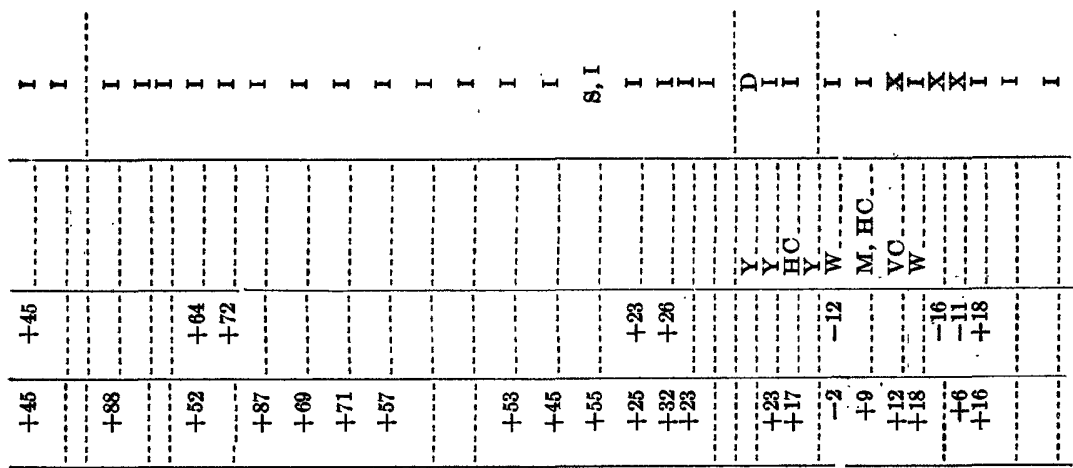

영 造

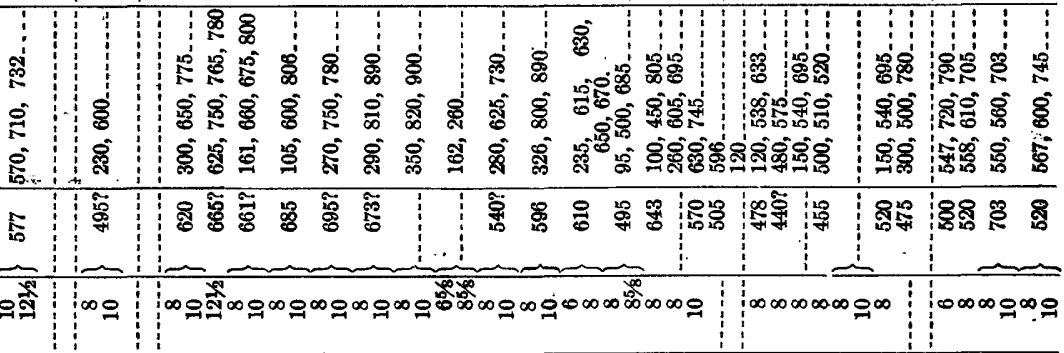

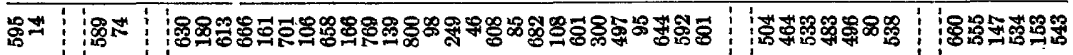

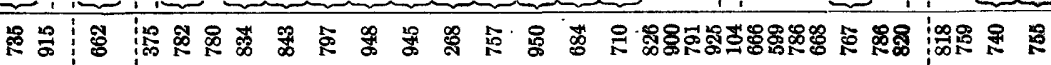

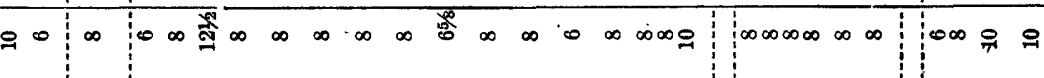

兽

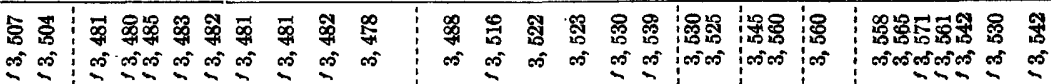

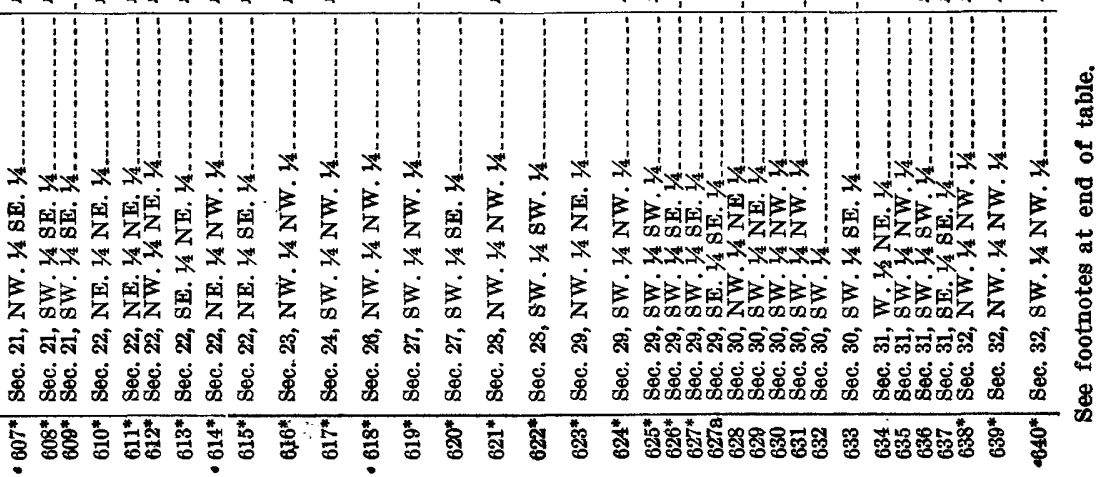




\begin{tabular}{|c|c|c|c|}
\hline & & & 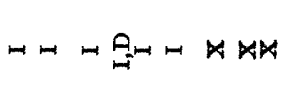 \\
\hline & & & $\begin{array}{c}1 \\
\vdots \\
\vdots \\
0\end{array}$ \\
\hline & 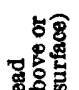 & 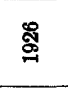 & สุง \\
\hline & 苾要 & · 恚 & 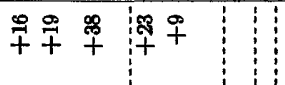 \\
\hline & 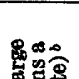 & ॐొ & 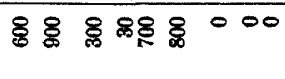 \\
\hline & 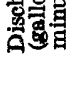 & 焉 & 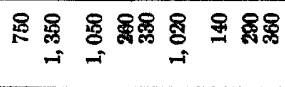 \\
\hline 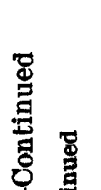 & 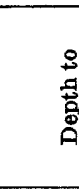 & & 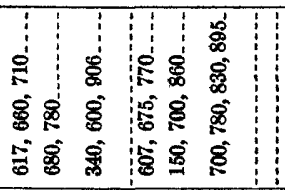 \\
\hline 恶 & 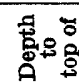 & & \begin{tabular}{l|l|l}
78 & 0 \\
\end{tabular} \\
\hline$\frac{5}{2}$ & 80 & क्षें & 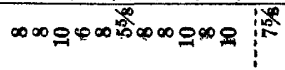 \\
\hline 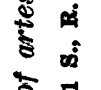 & 超 & 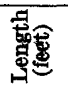 & 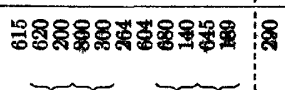 \\
\hline है & & & 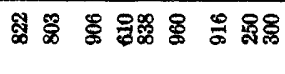 \\
\hline$\&$ & & & $\infty \infty \infty \infty_{\infty}^{\infty} \infty \infty \infty$ \\
\hline & & & 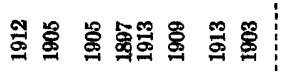 \\
\hline & 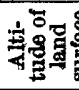 & $8:$ & 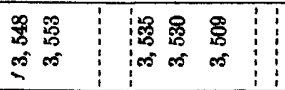 \\
\hline & & & $\begin{array}{l} \\
0\end{array}$ \\
\hline & & & 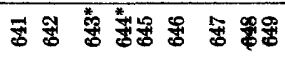 \\
\hline
\end{tabular}

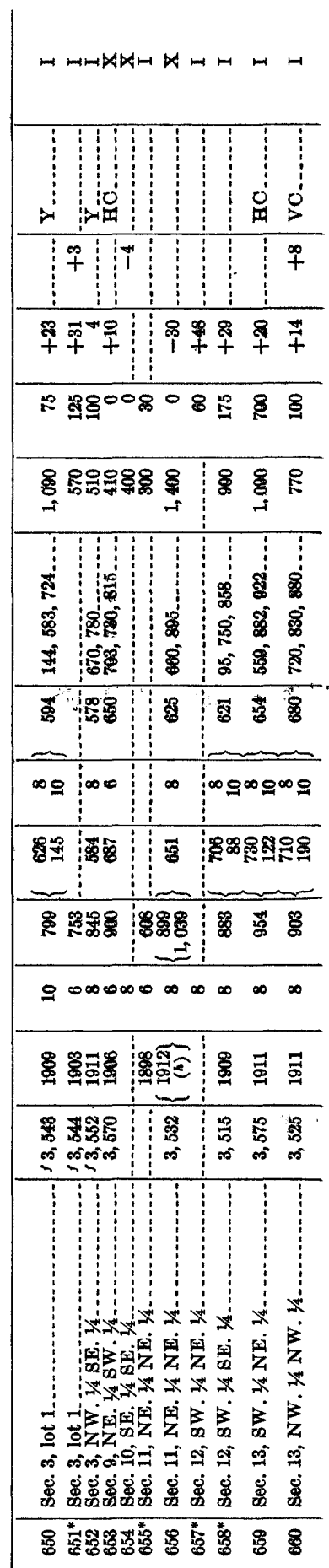




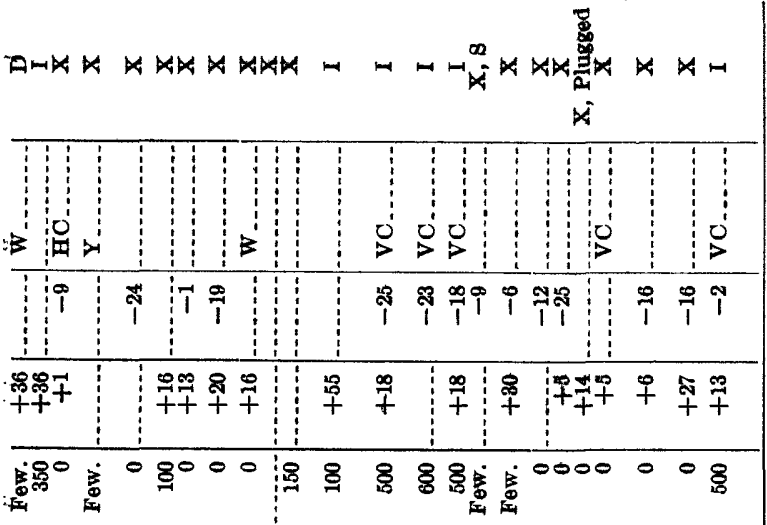
抙

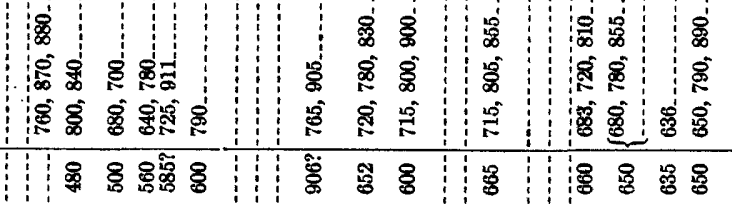

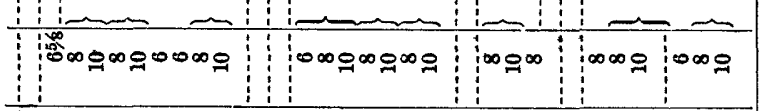

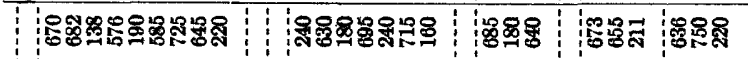

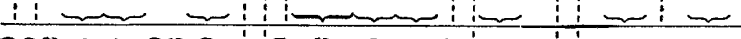

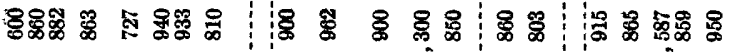

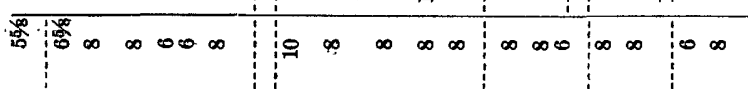

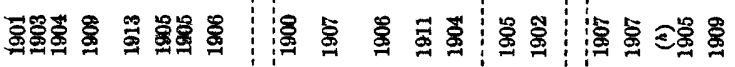

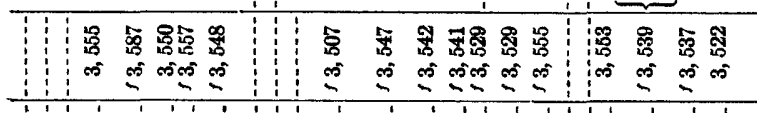

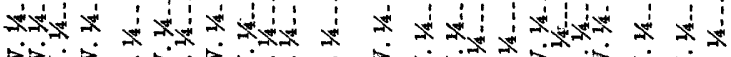

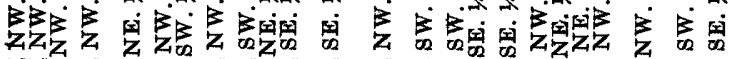

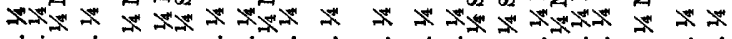

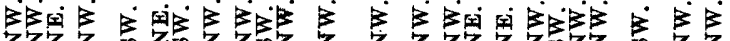

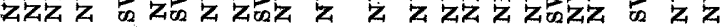

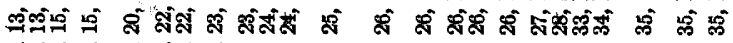

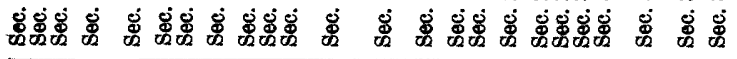

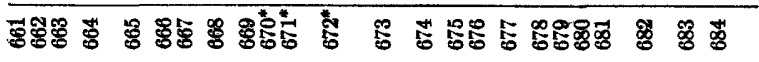

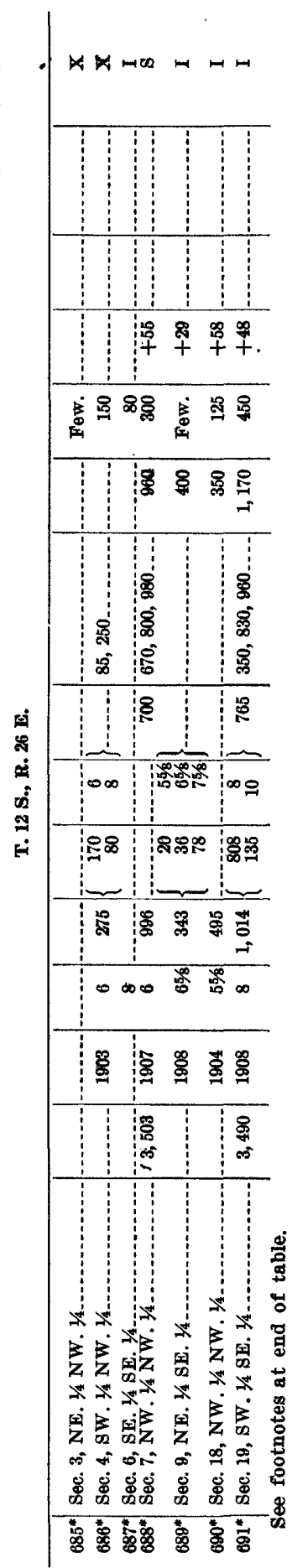




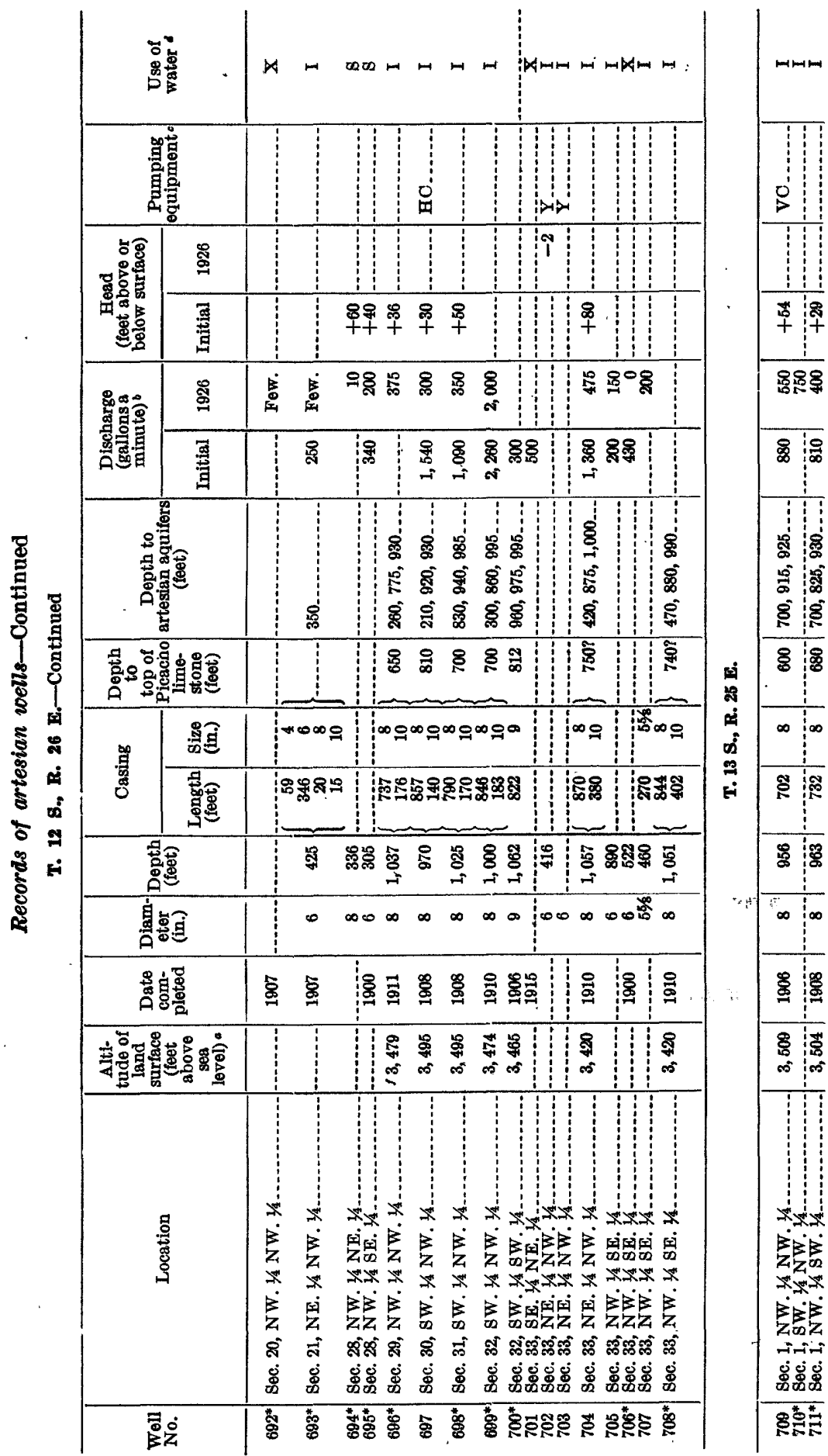




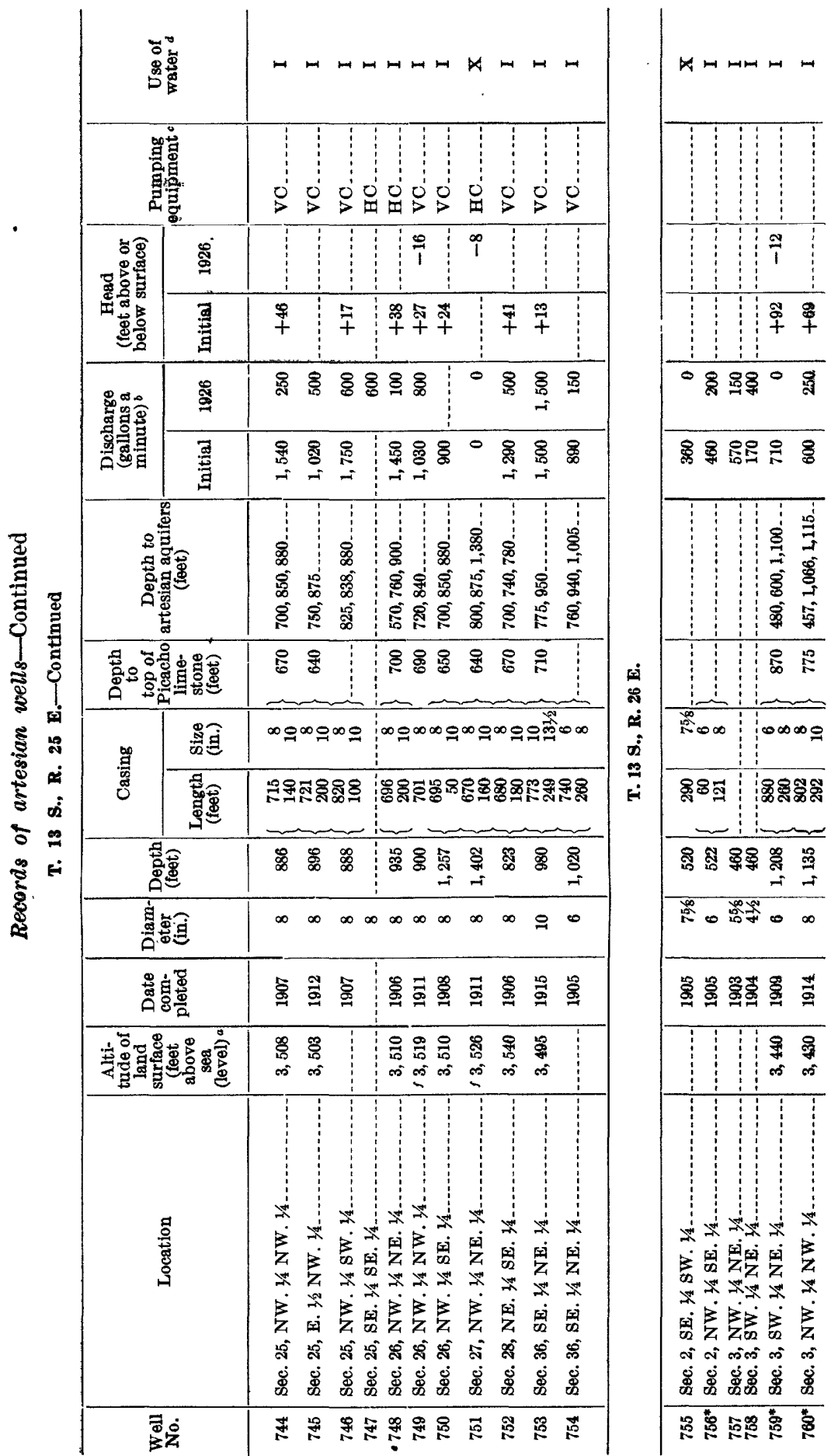




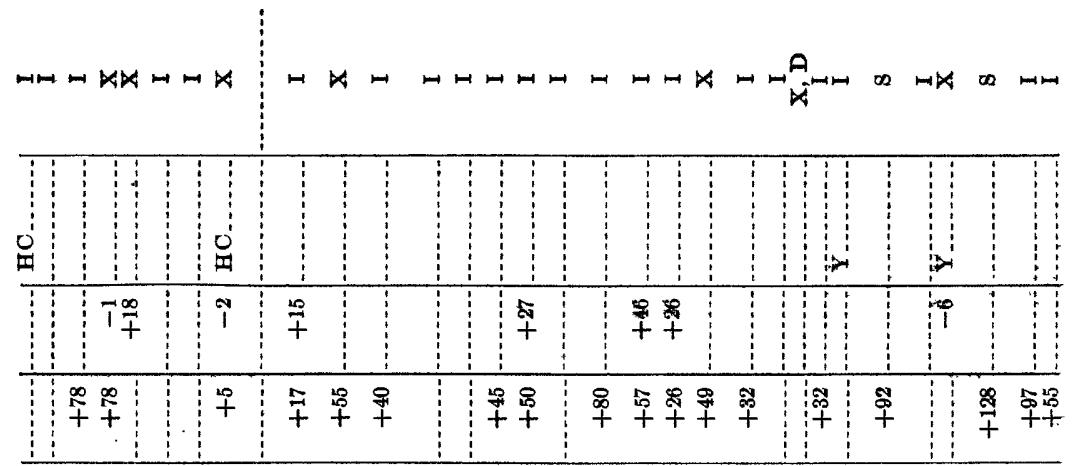

\begin{tabular}{|c|c|}
\hline 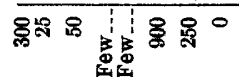 & 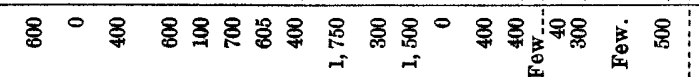 \\
\hline
\end{tabular}

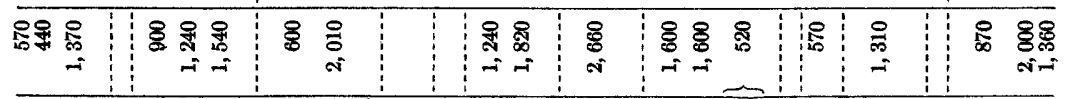

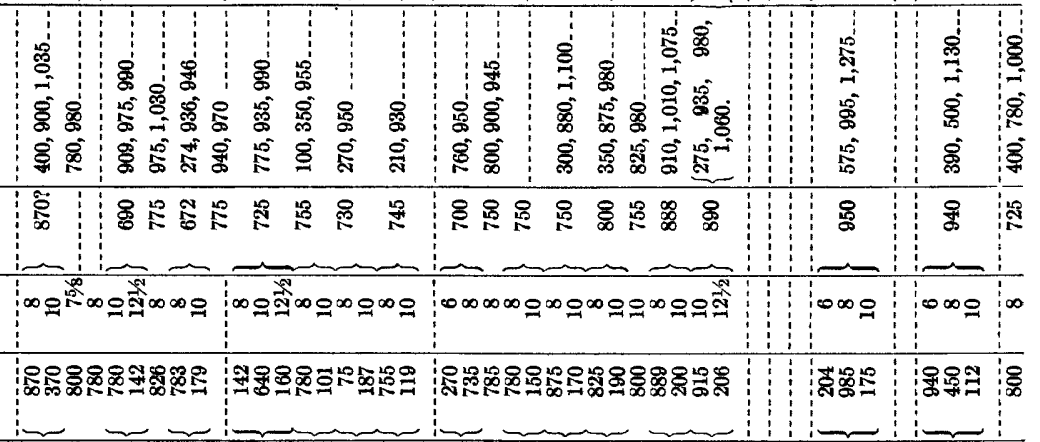

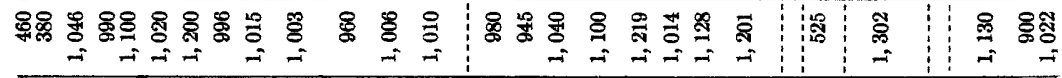

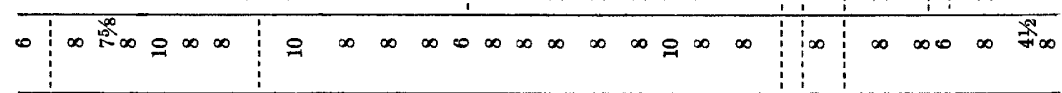

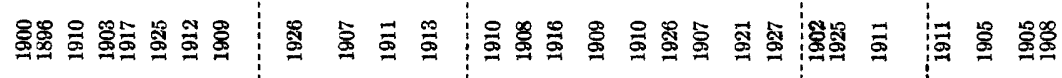

\begin{tabular}{|c|c|c|c|}
\hline 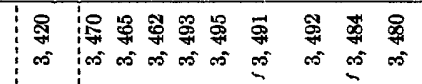 & 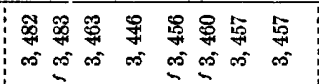 & $\underset{b}{\infty}$ & $\begin{array}{l:l}f & 8 \\
\infty & \infty\end{array}$ \\
\hline
\end{tabular}

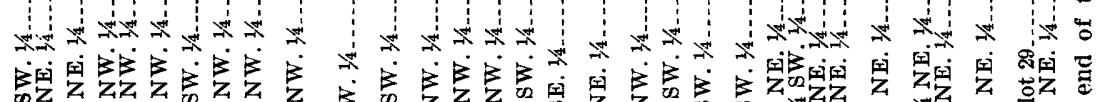

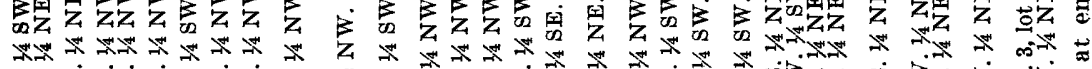

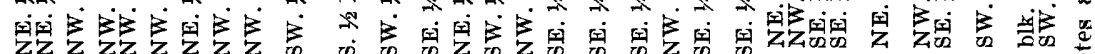
क⿱艹

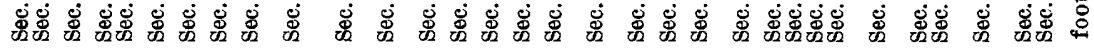

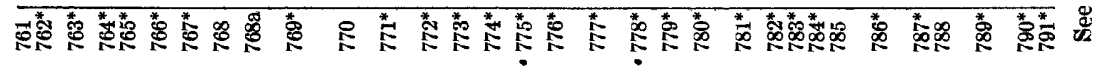




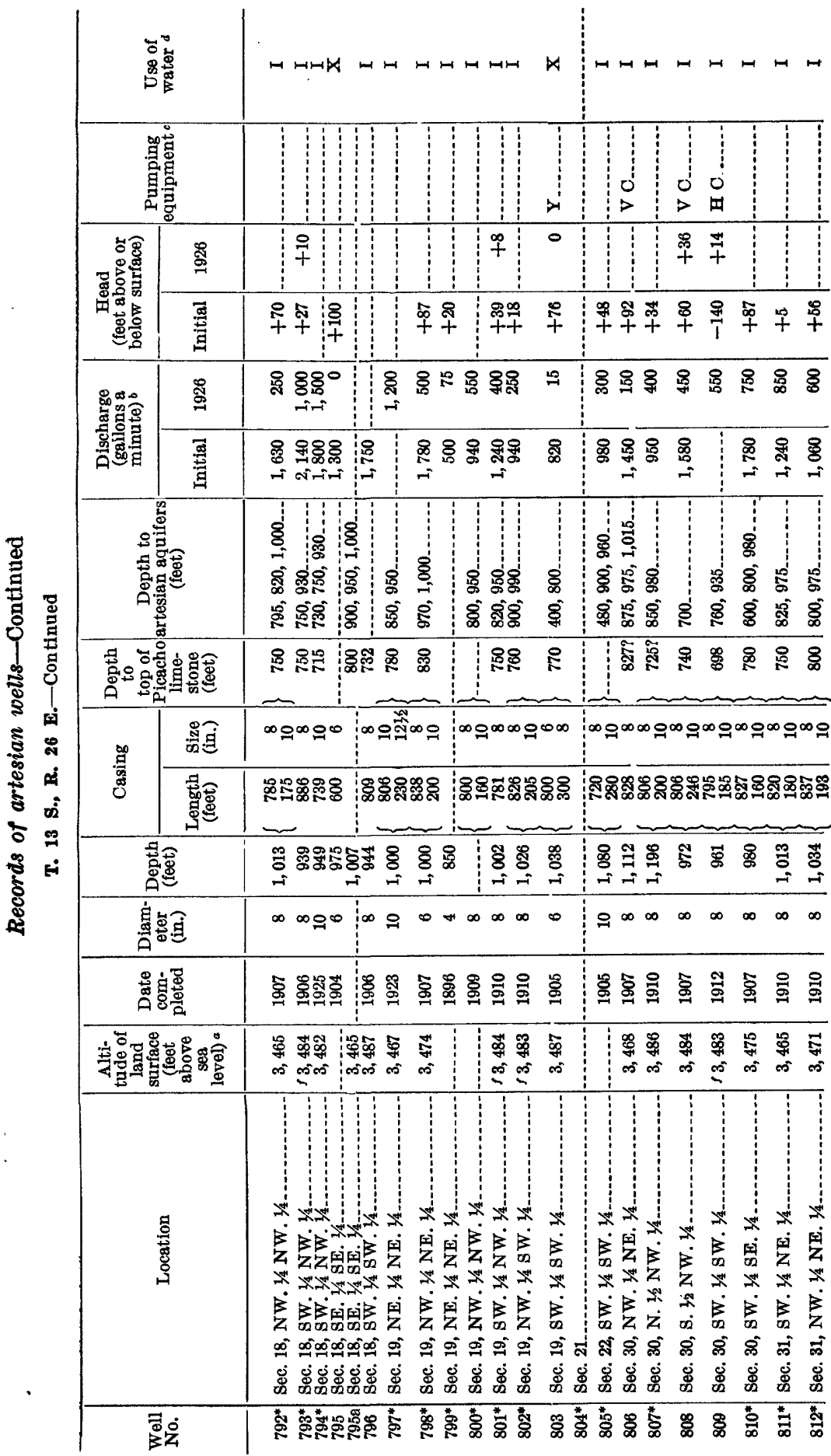




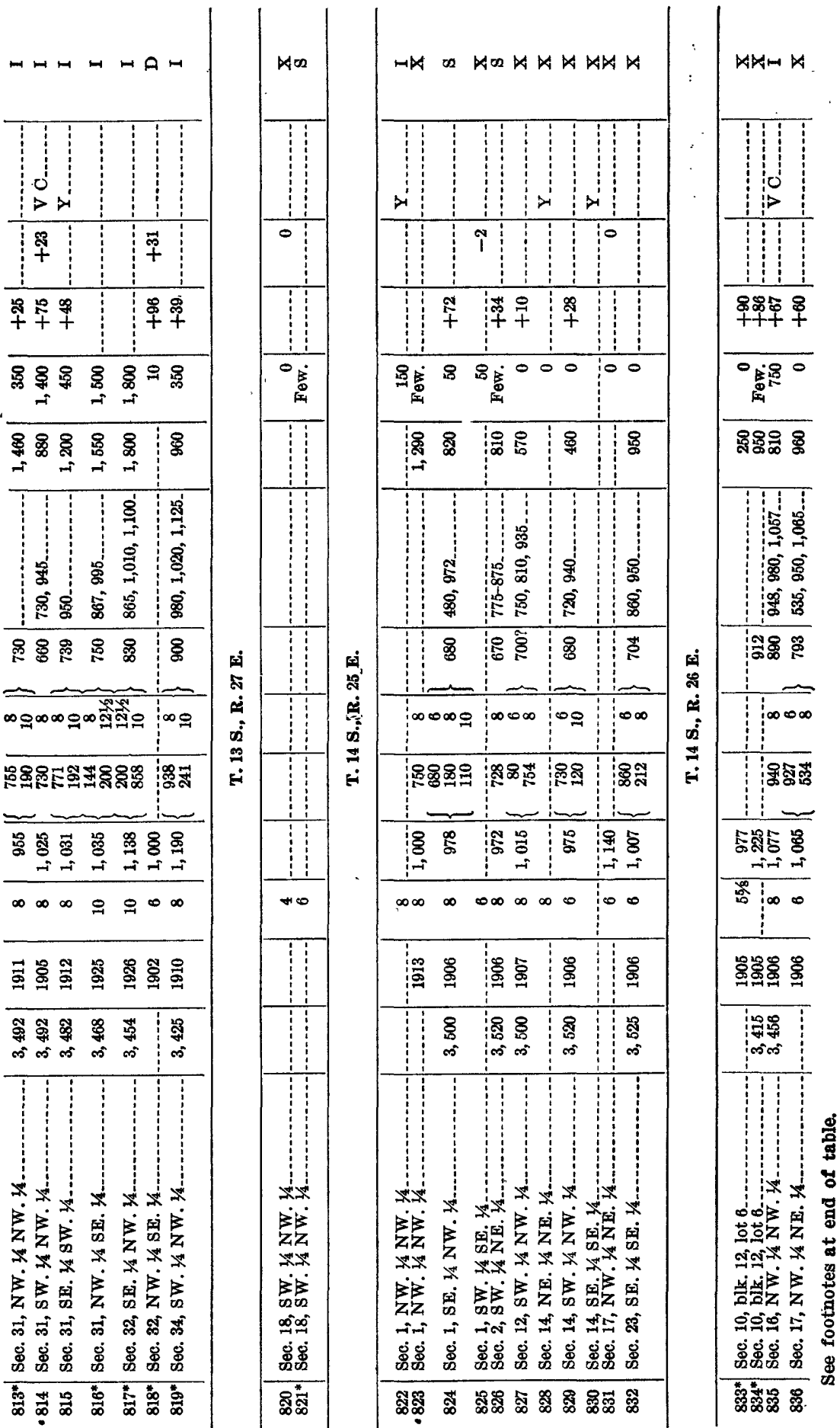




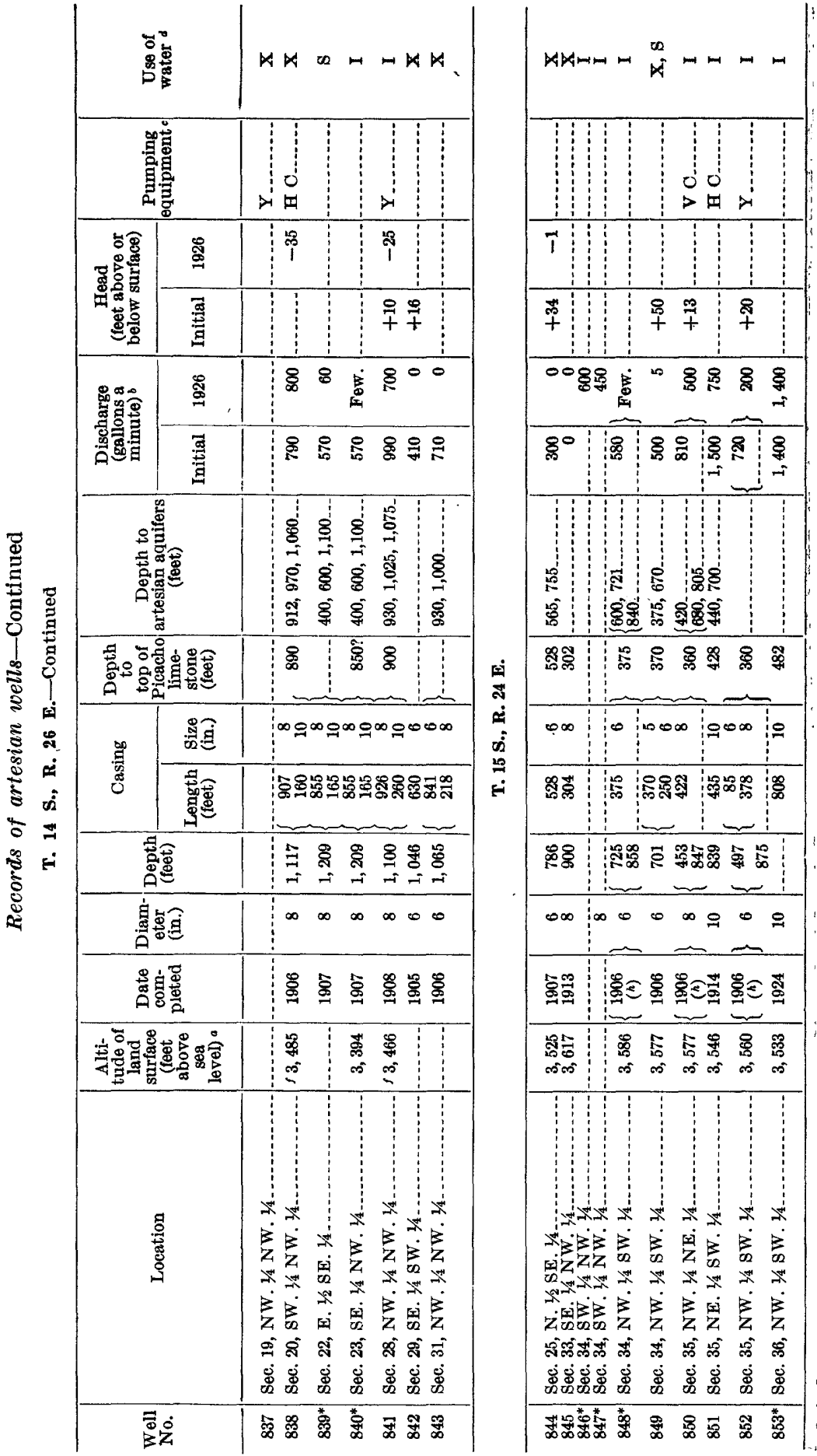




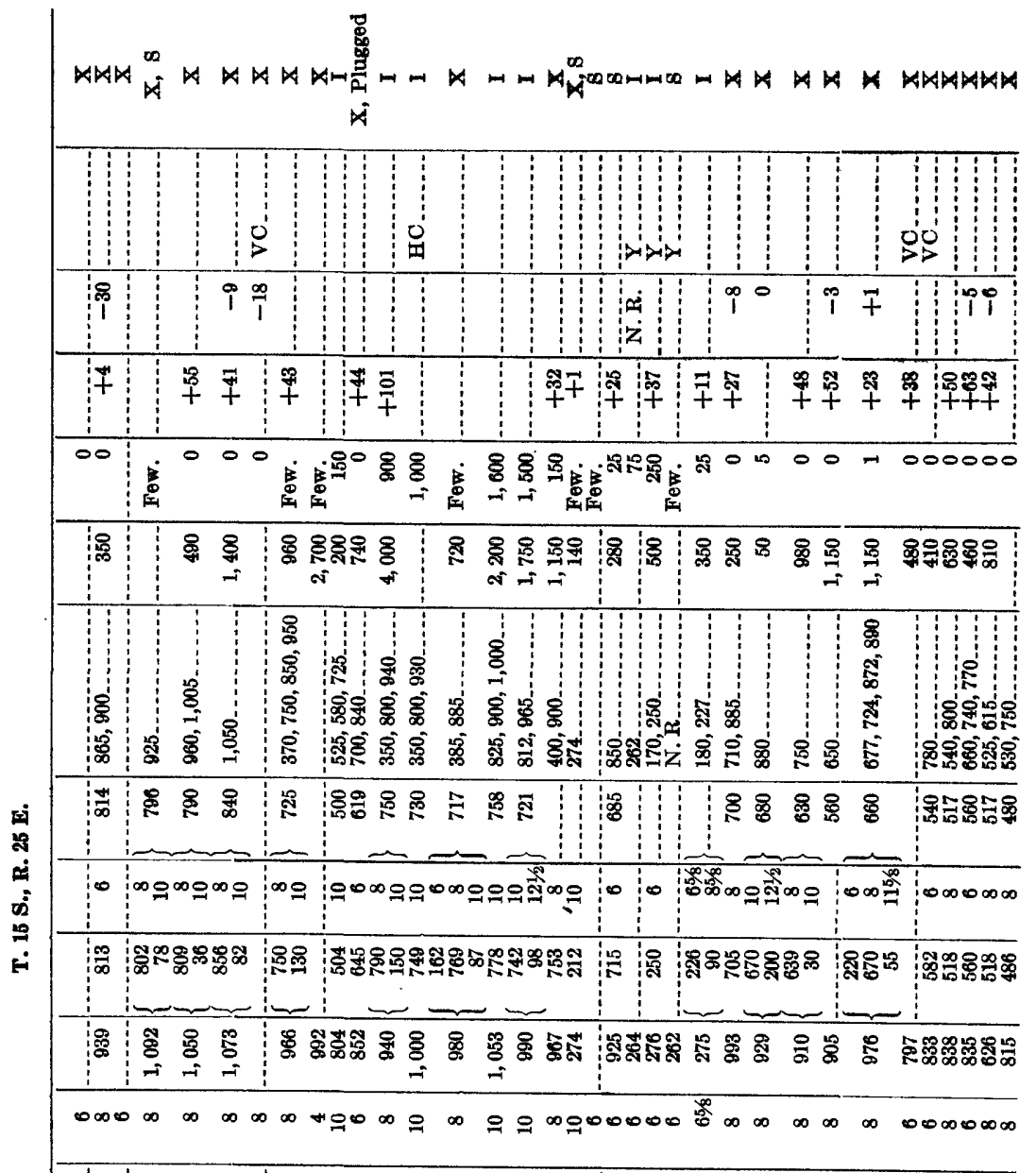

兽

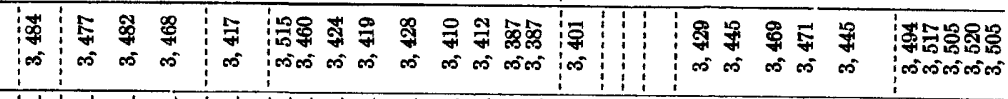

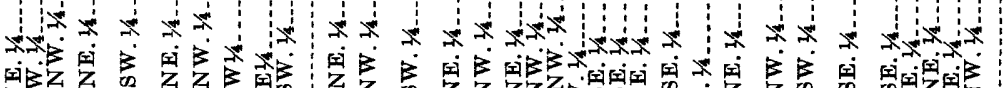

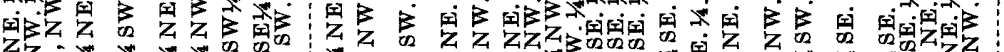

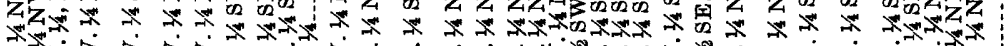

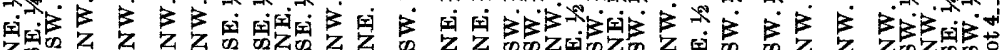

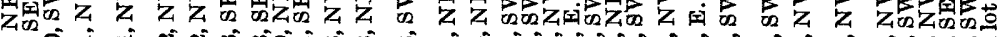

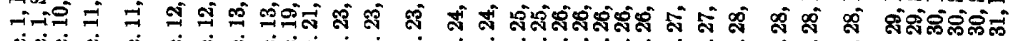

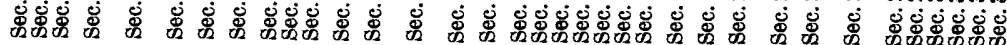

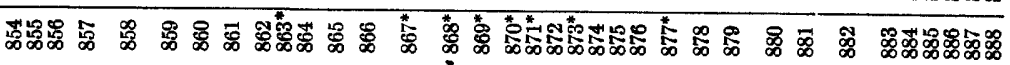

\section{这




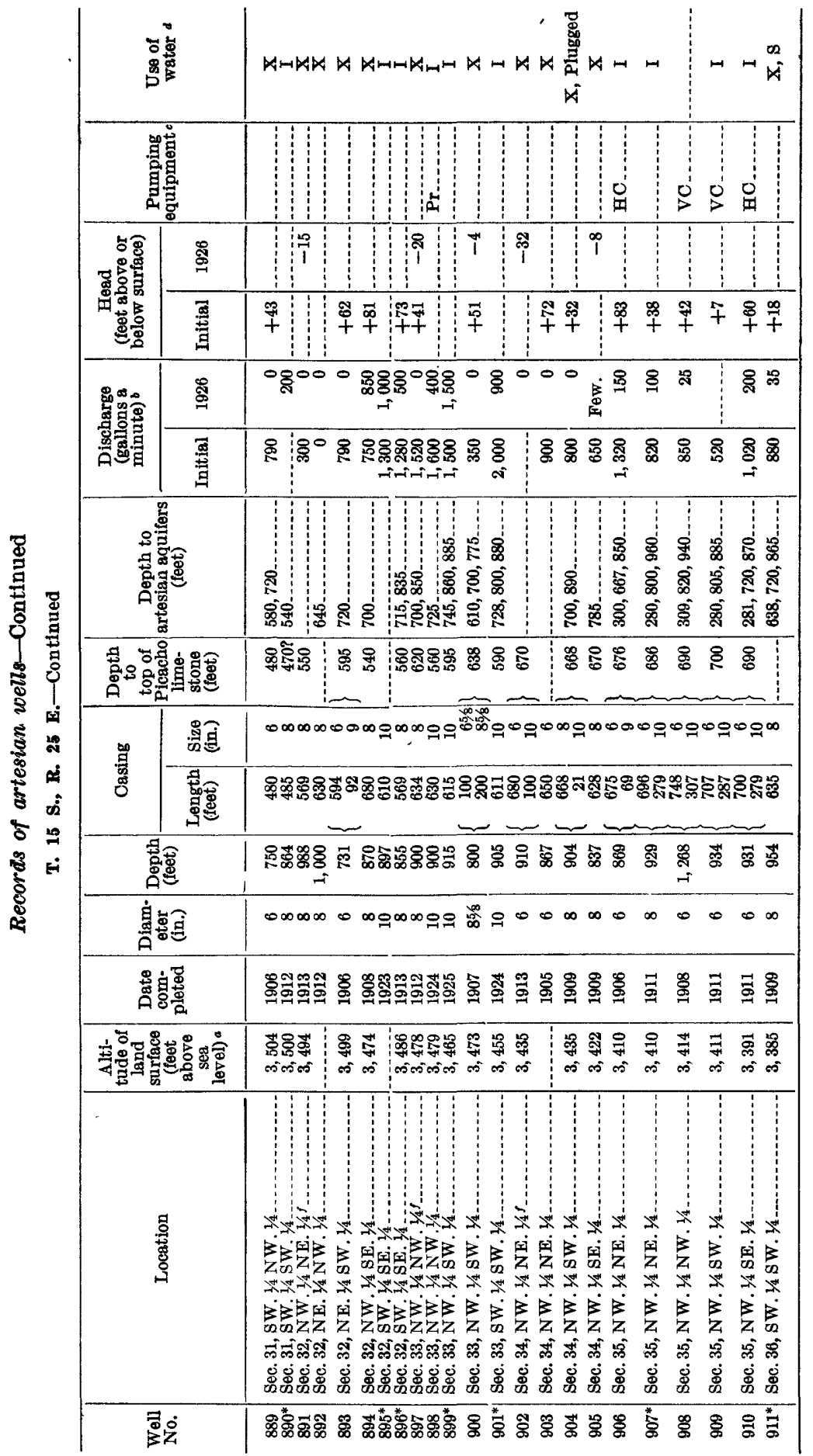




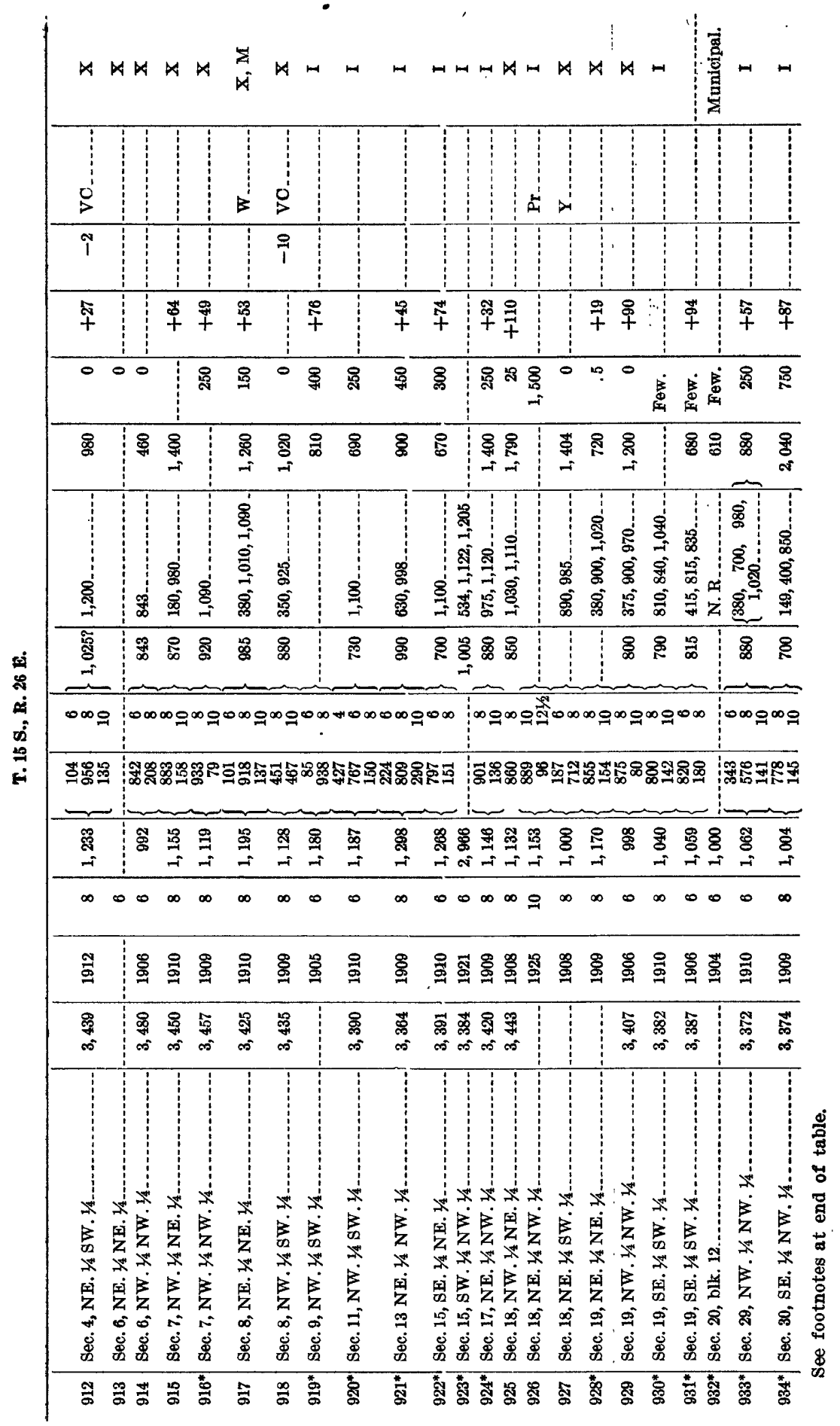



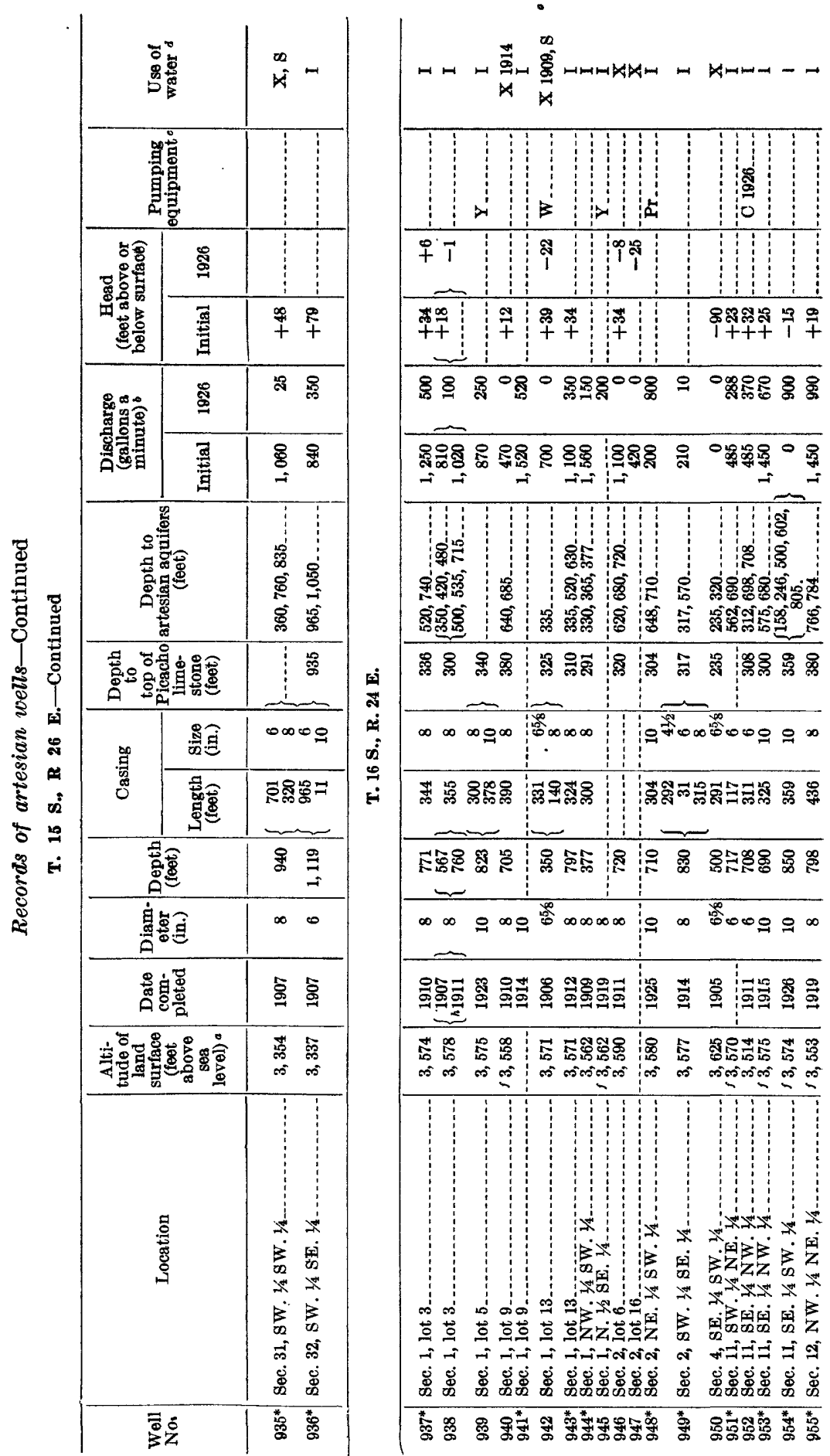

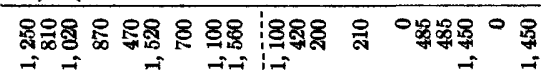

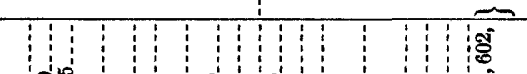
票

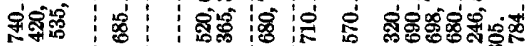

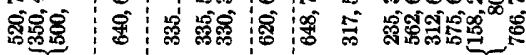

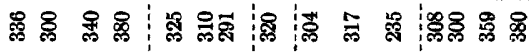

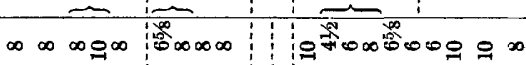

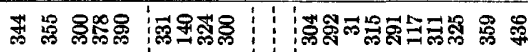

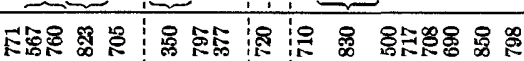

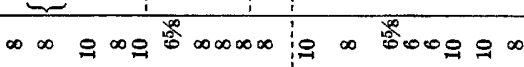

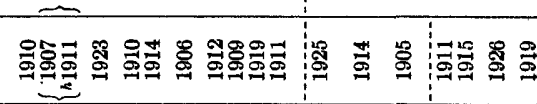

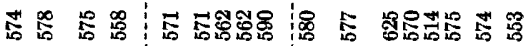

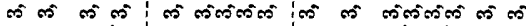

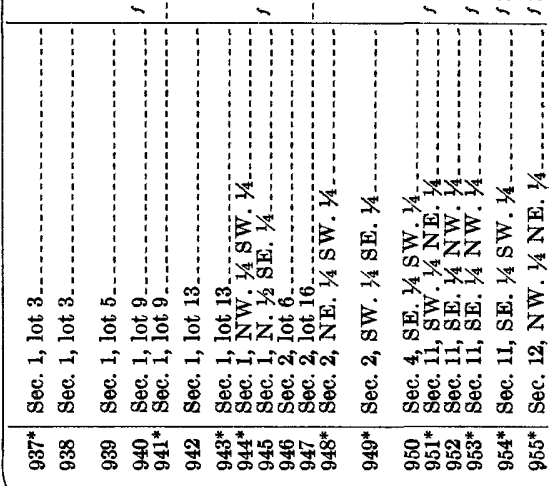




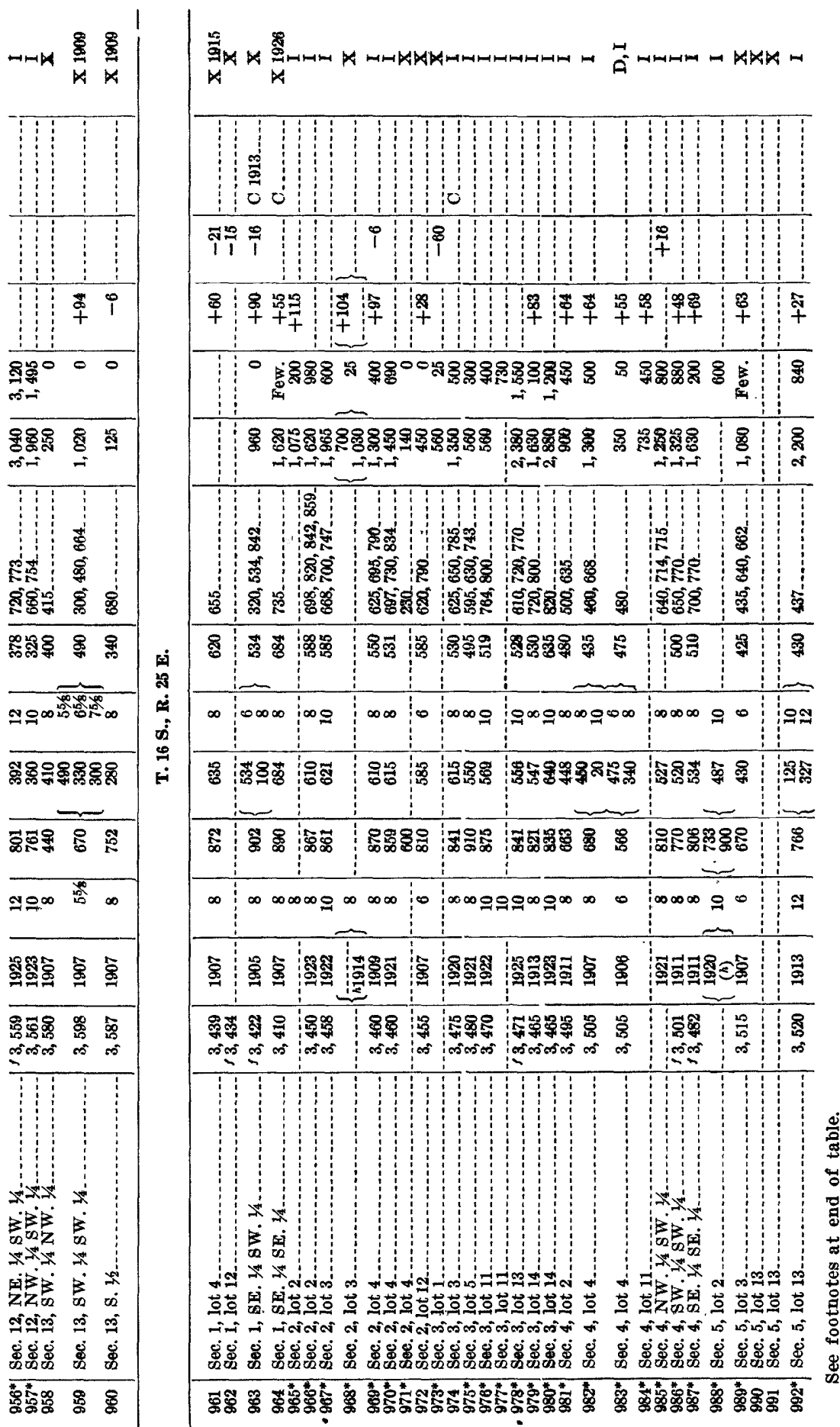

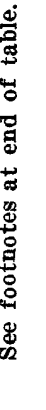




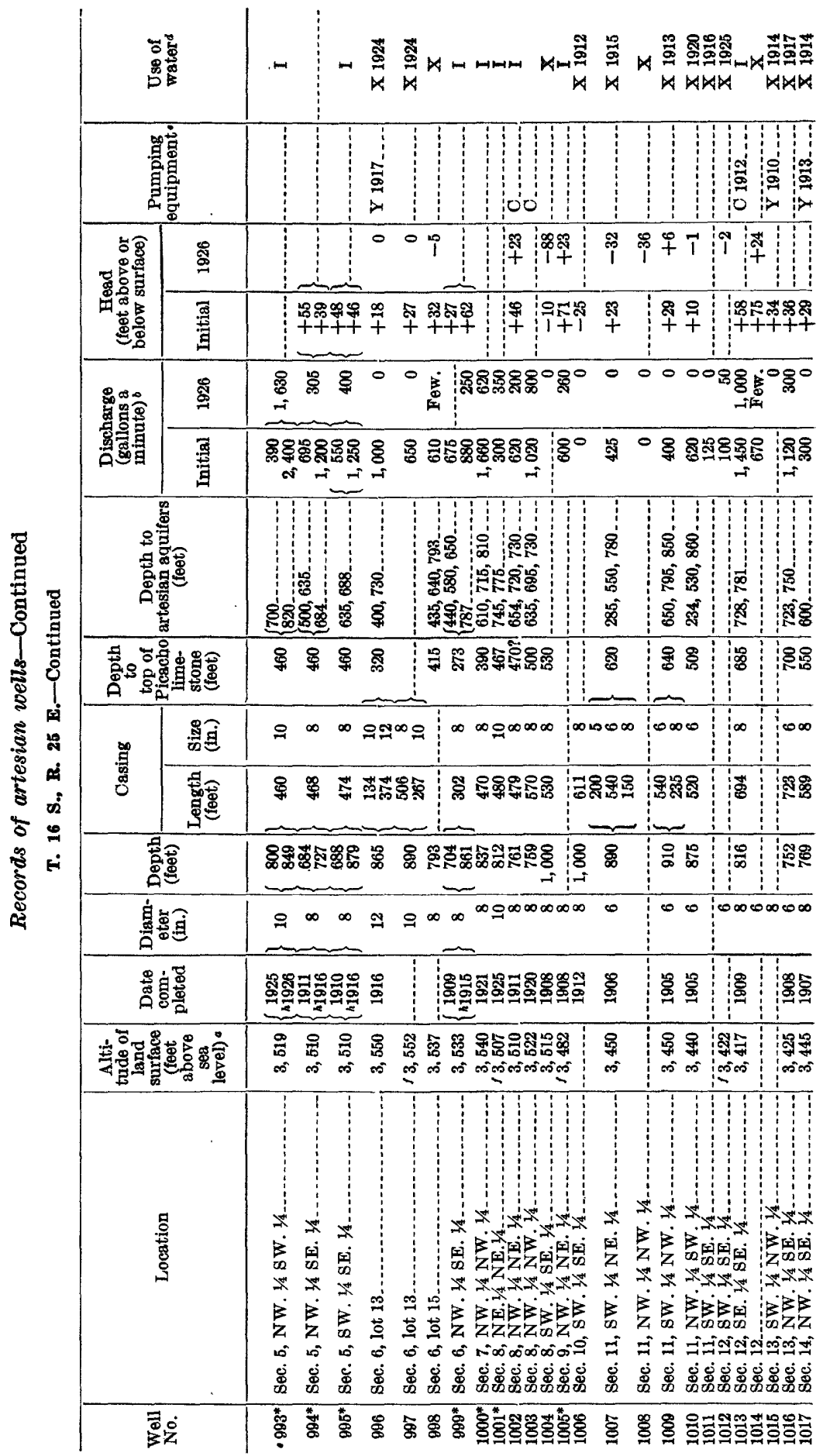




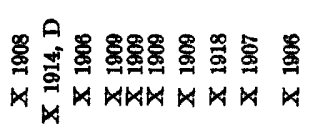

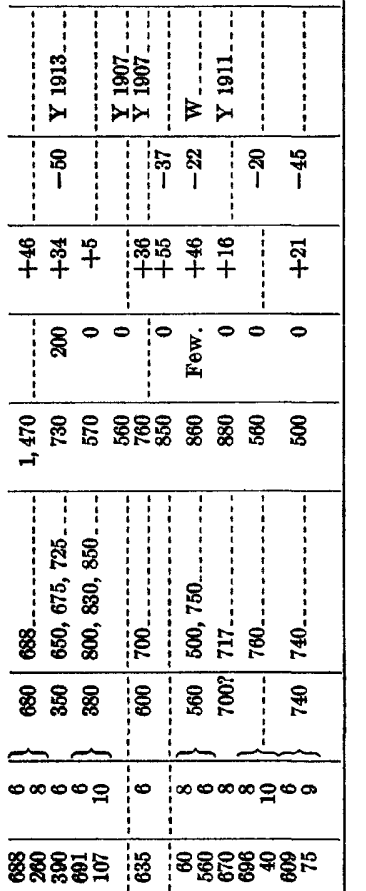

$\sim \mathrm{N}^{2} \sim$

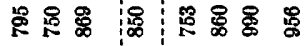

$\infty \infty \infty \infty \infty \infty \infty \infty \infty$

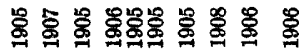

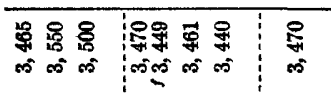

$x$

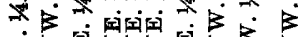

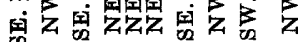

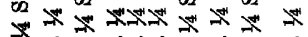

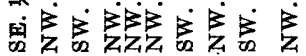

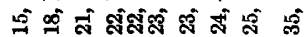

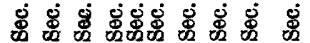

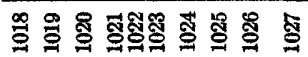

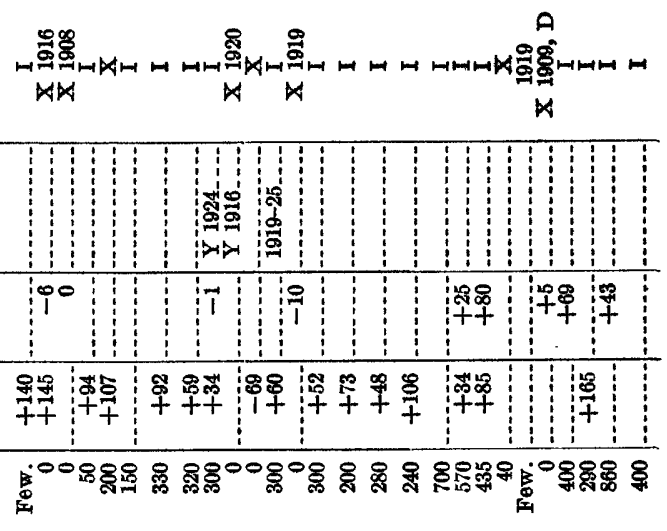

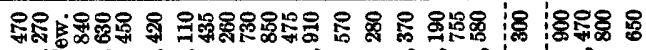

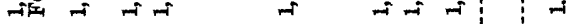

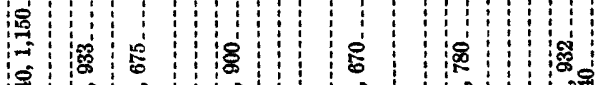

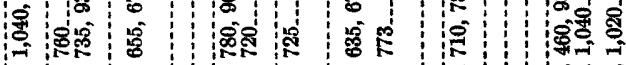

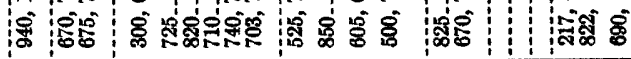

;

:

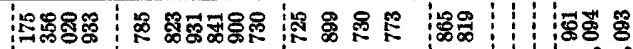

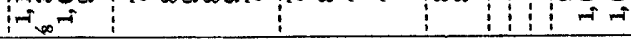

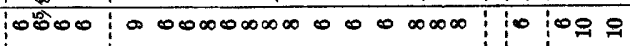

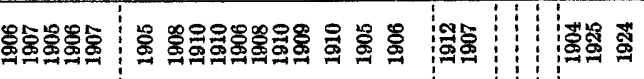

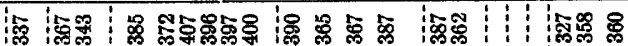

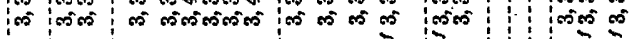

$x_{x}$

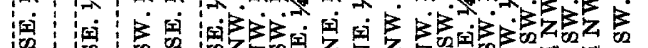

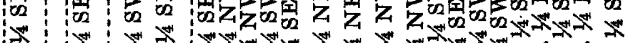
ond

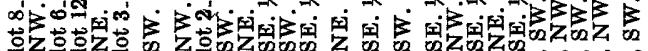

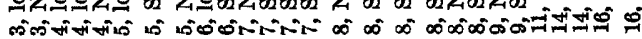

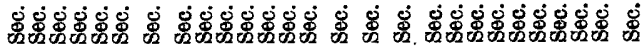

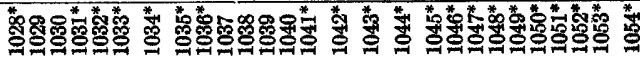




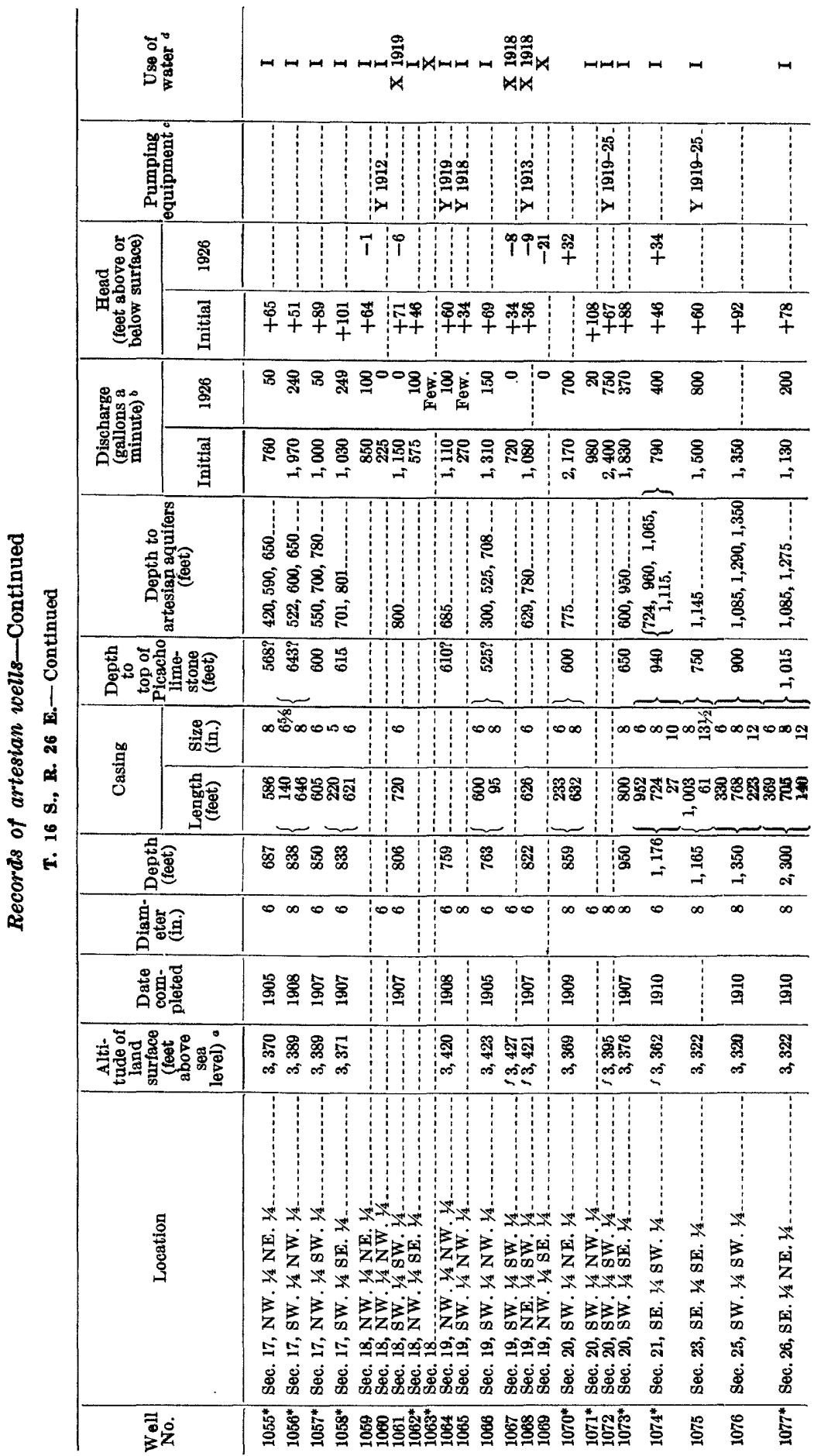




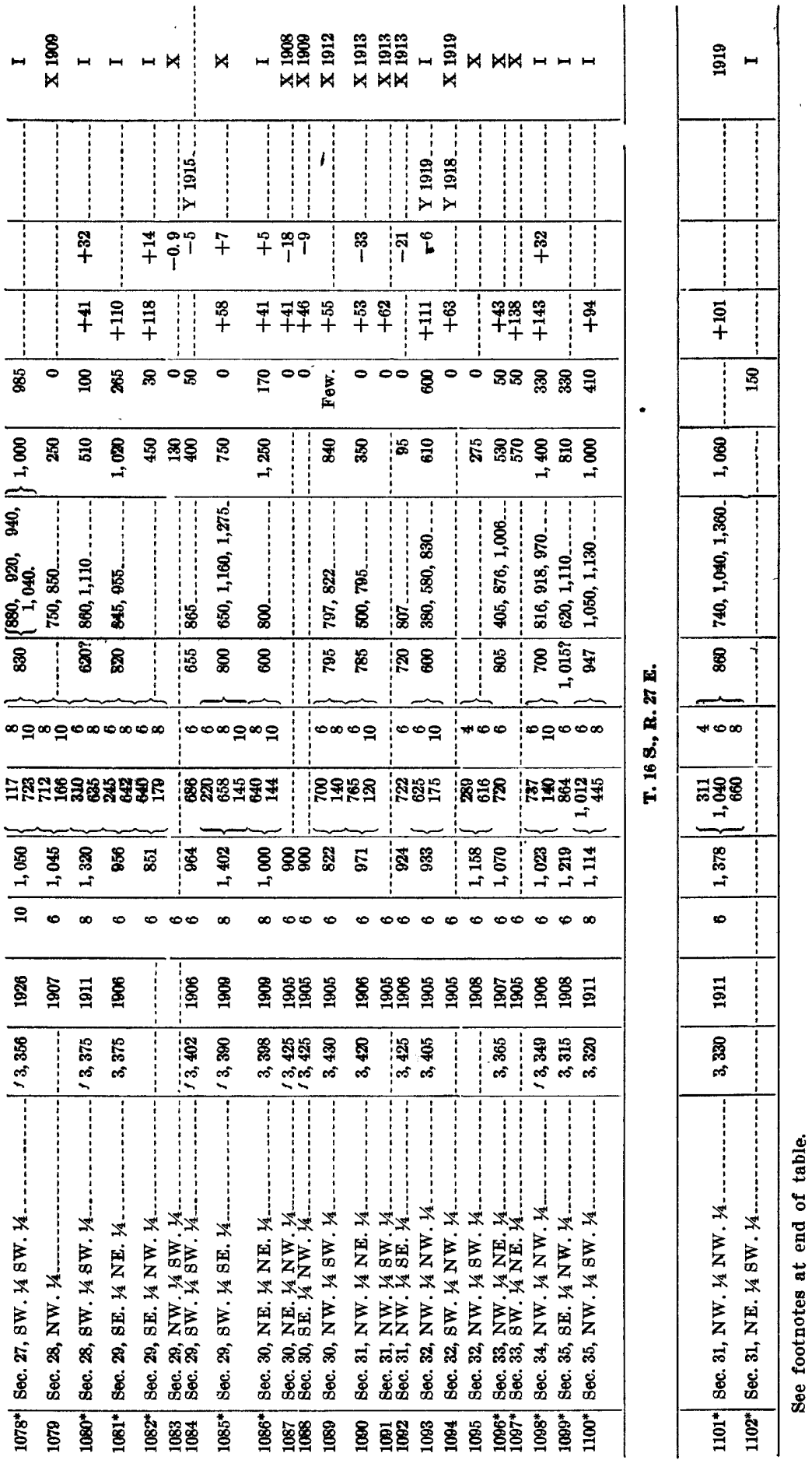




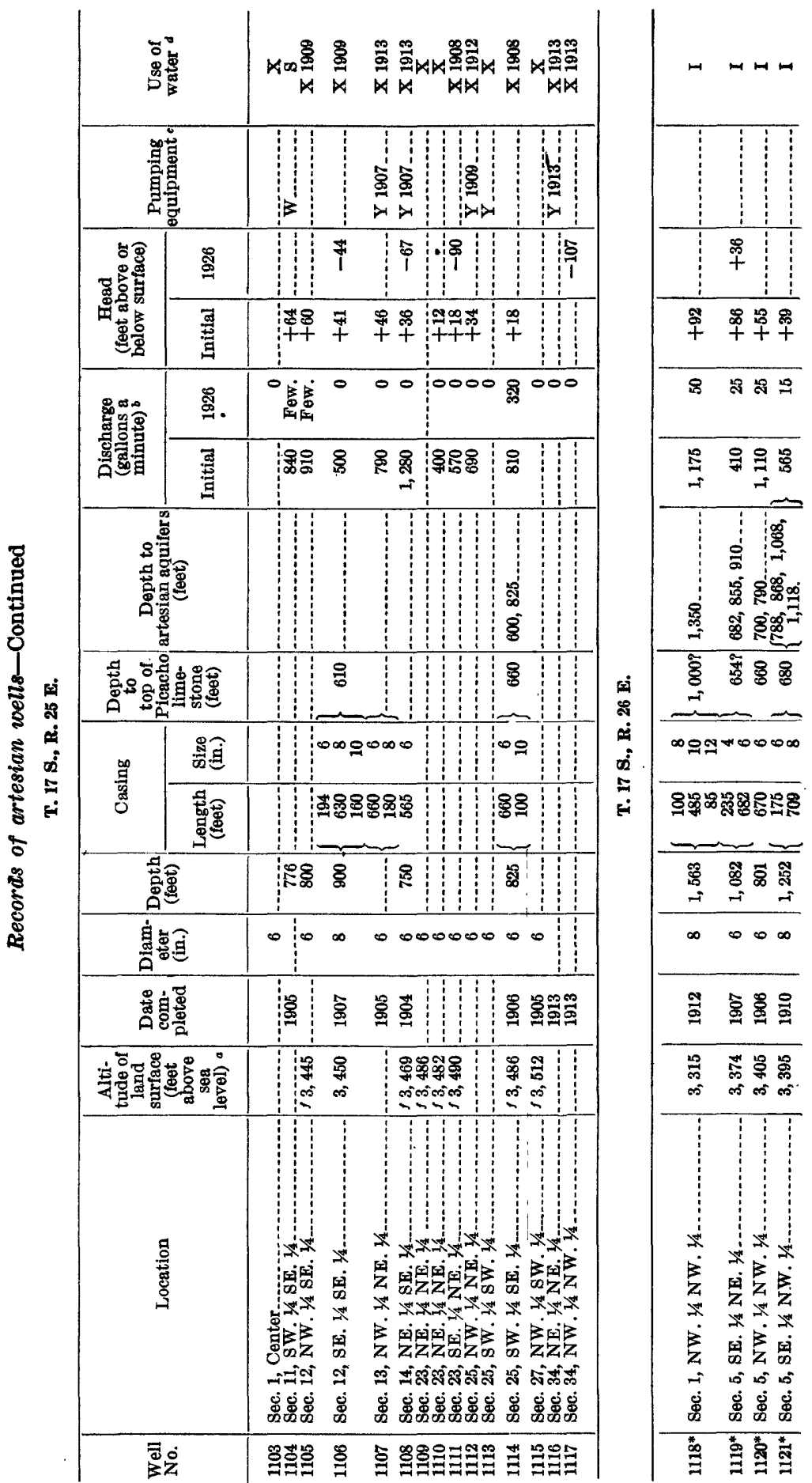




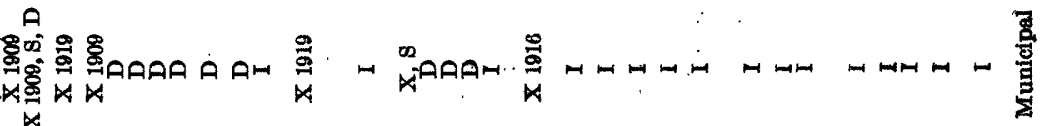

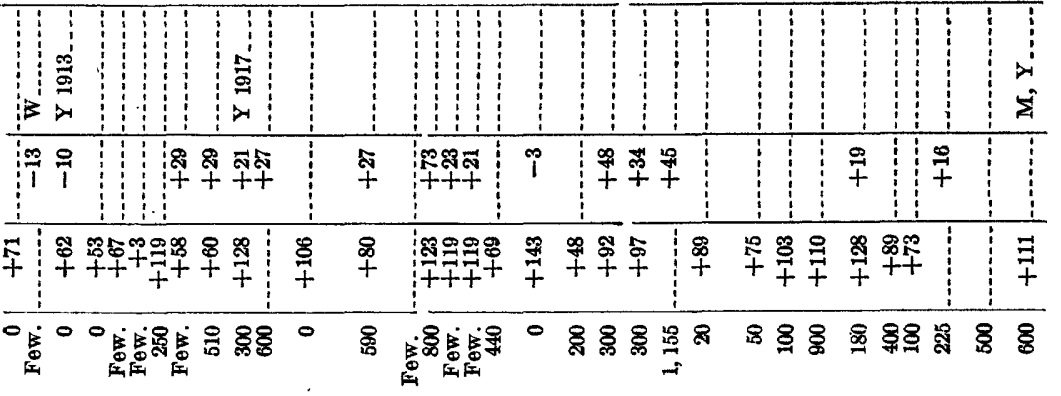

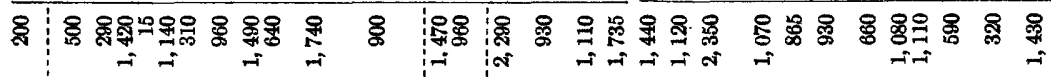

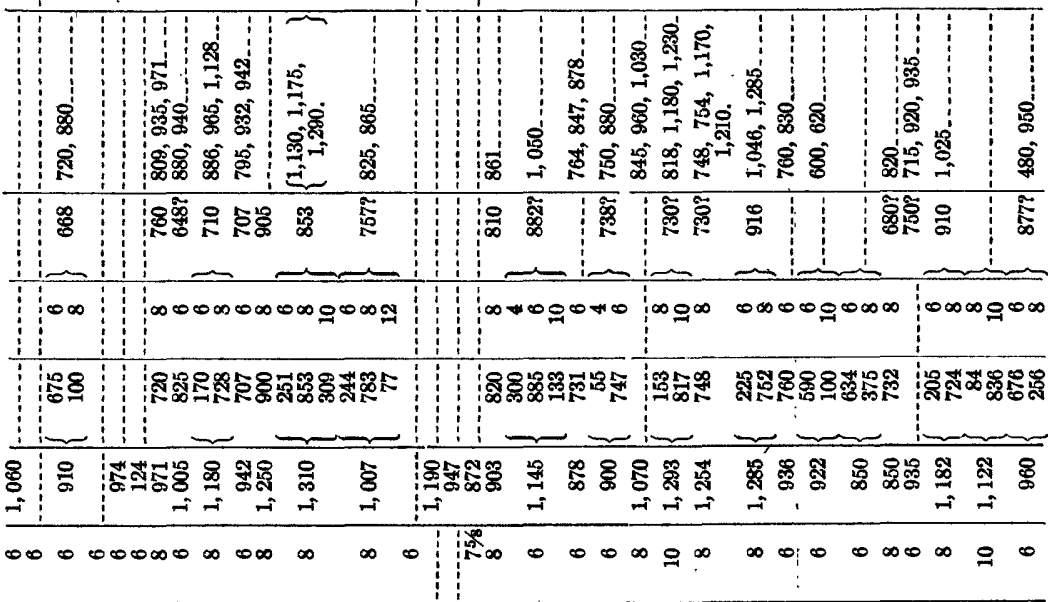

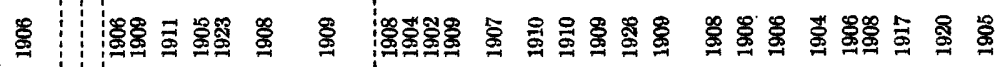

央

$\lim _{x \rightarrow+\infty}$

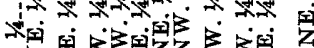

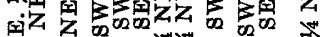

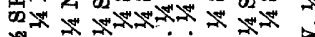
辰

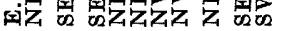

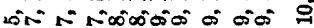

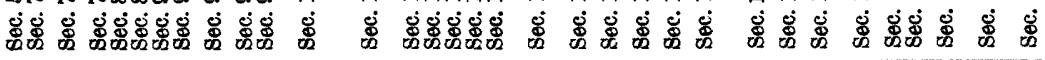

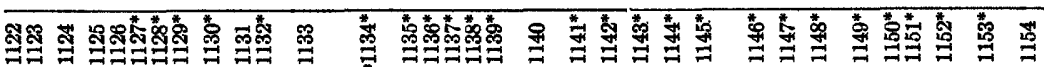
我

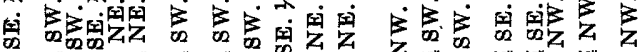
Х.

\section{位}

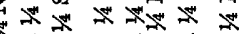
< 分安得落

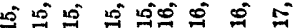
\$ू 


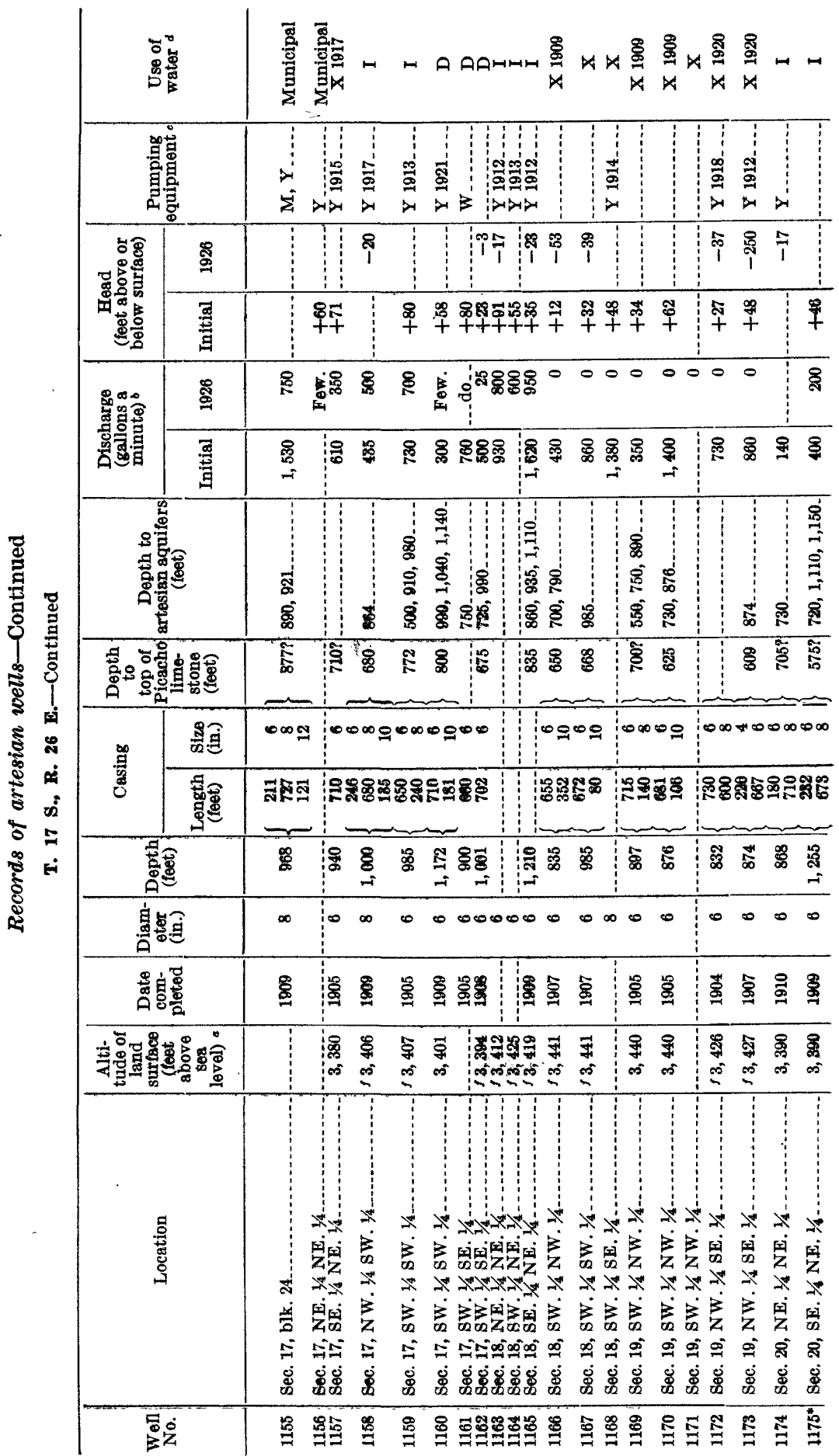




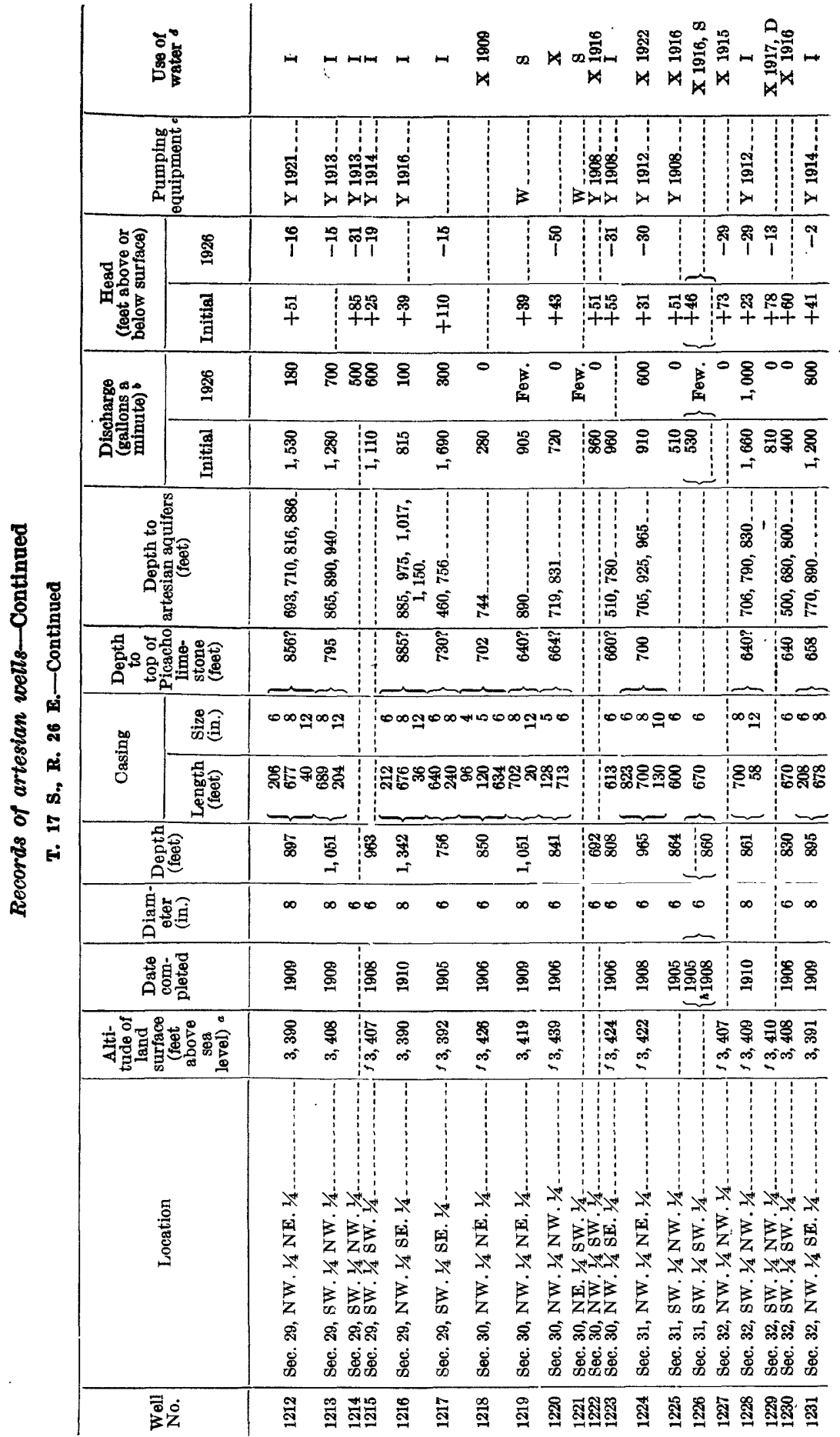




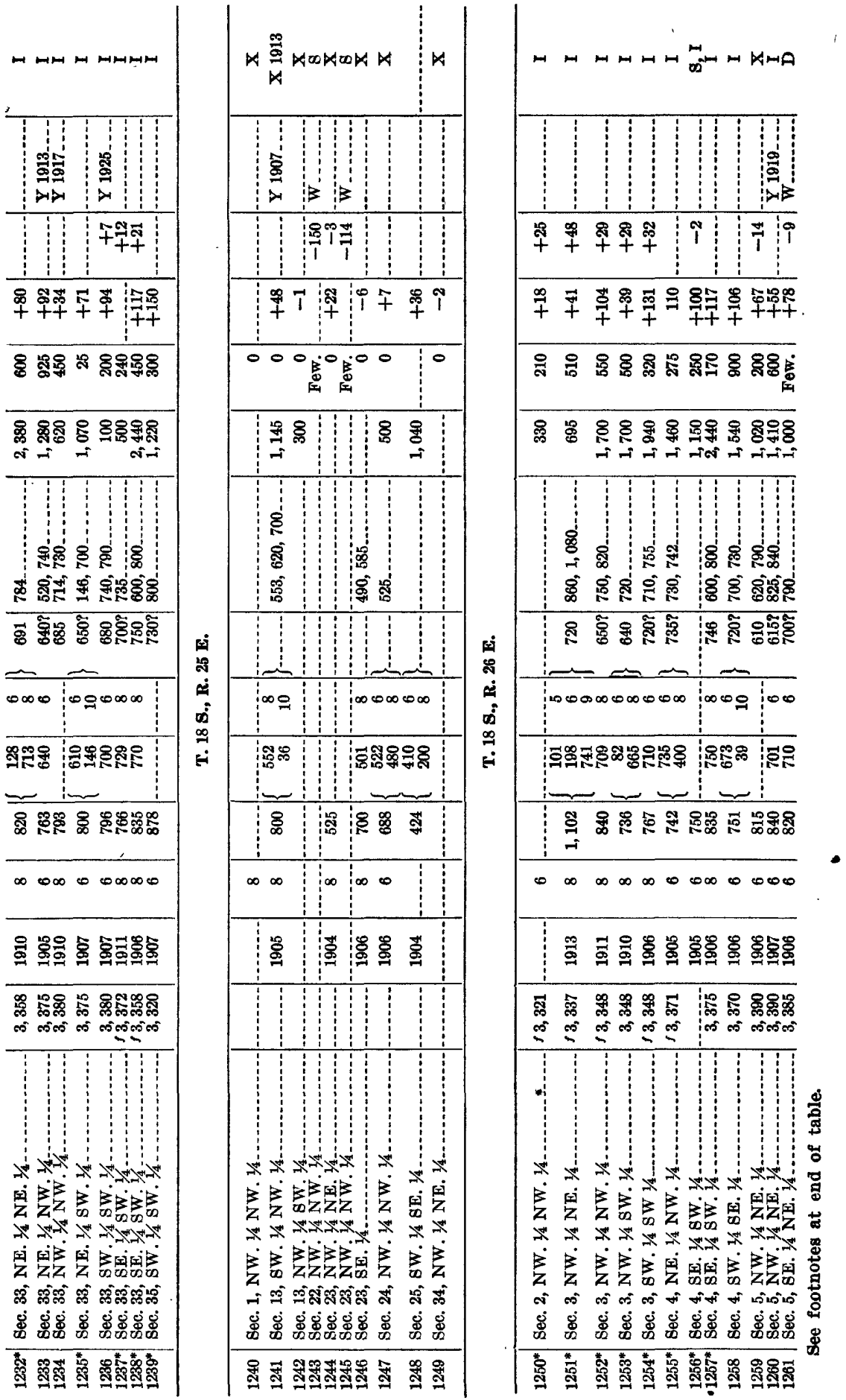




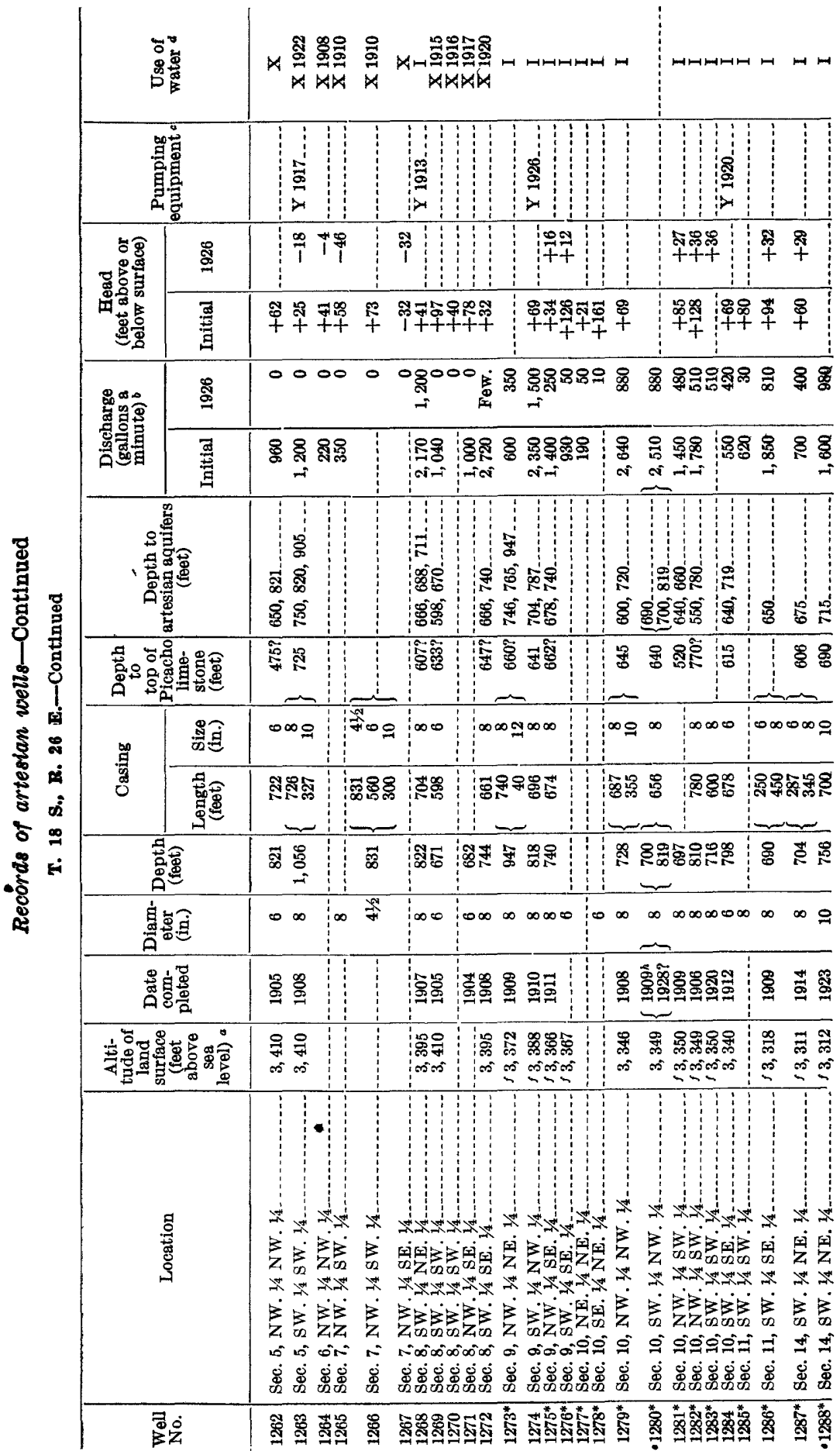




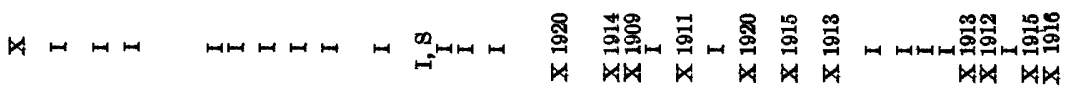

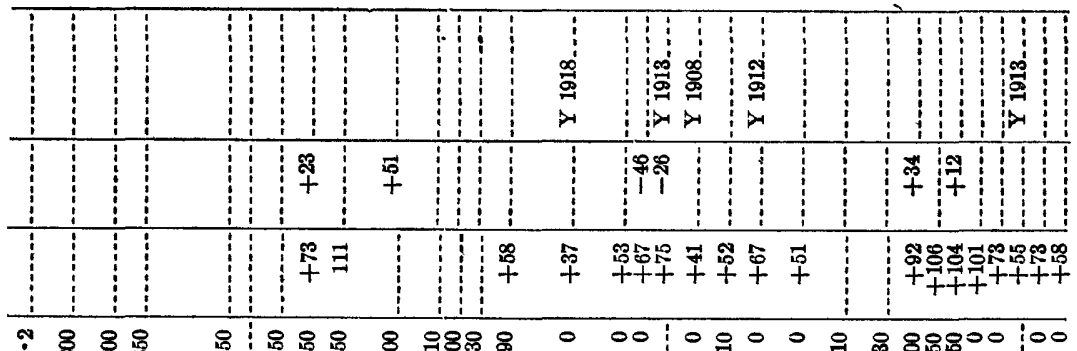

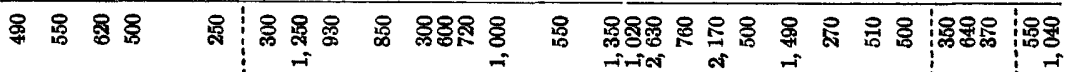

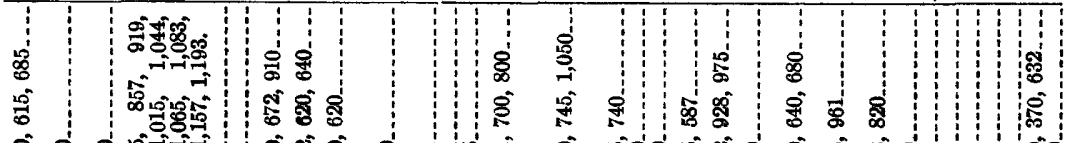

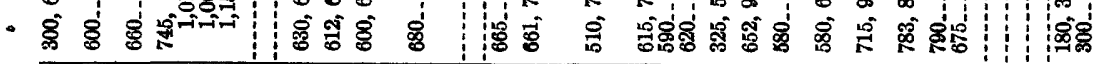

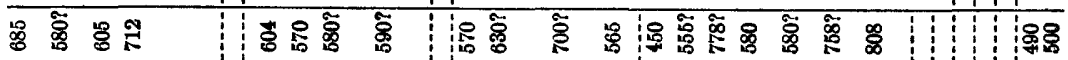

\begin{tabular}{|c|c|c|c|}
\hline mon & & $i$ & 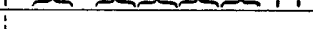 \\
\hline
\end{tabular}

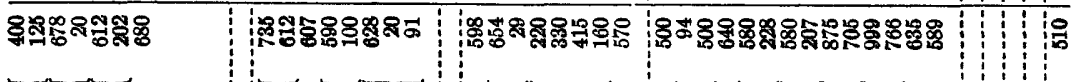

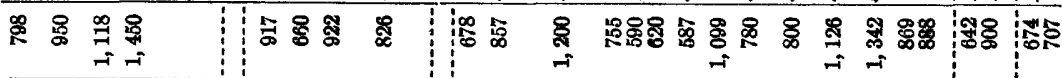

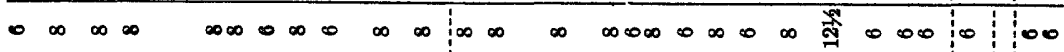

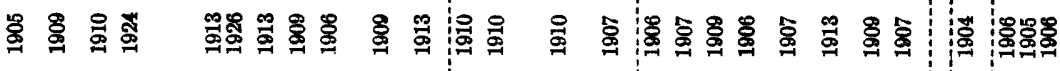

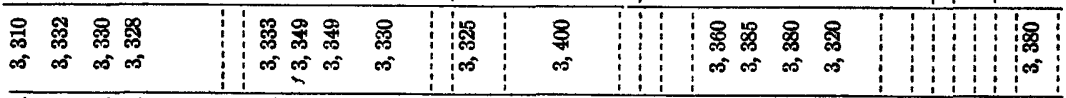

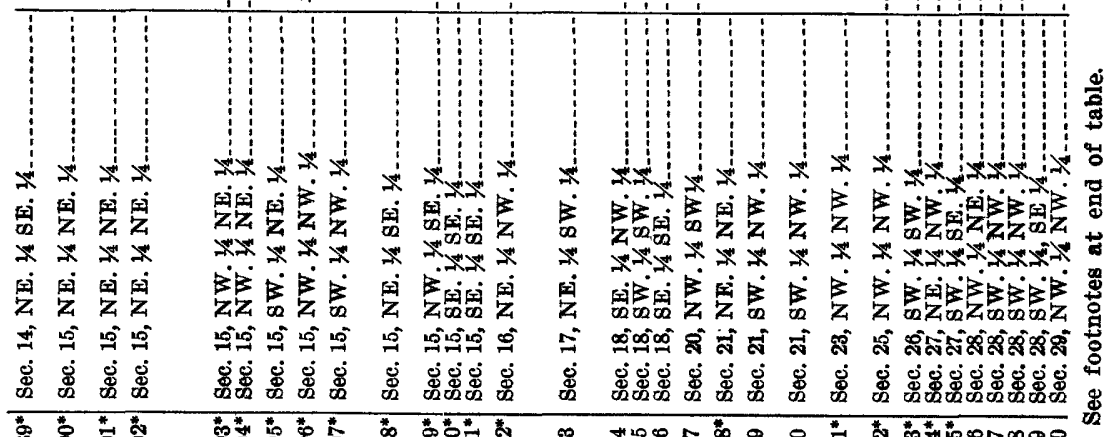

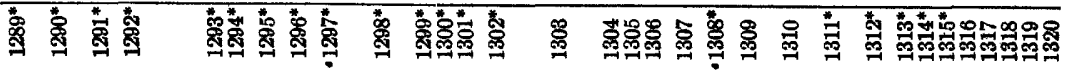
135252-33-23 


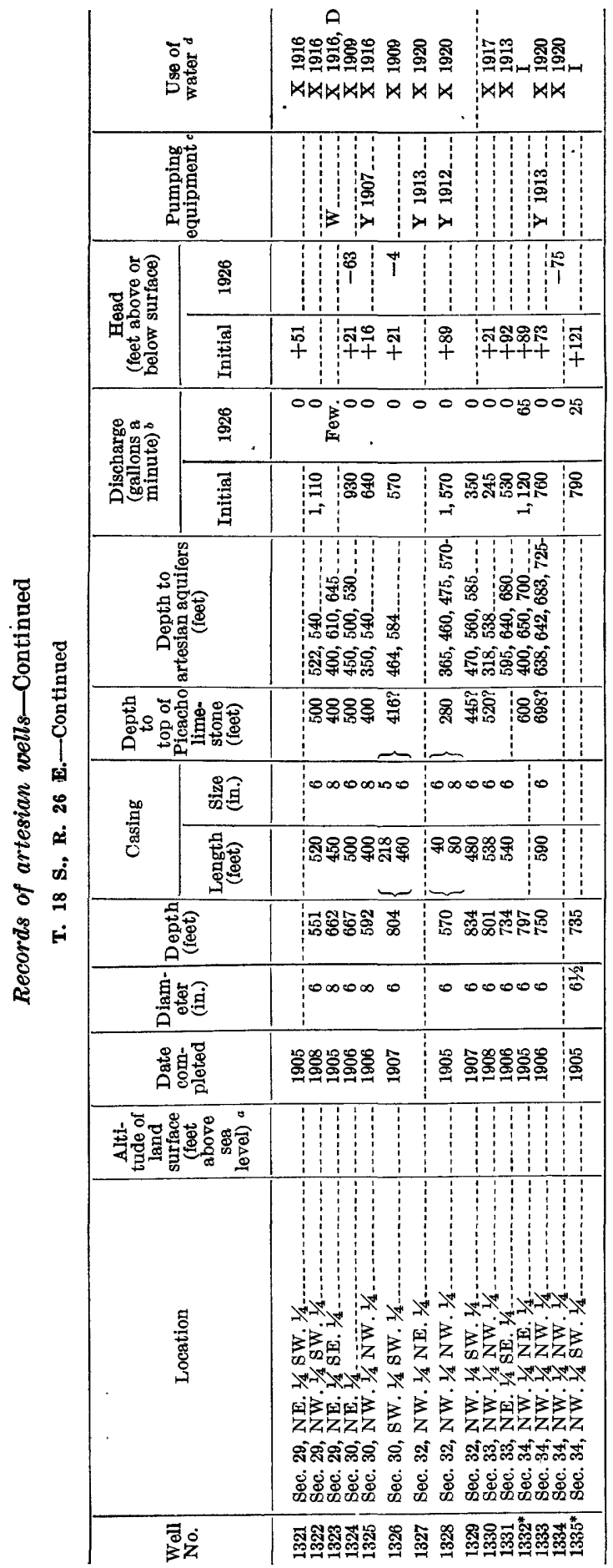

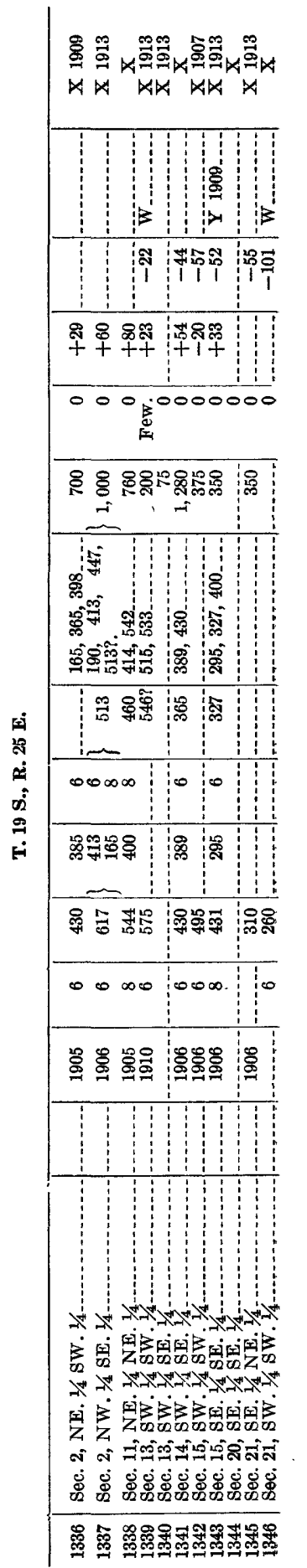




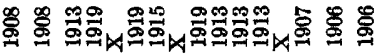

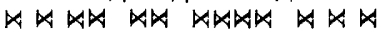

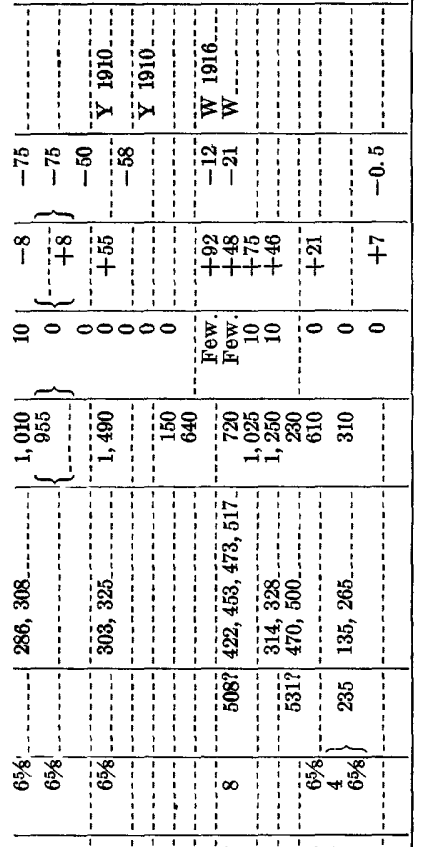

丞

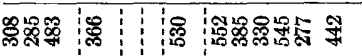

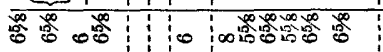

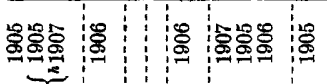

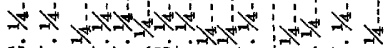

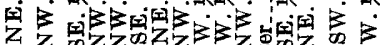

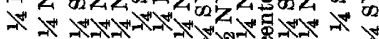

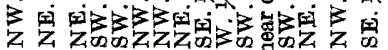

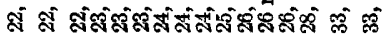

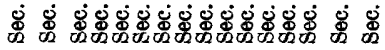

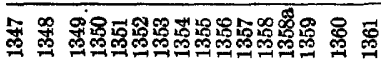

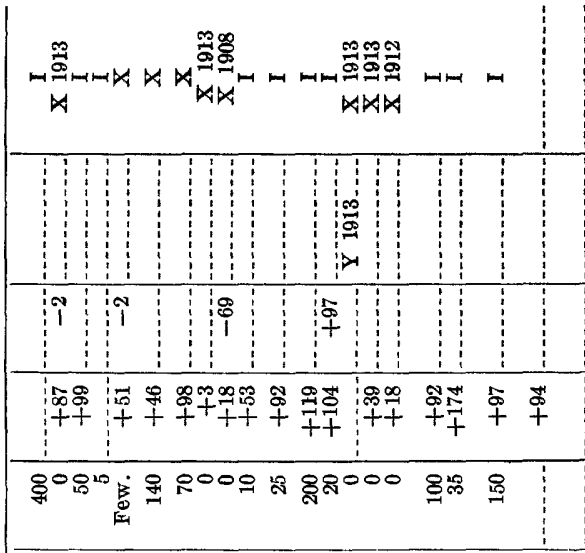

융

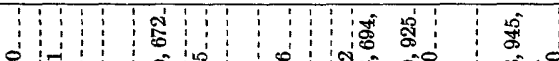
\& $\quad$ क ง \%

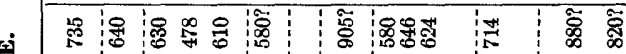
สิ

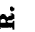
के i

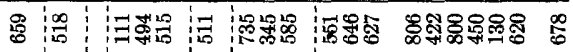

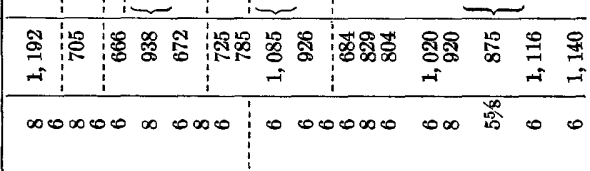

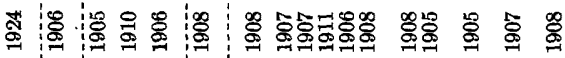

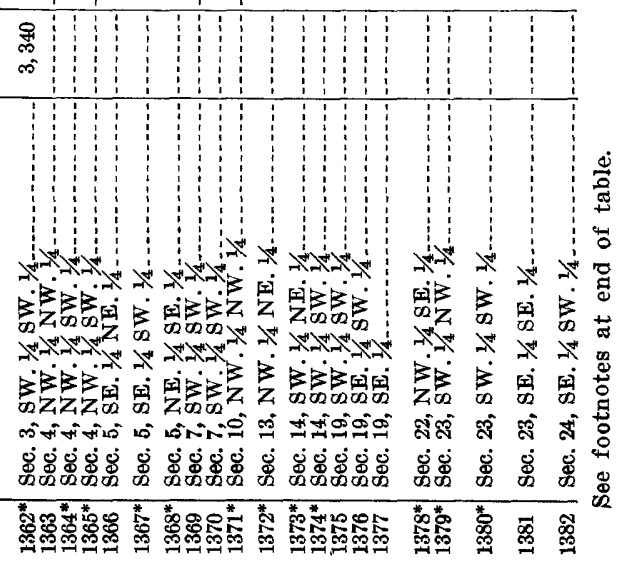




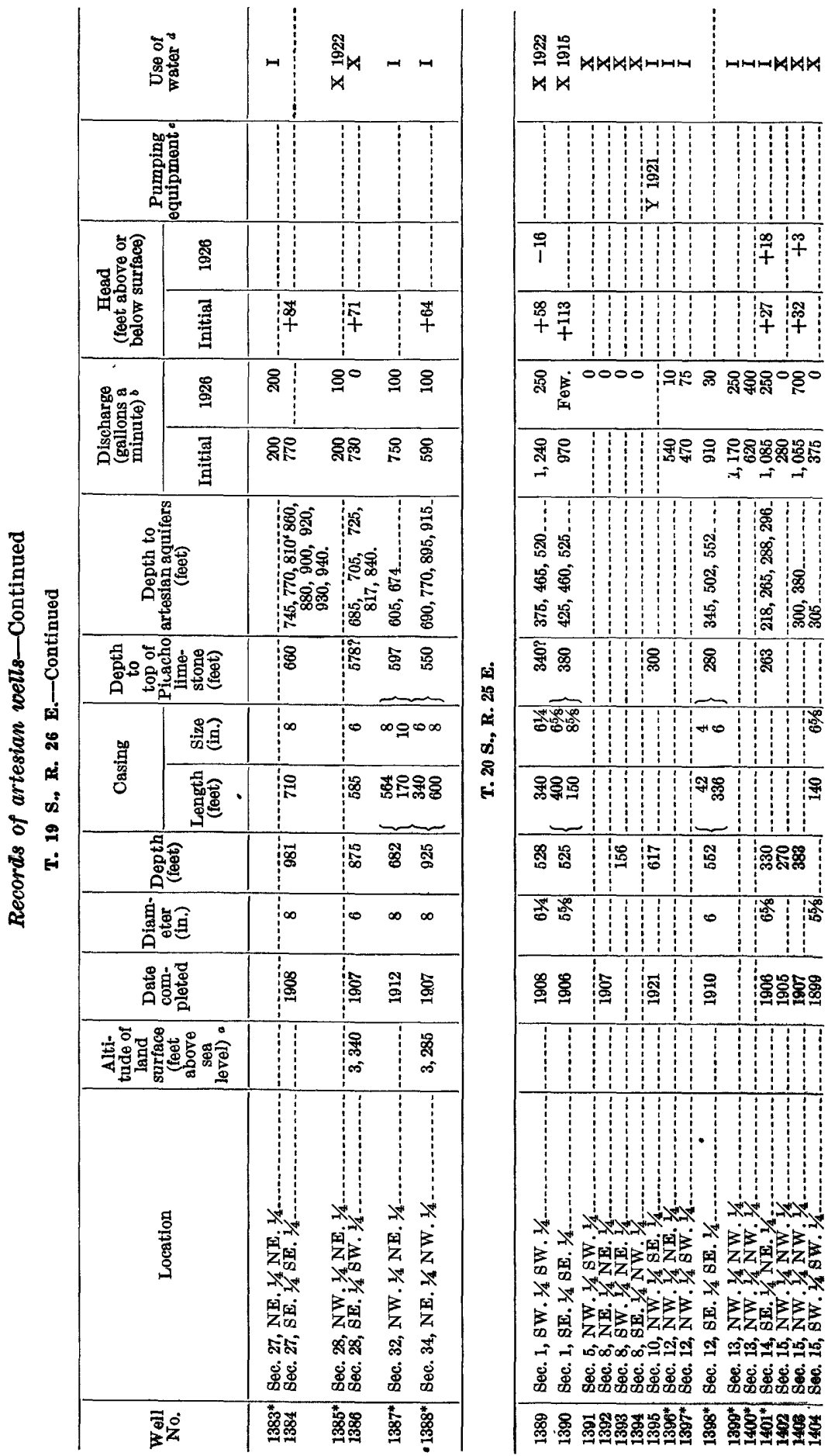




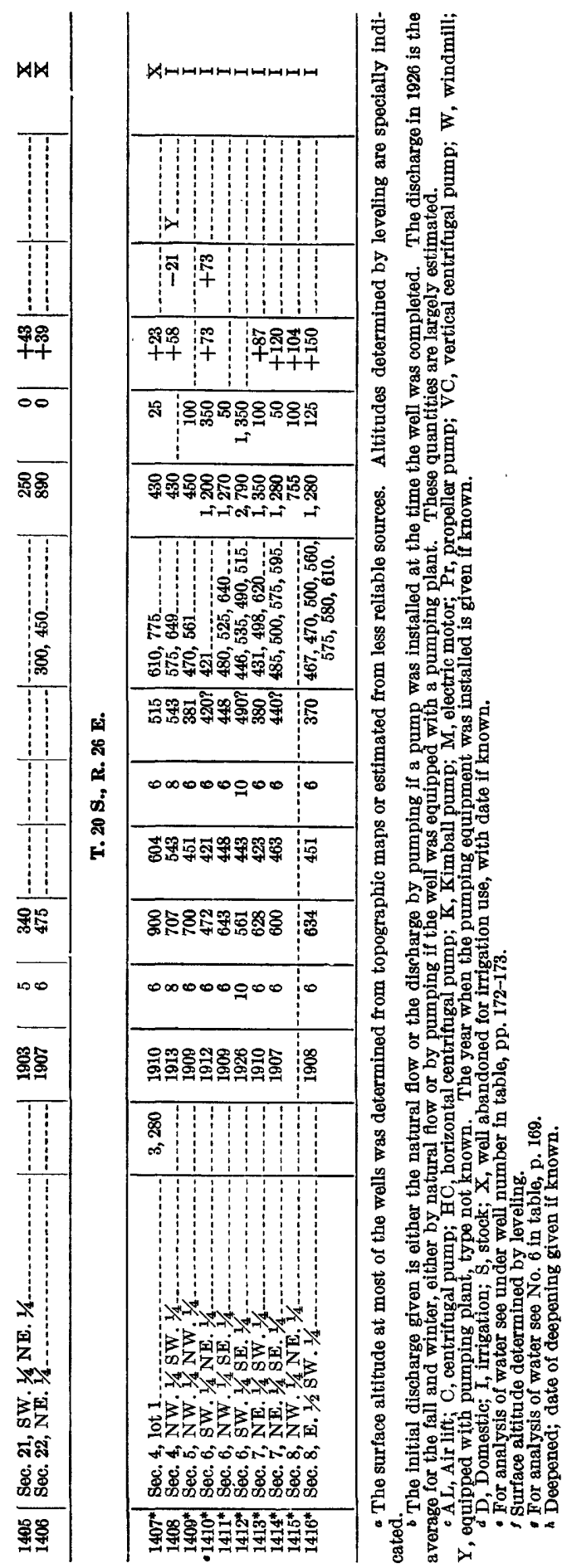




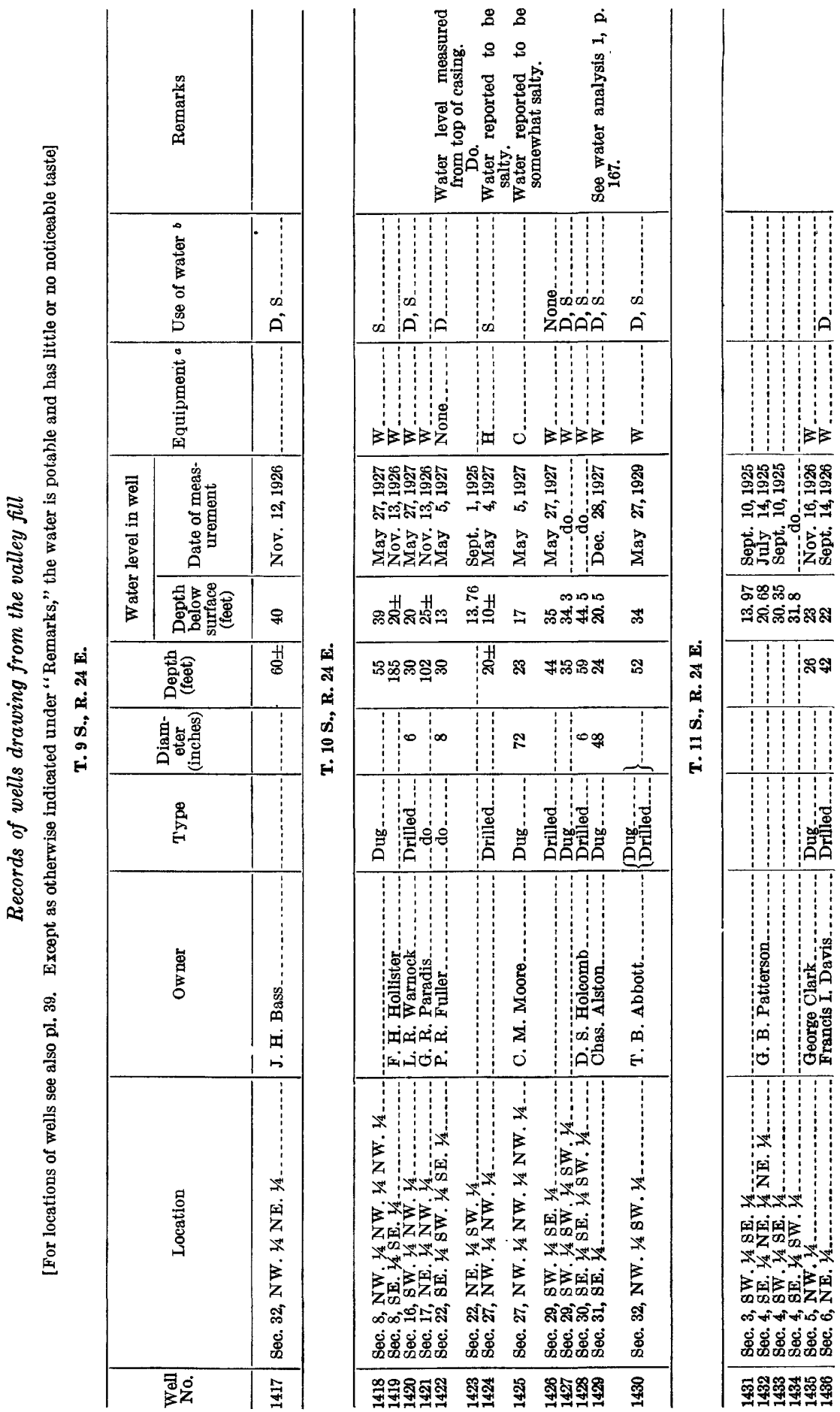




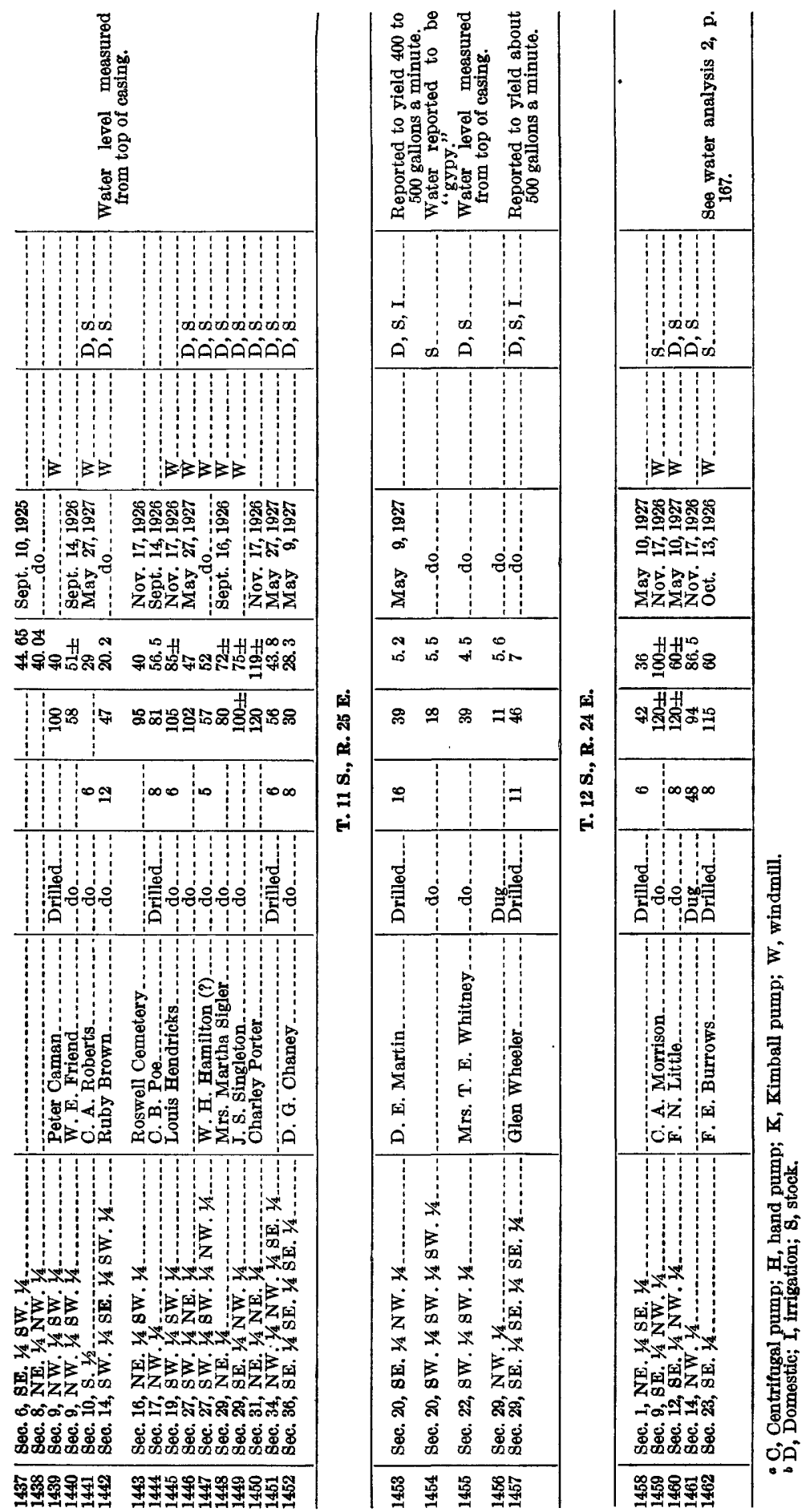




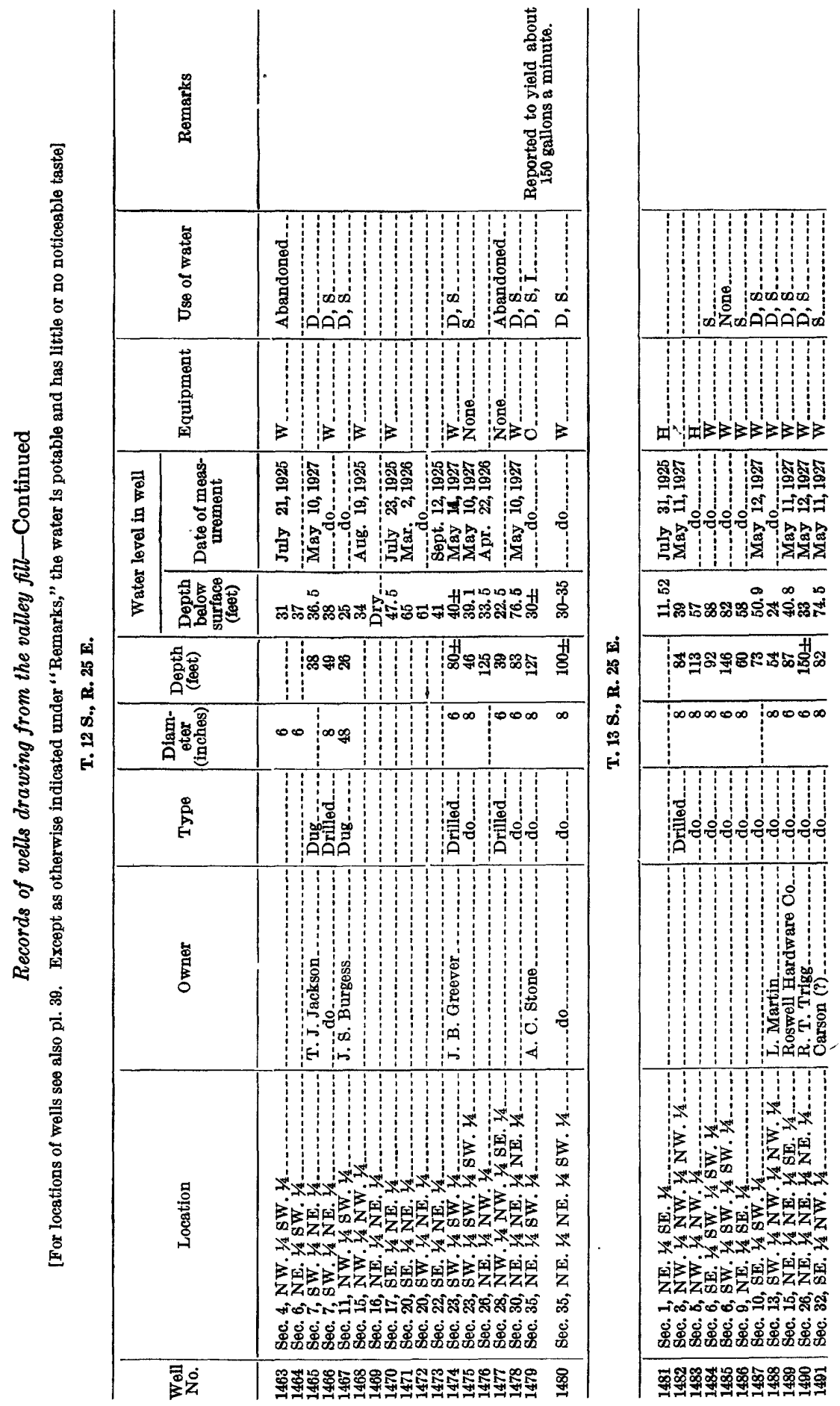




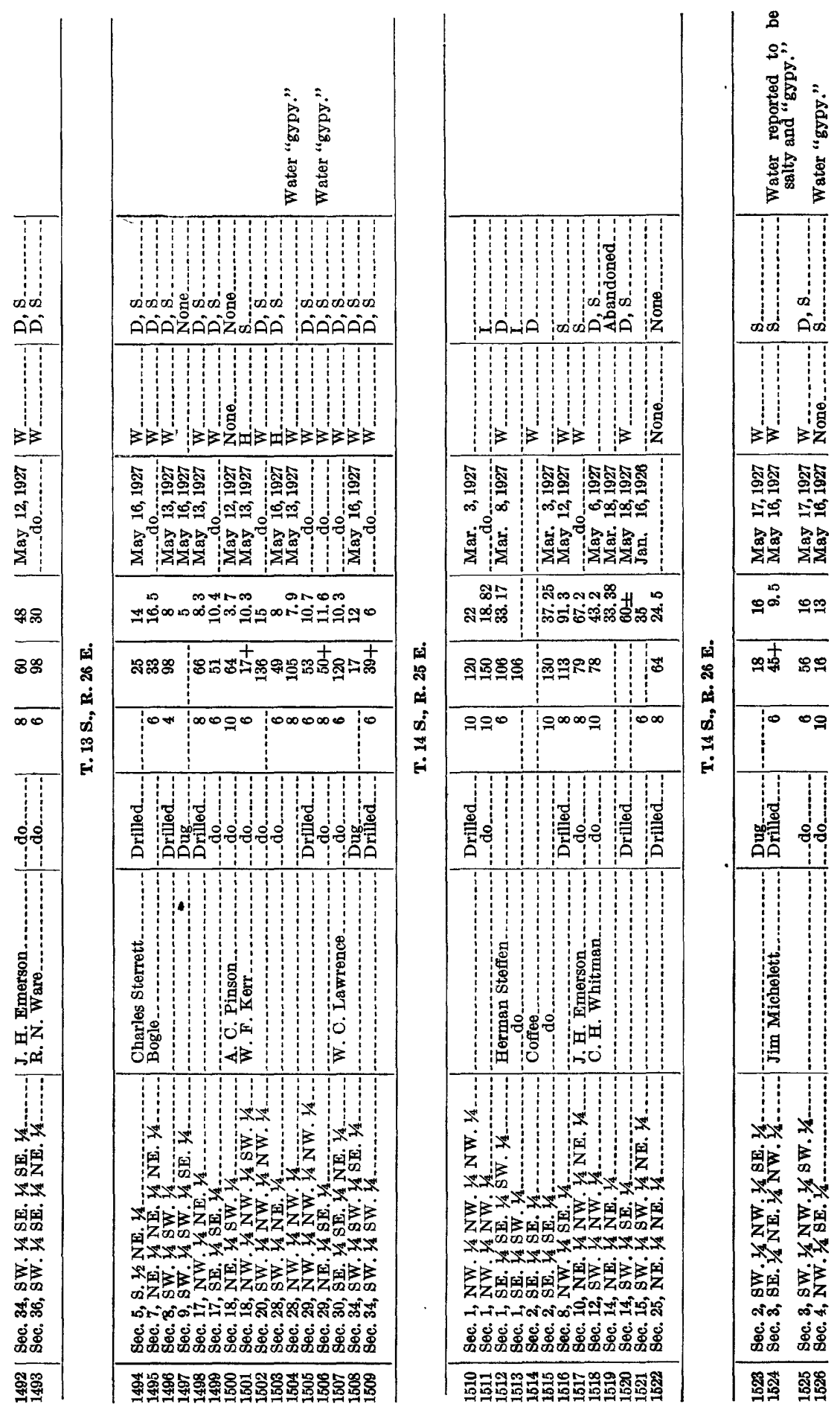




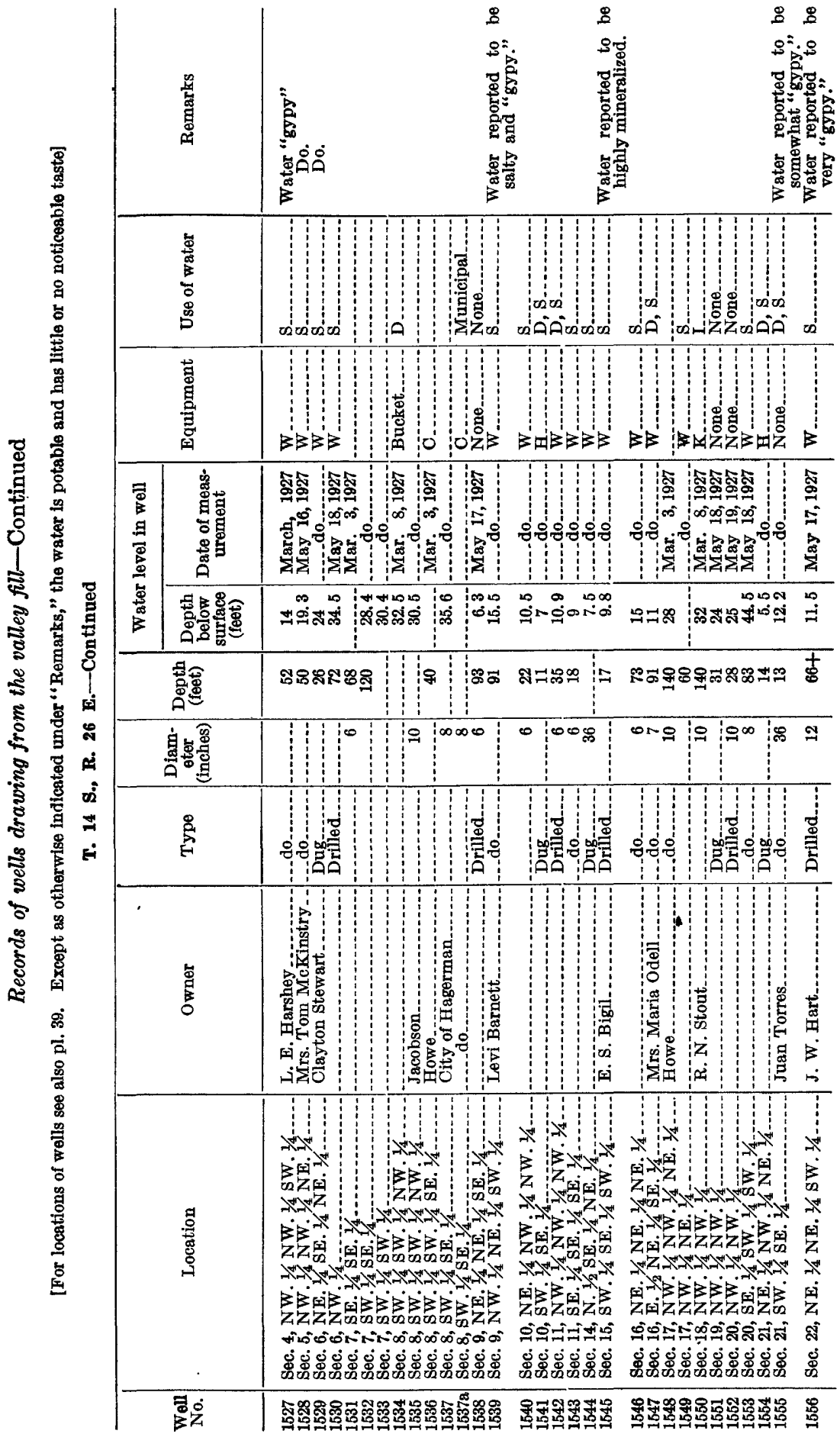



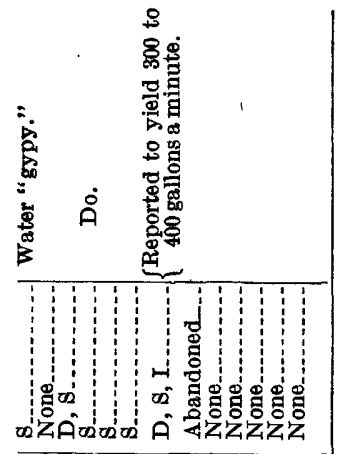

14\%

\begin{tabular}{|c|c|}
\hline 誌 & 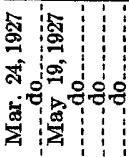 \\
\hline 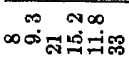 & 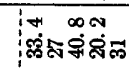 \\
\hline
\end{tabular}

\begin{tabular}{|c|}
\hline 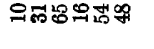 \\
\hline
\end{tabular}

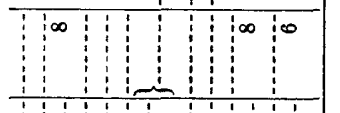

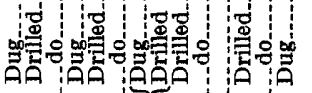

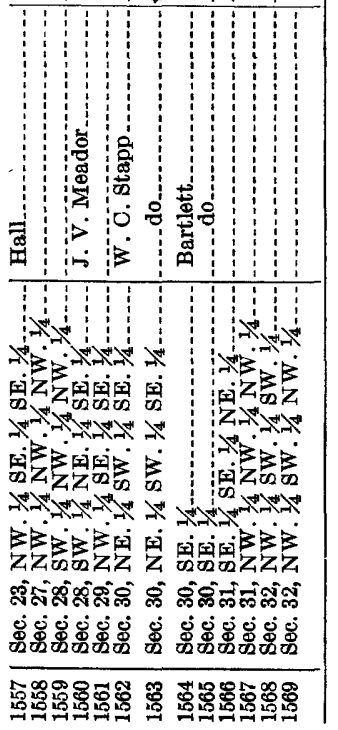

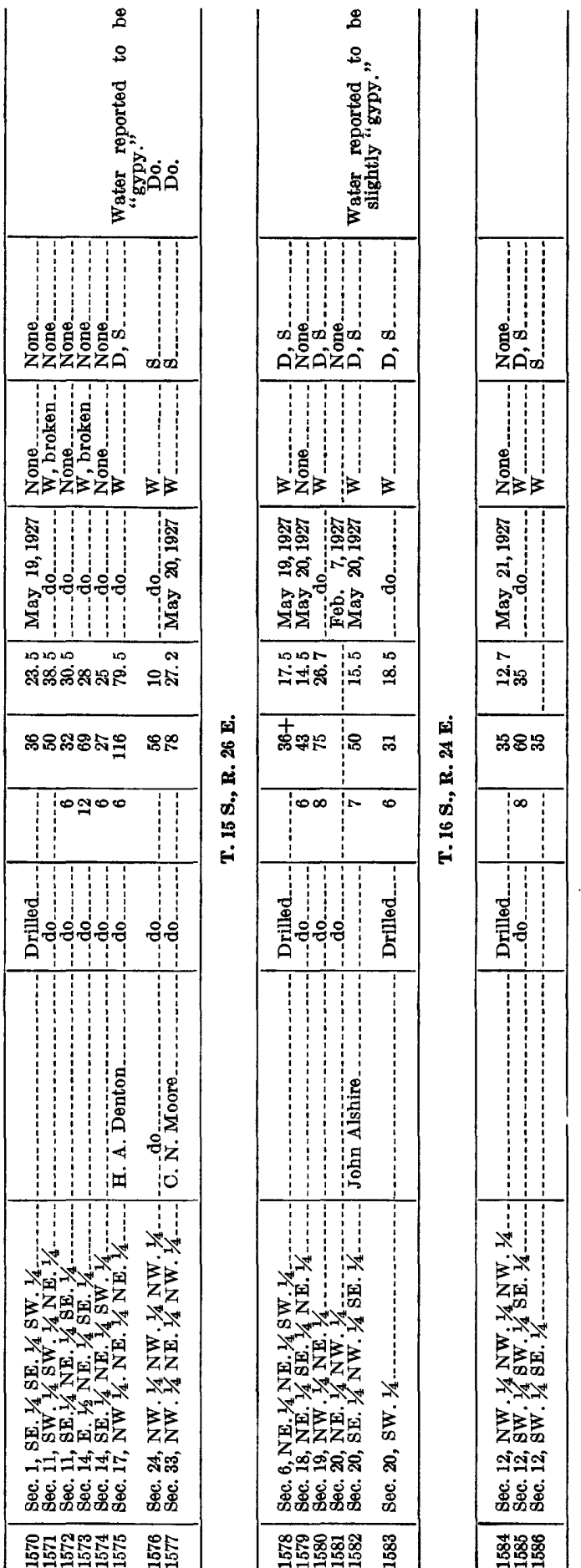




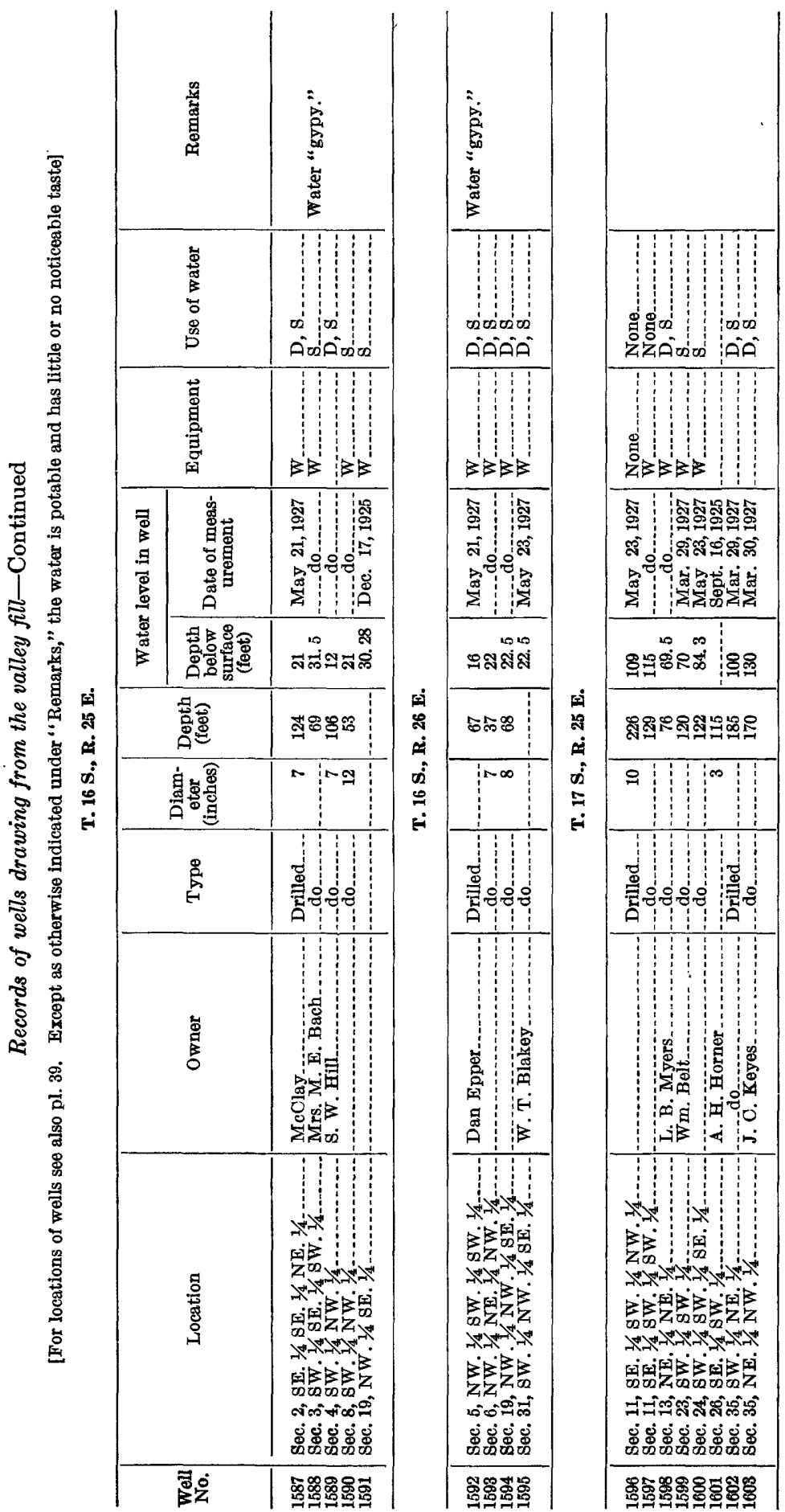




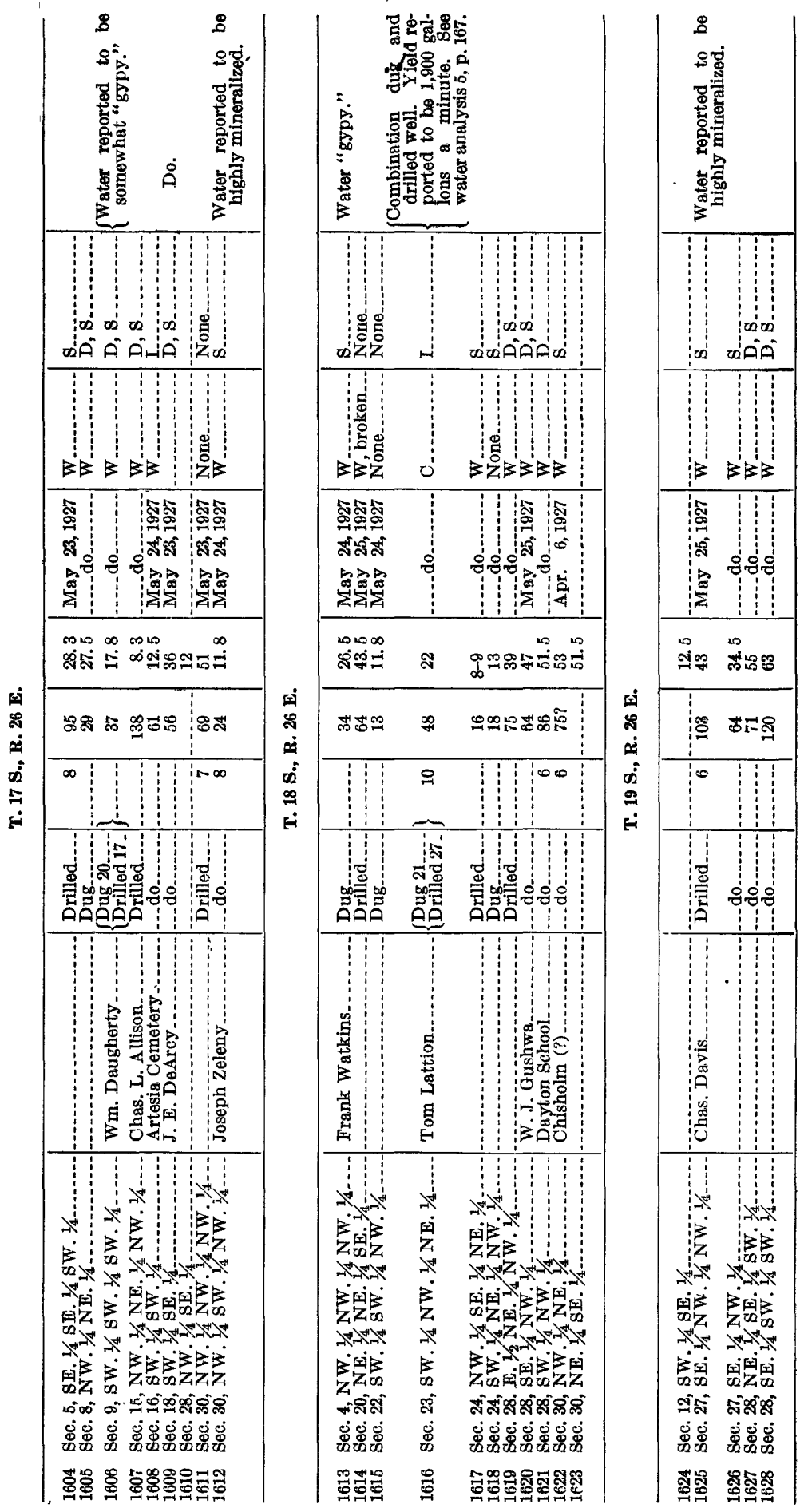




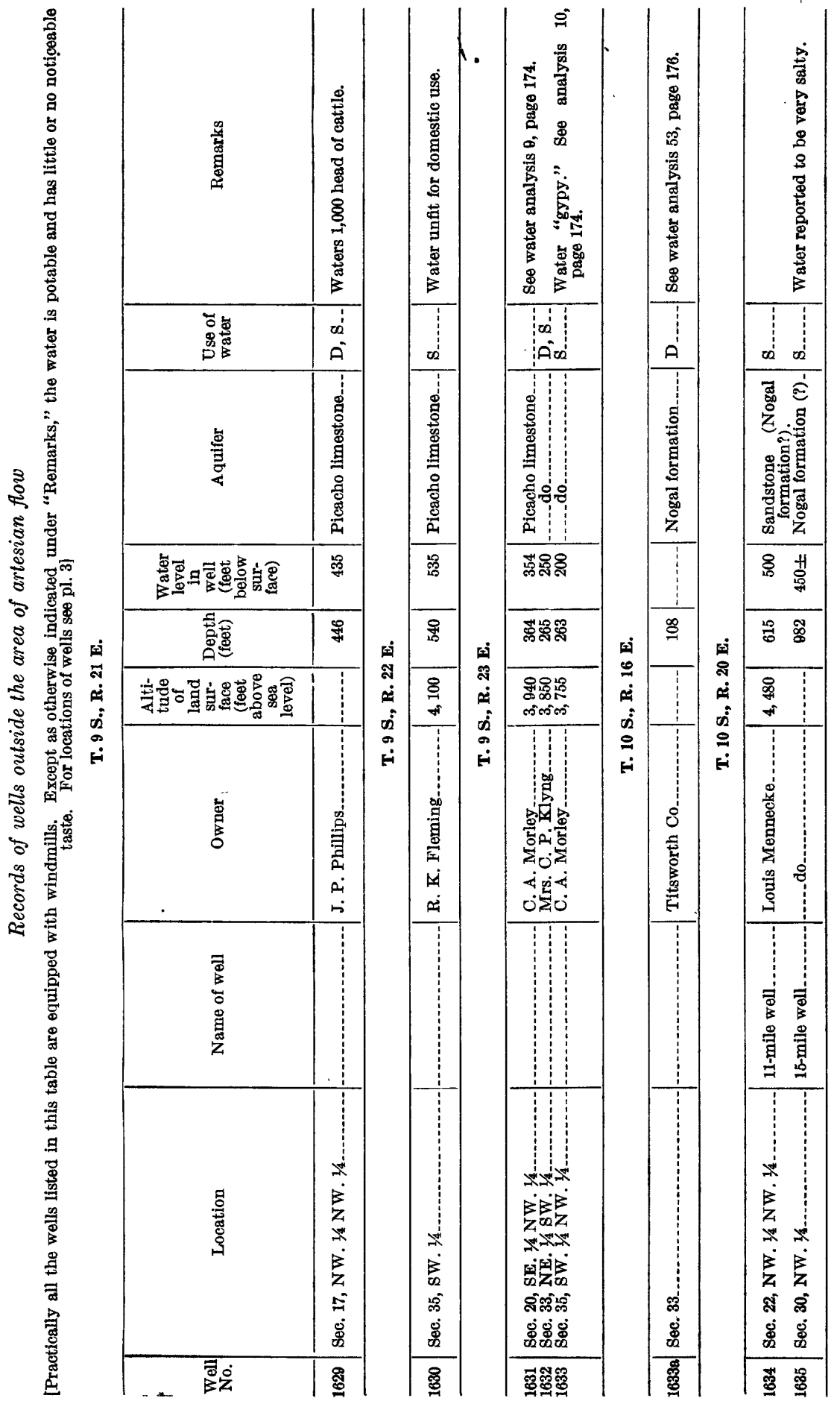




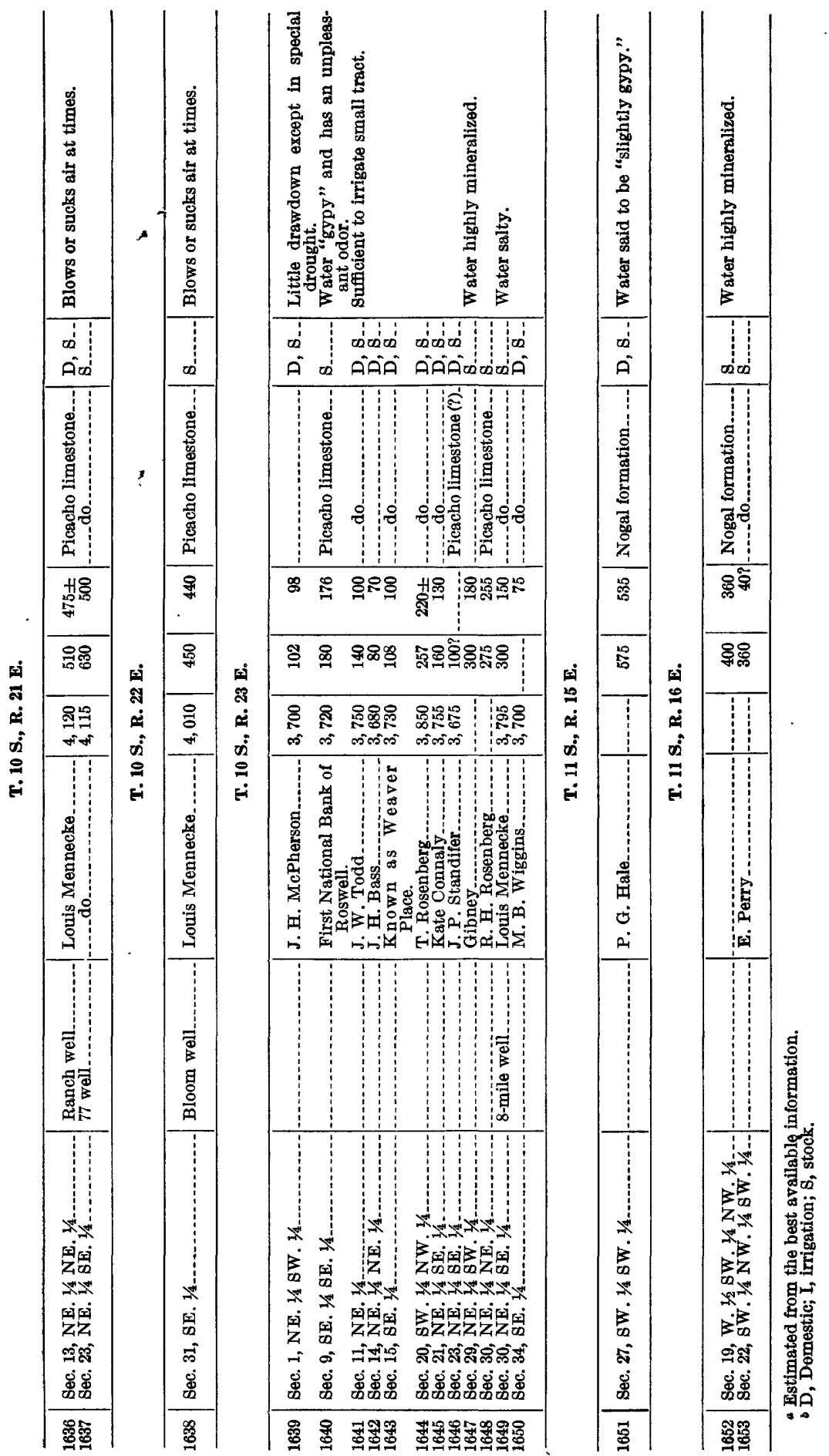




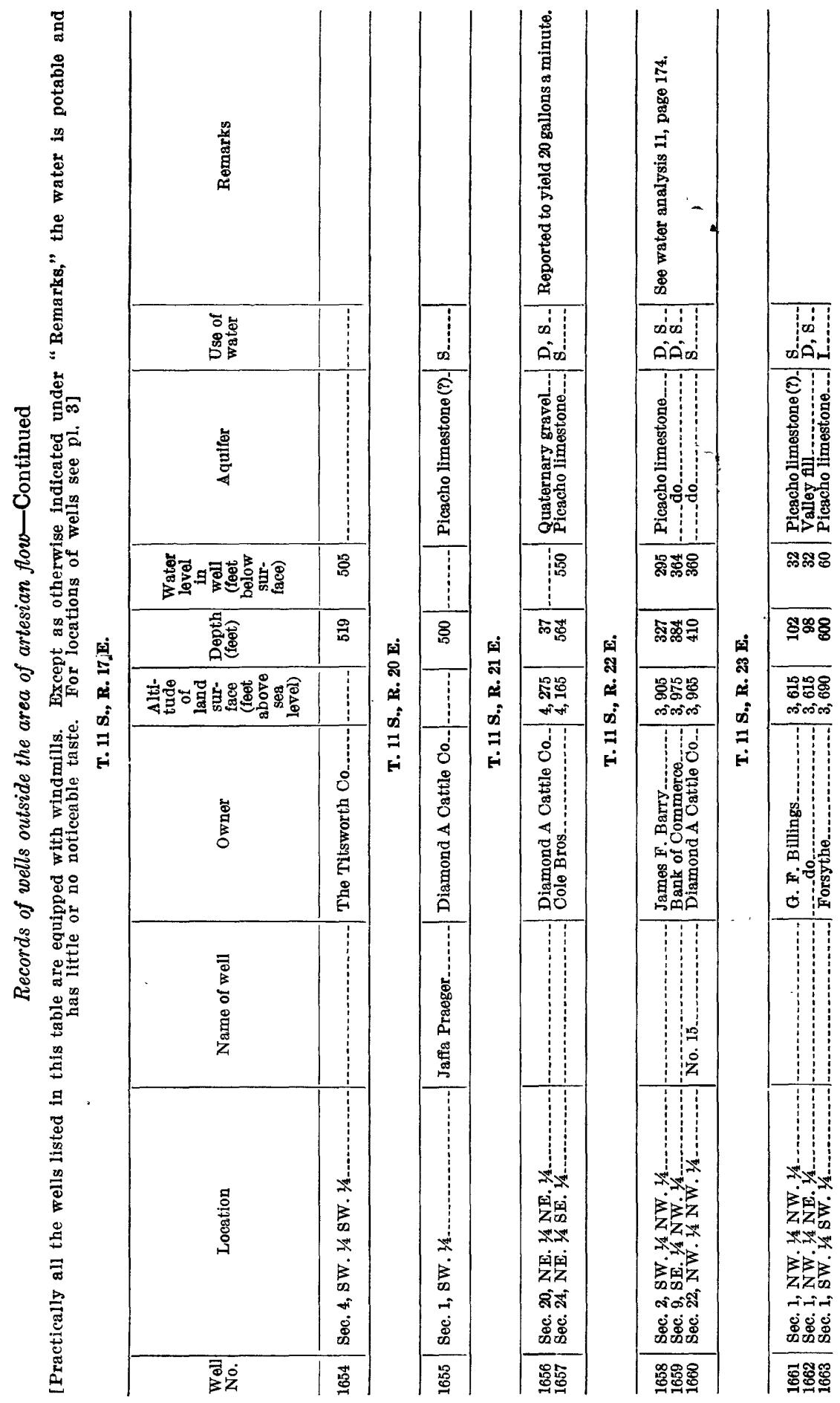




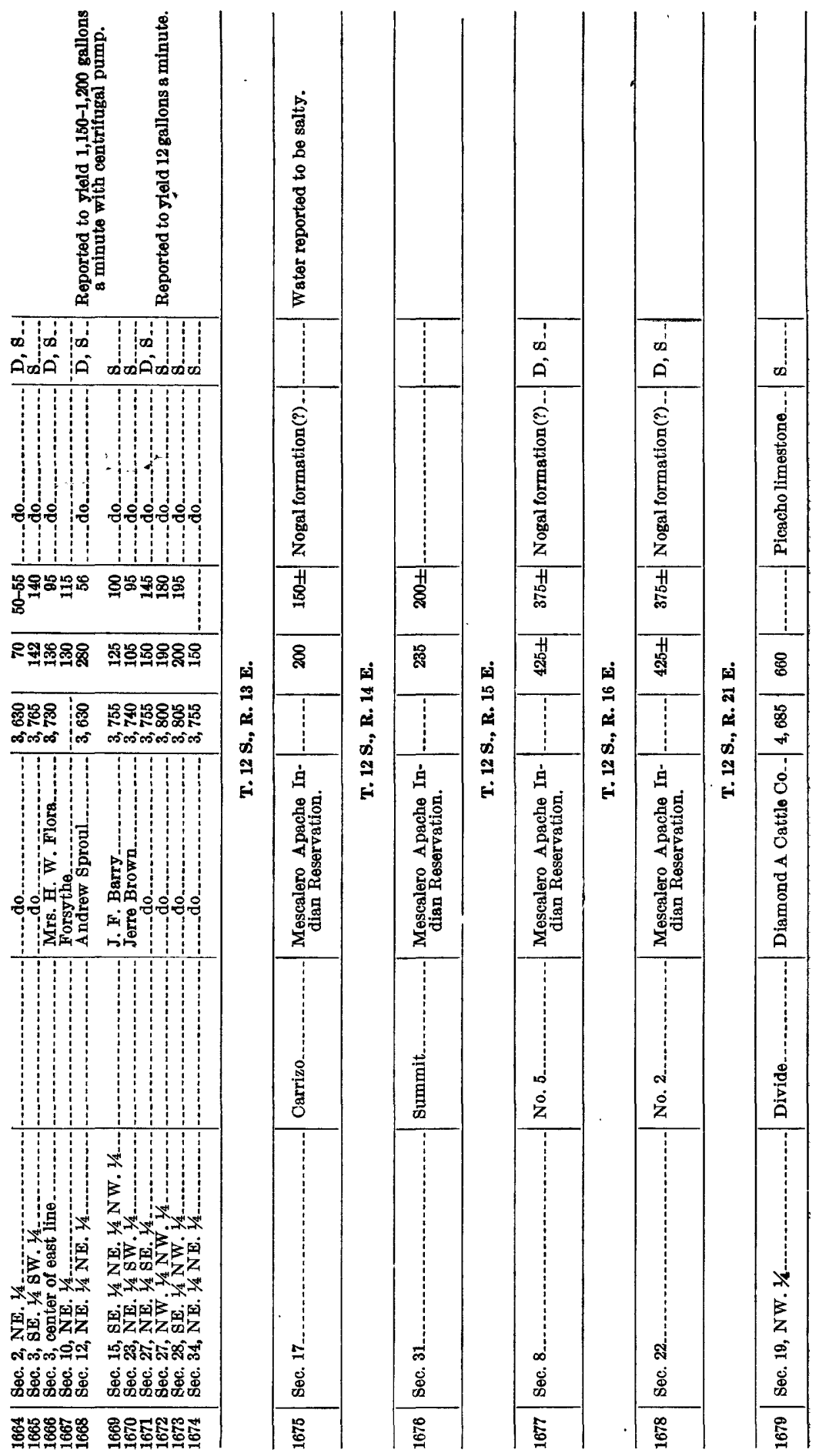




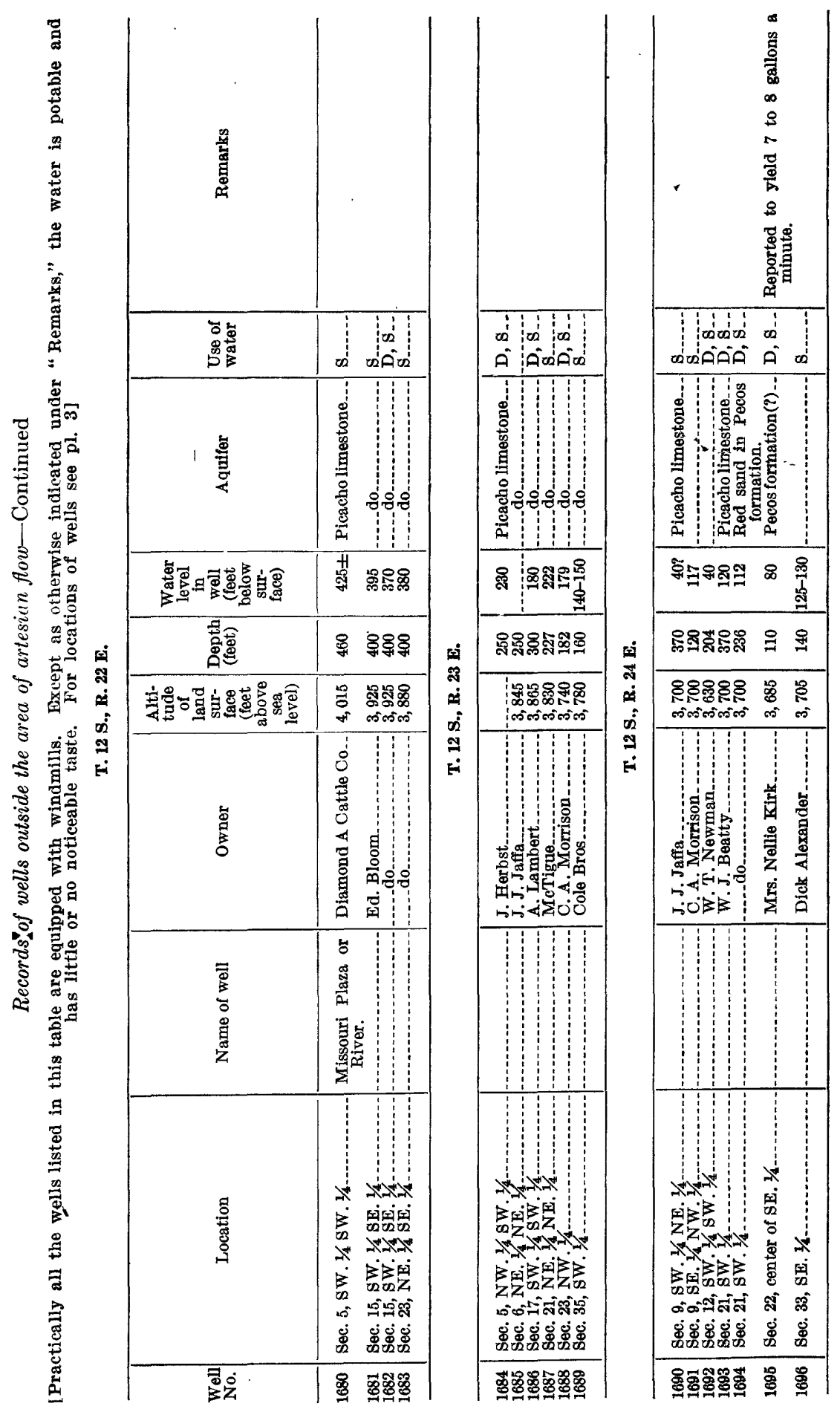




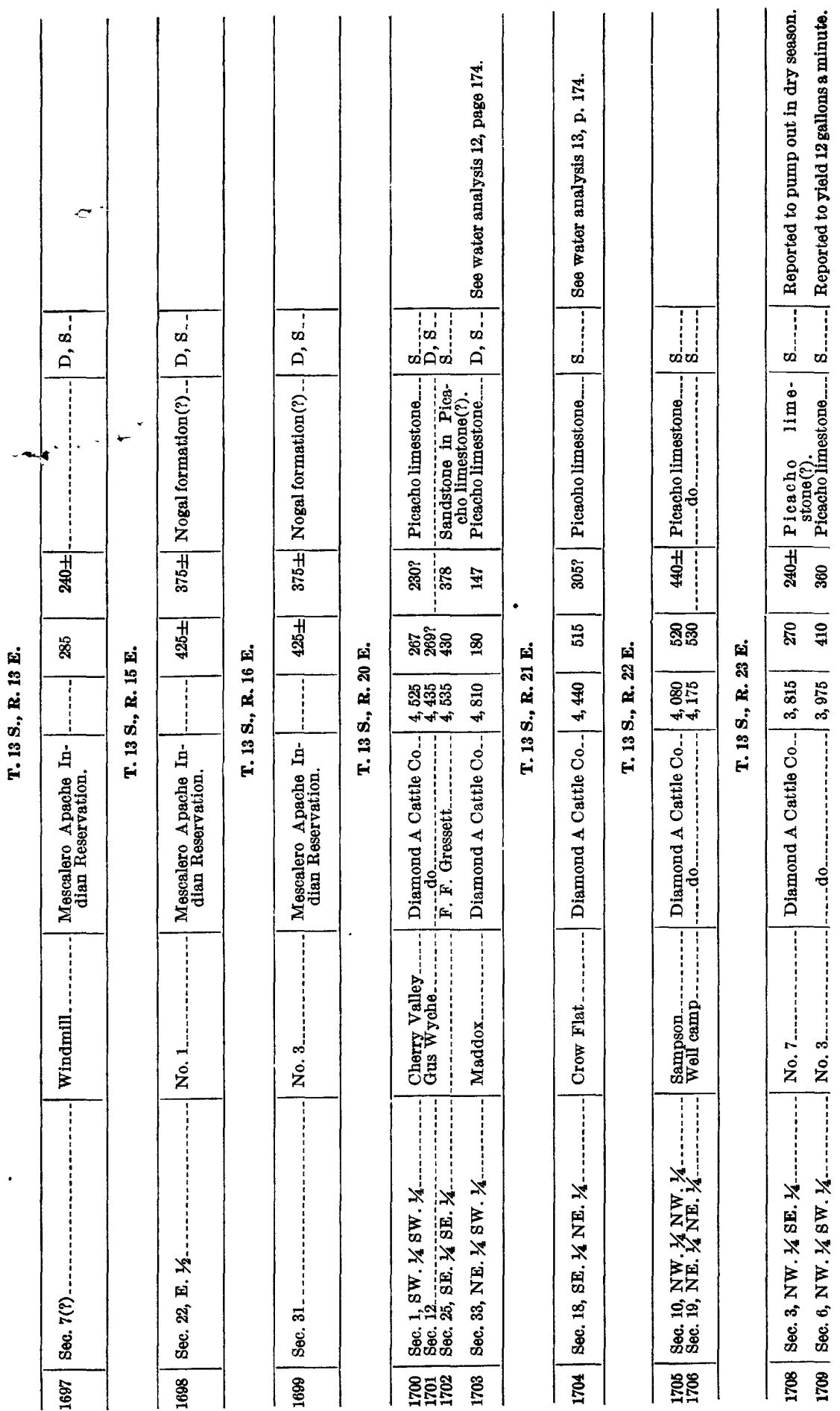




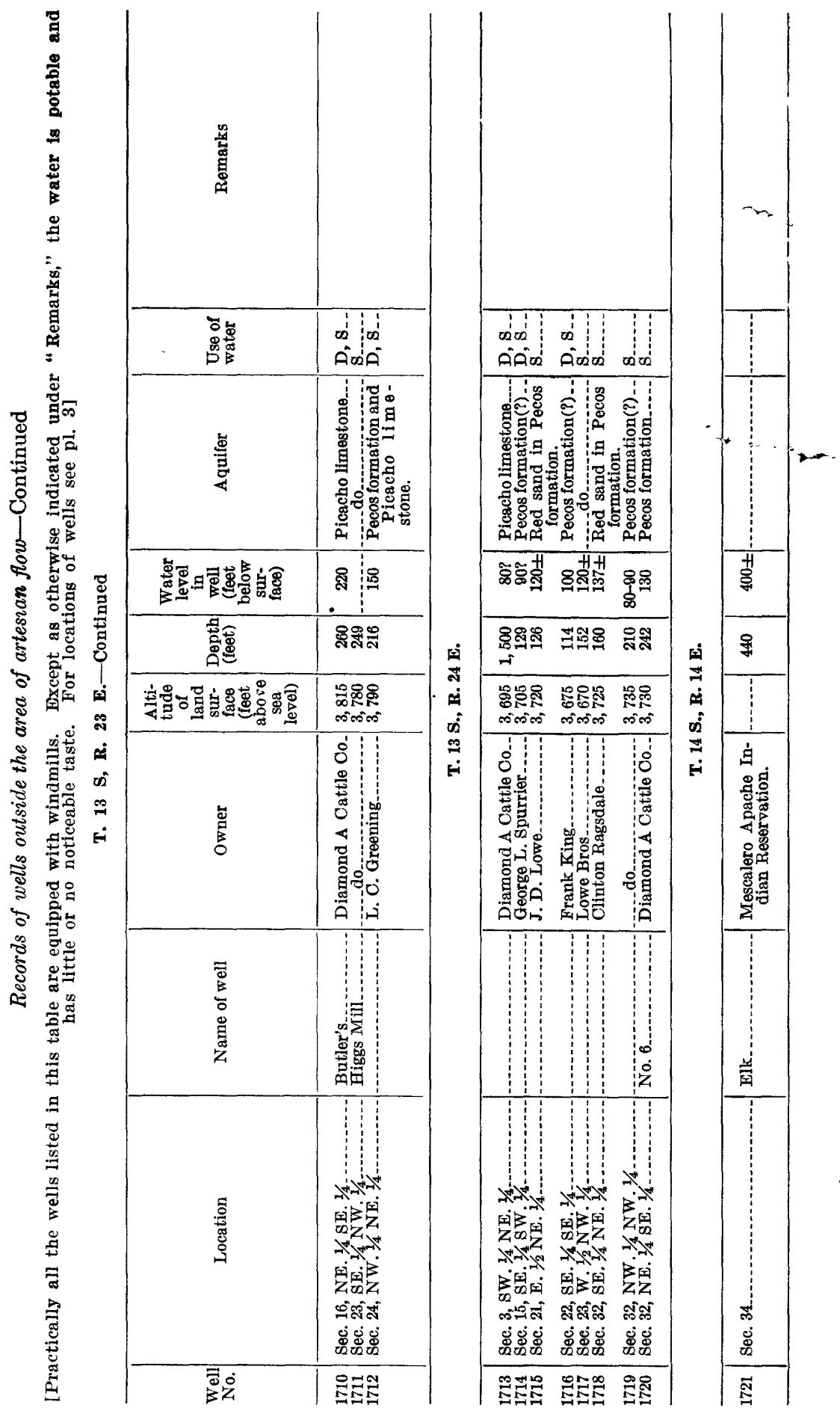




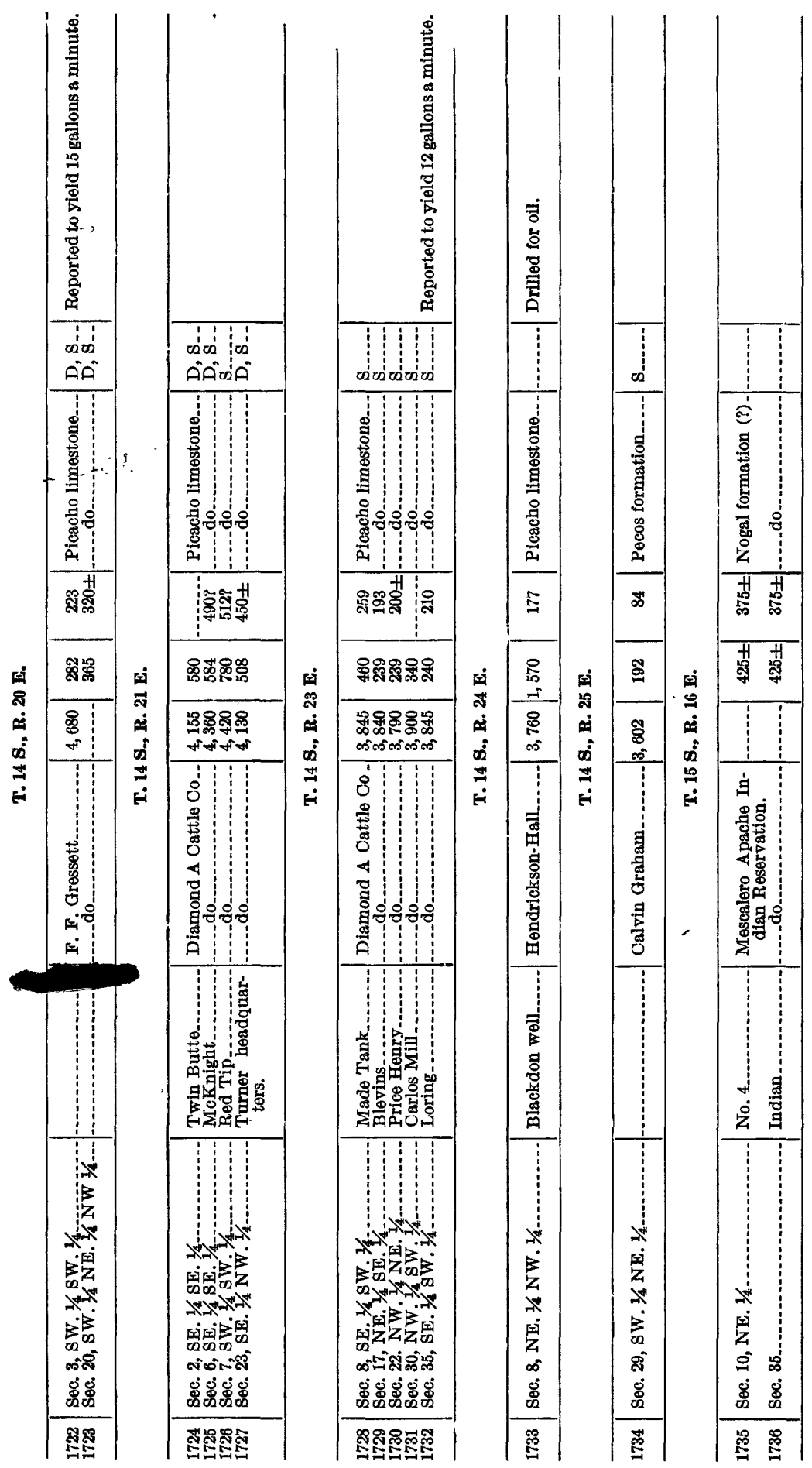




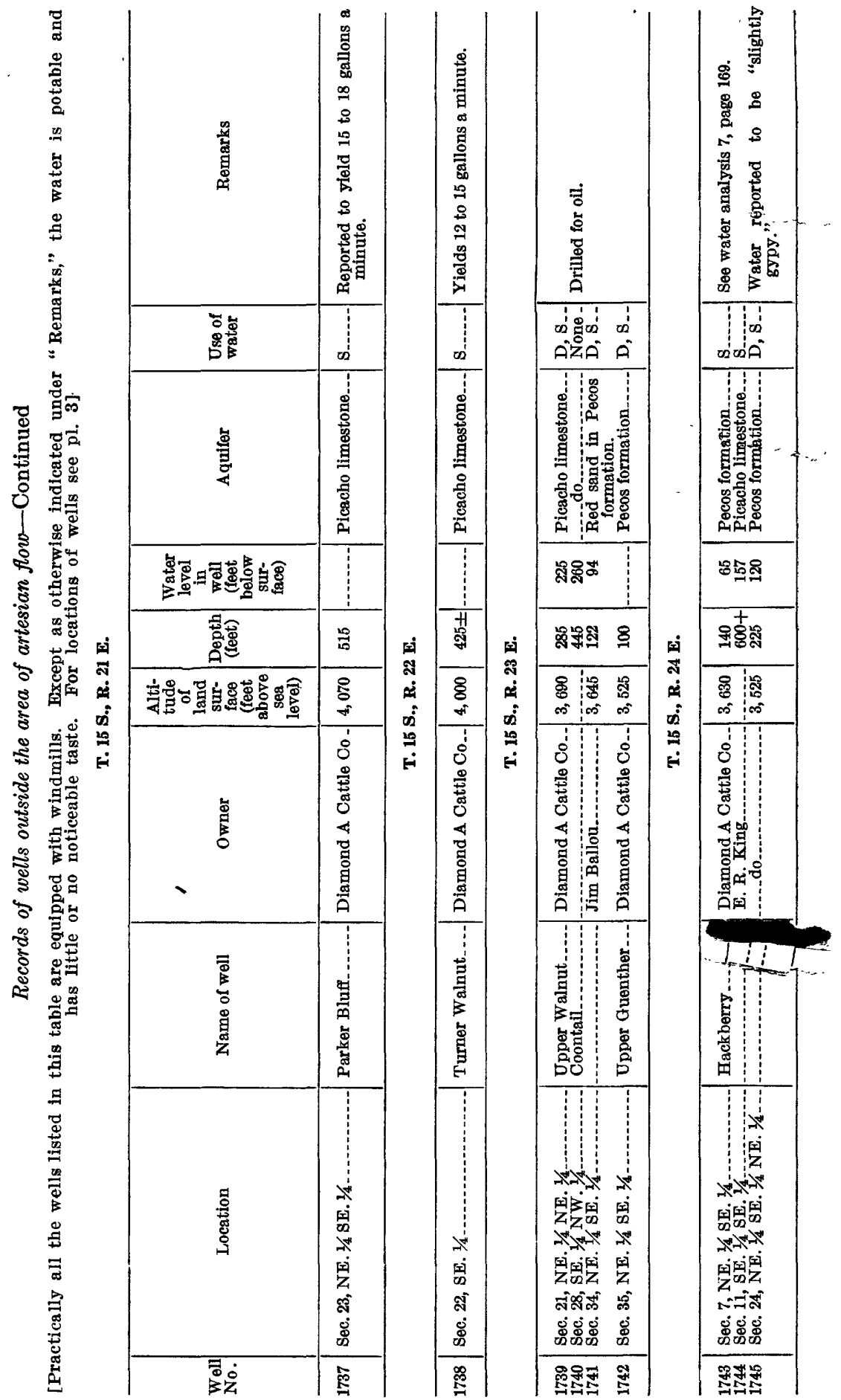




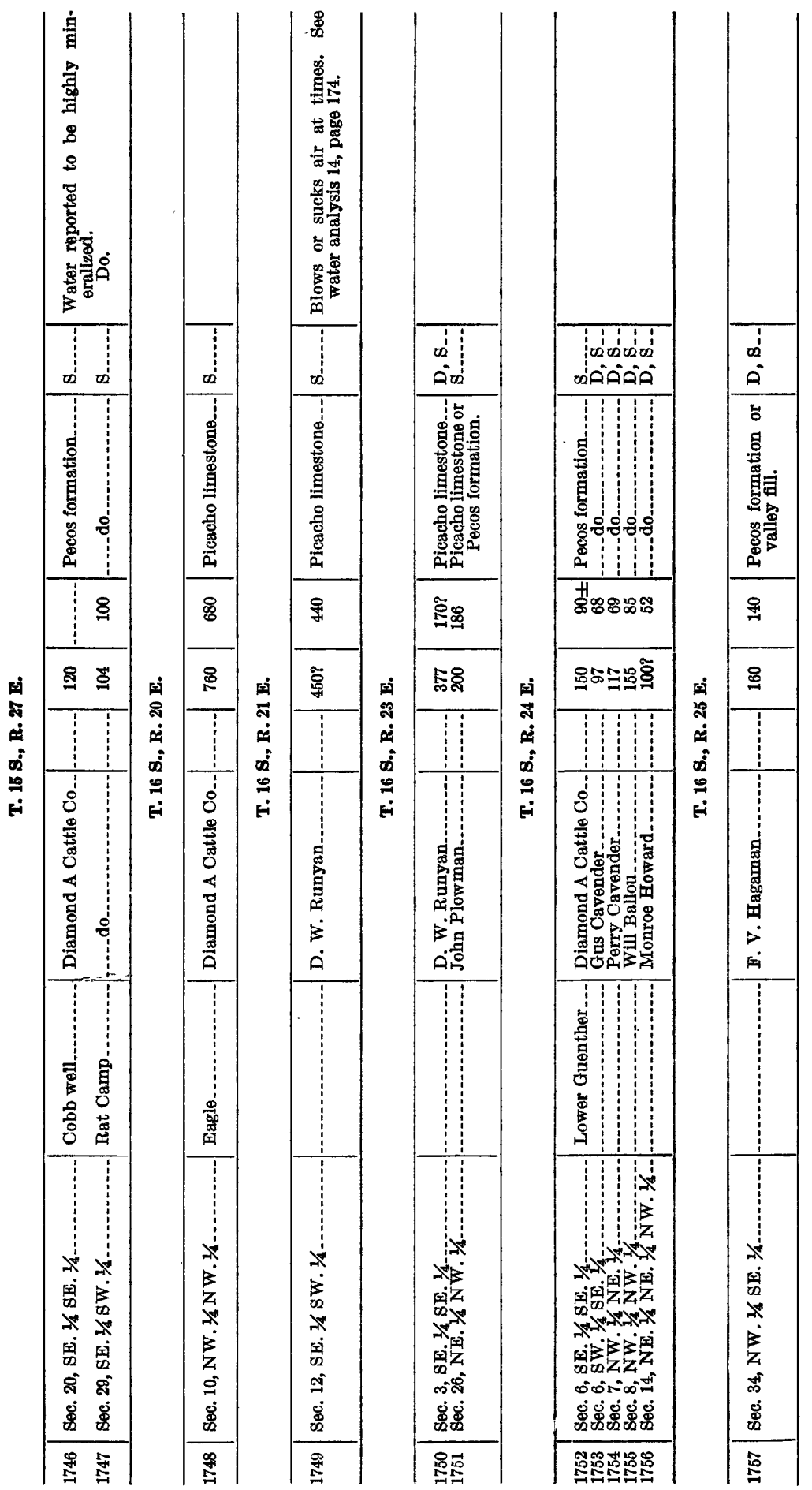




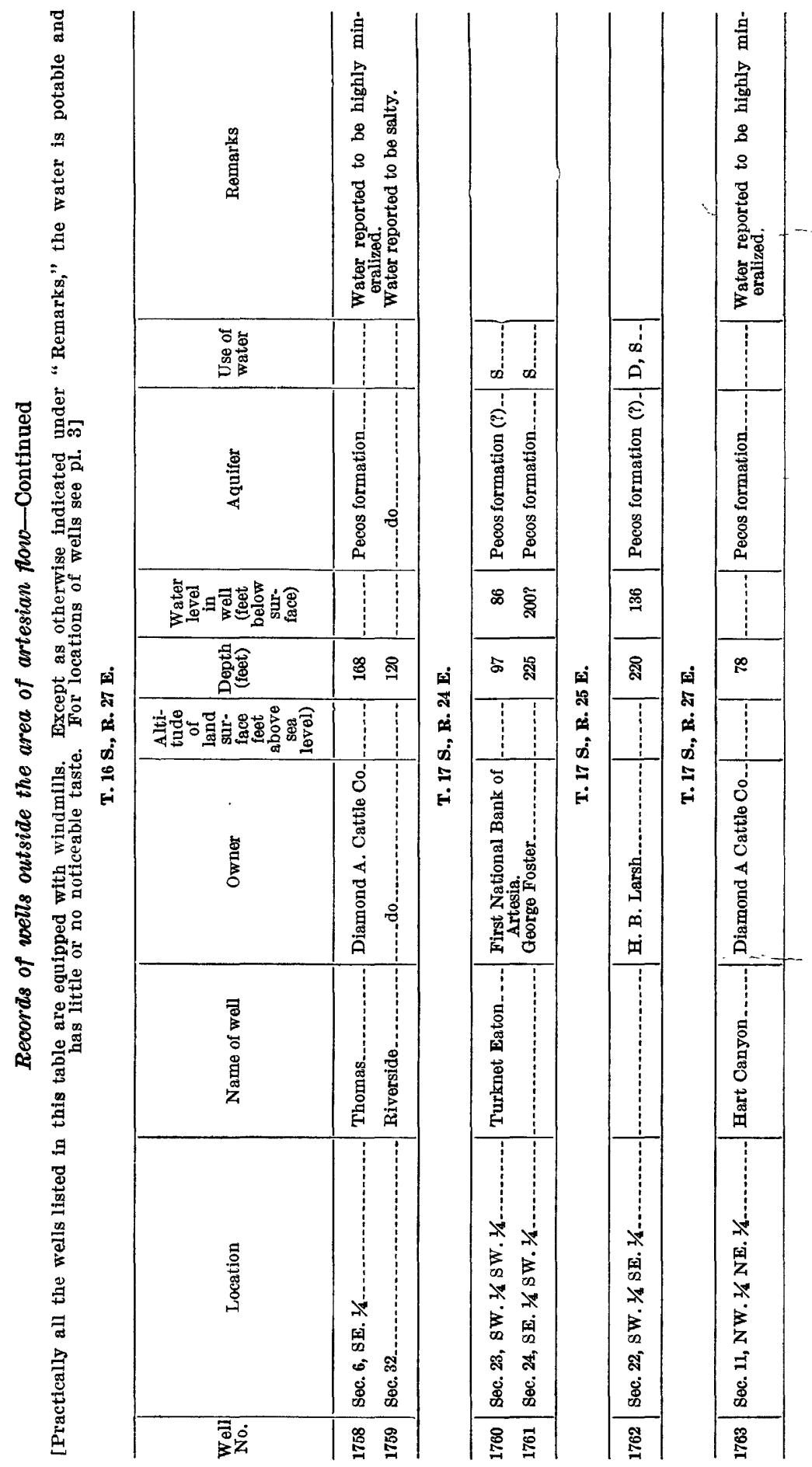


WELL RECORDS

365

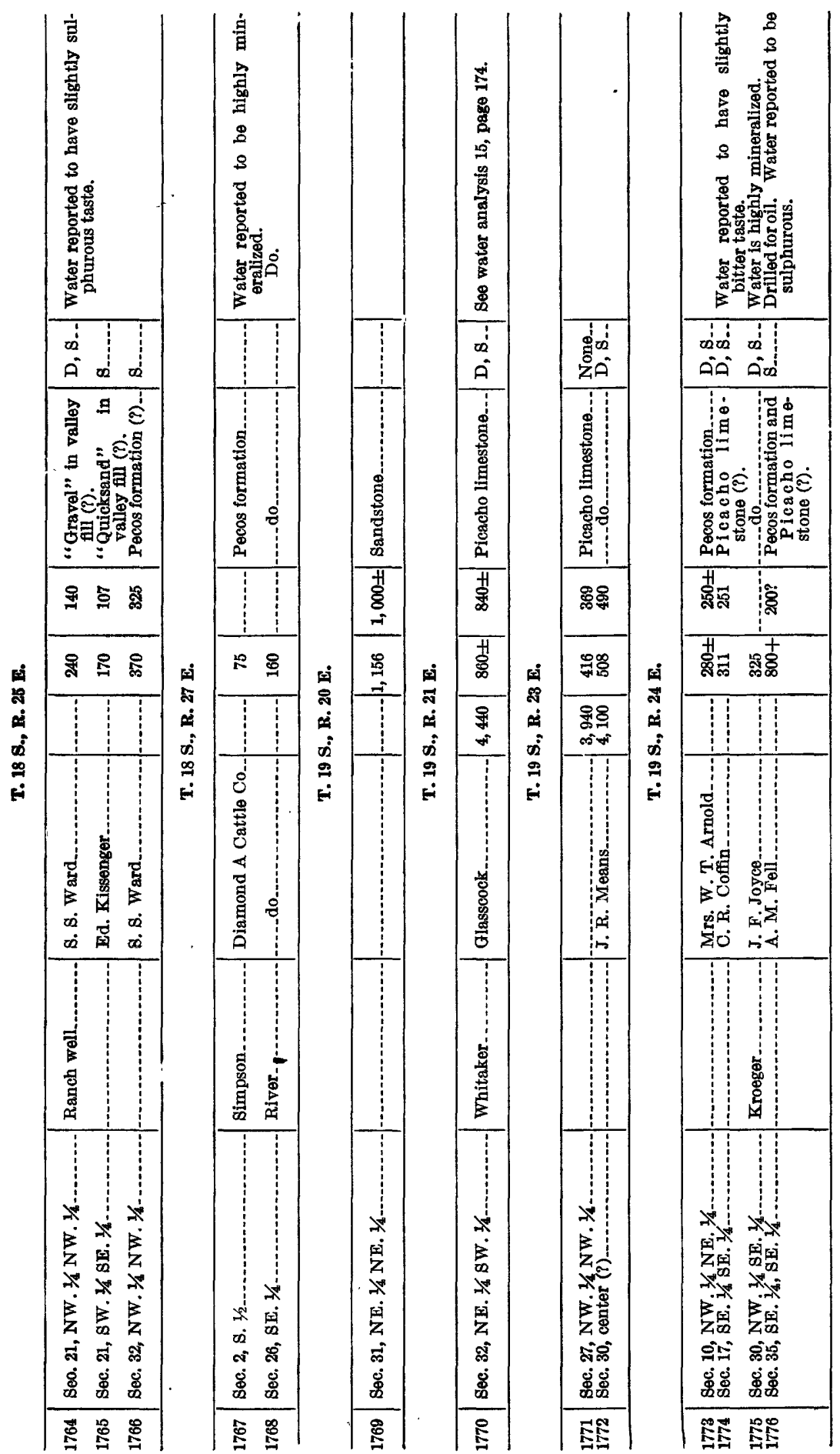




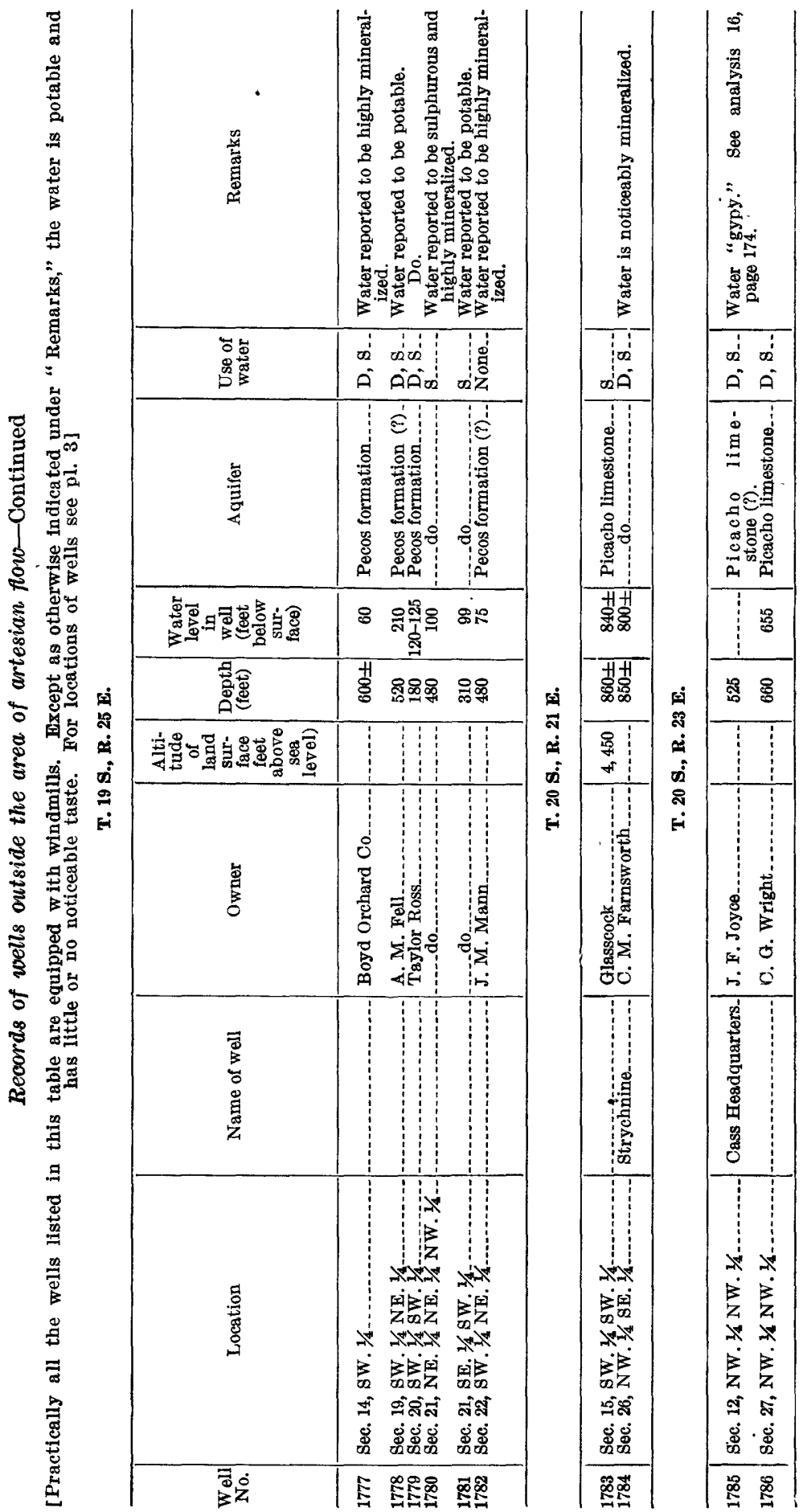




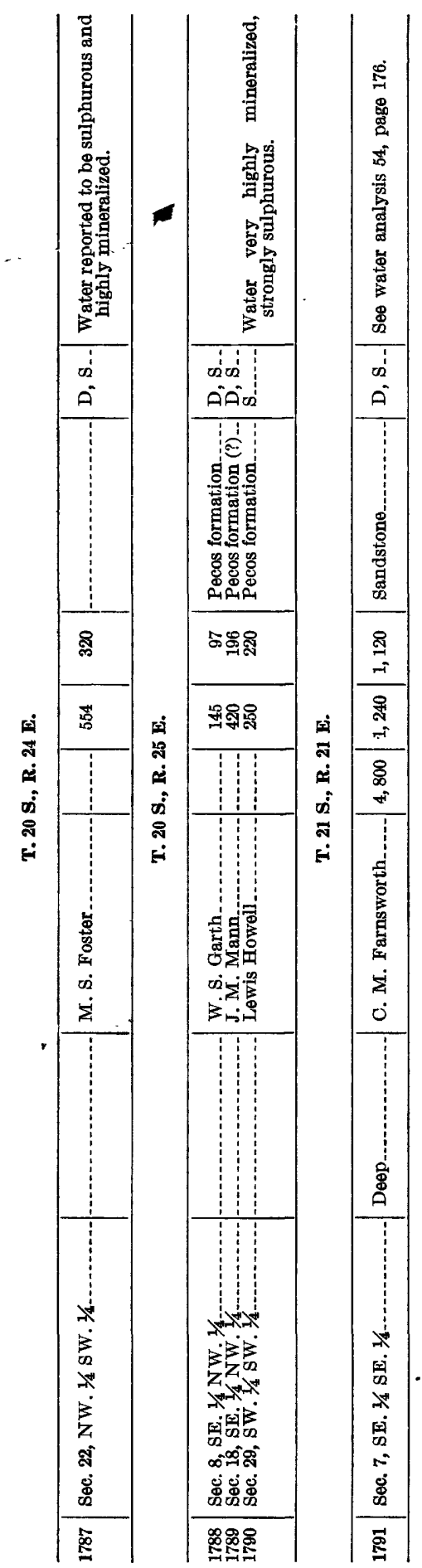





\section{INDEX}

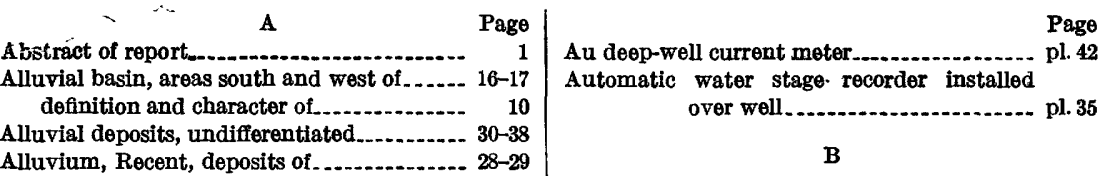

daily precipitation at ........................ pl. 36 decline of artesian head in wells near..... 201

Artesia well, artesian head in............... $\quad 198$ artesian head in, decline of............. 202-203 fluctrations in...................... pls. 32, 36 fluctuations in, seasonal.............. 215 mean monthly and mean annual_ pl. 34 artesian pressure in....................... pl. 37

Artesian aquifers, compression of ............ 242-245 head of .

Artesian flow, area of.......................... 212-221 records of wells outside area of........... 354-367

Artesian head, decline of, in artesian area.. 199-205 decline of, in intake area................... 205 fluctuations in.................... 207-219, pl. 28 caused by rainfall ................... 211-213 seasonal .............................. 213-216 mean monthly and moan annual, in representative wells................. pl. 34

relation of irrigated area to

Artesian supply, intake area of.............. 237-259

Artesian water, circulation of, during Pleistocene and Recent epochs, evidence of

circulation of, in Picacho limestone, conclusions regarding................ 188-189

contributions of, to ground water in valloy fill.

development of............................ 190-194

discharge of, at surface..................... 231

head of, in 1926-28 .................... 196-198

. original............................... 194-196

surface waste of .......................... 229-231

Artesian wells, aggregate capacity of........ 224-228 contributions of water from leaky, to ground water....................... 123-124

methods of drilling. . ...................... 263-267

number of, drilled............................ pl.28

quantity of water discharged by ....... 224-236

records of............................... 292-345

repair of .................................... 274-277

sealing of, outline of methods for.......... 277

size of ...................................... 191-192

underground waste from, conclusions re-

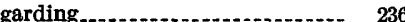

quantity of

Asphalt, possibility of use of, in sealing artesian wells....................... 279-280

Atmospheric pressure, effect of, on water level in wells. . ........... 218-219, pl. 38

Beede, J. W., quoted.......................... 54-55

Bent, partial section of mountain northwest

of . . .

Berrendo well 1, artesian head in ........... 197, 198

artesian head in, decline of ................ 202

fluctuations in ..................... pls. 32,36

fluctuations in, seasonal .............. 215

artesian pressure in . .

Bibliography

Blackdom terrace, deposits of

general features of ........ 12

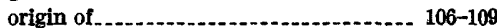

valley cut in ............................... pl. 5

Black Hills anticline, structure of............. 82

Border Hills, views of........................ pls. 18, 24

Border Hills fault, features of ................. 78-79

Bottomless Lakes, features of................. 8-9

Breccia near top of Picacho limestone ........ pl. 23

Bryan, Kirk, quoted . ..................... 103-104

Bryan, Kirk, Meinzer, O. E., Renick, B. C., and, quoted..................... 108

\section{C}

Caliche, deposits of............................ $39-40$

Capitan limestone, Carisbad limestone tongue

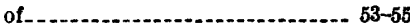

Capitan Mountains, features of........... 15, pl. 5

geology of . ................................. 23

Carboniferous beds, features of . ............. $42-76$

Carlsbad, climatic data for ..................... 7

Carlsbad limestone tongue of Capitan limestone, features of . . .

fossils of .................................. 54-55

relation of

Casing removed from defective well............ pl. 42

Castile formation, substitution of term "Pecos formation" for

Cavernous limestone from upper part of Picacho limestone, specimens of

Cenozoic era, events of ....................... 95-113

Chaves County, acreage of crops planted in ... 255

area irrigated by artesian wells in.......... 255

area of artesian flow in, size of............... 221

distribution of wells drawing from valley fill in, trom which records were obtained........................... 127

number of artesian wells in .......... 193, pl. 28 requirements of water for irrigation of different crops in ................. 256 value of crops produced in 
Chupadera formation, substitution of term Pecos formation for.

Climate, features of.

Clouderoft, climatic data for

Collins, W. D., and Riffenburg, H. B., quoted.

Conservation of artesian water, future policy for ................................ 287-291

Corrosion of well casing, prevention of ...... 272-274 theories of ........................... 269-272

Cottonwood Creek, artesian head on ......... 198 features of upper drainage basin of ....... 16 history of ............................... 100-102 irrigation along .......................... 259-260 masses of travertine along . . .............. pl. 8

Cottonwood segment, artesian conditions in . . .

Cretaceous deposits, distribution of

\section{D}

Darton, N. H., quoted .......... 90-91 Deposition, possible changes in conditions of. $88-89$ Diamond A plain, features of ............... 14 origin of ................................... 102-104

Drainage, features of ....................... 7-10

Drilling, cable-tool percussion method of . . . 265-267 cost of . hydraulic rotary method of ..... 263-265, pl. 46

Dunken dome, structure of.................. 82 Dunken dome well, water-bearing beds in.... 157

\section{$\mathbf{E}$}

Earth movements, regional

Eddy County, area of artesian flow in, areairrigated by artesian wells in.......... distribution of wells drawing from valley fill in, from which records were obtained. number of artesian wells in ........... 193, pl. 28 requirements of water for irrigation of different crops in.

Elk, climatic data for

Erosion, character of, during Permian time... 85-88

\section{$\mathbf{F}$}

Faults, features of. $77-81$

Felix shallow ground-water district, features

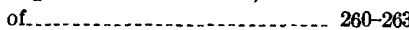

pumping well in .......................... pl. 46

Fisher, C. E., studies by

Folds, features of ....................... 81-82

Fort Stanton, climatic data for

Foster, Margaret D., chemical analyses by .................. 167, 169, 172, 174-176

Geologic history

G

Geology, previous studies of 90-113

Girty, G. H., quoted........................ 62-63

Glacial stages, relation of, to physiographic history ........................... 111-113

Glorieta sandstone, definition of ..............

Goldman, M. I., quoted.

Gravel, deposits of

Gravel-capped mesas, features of.
Gravel-pack method of finishing wells, features of.......................... 283, 284

Ground water, chemical character of........ 161-178 circulation of ............................ 179-180

during Permian time, evidence of. 186-188 development of, features of.............. 199-263 movement and disposal of, in artesian basin occurrence of, in artesian basin .......... 113-115 perched, occurrence of ................ 159-160 solvents in ................................ 178-179 source of, in artesian basin ............ 115-116 utility of . . ............................. 176-178 Ground-water conditions, general relations

$$
\text { of }
$$

Guadalupe Mountains, features of........... 15 Gypsiferous limestone from Picacho limestone, specimen of ............ pls. 19-22

Gypsum, beds of, in Picacho limestone..... 67-69 solubility of ................... 83-84

\section{H}

Head, artesian, fluctuations in ............ 207-219 artesian, of typical wells, 1904-1926........ pl. 33 Hondo Reservoir, impounding of water in... 289 Hope, ground-water conditions near........ 138-139 Hydraulic gradient along sections across area of artesian flow pl. 31

\section{I}

Igneous rocks, occurrence of . Interference of wells. . .

Investigation, history and scope of.......... 3-5 recommendations for further............. 290

Irrigated area, extent of...................... $\quad 259$

Irrigation, early development of ............ 189-190 quantity of artesian water used for..... 228-229 requirements of artesian water for ..... 254-257

\section{$\mathbf{K}$}

King, H. D., well of Knowland, R. G., Speller, F. N., and, quoted 269,271

\section{$\mathbf{L}$}

Lake McMillan, section of blufis on......... 47-48

Lakes, general features of .................... 8-9

Lakewood terrace, general features of........ 10-11 origin of ..................... 106-109

Leakage examination, equipment for.......... pl. 43 Leakage from artesian wells, causes of . . ... 268-274 underground, methods of determining - 232-234 policy regarding ....................... 288-289 problem of ............................. 231-236

test of specimen well for............ 234-236

Legal provisions governing use of the ground water.............................. 284-28i Limestone breccia, character of .... 52, 69-70, pl. 23 Limestone conglomerate, deposits of......... 38-39 Limestone uplands, definition and character of 
Liano Estacado, features of. features of area between Pecos River and. Location of the Roswell artesian basin........ Love, S. K., chemical analyses by

M

Manning dome, structure of

Map of area of artesien flow, showing altitude towfich water would rise in win. ter of 1926-27.

showing original area of flow, areas in 1916 and 1926, and location of wells pl. 39 (in pocket)

Map of southeastern New Mexico, showing outline of Roswell artesian basin. pl. 2

Map, reconnaissance, of Roswell alluvial basin..................... pl. 4 (in pocket)

reconnaissance geologic, of eastern part of Roswell artesian basin

(in pocket)

showing areas in New Mexico covered by Geological Survey reports.......... pl. 1

showing boundaries of areas having wells of large yield and those having wells of small yield.

showing depth to water table............. pl. 26

showing irrigated areas and height to which water would rise in wells... pl. 45

(in pocket)

Meinzer, O. E., quoted $90,251,218-219$

studies by.

Meinzer, O. E., Renick, B. O., and Bryan,

Kirk, quoted................................

Mescalero, climatic data for

"Mescalero sands," character of ............... 46

Mesozoic era, events of ........................ 94-95

Meters, installation of, upon wells, cost of ... 288

Midwest-Terry well, condensed log of ....... 61-62

Mills, R. Van A., quoted.

Mineral constituents of the ground water, source and significance of ....... 161-167

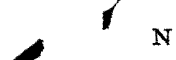

Nettleton, E. S., quoted.

New State Petroleurm Co, log of well of

Nogal formation, features of ......... $70-76$ sections of . ...................................... 71-74 water of, chemical analyses of.. ......... $\quad 176$ chemical character of ................ 175-176 movement and disposal of........... 158-159 occurrence of ......................... 156-158 source of ................................ 158 Northern Canal, features of.................. $189-190$

\section{o}

Oasis Cotton Co., artesian well of ... 193-194, pl. 29 Oil wells, methods used in sealing........... 278-279 Orchard Park well, artesian head in....... 197, 198 artesian head in, decline of ............... 202 fluctuations in ....................... pls. 32,36 finctuations in, seasonal ................ 215 mean monthly and mean annual... ... pl. 34 artesian pressure in rehard Park terrace, deposits of ............... 31-32

general features of.......................... 11-12

origin of ................................. 106-109

\section{'P}

Paleozoic era, events of .......................... $90-94$

Pebbles, solution-faceted, cemented by caliche................................. pl. 8

Pecos formation, artesian conditions in areas of ...................................... 130-133

artesian water in, head of............... 131-132 movement and disposal of ............. 132-133 occurrence and eharacter of..... 44-53, pls. 9, 10 outcrop areas of, general ground-water conditions in .................. 129-130

wells in ................................ 130 sections of ...................................... 47-48

sink hole developed in ....................... pl. 7 specimen of "worm-eaten" limestone

from lower part of ............. pls. 13, 14 water of, ehemical analyses of ............ 169 chemical character of . . .............. 168-169 in areas underlying alluvial basin... 130-133 in outcrop areas. ...................... 129-130 source of................................. 138-134

Pecos River, history of . ...................... 99-100 Perched ground water, conditions of 137-138, 159-161 Permian series, formations included in ....... 42-43 formations included in, nomenclature of - 43-44 Permian time, erosion and solution during.... $85-88$ Physiographic features............................ . 7 Physiographic history, relation of, to glacial stages.............................. 111-113

Picacho limestone, artesian aquifers in ...... 141-143 artesian basin in, general conditions in. 140-147 limits of ............................. 155-156 local conditions in .................. 147-148 wells in................................. 146-147 artesian water in, areas of large and small yield of ......................... 145-146

differences in head of ................... $\quad 145$ conditions in, west of artesian area... $\quad 136-140$ confining beds in. ........................ 143-145 contour map of ............................... pl. 25 disposal of water in . . fossils of .................................................. $62-63$ gypsum in ................ 67-69, pls. $19-22$ movement of water in .................. 152-154 occurrence and eharacter of ................ 55-70, pls. $9,11,12,15-23$ partial sections of...................... 55-60, 72-73 thickness of - 87 water of, ehemical analyses of ... 172-174, pl.27 chemical character of ................ 169-175 occurrence of............................... 134-136 source and quantity of .............. 148-152

wells in, west of artesian area ............. 138-139 Pleistocene deposits, features of .................. 30-40 Precipitation, amount of, during growing season.............................. 257 average annual................................ pl, 28 contributions of, to ground water........... 123 mean monthly and mean annual . ........... pl. 44 relation of, to recharge................... 245-250 Proterozoic era, event of ........................ 90 


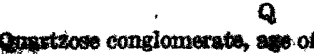

Page

occurrence and charecter of

Quaternary formations, character and distribution of

$25-26$

determination of age 27-28

origin of

stages of deposition of

thickness of....... 26-27

Quaternary period, ovents of..................98-113

$\mathbf{R}$

Rainfall, fuctuations in artesian head caused by

212-213

See also Precipitation.

Recharge, general conditions of

quantity of

relation of precipitation to............... 245-250

Renick, B. O., quoted $82,240-241$

Renick, B. C., Meinzer, O. E., and Bryan, Kirk, quoted.

Repair of artesian wells, inside recasing mothod of ........................... 274-275 outside recasing method of:............. 275-276 replacement of old casing for............ 276-277

Riffenburg, H. B., and Collins, W. D., quoted ........................... 177-178

Rio Felix, history of ......................... 100-102 quartzose conglomerate on ................ pl. 6

Rio Hondo, history of .......................... 100 section of Picacho limestone on north side of seepage losses on, study of ............. 239-242

Rio Penasco, history of....................... 102 seepage lasses on......................... 240-241 view down valley of ...................... pl. 6

Roswell, climatic data for..................... 7 dally precipitation at....................... pl. 36 decline of artesian head in wells near...... 201 map of city of, showing area of artesian flow and location of wells. .......... pl. 40

(in pocket)

Roswell-Alamogordo highway, section of Pícacho limestone along .......... 55-59

Rosvell artesian basin, artesian conditions in 118-120

correlation of glacial history of, with that of northern United States......... 112 events in Quaternary history of......... 112 general features of.......................... 2-3

\section{$\mathrm{S}$}

Sacramento Mountains, features of

Sacramento plain, features of

14-15

San Andreas limestone, correlation of......... 60,75

Sealing of artesian wells, methods of ........ 277-280 water-well method of, used in Hawaii.... 278

Sections across Roswell artesian area pl. 25 (in pocket)

Sections showing relation of ground water to stratigraphy and structure.

pl. 2

Seepage losses on tributary streams, study of 230-242

Seven Rivers cuesta, features of............ 17 , pl.9 ground-water conditions in................ 156 section near east end of.

Seven Rivers tongue of Pecos formation, exposures of. $46, \dot{p l} .9$
Bferta Blanca, Page geolocy of

Sirmile Eill fault, fuatures of.................. $79-80$

Blichter, C. 8., quoted....................... 117

Solution, character of, during Permian time $-85-88$ structural features resulting from......... 83-84

Solution openings in limestong of Foswall artesian basin, origh of ........ 178-189

origin of, hypotheses of ...

South Springs, view of.............. 35 Specific capacity of wells..................... 222-224 Speller, F. N., and Knowland, R. G., quoted 269-271

Springs, evidence of artesian circulation furnished by ........................... 181-182

source of ..................................... 160-161

Stovepipe method of constructing wells, features of

Stratigraphy, general relations of............... 22-25

Stream channels, features of....

Streams, general features of..................... 7-8 perched-water conditions affecting ....... 161

Structure, general features of.................. 76-77 of original area of artesian flow, sources of data for ............................... 84-85

Surface drainage, contributions of, to ground water. 121-122

\section{$\mathbf{T}$}

Terraces, features of 10-12 origin of 106-160 Tertiary deposits, character of................. $40-41$ Tertiary period, events of ........................ Travertine, deposits of........................... 29-30 Triassie beds, téatures of ...................... $41-48$ Tularosa, section of Nogal limestone northeast of $71-7$

\section{$\mathbf{V}$}

Valleys and stream channels, features of:.... 17-18

Valley fill, water in, chemical analyses of.... 167 water in, development of . ............ 128, 194 inovement and disposal iof.......... 125-126 occurrence of .................. 120-121 sources of ............................ 121-124

wells in .................................... 126-18 construction of ..................... 280-284 records of............................. 346-35i

\section{W}

Water table, features of ........... 116-117, 124-19k map showing depth to...................... pl. 24 Water-table conditions, evidence of solution under during Permian time.... 186-188

Wells, construction and repair of . ......... 263-277

interference of ............................ 207-2\1 permits for drilling, policy of granting... 279

records of................................... 291-897

Well-screen method of constructing weils, features of .

White Mountains. See Sierra Blanca.

"Worm-eaten" limestone, features of........ 51, 64-05, pls. 11, 13-10 $\mathbf{Y}$

Yeso formation, correlation of $6 C, 7$ $Y-0$ fanlt, teatures of................... 80-81, pl . 2

features of 